RITA DE CÁSSIA DE SOUZA

"NÃO PREMIARÁs, NÃO CASTIGARÁS, NÃO RALHARÁS..." dispositivos disciplinares em Grupos Escolares de Belo Horizonte (1925-1955) 
RITA DE CÁSSIA DE SOUZA

\section{"NÃO PREMIARÁS, NÃO CASTIGARÁS, NÃO RALHARÁS..." dispositivos disciplinares em Grupos Escolares de Belo Horizonte (1925-1955)}

Tese apresentada à Faculdade de Educação da Universidade de São Paulo na linha História da Educação e Historiografia como requisito parcial para a obtenção do doutorado em Educação.

Orientadora: Profa. Dra. Maria Cecilia Cortez Christiano de Souza

Co-orientador: Prof. Dr. Tarcísio Mauro Vago 
370.9 Souza, Rita de Cássia de

S729n "Não premiarás, não castigarás, não ralharás...": dispositivos disciplinares em Grupos Escolares de Belo Horizonte (1925-1955) / Rita de Cássia de Souza - 2006

464f. enc.

Orientadora: Maria Cecília Cortez Christiano de Souza Co-orientador: Tarcísio Mauro Vago

Tese (doutorado) - Universidade de São Paulo, Faculdade de Educação.

Bibliografia: f: 399-411

1. História da Educação 2. Disciplina escolar 3. Psicologia 4. Memória 5. Escola Nova I. Souza, Maria Cecília Cortez Christiano de; Vago, Tarcísio Mauro. II. Universidade de São Paulo. Faculdade de Educação. III. Título. 
No próprio círculo de nossos pais, nossos avós deixaram sua marca. Não percebiamos outrora, porque éramos sobretudo sensiveis ao que distinguiria uma geração da outra. Nossos pais caminhavam a nossa frente, e nos orientavam para o futuro. É chegado um momento em que eles se detêm e nós os ultrapassamos. Então, devemos nos voltar para eles e parece que no presente foram envolvidos pelo passado e que são confundidos agora por entre as sombras de outrora.

Maurice Halbwachs 


\title{
AGRADECIMENTOS
}

\begin{abstract}
Intercâmbios, leituras e confrontos que formam as suas condições de possibilidade, cada estudo particular é um espelho de cem faces (neste espaço os outros estão sempre aparecendo), mas um espelho partido e anamórfico (os outros aí se fragmentam e se alteram).
\end{abstract}

Michel de Certeau, 1994.

A concretização desta pesquisa é o resultado de um trabalho que envolveu muitas pessoas, como o espelho de cem faces que comenta Michel de Certeau. O autor se refere às leituras, aos autores, às fontes que auxiliam na construção de qualquer texto científico. Estas são, certamente, contribuições indispensáveis para a produção de uma pesquisa. No entanto, utilizo aqui a metáfora do espelho partido para dizer das contribuições, não teóricas, mas pessoais, que são também imprescindíveis para a realização de qualquer trabalho.

Esta tese é uma produção que reflete a contribuição de inúmeros amigos, companheiros de caminhada que, direta ou indiretamente, participaram da minha vida antes e durante este momento de elaboração.

Recuperando a minha trajetória para o doutorado, muitas pessoas foram essenciais como os professores do GEPHE - Grupo de Estudos e Pesquisas em História da Educação da UFMG - especialmente o professor Luciano Mendes Faria Filho que, desde o Mestrado, tem sido um direcionador dos meus caminhos acadêmicos e sugeriu o doutorado na USP.

Os amigos e amigas do GEPHE que, mais do que um grupo de estudos, é um grupo que reúne e une as pessoas através de laços de companheirismo e amizade. As discussões, as trocas de informações e materiais, o apoio para a participação de eventos e a disponibilidade de todos em ajudar têm criado um espaço de convivência saudável e rica que certamente se reflete na produção científica do grupo.

Aos diversos amigos e amigas do Mestrado: Carmem Andréa da Silva, Fernanda Mendes Resende, Walquíria Miranda Rosa, Cláudio Márcio Oliveira, Sheilla Brasileiro, Juca Garcia, Carlos Wellington Martins Melo, Marcus Vinícius Fonseca, e muitos 
outros que seria impossível citar aqui, mas que tiveram grande importância nesta produção.

As minhas três famílias: a de origem, a que me recebeu com todo o carinho em São Paulo - Valdemar Pinto de Souza, Maura dos Santos Souza, Júlio dos Santos Souza, Adriana Aparecida de Santos Souza e Yolanda Maria de Souza - e à minha mãe de Belo Horizonte, Maria do Rosário Fernandes Rodrigues, que tem sempre me alimentado material e espiritualmente.

Àqueles que me acolheram nas suas casas durante tantos períodos de estudo: Ana de Carvalho Vidigal, Neide do Carmo de Souza, Ana Milagres de Araújo, Margareth Freitas e seus familiares.

Agradeço à Nelma Marçal Lacerda Fonseca, do Centro de Referência do Professor, que me ajudou com as entrevistas, empréstimo de materiais preciosos e informações. Aos meus alunos Alex Eustáquio Gontijo e Júlio Elias Antunes por me auxiliarem com os dados para a pesquisa.

À Cynthia Greive Veiga e Ana Amélia Borges de Magalhães Lopes pelo empréstimo de materiais importantes para a pesquisa e pela amizade.

Agradeço ao Museu Histórico Abílio Barreto que me cedeu algumas fotografias para serem utilizadas na pesquisa, bem como a todas as instituições que me receberam e abriram suas portas e arquivos para a realização da pesquisa, especialmente às funcionárias dos Grupos Escolares que permitiram o acesso aos documentos $\mathrm{e}$ contribuíram para que novas fontes de pesquisa fossem reveladas.

Tenho muito que agradecer à Maria Cecília Cortez Christiano de Souza que me recebeu com carinho como sua orientanda e foi muito importante para a realização do trabalho. Aos colegas de São Paulo que também foram colaboradores na produção desta pesquisa.

À Capes cujo financiamento foi essencial para realizar a pesquisa com um pouco mais de tranqüilidade.

À Maurilane de Souza Biccas e Dislaine Zerbinatti Moraes que muito me auxiliaram com suas observações na qualificação.

A produção desta tese reflete a participação de uma pessoa muito especial que esteve presente principalmente ao final da pesquisa, meu co-orientador, Tarcísio Mauro Vago. Mais do que co-orientador, o Tarcísio foi um conselheiro, um amigo, alguém que 
conseguiu me auxiliar a organizar as minhas atividades do doutorado e paralelas a ele. À Aninha, sua esposa, que tinha sempre uma palavra amiga ao telefone, nos momentos mais difíceis, muitíssimo obrigada pela escuta solidária, atenciosa, pelo respeito, pelo carinho, pela disponibilidade e, principalmente, pela amizade.

Aos entrevistados e entrevistadas que foram muito solícitos ao abrir suas casas e corações para me receber e tiveram toda a boa vontade em contribuir para a pesquisa.

À minha irmã do coração Luzia Júlia de Souza Barbosa e familiares por sempre torcerem por mim e pelos almoços sempre deliciosos!

Às amigas e amigos que atenderam meus telefonemas, e-mails, encontros e desencontros e ouviram pacientemente meus dramas pessoais e profissionais: Adriana Luíza Ventura Marciano, Alexandre Ventura, Cibele Gonçalves Terra, Érica de Mello Silva, Larissa Assunção Rodrigues, Márcia Cristina Fernandes, Marcy Lima dos Santos, Maria Helena de Souza, Mauro Pinto de Souza, Regina Figueiredo Pinheiro, Ricardo Moreira Figueiredo Filho, Simone Garcia Rodrigues, Soélis do Prado Mendes, Wânia Terezinha Ladeira, e tantos outros e outras... Muito obrigada pela paciência de todos!

Por fim e, em primeiro lugar, a Deus e a todos os santos e santas aos quais eu insistentemente recorro para me ajudarem a percorrer os caminhos escolhidos.

A vocês, meus agradecimentos e a certeza de que todo trabalho se torna leve, gostoso e alegre quando se tem amigas e amigos por perto. 
Aos meus pais,

José Egídio de Souza \&L Júlia Barboza de Souza, por serem sempre companheiros, incentivadores, colaboradores e, especialmente, meus grandes amigos.

Ao Leandro Figueiredo Pinheiro, meu amor, por ter tolerado a distância, a ausência, as angústias e dificuldades e por estar sempre por perto, me apoiando e incentivando. 


\section{“NÃO PREMIARÁS, NÃO CASTIGARÁS, NÃO RALHARÁS...” dispositivos disciplinares em Grupos Escolares de Belo Horizonte \\ (1925-1955)}

\section{RESUMO}

Esta pesquisa problematiza alguns dispositivos disciplinares utilizados nos Grupos Escolares de Belo Horizonte num período em que a cidade foi denominada "capital pedagógica do Brasil”. Os trinta anos do estudo envolvem algumas Reformas Educacionais baseadas no movimento escolanovista que surgiu em fins do século XIX na Inglaterra. Apesar da longa delimitação temporal, pode-se afirmar que, durante esse período, houve uma certa permanência nas iniciativas educacionais. Isso se justifica porque a Reforma realizada em 1927 foi considerada um marco na educação mineira e não se ousava alterá-la radicalmente ou criticar seus princípios. A pesquisa se encerra nos anos cinqüenta, quando foi assinado um contrato entre Brasil e Estados Unidos chamado PABAEE - Programa de Assistência Brasileiro Americana ao Ensino Elementar - que teve em Belo Horizonte o centro-piloto de organização. Diversas fontes foram utilizadas para a pesquisa como jornais de circulação diária, jornais escolares, duas revistas pedagógicas produzidas no período - Revista do Ensino e Educando - a legislação escolar mineira relativa ao ensino primário e normal, Boletins publicados pela Secretaria do Interior e, mais tarde, da Educação, além de entrevistas com professoras, ex-alunos e ex-alunas e consulta aos arquivos de onze Grupos Escolares de Belo Horizonte. Foram utilizadas, ainda, quatro obras memorialísticas publicadas por professoras primárias e duas biografias de professoras desse período. Uma das características primordiais do movimento escolanovista era o repúdio ao uso das punições na escola, especialmente as mais drásticas e humilhantes, e a defesa à introdução de dispositivos que tinham por objetivo disciplinar, conformar, moldar e moralizar formando, desde os bancos escolares, cidadãos que se adaptassem à ordem social reinante sem revoltas e sem intentar transformá-la. A consulta a essas fontes teve por objetivo rastrear estes dispositivos e analisar de que forma os sujeitos escolares lidavam com as exigências de modernização de suas práticas educativas, especialmente no que se refere às punições e à disciplina escolar. A pesquisa divide-se em dois grandes eixos: no primeiro, estão os educadores e os educandos, suas experiências e lembranças, 
como eram representados e se representavam e, no segundo, a cultura escolar e alguns dispositivos disciplinares ali instaurados. Demarcar as percepções, as vivências, as tensões e os conflitos que permeavam esse momento de transição das prescrições em práticas de disciplinamento constitui o cerne da investigação desta pesquisa. Teriam os professores se submetido às mudanças pretendidas de forma tão simples e rápida como se esperava com a divulgação do modelo modernizador? Como reagiram professores e alunos diante das mudanças na concepção de escola, do papel do professor e, principalmente, diante das novas prescrições disciplinares que proibiam o uso dos castigos físicos e condenavam os que os utilizassem no ambiente escolar? De que forma os professores lidaram com as necessidades de adaptação a essas novas exigências pedagógicas? Tais questões permearam toda a pesquisa e permitiram compreender que o ideário escolanovista nem sempre foi tão moderna e neutra como apregoava. Há indícios de manutenção de princípios e preconceitos de classe, raça e gênero dissimulados pelo viés da cientificidade. Além disso, a transição da punição à disciplina se fazia de forma contraditória, confusa e, por vezes, não se realizava efetivamente. $\mathrm{O}$ brilhantismo da Reforma Francisco Campos, a qualidade sempre exaltada da escola pública neste período tendem a desconsiderar o sistemático processo de exclusão de alunos, considerados pobres, anormais, indisciplinados, pouco inteligentes que passavam pela escola sem usufruir seus benefícios, entre eles, o diploma escolar que a muitos era negado. A exclusão ou a sua ameaça eram formas de punição e disciplinarização, entre muitas outras existentes nas escolas. Foram submetidos a esse processo todos os personagens do universo escolar, de maneira mais ou menos intensa. Através da realização da pesquisa, das fontes consultadas, das páginas dos periódicos, dos documentos escolares, dos relatos de educadores e educandos daquele período puderam ser encontrados novos pontos de vista sobre a vida em Grupos Escolares de Belo Horizonte. Apesar disso, fica a certeza de que as apropriações do escolanovismo escondem, ainda, muitos enigmas que precisam ser decifrados para que se possa ter uma perspectiva mais heterogênea, multifacetada e plural do que foram as escolas primárias neste período. 


\title{
“DO NOT PRIZE, DO NOT PUNISH, DO NOT SCOLD...” disciplinary measures in Elementary Schools in Belo Horizonte (1925- 1955)
}

\begin{abstract}
This research aims at presenting he disciplinary measures employed in elementary schools in Belo Horizonte during the time the city was known as "Brazil's pedagogical capital. The span of 30 years in this study encompasses come of the educational reforms based on the Nwe School Moviment which started in the late XIX century England. Despite the broad temporal scope of the study, one can state that, during this period of time, there was a continuation of such education measures. It happened because the reform which took place in 1927 was considered to be a landmark in the educational landscape in the state of Minas Gerais and also because it did not dare to either change or criticize the educational panorama. This study ends by touching upon the events taken place in the 1950's when Brazil and the United states signed an agreement called PABAEE - Brazilian American program for elementary schools support - which was held in Belo Horizonte. Many sources of information such as newspapers, pedagogical magazines, periodicals,bulletins, intervieews with teachers and alumni, and a file research of 11 elementary schools were used to provide the study with information. Four memoirs published by schoolteachers and two bibliographies were also used. One of the main features of Escola Nova was its aversion to the use of punishments, especially those which resorted to humiliation and agression. It also objected the employment of disciplinary measures which aimed at conforming, molding and moralizing by forming citzens who would easily adhere to the existing social order. We examed these sources both in order to find out the measures and analyze how the school actors delt with the necessity to modernize their educational pratices, especially those related to punishments. The study is divided into two major parts: the first part deals with educators and students, their experiences and memories, the way they were portrayed and how they portrayed themselves. The second part deals with the day-byday activities in the schools and the measures taken place in that environment. This research deals with highlighting the perceptions, experiences, tensions and conflicts that permeated this time. Did the teachers subjectd themselves to the changes quickily as was expected from them? How did the teachers deal with the necessity to adapt
\end{abstract}


themselves to the new pedagogical demands? How did both teachers and students react to the changes, to the teachers' new role, and especially, to the new norms that prohibitted the employment of physical punishments? Such questions permeate the study in order to show that Escola Nova was not always modern and neutral as it was claimed to be. There are many traces of the continuation of some old pratices and also racial, gender and class prejudice. Besides that, the transition from punishment to discipline contradictory, confusing and sometimes, ineffective. The brilliance of the socalled Francisco Campos reform and the exaltation of the quality of public schools of that time tended to neglect the systematic process of students's exclusion, especially those considered to poor, indisciplined, handicapped and so on. Both the exclusion or the threat of it represented a form of punishment among the many others that existed at that time. All those involved wih schools at that time went through such experiences. Through the development of the research we could find new viewpoints about the everyday life in Belo Horizonte's public schools. Despite that, remains the certainty that Escola Nova in Minas Gerais hides many secrets that need to be revealed so as to allow a more heterogenous view of the public schools of that time. 


\title{
“IL EST INTERDIT: D’OFFRIR DES PRIX, DE CHATIER, DE REPROCHER ...”
} dispositifs disciplinaires dans les Grupos Escolares de Belo Horizonte (1925-1955)

\begin{abstract}
RÉSUMÉ
Cette recherche présente les dispositifs disciplinaires utilisés dans les Grupos Escolares de Belo Horizonte à une période pendant laquelle la ville a été appelée «capitale pédagogique du Brésil». Le temps de trente ans considéré par cette étude tient en compte quelques Réformes Éducationnelles basées sur le mouvement escolanovista déclenché à la fin du XIXe siècle en Angleterre. En dépit de la longue délimitation temporelle, on peut affirmer que pendant toute cette période il y a eu une certaine continuité dans les iniciatives éducationnelles. Cela se justife parce que la Reforma réalisée en 1927 était si considérée comme un repère dans l'éducation mineira, à tel point que l'on n'osait pas la modifier radicalement, ni critiquer ses principes. La recherche s'arrête aux années cinquante lorsque l'on a signé un contrat entre le Brésil et les États-Unis, appelé PABAEE - Programme d'Assistance Brésilien Américaine pour l'Enseignement Élémentaire - dont le siège de l'organisation était instalé à Belo Horizonte. De plusieurs sources ont été utilisées pour la recherche telles que les quotidiens, les journaux scolaires, deux hébdomadaires pédagogiques - Revista do Ensino e Educando - la législation scolaire mineira portant sur l'enseignement primaire et normal, des bulletins publiés par la Secretaria do Interior, devenue plus tard Secretaria da Educação, et des entretiens réalisés avec des anciennes enseignantes et des élèves. Ont été consultées les archives de onze Grupos Escolares de Belo Horizonte. On a encore utilisé quatre ouvrages mémorialistes publiés par des enseignantes primaires e deux biographies d'enseignantes de cette période. Une des caractéristiques primordiales da Escola Nova était l'avertion à l'emploi des punitions à l'école, surtout celles les plus drastiques et humiliantes, ansi que l'introdution des dispositifs qui avaient pour but de discipliner, conformer, mouler et moraliser, en formant, dès les bancs scolaires, des citoyens qui s'adapteraient à l'ordre social régnante, sans rébélions et sans l'intention de la transformer. Consulter ces sources a eu pour but de repérer ces dispositifs et, principalement, d'analyser de quelle façon les sujets scolaires se posicionaient devant les exigences de modernisation de leurs pratiques éducatives, surtout en ce qui concerne les châtiments et la discipline scolaire. La recherche est divisée en deux grandes axes :
\end{abstract}


dans le premier il se trouvent les éducateurs et les élèves, leurs expériences et souvenirs, tel qu'ils étaient réprésentés et tel qu'ils se réprésentaient; et dans le deuxième, le quotidien scolaire et les dispositifs disciplinaires y instaurés. Repérer les perceptions, le vécue, les tensions et les conflits qui marquaient ce moment de trasition des prescriptions en pratiques de disciplinarisation constitue le centre de la quête de cette recherche. Auraient les enseignants subis les chagements voulues de façon si simples e si rapide tel que l'on attendait avec la propagation de l'exemple mondernisateur? Comment les enseignants et les élèves réagiraient-ils devant les chagements de la conception de l'école, le rôle de l'enseigant et, surtout, devant les nouvelles prescriptions disciplinaires qui interdisaient l'utilisation des châtiments phisiques et reprochaient ceux qui les utilisaient dans l'espace scolaire? De quelle façon les enseignants se portaient-ils devant les besoins d'adaptation à ces nouvelles exigences pédagogiques? De telles questions ont marqué toute la recherche et ont permis de comprendre que l'Escola Nova n'etait pas toujours si moderne et si neutre comme on la voulait. Il y a des indices claires de la continuité des principes et des préjugés de classe, race et genre, dissimulés par le biais de la scientificité. En plus, la transition de la punition à la discipline se faisait de façon contraditoire, confuse et, parfois, ne se réalisait pas éfectivement. Le rayonnement de la Reforma Francisco Campos, la qualité toujours louée de l'école publique à cette période tient à ne pas considérer le processus sistématique de l'exclusion des élèves tenus par pauvres, anormales, indisciplinés et peu intéligents qui passaient par l'école sans profiter de ses bénéfices, tels que le diplôme scolaire, nié à beaucoup dentre eux. L'exclusion ou la ménace d'être étaient des exemples de punition et de disciplinarisation, parmi beaucoup d'autres existentes à l'école. Ont été soumis à ce processus tous les personnages de l'univers scolaire, de façon plus ou moins intense. À travers la réalisation de la recherche, des sources consultées, sur les pages des hébdomadaires, des documents scolaires, dans les rapports des enseignants et dans ceux des élèves de cette péridode là, il a été possible de trouver de nouveaux points de vue sur la vie dans les Grupos Escolares de Belo Horizonte. Malgré cela, il est sûr que l'Escola Nova au Minas Gerais cache encore beaucoup de mistères lesquels restent à être éclaircis pour que l'on puisse avoir une perspective plus hétérogène, multifacetée et plurale de ce qui ont été les écoles publiques primaires à cette période. 


\section{LISTAS DE FOTOGRAFIAS, FIGURAS \& QUADROS}

LISTA DE FOTOGRAFIAS E FIGURAS Pág.

Foto 1: Escola Normal Modelo - Belo Horizonte (s.d.)...................................................... 17

Foto 2: Grupo Escolar Bernardo Monteiro (s.d.).................................................................. 46

Foto 3: Grupo Escolar Flávio dos Santos (s.d.)................................................................. 47

Foto 4: Grupo Escolar Lúcio dos Santos (s.d.)............................................................... 48

Foto 5: Grupo Escolar Mariano de Abreu (s.d.).................................................................. 49

Foto 6: Grupo Escolar Olegário Maciel (s.d.)...................................................................... $\quad 50$

Foto 7: Grupo Escolar Pedro II (s.d.)............................................................................... 51

Foto 8: Grupo Escolar Sandoval de Azevedo (s.d.)............................................................ 52

Foto 9: Marta Nair Monteiro (s.d.).......................................................................................... 61

Foto 10: Alaíde Lisboa de Oliveira (s.d.)........................................................................... 62

Foto 11: Helena Antipoff (s.d.)................................................................................... 64

Foto 12: Capa do livro com a foto de Lúcia Casasanta........................................................ 69

Foto 13: Primeira página do jornal Estado de Minas de 17 de agosto de 1934 com um jornalista entrevistando Amélia de Castro Monteiro, diretora da Escola de

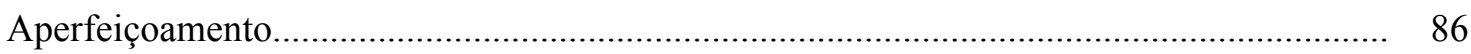

Figura 14: Imagens da Escola Antiga e da Escola Moderna.................................................. 96

Foto 15: Primeira Comunhão no Grupo Escolar Sandoval de Azevedo. À esquerda, a diretora Ondina Aparecida Nobre e abaixo, a professora Luíza Travassos Ribeiro Campos. (s.d.)...

Figura 16: Capa de Caderno da década de 30 "A Normalista"...

Foto 17: Sala de aula do G.E. Sandoval de Azevedo com a professora Luíza Travassos Ribeiro Campos (s.d.).

Foto 18: Instrutor e alunos num curso de marcenaria ou carpintaria no Grupo Escolar Lúcio dos Santos.

Figura 19: Capa de Caderno Escolar de 1940 _........................................................................ 362

Figura 20: Imagem do Jornal Voz Infantil............................................................... 370

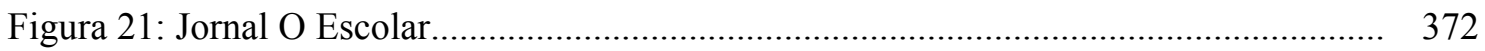

Figura 22: Jornal Voz da Criança................................................................................... 373 
Quadro 1 - Curso primário das professoras entrevistadas.................................................... 28

Quadro 2 - Locais de trabalho das professoras entrevistadas............................................ 29

Quadro 3 - Ex-alunos(as) entrevistados(as): período e Grupo Escolar estudado em Belo

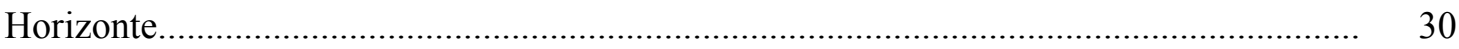

Quadro 4 - Qualidades de uma boa professora.............................................................. 127

Quadro 5 - Qualidades do professor, segundo as professoras-alunas do Instituto de Educação.

Quadro 6 - Defeitos do professor, segundo as professoras-alunas do Instituto de 129Educação.

Quadro 7 - Estado de saúde, conduta e caráter dos(as) alunos(as) de Grupos Escolares de Minas Gerais, segundo as professoras, em 1936.

Quadro 8 -Ocupações profissionais escolhidas por alunos(as) de Grupos Escolares......... 225

Quadro 9 - Relações entre o grupo social dos escolares e as profissões escolhidas........... $\quad 225$

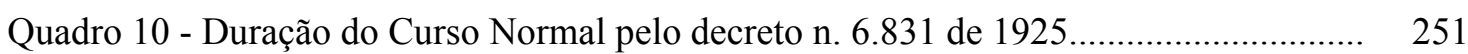

Quadro 11 -Divisão do Curso Normal a partir da Reforma de 1927................................. 252

Quadro 12 -Divisão do Curso Normal a partir do decreto n. 10.362 de 1932 ...................... 252

Quadro 13 - Comportamentos dos professores do Ensino Primário a serem reunidos no Registro de Notas em 1924 e 1927 261

Quadro 14 - Porcentagens esperadas e obtidas de aprovação em 1934 e 1938................... 270

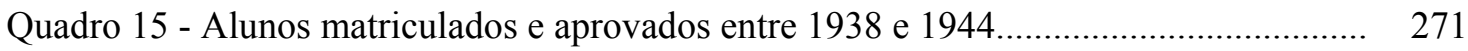

Quadro 16 - Classificação dos alunos, segundo os resultados obtidos no $1^{\circ}$ ano do Grupo

Escolar T.P. ${ }^{1} 1946-1^{\circ}$ ano.

Quadro 17 - Classificação dos alunos, segundo os resultados obtidos no $2^{\circ}$ ano do Grupo Escolar T.P. $1946-2^{\circ}$ ano.

Quadro 18 - Classificação dos alunos, segundo os resultados obtidos no $3^{\circ}$ ano do Grupo Escolar T.P. $1946-3^{\circ}$ ano.

Quadro 19 - Jornais escolares em Minas Gerais dos anos 1934 e 1935.

\footnotetext{
${ }^{1}$ Supostamente o teste utilizado.
} 
1. Legislações escolares mineiras do período....................................................................... 25

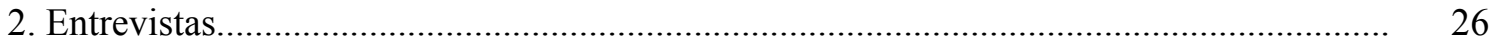

2.1. Entrevistas utilizadas na pesquisa.......................................................................... 26

2.2. Entrevistas produzidas pela pesquisa.......................................................................... 27

2.2.1. Entrevistas com professoras.......................................................................... 28

2.2.2. Entrevistas com ex-alunos e ex-alunas de Grupos Escolares de Belo Horizonte........... 29

3. Documentos apresentados pelos entrevistados.......................................................... $\quad 30$

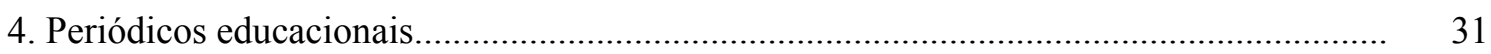

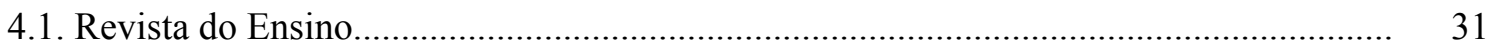

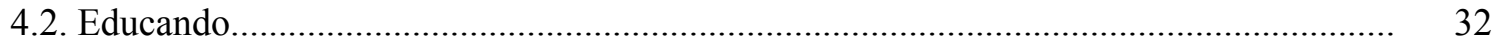

4.3. Boletins publicados pela Secretaria do Interior............................................................. 35

4.4. Considerações gerais sobre os periódicos educacionais................................................ 36

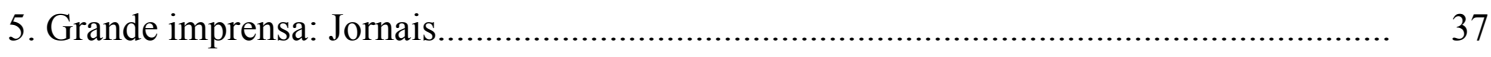

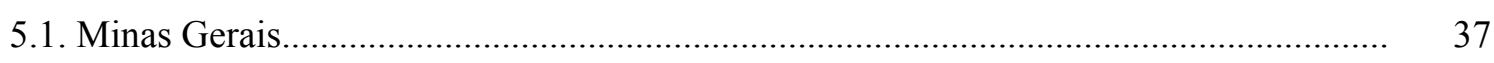

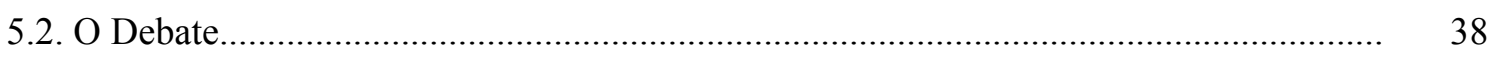

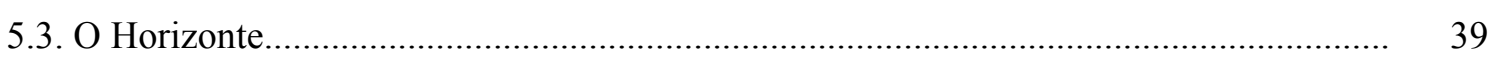

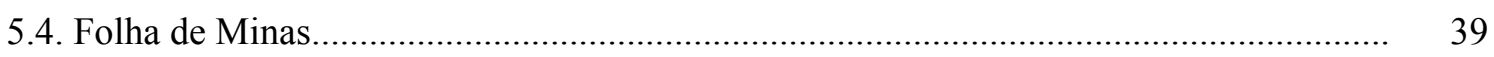

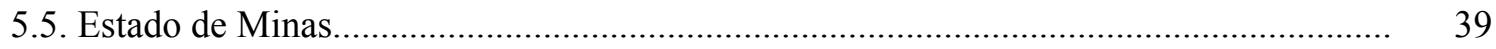

5.6. Considerações gerais sobre a grande imprensa do período no que se refere à temática

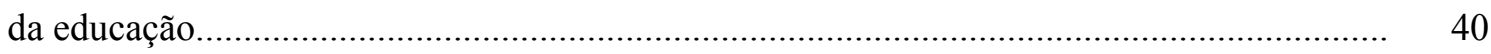

6. Memórias de professoras......................................................................................... 42

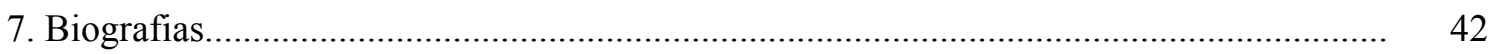

8. Documentos arquivados em Grupos Escolares de Belo Horizonte................................... 44

8.1. Grupo Escolar Afrânio de Melo Franco (noturno)........................................................... 45

8.2. Grupo Escolar Assis das Chagas (noturno).................................................................. 46

8.3. Grupo Escolar Bernardo Monteiro ............................................................................... 46

8.4. Grupo Escolar Flávio dos Santos................................................................................... 47

8.5.Grupo Escolar Lúcio dos Santos............................................................................ 48

8.6.Grupo Escolar Mariano de Abreu................................................................................... 49

8.7. Grupo Escolar Olegário Maciel............................................................................. 50

8.8. Grupo Escolar Pandiá Calógeras............................................................................. 51

8.9. Grupo Escolar Pedro II..................................................................................... $\quad 51$ 
8.10. Grupo Escolar Sandoval de Azevedo........................................................................ 52

8.11. Grupo Escolar Tomaz Brandão.................................................................................. 53

EIXO I: EDUCADORES \& EDUCANDOS........................................................... 54

CAP. 1 - De alunas a professoras: um percurso na educação........................................ 55

1.1. Nas páginas da memória.............................................................................................. 59

1.1.1. Memórias de uma professora - Maria da Glória D'Avila Arreguy.............................. 59

1.1.2. Memórias de uma professora primária - Benedita Dell'Isolla.................................... 60

1.1.3. Meu mundo - Marta Nair Monteiro..................................................................................... 61

1.1.4. Se bem me lembro... - Alaíde Lisboa de Oliveira............................................................ 62

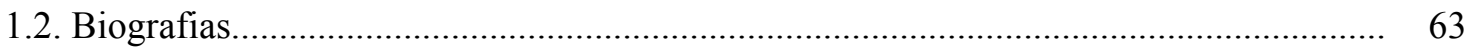

1.2.1. Helena Antipoff: sua vida, sua obra - Daniel Antipoff............................................. 63

1.2.2. Lúcia Casasanta, uma janela para a vida............................................................... 68

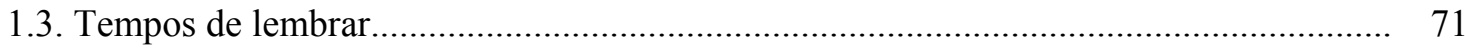

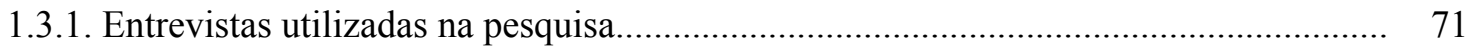

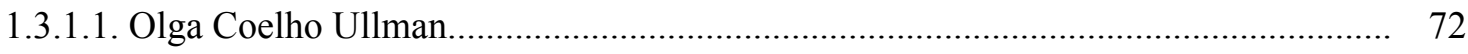

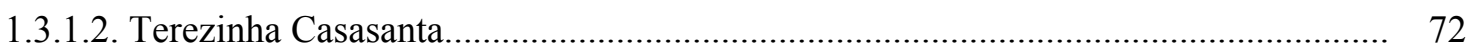

1.3.2. Entrevistas produzidas pela pesquisa....................................................................... 73

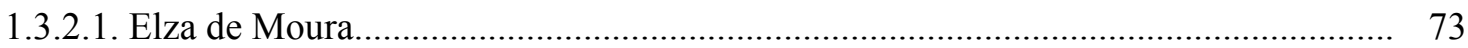

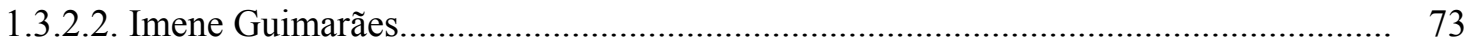

1.3.2.3. Luiza Travassos Ribeiro Campos......................................................................... 74

1.3.2.4. Maria Aparecida Trindade Santos (D. Yá)............................................................. 74

1.4. As professoras como alunas: um percurso de formação................................................. 75

CAP. 2 - Representações históricas acerca da professora primária............................... 94

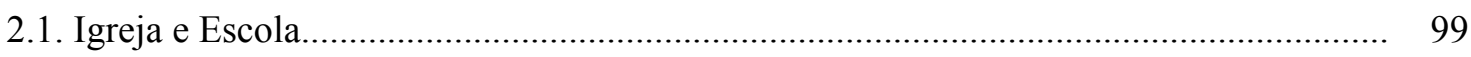

2.2. A remuneração das professoras............................................................................. 113

2.3. A aparência das professoras................................................................................ 119

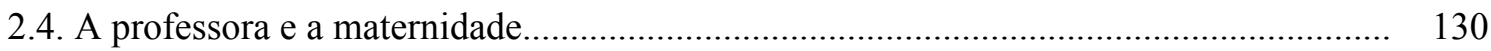

2.5. As lutas de representações....................................................................................... 133

CAP. 3 - Educadores em Grupos Escolares de Belo Horizonte: convivências e

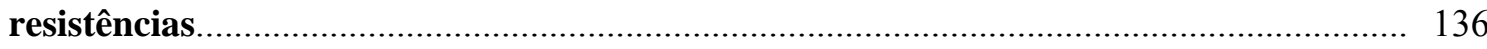

3.1. Diretoras, orientadoras, assistentes técnicas e professoras........................................... 139

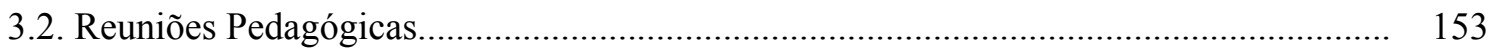

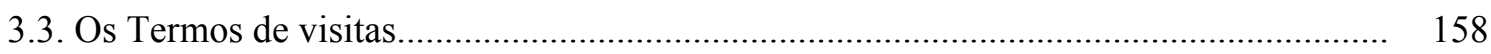

3.4. Das prescrições às práticas: a participação dos educadores............................................ 161 


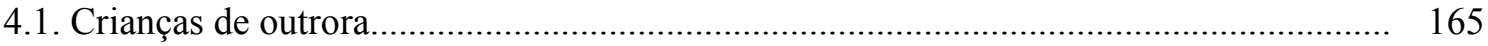

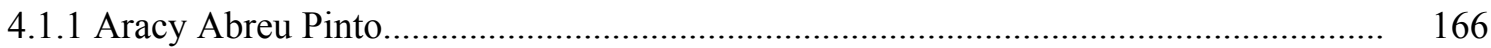

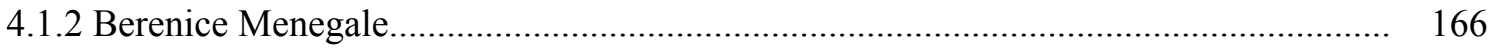

4.1.3. Geraldo Félix de Jesus....................................................................................... 166

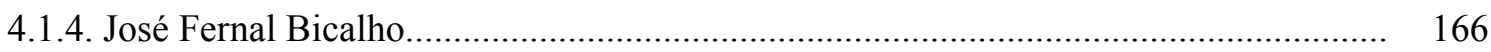

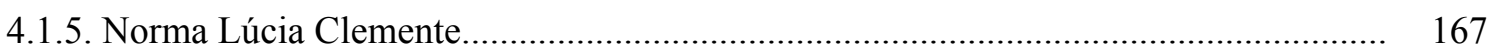

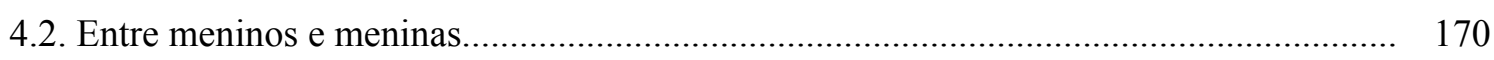

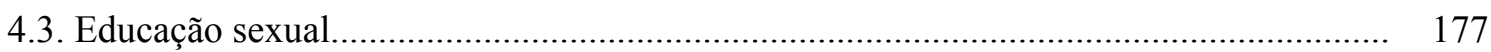

4.4. Colegas de Grupo Escolar ou Os alunos sobre eles mesmos........................................ 180

4.5. Representações acerca dos alunos e alunas dos Grupos Escolares................................. 185

EIXO II - CULTURA ESCOLAR E DISPOSITIVOS DISCIPLINARES.................. 207

CAP. 5- Representações sobre a família e a escola......................................................... 208

5.1. A escola a partir de representações familiares............................................................. 210

5.2. A família a partir das representações escolares......................................................... 217

5.3. Representações acerca do meio social dos escolares e de suas famílias.......................... 222

5.4. Dispositivos disciplinares: entre a escola e a família...................................................... 230

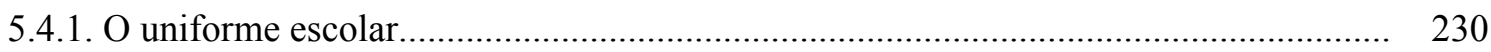

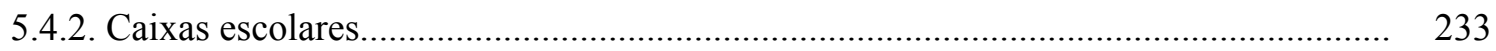

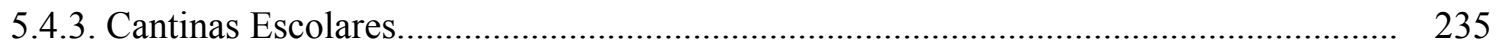

5.5. Medicina, higiene e saúde na escola: produzindo um corpo disciplinado....................... 238

5.6. Prêmios: dispositivos disciplinares de exemplaridade................................................... 244

5.7.Entre estratégias e táticas de disciplinarização........................................................... 248

CAP. 6 - Avaliações e testes escolares como dispositivos científicos de seleção e

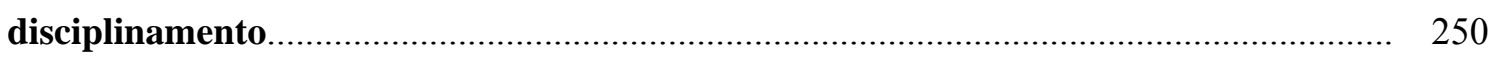

6.1. Avaliações das normalistas \& professoras.............................................................. 251

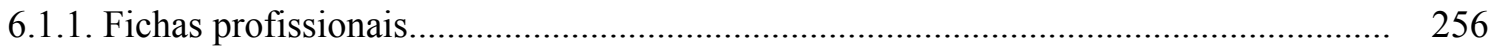

6.1.2. Avaliações de alunos e alunas em Grupos Escolares..................................................... 265

6.2. Avaliações e premiações: dispositivos disciplinares de seleção e exclusão...................... 273 
6.3. A Psicologia em Belo Horizonte: produzindo a escola moderna \& explicando o fracasso escolar

6.3.1. Dispositivos de controle: os testes psicológicos e pedagógicos................................... 277

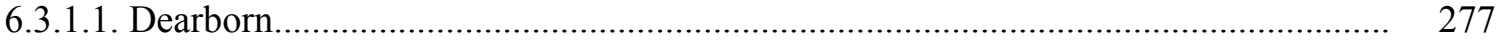

6.3.1.2. Goodenough............................................................................................... 278

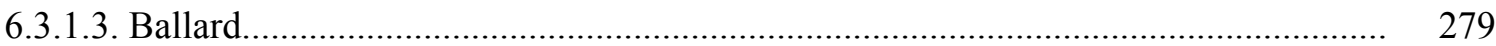

6.3.1.4. Teste de Vocabulário e Inteligência de Theodore Simon.......................................... 280

6.3.1.5. Teste Prime ou T.P.............................................................................................. 280

6.3.1.6. Teste E.A.(Escola de Aperfeiçoamento)........................................................................ 281

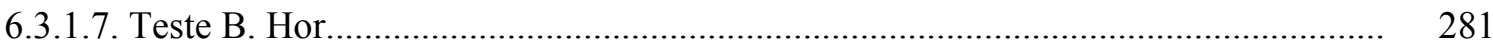

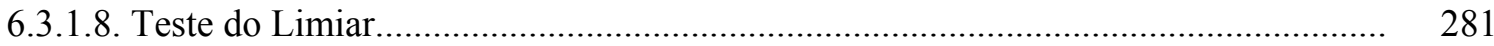

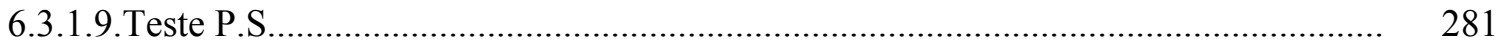

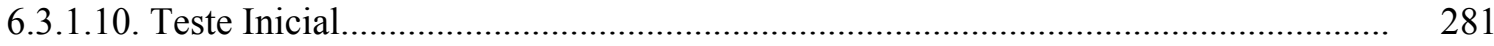

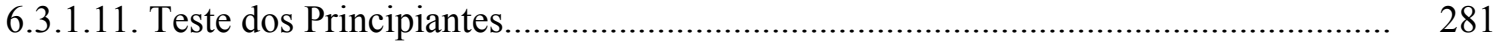

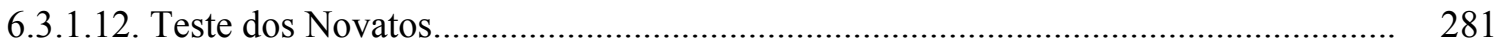

6.3.1.13. Teste MM ou "Minhas mãos"................................................................................. 282

6.4.Homogeneização: produzindo o fracasso escolar.............................................................. 285

CAP. 7 - Da escola punitiva à escola disciplinadora: nos rastros de uma transição....... $\quad 297$

7.1. No interior dos prédios escolares.............................................................................. 301

7.2. Dispositivos disciplinares nos Grupos Escolares de Belo Horizonte............................... 304

7.3. Estratégias disciplinares....................................................................................... 314

7.4. Táticas da indisciplina...................................................................................... 319

CAP. 8 - Atividades e Instituições escolares: ocupando e disciplinando alunos............. 327

8.1. Pelotão de saúde..................................................................................................... 331

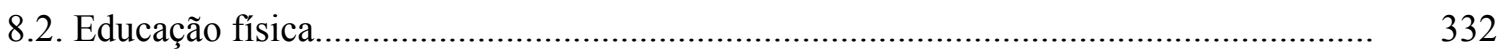

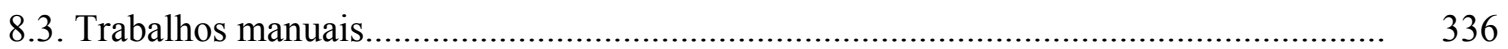

8.4. Clubes agrícolas e Horta escolar.............................................................................. 346

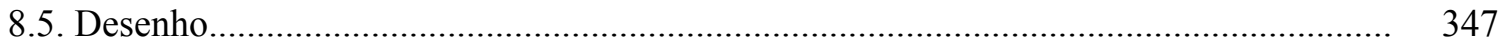

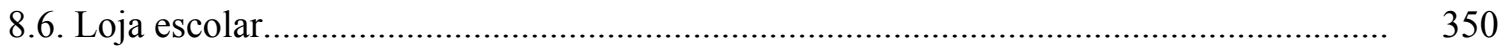

8.7. Hora da história \& Clubes de leitura........................................................................... 351

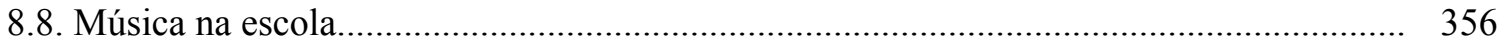

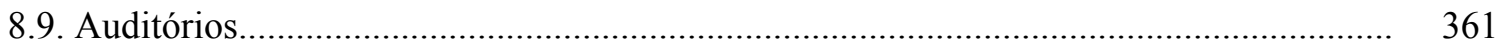

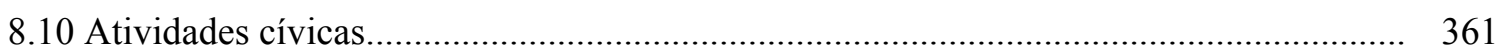

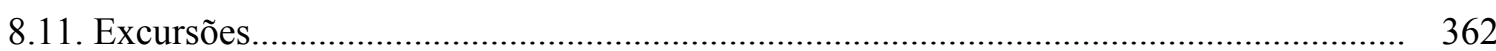

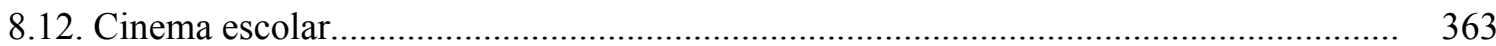




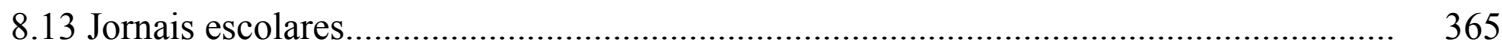

8.13.1. O Sandoval de Azevedo.................................................................................... 368

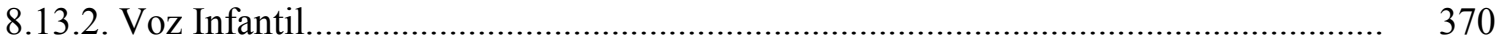

8.13.3. A Infância Moderna................................................................................................. 371

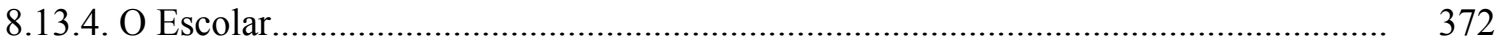

8.13.5. Voz da Criança................................................................................................ 373

8.14. O alcance das atividades e instituições escolares...................................................... 375

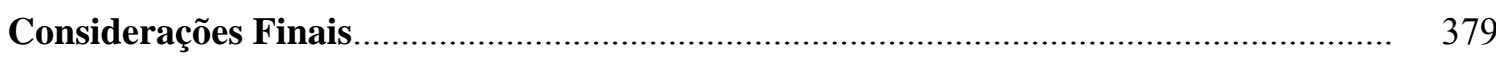

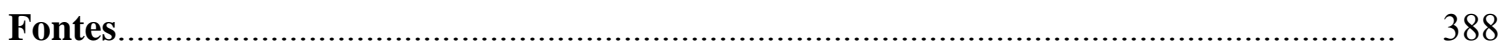

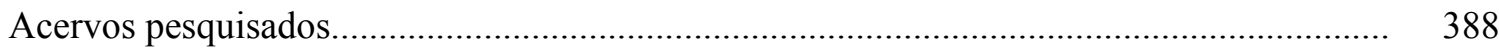

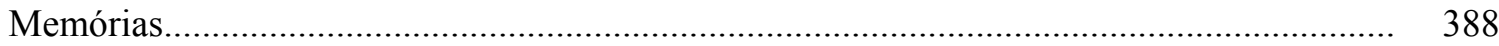

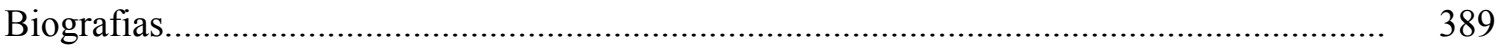

Publicações de Helena Antipoff.......................................................................................... 389

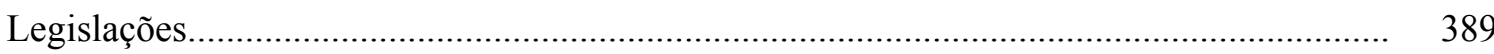

Boletins da Secretaria do Interior, posteriormente Secretaria de Educação e Saúde.............. 393

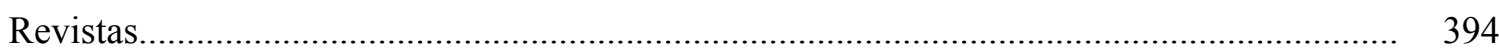

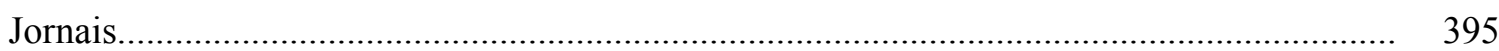

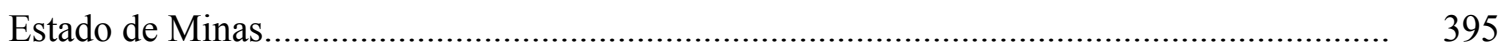

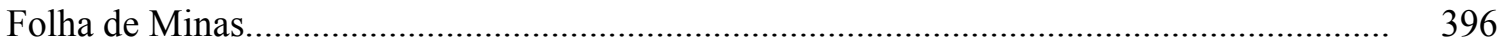

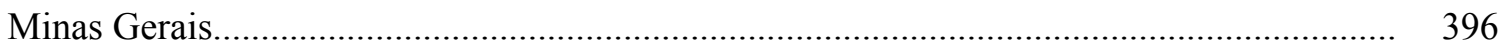

O Debate

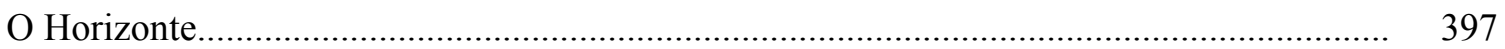

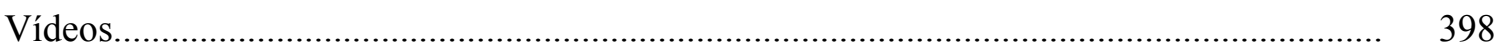

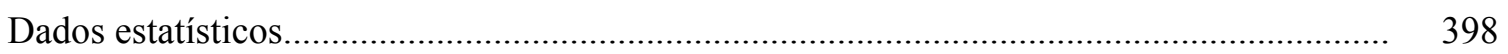

Referências Bibliográficas...................................................................................... 399 


\section{SUMÁRIO - ANEXOS}

ENTREVISTAS Pág.

Modelo da carta enviada aos entrevistados.................................................................... 412

Roteiro de entrevista para alunos e alunas (as professoras que estudaram em grupos de

Belo Horizonte também responderam a este questionário).................................................... 413

Parte II - Complementação da entrevista para professoras.................................................... 416

Ato de autorização da ex-aluna Aracy Abreu Pinto............................................................... 419

Ato de autorização da professora Elza de Moura............................................................. 420

Ato de autorização do ex-aluno Geraldo Félix de Jesus...................................................... 421

Ato de autorização da professora Imene Guimarães........................................................... 422

Ato de autorização do ex-aluno José Fernal Bicalho........................................................... 423

Ato de autorização da professora Luiza Travassos Ribeiro Campos....................................... 424

Ato de autorização da professora Maria Aparecida Trindade Santos (D. Yá)....................... 425

Ato de autorização da ex-aluna Norma Lúcia Clemente........................................................ 426

\section{DOCUMENTOS APRESENTADOS PELOS ENTREVISTADOS}

\section{ELZA DE MOURA}

Pág.

Roteiro de entrevista - Texto datilografado pela professora após o recebimento do questionário para a entrevista.

Artigo da professora intitulado "Saudades do meu grupo escolar" e publicado no jornal Estado de Minas em 19 de março de 2001

Artigo da professora sobre os museus na educação e cultura de Minas publicado no jornal Estado de Minas em 29 de outubro de 2000.

Artigo da professora sobre os 70 anos da Escola Nova publicado no jornal Estado de Minas em 15 de julho de 1998.

Artigo "A Polícia Militar e Olavo Bilac" publicado pela professora no jornal A velha guarda, órgão da União dos Reformados da Polícia Militar do Estado de Minas Gerais, em $1^{\circ}$ de junho de 1988 .

Artigo da professora com o título "O ensino rural foi ignorado" publicado no jornal Estado de Minas em 24 de fevereiro de 1998

Artigo "Uma lembrança: Marieta Leite" publicado na revista Amae Educando em novembro de 1984

Trabalho escolar da professora sobre o livro As escolas de amanhã de Ângelo Patri 
"Biografia" - texto escrito pela professora em 2001

Artigo "A Escola de Aperfeiçoamento de Professores com D. Helena Antipoff” publicado nos Anais do I Congresso Brasileiro sobre a experiência antipoffiana na educação. Belo Horizonte: Centro de Documentação e Pesquisa Helena Antipoff - CDPHA - 1992

"Bons tempos aqueles" artigo da professora publicado na revista Dois Pontos, vol. 1, n. 9 de julho de 1988

Artigo "A Escola de Aperfeiçoamento Pedagógico de Minas Gerais: Helena Antipoff, pioneira na defesa dos direitos humanos" publicado pelo Boletim do CDPHA - Centro de Documentação e Pesquisa Helena Antipoff - Ano III, n. 3, 1983

Diploma da Escola de Aperfeiçoamento de 1932.

\section{LUIZA TRAVASSOS RIBEIRO CAMPOS}

Alunas da Escola Normal de Belo Horizonte em 1935

Alunas da Escola Normal de Belo Horizonte em 1937

Cartão de Matrícula de Luiza Travassos Ribeiro Campos na Escola Normal de Belo Horizonte em 1936.

Imagem com a Lembrança da entronização de Cristo na Escola Normal em 1937 de Luiza Travassos Ribeiro Campos

Fotografias das alunas formandas de 1937 na festa das Bodas de Ouro da formatura.

Lembrança das Bodas de Prata das alunas formandas da Escola Normal em 1937 (1937 1962) 


\section{APRESENTAÇÃO}

A História da Educação, a partir das renovações propostas pela Nova História, tem se lançado em busca de fontes e documentos não-oficiais para obter uma compreensão dinâmica e globalizada dos processos de escolarização vivenciados ao longo do tempo. É dentro dessa proposta que se busca uma compreensão da realidade social e de processos de disciplinarização instaurados no interior de Grupos Escolares de Belo Horizonte nas décadas de vinte a cinqüenta do século XX.

As punições escolares têm sido pouco exploradas pelos historiadores da educação, seja por dificuldade de acesso às fontes, seja por interesse, consciente ou não, em ocultar um passado menos honroso da educação escolar e/ou cristalizar uma representação ${ }^{2}$ de que o ensino tradicional era, irremediavelmente, discricionário e violento. Foram os escolanovistas, entre os quais Fernando de Azevedo, que indicaram, por longo tempo, as linhas que a história da educação deveria percorrer e também os principais responsáveis pelas denúncias aos abusos no uso das punições na escola que intitulavam "tradicional". A presença dos castigos físicos no universo escolar é confirmada por autobiografias de alunos ${ }^{3}$ que, mais tarde, tornados escritores, relatavam as punições como epicentro de sua história escolar ${ }^{4}$, além dos relatos orais e da literatura sobre a infância. Nas obras em que se mencionam os usos punitivos do que genericamente se intitulou como "escola tradicional", os pesquisadores adotam muito rapidamente as categorias e julgamentos dos escolanovistas, não mantendo a distância necessária para um trabalho histórico, conforme indica Maria Cecília Cortez de Souza:

Assim, as reformas educacionais dos anos vinte aos dias de hoje, por exemplo, definem quase sempre o ensino passado como "tradicional", termo vago que designa uma

\footnotetext{
${ }^{2}$ Para Chartier (1990, p. 123) o conceito de representação "permite articular três modalidades da relação com o mundo social: em primeiro lugar, o trabalho de classificação e de delimitação que produz as configurações intelectuais múltiplas, através das quais a realidade é contraditoriamente construída pelos diferentes grupos; seguidamente, as práticas que visam fazer reconhecer uma identidade social, exibir uma maneira própria de estar no mundo, significar simbolicamente um estatuto e uma posição; por fim, as formas institucionalizadas e objetivadas graças às quais uns 'representantes' (instâncias coletivas ou pessoas singulares) marcam de forma visível e perpetuada a existência do grupo, classe ou comunidade."

${ }^{3}$ Optou-se por utilizar apenas o substantivo masculino na redação da tese, reservando-se o termo feminino, alunas, apenas para casos específicos.

${ }^{4}$ Algumas pesquisas, valendo-se de fontes literárias e autobiografias, trazem à tona a questão das punições escolares tais como: Alencar (1996); Galvão (1998); Oliveira (2001).
} 
espécie de mata-borrão indecifrável, capaz de absorver todos os erros e fantasmas que a mais nova inovação pretenda erradicar $(1997$, p.282)

Entretanto, é preciso conhecer as especificidades na implantação do ideário escolanovista em circunstâncias diferenciadas, conforme aponta Clarice Nunes:

$\mathrm{O}$ enfoque dos modelos dominantes de escolarização (Escola Tradicional x Escola Nova) é empobrecedor da realidade pedagógica. Seria oportuna, portanto, sua substituição nas pesquisas de história da educação pelo enfoque das múltiplas e diferenciadas práticas de apropriação desses modelos nas quais a ênfase da problematização recaia sobre os diversos usos que os agentes fazem da instituição escolar, sobre a apropriação de práticas não escolares no espaço escolar e os múltiplos usos não escolares dos saberes pedagógicos. (1996, p.221)

O que ficou classicamente designado como Escola Nova consistiu em um movimento deveras complexo e heterogêneo. $\mathrm{O}$ movimento escolanovista, que surgira em fins do século XIX na Europa, sofria, ademais, múltiplas alterações ao adentrar uma nação de economia dependente, que buscava se modernizar e cuja elite intelectual acreditava convictamente que a difusão do ensino escolar seria capaz de "transformar a massa em povo" ${ }^{5}$ ordeiro e civilizado, a fim de efetuar a transição da sociedade brasileira agrária, oligárquica e analfabeta para uma sociedade urbano-industrial, democrática e com uma população minimamente escolarizada.

As disputas em torno da educação revelam interesses diversos e, por vezes, contraditórios, como mostra, por exemplo, Marta Carvalho, ao descrever a história da Associação Brasileira de Educação ${ }^{6}$. Se havia consenso em modernizar o ensino e ampliar o acesso à educação no Brasil, muitos eram os impasses sobre como isso deveria se dar, o alcance das mudanças e os grupos envolvidos. Daí que falar nas apropriações $^{7}$ em torno da Escola Nova no Brasil e também em Minas Gerais exige uma atenção especial que permita identificar essas tensões no seu interior.

\footnotetext{
${ }_{6}^{5}$ Expressão utilizada por Marta Carvalho (1989).

${ }^{6}$ Associação fundada em 1924, no Rio de Janeiro, e que congregava diversos intelectuais envolvidos com a discussão acerca da importância da educação no Brasil. Sobre sua história, cf. Marta Carvalho (1988).

${ }^{7}$ A apropriação é aqui entendida como afirma Chartier (1990, p.26-7): "A apropriação, tal como a entendemos, tem por objectivo uma história social das interpretações, remetidas para as suas determinações fundamentais (que são sociais, institucionais, culturais) e inscritas nas práticas específicas que as produzem. Conceder deste modo atenção às condições e aos processos que, muito concretamente, determinam as operações de construção do sentido (na relação de leitura, mas em muitas outras também) é reconhecer, contra a antiga história intelectual, que as inteligências não são desencarnadas, e, contra as correntes de pensamento que postulam o universal, que as categorias aparentemente mais invariáveis devem ser construídas na descontinuidade das trajectórias históricas.”
} 
A própria concepção de "novo" consistia numa desqualificação dos métodos tradicionais de ensino, com os quais nem sempre rompia totalmente, como o método intuitivo, por exemplo. Entretanto, o qualificativo "novo" lhe atribuía um caráter de vanguarda e de modelo a ser seguido. Marta Carvalho explica que este qualificativo tinha, para Fernando de Azevedo ${ }^{8}$, basicamente, três acepções:

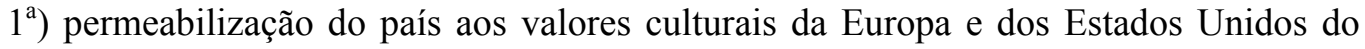
pós-guerra, com destaque especial para as "reformas educacionais com que se sonhava forjar uma humanidade nova em que se concentravam as últimas esperanças de uma vida melhor, da restauração da paz pela escola e da formação de um novo espírito, mais ajustado às condições e necessidades de um novo tipo de civilização";

$2^{\mathrm{a}}$ ) adaptação do sistema escolar "às exigências de uma sociedade nova, de forma industrial, em franca evolução para uma democracia social e econômica", sem que fosse descurada "condições específicas do meio social brasileiro, ainda não profundamente atingido pelos efeitos da revolução industrial";

$3^{\mathrm{a}}$ ) unificação do sistema educacional em nível nacional por uma "política orgânica traçada pelas elites governamentais", em outros termos, o que era entendido por uma "política nacional de educação". (1998, p.22-23)

Se o adjetivo "novo" parecia fundamental para autores como Fernando de Azevedo, o mesmo não se pode dizer de autores encarregados de realizar a renovação do ensino em Minas Gerais. Por ser um Estado de forte cunho religioso, muitas novidades educacionais da época eram vistas com reservas, sendo freqüentemente acusadas de um excessivo materialismo e distanciamento da moral cristã. Em decorrência, as Reformas Educacionais buscavam conciliar as propostas modernas com o conservadorismo e religiosidade característicos do Estado no período. Assim, o escolanovismo em Minas teve um caráter diferenciado, sofrendo influências tanto européias quanto americanas, mas construindo representações bastante singulares e específicas. No que diz respeito ao cerne deste estudo, no entanto, um consenso entre os reformadores $^{9}$ era a necessidade de uma melhoria da formação dos professores e a necessidade de prepará-los para uma nova forma de disciplinar os alunos, abandonando ou minimizando o uso das punições. Essas deveriam tornar-se menos físicas, como se

\footnotetext{
${ }^{8}$ Fernando de Azevedo (1894-1974) realizou uma ampla Reforma na educação do Distrito Federal durante 1927 e 1930, em 1933 era Diretor-Geral da Instrução Pública no Estado de São Paulo. Em 1947 tornou-se, novamente em São Paulo, Secretário da Educação e Saúde. Participou da ABE - Associação Brasileira de Educação fundada em 1924 no Rio de Janeiro, deixou 25 livros publicados, dentre eles, alguns clássicos na área da Educação e da Sociologia. Foi autor de dois manifestos em defesa da educação nos anos de 1932 e 1959 e ficou conhecido como um dos Pioneiros da Escola Nova.

9 Como reformadores, estão sendo considerados aqueles que estiveram à frente das Reformas Educacionais propostas neste período, sejam os legisladores, sejam os próprios educadores encarregados de difundir as inovações educacionais.
} 
pode perceber a partir do título escolhido para esta tese, retirado de uma máxima publicada em 1932 na Revista do Ensino mineira:

AVISO!

Tres mandamentos da pedagogia moderna:

- não premiarás, não castigarás, não ralharás... ${ }^{10}$

Este aviso revela a transição pretendida da punição física à disciplina introjetada. Em três proibições ao professor ${ }^{11}$ se concentrava a essência da pedagogia moderna. A renovação escolar pretendida caracterizava-se pela alegria e pela proximidade com os alunos, devendo acabar de vez com as humilhações e punições que haviam sido a marca da "escola antiga". É significativo que a pedagogia moderna fizesse uso de uma terminologia religiosa, os "mandamentos", para se apresentar. Além disso, o aviso determinava que a disciplina dos alunos deveria ser alcançada sem o uso de artifícios como as premiações. Neste aspecto, pode-se perceber uma outra incoerência das apropriações do ideário escolanovista em Minas Gerais que proibia a concessão de prêmios, mas o fazia com relativa freqüência.

Objetivando operacionalizar com essa tentativa de apreensão das tensões e disputas em torno das práticas punitivas e disciplinares da escola, optou-se por utilizar a definição dada por Michel de Certeau acerca das estratégias ${ }^{12}$ e táticas que circundam a disputa pelo poder. Conforme o autor, as estratégias partem de lugares de poder definidos e que, nesta pesquisa, podem ser identificadas pelas ações dos reformadores ${ }^{13}$ para convencer ou coagir os professores da necessidade de mudarem suas práticas de

${ }^{10}$ AFORISMOS Pedagógicos. Revista do Ensino, BH, ano VI, n.77, $1^{\mathrm{O}}$ de dezembro de 1932. p. 37.

${ }^{11}$ A maioria dos professores primários de Minas Gerais, no período estudado, é do sexo feminino. Nos documentos investigados, não foi encontrado nenhum professor, com exceção para a disciplina "Trabalhos manuais" destinada aos meninos, como a marcenaria. Ainda assim, optou-se por utilizar o substantivo masculino "professor" para se referir a todos os professores primários, com exceção para aqueles textos e falas que se dirigiam exclusivamente à professora. $\mathrm{O}$ mesmo foi feito em relação à palavra "alunos".

12 "Chamo de estratégia o cálculo (ou a manipulação) das relações de forças que se torna possível a partir do momento em que um sujeito de querer e poder (uma empresa, um exército, uma cidade, uma instituição científica) pode ser isolado. A estratégia postula um lugar suscetível de ser circunscrito como algo próprio e ser a base de onde se podem gerir as relações com uma exterioridade de alvos ou ameaças (os clientes, os concorrentes, os inimigos, o campo em torno da cidade, os objetivos e objetos de pesquisa, etc.) Como na administração de empresas, toda racionalização "estratégica" procura em primeiro lugar distinguir de um "ambiente" um "próprio", isto é, o lugar do poder e do querer próprios". (Certeau, 1994, p. 99)

${ }^{13}$ Entre os reformadores estariam tanto os quadros de níveis mais altos da Secretaria do Interior, posteriormente, da Educação, quanto os diretores e inspetores escolares que atuariam nos Grupos Escolares, com o objetivo de garantir a efetivação das Reformas realizadas e das legislações educacionais em voga. 
disciplinamento, embora não seja possível definir, a priori, que atores sociais ocupam os lugares de estrategistas. Tudo depende da circunstância em questão, já que os mesmos educadores podem utilizar táticas ${ }^{14}$ para se esquivar das exigências impostas. Exemplo disso são os professores. Enquanto funcionários públicos, estes estão numa posição de menor poder e, portanto, têm de agir num campo do outro, a escola pública, sob o governo e orientação de superiores que detêm um "lugar de poder". No entanto, em outro contexto, dentro do espaço da sala de aula, em relação à classe, são eles os estrategistas, enquanto aos alunos, cabe a posição tática.

As estratégias são portanto ações que, graças ao postulado de um lugar de poder (a propriedade de um próprio), elaboram lugares teóricos (sistemas e discursos totalizantes), capazes de articular um conjunto de lugares físicos onde as forças se distribuem. Elas combinam esses três tipos de lugar e visam dominá-los uns pelos outros. Privilegiam portanto as relações espaciais. [...] As táticas são procedimentos que valem pela pertinência que dão ao tempo - às circunstâncias que o instante preciso de uma intervenção transforma em situação favorável, à rapidez de movimentos que mudam a organização do espaço, às relações entre momentos sucessivos de um "golpe", aos cruzamentos possíveis de duração e ritmos heterogêneos etc... as estratégias apontam para as resistências que o estabelecimento de um lugar oferece ao gasto de tempo; as táticas apontam para uma hábil utilização do tempo, das ocasiões que apresenta e também dos jogos que introduz na fundação de um poder. (Certeau, 1994, p.102)

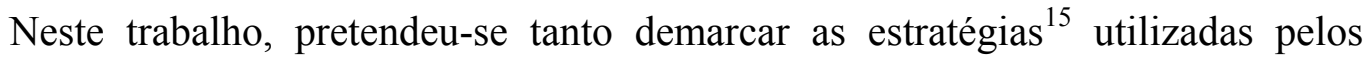
reformadores para conformar e cooptar os professores para atuarem dentro das novas normas, quanto inventariar as táticas destes para adaptar as prescrições ao campo das práticas escolares. Não obstante, os professores também se tornavam estrategistas em relação aos alunos e estes tinham as suas táticas para se adequarem e/ou escaparem das exigências impostas. Nesses movimentos, diversas questões podem ser levantadas: Os

14 “... chamo de tática a ação calculada que é determinada pela ausência de um próprio. Então nenhuma delimitação de fora lhe fornece a condição de autonomia. A tática não tem por lugar senão o do outro. E por isso deve jogar com o terreno que lhe é imposto tal como o organiza a lei de uma força estranha. Não tem meios para se manter em si mesma, à distância, numa posição recuada, de previsão e de convocação própria. Ela não tem portanto a possibilidade de dar a si mesma um projeto global nem de totalizar o adversário num espaço distinto, visível e objetivável. Ela opera golpe por golpe, lance por lance. Aproveita as "ocasiões" e dela depende, sem base para estocar benefícios, aumentar a propriedade e prever saídas. O que ela ganha não se conserva. Este não-lugar lhe permite sem dúvida mobilidade, mas numa docilidade aos azares do tempo, para captar no vôo as possibilidades oferecidas por um instante. Tem que utilizar, vigilante, as falhas que as conjunturas particulares vão abrindo na vigilância do poder proprietário. Aí vai caçar. Cria ali surpresas. Consegue estar onde ninguém espera. É astúcia." (Certeau, 1994, p.100-101)

${ }^{15}$ Pode-se afirmar que as estratégias de disciplinamento compõem todo o conjunto de dispositivos disciplinares em voga nos Grupos Escolares como a Educação Física, os testes psicológicos, os trabalhos manuais, entre outros. 
professores se apropriaram das mudanças em torno do papel da escola e de sua função como educadores? E no que se refere à disciplina? Que usos faziam das prescrições que lhes eram feitas? Que arranjos faziam entre as práticas punitivas antigas (que passavam a ser criticadas) e as novas técnicas disciplinares (que eram preconizadas)? Houve mudanças na punição/disciplinarização dos alunos? Os três mandamentos foram acolhidos por todos? Diante das exigências de modernização, o que teriam feito os professores diante das dispositivos disciplinares que lhes eram prescritos? A disseminação do ideário modernizador e a crítica contundente ao uso dos castigos tiveram ressonância no dia-a-dia escolar? Como os professores adequaram-se a essas novas exigências que passavam a fazer parte de sua prática profissional?

Em 1925, no governo de Fernando Mello Viana, foi realizada uma Reforma na Instrução Pública em Minas Gerais, sob a coordenação do Secretário do Interior, Sandoval Soares Azevedo. Tal Reforma tinha um cunho fortemente escolanovista que se manteve pelo menos até a década de cinqüenta no Estado, segundo as fontes consultadas. Em 1956, foi introduzido o PABAEE - Programa de Assistência Brasileiro Americana ao Ensino Elementar - que dava feições mais tecnicistas ao ensino primário $^{16}$. Dessa forma, foram delimitados trinta anos de investigação (1925-1955), buscando-se abordar o período de maior influência do movimento escolanovista no Estado.

A pesquisa foi delimitada à capital mineira ${ }^{17}$, cidade construída sobre o signo da modernidade e da República e a partir de um projeto "pedagógico-modernizador". Ainda que os lugares mais distantes do Estado tivessem acesso a informações sobre as

\footnotetext{
${ }^{16}$ O convênio que deu início ao Programa foi assinado em 22 de junho de 1956. No entanto, optou-se por finalizar a pesquisa em 1955 e não em 1956. A própria divulgação da assinatura do convênio antes mesmo dele se realizar poderia ter alguma influência na escola.

${ }^{17}$ Foram pesquisados apenas Grupos Escolares de Belo Horizonte, já que o objetivo do trabalho se circunscreveu ao pólo divulgador das Reformas: a capital. No entanto, outras fontes como as revistas, as memórias das professoras e as entrevistas realizadas remetem, em alguns momentos, para cidades do interior de Minas Gerais.. Pode-se dizer que Minas Gerais, em diversos momentos, se antecipou às mudanças no ensino nacional, a partir de experiências realizadas no Estado. No período em estudo, por exemplo, as Reformas de 1925 e 1927 estavam em sintonia com várias outras realizadas em diversos Estados no país, e, não por acaso, Francisco Campos, idealizador da Reforma de 1927, foi, três anos depois, convidado a ocupar o recém-criado Ministério da Educação e Saúde. Segundo Peixoto (1992, p. 8), "Nessa trajetória em busca de modernização, já em 1935, a escola mineira se apresenta como uma instituição altamente moralizante, abertamente dualista e excessivamente burocratizada, o que nos permite afirmar que, nesse setor, Minas se antecipa em vários aspectos à implantação do Estado Novo. Em 1937, a escola já se encontra de tal forma a serviço dos interesses oficiais e sua subordinação aos órgãos administrativos é tão estreita, que a explicitação do regime autoritário dispensa mudanças significativas em sua organização e nos processos de trabalho."
} 
Reformas do ensino, nenhuma outra cidade estava mais envolvida com estas transformações que a "capital pedagógica do Brasil" no final dos anos vinte. Portanto, eram também os seus professores e alunos os mais atingidos pelas Reformas. Nesse sentido, optou-se por investigar como estes participaram dessas mudanças no ensino, especialmente no que tange ao objeto desta pesquisa: a transição das punições para a disciplina escolar. Como propõe Chartier:

As percepções do mundo social não são de forma alguma discursos neutros: produzem estratégias e práticas (sociais, escolares, políticas) que tendem a impor uma autoridade à custa de outros, por elas menosprezados, a legitimar um projecto reformador ou a justificar, para os próprios indivíduos, as suas escolhas e condutas. Por isso esta investigação sobre as representações supõe-nas como estando sempre colocadas num campo de concorrências e de competições cujos desafios se enunciam em termos de poder e de dominação. As lutas de representações têm tanta importância como as lutas económicas para compreender os mecanismos pelos quais um grupo impõe, ou tenta impor, a sua concepção do mundo social, os valores que são os seus, e o seu domínio. (1990, p.17)

Problematizar a relação entre as prescrições disciplinares e as práticas utilizadas nas escolas implica adentrar os muros de escolas e paredes das salas de aulas, ainda que isso só seja possível através de meios indiretos, frestas abertas através dos documentos consultados que possibilitam uma aproximação com o universo dos Grupos Escolares pesquisados. E estes espaços abrigam os dois personagens básicos que dão vida à dinâmica escolar: os educadores ${ }^{18}$ e os educandos ${ }^{19}$. Sendo a formação docente um dos pontos centrais das Reformas Escolares, é essencial investigar as maneiras pelas quais os professores se apropriavam desse novo modelo, bem como as possíveis reinterpretações, silêncios, subversões, usos e indiferenças acerca das inovações.

Dominique Julia (2001), considerando o caráter ativo dos sujeitos envolvidos na tarefa educativa da escola, ressalta a importância de que a cultura escolar seja analisada a partir destes. Para o autor, as práticas escolares consistem em:

Normas e práticas que não podem ser analisadas sem se levar em conta o corpo profissional dos agentes que são chamados a obedecer a essas ordens e, portanto, a utilizar dispositivos pedagógicos encarregados de facilitar sua aplicação, a saber, os professores primários e os demais professores.

$[\ldots]$

\footnotetext{
${ }^{18}$ Como educadores, estão sendo compreendidos diretores, inspetores, assistentes técnicos, orientadores e, especialmente os professores, que, ao final da hierarquia pedagógica, eram os grandes responsabilizados pela modernização escolar.

19 São educandos os alunos e alunas dos Grupos Escolares e, por extensão, a sua família e a própria sociedade que, em última instância, a escola também pretendia moralizar e disciplinar.
} 
Enfim, por cultura escolar é conveniente compreender também, quando isso é possível, as culturas infantis (no sentido antropológico do termo), que se desenvolvem nos pátios dos recreios e o afastamento que apresentam em relação às culturas familiares (Julia, 2001, p.10-11)

A cultura escolar ${ }^{20}$ é dinâmica com a interferência direta dos sujeitos envolvidos na tarefa educativa. No caso das Reformas em estudo, a ampliação das atividades docentes, a exigência de conhecimentos mais elaborados e complexos, a vigilância por um ensino moderno e segundo os novos regulamentos provocaram mudanças no ambiente e na cultura escolar que merecem investigações. Para uma compreensão da cultura escolar é fundamental analisar os materiais, as legislações, a organização arquitetônica das escolas, a distribuição das salas, dos ambientes, das competências, mas também a vida dos personagens que produziram e vivenciaram essa cultura. Investigar a implementação destas Reformas educacionais, bem como as resistências e negociações entre os saberes da experiência e as exigências ditadas pelas normas, exige um contato mais íntimo com os atores que construíram e participaram dessa história. Tais atores, no entanto, não estavam apenas imersos no cotidiano escolar. Suas práticas revelam influências de outros meios e outras culturas das quais a escola não está isenta. A cultura escolar, como afirma Julia (2001), não pode ser compreendida fora do conjunto das relações que mantém com outras culturas que lhe são contemporâneas, como a cultura religiosa, política ou popular, sendo estas relações pacíficas ou não. Certamente, os educadores e as práticas educacionais que buscam implementar estão imbuídos de influências de todas essas culturas, bem como os educandos que sofrem influência principalmente da cultura familiar na qual estão inseridos.

Benito Escolano (1999) afirma que muitos estudos caem na falácia de se confundir a prática de ensino utilizada pelos professores com as práticas alardeadas no conjunto das legislações e da formação obtida no Curso Normal. Para se aproximar

\footnotetext{
${ }^{20}$ Segundo Julia (2001, p.10) a cultura escolar define-se como "um conjunto de normas que definem conhecimentos a ensinar e condutas a inculcar, e um conjunto de práticas que permitem a transmissão destes conhecimentos e a incorporação desses comportamentos". Chervel (1990) revela que a cultura escolar não se constitui numa adaptação da cultura global, ela é uma cultura especificamente escolar, gestada e disseminada pela escola e que tem por função não apenas formar o indivíduo, o escolar, mas influenciar a própria sociedade. Chervel (1998, p. 191) define: "La culture scolaire, à proprement parler, c'est toute cette partie de la culture acquise à l'école non seulement son mode de diffusion mais aussi son origine”. Para Viñao Frago (1995, p.69) “... la cultura escolar es toda la vida escolar: hechos e ideas, mentes y cuerpos, objetos y conductas, modos de pensar, decir y hacer. Lo que sucede es que en este conjunto hay algunos aspectos que son más relevantes que otros, en el sentido de que son elementos organizadores que la conforman y definen."
} 
destas práticas, o autor sugere a pesquisa em diários, memórias, romances, documentos iconográficos e administrativos:

A través de ellos, el investigador puede obtener una imagen real y una representación icónica y literaria de la vida cotidiana de los maestros, de su comportamiento social y escolar, del ajuar q utilizaron en sus trabajos y de los hábitos culturales y profesionales dominantes en el colectivo. Estos registros empíricos, y no los curricula de las normales, son los que en realidad acreditan las prácticas que configuraron en el pasado el arte de la enseñanza y las condiciones de vida de los docentes primarios, así como permiten evidenciar la disonancia entre estas observaciones y los discursos formales acerca de su preparación académica. $(1999$, p. 18)

Para inventariar os dispositivos ${ }^{21}$ disciplinares postos em circulação em Grupos Escolares da capital mineira, foi indispensável recorrer a fontes variadas que possibilitassem um contato mais próximo com os "modos de fazer" desses educadores e educandos e pudessem flagrar os instantes de atuação deste poder, rastrear seus caminhos, numa perspectiva da multiplicidade e da pluralidade de análises e interpretações. Cada uma dessas fontes exige metodologias diferenciadas de aproximação, análise e interpretação e constituem formas diversas de apropriação do objeto em estudo, como salienta Diana Gonçalves Vidal (1998, p.15) "Narrativas imagéticas diferem de narrativas orais e de narrativas escritas. Lógicas diversas organizam a construção dessas linguagens. A especificidade de cada fonte documental, assim, requer uma metodologia singular e impõe uma análise distinta”.

Não se pretendeu fazer uma análise dos discursos veiculados pelas diversas fontes consultadas, mas é certo que cada uma delas expressa, de forma distinta, o que se fez na educação escolar no período. Como mostra Foucault (1970/1998, p.10): “...o discurso não é simplesmente aquilo que traduz as lutas ou os sistemas de dominação, mas aquilo por que, pelo que se luta, o poder do qual nos queremos apoderar”. A análise das fontes permite uma maior aproximação com os discursos divulgados, os seus portavozes e os sujeitos a quem eles se endereçavam. Cada um desses aspectos pode certamente revelar nuances muito específicas sobre a disciplina escolar. Pesquisar os

\footnotetext{
${ }^{21}$ Como dispositivos estão sendo considerados todos aqueles recursos utilizados objetivando minimizar o uso das punições e instaurar o self-government entre os alunos. Tais dispositivos vão desde a arquitetura escolar, a distribuição das salas, dos alunos, as festas, as cerimônias religiosas, as avaliações escolares e todo um conjunto de mecanismos que estão no bojo do processo disciplinar e que constituem uma rede difusa e permanente de atuação sobre corpos e mentes de educandos e educadores no espaço escolar.
} 
dispositivos disciplinares exige um trabalho de investigação minucioso e preciso que permita captá-los nos seus diversos pontos de atuação.

Foucault adverte que, para estudar o poder, são necessárias cinco precauções metodológicas:

Em primeiro lugar: não se trata de analisar as formas regulamentares e legítimas do poder em seu centro, no que possam ser seus mecanismos gerais e seus efeitos constantes. Trata-se, ao contrário, de captar o poder em suas extremidades, em suas últimas ramificações, lá onde ele se torna capilar; captar o poder nas suas formas e instituições mais regionais e locais, principalmente no ponto em que, ultrapassando as regras de direito que o organizam e delimitam, ele se prolonga, penetra em instituições corporifica-se em técnicas e se mune de instrumentos de intervenção material, eventualmente violento. (1979/1990, p.182)

Por este motivo, escolheu-se compreender os dispositivos disciplinares utilizados em Grupos Escolares de Belo Horizonte, a partir de seus protagonistas. Esta opção está diretamente relacionada à segunda precaução indicada por Foucault que consiste em "estudar o poder em sua face externa, onde ele se relaciona direta e imediatamente com aquilo que podemos chamar provisoriamente de seu objeto, seu alvo ou campo de aplicação, quer dizer, onde ele se implanta e produz efeitos reais", ou seja, os Grupos Escolares, no caso desta pesquisa. A terceira precaução metodológica consiste em não conceber o poder como o domínio de um indivíduo ou grupo sobre outro ou outros, já que não cabe a divisão entre o grupo dos que têm poder e dos que a ele são submetidos:

O poder deve ser analisado como algo que circula, ou melhor, como algo que só funciona em cadeia. Nunca está localizado aqui ou ali, nunca está nas mãos de alguns, nunca é apropriado como uma riqueza ou um bem. O poder funciona e se exerce em rede. Nas suas malhas os indivíduos não só circulam mas estão sempre em posição de exercer este poder e de sofrer sua ação; nunca são o alvo inerte ou consentido do poder, são sempre centros de transmissão. Em outros termos, o poder não se aplica aos indivíduos, passa por eles. (1979/1990, p.183)

A quarta precaução metodológica implica em buscar o poder de baixo para cima, realizando uma análise ascendente que permita, posteriormente, uma percepção mais global de sua atuação. Por último, é necessário buscar os "instrumentos reais de formação e de acumulação do saber: métodos de observação, técnicas de registro, procedimentos de inquérito e de pesquisa, aparelhos de verificação" de infiltração e manifestação do poder. 
Como salienta Foucault, o poder não está na superfície, não pode ser localizado e apreendido com facilidade e é preciso rastreá-lo nos pontos fugidios por onde passa, já que ele não se localiza num lugar ou num determinado indivíduo. O poder disciplinar caracteriza-se, primordialmente, pela pulverização e é preciso buscar os indícios ${ }^{22}$ do seu funcionamento.

As fontes utilizadas para esta pesquisa buscam recompor um cenário histórico que abrange desde Reformas estaduais no ensino até as vivências de educandos e educadores em Grupos Escolares de Belo Horizonte. De um extremo ao outro, das prescrições ao ambiente escolar, há uma série de caminhos e descaminhos nos quais se interpõem as regras, as legislações, os ofícios, os programas e regulamentos. Entre os dois pólos encontram-se todos os personagens que fazem parte da obra educacional: Presidentes do Estado, Governadores ou interventores, Secretários de governo, Diretores gerais, inspetores, diretores, orientadores, professores, demais funcionários das escolas, alunos, seus familiares e a própria sociedade. Como instrumentos de comunicação entre essas partes estão as legislações, os documentos escolares, os ofícios recebidos e expedidos, os periódicos com ampla circulação entre os professores e no Estado de maneira geral.

Para mapear o percurso das prescrições às realizações, buscou-se localizar e analisar cada um desses componentes, direcionando os olhares para a questão primordial desta pesquisa: as punições e a disciplina nas escolas.

Tanto para os educadores quanto para os alunos, os castigos e as humilhações vivenciadas não eram, certamente, objeto de júbilo que merecesse fotografias ou discursos sobre a sua utilização e nem devem ter sido mencionados nas solenidades de formatura ou nas prestações de contas a serem feitas pelas escolas. Se as práticas punitivas mais incisivas eram duramente condenadas, os métodos disciplinares, por sua vez, deveriam ser capazes de garantir a adesão dos alunos, sem desordens ou rebeldias. Foi especialmente nos limiares, nos subentendidos, nas entrelinhas, que a temática central da pesquisa foi investigada, na medida em que as tentativas de se evitarem,

\footnotetext{
${ }^{22}$ Segundo Ginzburg (1989) o paradigma indiciário consiste em realizar um trabalho de investigação minuciosa, buscando pistas, indícios, detalhes quase imperceptíveis mas que podem contribuir de maneira fundamental para a compreensão de eventos e fenômenos investigados. Assim como o caçador busca rastros, pegadas, pulsações, o historiador precisa estar atento aos detalhes, às lacunas, às minúcias das fontes históricas pesquisadas.
} 
minimizarem e/ou ocultarem as punições escolares passavam a ser constantes, principalmente, a partir das Reformas estudadas.

Foram consultadas as legislações escolares; a Revista do Ensino e a revista Educando, produzidas no Estado durante o período em estudo, e direcionadas aos professores primários; jornais da grande imprensa; jornais produzidos por Grupos Escolares; Boletins publicados pela Secretaria do Interior e, posteriormente, Secretaria da Educação; biografias das professoras Helena Antipoff e Lúcia Casasanta e memórias de quatro professoras que atuaram em Belo Horizonte: Alaíde Lisboa de Oliveira, Benedita Dell'Isola, Maria da Glória D'Avila Arreguy e Marta Nair Monteiro. Foram realizadas entrevistas com ex-professoras, bem como com ex-alunos e ex-alunas, e analisados os documentos apresentados pelos(as) entrevistados(as). Também foram consultados os arquivos de onze Grupos Escolares de Belo Horizonte ${ }^{23}$ e selecionados documentos que pudessem contribuir para as questões problematizadas na pesquisa. A partir dessas fontes, buscou-se localizar o que representaram as práticas disciplinares e punitivas dentro da escola, suas modificações ao longo do tempo, bem como analisar diferentes percepções e interpretações dos momentos vividos. Almejou-se, dessa forma, trazer à tona vivências, procedimentos e métodos que têm sido ainda pouco abordados pela história oficial da educação, num período extremamente fértil para a educação mineira.

$\mathrm{Na}$ introdução, recupera-se brevemente o período anterior à pesquisa, abordando as vicissitudes do momento, a construção da capital mineira e o projeto pedagógico modernizador que a envolvia, bem como a importância atribuída a uma disciplinarização do povo brasileiro que se daria, primordialmente, a partir da educação escolar. Aborda-se, ainda, mais demoradamente, o período investigado e as fontes consultadas. A partir de então, o trabalho foi dividido em dois eixos. O primeiro está centrado nos dois principais personagens que compõem esta pesquisa: educadores e educandos. Dessa forma, buscou-se, especialmente, discutir o mundo escolar do ponto de vista dos educadores que vivenciaram as Reformas educacionais aqui estudadas e dos educandos dos Grupos Escolares de Belo Horizonte. O segundo eixo volta-se, mais

${ }^{23}$ Foram consultados os arquivos dos seguintes Grupos: Afrânio de Melo Franco (noturno e extinto), Assis das Chagas (noturno e extinto), Bernardo Monteiro, Flávio dos Santos, Lúcio dos Santos, Mariano de Abreu, Olegário Maciel, Pandiá Calógeras, Pedro II, Sandoval de Azevedo e Tomaz Brandão. 
especificamente, para a questão da cultura escolar e dos dispositivos disciplinadores envolvidos na missão educativa das escolas públicas primárias.

O primeiro eixo, referente aos educadores e educandos, contém quatro capítulos. O primeiro De alunas a professoras: um percurso na educação buscou resgatar a história de mulheres que foram alunas e professoras de Grupos Escolares de Belo Horizonte no período investigado. A recuperação e produção de suas lembranças foram de valor excepcional para o mapeamento dos dispositivos disciplinares a que foram submetidas ou que fizeram submeter, além, é claro, das táticas utilizadas para se esquivar das exigências impostas. O segundo capítulo Representações históricas acerca da professora primária dá continuidade às investigações sobre as vicissitudes do ser professora primária em Grupos Escolares da capital, no período em estudo. As oportunidades que se descortinavam, as cobranças sociais, os temores e receios, as angústias e necessidades de mulheres que deixavam o conforto e a segurança dos seus lares para se tornarem cidadãs e profissionais da educação foram algumas das problemáticas discutidas. A abertura de espaços e de possibilidades de estudo e trabalho para as mulheres fazia-se acompanhar de iniciativas que delimitavam e circunscreviam as atividades, os comportamentos, os jeitos de ser e fazer aos quais deveriam se adequar. Em Educadores em Grupos Escolares de Belo Horizonte: convivências e resistências, terceiro capítulo, buscou-se rastrear de que forma os educadores se relacionavam no espaço escolar. Para tanto, foram mapeados os conflitos e as conciliações entre professores, diretores, assistentes e inspetores diante das contingências de trabalho. O último capítulo deste eixo gira em torno dos educandos dos Grupos Escolares: Nas carteiras dos Grupos Escolares aborda as impressões dos ex-alunos e ex-alunas sobre o Grupo, sobre seus colegas, a questão da co-educação e da educação sexual, além de representações sobre os alunos e as alunas dos Grupos Escolares, buscando-se identificar como os educandos eram percebidos, como se dava a delimitação entre os considerados normais e os tidos por "anormais", entre os disciplinados e os indisciplinados e o tratamento implementado para cada caso.

O segundo eixo da pesquisa aborda a cultura escolar e, principalmente, os dispositivos disciplinares em uso no período em estudo e compõe-se também de quatro capítulos. No quinto capítulo, as Representações sobre a família e a escola constituem a investigação central, a partir da demarcação de como escola e família eram 
representadas e os usos de dispositivos disciplinares que almejavam melhorar a condição de penúria das crianças, mas também e, principalmente, evitar revoltas sobre as condições sociais nas quais viviam. Deve-se salientar que não apenas os alunos eram educandos, mas também a família e a própria sociedade.

Um dos dispositivos mais importantes de disciplinarização era o mecanismo de seleção escolar instalado pelas avaliações. As Avaliações escolares como dispositivos científicos de seleção e disciplinamento revelam como os exames são fundamentais no processo de disciplinamento: conhecer, controlar e selecionar são marcas importantes da escola moderna conferindo a esta um caráter de neutralidade, cientificidade e isenção, já que se baseavam em critérios definidos pela Psicologia do período. Com base em diagnósticos minuciosos dos alunos, de suas famílias e de seu meio social, as escolas preocupavam não apenas em selecioná-los, mas, primordialmente, em discipliná-los.

O sétimo capítulo, Da escola punitiva à escola disciplinadora: nos rastros de uma transição, é permeado pela discussão em torno da passagem de uma escola dita tradicional e representada como centrada nas punições, para uma escola considerada moderna porque fundamentada nos dispositivos disciplinares. As apropriações do escolanovismo nas Reformas Escolares pesquisadas contavam com a ajuda fundamental das Atividades e Instituições escolares que exerciam seu papel ocupando $e$ disciplinando os alunos. Dentre os dispositivos disciplinares mapeados pela pesquisa estão essas instituições que, a partir do discurso de envolver ativamente os educandos nas atividades escolares e de colaboração social e familiar na tarefa de educação das crianças, terminavam por impor um modelo de disciplinamento a que todos deveriam se adequar. Cuidar do corpo, da higiene, valorizar o trabalho, a atividade produtiva, as leituras, as músicas, o cinema, os jornais, os auditórios escolares e as excursões eram formas de habituar as crianças a realizar atividades representadas como sadias, honestas e adequadas aos bons cidadãos. Mais do que instruir, estas objetivavam educar, moralizar e disciplinar e, especialmente, preparar as crianças, desde os bancos escolares, para as atividades que deveriam desenvolver ao concluírem o curso primário. 


\section{INTRODUÇÃO}

A transição do século XIX para o século XX no Brasil foi marcada por mudanças políticas, culturais, econômicas, sociais e também pedagógicas. O advento da República, o fim do escravismo, a imigração, a instalação de uma economia cafeeira e, mais tarde, a industrialização e urbanização demandavam uma nova organização social presumida como mais moderna, democrática e civilizada. Tais exigências alteravam significativamente a noção de cidadania e, nesse sentido, implicavam mudanças nos objetivos educacionais para a formação de um sujeito que se adequasse à sociedade moderna.

Para os políticos de Minas Gerais, as montanhas, os sinuosos caminhos poeirentos e pedregosos, as ruas e vielas estreitas e escuras da capital não favoreciam o acesso à modernidade. Ouro Preto estava por demais carregada das marcas do passado. Era preciso uma nova capital. Entretanto, conforme a rigidez das exigências, nenhuma cidade do Estado parecia adequada para cumprir tão importante papel. A solução encontrada foi criar uma nova cidade, marcada pelo progresso e pelo planejamento racional, científico, objetivo e, sobretudo, pelas exigências da modernidade.

A nova capital, inaugurada em 1897, recebeu a denominação de Belo Horizonte. Seu projeto de construção envolvia um objetivo "pedagógico modernizador"24. Belíssimos prédios públicos foram construídos para a cidade. Curiosamente, entretanto, o prédio destinado à educação pública das crianças foi ocupado pelo Senado e, posteriormente, tornou-se Câmara dos Deputados. Em 1906, a Reforma Pedagógica estadual realizada no governo João Pinheiro implementou os Grupos Escolares como espaço ideal para a realização do ensino primário público, além de criar a Escola Normal da capital. Não somente ficava clara a necessidade de investir em educação, como de dar visibilidade a este investimento público. Por este motivo, os primeiros Grupos Escolares, bem como a Escola Normal, ocuparam palacetes na região mais central da cidade, embora não tivessem sido, inicialmente, construídos para tal função ${ }^{25}$.

\footnotetext{
${ }^{24}$ Cynthia Greive Veiga (2002) discute a função pedagógica da nova cidade.

${ }^{25}$ Cynthia Greive Veiga (2002, p. 234) informa que a Escola Normal, ao ser criada, ocupou o prédio destinado ao Tribunal de Relação e demais departamentos do Fórum. Segundo Tarcísio Mauro Vago (2002, p. 70), após a Reforma de 1906, foram adaptados para Grupos Escolares o palacete do Secretário do Interior e o prédio onde funcionava o $2^{\circ}$ Batalhão da Brigada Policial. Somente em 1914 foi inaugurado o primeiro prédio público destinado à educação primária estadual.
} 
Era a cidade moderna cedendo espaço para abrigar os também modernos Grupos Escolares. Ambos, cidade e escola, haviam sido pensados enquanto instituições fundamentais para a modernização política, cultural e econômica do país que passava, inevitavelmente, por um processo de modernização social e pedagógica:

As reformas urbanas buscaram conciliar as idéias sanitárias com a idéia de uma nova estética, buscando-se não somente a higienização como também o aformoseamento das cidades. Praças, ruas, edifícios públicos, bairros, moradias residenciais deveriam possibilitar um novo contexto de civilidade, de maneira a enterrar o passado das doenças, moléstias, de ruas mal demarcadas, de focos de perniciosidade moral. Dentre as inúmeras interferências nas cidades em fins do século XIX e início do XX, estiveram, sem dúvida, as edificações dos prédios escolares. (Veiga, 2000, p. 409)

Tais concepções marcaram todo o início do século XX, tornando-se mais significativas na década de vinte, como salienta Marta Carvalho:

Sedimentou-se nos anos 20, entre intelectuais que se aplicavam a pensar o Brasil e avaliar a República instituída, a crença de que na educação residia a solução dos problemas que identificavam. Este entusiasmo pela educação condensava expectativas diversas de controle e modernização social, cuja formulação mais acabada se deu no âmbito do nacionalismo que contamina a produção intelectual do período. Neste âmbito, o papel da educação foi hiperdimensionado: tratava-se de dar forma ao país amorfo, de transformar os habitantes em povo, de vitalizar o organismo nacional, de constituir a nação. Nele se forjava o projeto político autoritário: educar era obra de moldagem de um povo, matéria informe e plasmável, conforme os anseios de Ordem e Progresso de um grupo que se auto-investia como elite com autoridade para promovêlos. $(1989$, p.9)

A elite política e econômica do Brasil do século XIX, impregnada pelo poder imperial e pelas relações escravocratas, mantinha uma relação autoritária e punitiva com a população em geral. A sociedade republicana, que se inaugurou em fins do século, alterava significativamente estas relações sociais. Uma sociedade caracterizada pela urbanização, pela democracia, pela introdução do trabalho assalariado e industrial - em substituição ao típico trabalho agrário-escravocrata - exigia novas formas de relações sociais, cuja liberdade de trabalhar, de votar, de circular pelos espaços citadinos demandava maior civilidade e disciplina dos cidadãos comuns. Escola e cidade passam a constituir importantes lugares de disciplinamento dos cidadãos, cujos comportamentos não deveriam ser mais controlados pelo exterior (pelos capatazes ou pela polícia), mas, sobretudo, pelos próprios sujeitos, através do self-government. 
Em 1906 foi realizada uma importante Reforma na educação primária mineira com a instalação dos Grupos Escolares. O modelo das escolas isoladas não satisfazia mais à imperiosa necessidade de modernização educacional. Os Grupos ocupavam prédios majestosos dando visibilidade ao ensino primário no Estado. Ademais, permitiam que a educação se fizesse segundo as exigências da medicina higienista, oferecendo espaços adequados de estudo, com iluminação, carteiras e livros cuidadosamente preparados para a educação escolar, com uma organização seriada e recebendo melhor fiscalização e controle da burocracia estatal. Nesta Reforma também foi criada a Escola Normal Modelo localizada na capital mineira e que seria referência para todas as Escolas Normais do Estado ${ }^{26}$.

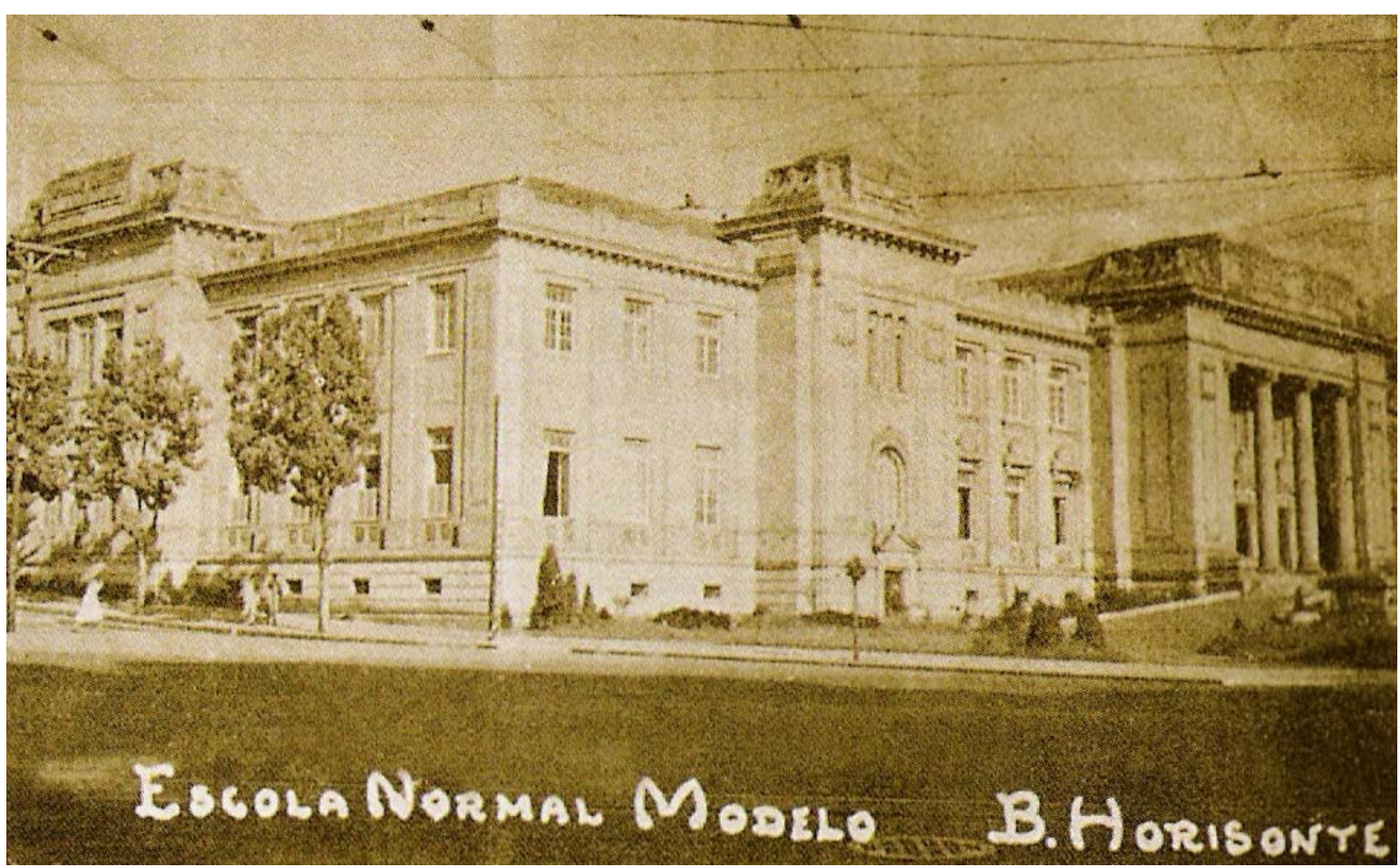

Foto 01: Escola Normal Modelo - Belo Horizonte

Fonte: Arquivo de Ricardo Moreira Figueiredo Filho

Após a instalação dos primeiros Grupos Escolares e com a criação da Escola Normal da capital mineira, foram se ampliando as Reformas educacionais no Estado até que, em $1925^{27}$, os ensinos primário e normal passaram por uma reformulação e, dois

${ }^{26}$ Outros estudos que se referem à Reforma realizada em 1906 no governo João Pinheiro: Luciano Mendes de Faria Filho (2000); Tarcísio Mauro Vago (2002); Irlen Antônio Gonçalves (2004) e Carla Simone Chamon (2005).

${ }^{27}$ Realizada no governo de Fernando Melo Vianna e executada pelo Secretário dos Negócios do Interior Sandoval Soares de Azevedo. 
anos depois, em 1927, realizou-se outra Reforma ${ }^{28}$, que não se diferenciava muito da primeira, ambas inspiradas no movimento escolanovista. A segunda, entretanto, obteve maior repercussão devido aos altos investimentos feitos no ensino ${ }^{29}$, chegando a criar uma escola superior de formação de professoras, chamada Escola de Aperfeiçoamento.

O movimento denominado Escola Nova teve como um de seus princípios básicos o que se chamava "a centralidade do aluno no processo de ensinoaprendizagem", dando, dessa forma, ênfase à participação dos alunos nas tarefas de aprendizagem, e à defesa de uma escola que utilizasse o menor número possível de punições ou, ainda mais radicalmente, que deixasse de utilizá-las ${ }^{30}$. Foi por essa característica, especialmente, que os escolanovistas demarcavam a sua distinção em relação à Escola que se passou então a denominar Tradicional. Era lugar comum afirmar-se que as punições seriam eliminadas da escola ou, para os mais céticos, minimizada, sendo necessário para isso uma única condição: a qualificação dos docentes segundo os novos modelos pedagógicos. Bastava, dizia-se, seguir os interesses das crianças, identificados a partir de estudos sobre o desenvolvimento psicológico infantil, respeitando seu potencial e suas limitações e promover um ensino ativo para se obter a disciplina sem necessidade de punições.

Freqüentemente era o professor percebido como o único culpado pela indisciplina dos alunos, pois a coerção e a punição dos pequenos eram vistas como atitudes daqueles que desconheciam os princípios do desenvolvimento infantil, exercendo uma violência desnecessária e perniciosa. Para modernizarem suas práticas e renovarem a educação escolar, os professores deveriam estudar principalmente as novas metodologias de ensino e as contribuições da Psicologia acerca das crianças. O trabalho que não contemplasse os modernos conhecimentos psicológicos a respeito da infância era tido como inadequado e incapaz de alcançar resultados satisfatórios. A disciplina

\footnotetext{
${ }^{28}$ Pode-se afirmar que a Reforma de 1927 foi uma ampliação da Reforma de 1925, já que a segunda deu continuidade às propostas da primeira.

${ }^{29}$ Entre tais investimentos, a própria dedicação pessoal do Secretário do Interior, Francisco Campos que, segundo Ana Maria Casasanta Peixoto (1983), teria redigido sozinho, trancado em seu gabinete, os textos da Reforma de 1927. Relatos de Lúcia Casasanta à Ângela Souza (1984) revelam que Campos, antes mesmo da Reforma, reunia diretoras de Grupos Escolares da capital em seu gabinete e as ensinava "com a segurança de um mestre". Ela ainda comenta que tantas foram as compras de livros da França, Estados Unidos, Espanha, Alemanha e Inglaterra feitas pelo Secretário que os livreiros europeus intrigados se perguntavam o que estaria acontecendo em Minas Gerais.

${ }^{30} \mathrm{O}$ movimento escolanovista é muito heterogêneo, embora a crítica às punições, especialmente as mais severas, fosse muito comum entre seus adeptos. Foulquié (1951) afirma que, em algumas escolas novas inglesas, cabia ao diretor a aplicação de varadas nos alunos rebeldes.
} 
escolar, nessa perspectiva, estava diretamente relacionada à competência do professor $^{31}$. Este passou a ser o núcleo de um processo reformador que criticava sua formação - ou mais propriamente o que se percebia como sendo a falta dela - suas posturas e a natureza do ensino por ele ministrado. Sobre o professor pesavam duras críticas, tornando-se a figura principal a ser remodelada pela Reforma Francisco Campos ${ }^{32}$, como atestava o próprio reformador:

Finalmente, todas as criticas que se dirigem ao ensino primario são, de modo indirecto e obliquo, dirigidas ao Ensino Normal, pois que o defeito do ensino primario não são os programas, a distribuição das materias, senão o modo de ministral-os, a sua dosagem, a qualidade do vehiculo em que a noção passa do mestre ao alumno, em uma palavra, a technica de apresentação dos assumptos e noções e, por conseguinte, em resumo e afinal, - o professor. ${ }^{33}$

A questão disciplinar era colocada como uma dessas principais mudanças. Esta problemática era essencial na identificação do bom professor que, basicamente, teria duas formas de conter a indisciplina em classe:

1. preparar aulas interessantes, segundo os interesses e características dos alunos identificadas pelos testes psicológicos;

2. selecionar os alunos de forma a homogeneizar as classes e oferecer um ensino adequado às condições apresentadas por estes.

Utilizando os métodos modernos, o risco da indisciplina estaria restrito aos casos graves de crianças “anormais" que deveriam ser tratados pela Medicina e/ou Psicologia. O professor bem preparado, fazendo uso de seus conhecimentos em Psicologia ${ }^{34}$, saberia encaminhar tal aluno para as classes especiais ou, até mesmo, compreender sua impossibilidade de freqüentar o ambiente escolar e enviá-lo para tratamento especializado.

Sendo os professores os principais alvos da Reforma Francisco Campos, não foram poupados, a partir daí, esforços para a sua formação. Desde a criação de cursos esporádicos até a Reforma no Curso Normal do Estado, bem como a criação de uma

\footnotetext{
${ }^{31}$ Estas foram algumas das conclusões de uma pesquisa realizada para o Mestrado. (Souza, 2001).

${ }^{32}$ A Reforma de 1927 também é conhecida como Reforma Francisco Campos, nome do Secretário do Interior que a implementou no Estado e que contribuiu de forma direta e efetiva para sua realização.

${ }^{33}$ MINAS GERAIS, 1928, p. 221 (Exposição de motivos do Regulamento do Ensino Normal).

${ }^{34}$ Com a Reforma de 1927, o ensino desta disciplina se tornou o mais extenso de todo o Curso Normal.
} 
Escola de Aperfeiçoamento Pedagógico para professoras ${ }^{35}$ em exercício, formadora de uma elite de técnicos da educação, o envio de cinco professoras para estudar nos Estados Unidos e a vinda de uma missão européia para a capital do Estado foram alguns dentre vários expedientes.

Demarcar as percepções, as vivências e as tensões e os conflitos que permeavam esse momento de transição das prescrições em práticas de disciplinamento constitui o cerne da investigação desta pesquisa. Teriam os professores se submetido às mudanças pretendidas de forma tão simples e rápida como se esperava com a divulgação do modelo modernizador? Como reagiram os professores e os alunos diante das mudanças da concepção de escola, do papel do professor e, principalmente, diante das novas prescrições disciplinares que proibiam o uso dos castigos físicos e condenavam os professores que os utilizassem? De que forma os professores lidaram com as necessidades de adaptação a essas novas exigências pedagógicas? De que forma os familiares dos alunos perceberam tais mudanças? Como a sociedade reagia a tais Reformas? Havia críticas, opiniões divergentes, denúncias, concordâncias, silenciamento? Como os jornais e revistas apresentavam as mudanças no cenário educacional? Teriam sido os castigos físicos efetivamente eliminados do ambiente escolar? O que teriam deixado em seu lugar? Se permaneceram, como se mantiveram com a constante vigilância e condenação por parte dos defensores do movimento escolanovista?

Esse momento de convivência entre o que era considerado velho e o que foi produzido como "novo", entre práticas que se pretendiam erradicar e outras que viriam substituí-las constitui um período rico em vivências, em questionamentos, em apropriações, representações que podem apontar algumas formas pelas quais educadores e educandos lidavam com o que era imposto e o que era efetivamente possível de ser realizado nas condições postas no ambiente escolar. Nesse sentido, pretende-se flagrar os dispositivos disciplinares em uso em Grupos Escolares de Belo Horizonte no

\footnotetext{
${ }^{35}$ A Escola destinava-se exclusivamente a mulheres e só admitiu rapazes através de uma medida judicial.
} 
período $^{36}$ compreendido entre 1925 até $1955^{37}$, antes da implantação do Programa de Assistência Brasileiro-Americana ao Ensino Elementar - $\mathrm{PABAEE}^{38}$.

Durante todo o período investigado, que contempla uma série de transformações políticas, sociais, culturais e econômicas que aconteceram no país e em Minas Gerais ${ }^{39}$,

${ }^{36}$ Sobre a história da educação mineira neste período, cf. Lopes, 1997; Duarte e Lopes, 1997; Prates, 1989; Duarte, 1988; Peixoto, 1983 e 1989; Maciel, 2001.

${ }^{37}$ Este período de trinta anos abrange muitas e significativas mudanças na história do Brasil e de Minas Gerais, bem como na História da Educação. Esta pesquisa tem início ainda no período conhecido como República Velha no final do governo Artur Bernardes. Em 1926, Washington Luís assumiu a Presidência do país. Com a Revolução de 1930, Getúlio Vargas tomou o poder e nele permaneceu por quinze anos, oito deles de intensa repressão às liberdades individuais, no período conhecido como Estado Novo (1937-1945). Ao final deste período, Getúlio Vargas foi deposto por um movimento militar, vindo a assumir a Presidência da República em caráter interino, o ministro do Supremo Tribunal, José Linhares. Em 1946, o marechal Eurico Gaspar Dutra foi eleito Presidente e, em 1951, Getúlio Vargas voltou ao poder, eleito pelo voto popular. Seu governo terminou tragicamente com o seu suicídio em agosto de 1954, quando Café Filho assumiu o poder, permanecendo apenas 3 meses. Tendo adoecido, foi substituído por Nereu Ramos que garantiu a posse do presidente eleito Juscelino Kubitschek, em 1956. Durante este conturbado período, vários foram os Ministros que tratavam da educação no país, boa parte deles, mineiros. Na República Velha, foram Ministros do Interior: Afonso Augusto Moreira Pena Júnior (no final do governo Artur Bernardes) e Augusto Viana de Castelo (durante todo o governo de Washington Luís). Na Era Vargas, foi criado o Ministério da Educação e Saúde Pública (decreto n. 19.402/30) e Francisco Luís da Silva Campos foi o primeiro a assumir o cargo até 1932, quando deixou o Ministério para assumir a Pasta da Justiça, sendo substituído por Belizário Augusto de Oliveira Pena e, depois, Washington Ferreira Pires. Em 1934, Gustavo Capanema assumiu o Ministério permanecendo onze anos à sua frente. No curto governo de José Linhares, Raul Leitão da Cunha assumiu a pasta e no Governo Eurico Gaspar Dutra foram Ministros: Ernesto de Souza Campos, Clemente Mariani Bittencourt, Eduardo Rios Filho (interino) e Pedro Calmon Moniz de Bittencourt. Com a eleição de Vargas para presidente, tornaram-se ministros da Educação: Ernesto Simões da Silva Freitas Filho, Péricles Madureira de Pinho (interino), Antônio Balbino de Carvalho Filho e Edgard Rego Santos. No seu governo, em 1953, foi criado o Ministério da Saúde e o então Ministério da Educação e Saúde Pública passou a se chamar Ministério da Educação e Cultura. No Governo Café Filho, Cândido Mota Filho assumiu o Ministério e o mineiro Abgar de Castro Araújo Renault foi o último ministro da Educação e Cultura no período estudado, no governo Nereu Ramos. O Brasil passou ainda pela elaboração de três Constituições (1934, 1937 e 1946) e por várias Reformas na educação com a estruturação de todos os níveis de ensino em esfera nacional. No final do período em estudo, a discussão voltava-se para a elaboração da primeira Lei de Diretrizes e Bases da Educação Nacional, proposta pela Constituição de 1946 e que levou quinze anos em discussões até a sua publicação em 1961 (Lei 4.024/61)..

${ }^{38}$ O PABAEE foi fruto de um acordo assinado entre Clóvis Salgado, Ministro da Educação no governo do Presidente Juscelino Kubistcheck, o governador de Minas Gerais, José Francisco Bias Fortes e Willian E. Warne, diretor da United States Operation Mission/Brazil (USOM/B). O acordo assinado em 16 de junho de 1956 previa seu encerramento para 1961, sendo posteriormente prorrogado para 01 de agosto de 1964. O INEP - Instituto Nacional de Estudos Pedagógicos - vinculado ao MEC, era responsável pela execução do programa e Minas Gerais foi seu centro-piloto. Os altos índices de evasão e repetência escolar foram a principal motivação para a sua instalação, cujos alvos eram a formação de professores nas escolas normais e a produção de material didático para o ensino primário.

${ }^{39}$ Em Minas Gerais, a presente pesquisa se circunscreve ao final do governo de Fernando Melo Viana (1924-1926) e posteriormente Antônio Carlos Ribeiro de Andrada, ambos ainda na República Velha. Em 1930, assumiu o cargo Olegário Dias Maciel sendo substituído, em 1933, por Gustavo Capanema, interventor nomeado por Vargas. Gustavo Capanema ficou no cargo entre setembro e dezembro deste mesmo ano quando foi nomeado o interventor Benedito Valadares Ribeiro. Este manteve-se doze anos à frente do governo do Estado. Em novembro de 1945, foi nomeado o interventor Nísio Batista de Oliveira que ficou até fevereiro do ano seguinte. Outros interventores: João Tavares Corrêa Beraldo (03/02/1946 a 12/08/1946), Júlio Ferreira de Carvalho (14/08/1946a 14/11/1946), Noraldino Lima (17/11/1946 a 20/12/1946)e Alcides Lins (21/12/1946 a 19/03/1947). Em março de 1947, tomou posse o governador eleito Milton Soares Campos que governou até janeiro de 1951. Teve início, então, o governo de Juscelino Kubitscheck de Oliveira que permaneceu no cargo até março de 1955, quando assumiu o governador Clóvis Salgado da Gama. Com tantos presidentes, interventores e governadores do Estado, Minas Gerais também foi pródiga em secretários que cuidavam da educação. Foram eles: Secretário dos Negócios do Interior: Sandoval Soares de Azevedo e Francisco Luís da Silva Campos; Secretário da Educação e Saúde Pública: Levindo Eduardo Coelho (07/09/1930 a 29/04/1931), Noraldino de Lima (29/04/1931a 05/09/1933), Carlos Álvares da Silva Campos e Guerino Casasanta (substitutos), Noraldino de Lima novamente (05/09/1933 a 31/01/1935), sendo substitú́do por Raimundo Felicíssimo de Paula, Bonifácio Olinda de Andrada (05/04/1935 a 02/09/1936), Cristiano Monteiro Machado (02/09/1936 a 
as fontes consultadas revelam que o ideário escolanovista permanecia ${ }^{40}$. Embora Ana Maria Casasanta Peixoto tenha constatado uma retração no investimento econômico em educação $^{41}$ por parte do governo mineiro no período estadonovista, ela também argumenta que:

Há no Estado e no país uma certa mística em torno da obra de [Francisco] Campos.

$[\ldots]$

Essa mística cresce graças à dimensão assumida pela questão educacional no período e ao prestígio de seus realizadores - Antônio Carlos e Francisco Campos - no cenário político do país.

Nesse quadro, o governo define sua política escolar, num programa que procura conciliar contenção e continuidade. A antinomia contenção/continuidade é solucionada pela manutenção do ideário escolanovista. Em outras palavras, levar à frente a Reforma Francisco Campos significa, para o novo governo, sobretudo, manter na abordagem dos problemas educacionais os princípios da Escola Nova. (Peixoto, 2003, p.55)

Francisco Campos, apesar de ser reconhecido como um político conservador por sua atuação à frente do Ministério da Justiça durante o Estado Novo ${ }^{42}$, mantinha a imagem, em Minas Gerais, do grande renovador do ensino no Estado. Conhecido como "Chico Ciência" pela sua inteligência brilhante, Campos marcou um período considerado áureo para a educação em Minas. Nos quatro anos (1926-1930) em que atuou como Secretário do Interior, participou ativamente das Reformas empreendidas reunindo-se com as diretoras de Grupos Escolares, promovendo um Congresso Mineiro

05/11/1945), Iago Vitoriano Pimentel (05/11/1945 a 01/02/1946), Orlinto Orsini de Castro (03/02/1946 a 17/11/1946), Tristão Ferreira da Cunha (17/11/1946 a 12/08/1946), Idelfonso Mascarenhas da Silva (21/12/1946 a 19/03/1947), Augusto Mário Caldeira Brant (14/04/1947 ou 19/03/1947 a 13/12/1947), Abgar de Castro Araújo Renault (19/12/1947 a 02/09/1950), Orlando de Magalhães Carvalho (02/09/1950 a 30/01/1951). Foram Secretários da Educação: Odilon Behrens (20/04/1951 a 17/08/1953), Cândido Gonçalves Ulhôa (17/08/1953 a 31/07/1954), Levindo Furquim Lambert (31/07/1954 a 30/03/1955) e, finalmente, Bolívar de Freitas (31/03/1955 a 31/01/1956). Não é objetivo desta pesquisa demarcar os feitos de cada um desses secretários, mas, pela descrição acima, pode-se depreender o quanto a política era fragmentária no período, o que certamente prejudicava todos os setores da vida pública, entre eles, a educação.

40 Segundo Maria Helena de Souza Patto $(1993$, p.86), “... os princípios escolanovistas tiveram profunda repercussão no pensamento educacional brasileiro a partir dos anos vinte, tendo norteado a política educacional até o início dos anos sessenta. Coerentemente com esta aceitação, seus introdutores no Brasil ocuparam cargos mais importantes nos órgãos oficiais; Lourenço Filho, por exemplo, foi diretor do INEP (Instituto Nacional de Estudos Pedagógicos) de 1944 a 1945; Anísio Teixeira esteve à sua frente por mais de dez anos (1952 - 1964)".

${ }^{41} \mathrm{O}$ decreto n. 9.892 de março de 1931 tomou diversas providências para efeito de redução de custos na educação mineira. $\mathrm{O}$ decreto reduzia os vencimentos dos professores e auxiliares de diretores, suspendia $\mathrm{o}$ funcionamento de todas as escolas rurais providas interinamente e de outras para as quais não houvesse verba, ficando os funcionários em disponibilidade não remunerada.

${ }^{42}$ Francisco Campos foi o autor da Constituição outorgada em 1937, quando era Ministro da Justiça e Negócios Interiores do governo Getúlio Vargas. Esta Constituição, que substituiu a Constituição elaborada democraticamente em 1934, ficou conhecida como Polaca, por inspirar-se na Constituição fascista da Polônia, bem como nas Constituições autoritárias da Alemanha, Itália e Portugal. 
de Educação ${ }^{43}$, favorecendo a formação de professores e técnicos da educação, através de cursos pagos pelos cofres públicos estaduais que ofereciam o que havia de mais moderno na área. Graças a seus investimentos e esforços, Belo Horizonte passou a ser conhecida como a "capital pedagógica do país" e não pretendia perder este posto. Por este motivo, todas as Reformas Educacionais que lhe seguiram, pelo menos até o período estudado, buscavam manter a mística da Reforma realizada na década de vinte e tentavam complementar e estender os "avanços" da Escola Nova, sem romper com este modelo.

A exposição de motivos apresentada pelo Secretário de Educação e Saúde Pública, Noraldino Lima ao decreto n. 11.501 em 1934 é muito reveladora nesse sentido:

A reforma do ensino [Francisco Campos] que, no carreiro dos padrões victoriosos em outros centros de cultura, se destinava a modificar o edifício da velha didática sob cujo tecto se aqueceram e desenvolveram gerações e gerações de mineiros, mal vencia, do ponto de vista de sua execução, o período de propaganda e adaptação ao meio para qual fora elaborada. Duas correntes de opinião se contrariavam no campo das novas realizações pedagógicas - uma, reaccionaria, de raizes profundas mergulhadas no tempo e nas tradições, lutando por uma existência, certamente gloriosa, mas confinada a horizontes que o panorama do mundo renovado precisava alargar; outra, batida de idealismo e de fé, mas cheia de incertezas, a fluctuar num ambiente que a recebia como se recebem, em regra, as innovações - com a desconfiança de uns e a pouca sympathia de muitos.

$[\ldots]$

Foi então que, apellando para as energias moraes nunca desmentidas, e inexcedíveis, do professorado mineiro, me foi possível manter nos trilhos a macinha montada num momento claro, de paz e de recursos, e destinada a correr num período escuro, de perturbações na ordem política e de penúria econômico-financeira.

$[\ldots]$

Esse decreto [10.362], que vinha juntar novas possibilidades de vida á reforma nascente, reajustando-lhe algumas peças do conjunto, accrescentando-lhe outras, sem lhe deformar a estructura antes, mantendo-a em substância e belleza, teve larga repercussão e pleno acceitamento no mundo escolar de Minas; creou caminhos e possibilitou, de muito, a integração dos novos methodos e processos em nossos hábitos educativos. ${ }^{44}$

De 1925 a 1955, muitas foram as alterações no ensino do Estado, até em função do longo período e das mudanças políticas, econômicas e sociais ocorridas. Entretanto, nenhuma legislação se propunha suplantar a Reforma ocorrida em 1927. Em 1950, por

\footnotetext{
${ }^{43}$ Esse Congresso realizado em Belo Horizonte em 1927 teve por objetivo preparar os professores para a Reforma que já estava em curso.

44 MINAS GERAIS. Decreto n. 11.501 de 31 ago. 1934. Approva modificações feitas no decreto n. 10.362, de 31 de maio de 1932.
} 
exemplo, o governo mineiro ${ }^{45}$ unificou todos os decretos e leis estaduais em relação ao ensino primário e o fez através do decreto n. 3.508, de 21 de dezembro, criando o Código do Ensino Primário. O novo código, no entanto, segundo sua própria apresentação, não criava algo novo, mas consolidava as leis e decretos do ensino primário já existentes. Para esta consolidação, foram retomadas todas as legislações em voga no período, começando pelo decreto n. 7.970 de 15 de outubro de 1927 que dava início à Reforma Francisco Campos. Ou seja, vinte e três anos após a Reforma, ainda se fazia dela o ponto inicial para se tratar do ensino primário em Minas Gerais. Aliás, segundo Paixão \& Paiva, nem mesmo o PABAEE pretendia uma ruptura maior ${ }^{46} \mathrm{com}^{\mathrm{a}}$ Reforma Francisco Campos:

A orientação tecnicista não supõe descontinuidades no campo do pensamento e da prática na escola primária dos anos 50 . Tomando a situação mineira e, em particular, o que se passou no Instituto de Educação, pode-se admitir que o PABAEE trouxe propostas metodológicas mais modernas, mais sistematizadas num conjunto de ações que tinha o sistema de ensino como objetivo. No entanto as práticas pedagógicas ali, fundadas nas reformas realizadas ao tempo de Francisco Campos, já tendiam a valorizar o método como perspectiva de enfrentamento do problema do ensino primário. (Paixão \& Paiva, 2000, p. 117)

A importância do método certamente é um dos pontos de ligação entre a Escola Nova mineira e o programa instalado nos anos cinqüenta. As autoras afirmam que havia oposições políticas e pedagógicas ao programa, embora alguns defendessem-no como a retomada dos propósitos da Reforma Francisco Campos. A intervenção direta de técnicos americanos na educação brasileira foi alvo de diversas críticas, e o programa, se não rompe definitivamente com o projeto escolanovista anterior, certamente traz dados novos à história da educação mineira. A orientação tecnicista na formação de professores, a formação de especialistas do ensino, bem como a ampliação dos sistemas de supervisão, têm aspectos específicos que diferenciam o programa da Reforma dos anos vinte. Além desses fatores, a própria inserção histórico-político-social desse programa merece ser compreendida em sua especificidade. Para efeito de realização desta pesquisa, optou-se por finalizar o estudo em 1955, evitando, dessa forma, adentrar em um período em que o PABAEE, se não promove uma ruptura com o projeto

\footnotetext{
${ }^{45}$ O governador era Milton Soares Campos e o Secretário da Educação, que ficara pouco tempo no cargo, Orlando de Magalhães Carvalho.

${ }^{46}$ Propostas que desqualificassem as reformas anteriores não eram bem recebidas. Um vídeo elaborado no PABAEE que tinha como título "A escola agora é outra" provocou muita polêmica e descontentamento, justamente por apagar uma experiência que era tida como de muito sucesso.
} 
educacional anterior, introduz elementos novos que precisam ser analisados com maior atenção.

Para esta pesquisa foram selecionadas diversas fontes que pudessem indicar os meandros do processo de disciplinarização em uso nos Grupos Escolares de Belo Horizonte. Tais fontes, abaixo relacionadas, foram de suma importância na tentativa de captar os sujeitos envolvidos nas práticas disciplinares no cotidiano escolar dos anos vinte aos cinqüenta.

\section{LEGISLAÇÕES ESCOLARES MINEIRAS NO PERÍODO ${ }^{47}$.}

As legislações são sempre fruto de disputas e compromissos no campo político que se relacionam, direta ou indiretamente, com as questões sociais as quais se aplicam. As lutas em torno da legislação não se encerram com a publicação destas, mas acontecem antes, durante e após a sua instalação. Este é, portanto, um processo dinâmico e que envolve interesses diversos, sobretudo num campo tão importante e conflituoso quanto o que envolve a educação. No que se refere ao período estudado, há muitas mudanças nacionais que repercutiam no interior dos Estados ${ }^{48}$. Períodos de maior abertura ou de cerceamento das liberdades, a centralização ou descentralização das políticas públicas, as tendências educacionais em voga são alguns dos fatores que interferem diretamente na construção dos ordenamentos legais para a educação.

Se a produção de legislações escolares revela as apropriações dos diversos discursos seja no âmbito político, educacional ou econômico, são os sujeitos que colocam em ação todo esse ordenamento jurídico, dando a ver o seu alcance,

\footnotetext{
${ }^{47}$ As legislações consultadas constam das fontes.

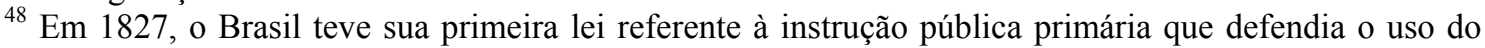
método mútuo nas escolas de primeiras letras. Entretanto, em 1834, o Ato Adicional a esta lei advogava que o encargo da instrução pública primária era das províncias, gerando uma situação de total diversidade entre as iniciativas levadas a cabo pelas diversas províncias brasileiras. Essa situação perdurou por quase um século, pois somente com a criação do Ministério da Educação e Saúde, o país voltou a ter uma legislação nacional sobre educação primária. Francisco Campos promoveu uma Reforma no ensino secundário através de dois decretos em 1931, mas não tratou do ensino primário e normal. O decreto $\mathrm{n}$. 19.850/31 criava o Conselho Nacional de Educação, órgão consultivo e colaborador do ministro e dos poderes federal e estaduais em assuntos relativos a esta área, cabendo-lhe a elaboração das diretrizes geral do ensino em todos os níveis e ramos. A Constituição brasileira de 1934 estabeleceu a necessidade de elaboração de um Plano Nacional de Educação. O Brasil ainda teve outras duas constituições no período: em 1937 e 1946. Neste último ano foi regulamentada ainda a Lei Orgânica do Ensino Primário pelo decreto-lei n. 8.592 e o decreto-lei federal n. 8.530 que dispunha sobre o funcionamento e a organização do ensino normal.
} 
repercussões e contradições. As exigências de cumprimento da lei, bem como as formas de esquiva e mesmo as tentativas de burlar os preceitos legais, são mostras de como a legislação pode ser diferentemente apropriada pelos sujeitos sociais que estão sob a sua regência ${ }^{49}$.

Foram localizadas e consultadas as legislações mineiras de educação nos trinta anos que circunscrevem a pesquisa e foi feita uma seleção daquelas que pudessem fornecer maiores esclarecimentos acerca da temática investigada ${ }^{50}$.

\section{ENTREVISTAS}

\subsection{ENTREVISTAS UTILIZADAS NA PESQUISA}

Foram realizadas entrevistas com diversos atores da história da educação mineira no período que ocupavam diferentes posições na hierarquia educacional, buscando-se compor um cenário da atuação dos sujeitos envolvidos nesse processo e especialmente das práticas pedagógicas de punição e disciplinamento que permeavam o ambiente escolar. A tentativa de iluminar as sombras e recantos do que seria a "caixa preta" da escola, este espaço quase que indevassável das salas de aula, implica flagrar os sujeitos que ali estiveram alguns anos de suas vidas. Por este motivo, optou-se por utilizar algumas entrevistas que fazem parte do acervo constituído pelo Banco de Depoimentos Orais do Museu da Escola no Centro de Referência do Professor da Secretaria da Educação de Minas Gerais ${ }^{51}$. As entrevistas que constituem o referido acervo abordam uma temática abrangente da escolarização, seja do período de estudante ou de atuação profissional dos entrevistados, e algumas tratam da história de vida temática dos depoentes. Os critérios de seleção obedeceram, então, ao recorte temporal

\footnotetext{
49 O estudo das formas de apreensão da legislação escolar pelos sujeitos escapa aos objetivos deste trabalho. Para uma melhor discussão do assunto, cf. Faria Filho (1998a).

${ }^{50}$ Não foram consultadas legislações municipais e, quanto às legislações federais, também se buscou apenas aquelas que, de forma específica, alterassem a educação mineira, como a que transformou a Escola de Aperfeiçoamento em Instituto de Educação.

${ }^{51}$ Este acervo teve início em 1998 e possui entrevistas gravadas em áudio e vídeo com educadores que estiveram, de algum modo, ligados à história da educação mineira. A maioria das entrevistas foi realizada pela pesquisadora Nelma Marçal Lacerda Fonseca. Algumas delas estão transcritas e também publicadas e constituem um rico material de pesquisa para os historiadores da educação mineira. Ressalte-se que algumas entrevistas com outros depoimentos sobre a disciplina e o uso das punições em classes escolares não foram utilizados por tratarem de escolas religiosas ou particulares que não constituem o alvo desta pesquisa. Nem todas as entrevistas estão transcritas; portanto, as análises aqui realizadas foram feitas a partir da gravação em vídeo.
} 
da pesquisa e a temática nela abordada. Foram selecionadas as entrevistas realizadas com as seguintes professoras: Elza de Moura, Imene Guimarães ${ }^{52}$, Olga Coelho Ullman, Alaíde Lisboa de Oliveira e Terezinha Casasanta. Embora não fosse professora, a entrevista de Berenice Menegale também foi incorporada porque ela fez o curso primário nas classes anexas à Escola de Aperfeiçoamento.

\subsection{ENTREVISTAS PRODUZIDAS PELA PESQUISA}

Além desse acervo, foram produzidas algumas fontes de pesquisa, a partir de entrevistas com ex-alunos e professoras de escolas primárias de Belo Horizonte no período. Para a realização de todas as entrevistas, as pessoas foram contatadas, com antecedência, por telefone e, caso se interessassem por participar da pesquisa, recebiam, pelo correio, uma carta explicativa acerca da finalidade da entrevista e um formulário contendo algumas questões a serem abordadas. Esse formulário possuía dupla função: informar o teor do assunto a ser tratado e auxiliar os entrevistados no processo de recordação. Foi encaminhado, ainda, um ato de autorização em que os depoentes autorizavam a utilização da entrevista para a pesquisa ${ }^{53}$.

As entrevistas aconteceram nas datas e locais definidos pelos entrevistados, por isso em algumas houve interrupções feitas por pessoas e/ou chamadas ao telefone, mas sempre num clima de informalidade e cooperação. Embora houvesse um formulário préestabelecido das questões a serem investigadas, não havia nenhum tipo de rigidez na sua aplicação. As entrevistas foram de tipo não estruturada, na modalidade focalizada ${ }^{54} \mathrm{e}$ algumas foram gravadas e/ou filmadas ${ }^{55}$. A história oral temática foi a modalidade utilizada na medida em que os detalhes da história pessoal do narrador interessavam somente para revelar aspectos úteis à temática central da pesquisa: a vida escolar, as punições e a disciplina vivenciadas neste espaço.

\footnotetext{
52 Imene Guimarães e Elza de Moura foram novamente entrevistadas já que a questão acerca das punições e da disciplina escolar, tema central desta pesquisa, não haviam sido suficientemente investigadas na entrevista arquivada no Museu da Escola. Elza de Moura chegou a pedir que se utilizasse a entrevista concedida ao Museu para que ela não tivesse que repetir as mesmas informações.

${ }^{53} \mathrm{O}$ modelo do material utilizado consta dos anexos.

${ }^{54}$ Segundo descrição de Marconi e Lakatos (1996, p. 85).

${ }^{55}$ As entrevistas de Imene Guimarães e Fernal Bicalho não estão em vídeo porque houve problemas com a gravação. Maria Aparecida Trindade Santos (D. Yá) pediu que não houvesse gravação em vídeo, portanto, desses três entrevistados(as) só há a gravação em áudio.
} 
Segundo uma outra classificação, realizada por Alice Beatriz Lang (1996, p.35), as entrevistas utilizadas para esta pesquisa podem ser caracterizadas como relatos orais de vida, em que o narrador é convidado a contar aspectos de sua vida com liberdade, mas dentro de uma temática prévia, indicada pelo entrevistador.

\subsubsection{ENTREVISTAS COM PROFESSORAS}

Complementando, portanto, o acervo de entrevistas pesquisado, foram produzidas assim novas fontes de pesquisa a partir de entrevistas realizadas com quatro professoras mineiras: Luíza Travassos Ribeiro Campos e Maria Aparecida Trindade Santos, que não possuem entrevistas gravadas no referido acervo, e Elza de Moura e Imene Guimarães que, embora já tivessem registrado suas lembranças, contribuíram significativamente para a discussão da temática central desta pesquisa.

As entrevistas realizadas com as professoras que estudaram em Grupos Escolares da capital ${ }^{56}$ foram divididas em dois momentos. No primeiro momento, elas falavam do período em que foram alunas do curso primário e, mesmo que essas memórias fossem de um período anterior ao da pesquisa, optou-se por utilizá-las como comparativo em relação à situação posterior da formação para o magistério (Escola Normal e de Aperfeiçoamento). O quadro abaixo mostra o período e local onde foi realizado o curso primário das professoras entrevistadas:

QUADRO 1

Curso primário das professoras entrevistadas

\begin{tabular}{|c|c|c|}
\hline Alunas-professoras & Período $^{57}$ & Local de estudo \\
\hline Elza de Moura & 1922 a $1927^{58}$ & G.E. Henrique Diniz \\
\hline $\begin{array}{ll}\text { Luíza Travassos } & \text { Ribeiro } \\
\text { Campos } & \end{array}$ & $\begin{array}{c}\approx 1921 \text { ou } 1922 \\
1925 \\
1926 \text { a } 1928\end{array}$ & $\begin{array}{l}\text { Jardim de Infância Delfim Moreira } \\
\text { Grupo Escolar Cesário Alvim }{ }^{59} \\
\text { Grupo Escolar Barão de Macaúbas }\end{array}$ \\
\hline Imene Guimarães & 1920 a 1923 & Aluna do G.E Barão do Rio Branco ${ }^{60}$ \\
\hline
\end{tabular}

Fonte: Entrevistas realizadas.

${ }^{56} \mathrm{Nem}$ todas as professoras haviam estudado em Grupos Escolares da capital e, nesse caso, a parte referente ao seu período enquanto aluna foi abreviada.

${ }^{57}$ Os períodos estudados sempre são um problema para a memória dos entrevistados. A maioria não sabia exatamente o período escolar, sendo, portanto, dados pouco precisos.

${ }^{58}$ Elza de Moura repetiu duas vezes a quarta série não por reprovação, mas para completar a idade de doze anos, necessária para o ingresso na Escola Normal.

${ }^{59}$ Inicialmente, Luíza Travassos afirmou ter estudado o primeiro ano numa escola que depois teria se tornado o Instituto dos Cegos São Rafael, de cujo nome ela não se lembrava. Depois achou que era o Grupo Cesário Alvim e se lembrou inclusive do nome da diretora no período, D. Ana Cintra.

${ }^{60}$ Os arquivos deste Grupo estão inacessíveis, pois o prédio passava por uma reforma no momento da pesquisa. 
Outra temática investigada foi a formação para o exercício do magistério, que envolveu todas as entrevistas, com exceção de Maria Aparecida Trindade Santos que fez o curso primário e normal no interior de Minas Gerais. As demais professoras realizaram o curso normal na Escola Normal Modelo de Belo Horizonte e suas recordações foram utilizadas para abordar a formação das professoras na então capital pedagógica. As entrevistas de Elza de Moura e Imene Guimarães abrangeram, ainda, a formação na Escola de Aperfeiçoamento, já que as outras entrevistadas não a cursaram.

Num segundo momento, buscou-se reconstruir as vivências profissionais dessas mulheres que estiveram à frente das salas de aulas e formaram centenas de alunos e alunas do ensino primário nas escolas públicas de Belo Horizonte, enredando suas lembranças e esquecimentos numa trama que auxiliasse uma maior compreensão acerca do universo da educação pública primária nos anos vinte aos cinqüenta na capital mineira.

QUADRO 2

Locais de trabalho das professoras entrevistadas

\begin{tabular}{|c|c|}
\hline Alunas -professoras & Local de trabalho \\
\hline Elza de Moura $^{61}$ & $\begin{array}{l}\text { Professora no Grupo Escolar Lúcio dos Santos e Flávio dos } \\
\text { Santos } \\
\text { Orientadora técnica no Grupo Escolar Sandoval de Azevedo } \\
\text { Orientadora técnica e diretora no G.E. Henrique Diniz } \\
\end{array}$ \\
\hline $\begin{array}{ll}\text { Luíza Travassos } & \text { Ribeiro } \\
\text { Campos } & \end{array}$ & Professora do G.E. Sandoval de Azevedo \\
\hline Imene Guimarães $^{63}$ & $\begin{array}{l}\text { Professora do G.E. Barão do Rio Branco } \\
\text { Professora das Classes Anexas à Escola de Aperfeiçoamento } \\
\text { Professora do Instituto Pestalozzi } \\
\text { Orientadora técnica e diretora do G.E. Barão do Rio Branco } \\
\end{array}$ \\
\hline 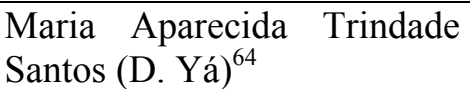 & Professora do G.E. Olegário Maciel \\
\hline
\end{tabular}

2.2.2. ENTREVISTAS COM EX-ALUNOS E EX-ALUNAS DE GRUPOS ESCOLARES DE BELO HORIZONTE

\footnotetext{
${ }^{61}$ Entrevista realizada em Belo Horizonte em 08 de junho de 2004, com duas horas de duração.

${ }^{62}$ A entrevista com Luíza Travassos Ribeiro Campos foi dividida em duas ocasiões. A primeira foi realizada em 17 de junho de 2004 com duração de 1 hora 50min. A segunda, no dia 25 de junho de 2004, durou 1 hora 28 minutos. Todas as entrevistas foram feitas na cidade de Belo Horizonte.

${ }^{63}$ A entrevista foi realizada em 02 de abril de 2004 e durou 1 hora e 30 minutos.

${ }^{64}$ Entrevista realizada em 21 de dezembro de 2004 com a duração de 1 hora.
} 
Do outro lado das carteiras escolares estão aqueles que sempre foram e serão a causa maior e única da educação escolar: os alunos e alunas. Era a sua formação que as Reformas Escolares pretendiam alterar e, quase sempre, com as melhores intenções. Eram a quem se dirigiam todas as estratégias de formação pedagógica e conformação disciplinar. Por este motivo, foram também produzidas algumas fontes de pesquisa que revelassem um pouco das lembranças do cotidiano escolar vivenciados por alunos e alunas que estiveram presentes nas carteiras dos Grupos Escolares em Belo Horizonte nos trinta anos que sucederam a Reforma de 1925. Foram entrevistados dois ex-alunos e duas ex-alunas de Grupos Escolares da capital no período:

\section{QUADRO 3}

Ex-alunos(as) entrevistados(as): período e Grupo Escolar estudado em Belo Horizonte

\begin{tabular}{l|c|l}
\hline \multicolumn{1}{c|}{ Ex-aluno(a) } & Período escolar & \multicolumn{1}{c}{ Local de estudo } \\
\hline Geraldo Félix de Jesus $^{65}$ & 1942 a 1948 & G.E.Tomaz Brandão \\
\hline Norma Lúcia Clemente $^{66}$ & 1945 a 1948 & G.E. Barão de Macaúbas \\
\hline José Fernal Bicalho $^{68}$ & 1933 a 1937 & G.E. Olegário Maciel \\
\hline Aracy Abreu Pinto $^{69}$ & $1945-1948$ & G.E. Mariano de Abreu \\
\hline
\end{tabular}

Fonte: Entrevistas realizadas com os ex-alunos e ex-alunas.

\section{DOCUMENTOS APRESENTADOS PELOS ENTREVISTADOS}

A todos os entrevistados fez-se um pedido para que apresentassem fotografias, documentos, cadernos, enfim todo o material que possuíssem do seu período escolar. Poucos foram os documentos apresentados e somente Elza de Moura apresentou uma atividade escolar feita no período. As professoras Imene Guimarães e Elza de Moura entregaram alguns artigos seus publicados em jornais e revistas. Imene Guimarães disponibilizou uma biografia com cinco páginas digitadas, e Elza de Moura redigiu um texto abordando alguns dos assuntos do roteiro de entrevista que lhe havia sido entregue. ${ }^{70}$

\footnotetext{
${ }^{65}$ Entrevista realizada em 01 de abril de 2004 com duração de 3 horas.

${ }^{66}$ Entrevista realizada no dia 02 de abril de 2004 com duração de 1 hora e 38 minutos.

${ }^{67}$ No arquivo deste Grupo não foram encontrados documentos referentes ao período estudado.

${ }^{68}$ Entrevista realizada no dia 02 de dezembro de 2004 com duração de 2 horas e 30 minutos.

${ }^{69}$ Entrevista realizada no dia 20 de outubro de 2004 com duração de 45 minutos.

${ }^{70}$ Todos esses materiais constam dos anexos.
} 


\section{PERIÓDICOS EDUCACIONAIS ${ }^{71}$}

Analisar os periódicos educacionais permite adentrar num terreno em que circulam importantes informações acerca do que se concebe como educação, quais os fins e meios mais adequados, qual o papel de seus profissionais e que conteúdos ela deve veicular. Como afirma Marta Carvalho:

Se, por um lado, é necessário situar o impresso de uso escolar relativamente às modalidades diferenciadas de concepção pedagógica que presidem a sua produção e distribuição, por outro lado é necessário pensar que, uma vez produzido e distribuído, o impresso de destinação escolar pode ganhar vida própria, sendo objeto de usos não previstos pelas regras que presidiram a sua produção. O que significa também que um mesmo impresso pode comportar usos muito diferenciados em tempos e em espaços distintos. O que significa ainda que sua credibilidade como fonte historiográfica que informa sobre os usos que dele foram feitos é largamente dependente da possibilidade de circunscrever, com o recurso a outras fontes, situações de uso bem configuradas. E que determinar as estratégias políticas, pedagógicas e editoriais que produziram e fizeram circular um impresso é condição necessária mas não suficiente para se dar conta dos usos que dele são feitos. (1998, p. 39)

Os periódicos foram aqui analisados como fontes para rastrear a temática da disciplina escolar, como ela era divulgada aos professores e em que medida interferiam nas práticas escolares. Três foram os impressos estudados:

\subsection{REVISTA DO ENSINO ${ }^{72}$}

A Revista do Ensino surgiu no século XIX, criada em 1892 numa Reforma realizada no Governo Afonso Pena, mas teve curta duração. Em 08 de março de 1925 ela foi reinaugurada com algumas mudanças de conteúdo e objetivos. Este periódico foi pesquisado entre os anos de 1931 e $1952^{73}$, já que houve uma interrupção da sua publicação nos anos de 1953, 1954 e 1955. Outra interrupção se deu em 1940 quando a revista deixou de ser publicada, tendo reiniciado em 1946. Foram consultadas 151

\footnotetext{
${ }^{71}$ Uma pesquisa sobre a produção, circulação e apropriação dos periódicos no Estado iria além do objetivo proposto. Os periódicos funcionaram, portanto, como fonte e não como objeto de pesquisa. Para maior conhecimento da Revista do Ensino entre os anos de 1925 e 1940, conferir Biccas (2001), para a revista Educando, consultar Prates (1998).

${ }^{72}$ Maurilane Biccas (2001) realizou um importante trabalho sobre este periódico, sistematizando e analisando toda a sua produção e veiculação entre 1925 e 1940, analisando os artigos, os autores e os assuntos relativos à revista. Vera Borges (1993) pesquisou a ideologia do caráter nacional da educação nos anos de 1925 e 1929 na Revista do Ensino.

${ }^{73}$ Em outra pesquisa (Rita de Cássia de Souza, 2001), pesquisaram-se os seis primeiros anos da Revista do Ensino, de 1925 a 1930, edições de número 1 a 52, especialmente no que se referia à disciplina escolar.
} 
edições (53 a 204) ${ }^{74}$, sendo selecionados 185 artigos que tratavam, direta e indiretamente, da disciplina escolar. A revista encerrou sua existência com a publicação da edição de número 239 no ano de 1971. Maurilane Biccas, que realizou um profundo estudo sobre a Revista do Ensino informa que, em fins dos anos trinta, o periódico já sofria com a crise financeira que se abatia sobre o Estado:

Por essas atribuições ao papel do professor e da escola e pela crise financeira, pode-se perceber como a educação em Minas Gerais foi se deteriorando no período. A Revista do Ensino, dentro deste contexto, foi tendo suas edições cada vez mais condensadas. Em 1938 foram publicados quatro exemplares, que correspondiam a 12 números; dois exemplares lançados no primeiro semestre e dois no segundo. Em 1939, foram publicados apenas dois exemplares, um por semestre. (2001, p. 86)

À diminuição de investimentos na publicação da Revista seguiu-se à sua interrupção em 1940, assim comentada por Joaquim Nabuco Linhares:

Com o número 174-175, de maio-junho de 1940 [a Revista do Ensino] deixou de circular, sob a alegação de o estado de guerra dificultar ou mesmo impossibilitar a aquisição de papel. Papel, no entanto, não faltou para a impressão de muita coisa sem utilidade e sem proveito para a coletividade, em detrimento da publicação da Revista. Outra foi, certamente, a causa determinante dessa medida, porquanto a alegada não procede. (1995, p. 233-4)

Publicada pela Diretoria de Instrução Pública, a Revista do Ensino constituía um importante instrumento de divulgação das Reformas realizadas no ensino para os professores do Estado de Minas Gerais, sendo enviada as mais distantes escolas do Estado, incluindo escolas infantis, particulares, municipais e federais. Através desta fonte, foi possível rastrear os caminhos pelos quais o ideário escolanovista chegava a Minas Gerais e de que forma era apropriado e repassado aos professores, especialmente no que tange à disciplina escolar, tema da pesquisa. Com a sua interrupção, a Associação de Professores Primários passou a publicar um periódico próprio que existiu justamente no período em que a Revista do Ensino não circulou, ou seja, entre 1940 e 1945.

\subsection{EDUCANDO ${ }^{75}$}

\footnotetext{
${ }^{74}$ Alguns números reuniam 2 ou 3 edições atrasadas do período.

75 Sobre a revista Educando e sua criadora, a Associação das Professoras Primárias, conferir Prates (1989).
} 
Esta revista ${ }^{76}$ era uma publicação da Associação dos Professores Primários de Minas Gerais - APPMG ${ }^{77}$. No ano em que foi publicada, a direção cabia a Marieta Leite e a redação a Maria Luísa Almeida Cunha, Letícia Chaves Campos, Ondina Amaral Brandão e Dulce Kanitz Viana. Segundo Marisa Ribeiro Duarte (1988), a publicação não tinha grande tiragem e era a diretoria da APPMG e da revista sempre formada por ex-alunas da Escola de Aperfeiçoamento e assistentes-técnicas do ensino.

Seus artigos estavam voltados para o cotidiano escolar, buscando fornecer ferramentas para o trabalho docente, oferecendo poesias, dramatizações, instruções sobre como trabalhar determinados temas, resumos e traduções de livros, assim como figuras para o professor ilustrar suas aulas. Sendo uma revista feita por professores e para professores, eram muito raros e cautelosos os artigos que, porventura, criticassem os docentes, a sua falta de preparo pedagógico, de esforço e interesse, coisa comum na Revista do Ensino. As seções não eram muito contínuas e a mais duradoura era a intitulada "Questões de Português" assinada por José Lourenço de Oliveira ${ }^{78}$. É interessante perceber, nos artigos publicados na revista, quais assuntos a diretoria da APPMG selecionava como importantes para o público a que se destinava. Segundo Marisa Duarte:

... o número mais expressivo de artigos refere-se, na seguinte ordem, aos temas: História pátria e Atividades para Comemorações Cívicas (50); Poesias (47); Língua Pátria (33) e Atividades Auxiliares ao Programa (25). O grupo intitulado "Psicologia e Pedagogia" [51 artigos] tratava de assuntos diversos, sem uma unidade característica, abordando sugestões de atividade em sala, resenha de livros, síntese de obras estrangeiras ou nacionais, etc. [...] Em síntese, o conteúdo abordado na Revista da Associação reafirmava as temáticas do Estado Novo e sua função como difusora deste ideário, ao fornecer a cada professora o conteúdo ideológico a ser disseminado pelo trabalho de ensinar. (1988, p. 66-7)

\footnotetext{
${ }^{76}$ Considerada uma revista de orientação pedagógica, era vendida a $24 \$ 000$ a assinatura anual; $18 \$ 000$ a assinatura especial para sócios da Associação e por $2 \$ 500$, o número avulso. Somente na edição de $\mathrm{n}^{\circ} 38$ de maio e junho 1945, os valores se alteram para 25,00 a assinatura anual; 20,00 a assinatura anual para sócios e 3,00 o número avulso. A revista também tinha muitas propagandas que ajudavam a custear as suas despesas.

${ }_{77}$ Associação criada em agosto de 1931 em Minas Gerais. Em 1940 contava com mais de 1.000 sócios que possuíam descontos em atendimentos médicos, odontológicos, jurídicos, em laboratórios, farmácias, livrarias, cinemas e salões de beleza.

${ }^{78} \mathrm{O}$ professor José Lourenço de Oliveira, marido de Alaíde Lisboa de Oliveira, era advogado e "latinista de erudição rara", segundo Daniel Antipoff. Ex-aluno do Colégio Caraça, José Lourenço foi professor de português de Helena Antipoff e de seu filho, quando vieram para o Brasil.
} 
Embora a autora não tenha comentado, eram também muito freqüentes artigos relacionados à religião que tinha uma seção assinada por Maria Luiza de Almeida Cunha, embora essa temática aparecesse também em diversas outras seções.

Um expediente muito comum utilizado em ambas as revistas era o de colocar, nas páginas do periódico, frases de efeito de personagens importantes como Getúlio Vargas, Francisco Campos, entre outros. Por diversas vezes, Educando estampava, na primeira página, fotografias e discursos de políticos mineiros como Benedito Valadares (governador de Minas Gerais), Juscelino Kubitschek (prefeito da capital) e Eliseu Laborne e Vale (Chefe do Departamento de Educação) exaltando suas realizações.

Em comum também era a ausência, nas revistas, de críticas à política de educação no Estado, aos programas ou à organização do ensino, e apenas um único artigo $^{79}$ da revista Educando tratava da baixa remuneração da professora. De maneira geral, os artigos buscavam doutrinar os professores a levarem à frente as Reformas estaduais, os programas de ensino, bem como suas exigências. Por vezes, isso era feito de forma bastante curiosa. Tentando não parecer impositivos, em algumas seções da revista Educando, eram respondidas as dúvidas de professoras que enviavam cartas sobre como executar este ou aquele ponto do programa. Tais cartas, entretanto, não traziam dados muito claros sobre seu remetente ${ }^{80}$, deixando-se supor que não passavam de um recurso para tratar do assunto, a partir da necessidade ou interesse de uma suposta leitora. Havia ainda outra estratégia interessante. Era a seção "Conversas no Bonde". A seção simulava uma situação em que uma professora encontrava uma colega no bonde e estas discutiam temas educativos. Nesse diálogo, informal e "despretencioso", uma das professoras informava à outra sobre como trabalhar com algumas atividades escolares, a auxiliava na resolução dos problemas do dia-a-dia escolar, passando informações preciosas e, freqüentemente, fazendo com que a colega, resistente às renovações do ensino, acabasse mudando completamente sua opinião.

A princípio, parece estranho que um periódico de autoria dos professores tivesse um discurso tão afinado com a ideologia política do Estado. Entretanto, toda a pesquisa revela que a Escola de Aperfeiçoamento, que formava a elite pedagógica em Minas, nada mais fez do que criar uma classe intermediária entre Estado e professores

\footnotetext{
${ }^{79}$ CONSCIENCIA de classe. Educando. BH, ano VI, n. 37, março e abril 1945, p. 875.

${ }^{80}$ Ora se mostravam apenas as iniciais do nome do(a) remetente, ora se afirmava "uma professora do interior".
} 
primários, classe esta que tinha por objetivo orientar e garantir a implantação das Reformas de ensino, e que deveria, portanto, se identificar muito mais com o aparelho burocrático no qual estavam inseridas do que com seus colegas professores, a quem lhes cabia orientar, assistir e fiscalizar.

A direção da APPMG estava confiada justamente a essa classe intermediária, encarregada de tornar visíveis as realizações do Estado na área educacional. Certamente por este motivo, e talvez por estar circunscrita a um período ditatorial enfrentado pela nação, os conflitos ficavam submersos e, com freqüência, pareciam não existir nos artigos da revista, como atesta Marisa Ribeiro T. Duarte:

... vedada a discussão das condições materiais para a realização do trabalho de ensinar, resta o reordenamento técnico deste processo de trabalho para se otimizar o rendimento desejado. Introduz-se a discussão técnica da organização do trabalho, justamente no lugar da discussão sobre as condições de trabalho, o que pode ser visto como uma forma de "recompensar" aqueles que atuavam nas escolas face a uma política de restrição financeira. (1988, p. 125)

Foram pesquisados os números 1 , de fevereiro de 1940, até o número 38 , de junho de 1945, sendo selecionados 58 artigos mais diretamente relacionados à temática pesquisada. Os números 22 e 23 de 1943 não foram encontrados. A última edição também não foi localizada, já que, segundo Maria Helena de Oliveira Prates (1998, p.24) e Maurilane de Souza Biccas (2001, p. 101), foram publicadas 39 edições da revista.

\subsection{BOLETINS PUBLICADOS PELA SECRETARIA DO INTERIOR ${ }^{81}$}

Foram, ao todo, produzidos vinte Boletins, entre os anos de 1929 a 1937, tendo sido, alguns, publicados na Revista do Ensino. Os cinco primeiros traziam conferências e exames realizados em Belo Horizonte pelo Dr. Theodore Simon ${ }^{82}$. A partir daí, a maior parte das publicações passou a ser de responsabilidade de Helena Antipoff e/ou

\footnotetext{
${ }^{81}$ Posteriormente, Secretaria de Educação e Saúde Pública.

${ }^{82}$ Theodore Simon (1873-1961) foi autor, junto com Alfred Binet, em 1905, do primeiro teste de inteligência na história da Psicologia. Esteve em Belo Horizonte, em 1929, lecionou Psicologia durante quatro meses na Escola de Aperfeiçoamento Pedagógico e aplicou alguns testes em alunos, professores e diretores de Grupos Escolares da capital.
} 
de suas alunas da Escola de Aperfeiçoamento, mas há também Boletins publicados pela Sociedade Pestalozzi ${ }^{83}$ e pela Inspetoria de Educação Física ${ }^{84}$.

\subsection{CONSIDERAÇÕES GERAIS SOBRE OS PERIÓDICOS EDUCACIONAIS}

Os três impressos aqui analisados revelam diferentes ângulos da educação no Estado. No primeiro deles, a Revista do Ensino, a educação é questão pública, norteada e modelada segundo princípios científicos repassados aos professores, o que não impedia também um uso político de divulgação das Reformas, dos Grupos Escolares e dos investimentos no setor. Sendo esta uma publicação oficial do Estado, não é possível identificar se havia críticas aos modelos propostos, mas, se houve, não foram divulgadas em suas páginas.

A revista Educando revela a escola vista por suas agentes, ou seja, professoras, assistentes técnicas e orientadoras que ocupavam a diretoria da publicação. Entretanto, como se pôde ver, isso não significou a oportunidade de questionar as Reformas estabelecidas, na medida em que estas profissionais eram a mola mestra das mudanças efetuadas na educação mineira e se posicionavam como divulgadoras das Reformas e, por conseqüência, do que havia de mais moderno e adequado em termos educacionais. A Associação dos Professores Primários de Minas Gerais era dirigida por mulheres que se identificavam com as Reformas e que eram a sua origem, já que haviam recebido sua formação pedagógica no templo maior da Reforma de 1927, que foi a Escola de Aperfeiçoamento. Na ausência da Revista do Ensino, Educando servia para disseminar a importância das Reformas e a necessidade de que todos a elas se convertessem. Além disso, exercia um papel político ao ressaltar os nomes daqueles envolvidos com a modernização educacional no Estado.

${ }^{83}$ Em 1932, Helena Antipoff criou a Sociedade Pestalozzi em Belo Horizonte junto com professores, médicos, advogados, agrônomos, engenheiros e outros profissionais, objetivando cuidar e atender das crianças "excepcionais" - termo cunhado pela psicóloga russa. Tais crianças eram justamente aquelas que a Psicologia qualificava como sendo "anormais" e que precisavam de um atendimento especializado tanto médico, quanto psicológico e educacional. Em 1935, através do decreto n. 11.908, foi criado o Instituto Pestalozzi de Minas Gerais, que funcionava sob os auspícios da Sociedade Pestalozzi, e que se destinava à educação, tratamento, estudo e assistência das crianças intituladas excepcionais.

${ }^{84}$ Nas fontes, encontra-se a relação de todos os Boletins pesquisados. 
Os Boletins, por sua vez, davam mais visibilidade às características científicas que políticas das Reformas efetuadas. Assim mesmo, reforçavam a necessidade das professoras adequarem suas práticas de ensino e adaptarem-se às mudanças realizadas.

Pode-se concluir, que constituíam todos em instituições mediadoras que objetivavam disciplinar a atuação dos docentes, visando sua submissão e aplicação das Reformas Educacionais propostas ao longo do período.

\section{GRANDE IMPRENSA: JORNAIS ${ }^{85}$}

Nos impressos pedagógicos consultados estavam menos evidentes as táticas da sociedade e, especialmente, dos professores para lidar com as exigências impostas pelas Reformas estudadas. Nessas publicações só tinham voz aqueles que mostrassem o quanto as mudanças introduzidas proporcionavam melhoras na qualidade do ensino escolar, seja para alunos, seja para professores.

Outros meios de comunicação, no entanto, poderiam ser utilizados para se rastrearem informações sobre o ensino em Minas. Nos jornais, a sociedade como um todo, alunos, familiares e educadores talvez pudessem encontrar uma via de acesso menos restrita para tratar das questões educacionais. Buscando-se captar opiniões diversas daquelas divulgadas nos periódicos, foram consultados alguns jornais em circulação no período.

\subsection{MINAS GERAIS}

Órgão Oficial dos poderes do Estado. Foram pesquisados números escolhidos aleatoriamente, verificando-se se continham informações sobre a disciplina escolar. As seções mais consultadas foram: "O ensino pelo Estado", posteriormente substituída pela

\footnotetext{
${ }^{85}$ São muitas e diversas as notícias sobre a educação no Estado, divulgadas pelos jornais: fotografias de diplomandas da Escola Normal e de Aperfeiçoamento, artigos de professores, notícias de eventos realizados nas escolas eram comuns em todos os jornais pesquisados, além de artigos que denunciavam problemas na educação estadual. Entretanto, não era objetivo desta pesquisa mapear as informações divulgadas nos noticiários do Estado. Foram selecionados apenas artigos mais diretamente relacionados com a temática da pesquisa desenvolvida. Estes artigos foram localizados a partir de outras pesquisas que sinalizavam fontes importantes nos jornais. Outros artigos foram selecionados a partir de números escolhidos aleatoriamente.
} 
Seção "Pelo ensino" 86 ; Seção "Governo do Estado - Secretaria do Interior" e, a partir de 1933, Seção "Secretaria de Educação e Saúde Pública". Em 1937, a coluna "Pelo Ensino" foi substituída pela coluna "Em nossas escolas".

\subsection{O DEBATE}

Publicado inicialmente a 14 de março de 1934, era um jornal diário vespertino cuja direção cabia a Paulo Pinheiro Chagas. O jornal publicava, em primeira página, um comentário crítico dos principais acontecimentos assinado pelo seu diretor. Essa coluna era importante porque evidenciava uma análise pessoal sobre notícias que, de maneira geral, os jornais publicavam sem maiores discussões. Seu conteúdo era eminentemente político, como afirma Linhares: "Era uma folha essencialmente política e, como tal, órgão oficial do PRM, sem, no entanto, constar do cabeçalho esse encargo ${ }^{87, "}$. $(1995$, p. 314)

\footnotetext{
${ }^{86}$ Segundo Peixoto: “A coluna 'Pelo Ensino', destinada aos profissionais da educação, explora aspectos teóricos e práticos relacionados à aplicação dos princípios, métodos e procedimentos recomendados pela Escola Nova, enfatizando a importância da ciência na abordagem dos problemas educacionais, o papel do técnico, o valor dos testes, a necessidade de homogeneização das turmas, etc." (2003, p. 157).

${ }^{87}$ O P.R.M., Partido Republicano Mineiro, organizou-se em 4 de junho de 1888, sob a liderança de João Pinheiro. Cinco anos após a proclamação da República, o Brasil teve seu primeiro presidente civil, Prudente de Morais. Seu sucessor, Campos Sales, instaurou a chama Política dos governadores que visava manter no poder as oligarquias, através de uma troca de favores políticos entre governadores e presidente. O presidente apoiava os candidatos dos partidos governistas nos estados, enquanto estes políticos davam suporte ao seu governo e à candidatura presidencial. A Constituição de 1891 favoreceu os grandes estados, principalmente São Paulo e Minas Gerais. No período que vai de 1894 a 1930, marcado pelo governo de presidentes civis ligados ao setor agrário, dois partidos políticos controlavam as eleições: Partido Republicano Paulista (PRP) e Partido Republicano Mineiro (PRM). Minas possuía o maior colégio eleitoral do Brasil e, por isso, tinha a maior bancada de deputados federais. A oligarquia mineira controlava o poder através do PRM. A maioria dos presidentes da chamada República Velha (1889-1930) eram políticos de Minas Gerais e São Paulo e, por isso, ficou conhecida como política do café-com-leite. Em 1930, ocorreram eleições para presidência e, de acordo com a política do café-comleite, era a vez de assumir um político mineiro do PRM. Porém, o Partido Republicano Paulista, ao qual pertencia o presidente Washington Luís, indicou um político paulista, Julio Prestes, à sucessão, rompendo o pacto anterior. Descontente, o PRM aliou-se a políticos da Paraíba e do Rio Grande do Sul (formando a Aliança Liberal) para lançar à presidência o gaúcho Getúlio Vargas. No entanto, foi Júlio Prestes quem venceu as eleições de abril de 1930, sob protestos da Aliança Liberal, que alegaram fraudes eleitorais. Liderados por Getúlio Vargas, políticos da Aliança Liberal e militares descontentes provocaram a Revolução de 1930. Com a chegada de Vargas ao poder, os membros do Partido Democrático em São Paulo que apoiaram a Revolução desejavam obter poder, mas não conseguiram. Diante disso, aproximaram-se do partido adversário, o Partido Republicano Paulista, e passaram a exigir a queda do interventor do Estado, João Alberto Lins e Silva, nomeado por Vargas. Em julho de 1931, Lins e Silva
} 


\subsection{O HORIZONTE}

Este periódico, órgão do Conselho de Imprensa da Diocese de Belo Horizonte, foi criado em 8 de abril de 1923 e permaneceu em atividade até, pelo menos, o ano de 1934. No ano seguinte, fora substituído por $O$ diário. Seus colaboradores eram, obviamente, membros reconhecidos da Igreja Católica ${ }^{88}$ e, no que tange à educação, seus artigos revelavam de que forma as modernizações introduzidas no ensino coadunavam-se ou não com os princípios desta instituição. Alguns dos temas abordados, por exemplo, eram a defesa da chamada "escola tradicional", cujas características os escolanovistas vinham desqualificando; o combate à co-educação e o pedido de votos para candidatos a deputados em sintonia com os princípios religiosos católicos, às vésperas da Assembléia Constituinte de 1934.

\subsection{FOLHA DE MINAS}

Surgiu em outubro de 1934 e teve como primeiro diretor Afonso Arinos de Mello Franco. Segundo Linhares (1954/1995, p. 320): “Folha de Minas tem sido órgão oficioso, refletindo o pensamento político dos governos que se sucedem”. Apesar disso, foram localizadas denúncias do descaso com a educação em Minas.

\subsection{ESTADO DE MINAS}

Terceiro jornal mineiro com esta denominação, o Estado de Minas começou a ser publicado em 07 de março de $1928^{89}$. Publicação diária, com exceção para as segundas-feiras, é o único jornal pesquisado ainda existente na atualidade.

demitiu-se. No entanto, os outros interventores nomeados pelo Presidente também não agradaram os paulistas que queriam um governo civil e do próprio Estado. Em 1932, foi a vez dos estados de Minas e Rio Grande do Sul romperem com o governo que não lhes havia concedido o poder almejado. A elite paulista liderou a chamada Revolução Constitucionalista que exigia a reconstitucionalização do país. A 9 de julho de 1932 estourou a Revolução em São Paulo até a rendição dos revolucionários em $1^{\circ}$ de outubro deste mesmo ano, já que as forças governistas estavam visivelmente melhor preparadas para o combate. Segundo Boris Fausto (2002, p.346), “A verdade é que, apesar das divergências com o poder central, as elites regionais do Rio Grande do Sul e de Minas não se dispunham a correr o risco de enfrentar, pelas armas, um governo que haviam ajudado a colocar no poder há menos de dois anos. São Paulo ficou praticamente sozinho, contando sobretudo com a Força Pública e uma intensa mobilização popular para enfrentar as forças federais". Em Minas Gerais, com a recusa do Partido Republicano Mineiro em aderir ao governo vitorioso de Vargas, Antônio Carlos Ribeiro de Andrada criou o Partido Progressista, organizado para apoiar o Governo Federal, sendo eleito seu primeiro Presidente. O PRM passou, assim, a fazer oposição ao governo Vargas e a seus interventores no Estado.

${ }^{88}$ Informações obtidas em Linhares (1995).

${ }^{89} \mathrm{O}$ primeiro jornal pesquisado é de $04 / 09 / 1930$ já que, no período anterior, não há jornais arquivados na Hemeroteca de Minas Gerais, como também não há para as edições entre 1940 e 1947. Um outro local 
A partir de setembro de 1948, foram consultadas todas as colunas do jornalista Jair Silva intitulada "Oropa, França e Bahia" ${ }^{90}$, publicada aos domingos ${ }^{91}$. Esta coluna foi escolhida porque, nas memórias da professora Benedita Dell'Isola, há uma referência à tal coluna na qual o jornalista comentava as atitudes de algumas diretoras e professoras dos Grupos Escolares de Belo Horizonte. Segundo a professora, ela lia todos os domingos a coluna ansiando para que uma de suas atividades desenvolvida no Grupo fosse comentada, mas temendo possíveis críticas do jornalista. A referida coluna trazia crônicas sobre fatos acontecidos durante a semana, sempre com comentários apimentados do jornalista. A maioria dos assuntos versava sobre política, e não foram encontradas muitas referências acerca da educação no Estado, nem mesmo aquela citada por Dell'Isola.

\subsection{CONSIDERAÇÕES GERAIS SOBRE A GRANDE IMPRENSA DO PERÍODO NO QUE SE REFERE À TEMATICA DA EDUCAÇÃO}

Cada um desses jornais, a partir de seus próprios princípios e finalidades, revelava a realidade educacional no Estado a partir de pontos de vista muito peculiares. O Minas Gerais, jornal oficial, divulgava as grandes realizações do governo mineiro, mostrando à sociedade, e especialmente aos educadores, como era possível modernizar a escola. Para isso, era apresentado o que cada escola vinha fazendo, sugeridas mudanças escolares, divulgados cursos e mudanças na burocracia escolar.

O Debate estampava em suas páginas tanto notícias favoráveis do cotidiano escolar, como também duras críticas ao governo do Estado. Nas páginas analisadas, foi possível perceber que o jornal mostrava as realizações escolares que eram tidas como

\footnotetext{
possível para pesquisa seria a Coleção Linhares da Biblioteca Central da Universidade Federal de Minas Gerais. Durante boa parte do tempo da pesquisa, entretanto, toda a coleção estava indisponível porque passava por um processo de digitalização.

${ }^{90}$ A sessão era publicada na primeira página de um suplemento do jornal, chamado "Órgão dos 'Diários Associados". Nesse número avulso, eram publicados artigos na primeira página incluindo-se a coluna analisada, uma seção agrícola, uma página feminina, uma página do Gurilândia, além de charges, tirinhas e informações sobre cinema. A partir de 12/03/1950, a coluna passa a fazer parte do Suplemento Literário do jornal, ocupando quase uma página inteira.

91 Nas datas a seguir a referida coluna não foi encontrada: 21/11/1948; 18/12/1949; 26/12/1948 e $02 / 04 / 1950$.
} 
benéficas à sociedade ${ }^{92}$, bem como investigava denúncias sobre escolas, por exemplo, de que não estariam fazendo bom uso do dinheiro da caixa escolar ${ }^{93}$. No último caso, os políticos eram diretamente responsabilizados pela pobreza das caixas escolares.

O jornal católico $O$ Horizonte, por sua própria origem, abordava a educação de maneira a salientar as iniciativas que estivessem de acordo com os princípios da Igreja Católica em Minas e denunciar as contrárias. Nos artigos analisados, era nítida a intenção de mostrar a importância da educação tradicional e, por outro lado, de desqualificar a co-educação, concebida como perniciosa e inadequada. Advogava-se a necessidade de uma renovação educacional, desde que esta não ferisse os princípios católicos.

Nas notícias analisadas no jornal Folha de Minas encontram-se tanto informações acerca dos feitos governamentais na educação, como o Congresso dos Assistentes Técnicos realizado em 1935, quanto denúncias sobre a falta de prédios escolares, a condição precária de outros, bem como os abusivos cortes de salários das professoras mineiras.

O Estado de Minas divulgava as realizações da educação no Estado, como as formaturas, os cursos, as visitas ilustres e os discursos proferidos. Por outro lado, noticiava denúncias contra as escolas e buscava investigar os acontecimentos, ouvindo os envolvidos.

As fontes investigadas caminham para uma proximidade cada vez maior com o universo das escolas públicas mineiras. No entanto, são ainda pontos de vista a partir do seu exterior: seja o governo, seja a sociedade, mesmo que organizada a partir da Associação de Professores. Outras fontes foram, portanto, necessárias, para se obter um ângulo interno dos processos educativos, visto a partir dos pátios e salas de aula. Para tal empreitada, optou-se por começar por aquelas que foram as principais responsáveis pela introdução das Reformas do ensino no cotidiano escolar: as professoras dos Grupos Escolares de Belo Horizonte.

\footnotetext{
${ }^{92}$ Um exemplo disso é o artigo: UMA FORJA de obreiros para amanhã. Visitando o curso complementar do Grupo Escolar "Lucio dos Santos". O debate. Anno I, n. 34, 23 abr. 1934, p.1e 3.

${ }_{93}$ Como no caso da denúncia: A POBREZA das Caixas Escolares - que se reserve alguma cousa dos banquetes politicos para soccorer a infancia necessitada. $O$ debate. 03 out. 1934, ano I, n. 173. p.1-2.
} 


\section{MEMÓRIAS DE PROFESSORAS ${ }^{94}$}

Jean Marie Goulemont (1991) distingue as autobiografias das memórias. Segundo o autor, a partir do século XVI, tornou-se moda escrever memórias e seus autores eram representantes mais eminentes da elite social, sendo raras as exceções. Dessa forma, pode-se afirmar que as memórias tratavam-se de um gênero aristocrático, limitando as experiências pessoais aos atos públicos vivenciados, excluindo de sua narrativa fatos privados e íntimos como se não existissem ou não tivessem qualquer interesse. A autobiografia, entretanto, se constituiria como o oposto das memórias tradicionais, tratando do íntimo e do privado.

De acordo com a classificação de Goulemont, as obras consultadas por esta pesquisa se compreendem no campo das memórias, já que são as atividades profissionais e, portanto, públicas, que constituem o cerne da trama. Foram encontradas quatro memórias de professoras mineiras que registraram suas lembranças em livros: Alaíde Lisboa de Oliveira, Benedita Dell'Isola, Maria da Glória D’Avila Arreguy e Marta Nair Monteiro. Com exceção de Alaíde Lisboa de Oliveira e Marta Nair Monteiro, que abordam temas familiares, nas outras duas obras são as temáticas profissionais que enredam toda a trama apresentada. Pode-se dizer, portanto, que, embora as autoras também tratem dos aspectos privados, da vida familiar e doméstica, é primordialmente pelo contato com a vida pública e social, pela sua identificação profissional que elas escrevem. As memórias referem-se, especialmente, a sua identificação com uma classe, a dos professores públicos do Estado de Minas Gerais. São as suas atividades, conquistas, impasses e tropeços nesse caminho que as impelem a publicar as suas vivências, portanto, suas memórias.

\section{BIOGRAFIAS}

Escritas por outros autores, as biografias sugerem a necessidade de se revelar a vida de pessoas consideradas importantes por seus escritores e que poderiam não obter, das gerações seguintes, o devido reconhecimento e respeito. O receio de apagamento de

\footnotetext{
${ }^{94}$ Essas memórias serão discutidas no Capítulo 01.
} 
uma história de vida percebida como brilhante é o que parece mover os autores das biografias.

Para esta pesquisa, foram utilizadas duas biografias de professoras da Escola de Aperfeiçoamento que atuaram nesse significativo momento para a educação em Minas Gerais: a da professora mineira Lúcia Casasanta e a de Helena Antipoff, pesquisadora russa que veio para Minas em 1929 para lecionar Psicologia na referida escola. Ambas participaram ativamente das renovações educacionais mineiras.

Lúcia Casasanta, uma mulher mineira que se dedicou ativamente à educação no Estado, auxiliou sua biógrafa a transpor para o papel as lembranças tidas como mais significativas de sua vida profissional e pessoal. Helena Antipoff, por sua vez, parece não ter podido contribuir diretamente para a produção de sua biografia por ter sido esta publicada por seu filho após a sua morte. No entanto, algumas descrições revelam que, ou Antipoff o teria auxiliado anteriormente nesta produção, ou ela the revelava com muita riqueza de detalhes suas memórias, de forma que ele pudesse escrever com clareza até mesmo sobre os períodos em que não esteve próximo da mãe, ou em que ainda não havia nascido.

As memórias e biografias nos remetem a lembranças do cotidiano escolar na medida em que, pelo que consta, foram escritas já quando as atividades de ensino não eram mais realizadas por suas autoras ou pelas biografadas. Ou seja, tratava-se de uma ressignificação de vivências passadas, de fatos que, pela distância temporal e espacial, já poderiam ter adquirido novos contornos e significados. Como teriam agido essas mulheres no cotidiano escolar? Em que medidas as Reformas propostas alteravam suas práticas quando em pleno exercício profissional? Que tensões permearam este caminho? De que forma lidaram com as exigências disciplinares?

Foram consultadas novas fontes que pudessem descortinar o mundo da escola no momento das Reformas, com a introdução de portarias e novas legislações, com a publicação dos periódicos e jornais. Que efeitos todas essas informações tinham no cotidiano escolar? De que forma participavam seus personagens? Como diretores, inspetores, professoras, assistentes e orientadores técnicos lidavam com essas novas injunções? Para responder tais questões, pesquisaram-se os arquivos de onze Grupos Escolares de Belo Horizonte, selecionando-se os documentos que pudessem indiciar as 
estratégias e táticas que permeavam as Reformas Escolares, os seus usos e a participação dos envolvidos nesta tarefa.

\section{DOCUMENTOS ARQUIVADOS EM GRUPOS ESCOLARES DE BELO} HORIZONTE

Acompanhar a história do surgimento, da manutenção e, por vezes, da extinção dos Grupos Escolares de Belo Horizonte envolve uma ampla pesquisa. Para uma pequena aproximação com esses espaços em que educadores e educandos se depararam com a tarefa de efetivar as Reformas Educacionais mineiras nas décadas de vinte a cinqüenta, foi traçado um breve perfil das instituições incluídas na pesquisa. Dos Grupos contatados, alguns não disponibilizaram o acervo ${ }^{95}$, outros foram excluídos por apresentarem um acervo muito pequeno ${ }^{96}$ ou ainda por uma grande proximidade com outro Grupo Escolar ${ }^{97}$. Dois Grupos noturnos, já extintos, foram incluídos na pesquisa, por facilidade de acesso às fontes ${ }^{98}$. No total, foram pesquisados onze ${ }^{99}$ Grupos Escolares e, dentre a documentação localizada em seus porões e depósitos, são comuns as listas de ponto de professoras e funcionários e livros de matrículas, nos quais eram

\footnotetext{
${ }^{95}$ Foram feitos vários contatos e as escolas que não permitiram a realização da pesquisa em seu acervo deram justificativas diversas. A Escola Estadual João Pessoa informou que nada havia nos seus arquivos. O único trabalho obtido com uma senhora indicada pela escola foi um histórico do Grupo realizado pela professora Cleonice de Melo Rodrigues em 1976 como parte da matéria "Integração Social". A E.E. Henrique Diniz também permitiu somente o acesso a um álbum com o histórico da escola, afirmando que os documentos ficavam na Secretaria e que a permanência da pesquisadora no local dificultaria o trabalho das funcionárias. A E.E. Barão do Rio Branco estava passando por uma reforma e não foi possível ter acesso aos documentos.

${ }^{96}$ Escolas Estaduais que foram excluídas da pesquisa, por insuficiência de material relacionado ao tema: Cristiano Machado, Diogo de Vasconcelos, Henrique Diniz, João Pessoa, José Bonifácio, Padre Matias e Sabino Barroso.

${ }^{97}$ A E.E. Cesário Alvim funciona no mesmo quarteirão da E.E. Olegário Maciel que disponibilizou um dos maiores acervos para consulta. Como ambas já funcionaram no mesmo prédio, foram obtidos alguns documentos do Cesário Alvim, mas estes não foram incluídos na pesquisa.

${ }^{98}$ Documentos do Grupo Escolar noturno Assis das Chagas foram encontrados na E.E. Olegário Maciel, prédio onde funcionou. Na E.E. Mariano de Abreu estão documentos do Grupo Afrânio de Melo Franco que funcionava no prédio no período noturno. Na E.E. Benjamim Guimarães, foram encontrados não somente os documentos do G.E. Flávio dos Santos, como do G.E. Cristiano Machado e do G. E. Sabino Barroso. Na Escola Estadual Pedro II foram encontrados documentos do G.E. Padre Matias.

${ }_{99}$ Nessas escolas, os materiais consultados foram aqueles autorizados pelos responsáveis. Nas escolas Tomaz Brandão, Pedro II, Olegário Maciel, Mariano de Abreu, Pandiá Calógeras e Bernardo Monteiro houve maior acesso aos materiais existentes e, possivelmente, boa parte do arquivo, senão toda, foi consultada. Embora os arquivos de outros Grupos não tenham sido consultados, informações sobre eles obtidas em outras fontes não foram desconsideradas.
} 
anotados os critérios de organização das classes, as notas e os motivos para transferência de alunos; os livros de Termos de Visita ou Inspeção; Termos de posse de professores e funcionários; Boletins Mensais com as atividades desenvolvidas ${ }^{100}$; livros com a freqüência diária dos alunos; livros da Caixa Escolar; livros da movimentação da Cantina Escolar; ofícios enviados e recebidos; livros com recortes do jornal Minas Gerais referentes à educação no Estado, especialmente avisos burocráticos. Encontram$\mathrm{se}^{101}$, também, atas de reuniões de professores, de reuniões da Caixa Escolar e de Clube de Leitura dos alunos, jornais escolares ${ }^{102}$, entre outros ${ }^{103}$. Foram encontradas pouquíssimas fotografias e a maioria não traz a data, nem o nome das pessoas fotografadas, o que dificultou as análises.

\subsection{GRUPO ESCOLAR AFRÂNIO DE MELO FRANCO ${ }^{104}$ (NOTURNO)}

As Escolas Reunidas de Cachoeirinha foram inauguradas no dia 10 de março de 1928 e em 22 de setembro de 1929 foram transformadas em Grupo Escolar Mariano de Abreu. A denominação Escolas Reunidas de Cachoeirinha foi utilizada, então, por um Grupo noturno que funcionava no mesmo prédio, cuja data de origem não foi localizada. O primeiro documento encontrado relativo a esta escola noturna é de março de 1937. Dez anos depois, a escola foi transformada em Grupo Escolar Afrânio de Melo Franco, que continuou a funcionar no período noturno ${ }^{105}$.

\footnotetext{
100 Os documentos encontrados em todos esses Grupos que participaram da pesquisa são muito heterogêneos. Aqueles que podiam conter dados importantes à pesquisa foram lidos e, em seguida, feita a transcrição dos trechos percebidos como mais significativos.

${ }^{101}$ O Regimento Interno dos Grupos Escolares poderia revelar de que forma a legislação teria sido adaptada para o funcionamento dentro nos Grupos. No entanto, este não foi encontrado, apesar de algumas reuniões de professoras comentarem sobre o Regimento. Talvez esse Regimento fosse o mesmo de 1907, estabelecido pelo decreto n.1969, mas não foi possível verificar isso.

${ }^{102}$ Somente na E.E. Sandoval de Azevedo foram encontrados números do jornalzinho escolar do período estudado. Na Coleção Linhares da Biblioteca da UFMG encontra-se outro jornalzinho do Grupo Sandoval de Azevedo, o Voz infantil publicado entre 1943 e 1944, além de alguns números do jornalzinho A infância moderna do Grupo Escolar Lúcio dos Santos e o jornal Voz da criança do Grupo Escolar Bernardo Monteiro. Na Hemeroteca de Belo Horizonte encontrou-se o jornal O escolar do Grupo Escolar Flávio dos Santos.

${ }^{103} \mathrm{Nem}$ sempre os livros traziam aquilo que estava anunciado em sua capa ou contracapa, sendo necessário ler todos os informes para analisar o que poderia ser utilizado na pesquisa.

${ }^{104}$ Os documentos do Grupo Escolar Afrânio de Melo Franco encontram-se nos arquivos da Escola Estadual Mariano de Abreu, onde ele funcionava.

${ }^{105}$ Não foi possível identificar quando este Grupo Escolar foi extinto.
} 


\subsection{GRUPO ESCOLAR ASSIS DAS CHAGAS ${ }^{106}$ (NOTURNO)}

Não foi possível precisar a data de surgimento do Grupo Escolar Assis das Chagas, a partir das fontes consultadas. O primeiro documento encontrado tratando de um curso noturno que funcionava no prédio do Grupo Escolar Cesário Alvim é de novembro de 1914. Neste mesmo livro, nas atas realizadas no ano de 1916, aparece a denominação de Curso Noturno Dr. Américo Lopes. Nos anos posteriores não há novas atas, até que a próxima, datada de 1923, já utilizava a denominação de Grupo Escolar Assis das Chagas. Pelos documentos encontrados, o Grupo parece haver existido até a década de sessenta.

\subsection{GRUPO ESCOLAR BERNARDO MONTEIRO}

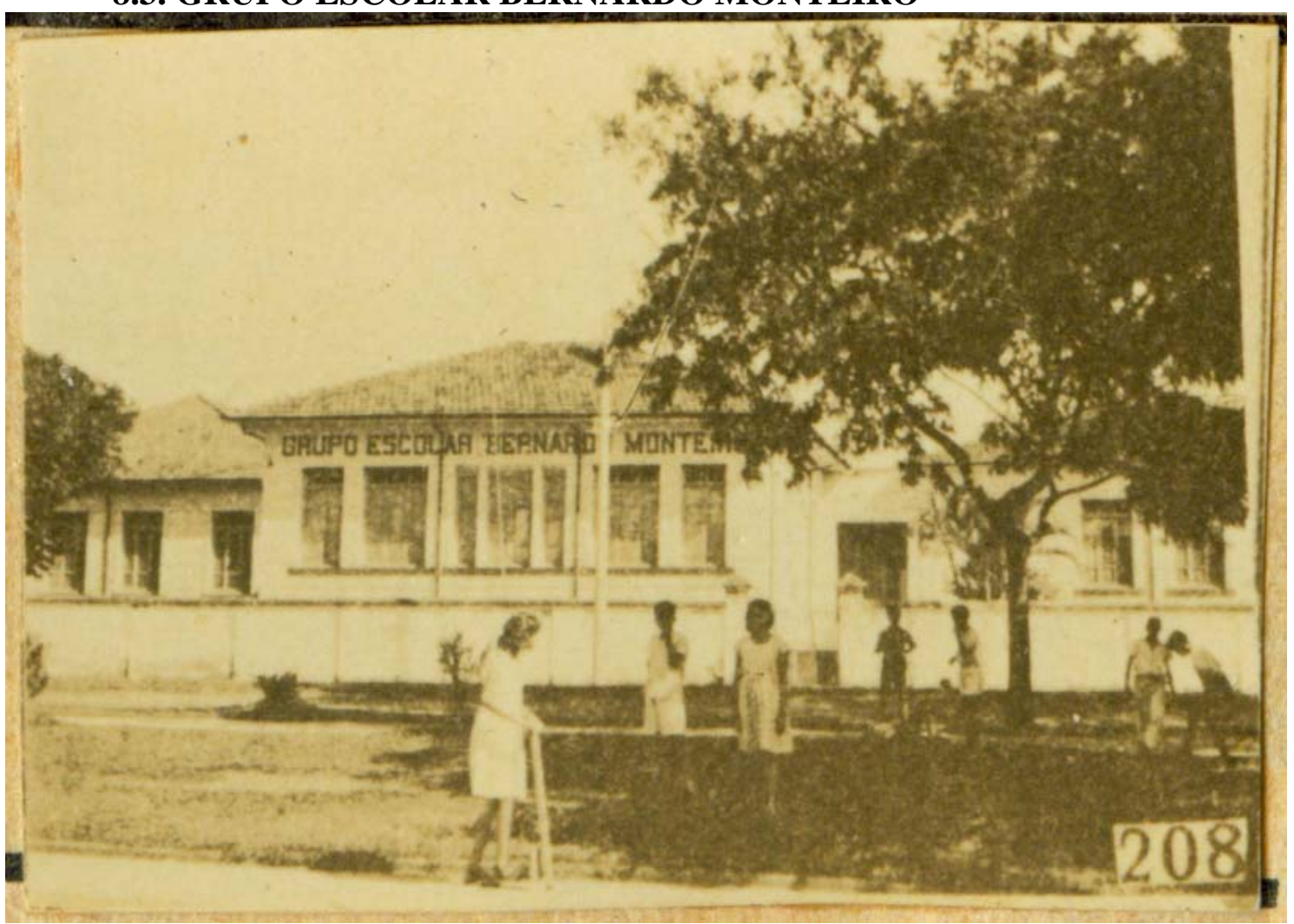

Foto 2: Grupo Escolar Bernardo Monteiro (s.d.)

Fonte: Acervo do Museu Histórico Abílio Barreto

O Grupo Escolar Bernardo Monteiro teve origem em uma cadeira criada em 1894 no município de Sabará e transferida para Belo Horizonte em 1896. Dois anos depois, esta cadeira foi transferida para o Bairro Calafate onde funcionavam apenas duas classes, uma de meninas com uma professora e outra de meninos com um

\footnotetext{
${ }^{106}$ Os documentos relativos a este Grupo foram encontrados na Escola Estadual Olegário Maciel, local onde ele funcionou.
} 
professor. Em 1914 foi criado o Grupo Escolar Bernardo Monteiro com o aumento de algumas novas salas. Em 1926, o prédio foi completamente demolido e reformado, passando por outra reforma em $1945^{107}$. Em fins da década de sessenta, o Grupo foi novamente demolido ${ }^{108}$ tendo sido o prédio novo concluído em 1972.

\subsection{GRUPO ESCOLAR FLÁVIO DOS SANTOS}

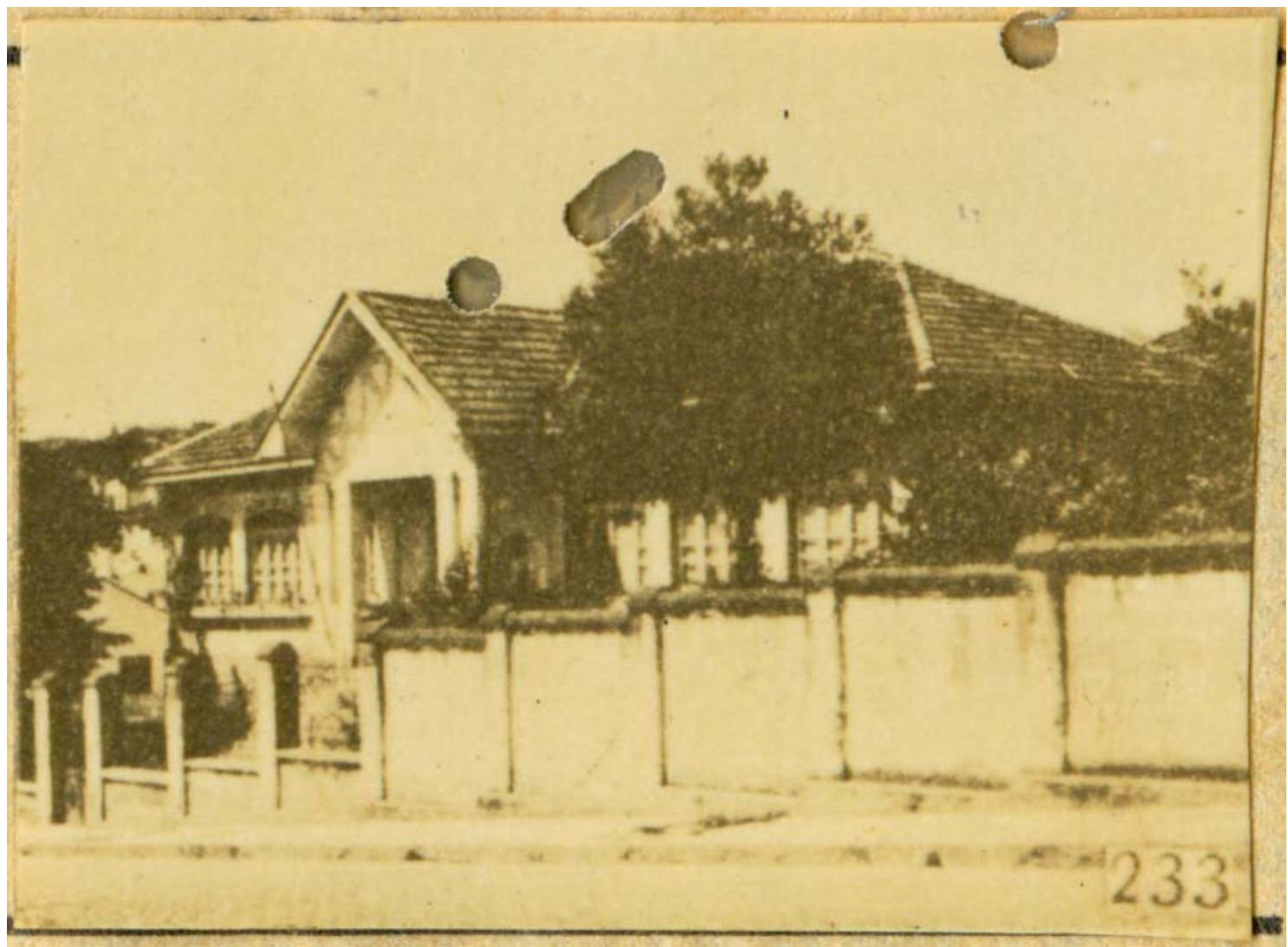

Foto 3: Grupo Escolar Flávio dos Santos (s.d.)

Fonte: Acervo do Museu Histórico Abílio Barreto

As Escolas - provavelmente reunidas - Flávio dos Santos criadas em 31 de agosto de 1926 e inauguradas em setembro deste mesmo ano, passaram por uma ampliação de seis salas ${ }^{109}$, transformando-se no Grupo Escolar Flávio dos Santos em

${ }^{107}$ Em um papel encontrado num dos livros do Grupo, há uma ata manuscrita acerca da entronização dos Sagrados Corações de Jesus e Maria no Grupo em 18 de maio de 1945, justamente para a benção do prédio que havia passado por uma reforma.

${ }^{108}$ Em um documento encontrado no Grupo, há a informação de que em 1967 foi adquirido um novo terreno para a construção do Grupo na rua Platina. Foram encontrados também recortes de jornais da época tratando da construção do novo prédio. Um deles, de 30 de março de 1972, noticia que o antigo prédio foi totalmente demolido. Em 29 de março de 1972 inaugurou-se o novo prédio.

${ }^{109}$ Cf. Cláudio Lúcio Fonseca, 2004, p. 124. 
1930. Segundo informações da diretoria do Grupo, não há documentos antigos nos seus $\operatorname{arquivos}^{110}$, embora ainda esteja em funcionamento.

\subsection{GRUPO ESCOLAR LÚCIO DOS SANTOS}

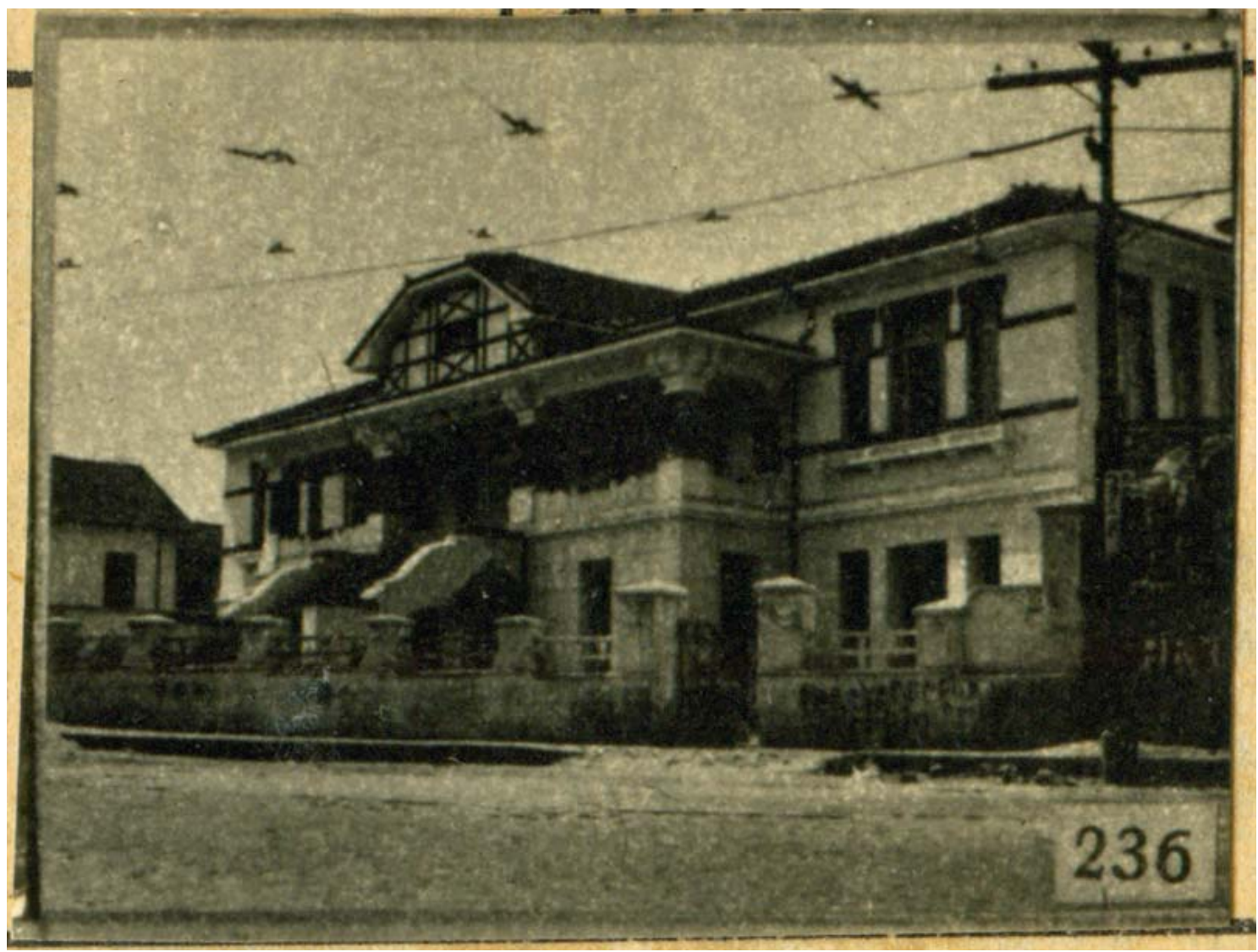

Foto 4: Grupo Escolar Lúcio dos Santos (s.d.)

Fonte: Acervo do Museu Histórico Abílio Barreto

O Grupo Escolar Lúcio dos Santos ${ }^{111}$ teve origem na primeira escola mista do Bairro Carlos Prates iniciada em 1903. Em 1926, com a reforma do espaço e construção de novas salas, foi transformada em Escolas Reunidas Lúcio dos Santos. Dois anos

\footnotetext{
${ }^{110}$ Funcionários da escola Flávio dos Santos informaram que nada havia em seus arquivos e que todo o material estava na Escola Benjamim Guimarães e lá foram consultados.

${ }^{111}$ Lúcio José dos Santos era professor de Ciência, jornalista e católico fervoroso. Atuou na Diretoria de Instrução Pública no governo de Fernando Melo Viana e foi diretor da Escola de Aperfeiçoamento em 1929, colaborando muito também para a Revista do Ensino. (Cf. Biccas, 2001, p. 33)
} 
depois, tornou-se Grupo Escolar e, em 29 de maio de 1929, foi transferido para o local onde funciona atualmente.

\subsection{GRUPO ESCOLAR MARIANO DE ABREU}

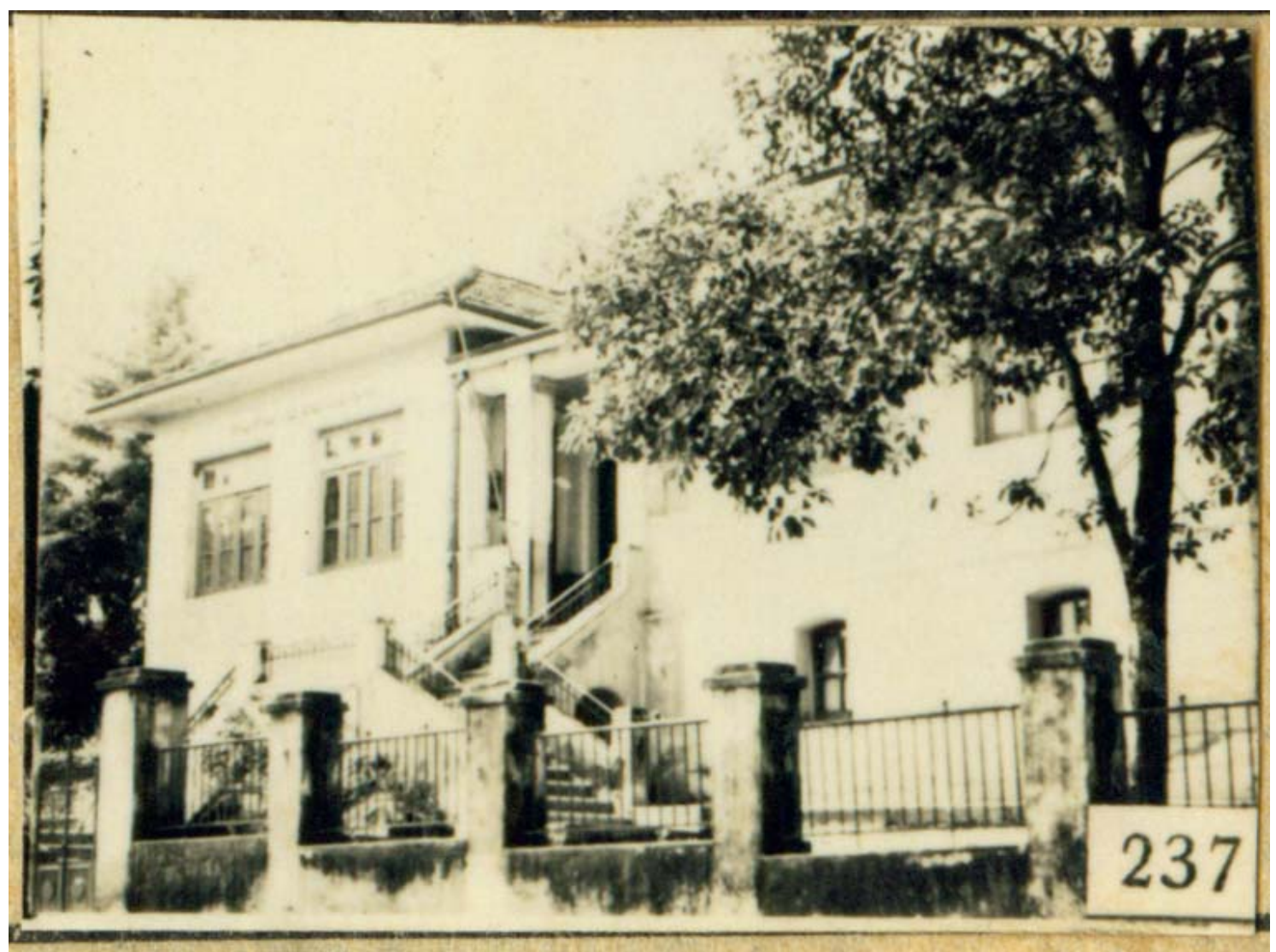

Foto 5: Grupo Escolar Mariano de Abreu (s.d.)

Fonte: Acervo do Museu Histórico Abílio Barreto

O Grupo Escolar Mariano de Abreu foi instalado em março de 1928 como Escolas Reunidas de Cachoeirinha e tornou-se Grupo Escolar em setembro de 1929. Antes disso, era uma escola rural mista criada em 19 de abril de 1927 pelo decreto $n$. 7.600. O terreno para a construção do prédio teria sido doado por uma fábrica de tecidos da região ${ }^{112}$ e, segundo entrevista concedida a Cláudio Lúcio Fonseca (2004) por uma ex-diretora, Margarida de Oliveira Guimarães, a inauguração do Grupo se deu com bastante pompa na presença do Secretário do Interior, do diretor da Fábrica de Tecidos, entre outras autoridades. Apesar disso, não havia água encanada na região e esta tinha que ser carregada em baldes para a escola. Mais uma vez, foi a Fábrica de Tecidos que

${ }^{112}$ Cf. Cláudio Lúcio Fonseca, 2004, p. 134 
resolveu o problema, fazendo uma ligação da água da fábrica para o Grupo. Em 1930, o Grupo passou por ampliações. No mesmo prédio funcionou o Grupo Escolar Afrânio de Melo Franco, no turno da noite.

\subsection{GRUPO ESCOLAR OLEGÁRIO MACIEL}

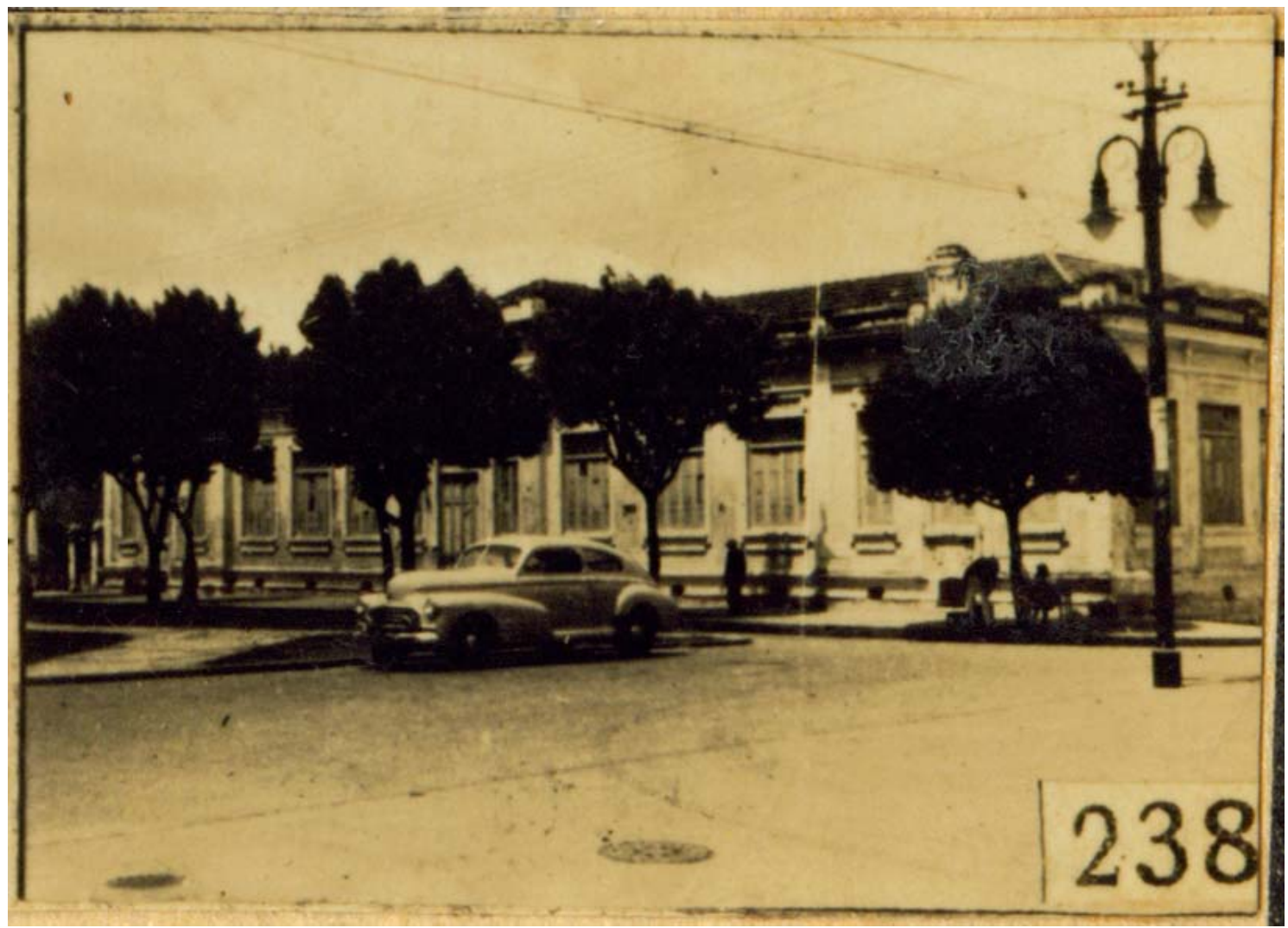

Foto 6: Grupo Escolar Olegário Maciel (s.d.)

Fonte: Acervo do Museu Histórico Abílio Barreto

O Grupo Escolar Olegário Maciel foi o nono Grupo Escolar de Belo Horizonte, criado em 20 de agosto de 1924 e inaugurado em 1925. A partir de 1926, o Grupo Escolar Cesário Alvim que funcionava no prédio do Instituto São Rafael ${ }^{113}$ - escola para deficientes visuais - foi transferido para o prédio. Nesse local ficaram funcionando, pela manhã, o Grupo Escolar Olegário Maciel; à tarde, o Grupo Escolar Cesário Alvim e à noite, o Grupo Escolar Assis das Chagas. Os alunos do Grupo Escolar Cesário Alvim foram transferidos, a partir de 1930, para uma sede própria ${ }^{114}$.

\footnotetext{
113 Atualmente, o Instituto São Rafael funciona em prédio próprio, construído na Av. Augusto de Lima. Naquela época, ele funcionava na rua Tupinambás esquina com a rua São Francisco (atualmente Av. Olegário Maciel).

${ }^{114}$ Os dados sobre o Grupo Escolar Olegário Maciel foram retirados de alguns trabalhos realizados pelos alunos sobre a história da instituição. Estes trabalhos encontram-se nos arquivos da escola, mas trazem alguns dados contraditórios. Portanto, não há garantia de que as datas estejam absolutamente corretas.
} 


\subsection{GRUPO ESCOLAR PANDIÁ CALÓGERAS}

O Grupo Escolar Pandiá Calógeras teve origem na antiga escola italiana "Dante Alighieri”, fundada em 1908 pela comunidade italiana. Em 1935, com o decreto n. 11.779 do então interventor do Estado, Benedito Valadares, a escola passou a se denominar Grupo Escolar Benito Mussolini. Em 1942, a escola mudou de nome e de endereço, como ainda encontra-se atualmente. O Grupo, no entanto, não estava pronto com a mudança; o prédio só seria inaugurado em 1947. Em 1942, o Brasil declarou guerra ao Eixo - Alemanha, Itália e Japão - e Mussolini ${ }^{115}$ passava a inimigo da Nação. Provavelmente, por este motivo, houve a alteração no nome do Grupo que passou a homenagear João Pandiá Calógeras, engenheiro carioca formado pela Escola de Minas de Ouro Preto, historiador, político e escritor.

\subsection{GRUPO ESCOLAR PEDRO II}

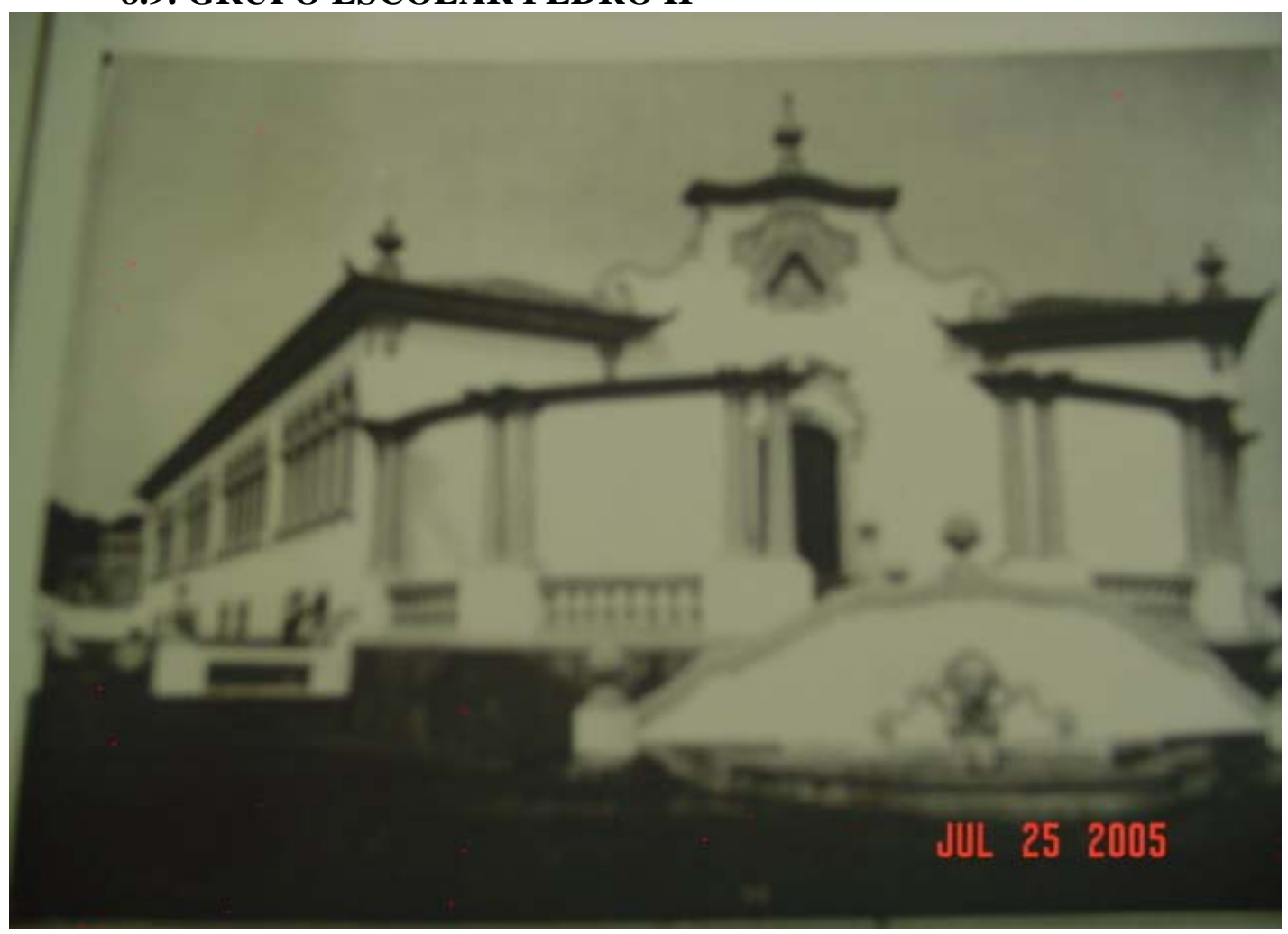

Foto 7: Grupo Escolar Pedro II (s.d. a data na foto é a da sua digitalização pela pesquisadora) Fonte: Arquivo público da cidade de Belo Horizonte.

O Grupo Escolar Pedro II foi o décimo Grupo da capital, inaugurado em 1926, a partir de uma divisão do Grupo Escolar Henrique Diniz. O Grupo passou por algumas reformas para manutenção do edifício, mas funciona até os dias de hoje no mesmo

\footnotetext{
${ }^{115}$ Benito Mussolini governou a Itália entre 1922 e 1945, instaurando o regime fascista.
} 
prédio. A arquitetura deste Grupo é única, distinguindo-se de todos os outros da capital, tendo sido criado com o objetivo de comemorar o centenário de Dom Pedro II:

Em estilo neocolonial, era de suntuosidade e luxo extremos, sendo totalmente diferente dos prédios escolares anteriores e dos posteriores. Localizado próximo ao Bairro dos Funcionários, sua entrada, com as imagens representativas do Progresso e da Instrução, era diferente das entradas dos outros num aspecto que poderia ser um símbolo do público ao qual se destinava: entre os dois lances da escadaria de granito havia uma entrada para automóveis. (grifos do autor) (Fonseca, 2004, p.102)

\subsection{GRUPO ESCOLAR SANDOVAL DE AZEVEDO}

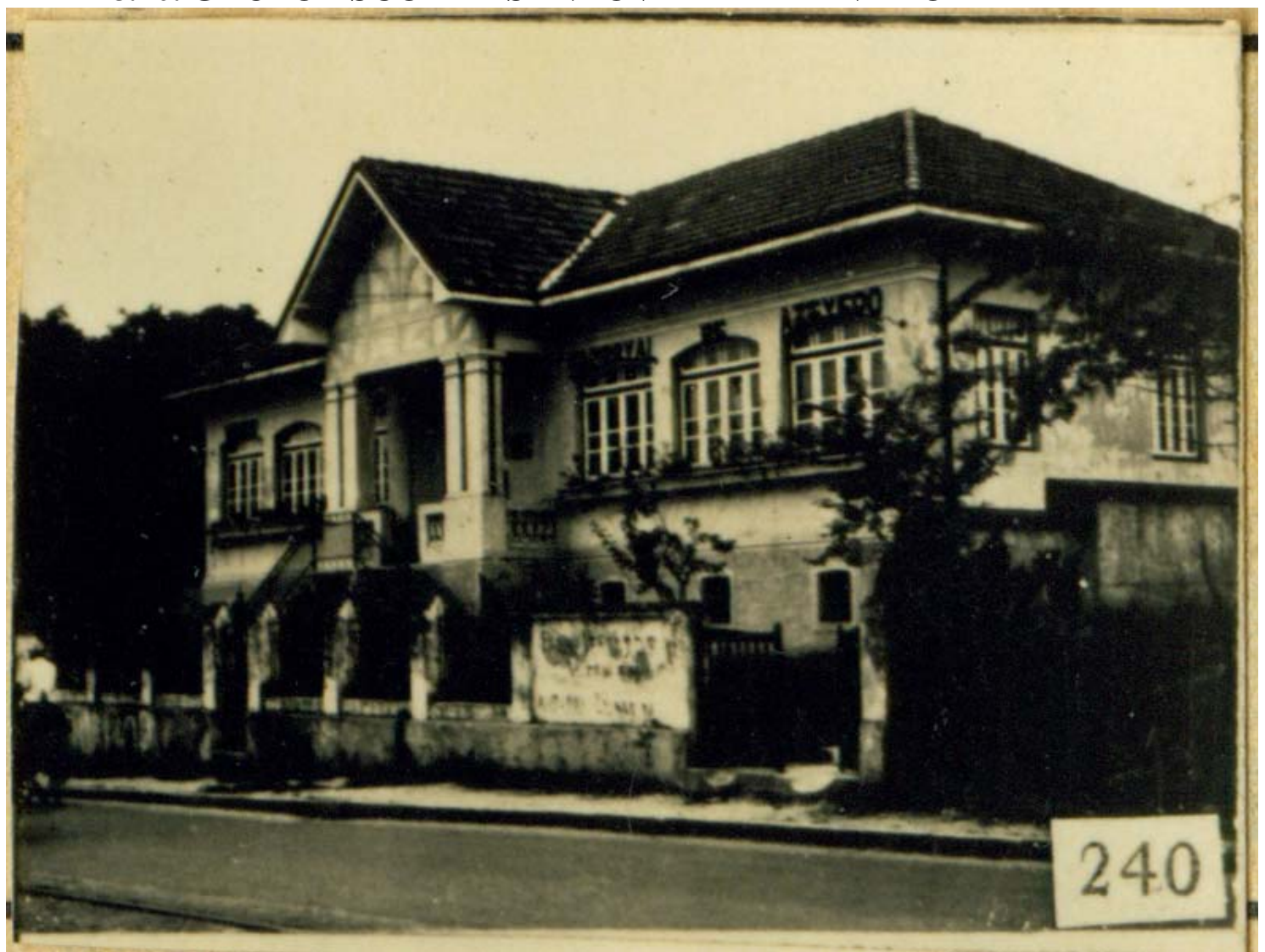

Foto 8: Grupo Escolar Sandoval de Azevedo (s.d.)

Fonte: Acervo do Museu Histórico Abílio Barreto

O Grupo Escolar Sandoval de Azevedo foi criado em 1926 e, já em 1928, passou por reformas para sua ampliação ${ }^{116}$. Lá estava sediado ${ }^{117}$ também o Grupo Escolar

${ }^{116}$ Cf. Fonseca (2004, p. 28).

${ }^{117}$ Esta informação está no Livro de Atas e Termos de Promoção e Exame dos alunos do Grupo Escolar Sandoval de Azevedo, de novembro de 1952. 
Diogo de Vasconcelos ${ }^{118}$, criado em 20 de janeiro de 1930, após a conversão das escolas noturnas. Ambos foram reunidos em um único Grupo em 15 de maio de $1960^{119}$.

\subsection{GRUPO ESCOLAR TOMAZ BRANDÃO}

O Grupo Escolar Tomaz Brandão foi criado em fevereiro de 1930 com a denominação de Grupo Escolar do Palmital e passou a ter a denominação atual em agosto do mesmo ano. Funcionava num dos meios mais pobres da capital. Segundo uma pesquisa realizada pelo laboratório de Psicologia da Escola de Aperfeiçoamento sobre o nível social dos alunos, a partir da profissão dos pais, ficou colocado em antepenúltimo lugar entre todos os Grupos da capital.

Estas fontes servirão de fio condutor para a pesquisa que se inicia, buscando dar voz aos sujeitos que fizeram a história da educação em Belo Horizonte, no primeiro eixo da pesquisa e investigando, de maneira mais pormenorizada, o universo escolar na capital mineira em três décadas do século XX. Comecemos pelas alunas que se tornaram professoras....

\footnotetext{
${ }_{118}$ As escolas noturnas da rua Pouso Alegre foram transformadas em Grupo Escolar em 20 de janeiro de 1930 pelo decreto n. 9.312 e, em 05 de fevereiro deste ano, pelo decreto n. 9.356, recebeu a denominação de Diogo de Vasconcelos.

${ }^{119}$ A denominação "Diogo de Vasconcelos" passou às Escolas Reunidas da Vila Salgado Filho.
} 
EIXO I

EDUCADORES \& EDUCANDOS 


\title{
CAPITULO 1
}

\section{DE ALUNAS A PROFESSORAS: UM PERCURSO NA EDUCAÇÃO}

\author{
Mas, o ancião não sonha quando \\ rememora: desempenha uma função \\ para a qual está maduro, a religiosa \\ função de unir o começo ao fim, de \\ tranqüilizar as águas revoltas do \\ presente alargando suas margens. \\ (Ecléa Bosi, 1987, p.40)
}

Este capítulo se vale dos fios das memórias das professoras que as deixaram publicadas, das biografias sobre professoras e de entrevistas com professoras que formaram e lecionaram no período. Busca constituir uma trama de uma história educacional em Belo Horizonte a partir de sujeitos históricos que dela participaram efetivamente, mas que foram pouco considerados pela história política da educação. São lembranças vagas e distantes, mas que auxiliam a iluminar os pátios internos das escolas, a galgar seus muros, adentrar por suas portas, sentar em seus bancos e, como num sonho, vislumbrar as crianças e professoras num relance das salas de aula. As impressões deixadas por este período e resgatadas pela memória durante as entrevistas permitem captar, ainda que fragilmente, as emoções, as vivências, as sensações vividas no passado, identificar os sujeitos por detrás das paredes, por cima dos livros, por dentro das carteiras. São os corações palpitantes, os suores, os tremores, os rubores que marcam as experiências e as lembranças. Ouvir as memórias de quem passou pelas escolas belorizontinas neste período em estudo foi essencial para flagrar o traço do humano nas legislações, normas, regimentos e teorias que envolveram a pesquisa.

As memórias não aparecem livre e espontaneamente, elas fazem parte de um trabalho ativo do pesquisador e dos sujeitos da pesquisa, no sentido de recuperar o passado à luz do presente. É o momento atual que dá significado às lembranças:

A lembrança é uma imagem construída pelos materiais que estão agora, à nossa disposição, no conjunto das representações que povoam a nossa consciência atual. Por mais nítida que nos pareça a lembrança de um fato antigo, ela não é a mesma imagem que experimentamos na infância, porque nós não somos os mesmos de então e porque nossa percepção alterou-se e, com ela, nossas idéias, nossos juízos de realidade e de valor. (Bosi, 1987, p. 17) 
Desta forma, deve-se ter a noção de que não é possível recuperar o passado tal como ele aconteceu. As memórias são uma construção no tempo presente e a partir de fatos e vivências passadas. Tais lembranças do passado não permanecem estáticas à espera de ser recolhidas, pelo contrário, o próprio trabalho de rememorar altera as lembranças conscientes e inconscientes. Freud advertia que são muitas as interferências que levam ao esquecimento de fatos vivenciados.

Portanto, entre os vários fatores que contribuem para o fracasso de uma recordação ou para uma perda de memória, não se deve menosprezar o papel desempenhado pelo recalcamento, e isso pode ser demonstrado não só nos neuróticos, mas também (de modo qualitativamente idêntico) nas pessoas normais. Pode-se afirmar, muito genericamente, que a facilidade (e em última instância, também a fidelidade) com que dada impressão é despertada na memória depende não só da constituição psíquica do indivíduo, da força da impressão quando recente, do interesse voltado para ela nessa ocasião, da constelação psíquica no momento atual, o interesse agora voltado para sua emergência, das ligações para as quais a impressão foi arrastada, etc. - não só de coisas como essas, mas também da atitude favorável ou desfavorável de um dado fator psíquico que se recusa a reproduzir qualquer coisa que possa liberar desprazer, ou que possa subseqüentemente levar à liberação de desprazer. ${ }^{120}(1898 / 1986$, p.264)

Também não se pode afirmar, conforme orienta a Psicanálise, que as lembranças dos fatos mais importantes vivenciados na infância ficarão marcados na memória com maior detalhamento e expressividade. Ao contrário, Freud aponta que freqüentemente são os fatos mais corriqueiros e destituídos de maior relevância os que vêem à lembrança, enquanto os fatos importantes e que causaram maior emoção naquele período, como a perda de uma pessoa querida, podem ser completamente apagados da memória consciente. Nesse caso, teria acontecido uma conciliação entre uma força que busca manter viva a lembrança e outra que tenta ocultá-la:

E a conciliação é a seguinte: o que é registrado como imagem mnêmica não é a experiência relevante em si - nesse aspecto, prevalece a resistência; o que se registra é um outro elemento psíquico intimamente associado ao elemento passível de objeção e, nesse aspecto, o primeiro princípio mostra sua força: o princípio que se esforça por fixar as impressões importantes, estabelecendo imagens mnêmicas reprodutíveis. $\mathrm{O}$ resultado do conflito, portanto, é que, em vez da imagem mnemônica que seria justificada pelo evento original, produz-se outra, que foi até certo ponto associativamente deslocada da primeira. É já que os elementos da experiência que suscitaram objeção foram precisamente os elementos importantes, a lembrança substituta perde necessariamente esses elementos importantes e, por conseguinte, é muito provável que se nos afigure trivial. ${ }^{121}$ (1899/1986, p.274)

\footnotetext{
${ }^{120}$ Freud, Sigmund. O mecanismo psíquico do esquecimento. Vol. III. Obras Completas.

${ }^{121}$ Freud, Sigmund. Lembranças encobridoras. Vol. III. Obras Completas.
} 
Apesar de todas as dificuldades ao se trabalhar com as memórias, e mesmo das limitações apresentadas, são elas um rico acervo dos fatos experimentados e fontes de extrema importância quando se pretende investigar a relação entre as propostas reformistas e o seu impacto no cotidiano escolar, conforme aponta Escolano:

Un estudio sistemático de estos y otros posibles testimonios, entre los que han de incluirse las fuentes orales para las épocas de memoria viva, ha de conducir a un conocimiento más realista y complejo de las reglas empíricas de la profesión docente, de la construcción social del rol de enseñante como expectativa de un oficio entre artesano e intelectual, y a la compresión de los modos de transmisión y apropiación de tales pautas entre los miembros de la corporación. (1999, p. 18)

Segundo o autor, memórias e autobiografías de professores, materiais pedagógicos, documentos administrativos sobre a gestão das escolas, entre outros, formam um "...conjunto de objetos, textos y registros que nos pueden ayudar a desvelar los "silencios" de la historia de la escuela y las claves de la construcción real del pasado del oficio de maestro" (1999, p.20).

Principalmente ao tratar de um assunto delicado no meio pedagógico, como a punição às crianças, o uso exclusivo de documentos oficiais como fontes para a pesquisa pode ser limitador no que tange à revelação de tensões, conflitos, ansiedades, temores ou satisfações provocadas pelas mudanças propostas e impostas pelas Reformas, conforme salienta Thompson (1998, p.178): "Não obstante, as entrevistas provavelmente proporcionam o melhor método para avaliar os meios comumente utilizados pelos professores de todo o país para manter a disciplina em sala de aula". Dessa forma, as fontes orais devem ser analisadas, não com exclusividade, mas como meios de identificação e análise do não-dito, dos sentimentos e atitudes que não mereceram ou não alcançaram reconhecimento oficial em documentos, artigos e textos escritos.

Nesse sentido, as biografias e autobiografias têm o mérito de recuperar, para a história da educação, vestígios desses homens e mulheres e suas obras, tornadas quase invisíveis. Em que pese todas as críticas ao seu subjetivismo, e sem isentá-los de outras, esses documentos biográficos e autobiográficos muitas vezes são as únicas testemunhas de práticas e idéias pouco notadas, ou porque corriqueiras, ou porque foram alvo de generalizações que as igualaram. (Souza, 2000, p.53) 
A memória constitui a identidade tanto individual quanto coletiva. Resgatar lembranças de punição nas escolas tidas como modelo para o ensino público em todo o país, num momento em que estas passam a ser duramente combatidas significa colocar em xeque uma imagem de escola que coadunava com os princípios renovadores da educação. Como adverte Maria Cecília C.C. Souza (1998, p. 86): "Vale lembrar também que o qualificativo 'repressivo', usado para descrever a pedagogia da época, é anacrônico, no sentido que apenas por referência às pedagogias permissivas posteriores é que se pode perceber o método anterior como tal."

As mudanças nas relações pedagógicas sofriam os efeitos das mudanças na concepção de educação e também de sociedade. Na década de vinte, mesmo com a introdução do ideário escolanovista em Minas Gerais, não havia um consenso quanto à não utilização das punições na escola. Embora a tônica fosse sempre maior em repudiar o seu uso, algumas poucas vozes defendiam a presença da punição, desde que se acercasse de diversos cuidados em suas aplicações.

As memórias de professoras e alunos surgem como uma possibilidade de se iluminarem aspectos obscurecidos pelos propagadores do escolanovismo, mas sua utilização demanda cuidados especiais na medida em que contenham ou possam conter dados que são tidos como inaceitáveis ou vergonhosos para a sociedade de hoje e também do passado, que possam revelar imagens pouco condizentes com o ideal de professor, de escola, de aluno, de família e de si próprios. Apesar das dificuldades, nenhuma outra fonte poderia revelar com tanta riqueza as resistências, os sentimentos, as dificuldades, as vicissitudes de um momento tão crucial para professores e alunos do que as suas memórias sobre as punições sofridas, aplicadas e observadas nas escolas que estudaram, trabalharam, nas quais, enfim, construíram um pouco de si mesmos e de suas histórias de vida.

É possível que as Reformas Educacionais aqui estudadas tenham resolvido todos os problemas de indisciplina como prometiam? Os professores deixaram de usar castigos físicos e punições? Sabe-se que, desde o século XIX, no Brasil, havia legislações proibindo os castigos físicos na sala de aula. É preciso salientar que essa proibição não era exclusiva do movimento escolanovista. O que a Escola Nova acrescentava eram os dispositivos disciplinares que deveriam evitar a necessidade das punições, além é claro, de uma campanha maciça em defesa de uma escola mais alegre 
e ativa, segundo as características infantis identificadas pela nascente Psicologia científica.

Importa saber, então, como as professoras lidaram com essas questões, como se submetiam ou não às exigências de renovação de suas práticas, como concebiam a questão da punição em sua classe e como manejavam os processos disciplinares. Nesse sentido, foram utilizadas as memórias escritas por professoras que deixaram registradas as suas lembranças do período de vida profissional e a história oral de professoras, alunos e alunas que deram vida aos Grupos Escolares de Belo Horizonte nas décadas de vinte a cinqüenta.

\subsection{NAS PÁGINAS DA MEMÓRIA ${ }^{122}$}

Foram utilizadas as memórias redigidas por quatro professoras ${ }^{123}$ que trabalharam em Belo Horizonte no período estudado:

\subsubsection{MEMÓRIAS DE UMA PROFESSORA}

Maria da Glória D’Avila Arreguy

Este livro foi escrito a pedido do filho, João Etienne Filho, em 1947. Futuramente, as anotações seriam reorganizadas para uma publicação semanal na página feminina do jornal $O$ diário em Belo Horizonte. Os 35 pequenos capítulos, mais o prefácio escrito pelo filho e uma carta da mãe aceitando o convite para redigir as suas memórias foram, posteriormente, reunidos no livro publicado em 1958.

A professora Maria da Glória D’Avila Arreguy fez o Curso Normal no Colégio Providência em Mariana entre 1910 e 1913. No ano seguinte, assumiu uma turma no Grupo Escolar Cesário Alvim na cidade de Caratinga. Depois de passar por diversas cidades e de, já como professora efetiva, ser rebaixada ao cargo de estagiária, por causa da transferência para a cidade de Itabirito, decidiu estudar na Escola de Aperfeiçoamento, após quinze anos de magistério. A Reforma do Ensino primário, a seu ver, estava lhe trazendo dificuldades e era preciso renovar sua bagagem pedagógica.

\footnotetext{
${ }^{122} \mathrm{O}$ objetivo deste trabalho é utilizar as memórias como fontes e não como objetos de pesquisa. Nesse sentido, uma análise da produção dessas memórias foge ao escopo dessa pesquisa.

${ }^{123}$ Com exceção de Alaíde Lisboa de Oliveira que é escritora de livros infantis, didáticos e acadêmicos, não foram encontradas outras produções bibliográficas das outras professoras memorialistas.
} 
Deixou marido e filhos e foi ingressar na primeira turma de alunas mestras da Escola de Aperfeiçoamento, em 1929. Após a formatura em 1930, regressou ao Grupo Escolar de Itabirito como orientadora técnica. Em 1934, a convite da Secretaria de Educação, foi trabalhar no Grupo Noturno Diogo de Vasconcelos em Belo Horizonte. Em 1938, retornou a Caratinga. Em 1944, foi nomeada diretora do Grupo Escolar de São Pedro dos Ferros. No ano seguinte, aposentou-se. Com dificuldades financeiras, em 1951 voltou à ativa como diretora no Grupo Escolar da cidade de Inhapim e, em 1952, muito abatida fisicamente, Maria da Glória requereu novamente a aposentadoria, com melhores vencimentos.

\subsubsection{MEMÓRIAS DE UMA PROFESSORA PRIMÁRIA}

Benedita Dell'Isolla

A autora nasceu na cidade de Andradas ${ }^{124}$, fez o curso primário em sua cidade e, em 1917, após passar por exames de suficiência na Escola Normal de Ouro Fino, foi nomeada professora adjunta efetiva da Escola do sexo feminino da Vila de Caracol. Iniciou seu trabalho em uma classe de cem alunas, encarregada da Disciplina, Religião e Caligrafia. A regente da classe era sua ex-professora. Em 1924, Benedita, estando a passeio em Uberabinha ${ }^{125}$, foi convidada, pelo diretor do Grupo Escolar, a fazer uma substituição. Resolveu ficar definitivamente e pediu exoneração em sua cidade de origem. Em Uberlândia, trabalhou primeiro no Grupo e depois no Ginásio. Ao deixar o Ginásio como professora, começou a cursar a Escola Normal de Uberlândia, mudandose para Belo Horizonte, ao finalizar o curso. Na capital, Benedita começou a trabalhar como substituta no Grupo Escolar Diogo de Vasconcelos e depois foi substituta no Grupo Mariano de Abreu. Trabalhou nos Grupos Escolares Flávio dos Santos, Cristiano Machado e Tito Fulgêncio. Depois de aposentada, trabalhou em diversas instituições privadas de ensino, além de dar aulas particulares em casa.

Os dez primeiros capítulos de seu livro não recebem uma denominação específica, depois deles, aparecem três outros de três a quatro páginas com algumas temáticas específicas. No último texto, com apenas três parágrafos e denominado "31 de março de 1964", ela finaliza o livro saudando as Forças Revolucionárias que lutaram

\footnotetext{
${ }^{124} \mathrm{Na}$ época do seu nascimento o lugar chamava-se Samambaia e depois São Sebastião do Jaguari.

${ }^{125}$ Hoje Uberlândia.
} 
"contra a tentativa de comunização do Brasil". O livro traz na capa duas datas, a primeira de agosto de 1968 e a segunda, da editora, de 1970. Provavelmente, a última seja a data da publicação da obra.

\subsubsection{MEU MUNDO}

Marta Nair Monteiro

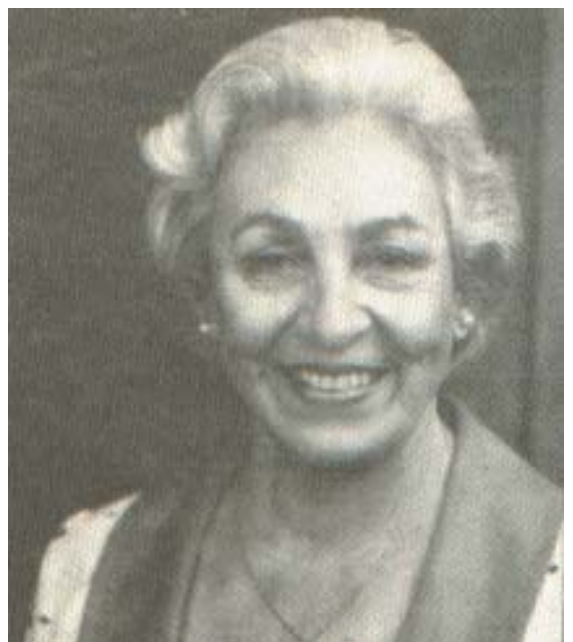

Foto 9: Marta Nair Monteiro (s.d.)

Fonte: Capa do livro Meu Mundo.

As memórias da professora Marta, publicadas em 1991, envolvem sua vida pessoal, profissional e suas atividades políticas. Na primeira parte do livro, encontramse: um primeiro texto explicando a capa do livro que traz uma rosa; uma justificativa da autora sobre os motivos que a levaram a escrevê-lo; os agradecimentos; um texto que explica a origem e algumas confusões no registro de seu nome e quatro pequenos prefácios de pessoas ligadas à autora. A partir daí, o livro se divide em duas partes. A primeira denominada "Alma e coração" traz trinta pequenos capítulos que abordam mais a vida pessoal e familiar de escritora, embora contemplem também o período no colégio, na Escola Normal e na Escola de Aperfeiçoamento. Entretanto, não há relatos sobre a sua experiência como professora nos Grupos Escolares. A segunda parte do livro, "Cabeça e energia"; discorre sobre o período de atuação política, desde a sua entrada como presidente interina na Associação de Professores Primários de Minas Gerais, liderando a primeira greve de professores no Brasil em 1959 e atividades posteriores em que esteve sempre à frente de movimentos reivindicatórios, lutando por melhorias para os professores e funcionários públicos de modo geral. 
Nascida em Campo Belo ${ }^{126}$, interior de Minas Gerais, Marta Nair foi alfabetizada por sua mãe e, aos oito anos, foi estudar como interna no Colégio São José daquela cidade. Aos treze anos de idade, sua família mudou-se para Belo Horizonte. Estudou no Colégio Sagrado Coração de Jesus. Terminado o Curso Normal, fez concurso e começou a lecionar como estagiária no Grupo Escolar Caetano de Azeredo. Estudou na Escola de Aperfeiçoamento e depois foi nomeada orientadora do Grupo Escolar Barão do Rio Branco que, segundo ela, era o melhor de Belo Horizonte e para onde eram designadas apenas orientadoras com notável experiência.

As memórias da professora Marta Nair Monteiro fazem raras referências ao interior das escolas nas quais estudou e trabalhou. Quase todos os comentários relativos ao campo profissional são posteriores a 1956, quando ingressou na Associação de Professores de Minas Gerais ${ }^{127}$.

\subsubsection{SE BEM ME LEMBRO...}

Alaíde Lisboa de Oliveira

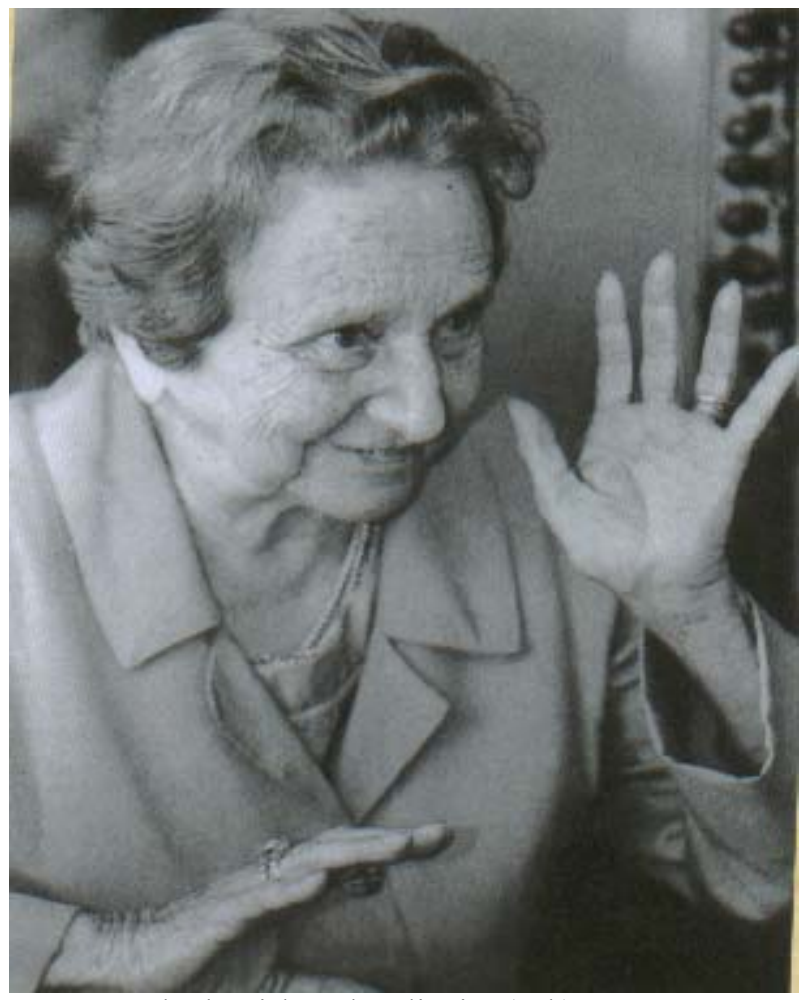

Foto 10: Alaíde Lisboa de Oliveira (s.d.)

Fonte: Folder da Secretaria de Estado da Educação de MG em comemoração aos 100 anos de Alaíde Lisboa em 2004.

\footnotetext{
${ }^{126}$ Marta Nair Monteiro nasceu a 24 de dezembro de 1913.

${ }^{127}$ Por este motivo, pouco de suas lembranças foram utilizadas na pesquisa.
} 
Alaíde ${ }^{128}$ nasceu na cidade de Lambari, interior de Minas Gerais. Estudou e trabalhou no Grupo Escolar João Bráulio Júnior desta cidade. Fez o Curso Normal no Colégio Notre Dame de Sion na cidade de Campanha, dirigido por freiras francesas e brasileiras e, mais tarde, cursou a Escola de Aperfeiçoamento Pedagógico em Belo Horizonte. Ao terminar o curso, foi nomeada Assistente Técnica do Ensino visitando escolas em Bom Sucesso, Itabira, Itaúna e Ouro Preto ${ }^{129}$. Publicou diversos artigos na Revista do Ensino e é autora de diversas obras ${ }^{130}$. Em 1945 exerceu, como Marta Nair, a Presidência da Associação de Professores Primários de Minas Gerais. No ano de 1950, tornou-se a primeira vereadora de Belo Horizonte. Foi professora da UFMG e é integrante da Academia Mineira de Letras.

Seu livro alterna textos de prosa e poesia que contam passagens importantes da sua vida. São, ao todo, 47 poemas e 9 capítulos que tratam de diversos temas, alguns mais pessoais como a família, namoro e casamento e outros relativos aos estudos e trabalhos realizados. A forma artística de apresentação dos eventos dificultaram as análises para a pesquisa já que muitas informações foram omitidas. É a única das memorialistas aqui estudadas ainda viva ${ }^{131}$.

\subsection{BIOGRAFIAS}

\subsubsection{HELENA ANTIPOFF: SUA VIDA, SUA OBRA}

Daniel Antipoff

\footnotetext{
${ }^{128}$ Parte das informações aqui tratadas fazem parte de duas entrevistas com a professora que se encontram no acervo do Centro de Referência do Professor da Secretaria Estadual de Educação de Minas Gerais, realizadas em Belo Horizonte em 1998, quando Alaíde contava 94 anos de idade. A primeira entrevista durou 2 horas e a segunda, 1 hora e 5 minutos.

${ }^{129}$ Concluída a Escola de Aperfeiçoamento, Alaíde foi nomeada Assistente Técnica do Ensino. Segundo ela, anteriormente, os inspetores eram apenas do sexo masculino, mas as assistentes técnicas mulheres estavam fazendo concorrência com os homens. Então o secretário acabou com o cargo de Assistente Técnico e criou o cargo de Inspetor de ensino que só podia ser assumido por homens. As Assistentes foram então chamadas para outro cargo e ela foi ser professora secundária do Instituto de Educação. A justificativa, que ela chama de desculpa, era de que o cargo exigia viagem e, por isso, era impróprio para mulheres.

${ }^{130}$ Entre suas obras encontram-se algumas infantis como $A$ bonequinha preta e $O$ bonequinho doce; didáticas como Nova Didática e Educação e língua, destinadas à educação formal primária como Meu coração e Poesia na escola,entre outras.

131 Devido a avançada idade da professora, optou-se por não entrevistá-la, utilizando-se apenas as entrevistas arquivadas no Museu da Escola.
} 


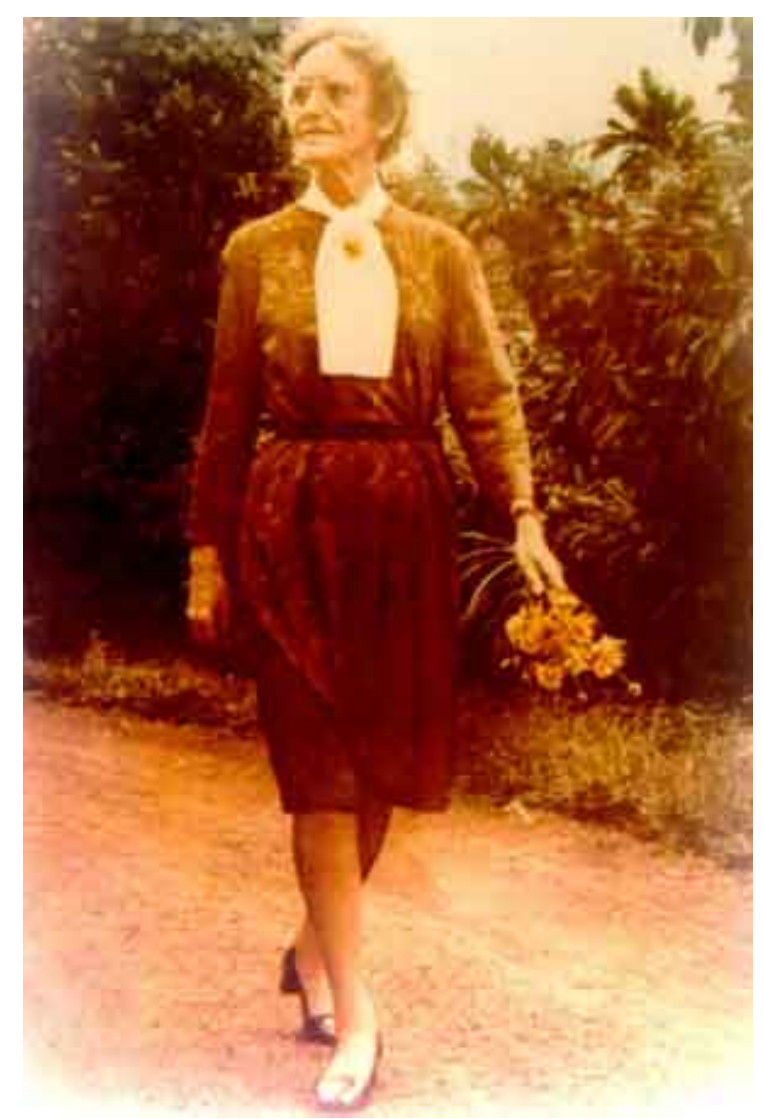

Diferentemente das memorialistas anteriores, Helena Antipoff é uma figura reconhecida nacional e internacionalmente por seu pioneirismo na introdução da psicologia na educação, tendo seu trabalho se incorporado na historiografia da paisagem mineira educacional.

Escrita por seu único filho ${ }^{132}$, a biografia de Helena Antipoff é, entre todos os documentos memorialísticos consultados, o mais completo, contemplando, como o próprio título indica, sua vida e obra.

Foto 11: Helena Antipoff (s.d.)

Fonte: http://www.pestalozzi.org.br/ASPX/historia helena.aspx Consulta em: 28 de julho de 2005

A riqueza de detalhes apresentada faz supor que o autor contou com um relato preciso da mãe, mas pode ter sido apenas devido ao diário íntimo mantido por esta e que teve algumas partes transcritas no texto. Além disso, em alguns momentos, parece que a narração é transformada em romance já que alguns fatos não presenciados nem pelo autor nem mesmo pela biografada são descritos ${ }^{133}$.

O autor não conta como obteve as informações para a produção da obra, especialmente ao relatar os fatos dos quais não participou, como os anteriores ao seu nascimento ou nos momentos em que não esteve junto da mãe. Por outro lado, ele

132 Outras obras produzidas pelo autor: ANTIPOFF, Daniel. Entre dois continentes. Belo Horizonte: [s.n.], 1997. 206 p.; ANTIPOFF, Daniel. Excepcionais e talentosos, os escolhidos. Belo Horizonte: Lastro Ed., 1999 2vol.; NAVA, Jose; ANTIPOFF, Daniel; MELO, Maria Alice Lisboa de. Aspectos da personalidade: em seleção de condutores de veículos. Belo Horizonte: Itatiaia, 1957. 97p.

${ }^{133} \mathrm{Um}$ exemplo disso é a narração sobre o comportamento do noivo de Helena, o espanhol Carlos Gonçalez Garcia, quando chegou ao seu apartamento e soube que a noiva teria descoberto que ele estava com tuberculose (1996, p.55). A descrição do que se passa no apartamento poderia ter sido dada por outra pessoa que presenciara a cena. No entanto, não há nenhum relato de que isso tivesse acontecido. 
comenta que a mãe lhe mandava do Brasil uma carta de pelo menos três páginas, semanalmente, contando suas observações e vivências.

Publicada um ano após a morte da biografada, a obra apresenta um prefácio de Otto Lara Resende e vinte e dois capítulos que abrangem desde o nascimento até a morte de Helena, compondo tanto os aspectos pessoais e familiares quanto os profissionais. Dentre os aspectos profissionais, estão narradas as experiências que mais interessam neste estudo. São apresentadas, ao final, uma cronologia com as condecorações recebidas por Helena Antipoff e as principais publicações da autora ao longo de sua vida. Metade da obra é dedicada à vida de Helena antes da chegada ao Brasil. O capítulo $\mathrm{X}$ traz a perspectiva de vir trabalhar no Brasil e, a partir do capítulo XIX, a sua chegada neste país e o trabalho aqui realizado.

Helena Antipoff nascera em Grodno (Rússia) a 25 de março de 1892. Era a filha mais velha do militar que chegara a General, Wladimir Vassilevitch Antipoff e Sofia Constantinova. Tinha duas irmãs, Zina, com quem compartilhava muitos momentos, e Tânia, caçula e bem mais nova que Helena ${ }^{134}$. Em 1909, a Rússia enfrentava uma série de problemas. Havia uma atmosfera de descontentamento no meio do povo em relação ao Czar e a introdução de idéias comunistas já era bem visível, o que provocava pânico especialmente entre famílias privilegiadas como a de Helena. Sua mãe decidira partir com as filhas para Paris, deixando o marido. Em julho de 1912, Helena fez um estágio na Inglaterra, trabalhando como preceptora de uma adolescente. Logo depois, estagiou num educandário para meninos considerados difíceis, Saint Helen's School. De volta a Paris, começou a estudar Medicina na Sorbonne, fazendo aulas também no Colégio de França. Começou a trabalhar com Theodore Simon na Sociedade para o Estudo da Criança, mas abandonou tudo e mudou-se para Genebra para trabalhar com Edouard Claparéde e, em 1914, tornou-se professora da Maison des Petits, uma escola de aplicação do Instituto Jean Jacques Rousseau. Este foi um ano bastante conturbado em toda a Europa com o início da Primeira Guerra Mundial. Helena recebera então a notícia de que seu pai estava ferido na Rússia e decidiu, mais uma vez, largar tudo e ir para sua terra natal ajudá-lo. Audaciosa, partira sozinha para a Rússia viajando por quarenta e oito horas em vagões de trem com pouquíssimas mulheres e muitos militares. Lá

\footnotetext{
${ }^{134}$ Criada em ambiente rico e com uma educação esmerada, Helena era uma menina ávida por leituras e conhecimentos de uma maneira geral. Buscava usufruir o máximo de cultura que a vida em Petersburgo lhe podia proporcionar, ia a teatros, balés, estudava piano e várias línguas.
} 
chegando, começou a trabalhar em Petersburgo cuidando de crianças deixadas órfãs e em miséria, devido à guerra. Casou-se informalmente, em 1918, com o jornalista Vítor Iretzky. Em março de 1919 nasceu Daniel Antipoff. Posteriormente, seu marido foi preso, considerado inimigo do povo. Segundo Helena, nada podia haver contra ele, mesmo assim, não conseguiu a sua liberação. Ela foi então morar num anexo do Reformatório de Menores de Petersburgo no qual começou a trabalhar. Em 1922, Vítor partira para o exílio na Alemanha e, em 1924, Helena e o filho foram ao seu encontro. Em janeiro de 1926, deixou o marido na Alemanha e transferiu-se com o filho para Genebra, retomando o trabalho com Claparède.

Alberto Álvares, em uma missão do governo mineiro, chegou ao Instituto Jean Jacques Rousseau para buscar professores para a Reforma Educacional que seria realizada no Estado. Leon Walther foi o primeiro a vir para o Brasil, embarcando em 1928, com um contrato de três meses de trabalho. Com a sua volta, Helena Antipoff veio substituí-lo. A professora resolvera deixar o filho na França aos cuidados de uma ex-aluna que havia criado uma escola-internato nos moldes escolanovistas. Helena desembarcou no Brasil em 6 de agosto de 1929 e, no dia 10, chegava a Belo Horizonte para um contrato de dois anos que se estendeu por mais tempo, instalando-se definitivamente no Brasil.

É surpreendente a capacidade de Helena Antipoff de conquistar as pessoas, mesmo os seus maiores adversários. Sua chegada a Belo Horizonte provocou desconfiança entre os mais conservadores. Mulher sozinha, russa, que deixara o filho na Europa $^{135}$; a professora despertava temores entre os belorizontinos, especialmente os católicos. Sua opção religiosa, comentada pelo filho, dá mostras do receio que ela devia despertar na conservadora capital mineira: “Ao que parece Helena Antipoff sempre se manterá independente em seu modo de sentir as religiões, respeitando-as todas, mas preferindo sempre dizer-se cristã, apenas" (1996, p. 83). O mais surpreendente é a habilidade da professora que conseguiu reunir em torno de si a sociedade mineira, alcançando reconhecimento e apoio para suas realizações, obtendo projeção, respeito e colaboração, inclusive dos antigos opositores. Um exemplo claro é o do Padre Álvaro

\footnotetext{
${ }^{135}$ Em outubro de 1938, Daniel Antipoff, às vésperas da Segunda Guerra Mundial e temendo sua situação na Europa como russo residente na França, decidiu mudar-se para o Brasil, contando então 19 anos de idade.
} 
Negromonte que se tornou vice-presidente da Sociedade Pestallozi criada por Antipoff em Minas Gerais ${ }^{136}$.

Em 1932, Helena Antipoff fundou a Sociedade Pestalozzi em Belo Horizonte que atendia aos alunos por ela chamados "excepcionais". Em 1939, quando a primeira turma do Instituto Pestalozzi se formara, se deparou então com a necessidade de pensar um espaço para os egressos do Instituto, criando uma escola rural denominada Fazenda do Rosário ${ }^{137}$.

Terminado o contrato com o governo de Minas Gerais, Helena transferiu-se para o Rio de Janeiro onde fundou a sociedade Pestalozzi do Brasil. Em 1947, a convite do prefeito da cidade de Brumadinho - cidade do interior de Minas e próxima da Fazenda do Rosário localizada em Ibirité - Helena Antipoff retorna à Fazenda, onde inicia cursos de formação de professores para o meio rural ${ }^{138}$. Em 1952 deixava definitivamente o Rio de Janeiro, voltando a residir em Belo Horizonte ${ }^{139}$. Entre 1939 e 1962, fora professora da Faculdade de Filosofia de Minas Gerais, posteriormente integrada à Universidade Federal de Minas Gerais. Foi fundadora da Faculdade e catedrática da cadeira de Psicologia Educacional. Apesar de sua aposentadoria como professora em

136 Para obter um relato do conflito entre o Padre e Helena Antipoff, bem como sua reconciliação cf. Daniel Antipoff (1996, p. 131).

${ }^{137}$ A Fazenda do Rosário ainda funciona atualmente e faz parte da Fundação Helena Antipoff. Localizase na cidade de Ibirité, a 26 quilômetros de Belo Horizonte. Sobre a Fazenda do Rosário e o trabalho de Helena Antipoff em prol da educação rural, cf. CENTRO DE Documentação e Pesquisa Helena Antipoff. Coletânea das obras escritas de Helena Antipoff. Belo Horizonte: Imprensa Oficial, 1992, vol. IV. "Educação rural" 209p.

${ }^{138}$ Em 1955, pelo decreto n. 4.830, de 12 de dezembro, foi criado o Instituto Superior de Educação Rural - ISER, integrado ao Centro Regional de Pesquisas Educacionais, com sede em Belo Horizonte e vinculada à Secretaria de Estado da Educação. O ISER foi inaugurado ainda em construção, no dia 06 de agosto de 1955. Sob o regime de internato, foram realizados muitos cursos de treinamento de professores, de orientadores e supervisores rurais. Em 25 de maio de 1970, foi promulgada a Lei Estadual n. 5.446/70, transformando o ISER em Fundação Estadual de Educação Rural Helena Antipoff. Em 1978, pela Lei n. 7.303, de 21/07/78, foi feita a fusão da Escola Estadual Sandoval Soares de Azevedo de $1^{\circ}$ Grau e Fundação Estadual de Educação Rural Helena Antipoff - FEER, em Fundação Helena Antipoff. O Governo do Estado, através do decreto n. 41.733, de 25 de junho de 2001, credenciou por cinco anos o Instituto Superior de Educação Anísio Teixeira autorizando o funcionamento do Curso Normal Superior. Em 28 de novembro de 2002, através do parecer de n 880 foi autorizado o funcionamento do Curso Superior de Educação Física e, em 27 de outubro de 2003, através do parecer 781, foi credenciado o Curso Superior de Matemática. De acordo com o atual Estatuto, aprovado pelo decreto n. 35.939 de 24/08/1994, a Fundação Helena Antipoff tem por finalidade instituir e manter cursos e atividades destinados à preparação de jovens para atuarem nas zonas urbanas e rural e à formação de recursos humanos para a educação. Informações retiradas do site: http://www.fundacaohantipoff.mg.gov.br/origem fha.htm - consultado em 06 de junho de 2005.

${ }^{139}$ Não fica claro na obra o período em que Helena Antipoff ficara no Rio de Janeiro, com a data exata de sua partida e sua volta. Em 1948, por exemplo, ela estaria dirigindo um curso para professores rurais em Ibirité. Entretanto, Daniel Antipoff revela que seria em 1952 a transferência da mãe, do Rio de Janeiro para Belo Horizonte. 
1962, continuou a trabalhar incansavelmente até a sua morte causada por um câncer em 09 de agosto de 1974.

Assim Lourenço Filho descrevia o trabalho de Helena Antipoff ao tratar da história da Psicologia no Brasil:

Grande influência tiveram, desde os primeiros anos, as lições de Helena Antipoff. A princípio, concorreram para a elevação do nível de formação especializada do professorado de Minas Gerais; depois, estenderam-se a grupos de professores de todos os Estados, que a Belo Horizonte acorreram; finalmente, passaram a influir no Rio de Janeiro, para onde Antipoff se transferiu por algum tempo, a fim de servir no Departamento Nacional da Criança, e na orientação de cursos para deficitários, no Instituto Pestalozzi. A obra que veio a realizar na Fazenda do Rosário, nas proximidades de Belo Horizonte, para o mesmo fim de educação de excepcionais da inteligência, é das mais belas do ponto de vista científico e humano. (Lourenço Filho, s.d, p. 284)

\subsubsection{LÚCIA CASASANTA, UMA JANELA PARA A VIDA}

Esta publicação é o resultado de uma monografia feita pela jornalista e escritora Ângela Leite de Souza. A autora ${ }^{140}$ comenta que pouco sabia de Lúcia Casasanta antes de iniciar o trabalho e que teve o auxílio direto da biografada na sua execução ${ }^{141}$ :

[Lúcia Casasanta] Cancelava compromissos, faltou à coroação de que participavam dois netos, varou noites e dias vasculhando a memória em busca de informações que me pudessem ser úteis. E as colocava pacientemente no papel, para que não se perdessem. Esses manuscritos, feitos com a correção de linguagem que se espera, foram o fio condutor de meu texto. Uma peça vital, portanto, dentro do presente trabalho. (1984, p.11)

\footnotetext{
${ }^{140}$ A autora é mineira de Belo Horizonte, cursou jornalismo na PUC do Rio de Janeiro tendo se formado em 1972. Trabalhou como redatora do jornal O Globo e da revista Veja, exercendo as funções de crítica literária. Possui ainda um livro de poemas: SOUZA, Ângela Leite de Castilho. Amoras com açúcar. Belo Horizonte: Imprensa Oficial, 1982. 114p.

${ }^{141}$ Lúcia Casasanta teria dado à autora uma agenda na qual escrevera lembranças livres que auxiliariam a realização da monografia. Além disso, Ângela teria feito também entrevistas com familiares e amigos da biografada. (Cf. Maciel, 2001, p. 58)
} 


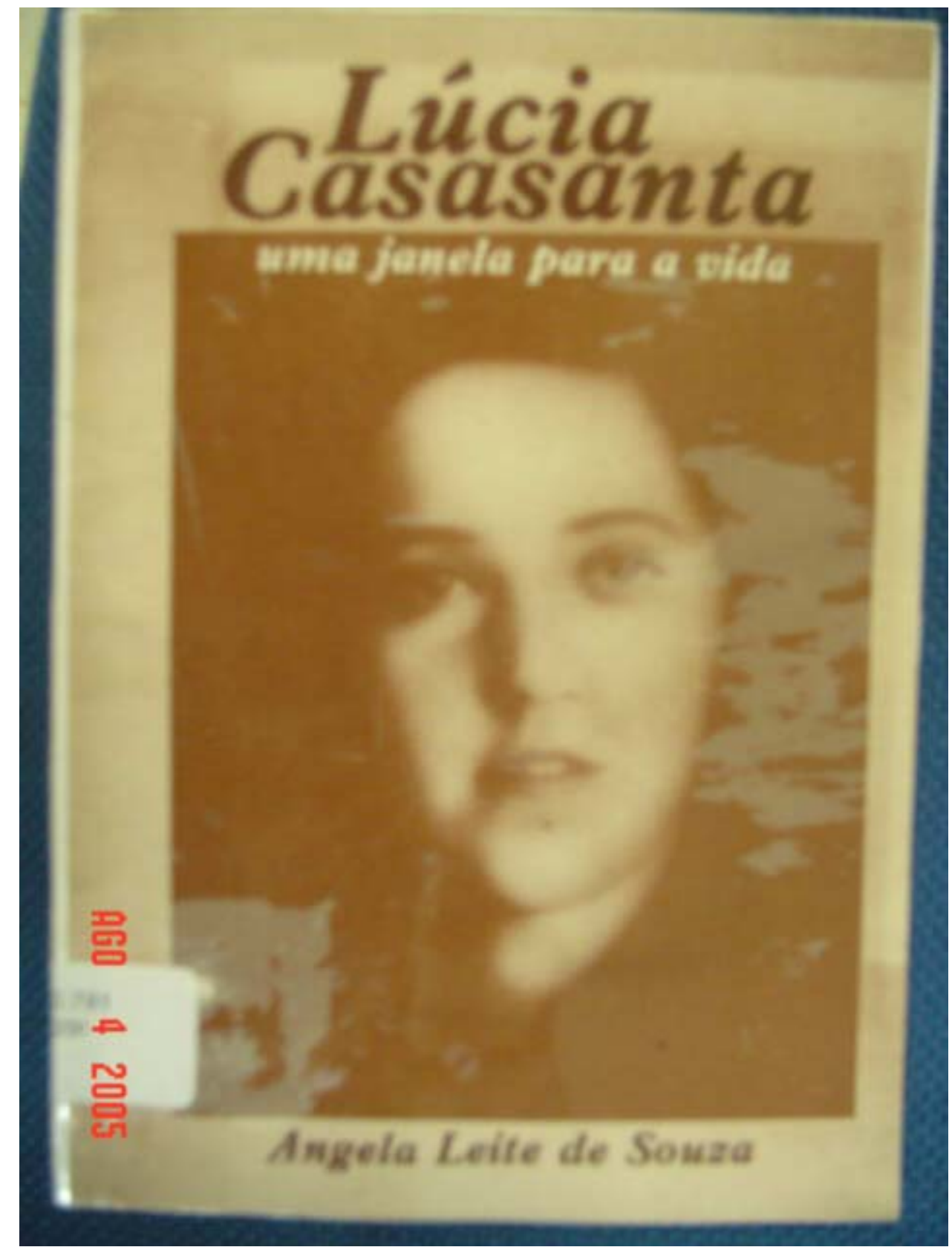

Foto 12: Capa do livro com a foto de Lúcia Casasanta (a data na foto é do dia da digitalização da imagem feita pela pesquisadora).

Fonte: SOUZA, Angela Leite de. Lúcia Casasanta, uma janela para a vida. Belo Horizonte: Imprensa Oficial, 1984.87 p.

O texto também integra a vida pessoal e profissional de Lúcia. A professora, nascida em 29 de maio de 1908, em Santa Luzia ${ }^{142}$, viveu parte de sua infância em Ouro Preto, onde iniciou sua vida escolar no Grupo Escolar Pedro II, finalizando o curso primário no Grupo Barão do Rio Branco, já na capital. Cursou a Escola Normal e era a

\footnotetext{
${ }^{142}$ Santa Luzia faz parte da região metropolitana de Belo Horizonte.
} 
mais nova do grupo de cinco professoras enviadas pelo governo mineiro para estudar no Teacher's College da Universidade de Colúmbia, Estados Unidos ${ }^{143}$. Segundo ela, só quatro horas antes do embarque teria recebido a permissão dos pais para esta viagem. Especializou-se em Metodologia da Língua Pátria e, após dois anos de estudos, voltou a Minas Gerais, tornando-se professora desta disciplina na Escola de Aperfeiçoamento.

Casou-se com Mário Casasanta ${ }^{144}$, viúvo e com quatro filhos, com quem teve outros seis, além de cuidar de uma neta que ficara órfã de mãe. Assim como as outras professoras aqui estudadas, as responsabilidades como mãe de família tinham que ser divididas com os compromissos profissionais. Foi grande divulgadora do Método Global de leitura, publicou livros de literatura infantil e didáticos ${ }^{145}$. O mais famoso deles, As mais belas histórias, compunha-se de um volume para cada uma das quatro séries do ensino primário, um pré-livro e um livro de leitura intermediária ${ }^{146}$. Teriam sido editados 4 milhões de exemplares desta obra, segundo um levantamento feito pela Editora do Brasil entre 1965 e $1984^{147}$. Lúcia Casasanta foi a primeira diretora do curso de Pedagogia no Instituto de Educação de Minas Gerais, permanecendo quatro anos neste cargo $^{148}$. Encerrou sua carreira profissional em 1977 como professora de Metodologia da Linguagem no referido curso.

A sua biografia tem início com uma exposição da autora sobre a biografada em que esclarece como foi a realização do trabalho. Os quatorze capítulos seguintes são organizados cronologicamente. Alguns deles tratam mais de aspectos pessoais como o primeiro Ouro e Palha, que discorre sobre seu nascimento, família e infância; o décimo segundo Uma doce devoção que trata da família constituída após o casamento com

\footnotetext{
${ }^{143}$ Em 1926, Lúcia Casasanta foi eleita a primeira presidente da Associação das ex-normalistas; ainda recém-formada, começou a atuar como professora substituta no Grupo Escolar Afonso Pena. Seu sucesso profissional foi importante para ser escolhida para integrar a comissão de professoras que iam aos Estados Unidos, quando Lúcia tinha apenas 19 anos. (Cf. Maciel, 2001,p. 17)

${ }^{144}$ Mário Casasanta (1898-1963) teve diversos cargos na burocracia educacional mineira: foi InspetorGeral da Instrução Pública, diretor do Instituto de Educação, entre outros cargos importantes. Foi professor, advogado e escritor, deixando várias obras publicadas.

${ }^{145}$ Segundo Francisca Maciel (2001), seu único livro teórico é: CASASANTA, Lúcia M. Métodos de ensino de leitura - didática da linguagem: comunicação e expressão. São Paulo: Editora do Brasil, 1972. Maciel afirma ainda que Lúcia não deixara grande produção teórica e que a co-produção teria sido uma de suas características ao preparar suas alunas para a produção de materiais didáticos.

${ }^{146}$ Maciel (2001) informa que a coleção didática As mais belas histórias é composta de seis volumes destinados aos alunos e cinco volumes de orientação aos professores.

${ }^{147}$ Cf. Ângela Souza, 1984, p. 54.

${ }^{148}$ Em 1946 a Escola de Aperfeiçoamento havia sido transformada em Curso de Administração Escolar que foi tornado curso de Pedagogia após a lei federal n. 5.540 de 28 de novembro de 1968. Lúcia Casasanta participou da reorganização do curso para transformá-lo em superior e tornou-se sua primeira diretora.
} 
Mário Casasanta e o último Toque de clarim, tratando do cotidiano de Lúcia naquele momento, seus interesses e impressões sobre a educação vigente. O livro traz ainda uma cronologia de sua vida e algumas fotos pessoais e do trabalho, ao final. Os capítulos são curtos e nem sempre é fácil distinguir a autora e a biografada, já que suas impressões e relatos ficam bastante entrelaçados no texto.

Sobre a professora, Francisca Maciel ${ }^{149}$ salienta:

É inegável a importância da professora Lúcia Casasanta no cenário educacional mineiro, como um das mais destacadas participantes da significativa inovação metodológica que ocorreu no ensino em Minas Gerais nos anos 30 do século XX, tendo se destacado sobretudo na área da alfabetização, como defensora e propagadora do método global para a aprendizagem da leitura e da escrita. (2001, p. 10)

Lúcia Casasanta faleceu em $1989^{150}$.

\subsection{TEMPOS DE LEMBRAR}

Para além das páginas em que se registraram os momentos difíceis e alegres que compuseram a vida destas professoras mineiras, existem outras personagens da história, também professoras que, por diversos motivos, guardam as passagens da sua vida escolar nas gavetas, nas fotos, nos diplomas já amarelados pelo tempo, mas não se dispuseram a escrever sobre este período. Por este motivo, optou-se por utilizar a história oral temática numa tentativa de reconstituir os pontos soltos da história, de remendar as falhas deixadas pelos escritos memorialísticos. Com este objetivo, alguns ex-alunos, ex-alunas e ex-professoras de Grupos Escolares belorizontinos foram convidados a recuperar as lembranças dos tempos da infância ou da juventude vividos na escola.

\subsubsection{ENTREVISTAS UTILIZADAS NA PESQUISA}

Uma parte dessas lembranças faz parte do Banco de Depoimentos Orais do Centro de Referência do Professor em Belo Horizonte:

\footnotetext{
${ }^{149}$ Francisca Maciel defendeu uma tese sobre Lúcia Casasanta e o método global de contos em 2001, na Faculdade de Educação da UFMG.

${ }^{150} \mathrm{O}$ arquivo pessoal da autora foi doado à Faculdade de Educação da UFMG, após o seu falecimento.
} 


\subsubsection{OLGA COELHO ULLMAN ${ }^{151}$}

Natural de Oliveira, interior de Minas Gerais, teve uma professora em todo o curso primário no Grupo Escolar Francisco Fernandes de Oliveira, único da cidade no período. Queria ser advogada, mas o pai a matriculou na Escola Normal Nossa Senhora de Oliveira. Ao terminar o curso, foi ser estagiária em Carmópolis de Minas ${ }^{152}$. Passados dois anos, cursou a Escola de Aperfeiçoamento em Belo Horizonte. Finalizado o curso, retornou a Carmópolis até a transferência para Oliveira, quando foi designada para diretora do Grupo Escolar Desembargador Continentino. Em 1948 veio a Belo Horizonte fazer um curso de Educação Sanitária e auxiliou Helena Antipoff no primeiro Curso de Educação Rural na Fazenda do Rosário. Ao final do curso, voltou para Oliveira e reassumiu como diretora. O então Secretário de Educação, Abgar Renault, esteve em Oliveira e a convidou para voltar à Fazenda do Rosário. Ela voltou e foi trabalhar no segundo Curso de Educação Rural na Fazenda do Rosário onde ficou até 1963, quando se aposentou.

\subsubsection{TEREZINHA CASASANTA ${ }^{153}$}

Natural de Campanha, sul de Minas, fez o curso primário nas classes anexas à Escola de Aperfeiçoamento, o curso ginasial em um colégio de freiras em Belo Horizonte e o Curso Normal no Instituto de Educação, que deixava de ser Escola de Aperfeiçoamento Pedagógico para ser um curso de formação de professores. Trabalhou como substituta no Grupo Escolar Bueno Brandão e Barão do Rio Branco, onde se efetivou. Fez parte da primeira turma a se especializar nos Estados Unidos no convênio do PABAEE.

\footnotetext{
${ }^{151}$ A entrevista com D. Olga Coelho Ullman foi realizada em dois dias diferentes em Belo Horizonte, no ano de 1998. A primeira entrevista durou 1 hora e 34 minutos e a segunda, 1 hora e 33 minutos. Ela estava com 78 anos no momento da entrevista podendo-se deduzir que ela tenha nascido no ano de 1920.

${ }_{153}^{152}$ Naquela época Carmópolis de Minas chamava-se Japão de Oliveira.

${ }^{153}$ A entrevista com Terezinha Casasanta ocorreu em Belo Horizonte no dia 04 de agosto de 1999 e durou 1 hora e 13 minutos.
} 
Além das entrevistas armazenadas no Centro de Referência do Professor, duas professoras foram convidadas a complementar as informações, direcionando as conforme as questões mais significativas desta pesquisa.

\subsubsection{ENTREVISTAS PRODUZIDAS PELA PESQUISA}

\subsubsection{ELZA DE MOURA}

Elza de Moura nasceu em 1915, cresceu e vive até hoje no bairro Santa Efigênia em Belo Horizonte, onde estudou no Grupo Escolar Henrique Diniz. Cursou a Escola Normal Modelo e, após a sua conclusão, ficou seis anos estudando piano e canto até uma amiga a convidar para lecionar no Grupo Escolar Flávio dos Santos. Matriculou-se na Escola de Aperfeiçoamento e depois trabalhou no Grupo Escolar Lúcio dos Santos e novamente no Grupo Flávio dos Santos, além de ter sido orientadora técnica no Grupo Escolar Sandoval de Azevedo e diretora do Grupo Escolar Henrique Diniz.

\subsubsection{IMENE GUIMARÃES}

Décima filha de uma família de onze irmãos, Imene Guimarães nasceu em Belo Horizonte em janeiro de 1911. Por causa da doença e morte de seu pai, ingressou aos nove anos no Grupo Escolar Barão do Rio Branco, onde estudou com a mesma professora durante todo o curso primário. Em 1924, foi aprovada no exame de admissão da Escola Normal Modelo de Belo Horizonte e, em 1928, ingressou na Escola de Aplicação criada pela Reforma Francisco Campos. Lecionou alguns meses como estagiária no Grupo Escolar Barão do Rio Branco até ser transferida como professora para as classes anexas à Escola de Aperfeiçoamento. Após dois anos de magistério, começou a cursar a Escola de Aperfeiçoamento de onde saiu para trabalhar no Instituto Pestalozzi. Foi também inspetora de ensino secundário em vários colégios de Belo Horizonte, orientadora e, posteriormente, diretora do Grupo Escolar Barão do Rio 
Branco. Mesmo após a aposentadoria em 1955, permaneceu trabalhando como inspetora de ensino secundário, entre outros trabalhos realizados.

Outras professoras entrevistadas para a pesquisa:

\subsubsection{LUÍZA TRAVASSOS RIBEIRO CAMPOS}

Caçula de uma família de quatorze filhos, Luíza nasceu em 1918, na cidade de Belo Horizonte. Estudou no Jardim de Infância Delfim Moreira, fez a primeira série no Grupo Escolar Cesário Alvim e as três últimas séries do primário no Grupo Escolar Barão de Macaúbas. Após o curso primário, ela ficou um ano estudando com professores particulares para o exame de admissão na Escola Normal Modelo. Depois de sete anos de curso, concluiu os estudos na Escola Normal, em 1937. No entanto, ficou dois anos sem conseguir emprego porque dependia de apadrinhamento político. Helena Antipoff lhe conseguiu então dois alunos particulares, egressos do Instituto Pestalozzi, além de outras aulas particulares que oferecia em sua própria casa. Quando houve um concurso, precisou apresentar duas cartas de recomendação: uma do Instituto Pestalozzi que lhe indicava alunos para trabalhar e outra do pai de um de seus alunos particulares. Aprovada na seleção, foi nomeada em 1946 como professora do Grupo Escolar Sandoval de Azevedo, onde trabalhou até 1972, quando se aposentou.

\subsubsection{MARIA APARECIDA TRINDADE SANTOS (Dª. YÁ)}

Nasceu na cidade de Oliveira, interior de Minas Gerais, em setembro de 1912. Estudou no Grupo Escolar Francisco Fernandes e fez o Curso Normal na Escola Nossa Senhora de Oliveira, ambos em sua cidade natal. Aos dezoito anos, mudou-se com a família para Belo Horizonte e foi trabalhar como professora do Grupo Escolar Olegário Maciel, onde lecionou até se aposentar. 


\subsection{AS PROFESSORAS COMO ALUNAS: UM PERCURSO DE FORMAÇÃO}

Conhecer um pouco da história de vida profissional dessas mulheres que fizeram a história da educação em Minas Gerais é de suma importância para compreender o universo das salas de aula e também as subjetividades que permeavam Reformas e currículos, afinal, como salienta Eliane Marta T. Lopes:

O professor, a professora não é uma abstração ou ente metafísico. Se tem uma inserção material concreta - econômica, social, política - tem também uma inserção psíquica concreta. Foi criança, sujeita às manifestações e expressões das idéias religiosas e às repressões da sexualidade. (2003, p.70)

As lembranças de todos os entrevistados foram sempre muito positivas do período escolar, desde o curso primário até a Escola de Aperfeiçoamento. Esta última, entretanto, ocupa um lugar especial nas memórias de suas ex-alunas. Para as moças de Belo Horizonte e interior, cursar a Escola de Aperfeiçoamento trazia uma distinção não apenas no campo profissional, mas também social. A vinda das alunas-professoras para a capital, morando em pensões, alterou o cenário da cidade, como comenta Imene Guimarães: "Então foi aquela turma que invadiu Belo Horizonte. Tinha gente de todo jeito, tinha até misses, naquele tempo que usava muito aquele negócio de miss. Elas todas usavam umas boinas na cabeça porque naquela época mulher nenhuma saia na rua sem chapéu". Entretanto, nem todas eram jovens, havia até avós que deixaram suas famílias e vinham estudar na capital. De acordo com Imene Guimarães, as primeiras turmas da Escola de Aperfeiçoamento foram escolhidas da seguinte forma: o governo mandou pedir em determinadas escolas que indicassem a melhor professora e elas vieram sem saber por que motivo haviam sido chamadas ${ }^{154}$.

O poema de Carlos Drummond de Andrade retrata um pouco das mudanças provocadas pela chegada das alunas-professoras na cidade de Belo Horizonte em finais dos anos vinte.

\footnotetext{
${ }^{154}$ Conforme Ângela Souza (1984, p. 38), as primeiras turmas da Escola de Aperfeiçoamento foram
} formadas por 142 professoras do interior de Minas, e o curso teve início em 13 de março de 1929. 


\section{As moças da Escola de Aperfeiçoamento}

São cinqüenta, são duzentas

são trezentas

as professorinhas que invadem

a desprevenida Belô?

São cento e cinqüenta, ou mil boinas azuis e verdes e róseas, alaranjadas

e negras também roxas,

os lábios coracionais

e os tom pouce petulantes

que elas ostentam, radiosas?

De onde vêm essas garotas?

Eu que sei?

Vêm de Poços, de São João

del Rei, Juiz de Fora, Lavras,

Leopoldina, Itajubá,

Montes Claros, Minas Novas,

cidades novas de Minas

ainda não cadastradas

no índice Coreográfico

de Pelicano Frade?

E são assim tão modernas,

tão chegadas de Paris

par le dernier bateau

ancorado na Avenida

Afonso Pena ou Bahia,

que a gente não as distingue

das melindrosas cariocas

em férias mineiras?

Que vêm fazer essas jovens?

Vêm descobrir, saber coisas

de Decroly, Claparède,

novidades pedagógicas,

segredos de arte e técnica

revelados por Helène

Antipoff, Madame Artus,

Mademoiselle Milde, mais quem?

Ou vêm para perturbar

se possível mais ainda

a precária paz de espírito

dos estudantes vadios

(eu, um deles)

que só querem declinar

os tempos irregulares

de namorar e de amar?

Ai, o mal que faz a Minas

a nós, pelo menos, tão frágeis

irresponsáveis, dementes

cultivadores da aérea

flor feminina fechada

em pétalas de reticência,
Carlos Drummond de Andrade

a Escola novidadeira, dita de Aperfeiçoamento!

A gente não dava conta de tanto impulso maluco doridamente frustrado ante a pétrea rigidez dos domésticos presídios onde vivem clausuradas as meninas de Belô, e irrompe essa multitude de boinas, bocas, batons escarlates, desafiando a nossa corda sensível. Que faz Mário Casasanta, autoridade do ensino, que não devolve essas moças a seus lugares de origem? Chamo seu Edgarzinho, responsável pela Escola. Que ponha reparo - peço-lhe nas crianças do interior que ficaram sem suas mestras. Convém restituí-las logo à tarefa habitual.

Ele responde: "São ordens do Doutor Francisco Campos, nosso ilustre Secretário de Educação e Cultura. Carece elevar o nível do ensino por toda a parte. Vá-se embora, não insista em perturbar nossos planos racionais."

Vou-me embora. Já na esquina a boina azul universal que faz de Belô um céu pousado em pelúcia verde. Sua dona, deslizante entre formas costumeiras é diferente de tudo e não olha para mim deslumbrado, derrotado, que vou bobeando assim. Não há professora feia? Pode ser que haja. A vista, até onde o sonho alcança, cinge a todas de beleza, e a beleza, disse alguém, é mortal como um punhal. 
Segundo Olga Ullman, a princípio, a Escola de Aperfeiçoamento não tinha muito bom nome por causa do comportamento das alunas. Certamente, como na imaginação do poeta Carlos Drummond de Andrade, os mineiros não viam com bons olhos aquelas moças e mulheres ${ }^{155}$, longe de suas famílias, morando numa cidade grande, muitas delas em pensões, e, o mais surpreendente, buscando uma qualificação profissional numa época em que o destino de uma moça de família era o casamento ${ }^{156}$.

A professora revelou que, para evitar maiores comentários, a diretora Amélia Monteiro $^{157}$ era muito exigente para melhorar o nome da escola ${ }^{158}$. Seu empenho foi recompensado. Estudar na Escola de Aperfeiçoamento tornou-se um marco para as

\footnotetext{
${ }^{155}$ Segundo uma pesquisa realizada em 1933 sobre as alunas da Escola de Aperfeiçoamento, as idades das alunas variavam entre 19 a 46 anos, com maior freqüência para aquelas de 22 e 23 anos sendo as solteiras $88 \%$ do total. VIOTTI, Julia de Magalhães. Contribuição à antropologia da moça mineira. Boletim n. 13. Belo Horizonte: Secretaria da Educação e Saúde Pública; Inspetoria Geral da Instrução, 1933.73p.

${ }^{156}$ Um romance intitulado República Decroly publicado em 1935 em Belo Horizonte revelava a história de uma moça do interior que veio para Belo Horizonte estudar no chamado Pedagogium (no romance os nomes são um pouco diferentes do original e a semelhança não é mera coincidência. Fica claro que esta instituição seria a Escola de Aperfeiçoamento de professoras.) A moça, chamada Zuleica, filha única de um poderoso fazendeiro, era ingênua, muito dedicada aos estudos, muito religiosa (queria mesmo ter se tornado freira), foi morar numa república de moças, chamada República Decroly. Apesar de ter deixado de morar em um colégio de freiras e ido para a República, ela mantinha um comportamento correto, ou melhor, adequado para uma moça da época. No entanto, enamorou-se de um funcionário da Secretaria de Educação, um rapaz aproveitador que só queria divertir-se com ela. Cheia de boas intenções e bons sentimentos, Zuleica se deixava envolver sem desconfiar da desonestidade do rapaz. Para piorar a situação, um jornal de oposição do governo criticava a Escola e suas alunas dizendo que haviam mudado para a capital para namorar e não para estudar, estando algumas morando livres em repúblicas. O pai de Zuleica, sabendo de tais notícias e recebendo uma carta da filha informando estar residindo em uma república, dirigiu-se à capital, preocupado com a situação da filha. Ao chegar lá, o jornaleiro na estação já divulgava a triste notícia: em um acidente de carro envolvendo três alunas do Pedagogium e dois funcionários da Secretaria de Educação, Zuleica fôra a única a falecer. $O$ jornal teria aproveitado a situação para piorar ainda mais a imagem do Pedagogium e de suas alunas, levantando todo tipo de especulações sobre a vida das moças e criticando o envolvimento dessas com funcionários da Secretaria de Educação, que se aproveitavam da ingenuidade das moças do interior. $O$ romance, portanto, reafirmava o perigo que sofriam as moças longe de suas famílias, morando em residências comuns e que, por mais bem intencionadas, sérias e dedicadas acabavam por se enredar em situações perigosas com rapazes aproveitadores. Segundo Paixão (1985), não eram raras as histórias de professoras rurais que se envolviam com fazendeiros que, certamente, lhe garantiam o emprego. Podemos deduzir que também no meio urbano tais histórias aparecessem, estando as professoras primárias sempre na dependência de intermediários políticos para obter uma colocação profissional. O romance, nesse caso, se basearia nessas representações sobre as relações entre as normalistas ou professoras e políticos locais. De acordo com Ângela Souza (1984, p. 42), este romance teria vendido 1.200 exemplares em apenas dez dias. O autor que satirizava a Escola teria, posteriormente, matriculado lá seu próprio filho: Francisco de Assis Andrade.

${ }^{157}$ O primeiro diretor da Escola foi Lúcio José dos Santos que, segundo Prates (1990, p.15), foi escolhido não por seus vínculos com o Ensino primário ou Normal, mas por ser um intelectual e fervoroso líder da Igreja Católica no Estado. Tendo permanecido por um ano na direção do estabelecimento, foi substituído por Amélia de Castro Monteiro que também era "católica fervorosa e profundamente rígida no que dissesse respeito a princípios morais".

${ }^{158}$ Segundo Prates (1990), a entrada na Escola de Aperfeiçoamento era feita de diversas formas durante o seu período de funcionamento: indicação e inscrição, testes e sistemas mistos em outros momentos.
} 
professoras mineiras. Talvez para ressaltar a importância da formação que receberam, as ex-alunas continuem a saudá-la como o que houve de melhor na educação em Minas no período. Todas as entrevistadas falaram do orgulho que sentiam de cursar a Escola Normal e, especialmente, a Escola de Aperfeiçoamento ${ }^{159}$, como revela o depoimento de Olga Coelho Ullman que reúne as percepções dos entrevistados e memorialistas aqui estudados acerca da referida instituição:

Era um prazer imenso ir à escola [de Aperfeiçoamento]. Aprender, como eu já lhe disse, algumas coisas que eu ignorava como professora. Então cada dia se descobria coisas que naquela vida rotineira de professora você nunca alcançou. E a escola vinha abrir os olhos, a mente e o coração por tudo aquilo de bom, de alegre. E tudo feito debaixo de uma satisfação imensa em descobrir as coisas.

$[\ldots]$

Os professores só faltavam abrir o coração e nos dar. Porque foram todos tão amáveis, tão bons, tão atenciosos, tão compreensivos. Tudo aquilo era motivo de alegria.

Em geral, as falas estavam sempre recheadas de grande saudosimo pelas exalunas e ex-professoras, seja no curso primário ou normal. Mas os elogios das professoras que cursaram a Escola Normal Modelo e a Escola de Aperfeiçoamento ${ }^{160}$ são surpreendentes. Não se poupam exclamações às professoras e colegas, cujos nomes vêm sempre associados aos adjetivos: extraordinária, notável, brilhante, entre outros. Entre todas, Helena Antipoff é seguramente lembrada por todas as alunas que passaram pela Escola de Aperfeiçoamento como uma professora excelente, e os comentários sobre o seu trabalho sempre relembram as grandes contribuições deixadas por ela em Minas Gerais e no Brasil. Para Alaíde Lisboa, Helena Antipoff era a mulher mais notável que já tinha visto na vida e é impressionante o quanto esta opinião é reiterada pelas outras colegas professoras.

\footnotetext{
${ }^{159}$ Faria Filho (2000) chama a atenção para o aspecto físico das escolas e de sua construção arquitetônica que visavam, também, educar. Não por acaso, a Escola de Aperfeiçoamento teria ocupado sempre prédios grandiosos.

${ }_{160} \mathrm{O}$ corpo docente da Escola de Aperfeiçoamento era composto de cinco professoras mineiras que haviam estudado nos Estados Unidos: Alda Lodi (professora das classes anexas da Escola Normal Modelo); Lúcia Schmidt Monteiro de Castro (posteriormente, Lúcia Casasanta) e Benedita Valadares Ribeiro (professoras do Grupo Escolar Barão do Rio Branco) e Amélia de Castro Monteiro (vice-diretora do Grupo Escolar Silviano Brandão), Inácia Ferreira Guimarães (professora na Escola Normal Modelo). Theodore Simon trabalhou quatro meses na Escola, lecionando Psicologia, assim como Leon Walther que ficara um semestre em Belo Horizonte. A professora de Desenho e Modelagem, Mme. Artus Perrelet lecionara por dois anos e foi substituída por Jeanne Louise Milde que permanecera no Brasil, naturalizando-se, bem como Helena Antipoff. A cadeira de Educação Física era ministrada por Renato Eloy Andrade e, após o seu falecimento, foi substituído por sua assistente, Guiomar Meireles Becker, que também permaneceu na Escola até o seu fechamento. (Cf. Prates, 1989 e 1990).
} 
Elza de Moura chegou a afirmar que não há, atualmente, professores que marcam os alunos como os de antigamente. A marca do bom professor seguia as alunas que se engrandeciam por ter participado de suas aulas. Maria Cecília C. C. de Souza (2000) comenta que, para além daqueles professores cujo comportamento era visto como pitoresco, às vezes beirando o ridículo, existiam também os que criavam fama e marcavam para sempre a memória de seus alunos:

Se o anedotário sobre os professores pontuava de imagens pitorescas essas memórias, como forma de distinguir os memorialistas das ingenuidades dos seus professores, o hábito de mencionar, entretanto, em muitas delas, os nomes completos dos professores e professoras, algumas vezes grafados em tipos graúdos, para que o autor fosse reconhecido como aluno do professor Fulano ou da professora Sicrana, dá bem a idéia da marca dos bons professores sobre os alunos, e o reconhecimento implícito da comunidade sobre a excelência do seu trabalho, extensivo aos discípulos. (Souza, 2000, p. 83)

A princípio, a relação com os professores é recheada de bons exemplos e boas lembranças. As professoras falam de uma exigência de muito respeito aos professores em todas as escolas pelas quais passaram. Os professores são representados como severos, rigorosos mas, ao mesmo tempo, compreensivos, simpáticos, envolvidos e interessados pelos seus alunos. A exigência de dedicação ao estudo, por parte de professores vistos como muito exigentes, contribui para construir esta imagem de escola de qualidade e seriedade. Segundo Elza de Moura, havia muita liberdade na Escola Normal e de Aperfeiçoamento para as alunas exporem as suas opiniões.

\footnotetext{
R: Como era o relacionamento com os professores na Escola Normal?

EM: Ah, muito livre. A gente falava o que queria [risos]

$\mathrm{R}$ : Com toda essa liberdade?

EM: Toda liberdade.

R: Uma liberdade tal como nos dias atuais?

EM: Não. Hoje é desrespeito. Nós éramos alunas de Biologia do Dr. Osvaldo Melo Campos da Escola de Medicina e ele nos tratava com certo desprezo. Meninas, né? E um dia ele falou assim. "Vou marcar uma argüição, quem não vier eu dou zero". Ele marcou, quase ninguém foi lá e ele não deu zero. Uma colega chegou na mesa dele e disse assim: "Professor precisa ter caráter, ter palavra. O senhor falou que ir dar zero por que não deu?" Ele sorriu. Ouviu, sorriu e não fez nada.
}

Adentrando um pouco mais nas memórias, vão surgindo algumas exceções. Encontram-se alguns professores, cujas lembranças não são assim tão grandiosas ou agradáveis. Conforme Elza de Moura, Osvaldo Melo Campos, pelo fato de ser professor da Escola de Medicina, não levava as alunas da Escola Normal muito a sério. Imene 
Guimarães também comentou que o professor José Olinto Ribeiro de Andrada não era muito bom. Ainda segundo ela, Martí Perrelet, professora de artes que veio com a missão européia para Belo Horizonte, não foi bem aceita porque as alunas a achavam muito grosseira. Então, Mademoiselle Milde ${ }^{161}$ veio substituí-la e agradou a todos: "era uma delicadeza em pessoa". Ela comenta ainda que Leopoldo Pereira era um grande professor, muito bom, mas muito bravo. Na sua opinião, era ótimo para ensinar, mas não era um bom educador. Quando uma de suas alunas errava a lição, ele gritava: "Moça de cabeça dura!”. Apesar disso, ela não deixa de elogiá-lo dizendo que aprendeu muito com suas aulas. As lembranças de Imene Guimarães sobre a professora de música, Branca de Carvalho Vasconcellos, também envolvem momentos difíceis:

I.G.: Ela era muito brava. Nossa Senhora! Todo mundo tinha medo dela, exigia muito. Eu me lembro que nós tínhamos um livro de solfejo, então a gente tinha que solfejar aquilo, depois ela falava assim: "Passa pra tal clave e tal tom" e eu nem sei o que era e eu que não tinha dom nenhum de música, porque eu não tenho nenhum dom artístico, eu sofria com a coisa e a minha mão até inchou de tanto marcar compasso.Pra poder estudar aqueles solfejos.

$\mathrm{R}: \mathrm{E}$ o que ela fazia quando ficava brava?

I.G.: Ela zangava, ela xingava, ela falava que ia dar não sei quantos zeros pra gente.Que ia reprovar, mas era só ameaça, acabou me dando distinção.

Segundo Imene Guimarães, na Escola Normal, exigia-se silêncio absoluto das alunas durante as aulas, em sinal de respeito aos professores. As punições eram sempre dar notas baixas para as indisciplinadas e ela chegou a presenciar um professor mandando uma aluna para fora de sala, mas não se lembra o motivo. Para ela, o professor de Geografia, que era médico, não sabia a matéria. Levava um papelzinho e ficava lendo para as alunas. Além das aulas ruins, três anos depois, as alunas tinham que fazer prova oral e escrita da matéria dada durante todo este período. Foi então que ela disse ter cometido uma indisciplina:

I.G: Caiu pra mim vulcão e ele queria que eu falasse aquela Coroa de Fogo do Pacífico, o nome de todos os vulcões e a ordem que eles apareciam, então eu virei pra ele e falei: "Não sei e não quero saber, isto não tem influência nenhuma na minha vida".

$\mathrm{R}$ : Na prova oral, Dona Imene?

I.G.: Na prova oral. Eu tinha feito uma prova escrita muito boa, mas eu não gostava dele e o professor de História, o tal de Cipriano de Carvalho, sacudiu a cabeça assim, me aprovando, eu saí da sala, era a prova final.

\footnotetext{
${ }^{161}$ Mme. Milde é a artista belga Jeanne Milde.
} 
Apesar da severidade dos professores, os comportamentos de Imene e Elza de Moura revelam que as alunas questionavam aqueles professores que não correspondiam às suas expectativas. Interessante notar que todos os docentes criticados eram do sexo masculino para quem, possivelmente, dar aulas na Escola Normal e de Aperfeiçoamento constituía uma atividade menor ${ }^{162}$. Como, para as mulheres, a educação era praticamente a única atividade profissional que podiam exercer e obter algum reconhecimento social, a docência nas Escolas Normal e de Aperfeiçoamento correspondia ao grau máximo na carreira profissional para o período. É interessante notar também que, segundo os relatos, os professores das Escolas Normal e de Aperfeiçoamento nem sempre conseguiam colocar em prática os preceitos da moderna pedagogia da época. Talvez porque a imagem da severidade, da exigência da disciplina e do aprendizado do conteúdo tivesse maior importância no ensino para professoras do que no curso primário.

As lembranças são bastante agradáveis, quando tratamos das entrevistas orais, mas, no caso das memórias escritas, as professoras se permitiram mostrar que nem sempre o universo escolar era isento de problemas, conflitos e injustiças. Marta Nair Monteiro discute os problemas da classe profissional no que tange à luta por seus direitos mas são, especialmente, as memórias de Benedita Dell’Isola e Maria da Glória Arreguy que revelam difíceis realidades vivenciadas pelas mestras de outrora. As memórias destas duas professoras são semelhantes em alguns aspectos. As duas nasceram e residiram no interior, fizeram algumas mudanças e moraram um período em Belo Horizonte. A situação de insegurança na carreira estava continuamente presente. As diversas mudanças, a necessidade de maior qualificação profissional, os conflitos com diretores de escolas e as injustiças sofridas vão compondo o cenário da vida profissional dessas mulheres. Outra semelhança no relato de ambas é a pouca ênfase à questão familiar. A vida na escola, as lembranças do trabalho ganham a cena nas memórias dessas escritoras. São memórias que retratam um duro caminho traçado por mulheres que deixavam casa, marido e filhos em busca de melhores condições profissionais.

\footnotetext{
${ }^{162}$ É preciso, no entanto, não generalizar. Segundo Maciel (2001, p. 60), os professores Oswaldo de Melo Campos e Ignácia Ferreira Guimarães foram os que mais influenciaram Lúcia Casasanta não somente pela sua competência profissional, mas também pelo compromisso com a educação. Por isso, não se pode afirmar que os homens não estivessem comprometidos com a educação.
} 
O cotidiano de incertezas e dificuldades, entretanto, não era exclusivo das duas memorialistas e começava ainda antes da formação profíssional. Luíza Travassos conta que passou um ano estudando para o exame de admissão na Escola Normal Modelo. Imene Guimarães comenta que as trinta vagas eram disputadíssimas por ser uma escola de boa qualidade e gratuita. Quando cursava o terceiro e penúltimo ano da Escola Normal Modelo, houve a Reforma Francisco Campos e a aluna ainda teve que fazer o Curso de Aplicação criado pela Reforma. Terminado o Curso Normal, nem todas conseguiam emprego nas escolas. Elza de Moura ficou seis anos sem lecionar por opção, mas Luíza Travassos conta que chegou a esperar, em vão, mais de oito horas na Secretaria de Educação tentando conversar com o Secretário e obter uma vaga. Sua situação profissional só se estabilizou quando, nove anos após a conclusão do Curso Normal, fez o primeiro concurso que apareceu, tendo sido aprovada ${ }^{163}$. Benedita Dell'Isola também precisou cursar a Escola Normal para se manter no cargo de professora. Mesmo casada, grávida e com filhos precisou estudar para obter maior segurança na carreira.

Também para aquelas professoras que passaram pela Escola de Aperfeiçoamento, não havia trégua. A exigência de dedicação era muito grande o que não garantia, no entanto, uma vida profissional tranqüila e segura, como comenta Maria da Glória Arreguy. Apesar de, segundo ela, sentir uma satisfação indescritível com as aulas na Escola de Aperfeiçoamento, surgiam dificuldades, desânimo e até mesmo um princípio de revolta:

Algumas colegas desistiram antes do término do primeiro semestre. Nesse primeiro ano não tínhamos biblioteca. Os professôres de Psicologia e desenho, Mr. Simon, Mr. Walter, Mme. Artus e mais tarde Mme. Antipoff só lecionavam e falavam em francês. Quando terminava o horário reuniamo-nos em grupos para traduzir as notas tomadas em aulas. Vimo-nos obrigadas a freqüentar aulas particulares para darmos conta do recado. O horário era apertadíssimo: devíamos chegar às sete horas da manhã e sair às cinco da tarde. Havia murmurações de várias espécies: umas achavam humilhação sermos argüidas e fazermos trabalhos escritos como alunas; outras não suportavam as aulas em francês. Houve choques tremendos nas aulas de desenho e modelagem, de Mme. Artus.

\footnotetext{
${ }^{163} \mathrm{O}$ decreto n. 10.362 de 1932 passou a exigir formação acadêmica e concursos como norma para o acesso aos cargos na hierarquia do ensino. No entanto, segundo Maria Inês Coelho (s.d), com o decreto $\mathrm{n}$. 1.876 de 29 de outubro de 1946 que reestruturava a carreira do magistério, o governo mineiro pretendia neutralizar os apadrinhamentos políticos que até aquele momento teriam sido o único critério para as nomeações de professores. Foi exatamente com essa medida que Luíza Travassos conseguiu fazer um concurso e iniciar sua carreira de professora do ensino primário público no Estado, em 1946.
} 
O regulamento interno da Escola era discutido sob todos os aspectos e sempre com espírito de revolta. O almôço obrigatório era considerado um crime e o mais apurado mestre da arte culinária não seria capaz de resolver os problemas que surgiam diariamente em tôrno dos pratos apresentados. Foi organizado o "Conselho de Estudantes" para tomar conhecimento dos problemas e estudar os meios de solucionálos. Melhorou um pouco a situação, mas o descontentamento lá estava sempre à espera de uma oportunidade para explodir. (Arreguy, 1958, p. 82)

As lembranças das ex-alunas estão recheadas de histórias em que, se não demonstram violência física entre alunas e professoras da Escola de Aperfeiçoamento, também não escondem as violências simbólicas presentes desde a rigidez no horário de entrada e saída na escola, as exigentes avaliações, as notas baixas, a ameaça de expulsão e reprovação, os sermões, a vigilância do comportamento das alunas nas salas de aulas, nos corredores da escola, nos espaços públicos da cidade. Este grau de exigência é confirmado por Prates:

O Estado, na regulamentação das normas, e a Escola de Aperfeiçoamento, no cumprimento das mesmas, exigiam severidade máxima por parte das que fossem aceitas, tanto nos estudos quanto no comportamento. Considerada incapaz ou relapsa primeiros meses do curso, a aluna era dispensada. O mesmo acontecia se houvesse reprodução em qualquer matéria. Nenhum período podia ser freqüentado mais de uma vez. As alunas eram tratadas com rigor em todas e quaisquer normas que dissessem respeito à disciplina: devia-se chegar à Escola, pela manhã, 10 minutos antes das aulas; havia chamada e fiscalização das respostas e a aluna permanecia no estabelecimento até o término do período letivo do dia, ou seja, até o final da tarde. Visitas só eram possíveis em dias fixos e horários que não prejudicassem os trabalhos escolares, permitindo-se - somente - a entrada de professoras, autoridades do ensino ou pessoas recomendadas pela Inspetoria Geral da Instrução. Sob prescrição médica, a aluna tinha direito a um regime alimentar especial. Caso contrário, era obrigada, sem alternativa, ao regime oferecido pela Escola. (1990, p.14)

Maria da Glória conta, ainda, que não tiveram férias em julho de 1930, mas no mês de agosto o cansaço era tanto que as próprias professoras perceberam a necessidade de um descanso. O Conselho de Estudantes solicitou, então, ao Secretário da Educação, José Francisco Bias Fortes, quinze dias de recesso. Segundo a professora, que fazia parte da turma que foi até a Secretaria, todas foram muito bem recebidas, e, além do pedido atendido, ganharam um passe de ida e volta para a cidade onde residiam e um passeio à escolha das alunas. Maria da Glória optou por conhecer a capital brasileira e foi, como ela diz, "graças à gentileza do Dr. Bias Fortes".

Nem sempre, no entanto, as professoras eram ouvidas em suas reclamações. Segundo Imene Guimarães, o horário na Escola de Aperfeiçoamento era de oito da 
manhã às cinco da tarde, e as alunas almoçavam na própria escola. Ninguém podia sair antes do horário. As alunas reclamavam que, ao chegarem em casa, não havia mais água quente e tomavam banho frio. Apesar dos insistentes pedidos, as professoras não liberavam as alunas mais cedo porque diziam que quem determinava o horário era o Presidente do Estado. Certo dia, então, três alunas burlaram a vigilância do porteiro e foram até o Palácio da Liberdade falar com o Presidente. Chegando lá, o chefe de gabinete perguntou se elas tinham hora marcada. Mesmo não tendo, elas insistiram na necessidade da audiência. Consultado sobre a possibilidade de atendê-las, o Presidente teria dito que professora não precisava marcar horário para falar com ele. O Presidente as atendeu e, segundo Imene Guimarães, conversou bastante, riu muito com as alunas, mas não mudou o horário de funcionamento da Escola.

Segundo Maria da Glória, ao final de 1929, as alunas concluíram o ano sem saber se seriam submetidas a provas ou mesmo se continuariam no ano seguinte. "Toda essa indefinição, ainda era acrescida dos questionamentos que a escola suscitava: A crítica à Escola era ferina, não faltando quem dissesse ser aquêle curso de absoluta inutilidade, desperdício das rendas do Estado, protecionismo a um grupo de professôras, etc".(Arreguy, 1958, p.85)

Maria da Glória conta que estava pronta para assumir sua classe como professora efetiva no Grupo de Itabirito, pois todas as estagiárias que haviam cursado a Escola de Aperfeiçoamento haviam sido promovidas a professoras efetivas. No entanto, recebeu um ofício da Secretaria afirmando que havia sido aprovada para o segundo ano da Escola de Aperfeiçoamento e deveria voltar para as aulas. Sua sensação foi de perplexidade e, sabendo que o primeiro ano, por si só, não lhe apresentava garantia alguma, decidiu retornar à capital. Mais da metade das suas colegas do primeiro ano, entretanto, optaram por não regressar.

Outro problema teria sido o da constituição das classes anexas já que "as famílias mineiras viam com desconfiança aquelas novidades pedagógicas e resistiam em matricular seus filhos". A solução para o problema foi curiosa. Não podendo contar com os alunos dos Grupos centrais de Belo Horizonte, de famílias mais favorecidas, a Secretaria do Interior expediu uma ordem compondo a primeira turma com crianças carentes do Grupo Escolar Caetano de Azeredo. "E, os resultados, segundo Alda Lodi, teriam sido muito bons" (Ângela Souza, 1984, p. 41). Tão bons que, em 1932, foi 
necessário criar três escolas primárias anexas à Escola para atender à demanda de alunos $^{164}$.

O segundo ano não fora menos conturbado que o primeiro. Apesar do horário de entrada da manhã ser prorrogado para oito horas, as alunas não teriam mais o bonde especial, nem fornecimento de material, além dos atrasos nos vencimentos e nas diárias. Tudo isso sempre incrementado por rumores "desencontrados e alarmantes". Mesmo com a conclusão do curso na Escola de Aperfeiçoamento em 1930, as professoras não tinham noção do que lhes estava previsto. Maria da Glória conta que esperava e desejava voltar para a sala de aula que havia deixado em 1929. No entanto, o Minas Gerais divulgou a saída da regência das professoras formadas na escola, classificandoas como orientadoras técnicas.

A situação de incerteza com relação à Escola de Aperfeiçoamento não se restringiu ao período inicial. Com a saída de Francisco Campos, a Escola passou por momentos difíceis ${ }^{165}$. Embora se quisesse dar continuidade à Reforma realizada, havia também o interesse por baratear os gastos com a educação. Numa entrevista dada à Ana Maria Casasanta Peixoto (2003), Lúcia Monteiro Casasanta afirmava:

As dificuldades enfrentadas pela Escola de Aperfeiçoamento não se limitaram à redução na matrícula e ao congelamento dos salários dos professores. A escola foi ameaçada de fechamento várias vezes, sob a alegação de falta de verbas. Este pesadelo durou até 1940, quando o Secretário Cristiano Machado conseguiu convencer o governador a fazer-nos uma visita. A partir daí, ele reconheceu a importância do nosso trabalho e não falou mais em fechá-la. ${ }^{166}$ (Peixoto, 2003, p.238)

Em agosto de 1934, o Estado de Minas divulgava uma denúncia contra a Escola, abaixo transcrita:

À ultima hora, quando nos era já impossivel obter maiores esclarecimentos sobre o assumpto, recebemos graves denuncias contra a orientação do ensino adoptado na Escola de Aperfeiçoamento da capital as quaes, de accordo com a orientação seguida pelo ESTADO DE MINAS, passamos a expôr linhas abaixo.

É interessante observar-se que a Escola de Aperfeiçoamento, educandario fundado com o fito de preparar professoras technicas e torna-las capazes de orientar o

\footnotetext{
${ }^{164}$ Decreto n. 10. 449 de 31 de julho de 1932.

165 Peixoto (1987, p.7) comenta que, em 1935, o governo cortou as bolsas de estudo concedidas a professoras do interior que vinham estudar na Escola de Aperfeiçoamento, reduzindo a matrícula para apenas 10 alunas.

${ }^{166}$ Trecho da entrevista concedida por Lúcia Monteiro Casasanta a Peixoto (2003). Segundo ela, Mário Casasanta, na época Diretor da Imprensa Oficial, tentou várias vezes sustar a publicação do ato do governador para fechamento da Escola de Aperfeiçoamento, pois se dizia que este seria expedido a qualquer momento.
} 
ensino nos grupos escolares, tem merecido, até do proprio sr. Noraldino Lima, secretario da Educação, os maiores elogios. Apontado sempre como um modelar estabelecimento, do qual têm sahido educadoras realmente competentes, mais extranhaveis ainda são as denuncias em apreço, que vêm ferir diretamente a sua organização interna, e apontam, como eivados de erros os mais condemnaveis, os methodos de ensino ali applicados.

\section{FALTA DE METHODOS}

Segundo essas informações a que nos aludimos, a falta de methodos naquella escola vem dando logar a varios e lamentaveis incidentes. O curso, que era para ser feito no espaço de quatro annos, por ser importantissimo, tem sido realizado, ali, em dois e ás vezes um anno.

Tal abreviação de tempo, exige, porém, das professoras, um enorme esforço, que, levadas a essa contingencia pelos mestres, dia e noite se curvam sobre os livros.

Os estudos forçados são constantes, não se concedendo folga ás estudantes nem mesmo após as refeições.

Quanto às aulas se observa a mesma falta de methodo, excedendo o numero de cadeiras ao tempo disponivel.

As alumnas entram em aulas ás 7 e 30 horas da manhã, e, apenas com a interrupção de uma hora para o almoço, permanecessem até as 16 e meia, e ás vezes mais, ouvindo preleções, não se respeitando entre as mesmas o habitual intervallo de 10 minutos para descanso.

Durante as aulas de "tests", que attingem a tres e mais horas, já foram registrados e continuam a se registrar, casos de vertigens, razão por que vive a enfermaria repleta de doentes.

\section{CASOS DE CEGUEIRA E DE MORTE}

Não ficam ahi, no entanto, as denuncias contra a Escola, de que é directora Madame Helena Antipoff, nome de grande relevo no mundo pedagogico.

Em consequencia dessa falta de methodo no estudo - segundo as informações que nos trouxeram - já se verificaram até casos de cegueira, citando-se entre as victimas da Escola de Aperfeiçoamento, a professora Alyce Rosa Toledo.

Essa jovem educadora, segundo nos declararam, está quasi cega de tanto estudar, forçada como é pelo professorado. Naquelle estabelecimento, já foram registrados até casos de morte, provenientes da falta de methodo no ensino. já o anno passado, victima de uma tuberculose contrahida na Escola, quando de uma aula de gymnastica, falleceu a senhorinha Alda Coutinho, "miss" Alfenas.

\section{LOUCURA}

Tambem casos de loucura, segundo nos declararam, já se tem verificado. O mais recente data de ante-hontem, quando foi internada no Instituto Raul Soares, com manifestações vesanicas, a professora Philomena, ha pouco chegada a esta capital, na turma que, do Estado do Piauhy, veio cursar a Escola de Aperfeiçoamento ${ }^{167}$.

Logo após a notícia, o jornal colocava o que chamou "Nota necessária", afirmando que estava sempre aplaudindo as obras realizadas na Escola de Aperfeiçoamento. Esta, segundo o jornal, seria um modelo para o país e a divulgação das denúncias feitas por uma aluna do estabelecimento tinha somente o objetivo de

\footnotetext{
${ }^{167}$ GRAVE DENUNCIA contra a Escola de Aperfeiçoamento - Segundo informações que nos foram trazidas hontem, já se registraram naquelle estabelecimento casos de morte, loucura e cegueira - Apontase o methodo de ensino ali adoptado como causador desses males. Estado de Minas. 16 ago. 1934, p.10
} 
chamar a atenção do Secretário da Educação para o caso, afirmando ainda que esperava que os fatos não fossem tão graves como pareciam.

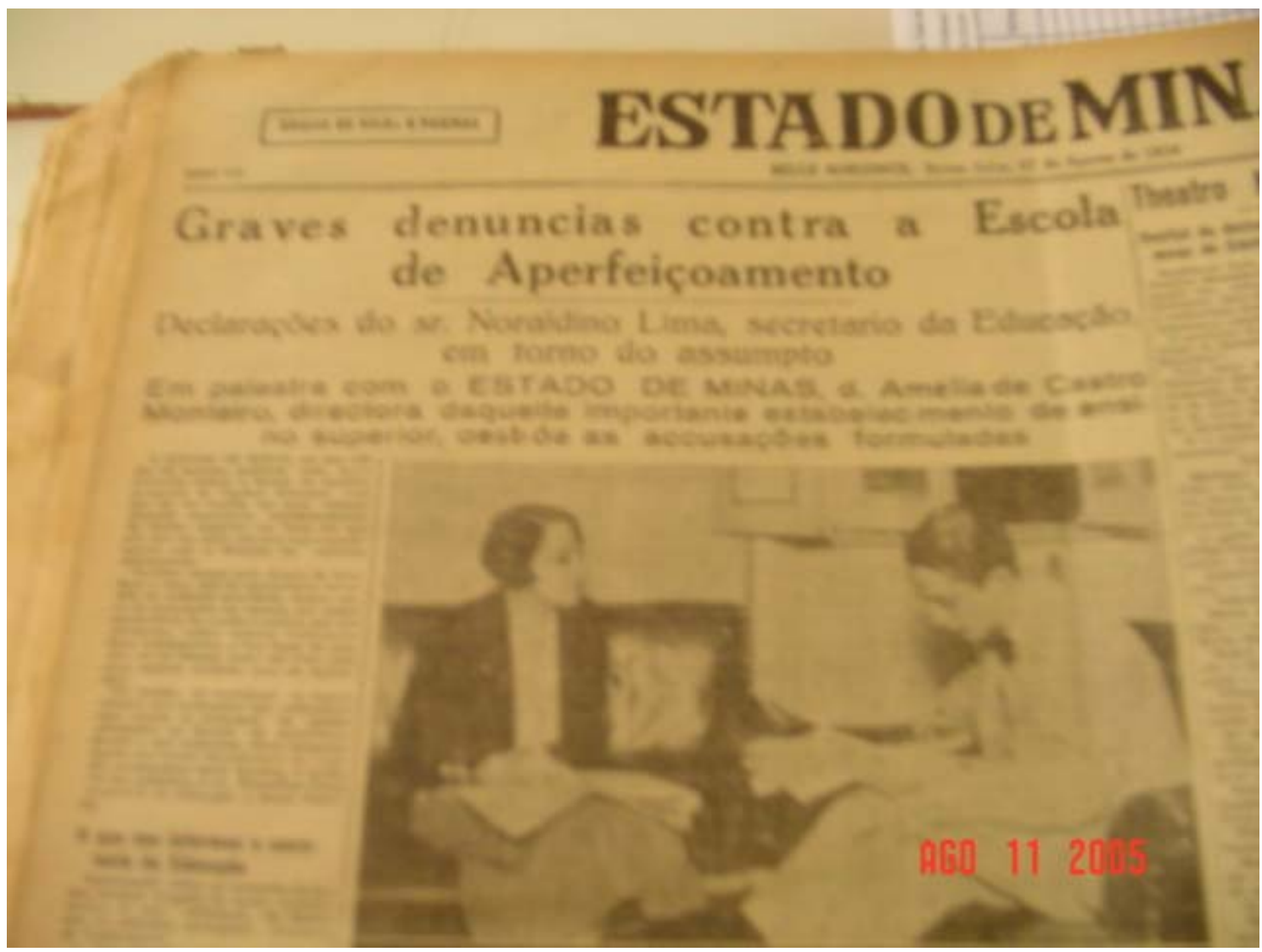

Foto 13: Primeira página do jornal com um jornalista entrevistando Amélia de Castro Monteiro, diretora da Escola de Aperfeiçoamento.

Fonte: Jornal Estado de Minas de 17 de agosto de 1934 [a data de 11 de agosto de 2005 é a de quando se fez a fotografia do jornal]

$\mathrm{Na}$ edição seguinte, o jornal publicou uma nova notícia ${ }^{168}$ afirmando querer esclarecer a situação já que reconhecia a boa fama da Escola. O Secretário da Educação, Noraldino Lima, argumentava que os fatos haviam sido levianamente deturpados e que, se o curso na Escola era mesmo apertado, não deixava de obedecer a "normas pedagógicas “defendidas e sustentadas pelos mais abalisados pedagogos do paiz", elogiando a escola-modelo. Em sua entrevista, Amélia de Castro Monteiro, diretora da Escola, argumentava que as acusações careciam de fundamento e que o curso seria mesmo intenso e pesado e, por este motivo, o programa havia sido reduzido ao mínimo

${ }^{168}$ GRAVES DENUNCIAS contra a Escola de Aperfeiçoamento - Declarações do sr. Noraldino Lima, secretario da Educação, em torno do assumpto - Em palestra com o ESTADO DE MINAS, d. Amelia de Castro Monteiro, directora daquelle importante estabelecimento de ensino superior, destróe as accusações formuladas. Estado de Minas. 17 ago. 1934. P.8 
essencial, salientando que a maior parte das alunas o fazia com relativa facilidade. Segundo ela, por razões econômicas, o Estado não teria podido estender o curso por mais tempo, embora se cogitasse em desdobrá-lo por três anos ${ }^{169}$. A diretora afirmava que não havia excesso de estudos capaz de causar o esgotamento das alunas. Disse ainda não haver aula de testes, e que os testes eram provas bimensais que deveriam se realizar em uma hora, mas, às vezes, se concediam duas ou três horas para a sua realização.

A diretora esclareceu pontualmente todos os casos citados na reportagem. Ela declarou que Alice Rosa de Toledo sempre sofrera da vista, chegando a ter que deixar o magistério por certo tempo. A aluna teria iniciado o curso em março de 1934, mas seu médico, dias depois, proibiu-a de continuar freqüentando as aulas. Tendo sido desligada como aluna, ela continuava trabalhando na Escola em serviços que não prejudicavam a sua visão. Ela confirmava que, em 1930, teria ocorrido um caso de vertigem durante uma aula, mas não em horário de prova. Sobre o falecimento da "miss" Alfenas, Alda Coutinho, Amélia Monteiro esclareceu que ela era aluna do Curso Intensivo de Educação Física que não pertencia à Escola de Aperfeiçoamento, mas funcionava no mesmo prédio e que a professora de ginástica do curso, Guiomar Meirelles Backer, declarara que a aluna já teria vindo doente de sua terra natal. Sobre o caso de loucura, argumentou que a jovem do Piauí "accusara o diagnostico medico apenas manifestações nervosas, sem caracter de gravidade, occasionadas por uma intoxicação gastrica, que deu origem a uma psychose toxica". Esta seria uma "molestia benigna" e, no máximo em oito dias, a aluna já poderia voltar às aulas. Aproveitando a oportunidade, a diretora salientou que, por tais motivos, o exame médico para a admissão na escola era muito rigoroso, ocasionando o impedimento da matrícula de muitas alunas ${ }^{170}$. Além disso, um médico visitaria a Escola duas vezes por semana. Segundo a diretora, eram raros os casos de descontentamento entre as alunas e que a diferença de clima e a falta de conforto nas acomodações fora da escola seriam os verdadeiros motivos pelos quais

\footnotetext{
${ }^{169}$ No entanto, a extensão do curso para três anos acabou não acontecendo. Em 1937, houve mudanças nos programas da Escola de Aperfeiçoamento, mas permaneceu o curso de dois anos. MINAS GERAIS. Decreto n. 887 de 30 jun. 1937. Aprova os programmas da Escola de Aperfeiçoamento.

${ }^{170}$ De acordo com Maria Inês Coelho et al. (s.d.), em fevereiro de 1930, 75 professoras se candidataram para admissão ao primeiro ano da Escola de Aperfeiçoamento e foram submetias a testes psicológicos de inteligência geral, a observações e a exame médico, sendo apenas 40 as matriculadas. Em 1942, o processo de seleção era composto de provas de cultura geral (Língua Pátria e História do Brasil), Aritmética e Ciências, bem como de nível mental e conhecimentos gerais. No ano seguinte, os exames de seleção incluíam também a Geografia.
} 
algumas alunas não conseguiam finalizar o curso, concluindo que não via motivos para estas reclamarem do regime da Escola.

As diversas reclamações sobre um regime escolar tão severo devem ser analisadas considerando-se que, naquele período, as mulheres, de uma maneira geral, tinham pouco acesso a níveis mais elevados de escolaridade. A Escola Normal em Minas Gerais começou a funcionar, em definitivo, em 1871 na cidade de Ouro Preto. Somente em 1906, ou seja, nove anos após a criação da nova capital mineira, é que se criou uma Escola Normal na cidade. Havia pouco tempo que estava ocorrendo uma feminização do espaço escolar, mas ainda era tipicamente masculino, especialmente nos níveis mais avançados de escolarização.

Assim como se temia o acesso das massas ao saber escolar - a escola para o povo sempre tentou mais disciplinar que instruir - assim também se temia o acesso das mulheres à cultura ${ }^{171}$. Vistas como menos inteligentes, pouco sábias, infantis e volúveis, as mulheres realizavam um curso de formação de professoras que, freqüentemente, as infantilizava. A inserção da mulher no mundo da cultura escolarizada despertava temores num período em que estudar demais era percebido como um risco, especialmente em se tratando das frágeis mocinhas neófitas nos bancos escolares de uma escola de nível superior, como a Escola de Aperfeiçoamento. Os fantasmas das doenças, da loucura, da morte permeavam o cotidiano das alunas que enfrentavam exigências demasiadamente novas para aquela geração. Num dos artigos da Revista do Ensino $^{172}$, por exemplo, se defendia que o excesso de leituras era perigoso e que os professores que assim procediam morreriam cedo "vitimas de uma intoxicação pedagógica". Mas o perigo não estava só nos estudos, nas leituras, nas avaliações. O risco estava para além dos muros da escola, nas ruas em que despertavam os olhares curiosos dos rapazes pouco acostumados a verem tantas moças jovens e sozinhas pelas ruas de Belo Horizonte, nas casas e pensões em que residiam longe dos olhares dos pais e irmãos, na liberdade de pensamento, de locomoção, de decisão, de fazer escolhas próprias. Moças mineiras que mexiam com o imaginário da sociedade da época, imaginário que ajudavam a construir e do qual eram tanto beneficiárias quanto vítimas.

171 No capítulo 02 "Representações históricas acerca da professora mineira" pode-se ver a ampla discussão a respeito das características ideais para a professora. Cultura, moralidade e beleza estavam entre os itens indispensáveis em qualquer discussão sobre o assunto.

${ }^{172}$ PRAZERES, Duntalmo. Gastrônomos, sóbrios e jejuadores. Revista do Ensino, BH, ano VII, n. 92, p. 14-16, jul. 1933 . 
Apesar de todos os temores, as acusações, os perigos, a Escola conseguiu superar as dificuldades tornando-se uma referência ${ }^{173}$ :

A projeção foi além, ultrapassou as fronteiras brasileiras. Sua experiência pedagógica atraía visitantes estrangeiros de passagem pela América do Sul. Um deles, o professor Washburne, de Chicago, escreveu mais tarde longa carta ao então Secretário da Educação, Cristiano Machado, em que citava a Escola de Aperfeiçoamento de Belo Horizonte como uma das instituições que mais o haviam impressionado em toda a viagem e fazendo elogios ao Programa em experimentação em Minas, igualava-o aos melhores de seu país.

O diploma da Escola de Aperfeiçoamento acabou também por se tornar o mais confiável atestado de competência pedagógica. (Ângela Souza, 1984, p.43) ${ }^{174}$

Estes "atestados de competência pedagógica" eram não somente para instituições brasileiras, mas também estrangeiras como a própria Universidade de Colúmbia e o Instituto Jean-Jacques Rousseau ${ }^{175}$.

No governo de Nísio Batista de Oliveira, cujo Secretário da Educação era Iago Pimentel e, em atendimento ao decreto-lei federal n. 8.530 de 02 de janeiro de 1946 que tratava da promulgação da lei orgânica do ensino normal ${ }^{176}$, a Escola Normal Modelo de Belo Horizonte foi transformada em Instituto de Educação pelo decreto-lei estadual $n$. 1.666, de 28 de janeiro deste mesmo ano, e a Escola de Aperfeiçoamento em Curso de Administração Escolar ${ }^{177}$. Embora se mantivesse a existência do laboratório de

173 Conforme Coelho et al. (s.d.), entre 1930 e 1945, a Escola de Aperfeiçoamento formou 487 orientadores técnicos do ensino, diretores e professores de escolas normais.

${ }^{174} \mathrm{O}$ professor Carleto Washburne, da Universidade de Chicago, havia criado um dos métodos ativos conhecido por "Sistema de Winnetka".

${ }^{175}$ A escola seria uma espécie de "abre-te-sésamo", ou seja, abria as portas para quem nela estudava. Cf. Ângela Souza (1984).

${ }^{176}$ A Lei Orgânica do Ensino Normal que foi a primeira lei nacional para formação de professores dividia o curso em dois ciclos. Três instituições de ensino de níveis hierárquicos distintos poderiam oferecer cursos de formação docente. O primeiro era o Curso Normal Regional que formava o Regente do Ensino Primário, a Escola Normal formava professores para o ensino primário e o Instituto de Educação que formava os profissionais anteriores, bem como o administrador escolar. O primeiro ciclo era de quatro anos e poderia ser oferecido por todas as instituições. O segundo ciclo de três anos só seria oferecido na Escola Normal e no Instituto de Educação.

${ }^{177}$ Como indica a lei: "O Interventor Federal no Estado de Minas Gerais, usando de suas atribuições legais e tendo em vista o decreto-lei federal n. 8.530, de 2 de janeiro do corrente ano, decreta:

Art. $1^{\circ}$ - Fica adaptada a Escola Normal de Belo Horizonte à lei Orgânica do Ensino Normal de Belo Horizonte à lei Orgânica do Ensino Normal, baixada com o decreto-lei federal n. 8.530, de 2 de janeiro do corrente ano.

Art. $2^{\circ}$ - Passa a denominar-se Instituto de Educação de Minas Gerais a atual Escola Normal de Belo Horizonte, compreendendo os seguintes cursos:

a) de ciclo ginasial do ensino secundário;

b) de segundo ciclo do ensino normal -curso de formação de professores-com a duração de 3 anos;

c) de especialização e administração escolar, com a duração de 2 anos. 
Psicologia, o contrato de Helena Antipoff com o Estado não foi mais renovado e ela se mudou para o Rio de Janeiro. Em 1952, retornou a Belo Horizonte e trabalhou na Faculdade de Filosofia como catedrática da cadeira de Psicologia Educacional.

Para Coelho et al. (s.d.), estas mudanças trouxeram perdas para a formação de educadores no Estado:

Entre a Escola de Aperfeiçoamento e o CAE [Curso de Administração Escolar] instauraram-se novas características no processo de formação dos especialistas em educação. A experiência de funcionamento em um só turno, com aulas de quarenta e cinco minutos, em 1938, e que havia acabado com os dois turnos foi tornada uma regra no CAE. A suspensão do regime de horário integral para as alunas implicava redução de programas de ensino bem como simplificação das atividades tais como a prática nas classes primárias de demonstração. Também para os professores do CAE, a escola em tempo parcial representou um corte nas suas atividades de pesquisa diretamente relacionadas ao ensino. Como conseqüências também sérias para a qualidade do trabalho que vinha sendo feito desde a criação da Escola de Aperfeiçoamento, a supressão das classes anexas de experimentação e de demonstração caracterizou a instalação do CAE. (s.d., p.324).

Ângela Souza (1984, p. 55) também constatou que: “... apesar de todos os esforços e de ser considerado um grande curso, o de Administração Escolar jamais conseguiu aproximar-se do que fôra a Escola de Aperfeiçoamento”. Daniel Antipoff reitera a percepção de perda com o fim da antiga Escola:

Um dia, acabou a Escola de Aperfeiçoamento Pedagógico, substituída por um curso de Administração Escolar. O governo se desinteressou por aquilo que durante muitos anos constituiu o celeiro das melhores professoras mineiras. Um material imenso advindo do antigo laboratório de Psicologia foi empilhado em sucessivas salas do Instituto de Educação de Minas Gerais. Ninguém mais quis tirar conclusões de precioso material de pesquisa, obtido mediante milhares de aplicações de testes em crianças, adolescentes e adultos. O que sobrou da antiga Escola criada pelo Presidente Antônio Carlos passou a ser entregue ao mofo, aos ratos ou à poeira, até o dia de um pavoroso incêndio que destruiu as salas do Instituto de Educação, consumindo os restos de uma obra de envergadura que tinha dado a Minas Gerais, durante duas décadas, a liderança da educação primária no país. $(1975 / 1996, \text { p. 134) })^{178}$

A vida dos alunos e das alunas professoras desmistifica a idéia de que a vida escolar era "risonha e franca" no período estudado. Apesar de a saudade dos tempos

Art $3^{\circ}$ - Funcionarão anexos ao Instituto de Educação de Minas Gerais um Grupo Escolar e um jardim de infância.

Art $4^{\circ}-\mathrm{A}$ atual Escola de Aperfeiçoamento passa a fazer parte do Instituto de Educação de Minas Gerais, constituindo os cursos especializados da letra "c" do art. $2^{\circ}$ dêste decreto-lei". Minas Gerais, 1946.

${ }^{178} \mathrm{O}$ incêndio no Instituto de Educação de Minas Gerais ocorreu em 13 de setembro de 1953. 
passados ressaltarem as boas lembranças; o sofrimento, as angústias, as injustiças também estiveram lá.

Nos cursos de formação de professoras evidencia-se, de maneira mais nítida, a transição de uma perspectiva punitiva para a disciplinar. As moças de família que viviam, anteriormente, sob rígida proteção familiar, vigiadas constantemente pelo meio que restringia o seu acesso aos espaços públicos, ganhavam a cena e adquiriam poder. $\mathrm{O}$ poder da maternidade estendia-se aos alunos e alunas. O poder de administrar a casa ampliava-se para a administração do espaço escolar. O espaço doméstico avançava até a escola. Inaugura-se um período de conflitos entre as exigências do casamento, da maternidade, da gestão familiar com as exigências do espaço público e da profissionalização.

De acordo com Diana Vidal e Marília Carvalho (2001), na Segunda Conferência Nacional de Educação realizada em 1928 em Belo Horizonte, o único tema que despertou polêmica entre os participantes foi o voto feminino. As autoras comentam que estavam presentes 30 mulheres entre os 66 conferencistas, entretanto, nenhuma opinou sobre o assunto ou, se opinaram, não tiveram suas posições registradas. As autoras ressaltam as discussões acirradas sobre o celibato pedagógico feminino na época:

A Igreja via na crescente emancipação feminina a destruição das bases do casamento sadio. O discurso higiênico moderno reforçava essa associação, afirmando que o lugar da mulher era no lar e sua função prioritária o cuidado de filhos e filhas. Na família ideal, a mulher não deveria trabalhar fora. A guarda da prole e sua educação seriam atividades naturais da mulher, que passaria todo o seu tempo amando e brincando com os filhos e filhas. (Vidal e Carvalho, 2001, p. 29)

É fato que, apesar das inúmeras controvérsias e polêmicas, as mulheres ganharam o direito de participação no espaço público e na vida política do país. Deixaram os cárceres familiares, amenizaram a vigilância de pais e irmãos, mas de maneira nenhuma deixaram de ser controladas: pela família, pela Igreja, pela sociedade e, antes de tudo, por si mesmas. Pelos valores adquiridos, inculcados e defendidos. É o self-government estendido às mulheres que, por sua vez, responsabilizam-se por incutilos nas crianças, seus filhos e/ou alunos.

As representações sobre a professora mineira que se formava nos bancos escolares da cidade de Belo Horizonte neste momento incluíam atributos relacionados à religiosidade, maternidade, estética e desprendimento, tidos como indispensáveis à 
professora do ensino primário. Tratava-se, sem dúvida, de uma estratégia de disciplinamento que permitia alargar os espaços de inserção das mulheres e, simultaneamente, restringir seus comportamentos e atitudes. Às mulheres era permitido falar, desde que pouco, num tom baixo e excluindo assuntos como economia, política e sexualidade; era permitido circular pela cidade, mas evitando determinados lugares, horários e companhias; era permitido estudar, desde que em áreas de conhecimento consideradas femininas e com moderação; era permitido obter ganhos financeiros, mas sempre como complemento à renda familiar que deveria ter o homem como principal provedor; era permitido se profissionalizar, desde que não abrindo mão do papel de "natural" de mãe, dos próprios filhos e/ou dos alunos e alunas.

O percurso de alunas a professoras foi, sem dúvida, um percurso de disciplinamento constante. Das recordações dos professores e professoras que amedrontavam, mas também ensinavam, daqueles cuja convivência é lembrada com orgulho e satisfação, foram se forjando modelos de professores, representações do bom e do mau educador, do que sabe e do que não sabe ensinar, do que cativa os alunos, do que os humilha e despreza. Para além de todas as metodologias estudadas, a formação dos professores se dá, sobretudo, nesse encontro cotidiano com a arte de ensinar encenada nas salas de aula.

Nos espaços escolares, familiares e sociais se forjavam novas mulheres que ocupavam, pela primeira vez, cargos e funções públicas e que construíam novas relações com a cultura e a sociedade. Nessa trama de espaços, redes e relações inauguradas por estas mulheres foram se constituindo representações históricas sobre o ser professora e, o que interessa para este estudo em especial, sobre o ser professora nos Grupos Escolares primários públicos da cidade de Belo Horizonte. 


\section{CAPÍTULO 2 \\ REPRESENTAÇÕES HISTÓRICAS ACERCA DA PROFESSORA PRIMÁRIA}

Segundo Antônio Nóvoa (1986), em Portugal, a influência das teses da Educação Nova foi maior entre os professores do que nas práticas escolares:

Nos anos vinte a definição do professor profissional passa inevitavelmente por uma referência (implícita ou explícita) à Educação Nova. É por isso que este movimento que coincide com a institucionalização de processos específicos e autônomos de formação dos professores e com a consolidação de associações de professores, e que atinge o clímax no período em que os professores primários conseguem impor-se socialmente como corpo profissional usufruindo de um estatuto sócio-economico de acordo com a missão que lhes é confiada - apresenta um tão grande interesse para a análise do processo de profissionalização da actividade docente. (grifos do autor) $(1986$, p.53)

Em Minas Gerais, o escolanovismo implantado nas Reformas de 1925 e 1927 também introduziu mudanças na formação e atuação do professorado. A feminização dessa classe profissional não foi um processo aí instituído, pois esta já vinha acontecendo desde a segunda metade do século XIX $^{179}$ e foi reforçada com a Reforma de 1906 que criou a Escola Normal de Belo Horizonte, na qual era vetada a matrícula aos alunos do sexo masculino. Também na Escola de Aperfeiçoamento só se admitia a matrícula de alunas do sexo feminino. Imene Guimarães conta que três inspetores de ensino solicitaram matrícula na Escola de Aperfeiçoamento e esta lhes foi negada. Eles recorreram alegando que era Escola de Aperfeiçoamento de professores e não de professoras. O Secretário de Educação então mandou matriculá-los e eles foram os primeiros homens ${ }^{180}$ a cursarem a Escola de Aperfeiçoamento. No entanto, não parece que tenham aberto caminho para outros interessados, já que sua matrícula foi condicionada a um processo judicial e nenhum outro caso foi relatado.

Para a primeira geração de mulheres entrevistadas, trabalhar com educação infantil era a saída profissional digna para as moças. Não se questionava a vocação profissional e os pais, sem consultarem as filhas, as matriculavam na Escola Normal porque não havia outro caminho a seguir. As mulheres da geração mais jovem,

\footnotetext{
${ }^{179}$ Cf. GOUVEA \& ROSA, 2000.

${ }^{180}$ Antônio Benedito de Carvalho publicou um artigo na revista Educando de $\mathrm{n}^{\circ} .31$ em março de 1944 que o identificava como aluno da Escola de Aperfeiçoamento. De acordo com Ângela Souza (1984, p. 42), Moacir Andrade, autor do livro República Decroly, que satirizava a Escola teria, posteriormente, matriculado lá seu próprio filho: Francisco de Assis Andrade.
} 
entretanto, tiveram outras possibilidades. Berenice Menegale, por exemplo, saiu ainda adolescente de Belo Horizonte para estudar música em Paris.

A mulher ganhava, nesse momento, uma importante tarefa social. Ainda que a educação tivesse sido a única opção honrosa para o campo profissional e, mesmo assim, motivada pela proximidade alegada com o mundo privado, da família e da maternidade, construía-se a imagem de uma mulher com maior autonomia e liberdade de expressão e de participação social, inclusive com o direito de voto conquistado na década de trinta e o direito de exercer cargos políticos como foi o caso de Alaíde Lisboa e Marta Nair.

As Escolas Normal e de Aperfeiçoamento eram, portanto, destinadas às mulheres. Para a implantação da Escola de Aperfeiçoamento, Francisco Campos enviou à Universidade de Chicago cinco $^{181}$ professoras mineiras para que se formassem e voltassem preparadas para lecionar na Escola, colocando as alunas à par das tendências pedagógicas mais modernas em voga nos Estados Unidos. A sua escolha por enviar mulheres não se deve a um mero acaso. A concepção de que educar era uma tarefa essencialmente feminina fazia parte do imaginário escolanovista e numa escola para moças era preciso que houvesse mulheres em quem se espelhar.

Duas imagens publicadas na Revista do Ensino em outubro de 1927 numa edição comemorativa do centenário da primeira lei de instrução primária no Brasil mostravam a representação da escola antiga e da escola moderna. Diante de uma mesma cena escolar, mudavam tão somente as imagens dos personagens.

Na primeira cena, o professor, nitidamente velho, com óculos e barba branca, bradava com a palmatória intimidando o aluno encolhido diante do autoritarismo do mestre. Essa era a imagem da Escola Antiga divulgada pelos escolanovistas. A escola moderna, pelo contrário, apresentava uma professora jovem, afinada com as tendências da moda, conversando com os alunos sem amedrontá-los. Diante dessa professora, o aluno se permitia participar, dar opiniões, ser uma presença ativa no processo de aprendizagem.

\footnotetext{
${ }^{181}$ Inácia Ferreira Guimarães, Amélia de Castro Monteiro, Alda Lodi, Benedita Valadares Ribeiro e Lúcia Schmidt Monteiro de Castro.
} 

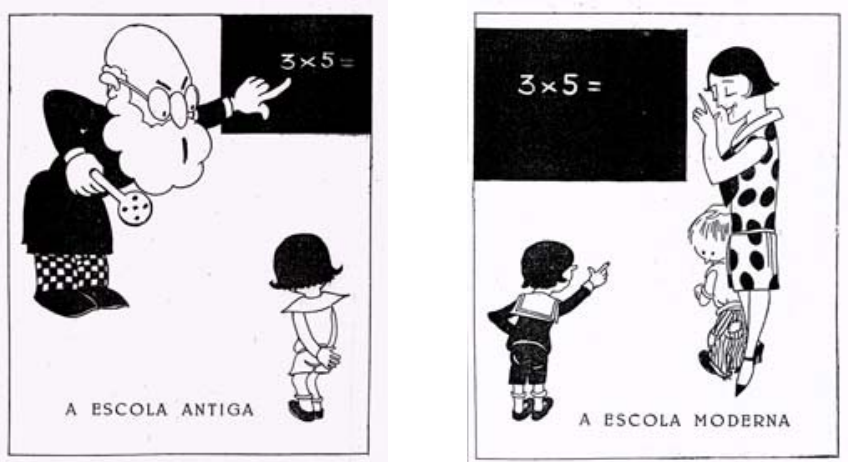

Figura 14: Imagens da Escola Antiga e da Escola Moderna. Fonte: Revista do Ensino, BH, n.23, out.1927.

Se a mulher ganhava a cena como melhor preparada para a educação das novas gerações, não se pode dizer que tenha conquistado a imagem de eqüidade intelectual perante os homens. Pelo contrário, era a ausência de dotes intelectuais que lhe garantia a prioridade na educação infantil. $\mathrm{O}$ fato de ser considerada menos inteligente e mais imatura lhe conferia uma maior proximidade com o mundo da infância. Acreditava-se que ela tinha mais facilidade para compreender as crianças e atuar num processo de ensino em que já não cabia transmitir conhecimentos, mas investigar para aprender. Nesse sentido, o grande sábio perdia espaço para a professora.

Embora sempre em condição de inferioridade profissional diante do sexo masculino, as professoras vinham conquistando espaços novos na cena pública que começaram a se reunir numa classe profissional que lhes garantia visibilidade e importância. Elas participavam de cerimônias concorridas como as formaturas de cursos que contavam com a presença de educadores notáveis e políticos de alto escalão, e participaram de outros eventos sociais divulgados nos jornais da cidade. A própria criação de um periódico dedicado a este público mostrava a importância que lhe vinha sendo atribuída pelo governo do Estado e, na década de quarenta, a criação de um periódico próprio revela o grau de organização desta classe e a segurança de seu papel no destino da educação pública mineira. Além disso, a professora dos Grupos Escolares era o alvo primordial das Reformas implementadas no ensino. Para ser disciplinadoras, as mulheres deveriam antes ser disciplinadas. Levar as inovações pedagógicas para o cotidiano escolar era uma tarefa a ser realizada pelas mulheres:

Finalmente, todas as criticas que se dirigem ao ensino primário são, de modo indirecto e obliquo, dirigidas ao Ensino Normal, pois que o ensino primario não são os programas, 
a distribuição das materias, senão o modo de ministral-os, a sua dosagem, a qualidade do vehiculo em que a noçao passa do mestre ao alumno, em uma palavra, a technica de apresentação dos assumptos e noções e, por conseguinte, em resumo e afinal, - o professor. ${ }^{182}$

Conferir às mulheres uma tarefa tão significativa naquele momento para o Estado implicava preparar todas as contingências que garantissem o cumprimento dos objetivos educacionais. Maria Cecília C.C. de Souza (1997, p.286) alerta que: "Educadas [as mulheres] para serem submissas - era natural que o saber sobre o que faziam emanasse do topo da pirâmide acadêmica ou administrativa, e não de suas próprias cabeças". Por isso, foram implementadas Reformas no Ensino Normal, oferecidos cursos de aperfeiçoamento para as professoras em exercício, foram criados um Corpo Técnico de fiscalização nas escolas e outros expedientes que visavam assegurar que o trabalho realizado pelas professoras estaria em consonância com as legislações e as normas ditadas pelo governo do Estado.

O controle sobre a professora era feito pelos Termos de Visitas dos inspetores; pelas orientadoras e assistentes técnicas que fiscalizavam o trabalho; pelas diretoras que direcionavam as atividades a ser realizadas; pela Revista do Ensino, produzida pela Secretaria do Interior e, posteriormente, da Educação, e ainda pela revista Educando que divulgavam as representações acerca do que era ser uma professora moderna e atualizada. A oração escrita por Gabriela Mistral ${ }^{183}$, poetisa chilena, publicada em ambas as revistas, pode auxiliar a compreender as representações sobre a mulherprofessora que circulavam nos meios escolares pesquisados.

\section{Oração da mestra}

Senhor! Tu que ensinaste, perdôa que eu ensine e que tenha o nome de mestra, que tiveste na terra. Dá-me o amor exclusivo de minha escola: que mesmo a ânsia da beleza não seja capaz de roubar-lhe a minha ternura de todos os instantes.

Mestre, faze perdurável em mim o entusiasmo e passageiro o desencanto. Arranca da minha alma o subalterno desejo de justiça que ainda me perturba, o mesquinho assomo de protesto que sobe ao coração, quando me ferem. Não me doa a incompreensão nem me entristeça o olvido dos que ensinei.

Dá-me que eu seja mais mãe do que as mães, para poder amar e defender, como as mães, o que não é carne da minha carne.

Dá que eu alcance fazer de uma das minhas discipulas o meu verso perfeito e deixar cravada na sua alma a minha mais penetrante melodia, que assim ainda há de cantar,

\footnotetext{
182 MINAS GERAIS, 1928, p.221. Exposição de motivos do Regulamento do Ensino Normal.

183 Segundo Berenice Menegale, Gabriela Mistral esteve em Belo Horizonte no período em que ela era aluna das Classes Anexas à Escola de Aperfeiçoamento e fez uma visita à Escola.
} 
quando meus labios não cantarem mais. Torna-me possivel o teu Evangelho nos tempos que correm, para que eu não renuncie á batalha de cada dia e de cada hora, em pról do seu ensinamento.

Põe na minha escola democrática o resplendor que aureolava o teu bando de meninos descalços. Faze-me forte no desvalimento de mulher e de mulher pobre; faze-me que eu despreze todo poder que não seja puro, tôda pressão que não seja a da tua vontade ardente sôbre a minha vida.

Amigo, acompanha-me! Ampara-me! Muitas vezes só te terei a Ti a meu lado. Quando a minha doutrina fôr mais casta e mais queimante a minha verdade, ficarei abandonada dos homens, mas Tu me apertarás então contra o teu coração - êle que foi cheio de soledade e desamparo. Dá-me sensibilidade e dá-me profundeza, livra-me de ser confusa e banal no meu ensino quotidiano. Dá-me que eu possa levantar os olhos do meu peito ferido, ao entrar cada dia na minha escola. Que eu não leve à mesa de trabalho os meus pequenos desalentos materiais, as minhas mesquinhas dores de cada hora.

Torna-me leve a palavra no castigo e suavíssima na carícia; repreenda sofrendo, para que saiba que corrigi amando! Faze-me que seja cheia de espírito a minha escola de ladrilhos. Envolva a chama de meu entusiasmo o seu átrio pobre, a sua sala núa. O meu coração lhe seja coluna e a minha bôa vontade mais ouro que as colunas e o ouro das escolas ricas.

E, enfim, ensina-me como a palidez da tela de Velasquez, que ensinar e amar intensamente sôbre a terra é chegar ao último dia com a lançada de Longuinos no flanco ardente do amor.

Esta oração aborda diversos aspectos interessantes. Em primeiro lugar, pode-se notar que, embora em algumas publicações fosse intitulada Oração do Mestre ${ }^{184}$ é uma oração feita por uma mulher que pede que "mesmo a ânsia da beleza não seja capaz de roubar-me a minha ternura de todos os instantes”. A questão da beleza feminina e, especialmente da professora, é retratada em diversos documentos consultados. Também a maternidade é um aspecto importante. $\mathrm{Na}$ oração, a mestra não quer apenas ser comparada à mãe, mas deseja ser ainda mais desprendida, na medida em que deve amar aqueles que não são seus filhos legítimos. Trata-se, ainda, de um texto religioso e, como já foi dito, o escolanovismo em Minas Gerais possui uma importante vinculação religiosa. A concepção de que ensinar é uma missão sagrada ${ }^{185}$ é recorrente em todos os documentos analisados. Por esse motivo, o envolvimento com a tarefa de ensinar jamais pode visar o interesse pessoal em qualquer nível e, portanto, “os desalentos materiais” já previstos na oração, não devem fazer com que a professora perca a noção da sacralidade de sua tarefa e almeje obter recompensas financeiras.

\footnotetext{
${ }^{184}$ ORAÇÃO do mestre. Revista do Ensino, BH, n. 11 fev. 1926, p. 33. Outras publicações: MISTRAL, Gabriela. Oração do Mestre. Revista do Ensino, BH, n. 95, out. 1933, p.1-2. Na revista Educando n. 20 ago.1942, p. 497, foi publicada com o título "Oração da Mestra".

${ }^{185}$ Esta temática foi analisada por Eliane Marta Teixeira Lopes (2003).
} 
Embora a oração traga muitos outros aspectos que podem ser comentados, foram estes aqui escolhidos para focalizar as representações de professor vigentes no período: a religiosidade, a aparência pessoal, a maternidade e a questão financeira.

\subsection{IGREJA E ESCOLA ${ }^{186}$}

Embora a Reforma Francisco Campos tenha suscitado reações por parte da Igreja Católica, temerosa em perder espaço diante das investidas governamentais em educação, é possível dizer que a Escola Nova em Minas Gerais assume características essencialmente religiosas ${ }^{187} \mathrm{e}$, principalmente, vinculadas à Igreja Católica. A modernização do ensino não poderia se opor a uma das mais importantes e poderosas instituições no Estado. Por esse motivo, a tentativa de conciliação entre governo e Igreja eram freqüentes na educação, conforme alerta Peixoto:

A Igreja tem papel preponderante na organização e manutenção da ordem sócio-moral daquele período. Sua estrutura, hierarquicamente organizada, sua pregação da igualdade das almas e do não conflito entre as classes sociais são pontos de atração para esse governo que quer modernizar sem quebrar com as estruturas tradicionais. Nesse sentido, a Igreja é aliada e, como tal, concessões devem-lhe ser feitas. Frente às críticas da Igreja à reforma do ensino, o governo busca mostrar que os princípios adotados pela reforma foram pregados e difundidos não por educadores modernos mas pelo próprio Cristo. Mediante o conflito surgido entre liberais e católicos no processo de legalização da introdução do ensino religioso na escola primária, o governo despreza os argumentos liberais em favor da solicitação católica. Da escolha do diretor da Escola de Aperfeiçoamento a um orientador católico para o corpo docente aos atos miúdos no cotidiano da Escola, leva-se em conta a política da "boa vizinhança" e a preocupação em não abalar as bases sócio-morais em vigor. (2003, p.135)

\footnotetext{
${ }^{186}$ Este tema seria o bastante para a realização de uma tese de doutorado. As relações entre Igreja, Estado e educação no período estudado são muito conflituosas. Para se ter uma idéia do assunto, pode-se analisar como ele era tratado em Constituições Brasileiras do período. Em 1891, a Constituição afirmava: "Será leigo o ensino ministrado nos estabelecimentos públicos". Em 1934: "O ensino religioso será de freqüência facultativa, e ministrado de acordo com os princípios da confissão religiosa do aluno, manifestada pelos pais ou responsáveis e constituirá matéria dos horários nas escolas públicas primárias, secundárias, profissionais e normais". Constituição de 1937: "O ensino religioso poderá ser contemplado com matéria de curso ordinário das escolas primárias, normais e secundárias". Mas não era obrigatório aos mestres assim como a freqüência do aluno. Na Constituição de 1946, o art. 133 estabelecia que o ensino religioso poderia ser contemplado como matéria do curso das escolas primárias, normais e secundárias, mas de freqüência facultativa por parte dos alunos. Entretanto, entre o que as Constituições estabeleciam e o que era realmente realizado nos Grupos Escolares de Belo Horizonte no período, parecia haver grande distância.

${ }^{187} \mathrm{Na}$ verdade, a religiosidade mineira não influenciou apenas o Escolanovismo no Estado. No vídeo $A$ escola agora é outra, criado para divulgação do PABAEE, duas freiras aparecem aprendendo as novas técnicas de ensino. A participação das freiras no vídeo certamente não foi um mero acaso, já que também a influência americana na educação atemorizava os católicos mineiros. A participação das freiras, portanto, auxiliava a diminuir os receios quanto à implementação do PABAEE.
} 
Desde a lei n. 1.092 de 1928 que permitiu o ensino religioso dentro do horário escolar nos estabelecimentos de ensino do Estado, Antônio Carlos e Francisco Campos ${ }^{188}$ selaram um acordo entre o governo e a Igreja Católica em Minas Gerais. A conciliação mostra que havia disputas de interesses e que a educação consistia em uma das questões que podiam unir ou opor seriamente Estado e Igreja. Nos governos posteriores, a união entre ambos permaneceria forte em Minas Gerais e o retrocesso nos investimentos educacionais públicos no período estadonovista consistiu num forte impulsionador para as iniciativas católicas em educação.

Em 1933, o Inspetor da Instrução Pública em Minas Gerais tentava minimizar os problemas com a Igreja Católica, especialmente no que se referia aos colégios particulares:

A escola cristã, ao contrario do que por aí se afirma, não se opõe á escola moderna. Em Minas Gerais, os estabelecimentos de ensino dirigidos por religiosas aplicam os meios mais modernos, sem prejuízo dos fins que se propõem alcançar. Guerrino Casasanta Inspetor Geral da Instrução Pública. ${ }^{189}$

No mesmo ano, Guerino Casasanta ${ }^{190}$ dirigiu pessoalmente um curso para professoras religiosas de Metodologia e Psicologia com duração de seis meses e um ano. Em novembro de 1934, o jornal católico O Horizonte divulgava, em primeira, página a festa de encerramento do curso que contou com a presença do Dr. Noraldino Lima e do Arcebispo Metropolitano que celebrou uma missa em ação de graças. A busca por uma aproximação entre Estado e Igreja era visível na Revista do Ensino, como observa Maurilane Biccas:

Observa-se, em vários textos da Revista do Ensino, no período de 1931 a 1934, a publicação de conferências e discursos proferidos em formaturas realizadas em escolas católicas e nas oficiais do Estado. O que chama a atenção é que, nas escolas católicas, os convidados para paraninfos das turmas quase sempre eram figuras públicas eminentes e que ocupavam cargos importantes na educação e, nas escolas públicas,

\footnotetext{
${ }^{188}$ Quando Ministro da Educação e Saúde, Francisco Campos decretou a volta do ensino religioso facultativo nas escolas públicas, em abril de 1931.

${ }^{189}$ CASASANTA, Guerino. Ensino leigo nas escolas. Minas Gerais. Belo Horizonte: 05 jan.1933. Seção Pelo Ensino.

${ }^{190}$ Embora o inspetor utilize o termo escola cristã, incluindo também outras escolas religiosas não católicas, pode-se dizer que a grande preocupação em Minas Gerais era, sem dúvida, não criar problemas com uma das instituições mais poderosas do período: a Igreja Católica.
} 
destacados paraninfos eram representantes da alta hierarquia da Igreja Católica. (2001, p. $65-6)^{191}$

Não por acaso este curso acontecera neste momento. A publicação do "Manifesto dos Pioneiros da Educação Nova" ${ }^{192 "}$ em 1932 foi um divisor de águas ${ }^{193}$ na Associação Brasileira de Educação. Os educadores católicos se uniram num grupo contrário ao Manifesto e retomaram sua luta em prol do ensino religioso, criando a Confederação Católica de Educação. Em Minas Gerais, Mário Casasanta, diretor da Imprensa Oficial e ex-Inspetor Geral da Instrução, sofreu perseguições por parte da Igreja Católica por ter sido um de seus signatários ${ }^{194}$. No entanto, nos informa Biccas (2001, p. 64): "Minas Gerais pode ser considerado um caso à parte no que se refere às tensões e disputas colocadas entre o Estado e a Igreja Católica nesse período, pois, nesse estado, os liberais que ocupavam cargos importantes eram quase todos católicos."

Em 1933, Getúlio Vargas convocou eleições para a Assembléia Nacional Constituinte. A Igreja Católica, então diante da oportunidade de fazer valer seus interesses na nova Constituição ${ }^{195}$, criou, entre outros expedientes, a LEC - Liga Eleitoral Católica ${ }^{196}$ - que fiscalizava a atuação dos políticos indicando para votação

\footnotetext{
${ }^{191}$ Biccas (2001, p.65) apresenta um quadro ilustrando tal afirmação.

${ }^{192}$ Em 1931, durante a IV Conferência Nacional de Educação, o próprio Getúlio Vargas solicitou aos conferencistas a elaboração de uma proposta educacional. Como tal proposta não fora elaborada, Fernando de Azevedo ficou encarregado de redigi-la. Em 19 de março de 1932 o texto "A reconstrução educacional do Brasil" redigido por Fernando de Azevedo e tendo 26 signatários veio a público. Conhecido como Manifesto dos Pioneiros da Escola Nova, a publicação constituiu-se num divisor de águas na Associação Brasileira de Educação, pois contemplava as concepções de um grupo apenas, grupo este também não muito homogêneo. Segundo Biccas (2001, p. 66), foram os liberais católicos mineiros defensores da disciplina de ensino religioso nas escolas públicas nas II, III e V Conferências Nacionais de Educação. Biccas (2001, p. 139) observa, ainda, que algumas edições da Revista do Ensino eram verdadeiros catecismos já que esta constituía a temática central da publicação. Não por acaso estas edições, de números 74, 75 e 76, foram publicadas em outubro e novembro de 1933, logo após, portanto a divulgação do Manifesto. Também a revista Educando trazia discussões sobre religião, boa parte delas assinada por Maria Luisa de Almeida Cunha, professora católica que objetivava modernizar o ensino da religião nas escolas públicas primárias.

${ }^{193}$ Expressão usada por Libânia Nacif Xavier na obra organizada por XAVIER, Maria do Carmo (2004)

${ }^{194}$ Mário Casasanta foi o único mineiro a assinar o Manifesto. Cf. Peixoto (2004) In: XAVIER (2004).

${ }^{195}$ Em 16 de julho de 1934, foi promulgada a Constituição que estabelecia uma república federativa para o país e apresentava feições bastante democráticas. Entretanto, em 1937, com o Estado Novo, foi outorgada uma nova Constituição elaborada por Francisco Campos, Ministro da Justiça e Negócios Interiores, a qual ficou conhecida como Polaca, por inspirar-se na Constituição fascista da Polônia, sofrendo influência das Constituições autoritárias da Alemanha, Itália e Portugal.

${ }^{196}$ Entre as iniciativas de conquista e manutenção de poder pela Igreja Católica nos anos vinte e trinta, especialmente diante da maior organização comunista, pode-se destacar: publicação da Revista A Ordem em 1921; a criação do Centro Dom Vital em 1922; a eleição de Nossa Senhora Aparecida como padroeira do Brasil em 1929 (a imagem da santa havia sido encontrada por pescadores do Rio Paraíba em São Paulo no ano de 1717); a inauguração do Cristo Redentor na capital brasileira no período, em 12 de outubro de 1931; a criação da Liga Eleitoral Católica em 22 de novembro de 1932; a criação da Confederação
} 
dos católicos somente aqueles que tivessem reconhecidamente trabalhado em prol dos objetivos da Igreja ${ }^{197}$.

Em fins de 1934, o jornal católico mineiro $O$ horizonte publicou a carta-resposta de Noraldino Lima sobre uma consulta feita por Olyntho Orsini, Secretário Geral da Junta Estadual da Liga Eleitoral Católica, a respeito de sua candidatura ao cargo de deputado federal por Minas Gerais. Na carta, Noraldino enfatizava o fato de ser católico e de estar atuando em prol da Igreja como Secretário da Educação e Saúde Pública no Estado desde 30 de abril de 1931 até aquele momento.

Num trecho da carta, abaixo transcrito, o seu autor esclarece de que forma estaria contribuindo para o ensino católico nas escolas mineiras.

Como Secretário da Educação tenho não só permittido, mas estimulado o ensino da doutrina christã nos estabelecimentos de ensino primário, normal e secundário do Estado bem como a celebração de missas e o exercício de primeiras communhões aos alumnos nos mesmos estabelecimentos, contribui, ainda há pouco, para a realização da paschoa dos professores públicos de Bello Horizonte, dispensando-os do trabalho escolar e applaudindo com enthusiasmo a feliz iniciativa; tenho feito respeitar os dias santos da Egreja nas casas de ensino e dispensado alumnos e professores para a pratica das sagradas missões no interior do Estado, não só tenho consentido na enthronização de Jesus, mas eu mesmo, com as minhas mãos, o tenho feito nas casas de educação sob minha guarda, tenho moralmente, pela palavra e pelo exemplo, prestigiado a acção social da Egreja, pregando, em varias opportunidades a grandeza da Egreja, pregando, em varias opportunidades a grandeza da fé catholica e affirmando, com a responsabilidade de meu nome e de meu cargo, que não comprehendo a escola sem Deus, meus discursos - vide o "Momento Pedagógico" [parece ter sido escrito por ele] - constituem permanente grito de fé para accordar, na consciencia de mestres e de alumnos, a idea de Deus e a necessidade de incorporal-o á prática escolar; todas as obras materiais em que tenho podido collaborar Egrejas que se constroem e collegios e congregações sem recursos, têm recebido minha contribuição official e particular. ${ }^{198}$

O jornal, então, publicou o seguinte comentário:

Católica de Educação e os Congressos Eucarísticos Nacionais que passaram a ocorrer a partir de 1933. Tais iniciativas obtiveram êxito no setor educacional. A Constituição de 1934, embora tivesse assumido algumas das reivindicações dos pioneiros, também incorporava o ensino religioso ao horário escolar nas escolas públicas primárias, secundárias e normais, que deveria ter freqüência facultativa, e ser ministrado de acordo com os princípios da confissão religiosa do aluno, manifestada pelos seus responsáveis.

${ }^{197}$ Para se ter uma idéia do alcance político dos católicos em Minas Gerais, em 1940, a população do Estado de Minas Gerais era de 6.803.410 habitantes e, destes, 6.572.947 eram católicos. Ou seja, 96,61\%, segundo dados do Anuário Estatístico de Minas Gerais de 1949.

${ }^{198}$ AS CONVICÇÕES religiosas do Dr. Noraldino Lima. O Horizonte. Belo Horizonte, 09 out. 1934, ano XII, n.1.144, p.1. Na carta, o Secretário afirma, ainda, que enviou uma delegação de professores mineiros nomeada por ele, por indicação do sr. Arcebispo Metropolitano, para participarem do $1^{\circ}$ Congresso Católico de Educação no Rio de Janeiro que teria ocorrido entre 20 a 27 de setembro de 1934, afirmando também ter sido ele o idealizador do curso para religiosas na Escola de Aperfeiçoamento. Neste congresso, o livro Novos caminhos e novos fins publicado por Fernando de Azevedo, autor do Manifesto dos Pioneiros foi indexado como leitura perniciosa pelo Pe. Helder Câmara, segundo Carvalho (2002, p.22) 
A actuação do Dr. Noraldino Lima, na Secretaria da Educação, não só lhe dá credenciais do mais alto valor para a approvação da sua candidatura, pela L.E.C., mas, especialmente, impõe ao eleitorado catholico o dever imperioso de suffragar o seu nome nas próximas eleições federaes.

Sempre dando, à temática, espaço na primeira página do jornal, foram ainda publicados um artigo sobre "As credenciais catholicas do Dr. Noraldino Lima"199, ilustrado com uma foto sua e reafirmando seus valores, seus feitos e pedindo votos para o candidato, além de um telegrama ${ }^{200}$ do próprio Noraldino agradecendo a recomendação de sua candidatura, afirmando "Si eleito não desmerecerei honrosa confiança" seguido de um novo pedido de votos feito pelo jornal.

Num dos livros do Padre Álvaro Negromonte destinado ao ensino do catecismo nas escolas, pode se ter uma idéia do poder atribuído à Igreja Católica:

Todos devem acreditar no que a Igreja ensina, porque os seus ensinamentos são os mesmos de Deus e de Jesús.

E ninguém pode duvidar. É um grande pecado duvidar voluntariamente do que Deus disse. Devemos crer fielmente, sem duvidar. (1950, p.15)

A Igreja era associada ao próprio Deus e o Padre acrescentava ainda: "para ser um bom cristão não basta ser batizado e crer em tudo o que a Igreja ensina. É necessário também fazer tudo o que ela manda”. Com a garantia da obediência dos fiéis a Deus e, por extensão, à Igreja, não foi difícil garantir a conquista de seus interesses. Apesar disso, é flagrante a contradição com o movimento escolanovista, que defendia a formação de um sujeito capaz de realizar suas próprias escolhas. Este era um período de retomada do poder da Igreja Romana contra o descaso de séculos da época da colônia e do Império, que se fez principalmente num combate ao catolicismo popular com o culto dos santos, às procissões, às romarias, o combate às Irmandades, e a procura de exercício do poder da Igreja sobre a família, principalmente através do reforço da piedade da mulher e da educação das crianças. Na Igreja Católica em processo de romanização era imprescindível o reforço da estrutura hierárquica da Igreja herdada do Império Romano.

Após a promulgação da Constituição de 1934, Minas Gerais regulamentava o ensino religioso nas escolas públicas do Estado que deveria ser ministrado sem ônus

\footnotetext{
199 TAVARES, Waldemar. As credenciais catholicas do Dr. Noraldino Lima. O horizonte. Belo Horizonte, 11 out.1934, ano XII, n.1.145, p.1.

${ }^{200}$ LIMA, Noraldino. Telegrama. O horizonte. Belo Horizonte, 28 out.1934, ano XII, n.1.152, p.1.
} 
para o Estado, de freqüência facultativa, dentro do horário escolar, em três aulas semanais. Embora a Constituição recomendasse que o ensino religioso fosse oferecido segundo a confissão religiosa do aluno, manifestada pelo pai ou responsável, não esclarecia como isto deveria acontecer. O professor da disciplina seria escolhido por uma autoridade religiosa, podendo ou não ser o mesmo professor do estabelecimento. Os estabelecimentos particulares de ensino poderiam oferecer ensino religioso segundo a orientação do estabelecimento. Seguramente, pode-se afirmar que o art. $4^{\circ}$ que dizia que "o ensino religioso é privativo da respectiva cadeira, e, fora desta, a bem da disciplina e da liberdade espiritual dos alumnos, os professores deverão se abster da propaganda de qualquer credo dentro das escolas" ${ }^{201}$ não era cumprido nas escolas públicas primárias estudadas. $\mathrm{O}$ ensino religioso ia muito além das aulas, sendo parte das excursões, das festas e de todo o cotidiano escolar.

Como afirma Marta Carvalho:

O embate doutrinário no campo pedagógico foi estrategicamente fundamental para católicos e pioneiros na luta pelo controle do aparelho escolar na primeira metade da década de trinta, prolongando-se até o limiar do Estado Novo. [...]

A militância educacional católica se mobilizou na propaganda e difusão das novas pedagogias, depurando-se de tudo o que pudesse contrariar os princípios fixados na encíclica Divini Illius Magistri. As estratégias que adotou fornecem o contraponto necessário para que se possa aquilatar melhor o sentido das práticas de seus oponentes, os pioneiros, permitindo compreende-las como programa de organização da cultura e da sociedade centrado em iniciativas políticas de reforma estrutural da escola e do sistema escolar.

As estratégias católicas caracterizaram-se por operar a explicitação do significado do termo no campo teórico e doutrinário da Pedagogia, tendência manifesta, já, na preferência dada à expressão pedagogia da escola nova. Tal preferência era recurso ardiloso. No campo pedagógico, a questão dos fins educacionais era instanciada como fundamento de toda e qualquer discussão. Firmado o império da doutrina católica nesse domínio, passava-se a julgar as novas pedagogias. Nesse tribunal, aquelas que não contrariassem os princípios estabelecidos tinham seu estatuto disciplinar reconhecido e as que deles discrepassem eram rebaixadas como "má pedagogia". A encenação tinha dois alvos principais. Por um lado, construir um discurso escolanovista católico que ganhasse a adesão do professorado. Por outro, instanciar-se como autoridade tecnicamente competente para ajuizar as palavras e as obras dos seus adversários. (2002, p.19-20)

A eleição de políticos comprometidos com a causa católica objetivava garantir a adesão aos princípios católicos, entre eles, os relacionados à educação. Indubitavelmente, este constituía-se num ponto nevrálgico da Igreja Católica,

201 MINAS GERAIS. Decreto n. 151 de 29 jul. 1935. Dispõe sobre o ensino religioso nos estabelecimentos officais de instrucção primaria, secundaria, profissional e normal. 
especialmente no que se refere a três personagens centrais: a criança, cuja educação garantiria a catequização e a inserção nos valores e princípios religiosos desde a mais tenra idade; a mulher ${ }^{202}$, tradicionalmente formadora de novas gerações, fossem seus filhos ou alunos; e a elite, por ser aquela que conduziria a $\mathrm{Nação}^{203}$.

Em janeiro de 1938, no governo de Benedito Valadares, o Secretário da Educação, Cristiano Machado suprimiu seis Escolas Normais oficiais com a seguinte justificativa:

Considerando que existe no Estado grande número de Escolas Normais reconhecidas que preenchem os fins a que são destinadas dentro da organização atual; considerando que, em muitas cidades, o Estado mantém, ao lado dessas escolas, estabelecimentos oficiais, cujos alunos poderão continuar o curso sem prejuízo do ensino. ${ }^{204}$

No caso das escolas normais, fica claro que a mulher, enquanto formadora das novas gerações tanto na família quanto na escola, consistia em um importante personagem nos interesses políticos da Igreja Católica, como ressalta Peixoto:

O interesse da Igreja pelo ensino normal é, sobretudo, político. A mulher ocupa importante papel em seu programa de recristianização da sociedade, enquanto elementochave no equilíbrio da família e principal responsável pela educação da criança. $\mathrm{O}$ ensino normal, na medida em que é considerado um curso destinado por excelência ao sexo feminino, é visto como elemento estratégico nesse programa, pois, por meio dele, a Igreja garantiria sua presença no lar e na escola, impedindo a desagregação da família e a influência, sobre a criança, de credos nocivos à sua formação. (Peixoto, 2003, p. 70.)

Como as outras escolas eram religiosas, o governo, além de não mais lhe fazer concorrência, aumentava a sua clientela, já que estas ficavam obrigadas a receber os alunos que viessem das escolas fechadas. Como se não bastasse, os prédios e o material das Escolas Normais fechadas eram cedidos às escolas normais das cidades e os funcionários ficavam em disponibilidade remunerada até que fossem aproveitados em outros cargos. Segundo a autora, o fechamento de diversas escolas normais estaduais no interior de Minas pelos governos que sucederam Antônio Carlos se constituiu numa vitória para a Igreja Católica, e teria sido um dos motivos para o esvaziamento da

\footnotetext{
${ }^{202}$ Uma conquista da Igreja Católica neste sentido foi o fechamento das Escolas Normais Oficiais nas cidades mineiras onde já havia Escolas Normais Religiosas pelo decreto n.132 de 1938.

${ }^{203}$ Neste caso, a atenção se voltava para os colégios que ofereciam curso secundário, estes voltados exclusivamente para os homens, naquele momento.

${ }^{204}$ MINAS GERAIS. Decreto-lei n. 63 de 15 jan. 1938. Suprime seis Escolas Normais Oficiais e revoga os artigos $157,158,159$ e 160 do decreto n. 11.501 de 31 de agosto de 1934 .
} 
Escola de Aperfeiçoamento que tinha como uma de suas funções formar professoras para as Escolas Normais.

Quanto à laicidade, no sentido de uma escola neutra em termos religiosos, esta parece não ter sido mesmo aplicada à escola pública mineira. Mas havia ainda um outro problema a solucionar. A escola pública que se queria moderna e sinal de avanço e progresso nas práticas educativas não poderia também desqualificar as práticas educacionais dos colégios católicos para não perder o apoio desta instituição de tão grande importância no Estado. Daí a necessidade do Inspetor da Instrução Pública sair em defesa das escolas católicas e de colocar a escola pública sob o manto protetor da Igreja o que torna a Escola Nova em Minas Gerais uma instituição profundamente religiosa, melhor dizendo, profundamente católica. A própria denominação Escola Nova parece ter sido um problema na medida em que representava a introdução de um ideário às vezes associado a um excessivo materialismo, visto com desconfiança pelos católicos. Além disso, muitos dos princípios escolanovistas como a co-educação, a liberdade dada aos alunos, a atividade livre do pensamento eram duramente combatidos pelos católicos. Nesse sentido, outras denominações como Escola Ativa ou Escola Moderna eram preferidas, como ressalta Imene Guimarães na entrevista concedida ao Museu da Escola:

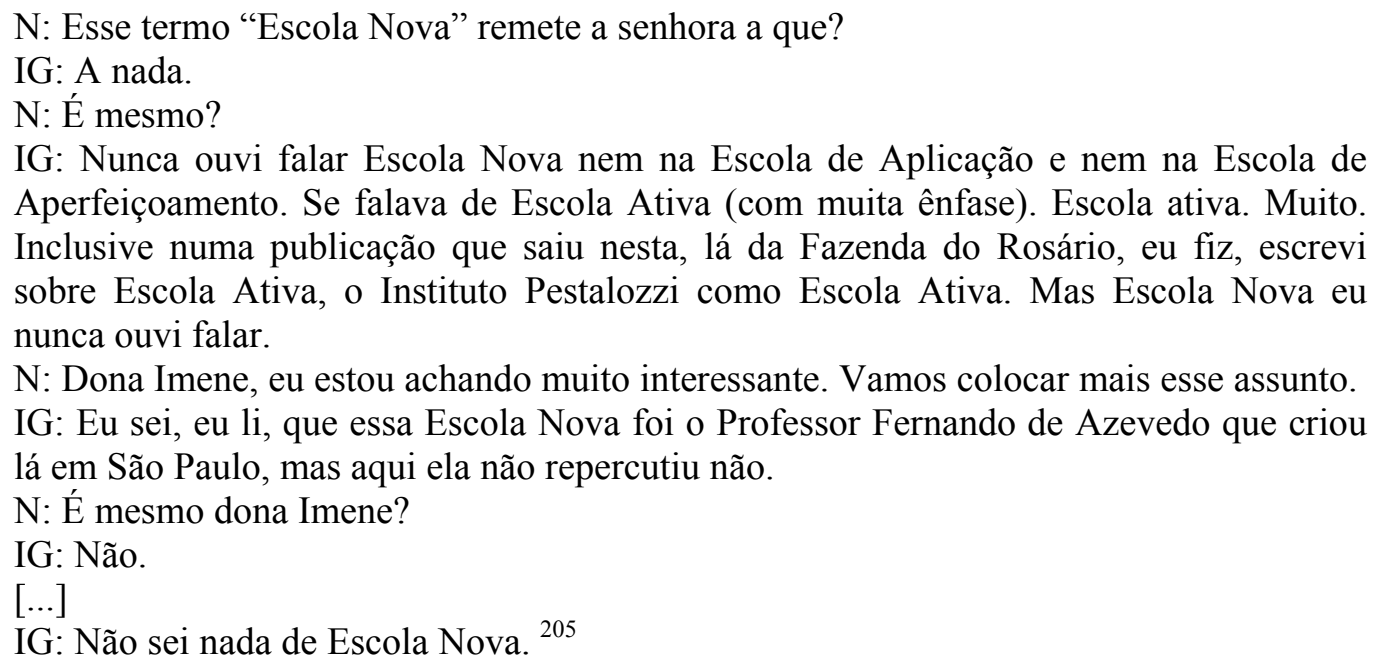

${ }^{205}$ Este trecho da entrevista realizada por Nelma Marçal do Museu da Escola de Minas Gerais foi selecionado pela ênfase dada pela entrevistada ao afirmar a não utilização do termo Escola Nova em Minas. 
$\mathrm{Na}$ entrevista realizada para esta pesquisa, Imene foi menos enfática, embora tivesse confirmado que a denominação Escola Nova não era utilizada em Minas Gerais. A professora chegou a dizer na entrevista que concedeu ao Museu da Escola que, em Belo Horizonte, não se falava em Escola Nova e todos utilizavam a terminologia Escola Ativa. Entretanto, os documentos e materiais consultados para esta pesquisa não confirmam a sua declaração. Tanto na legislação quanto nos documentos escolares pesquisados e até mesmo entre as outras professoras entrevistadas, havia referências à Escola Nova. Elza de Moura chegou a declarar: "Sou 100\% Escola Nova". Embora este não parece ser um problema muito evidente aos educadores mineiros, o comentário de Imene deixa claro que, para alguns, a denominação não era aceita. Para a professora, a expressão Escola Nova, tão cara a Fernando de Azevedo, redator do polêmico Manifesto dos Pioneiros, não se aplicava a Minas Gerais, enfatizando que a experiência da modernização do ensino no Estado era diferente da proposta encabeçada pelos pioneiros.

Se a denominação Escola Nova estava eivada de conflitos, havia que se encontrar um meio termo, já que a imagem da escola tradicional ou antiga estava sendo associada aos atributos pouco honrosos como os de ser ultrapassada, ineficiente, avessa à ciência, enfim, pouco apropriada para a sociedade que se desejava construir ${ }^{206}$. Por isso, os termos Escola Ativa e Escola Moderna são também aplicáveis à Escola Nova mineira.

A partir dos documentos pesquisados, foi possível perceber que nem sempre as escolas públicas se davam ao trabalho de respeitar as diferenças religiosas. Embora Elza de Moura afirme que as aulas de religião não eram freqüentadas pelos não católicos ${ }^{207}$, Luíza Ribeiro Campos admite que nem perguntava a doutrina religiosa da família dos alunos, preparava todos para a Primeira Eucaristia. Se, como Elza de Moura afirma, os alunos não católicos ficavam dispensados das aulas de religião, não podiam, entretanto escapar das inúmeras manifestações religiosas realizadas pelos Grupos Escolares.

\footnotetext{
206 A construção de uma imagem nada agradável para a "escola antiga" foi um recurso utilizado pelos escolanovistas para se consolidarem como os portadores da modernidade e da atualização nas práticas educativas.

${ }^{207}$ A própria Elza de Moura é metodista e, provavelmente, não participava dessas aulas de religião.
} 


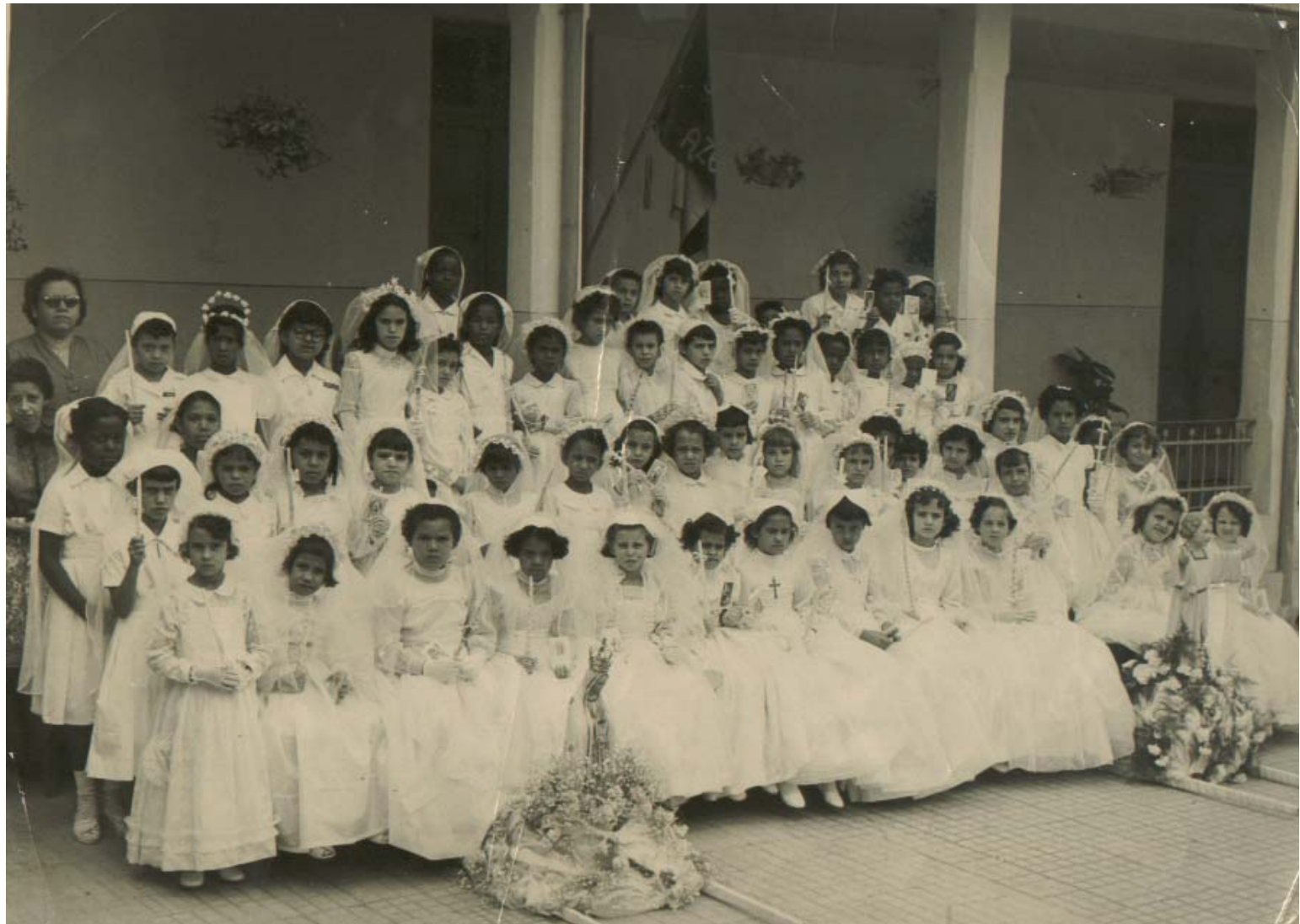

Foto 15: Primeira Comunhão no Grupo Escolar Sandoval de Azevedo. Á esquerda a diretora Ondina Aparecida Nobre e abaixo a professora Luíza Travassos Ribeiro Campos. (s.d.)

Fonte: Álbum de fotografia de Luíza Travassos Ribeiro Campos.

“...igreja e escola eram quase uma coisa só” comentou o ex-aluno Geraldo Félix sobre a realidade dos Grupos Escolares estaduais naquele período. A documentação pesquisada confirma essa afirmativa. É surpreendente a participação da Igreja nas escolas e vice-versa. São infindáveis os relatos de festas religiosas ocorridas nos pátios escolares: coroação a Nossa Senhora, entronização de imagens sagradas, preparação para a Primeira Comunhão ${ }^{208}$. Também as excursões serviam como pretexto para levar os alunos a atividades nas paróquias próximas, a festas religiosas, aos Congressos Eucarísticos ${ }^{209}$ ocorridos em Belo Horizonte. Obviamente, nada disso se fazia sem a devida preparação anterior, ocupando assim um bom tempo do horário escolar como confirma o ex-aluno:

\footnotetext{
${ }^{208}$ É interessante notar que sempre que os alunos participavam de festividades, entre elas, as religiosas, lhes era oferecido um lanche mais caprichado, o que certamente contribuía para deixar as festas mais concorridas, garantindo a participação dos alunos.

${ }^{209}$ A Praça Raul Soares em Belo Horizonte foi inaugurada em 1936, quando ocorreu o II Congresso Eucarístico na cidade. Foi construído, ainda, um monumento que simbolizava a Hóstia Sagrada.
} 
G.F.: Mas na preparação para esse Congresso teve muita preparação, muito ensinamento lá dentro da escola, pro Congresso Eucarístico, toda $\mathrm{BH}$ correu para a praça Raul Soares, cada escola tinha um dia. A escola que levou. Isso foi mais ou menos 1943, 1944. todos foram pra comungar. A escola que conduziu.

Mesmo que as aulas de religião não estivessem incluídas no programa escolar não se pode dizer que não fizessem parte de outras iniciativas. Em suas memórias, Maria da Glória mostra como tentava respeitar o regulamento que proibia o ensino do catecismo no horário escolar sem deixar seus alunos sem tais ensinamentos:

Como funcionária do Estado, eu desejava o regulamento. A consciência de católica, porém, falava mais alto. Não me conformava em ver aquelas alminhas em flor crescerem sem Deus. Em companhia de Dona Isabel fui ao chefe político local e solicitei permissão para utilizar um dos salões do grupo, fora do horário escolar. Meu intento era arrebanhar o maior número possível de alunos. Fomos muito bem recebidas pelo coronel Joaquim Monteiro de Abreu que, atenciosamente, deferiu nosso pedido. Antes, porém, que eu iniciasse o trabalho o jornal da terra dava o grito contra a iniciativa. Faltou-me todo o apoio. O próprio vigário defendeu-se pelo púlpito, declarando que não partira dêle o pedido. (Arreguy, 1958, p.58)

Ainda assim, a professora iniciou o trabalho numa igrejinha aos domingos, mesmo com um número diminuto de alunos. Depois disso, um professor - talvez diretor do Grupo - lhe permitira dar aulas de religião na própria sala, após o horário regular das aulas. Nos anos quarenta, após passar por várias cidades, Maria da Glória voltou para a cidade de Caratinga e retomou o trabalho de catequista na Igreja de sua cidade e também no Grupo, com o apoio da diretora. No Grupo Escolar, fundou a Cruzada Eucarística, promovia festas religiosas e coroações a Nossa Senhora no mês de maio.

Benedita Dell'Isola, ao assumir sua primeira turma, ensinava Religião. Sua primeira aula para as cem alunas da Escola do sexo feminino da Vila de Caracol foi exatamente sobre catecismo e, quando professora do Grupo Escolar Cristiano Machado, comenta:

O mês de Maria era comemorado com o maior entusiasmo possível. Havia coroação da Virgem, diariamente, no pátio. Os meninos comportavam-se tão bem! Os pais dos alunos iam assistir a essas solenidades. A Primeira Comunhão era feita na Capela do Colégio Santa Maria; íamos em procissão, os meninos vestidos de anjo e as meninas de Virgens, conduzindo a Imagem de Nossa Senhora, com a banda de música tocando atrás. As Ruas Guanhães, Itaúna, Pouso Alegre e Jacuí eram enfeitadas e os moradores se aglomeravam nas janelas, nas portas e nas esquinas, mesmo sendo hora imprópria, muitas vezes com a temperatura muito baixa, para verem os meninos do Grupo Cristiano Machado. A Diretora, D. Edith não cabia em si de tão contente nesses dias. (1970, p. 80) 
Tais festas poderiam ser um resquício do catolicismo popular que sobrevivia nas práticas escolares, com as coroações, os aniversários de professoras e diretoras, as formaturas e as primeiras comunhões dos alunos. Após 32 anos e 7 meses de magistério, Dell'Isola se aposentou recebendo uma expressiva homenagem no Grupo Cristiano Machado junto com uma imagem de Nossa Senhora de Lourdes. A professora afirmava ainda ser muito religiosa, comungando todos os dias.

As aulas de religião podiam ser dadas pelas próprias professoras das classes, por professoras especializadas ou ainda pelo vigário local. Nos Grupos Escolares Tomaz Brandão, Olegário Maciel, Assis das Chagas e Afrânio de Melo Franco o vigário ia à escola, ou para dar as aulas de religião ou para acompanhar as aulas de religião dadas pela professora. Nos dois Grupos noturnos pesquisados, o padre comparecia para ensinar aos alunos. Talvez isso se devesse à especificidade do ensino noturno. A diretora do Grupo Escolar Assis das Chagas assim enumerava os objetivos da escola noturna: a formação moral e física, econômica, intelectual e a formação moral pela religião $^{210}$.

A inauguração e reforma dos Grupos Escolares era sempre um momento propício para a benção do prédio e a entronização de imagens religiosas. Após a reforma do Grupo Escolar Bernardo Monteiro, por exemplo, foi feita a entronização dos Sagrados Corações de Jesus e Maria como está relatado abaixo:

Aos dezoito dias do mês de maio de mil novecentos e quarenta e cinco (18-5-1945) realisou-se neste Grupo Escolar a cerimonia da Benção da Casa, que foi toda reformada e a Entronisação dos Sagrados Corações de Jesus e Maria; essa cerimonia teve inicio ás 7,30 com a celebração da Santa Maria, na varanda central do predio; celebrada pelo entao Vigario da Paroquia, Reverendissimo Pe. Avelar, auxiliado pelo Reverendo Pe. Jorge Cunha. Celebramos neste dia a Pascoa das crianças do grupo, havendo recebido a Santa Comunhão 550 crianças, varias professoras. Após a Santa Missa, o Revmo. Vigario percorreu toda a casa e suas dependencias, abençoando tudo. Seguiu-se a cerimonia da Entronisação, no Salão Nobre. Nesse momento, em breve alocução, lembrou a importância da Entronisação e pediu aos Céus bençãos abundantes para todos que aqui trabalham.

Após essa tocante cerimonia, foi servida lauta merenda aos presentes e às crianças.

Compareceram: representantes do Exm Secretario da Educação e Chefe do Departamento - Zenith Baia e Maria José Tuber[?], familias das professoras e dos alunos, autoridades do bairro, diretoria da Caixa Escolar, Dr.[o verso colado está tampando a primeira linha] ... escolar, Barbara Diniz Mascarenhas, enfermeira, todo o corpo docente e administrativo.

Para constar, lavrei a presente ata, a qual será assinada por todos.

Belo Horisonte, 18 de maio de 1945.

Maria de Lourdes Pereira da Silva, diretora [Não há mais assinaturas]

${ }^{210}$ Ata da reunião de 21 de junho de 1951. 
Quatro anos depois, há novamente um relato da entronização da imagem de Nossa Senhora Aparecida ${ }^{211}$ no Grupo. Antes do evento, foram realizadas uma novena, rifas e houve recolhimento de contribuição dos alunos ${ }^{212}$. A imagem foi levada pelas crianças em procissão para a sua benção na Igreja paroquial do bairro e, na volta ao Grupo, foram feitas diversas apresentações. Curiosamente, a festa aparece no relato não como uma festa religiosa, mas como uma festa cívica, que foi realizada no dia 07 de setembro. Houve palestra sobre a independência e foram cantados o Hino Nacional e o Hino da Independência. Nossa Senhora Aparecida teria sido escolhida para a festa por ser a padroeira do Brasil.

Os alunos de diversos Grupos Escolares participavam de Maratonas catequéticas $^{213}$ com distribuição de prêmios. A primeira delas realizou-se em 1949 e até 1955 há notícias de sua realização. Também as aulas de trabalhos manuais constituíamse uma ocasião propícia para o ensino da religião. No Grupo Escolar Pedro II foi realizada uma "Exposição Catequética" em que se apresentaram os materiais produzidos pelos próprios alunos para o ensino desta disciplina.

Além das costumeiras orações feitas no início das aulas, algumas reuniões de professoras também eram iniciadas por orações. Além disso, a temática religiosa invadia a discussão acerca de questões pedagógicas. Nas reuniões se falava das Páscoas a serem realizadas ${ }^{214}$, de missas $^{215}$, da freqüência de professoras e alunos aos eventos religiosos, da Semana Santa, da Primeira Eucaristia, dos ensinamentos religiosos, entre muito outros.

A introdução do ensino religioso, como disciplina obrigatória no currículo das escolas públicas [nível nacional] se deve, entre outros motivos, à visão que Campos tem da educação como um processo destinado à "recuperação de valores perdidos... como a 'religião', a 'família', e a 'pátria". Nesse sentido, o ensino religioso seria um poderoso aliado na preservação das instituições nacionais e no combate à anarquia espiritual, produzida pelo dogma da liberdade de pensamento defendido pelo liberalismo e, conjunturalmente, pelo comunismo. (Peixoto, 2003, p. 44-5.)

\footnotetext{
${ }^{211}$ Em 1930, o Papa proclama Nossa Senhora Aparecida como padroeira do Brasil.

${ }^{212}$ Não fica claro se para a compra d imagem ou para oferecer o dinheiro a Nossa Senhora.

${ }^{213}$ Embora os documentos consultados não informassem como se davam tais maratonas, é possível que tratassem de uma competição de memorização dos alunos acerca do catecismo, decorado completamente, o que entrava em flagrante contradição com a Escola Ativa.

${ }^{214}$ Há muitas notícias de páscoas dos alunos e das professoras. Nas fontes consultadas, entretanto, não foi possível compreender como elas eram realizadas.

${ }^{215}$ As professoras chegavam a fazer gráfico acerca do comparecimento dos alunos à missa.
} 
A ameaça do comunismo ${ }^{216}$ era tratada em diversas reuniões como uma "brilhante" preleção feita por Leonilda Montandon, que discuti os seguintes temas:

A belissima Enciclica de Pio XI - Educação; o papel da professora; futuro do país em suas mãos; como preparar o homem $\mathrm{p}^{\mathrm{a}}$ viver bem. Correntes filosóficas: socialismo, nacionalismo, etc. Não se pode separar a vida do homem de Deus; o fim do homem Como compreender e guiar cada criança - $\mathrm{O}$ auxílio da graça $\mathrm{p}^{\mathrm{a}}$ educar e tudo conseguir - A responsabilidade da professora perante Deus - Não há educação perfeita sem a educação cristã - O papel da professora cristã.

Em outra reunião, novamente o tema vinha à tona por uma professora do Grupo Escolar Tomaz Brandão:

Apresentou alguns dados biográficos: Nasceu Marx em 1818. batizado no protestantismo, viveu e agiu como pagão. Só se preocupava com a matéria.

$[\ldots]$

A Igreja Católica é a reabilitadora do trabalho e da mulher que, na antiguidadee, era uma escrava.

O matrimônio cristão deu à mulher seu lugar verdadeiro e dignificante na sociedade.

[...]

A Igreja sempre condenou o comunismo. A primeira vez que se ergueu contra "o materialismo histórico" foi a de Pio XI publicando o Sillabus e advertindo: "O comunismo é uma peste destruidora"

Outras encíclicas papais que condenam o marxismo e indicam grande e salutares remedios para os males sociais: "Quod Apostolica Numeris", Leão XVIII (1878) "Divim Redemptoris", Pio XI (março de 1937) e a famosa "Rerum Novarum" de Leão $\mathrm{XIV} .{ }^{217}$

Na reunião seguinte, a professora continuou a preleção afirmado que Lênin, defendendo a idéia de que a escola é sempre política, e não uma instituição neutra, era um apologista do professor agitador e que o marxismo precisava da ajuda de professores comunistas para realizar a almejada revolução proletária. Segundo a professora, era impossível haver igualdade entre as classes sociais. Ela então discorria sobre a organização e hierarquia da Igreja, sobre o "aspecto falso e mentiroso" da desigualdade de classes na Rússia bolchevista e salientava que o trabalho do educador deveria ser o de minorar os problemas sociais com a caridade, como fazia o fundador da Conferência de São Vicente de Paulo. As iniciativas de nomear e combater os inimigos da Igreja

\footnotetext{
${ }^{216}$ O combate ao comunismo em Minas Gerais estava previsto na legislação do início do Estado Novo, através dos decretos n. 1.007 e 1.008 de 25 de outubro de 1937. apesar disso, é pouco provável que tais mulheres, professoras mineiras, estivessem envolvidas com o comunismo. Muitas, certamente, pouco sabiam exatamente do que se tratava. É curioso que as estratégias de combate ao comunismo começassem na escolas, com as professoras, que repassariam aos alunos o temor pela doutrina.

${ }^{217}$ Ata da reunião de 06 de outubro de 1945.
} 
Católica não se restringiam a projetos sociais e políticos, mas também a outras doutrinas religiosas como o Espiritismo, duramente condenado nessas reuniões.

Além dos temas tratados nas reuniões pedagógicas, nas reuniões de quinta-feira destinadas à leitura do professorado, eram escolhidos livros de teor religioso como Pedagogia do Catecismo ${ }^{218}$, do padre Álvaro Negromonte.

A religiosidade dos alunos, através da escola, só seria desenvolvida se estivesse assegurada também entre as professoras. Por este motivo, a formação moral e a participação destas nos eventos religiosos precisava ser fomentada ou mesmo exigida, conforme salienta Maurilane Biccas:

A solução encontrada pela igreja para assegurar o ensino religioso nas escolas foi bastante original e racional. Em primeiro lugar, utilizariam os próprios professores para ministrar aulas de catecismo nas salas de aula. Seria impossível contratar pesoas que cobrissem as inúmeras salas de aulas existentes em todo o Estado. Em segundo lugar era necessário adaptar as lições do catecismo às novas metodologias da escola ativa, Jesus tornava-se o foco central do centro de interesse. (2001, p.266-7)

Como foi visto, apesar de serem as professoras responsáveis pelo ensino de catecismo, os padres não deixavam de ir aos Grupos Escolares, pelo menos em Belo Horizonte, complementando o trabalho realizado por estas. Não se pode desconsiderar a importância da Igreja como um dos dispositivos centrais da estratégia disciplinar. Formar o cidadão, a partir das escolas públicas da capital mineira, constituía, com grande ênfase, em formá-lo a partir da doutrina religiosa católica.

\subsection{A REMUNERAÇÃO DAS PROFESSORAS MINEIRAS}

O decálogo do professor, de autoria de Mário Rabelo, e publicado na Revista do Ensino de 1943, abaixo transcrito, reiterava as qualidades que já foram tratadas aqui como abnegação, religiosidade, dedicação, a exemplaridade do professor e ainda acrescentava o civismo, também muito ressaltado no período.

\footnotetext{
${ }^{218}$ O livro Pedagogia do Catecismo era destinado aos alunos do Curso Normal ou a professores do curso primário, mas não foi localizado. O Padre Àlvaro Negromonte mudou-se para o Rio de Janeiro onde se tornou diretor de ensino religioso na Arquidiocese. Ele publicou a obra Meu Catecismo que tinha quatro volumes, um para cada ano do ensino primário, além de outras como: As fontes do Salvador (sobre a missa e os sacramentos), A doutrina viva, O caminho da vida (sobre a moral cristã) e Manual de religião (destinado ao curso elementar). A única obra encontrada foi Meu catecismo, destinada ao quarto ano do ensino primário.
} 


\section{Decálogo do Professor ${ }^{219}$}

I

Amarei a criança acima de tudo e mais que a mim mesmo.

II

Não a humilharei nem com palavras nem com atos.

III

Serei solícito, prestando-lhe a assistência do meu amor e de minha fé.

IV

Honrarei a minha profissão e, pelo estudo, identificar-me-ei com ela.

$\mathrm{V}$

Não guardarei ressentimento para não me tornar criminoso pelo coração.

VI

Respeitarei na criança a personalidade, deixando-a ser criança, como deve.

VII

Com a esperança do semeador, farei de minha escola a sementeira de minha Pátria.

VIII

Cultuarei a verdade e, com o meu exemplo, incutirei essa virtude no coração dos meus discipulos.

IX

O interêsse da criança, sua felicidade, sua vida serão meu ideal, minha alegria e minha razão de existência.

$\mathrm{X}$

Jamais serei um mercenário, e pontificarei na escola como num altar, -porque o magistério é um sacerdócio.

A décima e última máxima revela como a aproximação da imagem do mestre da de sacerdote afastava qualquer pretensão de recompensa financeira, vista até mesmo como pouco digna para alguém cujo objetivo jamais poderia ser o próprio bem-estar, mas, primeiramente, o de seus alunos e alunas. Embora o texto utilize o vocábulo “professor”, Maria Cecília C. C. Souza afirma que os ideais de dedicação altruística eram preferencialmente dirigidos às mulheres:

Para que a escolarização se democratizasse era preciso que o professor custasse pouco: o professor homem, que tem reconhecido o investimento na formação, tem consciência de seu preço e se vê com direito à autonomia - senão ao conhecimento, pelo menos ao modo de transmiti-lo -, procura espaços não desvalorizados pelo feminino. Por outro lado, não se podia exortar as professoras a serem ignorantes, mas podia dizer que o saber não é tudo nem o principal. Exaltar qualidades como abnegação, dedicação, altruísmo e espírito de sacrifício e pagar pouco: não foi por coincidência que este discurso foi dirigido às mulheres. (1997, p. 288)

Apesar dessa constatação, os baixos salários obtidos por professores em Minas Gerais não pareciam ser exclusivos para as professoras do ensino primário, como mostrava um artigo da revista Educando:

${ }^{219}$ REBELO, Mário. Decálogo do professor. Revista do Ensino, BH, ano VIII, n. 100, p. 2, abr. 1934. 
Não haverá no mundo professores mais dignos e mais decentes do que os nossos. A provincia fez da equipe de nossos intelectuais uma equipe de mestres. Quasi sempre êles teem outras atividades a cátedra representa somente um "amor" a mais na vida. Apaixonam-se pela cadeira, pela escola, pelas suas turmas lhes sacrificam tudo. Resultado: uma cidade de bons professores, bons e abundantes (saindo das repartições, das profissões liberais, da imprensa, dos bancos, de toda parte), que conseguiram outro "record": são também os mestres mais baratos do mundo. Para êles não há salário mínimo. (Temos em mão um "contrato" de professor de uma academia de Comércio e outra de Ginásio, fixando a remuneração "por aula" abaixo de cinco cruzeiros!) Há colégios, (segundo planos de ensino secundário) que se propõem a pagar lições a Cr\$7,50. os professores vão a qualquer por qualquer preço: vão mesmo de graça, graças ao béguin da cátedra. Se amanhã se tentar uma "cooperativa" - êles se recusarão a participar dela: não querem "explorar" o ensino, querem ensinar pelo gôsto de semeadores. ${ }^{220}$

Todas as professoras afirmaram que a compensação financeira pelos seus trabalhos sempre foi mínima ${ }^{221}$. Alaíde Lisboa relatou na entrevista que a professora ganhava para os alfinetes, ou seja, os extras, e ela concorda com esta situação, acreditando que ser professora é mais uma missão do que uma profissão e que a professora deve ganhar mesmo o básico. Ela conta, no entanto, que no período de transição da ditadura, como seu pai fazia parte do Conselho Executivo do interventor Júlio de Carvalho, ela pediu aumento para as professoras e conseguiu. Embora não o tivesse afirmado, deixa a entender que, nesse momento, as professoras não obtinham sequer o básico, o que lhe impulsionou a agir em favor de suas colegas. Elza de Moura também confirma que o professor sempre foi mal pago, mas, segundo ela, as professoras não se importavam: "Uma vez dentro da sala de aula, ninguém tava preocupada com o que tava ganhando. E, naquela ocasião, raramente o professor dobrava. Então tinha tempo de estudar, fazer seu plano de aula". Ela explica que, apesar dos baixos salários, o custo de vida também era mais baixo: "As coisas eram mais fáceis. [...] Aluguel de casa era barato, alimentação era barato, condução era barato. E, geral, as professoras moravam perto de casa. O governo já facilitava. Trabalhava perto de casa”. Esta situação talvez possa ser indicada como um dos motivos pelos quais as professoras, mesmo ganhando pouco, se mantivessem resignadas. Olga Ullman conta

\footnotetext{
${ }^{220}$ LISBOA, J. Carlos. Instantâneos urbanos. Educando, p. 598-599, mar. 1943.

221 Apesar disso, uma pesquisa com 35 professoras deste período revelava que, destas, pelo menos 12 começaram a trabalhar porque precisavam do salário para auxiliar a família que estaria enfrentando situações difíceis. Além disso, a profissão significava, para algumas, uma certa ascensão social. Ainda assim, todas tentaram minimizar a busca do retorno financeiro, enfatizando a vocação e o amor às crianças. (Paixão, 1985)
} 
que, quando o governo do Estado promoveu um Curso Normal Rural ${ }^{222}$, ela pedira a Abgar Renault, Secretário da Educação, para que os rapazes não fizessem o curso porque não era bom que homens ganhassem tão pouco na profissão.

$\mathrm{Se}$ as entrevistadas mostravam-se bastante conformadas com a baixa remuneração profissional, nas memórias das professoras fica mais evidente a situação de penúria enfrentada.

Maria da Glória, já aposentada e residindo em Belo Horizonte com sua família, começou a ter dificuldades no orçamento. Os professores haviam recebido aumento de salários, havia sido decretada a contagem de qüinqüênios, mas ela, aposentada, não recebia nada disso, após 29 anos de exercício de magistério. Diante dessa situação, solicitou à Secretaria seu retorno ao trabalho. Em 1951, ela tomou posse como diretora no Grupo Escolar de Inhapim e, em julho do ano seguinte, conseguiu aposentar-se em definitivo. Apesar dessa história de lutas e de apertos financeiros, ao finalizar suas memórias, Maria da Glória dirigi-se às professoras do II Congresso Nacional das Professoras Primárias, reforçando a imagem do desprendimento e das dificuldades a ser enfrentadas:

É a todas as abnegadas companheiras que me dirijo, com verdadeira emoção, para darlhes uma palavra de estímulo e dizer-lhes que não será vão seu, o nosso trabalho, pela dignificação da classe, pelo futuro do Brasil. É árdua, é áspera é muitas vezes incompreendida a missão de uma professôra. Lida ela com o que há de mais delicado na criação: a alma da criança. Mas por isso mesmo, console-nos aquele pensamento de Georges Bernanos: "Bem-aventurado o que livrou do desespero um coração de criança". (Arreguy, 1958, p. 152)

Benedita também comenta a sua temerária situação financeira como professora do Estado. Mudando-se para Belo Horizonte, teve a oportunidade de realizar um concurso para professora na cidade. Entretanto, havia a exigência do diploma de Normalista. Tendo concluído seu curso em Uberlândia, ela não havia retirado o diploma porque era preciso era preciso pagar uma taxa ${ }^{223}$ cujo valor não dispunha. Precisando do diploma para se inscrever no concurso, ela encontrou uma solução não muito meritória, já que, embora trabalhasse como substituta no Grupo Escolar, o ordenado estava

\footnotetext{
${ }^{222}$ Esse curso durava quatro anos e era um período integral e funcionava na Fazenda Rosário, criada por Helena Antipoff. Era um curso gratuito, com alimentação e moradia custeadas pelo Estado.

${ }^{223} \mathrm{~A}$ taxa correspondia a duzentos e cinquenta mil réis no período.
} 
atrasado, como de costume. A professora resolveu sair às ruas pedindo esmolas para os Sagrados Corações de Jesus e de Maria. Em menos de duas horas, segundo ela, arranjou não apenas o dinheiro do diploma, mas ainda para todas as despesas de postagem no Correio. Obviamente, foi apenas um empréstimo paga tão logo se deu o pagamento dos salários atrasados. Dell'Isola, de forma curiosa, conseguiu instrumentalizar o próprio catolicismo em seu favor. Segundo o relato da professora, pode-se inferir a situação ainda mais precária daquelas que não podia contar com o auxílio do marido ou de familiares para a sua sobrevivência. Embora não comente mais sobre suas finanças, ela também buscou diversos trabalhos após a aposentadoria, lecionado em escolas particulares e dando aulas de reforço em sua própria casa, o que pode indicar que o valor recebido da aposentadoria não era suficiente para suas despesas.

Apesar das dificuldades financeiras, todo o discurso direcionado às professoras era de conformismo e resignação diante dos obstáculos, como mostra um artigo da Revista do Ensino:

A obra formadora da escola está presa a uma qualidade primordial, imprescindível, absoluta - a dedicação, porque a lei única que dirige a educação é a lei do sacrifício.

$[\ldots]$

Mestre é sinônimo de apóstolo. O mestre esclarecido, sustentado, dirigido pela esperança firme em seus sacrifícios, abnegado, que nada quer para si e só espera a recompensa de Deus e da Pátria, realiza uma obra de algo sentido humano e até sobrenatural.

Mister árduo, que exige antes de tudo vocação. A vocação pressupõe certo número de virtudes morais: renúncia, dedicação, espírito de sacrifício. ${ }^{224}$

A luta por melhor remuneração, bem como a participação política das professoras não costumavam ser bem vistas. O artigo 60 do decreto n. 10.362 de 1932 proibia expressamente que funcionários do ensino fizessem parte de diretórios políticos. Em 1937, um aviso da própria presidente da Associação da Professoras no Grupo Escolar Olegário Maciel pedia que as professoras não entrassem publicamente em comitês políticos, o que poderia prejudicar os interesses da Associação. Em 27 de agosto de 1931, foi criada a Associação das Professoras Primárias de Minas Gerais ${ }^{225}$

${ }^{224}$ PAES, Waldemar Tavares. O apostolado do professor. Revista do Ensino, p. 189-190, jul.set. 1952.

${ }^{225} \mathrm{O}$ artigo $2^{\circ}$ do Estatuto da APPMG de 1940 definia como finalidades da Associação: defender os interesses do professorado; elevar a classe por todos os meios a seu alcance; incentivar o espírito de solidariedade e união enre seus associados; favorecer o desenvolvimento intelectual e moral e a cultura 
com o objetivo de minorar as dificuldades e a situação de penúria vivenciada pelas professoras mineiras. A criação da Associação se deu cinco meses após o decreto $n$. 9.892 que estabelecia uma classificação das escolas em quatro níveis, variando a remuneração dos professores. Tal medida reduzia os salários dos funcionários do ensino, além de abolir benefícios concedidos no governo Antônio Carlos. A princípio, a Associação estava envolvida com a formação das professoras, oferecendo cursos e prestando assistência em casos de doença e outras necessidades. Já no final da década de trinta, sua atuação apresentava um perfil mais político e reivindicativo. Em $1942^{226}$, a Associação se mobilizou para conseguir melhores salários para as professoras e novamente, em 1945, teve que pleitear novos salários e a revisão nos critérios para acesso e promoção na carreira do magistério. Tal situação revela que nem toda a ideologia do sacerdócio, da dedicação e do sacrifício eram suficientes para conter a organização das professoras por melhores condições financeiras, o que, mais uma vez, denuncia a precariedade financeira em que deveriam se encontrar.

Marta Nair Monteiro afirma, em suas memórias, que o magistério tinha, tradicionalmente, uma equivalência salarial com algumas patentes da Polícia Militar. Segundo ela, uma professora contratada ou substituta recebia o mesmo que um cabo da Polícia Militar e a professora no início de carreira, concursada e nomeada, recebia valores entre os que auferiam o $2^{\circ}$ e $1^{\circ}$ sargento. A diretora técnica recebia salários próximos ao de um aspirante a oficial e $2^{\circ}$ tenente. Esta professora atuou na liderança de sua categoria profissional buscando conquistar uma melhoria na qualidade de vida de suas companheiras. Apesar disso, num documento encontrado no Grupo Escolar Bernardo Monteiro, a própria Marta Nair escrevera:

Ser mestre, hoje como ontem, é missão de amor...ai dos mercenários! Na voragem da vida escolar seriam tragados pelo maquinário de comodismo, pois que escolas não são

pedagógica do professor e prestar assistência moral e, oportunamente, pecuniária aos sócios, em caso de necessidade. Segundo o artigo $5^{\circ}$, para se associar, o professor público deveria: estar em perfeito gozo de saúde, não estar sujeito a pena infamante, nem responder por processo disciplinar e ter idoneidade moral e profissional. Além disso, era preciso a assinatura de dois outros sócios e uma comissão de sindicância apuraria os dados, admitindo ou não o novo sócio.

${ }^{226}$ Segundo Peixoto (2003, p. 357), o que se reivindica era a reposição do que havia sido retirado pela Revolução de 1930 e em 1932, quando ocorreu uma perda de valor de 100\$00, para fazer face às despesas com a Revolução Constitucionalista de 32. os professores teriam tido um corte de $30 \%$ e os salários ficaram congelados até 1942, quando a APPMG conseguiu a reposição desses 30\% (Peixoto, 1992, p. 7) 
lugares para desanimados nem desanimadores. Ser mestre não é ter profissão, é ser apóstolo de uma pátria. ${ }^{227}$

A necessidade de melhorias profissionais entrava em contradição com a ideologia de renúncia a que se apegavam as professoras e as imposições a que eram submetidas dificultavam a união da categoria e, conseqüentemente, a conquista de benefícios. Numa reunião do Grupo Escolar Tomaz Brandão em 1951, por exemplo, as professoras se uniram em sinal de sua abnegação.

Com a palavra, a sra. Diretora leu um memorial sôbre os vencimentos, mandando por um funcionário da Secretaria da Educação, para ser assinado pelo professorado e dirigido ao Exmo. Sr. Governador Dr. Juscelino Kubitschek. Contendo àquele palavras duras, pesadas e mesmo fortes e em desacôrdo com o sentimento da abnegada mestra mineira, foi resolvido por unanimidade que não seria assinado. ${ }^{228}$

Nesse período, a luta das professoras por melhorias salariais já não tinha o mesmo teor de antes. Em 1954, por exemplo, a Diretora do Grupo Escolar Olegário Maciel recomendava que as professoras tomassem parte no movimento a favor do aumento salarial, mas pedia calma e prudência, evitando-se atitudes contrárias à ética profissional. Em 1959, Marta Nair Monteiro, na condição de Presidente interina da Associação dos professores Primários, liderou a primeira greve da categoria no Brasil.

Após décadas de luta para se manter com dignidade com a remuneração obtida em muitas horas de duro trabalho, finalmente as professoras compreendem que " $\mathrm{O}$ desprezo por uma função se traduz primeiro na remuneração mais ou menos irrisória que lhe é atribuída" como afirma Bourdieu (1998, p. 11). A precariedade das condições de vida não se adequava à nobreza da missão, e a dedicação e o compromisso não se opunham a uma melhor remuneração pelo trabalho.

\subsection{A APARÊNCIA DAS PROFESSORAS}

\footnotetext{
${ }^{227}$ Discurso pronunciado em 21 de setembro de 1950 por Maria Nair - supostamente a Marta Nair - e transcrito no caderno com o Histórico da Escola Estadual Bernardo Monteiro.

${ }^{228}$ Reunião de 29 de setembro de 1951.
} 
A sociedade moderna que se pretendia implantar no país exigia uma população de constituição física saudável e esbelta. A eugenia auxiliava a estabelecer o modelo ideal de cidadão que associava saúde, força e beleza como aspectos essenciais para a produção de uma nação forte. Corpo e mente eram diretamente associados nesse processo, ou seja, um corpo forte, disciplinado, com uma postura ereta e um funcionamento saudável constituía-se num indicativo de uma mente em idênticas condições.

A questão da aparência física é crucial, especialmente entre aqueles que se colocavam como modelos para a sociedade, como as professoras primárias. Por este motivo, é significativa a relação da professora com a aparência física ${ }^{229}$ e a seleção destas profissionais bastante rígida com relação a este aspecto.

O Regulamento de Ensino de 1927 determinava, no artigo 107, que, no início do ano, diretores,professores, pessoal administrativo e enfermeiras deveriam ser submetidos a uma inspeção de saúde e, se fosse o caso, serem vacinados pelos médicos escolares. Este teria também autoridade para afastar temporária ou definitivamente "os que fossem suspeitos de moléstias contagiosas ou portadores de repulsivas”. O pessoal docente, técnico e administrativo das escolas teria direito a consultas gratuitas na Inspetoria médico-escolar. Difícil era, porém, passar pelo crivo dessa inspetoria para conseguir um emprego no magistério primário, especialmente a partir de 1927, como se pode perceber pelas exigências do Regulamento ${ }^{230}$ :

Art. 114. As pessoas attingidas de alguma das moléstias ou anomalias abaixo especificadas serão recusadas ou a sua admissão será adiada para quando o medico escolar julgar conveniente:

a) estado geral: desenvolvimento physico insufficiente; deformação evidente do esqueleto; falta de membro; ankylose de uma articulação importante; claudicação notável;

b) systemas orgânicos: doenças chronicas do coração e dos vasos com pertubações de compensação; doenças chronicas dos órgãos respiratórios, principalmente a tuberculose pulmonar; doenças chronicas dos órgãos da digestão, exigindo regime e precauções especiais, ou podendo, occasionar complicações graves; doenças chronicas do apparelho genito-urinario, exigindo tratamento especial e precauções

\footnotetext{
${ }^{229}$ Uma ex-diretora do Grupo Escolar Bernardo Monteiro, solicitada a participar da pesquisa, pediu para não ser filmada porque, segundo ela, não desejava mostrar-se já velha. Disse ainda que, toda vez que sabia que se encontraria com algum ex-aluno, ia ao salão de beleza porque não podia apresentar-se desarrumada. Esta diretora também não queria que as entrevistas fossem gravadas porque disse que podia cometer algum engano e preferia que não houvesse gravador. Posteriormente, argumentou que estava acompanhando uma filha adoentada e não poderia mais participar da pesquisa.

${ }^{230}$ O Regulamento do ensino Primário de 1924 não traz indicações sobre a seleção física para exercer atividade no magistério primário do Estado.
} 
hygienicas; doenças do systema nervoso central; paralysias importantes; crises graves de hysteria; epilepsia; doenças mentaes; alcoolismo; vícios entorpecentes;

c) doenças graves e constitucionaes: rheumatismo com deformidade; anemias graves; tuberculose sob todas as suas fórmas; syphilis com manifestações contagiantes; bócio volumoso e bócio exophtalmico, hérnias volumosas;

d) affeç̧ões do ouvido, nariz e garganta: surdez esencial ou symptomatica dos dois ouvidos, suppuração chronica do ouvido; ozena; laryngite chronica, com diminuição do poder vocal; tumores no nariz, do pharynge e das cordas vocaes, vícios de articulação d palavra;

e) affecções dos olhos: acuidade visual: si o valor funccional dos olhos é pouco mais ou menos egual, a acuidade visual de cada olho separadamente examinado não deverá ser inferior a 0,5 depois de corrigidos os vícios de refracção si um dos olhos tem acuidade visual inferior a 0,5 , ou não enxerga, o outro deverá ter uma visão corrigida de ao menos $0,7 \%$; nos casos que exijam o emprego de uma lente correctiva, o poder desta não deve ser superior a oito dioptrias; tumores (á excepção dos pequenos tumores benignos); affecções chronicas do aparelho lacrimal, da íris, do corpo ciliar, da choroide, da retina e do nervo óptico; glaucoma; catarata; strabismo com diplopia;

f) affeç̧ões da boca e dos dentes: tumores do maxilares; lábios leporinos; caries numerosas; boccas desdentadas, desprovidas de apparelhos de prothese;

g) affecções da pele: de grande dimensões ou repulsivas, ou exigindo tratamentos especiaes prolongados e freqüente;

h) moléstias contagiosas: todas as moléstias contagiosas, durante o período de contagio. ${ }^{231}$

A exigência de saúde era um critério muito importante também na admissão às Escolas Normais e de Aperfeiçoamento. Entretanto, não era somente a questão da saúde o que importava, mas a imagem física dos estudantes mineiros de uma forma geral. É muito difícil saber como eram estes educadores. Uma pesquisa realizada entre as alunas da Escola de Aperfeiçoamento em 1933 buscava revelar quais as características dessas moças que vinham se preparar pedagogicamente para exercer o ensino no Estado. A pesquisa, realizada pela também aluna Júlia de Magalhães Viotti contou com 101 moças mineiras, estudantes da referida escola. A pesquisa é bastante detalhista, utilizando observações e inquéritos, buscava identificar a idade, o estado civil, a raça, a hereditariedade, as condições de saúde, o meio social, o modus vivendi, entre outros aspectos.

Sobre a questão racial, por exemplo, os inquéritos feitos revelam um índice baixo de mestiçagem na população pesquisada $(79,6 \%$ indicaram ascendentes brancos até bisavós; $12,9 \%$ indicaram mestiçagem de raça branca com negra e 7,4\% indicaram mestiçagem de raça branca com indígena) e levantaram suspeitas a investigadora: " $O$ preconceito de raças ainda bem enraizado entre nós, poderia nos fazer duvidar até certo

${ }^{231}$ MINAS GERAIS, 1927, p. 1.177-8 (Regulamento do Ensino Primário) 
ponto da sinceridade das respostas e portanto da exatidão dos nossos resultados." Deste modo, foi feita uma observação minuciosa de 50 alunas que se submeteram a exames de cor e qualidade dos cabelos, de cor dos olhos e da pele, forma do nariz e espessura dos lábios, assim justificados:

A influência da raça em qualquer um destes característicos é bem conhecida, pois, é por meio deles que a sabedoria popular faz seus diagnósticos raciais. Quem já não pressentiu a existência de sangue negro em um indivíduo que, embora de péle muito clara, tenha o nariz e os lábios grossos e roxos? (Viotti, 1993, p. 19)

Além desses dados, foi analisada ainda a presença de traços de hereditariedade mórbida (doenças e alcoolismo nas famílias), crise puertária (dificuldades vividas neste período que foi localizado entre 13-14 anos para estas moças), períodos menstruais (dias e presença ou não de cólicas e outros incômodos), condições gerais de saúde, bem como o meio social, a educação, o gênero de vida e as preferências.

Uma análise tão pormenorizada indica a importância que tais aspectos assumiam no ensino primário do período. Diversos artigos da Revista do Ensino tocam no tema, as memorialistas e algumas entrevistadas também abordam a questão e se lembram inclusive como era a postura e o vestuário de suas professoras. Segundo Maria Cecília C. C. Souza (200, p. 119), a própria sociedade cobrava da mulher, e em extensão da professora, muito mais uma aparência atraente do que qualificações intelectuais: "O mundo social, principalmente para as mulheres, foi sempre mais sensível às incorreções do gosto e do comportamento que do raciocínio - assim, a ênfase do ensino feminino nas boas maneiras, na vigilância sexual, na aparência, na formação moral”.

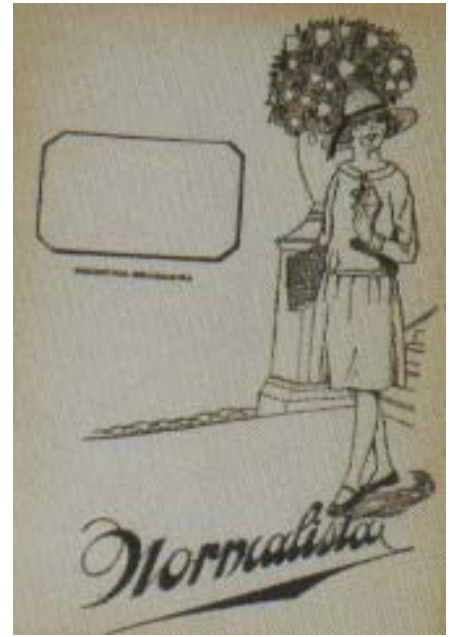

Figura 16: Capa de Caderno da década de 30 Fonte: Folder do Centro de Referência do Professor 
Pode-se supor que, com a introdução do ideário escolanovista, características de jovialidade e modernidade passaram compor as representações sobre a professora. A figura da normalista, colocada acima, revela claramente a imagem de uma jovem em sintonia com a modernidade, demonstrada através do corte de cabelo e do vestido moderno para uma moça dos anos vinte e trinta.

$\mathrm{Na}$ opinião do cronista Carlos Drummond de Andrade, a beleza das professoras era um fenômeno recente na capital mineira:

Antigamente, as professoras usavam óculos e não eram bonitas. Por isso mesmo o ensino se fazia com dificuldades horríveis e ninguém aprendia a ler e escrever, ou aprendia sem gosto, para se utilizar desses conhecimentos lendo ou escrevendo artigos contra a feiúra das professoras. Feiúra respeitável, que se apoiava na palmatória, na varinha de marmelo inquieta sobre a mesa, e no capacete de papel que, apesar de tudo, era o lado mais ameno da escola e dava à gente uma ilusão tímida de Carnaval. Todo mundo se julgava profundamente infeliz, e as professoras também.

Hoje elas são bonitas e não usam óculos. $\mathrm{O}$ ensino mudou. ${ }^{232}$

Segundo o poeta, as moças da Escola de Aperfeiçoamento lançavam moda na capital mineira:

Quando a primeira boina apareceu (por sinal que na cabeça gentilíssima de certa professora-aluna da Escola de Aperfeiçoamento), a cidade julgou que se tratava de um fenômeno esporádico. A cabeça era linda e mais linda ficava com o ligeiro chapéu basco caído indolentemente para a esquerda. Era um "trouvaille" pessoal. Não era moda. A moda era o chapéu "cloche", o chapéu exíguo modelando a cabeça e esticando furiosamente os cabelos - e, mais tarde, o chapéu capacete, que deixa a testa de fora e esconde o pescoço. Isto é que era moda.

Porém essa moda passou, veio outra, e as boinas invadiram, alegremente, a cidade. Pode-se lá viver sem boina? ${ }^{233}$

A afinidade das normalistas e professoras com a modernidade e com o progresso era visível pelo vestuário que indicava que um novo modelo educacional era agora implantado. A juventude, a graça, a beleza deveriam estar dentro dos muros da escola, na aparência física das educadoras ${ }^{234}$ e nas metodologias de ensino utilizadas.

\footnotetext{
232 ANDRADE, Carlos Drummond de. Crônicas 1930-1934. Secretaria de Estado da Cultura de Minas Gerais: Banco de Desenvolvimento de Minas Gerais, 1987. 227p. Esta crônica foi publicada no jornal Minas Gerais na Coluna "Notas Sociais" em 24/04/1930 na página 11. O autor usava o pseudônimo Antônio Crispim.

${ }^{233}$ Crônica publicada no jornal Minas Gerais na Coluna "Notas Sociais" em 10/04/1930 na página 9. O autor usava o pseudônimo Antônio Crispim. No livro Crônicas 1930-1934 está na página 40.

${ }^{234}$ Embora se exigisse todo um cuidado com a aparência física das professoras e com o seu vestuário, a remuneração profissional não parecia ser suficiente para tais investimentos, pelo menos para aquelas que
} 
As lembranças dos(as) entrevistados(as) evocam imagens de professoras bem vestidas e cabelos muito arrumados, o que parecia ser uma exigência da própria sociedade. Em 1943, as professoras do Grupo Escolar Tomaz Brandão dirigiram uma petição verbal ao Conselho Arquidiocesano para que fossem desobrigadas de usar meias durante o exercício de suas funções. Norma Lúcia contou que sua professora temia que as pessoas comentassem o fato de ela retirar o salto alto e utilizar sandálias dentro da sala de aula.

E ela chegava de sapato alto, muito elegante e ela chegava na escola, ela calçava uma sandália. Ela não dava aula de sapato de salto não. Então em tom agressivo, ela falou conosco assim, vocês podem ir lá falar com este pessoal que está falando mal, atacando as professoras, que eu calço sandália aqui dentro da sala. Quer dizer, ninguém falou nada ela estava calçando uma sandália pra comodidade dela, ficava quatro horas andando pra lá e pra cá.

Professoras que não se vestiam bem podiam se tornar alvos de preconceitos. Benedita Dell'Isola comenta que uma de suas amigas, também sua colega e depois diretora, a alertava sempre que a boa aparência e altivez eram indispensáveis a uma professora. Entretanto, ela não dava ouvidos à colega, o que lhe trazia alguns transtornos. Certa vez, ofereceu um auditório à mãe de uma de suas alunas que muito auxiliava a Caixa Escolar. A mãe da menina, uma senhora distinta, como conta a professora, chegou até a sala de aula e achou que ela fosse uma servente escolar. Benedita ficou tão desconcertada que nem conseguiu desfazer a confusão. Uma outra vez, voltando a trabalhar após a aposentadoria, uma diretora começou a lhe ensinar a escrever o alfabeto o que ela considerou a maior humilhação sofrida durante toda a sua vida. Para ela, o único motivo plausível para o ocorrido era a sua aparência descuidada. Ela comenta, ainda, que seu descuido com a aparência fez com que uma aluna, certa vez, a considerasse bem mais velha do que realmente era.

A beleza feminina incluía diversos fatores: a forma de andar, de se vestir e até o tom de voz. A voz das professoras era sempre uma preocupação dos assistentes técnicos, pedindo que fossem mais suaves. As vozes altas e estridentes eram a marca de uma mulher pouco educada, irritada e impaciente. Benedita Dell'Isola teria sido reprovada em um Curso de Aplicação de Testes na Escola de Aperfeiçoamento por não ter uma boa entonação de voz e trocar a letra "l” pela letra "r". Não apenas o tom de voz 
das professoras deveria ser adequado, mas o conteúdo de suas conversas também era motivo de preocupação. Durante uma reunião, em 1947, a diretora do Grupo Escolar Tomaz Brandão ${ }^{235}$ aconselhava as professoras a não conversarem entre si na porta da sala, não levar para o espaço de trabalho assuntos que não estivessem relacionados ao ambiente escolar e "falar menos para serem evitadas as discórdias e desavenças, cousas que não ficam bem a 'educadoras"'.

Ser professora era, antes de tudo, ser disciplinada, como afirma em um trecho de seu Termo de Visitas no Grupo Escolar Tomaz Brandão, Mariana Jofrina Mourão de Miranda:

Sempre achamos que uma boa professôra para ser boa professôra, não precisa ser uma "fonte de saber". Mas, é indispensável que seja entusiasmada, amiga das crianças, fale com voz moderada e tenha boa disciplina. Principalmente, isto: BOA DISCIPLINA! Aqui encontramos ótimos elementos, mas, alguns têm a disciplina um pouco fraca. Sabemos que cada um de nós conhece muito bem as suas falhas. Fazemos um apêlo para que aquelas que se julguem com esta falha se esforcem no sentido de irem se aperfeiçoando, para conseguirem uma disciplina ideal, aquela sem gritarias, sem as ameaças de mandar alunos para fóra da sala (isto então nunca se deve fazer,) etc. e nosso trabalho ficará muito mais suave quando conseguirmos esta disciplina. Vamos frisar aqui: o tom de voz da professôra é muito importante. Nunca deve ser gritante, estridente se ela quer ser realmente uma educadora. ${ }^{236}$

As mulheres alcançavam novos espaços profissionais, mas deviam submeter-se aos ditames sociais que determinavam as roupas consideradas adequadas, o tom de voz e até mesmo o quanto deveriam conversar. Os preconceitos contra a mulher considerada faladeira, irritadiça e nervosa revelam como a cultura social permeava a cultura escolar. Nas reuniões escolares, o tema era também debatido. Numa sessão de quinta-feira no Grupo Escolar Tomaz Brandão, foi feita uma eleição das principais qualidades de uma professora, segundo elas mesmas. Em primeiro lugar teriam ficado o amor, para algumas, e a justiça para outras. Em outra sessão, uma das professoras apresentou uma discussão sobre a firmeza como sendo um atributo indispensável ao educador.

...a firmeza consiste na exacta fidelidade em observar tudo que póde conduzir ao fim que se propõe. Continua dizendo que a maioria das professoras se esforçam para empregar o maximo cuidado em se mostrarem severas e inflexiveis para com as creanças convictas de que o terror é que deve dominar as mesmas; outras alarmadas com tal systema caem no extremo opposto não deixando, pois, de prejudicar os alumnos

\footnotetext{
${ }^{235}$ Reunião de 01 de março de 1947.

${ }^{236}$ Termo de Visitas deixado em 15 de outubro de 1955 por Mariana Jofrina Mourão de Miranda que contém um relatório com cinco páginas datilografadas.
} 
com a bondade excessiva. Diz então que o que se deve adoptar não é o excesso ou o minimo, mas, sim, o meio termo que consiste na reunião da severidade e da brandura. Diz ainda que a professora deve fazer-se respeitar e ser amada por elles pois esta parte é o grande segredo da direcção de uma escola.

Segundo sua preleção, o respeito pela autoridade da professora deveria vir do temor dos alunos e do desejo de não contrariá-la, querendo-a sempre bem. Apesar disso, o aluno precisava estar convencido de que a bondade da professora não a impediria de castigar as faltas cometidas, o que deveria ser feito com muita prudência, justiça e retidão, buscando provocar o arrependimento do faltoso. Em 1950, um inspetor enumerou, em reunião no Grupo Escolar Tomaz Brandão, as principais qualidades de uma professora:

$1^{\circ}$ ) Para que uma professôra possa bem desempenhar seu papel é necessário a bôa condição fisica, pois uma pessôa que não tem bôa saude é claro que não pode desempenhar bem todo e qualquer trabalho.

$2^{\circ}$ ) Capacidade moral. Ser dotada de bons costumes. A professora é o espelho em que a criança se mira, deve esta portanto, ter bôa atitude para não perverter às crianças, pois que, a função da professora é formar homens, é educar. Cabe portanto a nós professoras, formar homens que sejam uteis pelo menos a si mesmo.

$3^{\circ}$ ) Capacidade intelectual. Esta claro que uma professora inculta é um desastre. Ela tem obrigação de conhecer a matematica, ciencias sociais e pedagogicas

Em $4^{\circ}$ lugar vem a capacidade pedagogica. É o que lustra a professora. Toda professora deve saber metodologia, psicologia e pedagogia.",237

Uma boa aparência física, saúde, beleza e disciplina estavam interligados no discurso escolanovista. Por outro lado, começava a se notar a emergência de outros aspectos como a cultura pedagógica.

$\mathrm{Na}$ Revista do Ensino diversos artigos comentavam as qualidades que uma professora deveria apresentar. Num deles, por exemplo, a aparência pessoal ficava em segundo lugar, já a cultura vinha em último. Curiosamente, era um artigo escrito por um homem. As professoras, entretanto, pareciam se esforçar para alterar estas concepções. Comparando as colunas abaixo, pode-se observar qual era a ordem de importância dada às características da professora pelo autor do artigo na primeira coluna e na segunda, para as alunas do Curso de Aplicação na Escola Normal Oficial de Juiz de Fora:

\footnotetext{
${ }^{237}$ Ata de número 65 de 04/03/1950, com participação do inspetor Fábio de Vilhena.
} 
QUADRO 4

Qualidades de uma boa professora

\begin{tabular}{|c|c|}
\hline $\begin{array}{c}\text { Para Raymundo de Almeida, autor de um } \\
\text { artigo na Revista do Ensino }\end{array}$ & $\begin{array}{l}\text { Para alunas do Curso de Aplicação da Escola } \\
\text { Normal de Juiz de Fora } \\
\end{array}$ \\
\hline $1^{\circ}-$ Acolhimento & 1- Cultura \\
\hline $2^{\circ}-$ Aparência pessoal & 2- Acolhimento \\
\hline $3^{\circ}-$ Otimismo & 3- Sympathia \\
\hline $4^{\circ}-$ Reserva ou dignidade & 4- Imparcialidade \\
\hline $5^{\circ}-$ Entusiasmo & 5- Optimismo \\
\hline $6^{\circ}$ - Imparcialidade & 6- Dignidade \\
\hline $7^{\circ}-$ Sinceridade & 7- Sinceridade \\
\hline $8^{\circ}-$ Simpatia & 8- Vitalidade \\
\hline $9^{\circ}-$ Vitalidade & 9- Enthusiasmo \\
\hline $10^{\circ}-$ Cultura & 10- Apparencia pessoal. \\
\hline
\end{tabular}

Fonte: Artigos da Revista do Ensino de 1934 e 1935.

Embora não desconsiderassem a aparência pessoal, ressaltada mesmo em um momento em que a beleza mostrava a saúde e vitalidade de um povo e que a professora deveria ser um modelo para a sociedade, as alunas alteraram completamente a ordem dos quesitos cultura e aparência. Esta última não poderia ser desconsiderada já que a saúde e a ausência de problemas físicos fazia parte da seleção profissional, segundo o próprio Regulamento de Ensino. Por outro lado, a formação profissional e a aquisição de conhecimentos se tornavam mais importantes com a introdução de Reformas no ensino e a exigência de que as professoras estivessem afinadas com as discussões mais modernas no âmbito da educação. O conhecimento da Psicologia, da forma de aplicação e correção dos testes psicológicos, das novidades em técnicas educacionais como o uso do método de projetos, o planejamento das aulas, entre outras exigências, tornavam de significativa importância a cultura da professora, especialmente a cultura pedagógica.

A centralidade da formação dos docentes para a Reforma Francisco Campos pode ser observada nos esforços contínuos de aprimoramento e capacitação desses profissionais. Em 1926, pouco antes da Reforma, foi realizado um Congresso de Educação em Minas Gerais organizado pelo governo que reuniu professores de todo o Estado. Esta foi uma das formas encontradas pelo executor da Reforma de prepará-los para as mudanças que estavam por vir e de conquistar a sua adesão. Além disso, a Reforma incluía o Curso Normal e criava a Escola de Aperfeiçoamento que tinha por

${ }^{238}$ ALMEIDA, Raymundo de. Ensino moderno e religião. Revista do Ensino, BH, ano VII, n.98, 99,100, p. 39-46, jan.fev.mar.1934, p.42.

239 JUNQUEIRA, Dulce Botelho. A orientação profissional. Revista do Ensino, BH, ano IX, n. 118, p.218, set. 1935 . 
objetivo aperfeiçoar a formação de professoras já em atividade, selecionando uma elite de educadores que iria fiscalizar, orientar e organizar o trabalho realizado dentro das escolas. O investimento na formação profissional dos educadores era alto: renomados pesquisadores do exterior foram convidados a vir até Minas para promoverem cursos na Escola de Aperfeiçoamento, e professoras mineiras foram enviadas aos Estados Unidos para se atualizarem nas novas metodologias educacionais ${ }^{240}$. A Revista do Ensino, órgão de divulgação das Reformas promovidas no Estado, passou por uma reformulação objetivando uma maior divulgação entre os professores, em especial, os de localidades mais afastadas da capital, centro da Reforma.

Todos estes investimentos reiteram a necessidade de formação de profissionais sintonizados com as Reformas Educacionais. Foram as professoras as responsáveis pela transposição das técnicas e propostas das Reformas para o cotidiano escolar. Transitando entre o mundo dos programas, das normas, das legislações e o da implementação destes no meio educacional constituem-se vozes de significativa importância na análise do como as Reformas foram interpretadas e convertidas em práticas efetivas de educação nas escolas públicas primárias mineiras. É preciso considerar, no entanto, que, dentre tantas normas e exigências, por vezes confusas e contraditórias, entre ter beleza ou ter conhecimento, estudar ou usar os sapatos adequados, ser disciplinada e também autônoma e disciplinadora, as mulheres tiveram de encontrar os melhores caminhos, improvisando e criando saídas possíveis para as práticas educativas que efetivamente implementavam.

Se havia interesse e disposição por parte do governo do Estado em formar as professoras para um melhor trabalho pedagógico, o movimento foi recíproco por parte delas. Apesar de inúmeras dificuldades a serem vencidas, elas se fizeram presentes em todas as iniciativas para o aumento da qualificação profissional. De acordo com Peixoto (2002), com o fim do governo Antônio Carlos - Francisco Campos, houve retração na

\footnotetext{
${ }^{240}$ Segundo Ângela Souza (1984), Francisco Campos solicitou à diretora da Escola Normal, Ignácia Guimarães, que indicasse algumas professoras para irem com ela aos Estados Unidos estudar na Universidade de Colúmbia e se preparar para a Reforma no ensino primário e normal a ser implantada em Minas. Foram escolhidas: Amélia de Castro Monteiro, vice-diretora do Grupo Silviano Brandão; Alda Lodi, professora das classes anexas da Escola Normal; Benedita Valadares Ribeiro, professora do Grupo Barão do Rio Branco e Lúcia Schimdt Monteiro de Castro. Lúcia, a mais jovem do grupo, teria recebido autorização de seus pais para a viagem quatro horas antes do embarque e, segundo ela, estas foram as palavras de Francisco Campos na estação de embarque: "Não quero diplomas, nem certificados. Venham preparadas". Benedita, Amélia e Lúcia voltaram para o Brasil em fevereiro de 1929, Alda Lodi ficou mais um semestre e Ignácia Guimarães viajou para a Alemanha.
} 
oferta de ensino no nível primário e normal. Muitas escolas foram fechadas e diminuídas as vagas na Escola de Aperfeiçoamento, sendo um período de pouco investimento em todo o setor educacional no Estado. Prevalecendo a dúvida se a cultura era ou não significativa para formação das professoras, não havia porquê investir em sua qualificação profissional.

Em 1947, numa pesquisa com professoras e alunas do Instituto de Educação sobre as qualidades mais importantes para a professora, uma nova característica era ressaltada: 69 indicações (7,3\%) referiam-se ao aspecto físico, $250(26,6 \%)$ ao intelectual e $619(65,9 \%)$ aos aspectos morais.

QUADRO 5

Qualidades do professor, segundo as professoras-alunas do Instituto de Educação

\begin{tabular}{llcc}
\hline & Qualidades na ordem crescente de indicações & Indicações & Porcentagem \\
\hline 1 & Retidão moral & 150 & 15,9 \\
2 & Bondade e afabilidade & 140 & 14,9 \\
3 & Solidariedade e camaradagem & 119 & 12,6 \\
4 & Ascendência moral, liderança & 113 & 10,9 \\
5 & Bons métodos de ensino & 75 & 7,9 \\
6 & Clareza ao expressar-se & 54 & 5,7 \\
7 & Bom humor & 52 & 5,5 \\
8 & Interesse profissional & 49 & 5,2 \\
9 & Cultura geral & 38 & 4,0 \\
10 & Vivacidade de espírito & 33 & 3,5 \\
11 & Auto controle & 32 & 3,4 \\
12 & Aparência agradável & 31 & 3,3 \\
13 & Distinção no porte, maneiras corretas & 23 & 2,4 \\
14 & Respeito à personalidade & 18 & 1,9 \\
15 & Voz agradável & 13 & 1,3 \\
16 & Espírito religioso & 3 & 0,3 \\
17 & Senso artístico & 2 & 0,2 \\
18 & Patriotismo & 2 & 0,2 \\
19 & Saúde & 2 & 0,2 \\
\hline
\end{tabular}

Fonte: LUSTOSA, Irene. Uma pesquisa vocacional. Revista do Ensino, BH, ano XV, n.184, p.26-37, jan.mar.1947, p. 34-35.

QUADRO 6

Defeitos do professor, segundo as professoras-alunas do Instituto de Educação (Continua)

\begin{tabular}{llcc}
\hline & Defeitos do professor & Indicações & Porcentagem \\
\hline I & Usar maus métodos de ensino & 80 & 20,2 \\
II & Defeitos de caráter & 76 & 19,2 \\
III & Aspereza no trato & 54 & 13,6 \\
IV & Falta de clareza & 43 & 10,8 \\
V & Mau humor & 29 & 7,3 \\
VI & Enfado e desinteresse & 24 & 6,0 \\
VII & Anti-sociabilidade & 23 & 5,5 \\
VIII & Falta de energia & 16 & 4,0 \\
IX & Não respeitar a personalidade & 14 & 3,5 \\
\hline
\end{tabular}


QUADRO 6

Defeitos do professor, segundo as professoras-alunas do Instituto de Educação (Conclusão)

\begin{tabular}{llcc}
\hline & Defeitos do professor & Indicações & Porcentagem \\
\hline X & Falta de cultura & 8 & 2,0 \\
XI & Debilidade física & 8 & 2,0 \\
XII & Defeitos do aparelho fonador & 8 & 2,0 \\
XIII & Lentidão de espírito & 6 & 1,5 \\
XIV & Aparência desagradável & 6 & 1,5 \\
\hline
\end{tabular}

Fonte: LUSTOSA, Irene. Uma pesquisa vocacional. Revista do Ensino, BH, ano XV, n.184, p.26-37, jan.mar.1947, p. 35-36.

Nesta pesquisa, nem a aparência nem a cultura foram indicadas como a qualidade primordial do professor. Os atributos relacionados à moralidade foram os mais ressaltados, alcançando a larga maioria dos votos. Também com relação aos defeitos, o caráter esteve quase empatado com a falta de métodos adequados do ensino. Fica evidente que, à cultura pedagógica, associava-se a necessidade de uma moralidade que deveria se constituir como exemplar, tanto para os educandos quanto para a sociedade. Talvez por isso a questão da religiosidade apareça com tanta freqüência, já que a moral religiosa era sempre indicada como essencial à boa professora.

\subsection{A PROFESSORA E A MATERNIDADE}

Um artigo na Revista do Ensino discutia a questão do celibato pedagógico, defendendo a idéia de que a mulher celibatária não era a mais indicada para o exercício da tarefa de ensinar. Dos quinze argumentos a respeito da função pedagógica a ser exercida pela mulher, especialmente, a mulher casada e mãe, pode-se destacar:

1- $\quad$ Tendo a escola primária por missão mais educar do que instruir (ao contrário das escolas secundária e superior), segue-se que o melhor professor primário é aquele que possui mais apuradas as qualidades de educador;

2- $\quad$ Ninguem melhor do que a mulher exerce êsse mister na escola primária e nas instituições pré-escolares;

3- $\quad$ Entre uma professora solteira e outra casada, esta, regra geral, é melhor educadora do que aquela, em virtude do tirocínio materno no lar;

4- $\quad$ Para que a escola seja efetivamente a "continuação do lar" é preciso que entre ambos haja o equilíbrio de vasos comunicantes, levando a professora para a escola as qualidades educadoras da mãe de família;

5- A professora-mãe é mais paciente, compreende melhor a alma da criança, adivinha-lhe os desejos, é mais estimada pelos discípulos, realizando assim, num ambiente de confiança, a disciplina suave na escola;

6- A professora solteira tem uma vida "errante" no magistério, mudando todos os anos de lugar, com grave prejuizo para a continuidade da educação escolar. Êsse "nomadismo" não se dá com a professora casada, que se fixa em determinada 
localidade, preparando várias gerações de educandos, que continuam, depois da escola, a ouvir-lhe os conselhos.

7- $\quad$ A professora solteira, no interior do Estado, longe da família, é obrigada a viver pela casa de estranhos ou em pensões promíscuas; ${ }^{241}$

A idéia de que a professora deveria se espelhar na mãe era constante, inclusive entre as próprias professoras. Em 1950, por exemplo, a orientadora Maria Nair ${ }^{242}$ pronunciava um discurso em comemoração ao aniversário da diretora do Grupo Escolar Bernardo Monteiro, afirmando:

Se a mãe desdobra fibra por fibra a própria alma, mais glória cabe a quem cuida daqueles que não são carne de sua carne.

Mãe e Mestra, contudo são cores que se juntam nos painéis da vida e então, a criança nivela que se equivalem em grandeza e que se confundem no relicário do coração! ${ }^{243}$

A professora não era apenas identificada à figura da mãe, freqüentemente se afirmava que ela deveria superá-la: "A mãe, defeituosa, prejudica, apenas, a seus próprios filhos. A professora, de caracter falho, contamina os filhos de muitas outras mulheres...". 244

No entanto, muitas professoras deixaram de se casar $^{245}$, dedicando-se inteiramente à tarefa da educação pública, como nos indicam Diana Vidal e Marília Carvalho:

O estatuto ambíguo da inserção da mulher no universo escolar, ora positivado por atributos tidos por naturais, como a maternidade e a socialização infantil, ora negativado pela função social que ocupava, fazia da escola um lugar freqüentado por mulheres, mas onde a ascensão e mesmo a permanência na profissão era de gênero masculino. Isto é, muitas chegaram a aposentar-se como professoras e parte delas ascendia na carreira, mas fizeram-no à custa de renunciar a comportamentos, práticas e valores que associavam a feminilidade, especialmente a um dos aspectos centras da identidade feminina no período estudado, a maternidade.(2001, p.32)

Apesar dessa estreita ligação que se fazia entre a figura da professora e da mãe, as professoras demonstram que não era simples conciliar as duas funções. Em suas

\footnotetext{
${ }^{241}$ CELIBATO Pedagógico. Revista do Ensino, BH, ano VII, n.9, p.105-107, dez. 1933. p.106.

${ }^{242}$ Supostamente trata-se da mesma Marta Nair que escreveu as memórias utilizadas nesta pesquisa.

${ }^{243}$ Discurso pronunciado em 21 de setembro de 1950 no caderno Histórico da E.E. Bernardo Monteiro.

${ }^{244}$ SANTIAGO, Alice de Andrade. A personalidade em formação e a responsabilidade do professor. Revista do Ensino, BH, ano VIII, n. 104, p. 68-71, ago.1934.

${ }^{245}$ Foi este o caso de Imene Guimarães e Elza Moura, entrevistadas para este estudo. É curioso que o salário da professora pudesse ser menor em função se ser um salário complementar ao do marido, quando se percebe que muitas não se casaram e precisavam se sustentar com a parca remuneração recebida.
} 
memórias, elas pouco escrevem sobre os filhos, o casamento ${ }^{246}$, ou outras relações sociais. As memórias são, como algumas intitulam seus livros, memórias de professoras. Apesar dos muitos filhos, eles aparecem com um pano de fundo que, vez ou outra, são postos na trama, mas sem atingir o foco principal, que é sempre a escola. Maria da Glória conta que, ao final do livro, a caçula havia ficado triste porque não havia nascido na narrativa. Também a chegada do primeiro neto não havia sido comentada. Benedita, por sua vez, não conta o nome do marido ou dos filhos, embora nomeie suas colegas de classe no Curso Normal, seus primeiros alunos e alunas, seus vizinhos em Uberlândia, entre outros, lembrando-lhes o nome e sobrenome. Mesmo Marta Nair que fala da sua vida pessoal na primeira parte da obra, reserva a segunda exclusivamente para as atividades de cunho profissional. Alaíde Lisboa de Oliveira trata da família, mas também reserva muitos poemas para a vida escolar e profissional.

Tais esquecimentos e omissões não nos parecem isentos de significação. Ser professora significava um afastamento do meio familiar. Durante várias vezes, Maria da Glória ficava distante da família, ou de parte dela, para poder levar adiante suas atividades profissionais. Foi assim durante a Escola de Aperfeiçoamento, e durante alguns trabalhos como professora. Benedita conta também que, em 1930, o marido veio trabalhar como contador em Belo Horizonte e ela ficou com as crianças em Uberlândia para terminar o Curso Normal. Conciliar atividades domésticas como o cuidado com os filhos e a família, e as exigências profissionais não pareciam ser tarefas simples para essas mulheres. Na Escola Normal Oficial de Juiz de Fora uma pesquisa com alunas do Curso de Aplicação indicava que estas já tinham idéia da dura tarefa pela frente. Foi solicitado que elas escrevessem cartas a uma pessoa que quisesse fazer o Curso Normal, animando-a ou dissuadindo-a da idéia. Das 60 cartas enviadas, 43 aconselhavam a carreira, 11 diziam que aconselhavam dentro de algumas condições e 6, ou seja 10\%, não aconselhavam por considerarem o trabalho excessivo, penoso e mal remunerado.

\footnotetext{
${ }^{246}$ Léa Pinheiro Paixão (1985), numa pesquisa com 35 professoras primárias em Minas Gerais que iniciaram na profissão ente os anos de 1924 e 1938, revelava o preconceito contra o "marido da professora", expressão utilizada para designar homens preguiçosos que se mantinham às custas do trabalho da mulher. Por isso, alguns homens não incentivavam as filhas e esposas a estudarem, acreditando, ainda, que teriam o seu reconhecimento reduzido, na medida em que as pessoas se referiam sempre à casa da professora, mudança da professora, não se referindo a seus maridos. Nas fontes consultadas não foi possível detectar esses preconceitos. Luíza Travassos, no entanto, afirmou que casar com uma professora era um sinal de distinção social almejado entre os homens.
} 
Curiosamente, uma pesquisa realizada com alunas-professoras da Escola de Aperfeiçoamento em 1933 revelou que 65,5\% estavam satisfeitas e exerciam com agrado a sua profissão, entretanto $31 \%$ estavam descontentes e $3,4 \%$ se mostraram indiferentes ${ }^{247}$. Para uma escola tão afamada e cuja admissão era sempre muito difícil, este é um dado bastante significativo.

Talvez estivesse ficando claro para as normalistas que a conciliação entre a carreira profissional e as tarefas domésticas não era uma tarefa simples e que, apesar dos atributos de fragilidade, docilidade e vulnerabilidade, a formação e o exercício profissional no magistério exigiam coragem para enfrentar diversas situações, como os cursos exigentes, as avaliações rígidas, a fiscalização da burocracia estatal, a dedicação ao trabalho. Além disso, às vezes era necessário deixar a família em segundo plano, dando preferência pelos filhos alheios, os alunos, em detrimento dos filhos naturais, além da remuneração pouco compensatória.

\subsection{AS LUTAS DE REPRESENTAÇÕES}

Se o próprio Estado não conseguia se desvencilhar do poder absoluto da Igreja Católica no período, não seriam as mulheres, tradicionalmente veiculadoras da doutrina religiosa católica, as que o fariam. Entretanto, pode-se perceber que, mesmo aquelas que mais despertavam temor na cúpula da Igreja, como a russa Helena Antipoff, podiam não somente vencer os inimigos, mas até mesmo transformá-los em aliados. Certamente, outras mulheres tiveram astúcia e coragem para alterar as representações que se faziam acerca delas.

Quanto à remuneração, fica claro que, junto com o discurso do desprendimento e da abnegação, as mulheres se organizaram e lutaram pelos seus direitos e, entre eles, o de maior reconhecimento financeiro pelo trabalho realizado. Desde a criação da Associação dos Professores Primários até as greves iniciadas em fins da década de cinqüenta, as mulheres estiveram à frente de reivindicações em torno de melhorias na educação pública primária que passam, sobretudo, pelo reconhecimento dos profissionais que nela trabalham.

${ }^{247}$ VIOTTI, Julia de Magalhães. Contribuição à antropologia da moça mineira. Boletim n. 13. Belo Horizonte: Secretaria da Educação e Saúde Pública; Inspetoria Geral da Instrução, 1933.73p. 
No aspecto referente à beleza física também é clara a manifestação das mulheres no sentido de valorizar a cultura e, especialmente, a cultura pedagógica como sendo fundamentais para o exercício do magistério. Apesar da força das teses eugênicas em voga na época, dando estatuto científico à necessidade de uma bela estética, as mulheres investiram na sua qualificação profissional, deixando de lado mesmo o reino doméstico para o qual sempre foram preparadas, objetivando alcançar uma formação que melhor lhes preparasse para o exercício profissional. Duas reivindicações se complementavam: a das mulheres que ambicionavam maiores níveis culturais e da própria corporação que exigia uma maior cultura pedagógica. Dessa reunião, dessa junção de esforços, as mulheres foram deixando paulatinamente a imagem da fragilidade, da incapacidade e da labilidade emocional para alcançar novos papéis sociais, ainda que estes lhe trouxessem muitos outros desafios e exigências.

A educação para a mulher estava, desde o ensino primário, voltada para o ambiente doméstico. Nos trabalhos manuais, o exercício do bordado treinava a paciência e a concentração, a quietude e o auto-controle. Nenhuma das fontes consultadas discutiu o maior êxito feminino no universo escolar, nem a preferência das meninas pela aritmética, verificada através de pesquisas realizadas pelo Laboratório de Psicologia. A ênfase nas diferenças entre meninos e meninas era sempre retratada de forma natural. A participação da mulher na vida pública iniciava um processo irreversível e, de forma lenta e cautelosa, as mulheres se desvencilharam do papel de mãe e esposa a que estavam confinadas, alcançando novos objetivos. Talvez por ter sido um movimento silencioso e crescente, não tenha despertado maior alarde. Talvez porque a conquista no plano profissional não significasse, naquele momento, autonomia e liberdade de pensamento. Ou ainda porque as mulheres foram levadas por um projeto capitalista de colocar todos, sem exceção, a serviço do capital. Apesar das mazelas e do esforço multiplicado para atender às diversas exigências que se colocaram com a saída da mulher do espaço doméstico, não se pode desconsiderar que as professoras foram pioneiras no sentido de demonstrar que as capacidades femininas não se reduzem à maternidade. Mais do que as Reformas Pedagógicas oficiais, esta foi uma revolução anônima e silenciosa, realizada sem alardes, mas efetiva e que, paulatinamente, contribuiu para estabelecer uma nova cultura escolar e social. 
Como nos indica Maria Cecília C.C. Souza (2000, p.38): "Revisitar a imagem da antiga escola pública consiste num esforço de capturar a razão pela qual, afora todo o saudosismo, ela permanece viva na educação, suspendendo, pelo menos por enquanto, a acusação de uma imagem reacionária”. Esta visita, implica, sobretudo, reconhecer os avanços e recuos da educação e reconhecer a herança que nos foi deixada por nossos antecessores. Foram as suas estratégias e táticas para o seu exercício profissional nos Grupos Escolares que auxiliaram a construir o sistema de ensino que hoje vivenciamos. 


\section{CAPÍTULO 3 \\ EDUCADORES EM GRUPOS ESCOLARES DE BELO HORIZONTE: CONVIVÊNCIAS E RESISTÊNCIAS}

A partir das memórias das educadoras e de documentos arquivados nos porões das escolas, pode-se buscar pistas das estratégias e táticas levadas a efeito nos espaços escolares, bem como das apropriações dos discursos normativos e da implementação destes no ambiente escolar. Um aspecto interessante, percebido a partir dos documentos dos arquivos, especialmente as atas de reuniões de professoras, consiste na ambígua situação das diretoras, orientadoras, inspetores e assistentes técnicas que atuavam como intermediários entre as professoras e os órgãos estaduais responsáveis pela educação pública. Eram eles que levavam aos Grupos as recomendações e exigências acerca do funcionamento destas instituições e, deste modo, lidavam mais diretamente com a transição entre as normas e as suas efetivas aplicações.

Sobre a administração da educação em Minas Gerais, Ana Maria Casasanta Peixoto esclarece:

Até 1930, a administração do sistema escolar mineiro ficava a cargo da Secretaria dos Negócios do Interior e da Justiça, que mantinha como órgão consultivo para assuntos relativos à educação o Conselho Superior de Instrução e como órgão executivo, a Inspetoria Geral de Instrução.

Em 1930, antecipando-se ao governo federal, o Estado cria um órgão próprio para os assuntos relacionados ao setor - a Secretaria de Educação e Saúde (Lei n ${ }^{\circ}$ 1.147, 6/9/1930). O novo serviço, mantém, em seus primeiros momentos, a estrutura original, cabendo à Inspetoria Geral de Instrução as primeiras responsabilidades na administração do ensino. Essa estrutura vai, aos poucos, sendo modificada, e embora só assuma contornos definitivos em 1934, inovações introduzidas pelo decreto 10.362/32 indicam o formato que, em breve, assumirá o aparelho escolar. (Peixoto, 2003, p. 127)

Em 1932, no governo de Olegário Maciel, o Secretário da Educação, Noraldino Lima instituiu o decreto n. 10.362 que intensificou o controle sobre o trabalho escolar com a criação do cargo de professoras técnicas nos Grupos Escolares. Este decreto visava adaptar a Reforma Francisco Campos ao novo governo.

Se esses serviços, por um lado, detêm uma soma de poder considerável - no plano interno da escola, por exemplo, a última palavra é, como foi dito, a do técnico, cabendolhe decidir sobre as medidas a serem tomadas nos planos a serem executados, orientar o ensino nas diversas classes..., acompanhando a organização dos planos de lições e a execução dos programas, de modo que obedeçam às normas práticas pedagógicas -, por 
outro lado têm sua ação limitada e controlada em esferas mais altas. (Peixoto, 2003, p. 133-134).

Além de uma divisão de trabalho e uma expropriação de saberes de professores e diretores, passou a haver um maior controle por parte da Secretaria de Educação ${ }^{248}$ que tinha, em seus inspetores e assistentes, uma forma de intervenção direta no trabalho escolar, às vezes, dentro da própria sala de aula. De acordo com Foucault (1987, p.153), o olhar hierárquico é um dos instrumentos simples que possibilitam o sucesso do poder disciplinar. A vigilância ${ }^{249}$ de inspetores e diretores no ambiente escolar tornava o trabalho das professoras suscetíveis à crítica e intervenção de outros, destituindo ou limitando-lhes a autoridade sobre a classe. O corpo técnico fiscalizava a pontualidade de professoras e alunos, as atividades intra e extra-classe, o comportamento das professoras, fazendo das reuniões um momento crucial para lembrá-las dos compromissos assumidos e chamá-las à ordem.

O decreto n. 10.362 criou o Corpo Técnico da Assistência, na Secretaria de Educação e Saúde e um serviço de assistência técnica, junto às escolas. Os cargos de assistente técnico seriam ocupados por diplomadas pela Escola de Aperfeiçoamento, normalistas de $2^{\circ}$ grau diplomadas após o Regulamento de 20 de janeiro de 1928 e candidatos classificados em concurso. A capital seria provida de sete assistentes técnicos, dois destes teriam funções especiais: um como inspetor do ensino técnico e o outro como inspetor do ensino de trabalhos manuais e modelagem. Para o interior, haveria um assistente para cada circunscrição do Estado.

\footnotetext{
${ }^{248}$ Segundo Peixoto (2003, p. 127), até 1930, a administração do sistema escolar mineiro ficava a cargo da Secretaria dos Negócios do Interior e da Justiça, que mantinha, como órgão consultivo para assuntos relativos à educação, o Conselho Superior de Instrução e como órgão executivo, a Inspetoria Geral de instrução. Em 1930, antecipando-se ao governo federal, o Estado criou um órgão próprio para os assuntos relacionados ao setor - a Secretaria de Educação e Saúde, mantendo, em seus primeiros momentos, a estrutura original, cabendo à Inspetoria Geral de Instrução a responsabilidade na administração do ensino. Essa estrutura adquiriu contornos definitivos com o decreto n. 10.362./32.

${ }^{249}$ De acordo com Foucault (1987, p.158), a vigilância hierarquizada, contínua e funcional é uma das características do poder disciplinar e: "Organiza-se assim como um poder múltiplo, automático e anônimo; pois, se é verdade que a vigilância repousa sobre indivíduos, seu funcionamento é de uma rede de relações de alto a baixo, mas também até um certo ponto de baixo para cima e lateralmente; essa rede 'sustenta' o conjunto, e o perpassa de efeitos de poder que se apóiam uns sobre os outros: fiscais perpetuamente fiscalizados. O poder na vigilância hierarquizada das disciplinas não se detém como uma coisa, não se transfere como uma propriedade; funciona como uma máquina. E se é verdade que sua organização piramidal the dá um 'chefe', é o aparelho inteiro que produz 'poder' e distribui os indivíduos nesse campo permanente e contínuo. O que permite ao poder disciplinar ser absolutamente indiscreto, pois está em toda parte e sempre alerta, pois em princípio não deixa nenhuma parte às escuras e contra continuamente os mesmos que estão encarregados de controlar; e absolutamente 'discreto' pois funciona permanentemente e em grande parte em silêncio."
} 
No governo seguinte, de Benedito Valadares, Noraldino Lima realizou algumas alterações na lei anterior definindo as funções dos assistentes técnicos e das professoras técnicas, a partir do decreto n. 11.501 de 1934:

Art. 60 - Aos Assistentes Técnicos do ensino incumbe: [...]

$3^{\circ}$. - visitar os estabelecimentos de ensino que lhes forem distribuídos, inspeccionandoos quanto á installação e organização, á technica e efficiencia do ensino, á idoneidade dos professores e á disciplina, hygiene e approveitamento dos alumnos;

$4^{\circ}$ - orientar technicamente os directores e professores no trabalho educativo, estimulando-os e assistindo-os na applicação dos methodos e processos de ensino, suggerindo ou realizando experiências e demonstrações praticas.

$5^{\circ}$ - proceder, ao fim de cada visita, á critica dos trabalhos escolares assistidos, suggerindo modificações nos methodos e processos que a Secretaria da Educação determinar, e propor á aprovação desta as que pretenda realizar por iniciativa própria.

[...]

Art. 65. - O Secretario da Educação e Saúde Publica designará annualmente, na primeira quinzena de janeiro, professoras technicas assistentes para os grupos escolares do Estado, escolhidas entre as professoras diplomadas pela Escola de Aperfeiçoamento que tiverem demonstrado capacidade de direcção e orientação. [...]

Art. 68 - Á professora technica assistente incumbe:

$1^{\circ}$ - testar os alumnos do estabelecimento, organizar as classes homogêneas com a collaboração do director e professores, iniciando os testes individuaes com as creanças novatas uma semana antes da abertura das aulas e nos primeiros dias de aula ou tests collectivos com os alumnos matriculados nos annos anteriores, terminando a organização das classes em $1^{\circ}$ de março;

$2^{\circ}$ - orientar o ensino nas diversas classes do grupo, especialmente nas de retardados, acompanhando a organização dos planos de lições e a execução dos programmas, de modo que obedeçam ás novas praticas pedagógicas. [...]

$8^{\mathrm{o}}$ - orientar os trabalhos de socialização e o funccionamento das instituições e associações escolares, e cooperar na obra de aproximação entre a escola e a família; ${ }^{250}$

Em 1938, Cristiano Machado, através do decreto-lei n. 38, extinguiu o Serviço de Assistência Técnica, criando a Inspetoria de Assistência Técnica do Ensino. A Inspetoria criada teria 27 inspetores de ensino, um para cada circunscrição criada no Estado. Os assistentes técnicos que mais houvessem se destacado seriam aproveitados na nova Inspetoria, os outros se manteriam em disponibilidade remunerada até serem aproveitados em outros cargos ou seriam aposentados. No ano de 1950, os inspetores técnicos regionais $^{251}$ já eram quarenta, conforme o aumento das circunscrições no Estado. Para se tornar inspetor técnico nesse momento era necessário ter diploma da já

${ }^{250}$ MINAS GERAIS. Decreto n. 11.501 de 31 ago. 1934. Approva modificações feitas no decreto n. 10.362, de 31 de maio de 1932 .

${ }^{251}$ A Lei n. 1.127 de 1954, no governo de Juscelino Kubitschek de Oliveira e do Secretário Levindo Furquim Lambert, concedeu aos Inspetores Regionais do Ensino os mesmos direitos dos professores, sendo considerados como cargo de magistério. 
extinta Escola de Aperfeiçoamento ou do curso de Administração Escolar do Instituto de Educação. Em 1955, no governo de Clóvis Salgado Gama, o Secretário Bolívar de Freitas baixou o decreto n. 4.565 que exigia que a admissão à carreira de inspetor regional do ensino se desse através de concurso de provas e títulos e que os diplomas no Curso de Administração Escolar do Instituto de Educação, no Curso de Pedagogia da Faculdade de Filosofia e o fato de ser membro do magistério federal ou estadual contassem como pontos diferenciais.

A entrada súbita de inspetores e diretores nas escolas e salas de aula era uma forma de vigilância bastante comum sobre o trabalho realizado nas escolas. Segundo Imene Guimarães, o Dr. Mário Casasanta, Diretor Geral da Instrução Pública, tinha o costume de ir assistir às aulas dadas nas escolas. Toda manhã ia visitá-las de surpresa. Pelas atas e documentações consultadas, é possível perceber que Mário Casasanta estava mesmo sempre presente nas escolas, especialmente nos dias de solenidade, como no encerramento do ano letivo, nas exposições de trabalhos manuais ou em outras datas comemorativas, o que denota uma proximidade de alunos e professoras com a Secretaria de Educação, mas também a ingerência desta dentro dos Grupos Escolares. Apesar disso, Imene Guimarães conta que as alunas da Escola Normal lhe fizeram uma homenagem já que se sentiam próximas a ele, pois este, às vezes, passava toda a tarde na escola e ouvia as alunas. Outras professoras, no entanto, não sentiam o mesmo prazer em receber, de surpresa, essas autoridades da educação em suas classes. Dell'Isola mesmo afirma que tinha verdadeiro horror a essas visitas.

\subsection{DIRETORAS, ORIENTADORAS, ASSISTENTES TÉCNICAS E PROFESSORAS}

Dentre os Grupos Escolares estudados para esta pesquisa, apenas o Grupo Escolar Olegário Maciel teve um diretor do sexo masculino, Francisco José Bernardes, que atuou entre 1926 e $1929^{252}$. Entretanto, no seu período de atuação, ora ele, ora Maria Carmem da Silva assinava como substituta e ora assinava o inspetor regional, Ernesto C. Santiago, o que indicia que o diretor deveria estar passando dificuldades para se manter constantemente na diretoria do Grupo.

${ }^{252}$ Os homens, em geral, ocupavam cargos de inspeção e outros postos na Secretaria. 
As diretoras ficavam durante muitos anos na direção da escola. A relação de Emma Ciodaro com o Grupo Escolar Pandiá Calógeras, por exemplo, era anterior à própria criação deste. Ela teria sido orientadora técnica na Escola Dante Alighieri que dera origem ao Grupo. Em 1935, com sua fundação ${ }^{253}$, ela se tornou sua diretora, cargo no qual permaneceu durante 51 anos. Aos 85 anos, afastou-se por motivo de doença, vindo a falecer dois meses depois de sua saída.

A escolha dos diretores dos Grupos Escolares mineiros, pelo menos em Belo Horizonte, parecia ser feita pela Secretaria do Interior antes da criação da Escola de Aperfeiçoamento. No livro de Termos de Ata e Promoção do Grupo Escolar Olegário Maciel há um registro de uma prova realizada, em março de 1927, por um estagiário candidato a diretor de Grupo Escolar. A comissão examinadora, composta por um inspetor regional e o diretor do referido Grupo, após as provas ${ }^{254}$, leu o relatório do referido estagiário inabilitando-o para dirigir qualquer Grupo Escolar do Estado.

O decreto n. 10.362 de 1932 definia as exigências para a escolha das diretoras dos Grupos:

Art. 14. Os cargos de diretores de grupos escolares serão providos por merecimento, sendo os candidatos escolhidos, por concurso, exclusivamente, entre os professores efetivos e em exercício no magistério primário, respeitadas as preferências estabelecidas pelo regulamento da Escola de Aperfeiçoamento. ${ }^{255}$

Com a criação da Escola de Aperfeiçoamento, a passagem por esta instituição passava a ser condição sine qua non para o exercício da direção das escolas, como revelam as alterações no Regulamento do ensino primário, feitas em 1932:

Art. 16. As atuais diretoras de grupos escolares, solteiras ou viúvas sem filhos, que tenham menos de trinta e cinco anos de idade, quando convocadas pela Inspetoria Geral da Instrução, são obrigadas, sob pena de perda do cargo, a cursar a Escola de Aperfeiçoamento, salvo por motivo de moléstia, que será provada perante junta médica, designada pelo Secretário da Educação.

$[\ldots]$

\footnotetext{
253 Segundo informações de uma secretária do Grupo, o terreno para a construção da escola havia sido doado pela família da diretora. Emma Ciodaro teria sido aluna da segunda turma da Escola de Aperfeiçoamento em 1930.

${ }^{254}$ Não há informações do que teriam sido estas provas.

255 MINAS GERAIS. Decreto n. 10.362 de 31 maio 1932. Aprova modificações aos regulamentos que baixaram com os decretos n. 7.970-A, e 9.450, de 18 de fevereiro de 1930.
} 
Art. 17. Os diretores de grupos não compreendidos no artigo anterior, serão obrigados, sob pena de exoneração e á medida que forem convocados, a freqüentar o curso de férias que o Secretário da Educação organizar na Escola de Aperfeiçoamento. ${ }^{256}$

Em 1932, a Revista do Ensino noticiava um concurso para professores primários e diretores de Grupos Escolares do Estado. Para a diretoria de Grupos Escolares distritais poderiam concorrer professores efetivos em exercício, com pelo menos três anos de experiência. A vaga para diretores dos Grupos Escolares urbanos deveria ser preenchida por ex-alunas da Escola de Aperfeiçoamento e, não sendo possível, por diretores de Grupos Escolares distritais com pelo menos dois anos de exercício do cargo, ou professores efetivos dos Grupos Escolares urbanos com pelo menos quatro anos de magistério. Teriam preferência as professoras que tivessem feito o Curso de Aplicação e as auxiliares de diretoras. $\mathrm{O}$ concurso seria das notas existentes na Secretaria e documentos comprovando a idoneidade moral e profissional dos candidatos. Não há informações sobre como seria feito o concurso para professora. Segundo Peixoto, no entanto, “... embora os textos legais enfatizem os concursos como forma de acesso aos cargos na carreira do magistério, na prática, estes não se realizam, permanecendo o critério do apadrinhamento político" (2003, p. 235).

Em 1927, foi criado o cargo de Assistente Técnico, a ser ocupado por membros do magistério público escolhidos pelas notas de merecimento registradas na Secretaria do Interior. Com a criação da Escola de Aperfeiçoamento, estes assistentes teriam que ser diplomados pela referida escola. Entre suas funções estavam: visitar as escolas públicas e particulares, inspecionar pessoalmente as classes, dar instruções reservadas aos professores e diretores para melhor desenvolvimento dos programas, enviar quinzenalmente à Inspetoria Geral de Instrução Pública um relatório das inspeções realizadas além de um relatório anual, registrar em livro próprio nas escolas as suas visitas, entre outras.

Prates (1990, p.13) informa que a função do orientador técnico (ou professora técnica) foi criada após a Escola de Aperfeiçoamento. A hierarquia na escola primária estava circunscrita, até aquele momento, aos professores de Curso Normal, diretores, assistentes técnicos e professores. Para a autora, tal alteração hierárquica vinha sendo

\footnotetext{
${ }^{256}$ MINAS GERAIS. Decreto n. 10.362 de 31 maio 1932. Aprova modificações aos regulamentos que baixaram com os decretos n. 7.970-A, e 9.450, de 18 de fevereiro de 1930.
} 
explicada pelo avanço do capitalismo e a divisão social e técnica do trabalho. No entanto, ela introduz uma outra hipótese. Com a formatura das professoras que vieram à capital aprimorar seus conhecimentos pedagógicos, havia se criado um problema político. Como os mais altos cargos na hierarquia escolar eram ocupados por indicados políticos prática que se perpetuou em todo o período estudado - não era simples desfazer-se desse jogo político que sustentava as relações governamentais. Dessa forma, a criação de um novo cargo, diferente dos anteriores, permitia uma conciliação entre as práticas renovadoras - de formação pedagógica - e as tradicionais - de troca de favores políticos.

Segundo o decreto n. 10. 362 de 1932, eram atribuições das professoras técnicas:

a) testar os alunos do estabelecimento, organizar as classes homogêneas com a colaboração do diretor e professores;

b) ter sob sua imediata responsabilidade técnica quatro classes médias do estabelecimento, uma de cada ano;

c) promover a organização dos clubes de leitura do $3^{\circ}$ e $4^{\circ}$ anos, cujo funcionamento e atividade ficarão a cargos dos alunos, guiados pelos professores;

d) promover as dramatizações nas diversas classes e a hora de história nas de $1^{\circ} \mathrm{e}$ $2^{\circ}$ ano;

e) incentivar, com o auxilio do diretor, professor e alunos, a organização da biblioteca;

f) expor nas reuniões das quintas-feiras, as medidas a serem tomadas ou os planos a serem execcutados, trocando idéas com o diretor e professores sobre o meio de pôrem em pratica os diversos processos adotados, e bem assim os projetos adotados, e bem assim os projetos em andamento, ou a iniciarem-se, sugerindo idéas sobre a organização de cadernos de preparo de lições, sobre os jogos pedagógicos, socialização, projetos e outras atividades escolares;

g) apresentar relatório trimestral ao Inspetor Geral da Instrução sobre os trabalhos em andamento, os realizados, as dificuldades encontradas e sobre o resultado observado no estabelecimento, remetendo a uma cópia á Escola de Aperfeiçoamento;

h) agir em harmonia com o diretor e professores no sentido de obter a maior eficiência nos seus trabalhos, cultivando sempre o maior espírito de cordialidade no grupo e promover com eles a associação entre a cidade e a escola. ${ }^{257}$

É possível perceber o quanto a situação das diretoras, enquanto intermediárias da relação entre as professoras e o governo do Estado era desconfortável. Se, por um lado, tinham um poder considerável na comunidade escolar, por outro, carregavam uma série de responsabilidades que eram compartilhadas com as professoras, levando-as, por vezes, a intervir diretamente nos trabalhos escolares. Em 1935, a diretora do Grupo Escolar Tomaz Brandão avisou às professoras que passaria a maior parte do dia

${ }^{257}$ MINAS GERAIS. Decreto n. 10.362 - 31 maio 1932 - Aprova modificações aos regulamentos que baixaram com os decretos n. 7.970-A, e 9.450, de 18 de fevereiro de 1930. 
assistindo as aulas nas classes, para ficar ciente do que se passava dentro das salas de aulas já que, a partir daquele momento, ela seria responsável pelo ensino oferecido no Grupo.

As diretoras, acostumadas a lidar com o Grupo Escolar como sua própria casa, a reinarem absolutas sem grandes interferências dos órgãos de Educação, foram as que mais sofreram a invasão do corpo técnico que não apenas vinha para orientar as professoras, mas também para cobrar a aplicação dos regulamentos, exigências, testes psicológicos, além de enviarem à Secretaria relatórios detalhados sobre o cotidiano escolar. Por outro lado, as professoras também tinham que admitir a interferência não apenas da diretora e dos inspetores, mas também das orientadoras técnicas que estavam nos Grupos para garantir a modernização das técnicas de ensino. Havia ainda reclamações, por parte das professoras recém saídas da Escola de Aperfeiçoamento, acerca da objeção das diretoras sobre os trabalhos realizados. Em uma pesquisa realizada em 1932 pelo Laboratório de Psicologia da Escola de Aperfeiçoamento, 27 relatórios de vários pontos do Estado e 5 da capital tratavam das dificuldades encontradas referentes à aplicação dos testes para homogeneização das classes. Dentre as dificuldades, quatro indicavam oposição por parte da diretoria do Grupo.

As diretoras eram vigiadas pelos inspetores e assistentes técnicos que deixavam no livro de atas de visitas suas impressões sobre o Grupo Escolar e, conseqüentemente, sobre o trabalho realizado por elas. Num Termo de Visitas do Grupo Escolar Assis das Chagas, por exemplo, o inspetor deixou algumas recomendações para as professoras e a diretora que consistiam mais numa crítica ao comportamento destas:

k) o açodamento que [palavra incompreensível] a docencia em afastar-se do grupo como quem foge de um carcere, causa má impressão nos proprios discentes e no pessoal administrativo; 1) A directora deverá ser a ultima, dentre as professoras, a afastar-se da casa e, antes de fazel-o, deverá fazer rapida inspecção em todas as salas, providenciando sobre o asseio dellas. ${ }^{258}$

Apesar de ser um curso noturno, o inspetor exigia que professoras e diretora não tivessem pressa de deixar o estabelecimento. Outra inspetora no Grupo Escolar Tomaz Brandão pedia à diretora que estivesse mais atenta ao comportamento das professoras:

${ }^{258}$ Termo de Visitas de 28 de abril de 1927, assinado pelo inspetor regional e municipal, Ernesto C. Santiago. 
... disse à sra. Diretora que ela precisava impor às professoras mais disciplina com os seus educandos e também com algumas educadoras, pois, infelizmente viu professoras sentadas nas mesas e que essa falta é bem pouco elegante; chamou a atenção sôbre as chegadas atrasadas e falou sôbre os planos de excursão e que deve ser feita de manhã por causa do sol ... ${ }^{259}$

As diretoras poderiam ser penalizadas com o corte dos seus vencimentos, caso não enviassem os boletins mensais à Inspetoria da educação e, nas reuniões, elas dividiam com as professoras tais responsabilidades, convocando-as ao trabalho. As reuniões eram o momento privilegiado para a atuação das diretoras e orientadoras, exigindo uma postura, por parte das professoras, que não fugissem aos ditames e expectativas da sua função.

Imene Guimarães comenta que as primeiras orientadoras técnicas não foram muito bem recebidas nas escolas. Havia um certo ciúme natural. Mas, aos poucos, a situação foi mudando e as próprias professoras pediam auxílio à orientadora técnica. Segundo suas lembranças, as professoras mais antigas reutilizavam sempre os mesmos planos de aula, sem atualizá-los. Certo dia, ela pegou um plano de aula constando que o rio São Francisco nascia na Serra da Canastra no município de Piunhí. A orientadora chamou a professora e lhe disse que o rio nascia no município de São Roque. A professora retrucou: "Você quer mudar até o município onde o rio nasceu?" Imene então explicou que o que havia mudado era a divisão administrativa do Estado. De acordo com Imene, algumas orientadoras não se davam bem com as professoras por culpa própria. Ela não fazia repreensões em público, conversava delicadamente com as professoras em particular e sempre elogiava primeiro, para depois falar dos detalhes que precisavam ser aperfeiçoados. Portanto, no seu entendimento, a forma de a orientadora agir determinava se ela seria bem recebida ou não pelas professoras.

Maria da Glória também sentiu as resistências aos novos métodos por parte da diretora. Numa reunião pedagógica, ela sugeriu diversas excursões às professoras, mas em seguida, a diretora pediu que as professoras tomassem nota de outras excursões, que ela indicaria, de acordo com o Regulamento:

Não fui compreendida. Pouco a pouco foram surgindo os obstáculos: o barulho na competição dos jogos era anarquia; a organização dos programas de auditórios pelas crianças era perda de tempo; as sessões de clubes de leitura, com assistência de comissões de outras classes; era prejuízo do horário; as excursões eram meros passeios;

${ }^{259}$ Ata de 15 de outubro de 1949. 
enfim, todo o movimento era considerado apenas como passatempo de uma técnica para fazer jus ao ordenado e se apossar, indevidamente, do lugar da diretora... (Arreguy, 1958, p. 98-99)

Essa mesma diretora não quis assinar a divisão das classes de 1932, realizada de acordo com os Testes Prime, alegando não se responsabilizar pelo fracasso ao final do ano. Maria da Glória veio a Belo Horizonte explicar o acontecido ao Diretor da Instrução, Carlos de Campos. Este, analisando o caso, pediu a ela que dissesse à diretora que ele assumiria toda a responsabilidade. A orientadora conta que regressou a Itabirito, mas não tocou mais no assunto. A diretora, pouco depois, reclamou ao Inspetor que a orientadora não lhe dava conhecimento dos trabalhos realizados e da divisão das classes. Maria da Glória explicou tudo e o Inspetor compreendeu seu ponto de vista. Não satisfeita, a diretora reclamou ao Secretário da Educação, Noraldino Lima, e, novamente, recebeu a visita do Inspetor para se certificar da situação. Pela segunda vez, segundo a orientadora, o Inspetor concluía que as objeções não se referiam ao seu trabalho especificamente, mas à contraposição entre Escola Nova e Escola Antiga.

Maria da Glória, ao saber, numa viagem a Belo Horizonte, sobre a reclamação da diretora de seu Grupo a respeito das suas atividades como professora técnica, decidiu organizar uma Feira de Amostras da produção da cidade de Itabirito e levou a idéia até os alunos. Pode-se pensar que a organização da Feira tinha como um dos objetivos dar a ver, à Secretaria da Educação, à comunidade e à própria diretora, a importância de seu trabalho. De fato, a Feira foi realizada e foram convidados os colaboradores, familiares dos alunos, pessoas da comunidade, além das autoridades locais e da Secretaria de Educação, de onde vieram Mário Casasanta, Guerino Casasanta e Levindo Lambert. Também compareceram Noraldino Lima, seu oficial de gabinete e respectivas esposas. Curiosamente, a diretora do Grupo sentiu-se indisposta e não pode comparecer no dia de abertura dos trabalhos. Maria da Glória teve certeza de que a impressão sobre o seu trabalho tinha sido excelente, ao receber um cartão oferecendo-lhe um cargo num dos Grupos da capital $^{260}$. Em outro momento, ao retornar à cidade de Caratinga, Maria da Glória enfrentou dificuldades com outra diretora:

Tais atividades até então eram bem recebidas e aplaudidas pela sra. diretora. Ela passara pela Escola de Aperfeiçoamento e se mostrava favorável aos novos métodos

\footnotetext{
${ }^{260}$ Esta afirmação confirma a hipótese de que os Grupos Escolares da capital eram modelos para os do interior do Estado.
} 
pedagógicos. Com o decorrer dos fatos, porém, pareceu-lhe que eu queria com todo aquêle movimento tomar-lhe indevidamente o lugar.(Arreguy, 1958, p. 125)

Os relatos de Maria da Glória revelam o constrangimento e a situação de constante vigilância a que estavam submetidas as educadoras nos Grupos Escolares. As mudanças no ensino, por mais que tivessem repercussão na imprensa e que se buscasse fazê-las chegar às professoras, pareciam externas à compreensão destas, acostumadas a um meio social e escolar nos quais a criança disciplinada era compreendida como aquela que fosse quieta e obediente. Além das dificuldades de se internalizarem e executarem as Reformas Educacionais em voga, é muito claro o quanto se produziam fórmulas fáceis para humilhar as professoras e o quanto o caráter externo, as disputas de poder político e social, as lutas por status e o propósito de obter cargos públicos se misturavam e tornavam mais complexas as relações pedagógicas e profissionais nos Grupos.

Benedita Dell'Isola também passou por várias dificuldades com os diretores, embora não tivesse cursado a Escola de Aperfeiçoamento. Quando trabalhava em Uberlândia, suas aulas no Grupo tiveram tanto sucesso que ela fôra convidada para dar aulas no Ginásio ${ }^{261}$. Os alunos do Ginásio tinham um meio social mais rico e contribuíam com materiais que enriqueciam as aulas. Para não fazer feio, Benedita pedia ao cunhado, calígrafo, que fizesse os cartazes para a aula e, como a turma do Ginásio era mais adiantada, esses materiais eram utilizados lá primeiramente, e só posteriormente no Grupo. O novo diretor do Grupo visitou a sua sala no Ginásio e constatando a diferença, chamou-a ao gabinete para lhe passar uma "descompostura" dizendo, entre outras coisas, que o entusiasmo dela pelos alunos do Ginásio era maior porque esses eram ricos. A professora, sem conseguir se justificar, saiu chorando. No ano seguinte, esse mesmo diretor aposentou-se do trabalho no Grupo, comprou o Ginásio e um dos seus primeiros expedientes foi demitir a professora, alegando que ela não dava conta de trabalhar em duas turmas. Esta história, assim como outras reveladas pelas fontes, demonstra o quanto os pequenos poderes exercidos pelos diretores, inspetores, orientadores tornava mais difícil a vida das professoras, submetidas a uma

\footnotetext{
261 Segundo ela conta, era uma turma de $4^{\text {a }}$ série no Ginásio. Talvez esse ginásio fosse um colégio
} particular da cidade, porque ela comenta que os alunos vinham de um meio social muito mais rico. 
hierarquia que, cada vez mais, se acentuava fazendo decrescer, paulatinamente, a sua autonomia sobre o fazer pedagógico.

Foi criada, então, a Escola Normal de Uberlândia e Benedita via chegada a hora de realizar seu tão sonhado curso de normalista. No entanto, o mesmo ex-diretor foi convidado para dirigir a referida Escola. A professora temia que este a julgasse incapaz de lecionar e estudar e the impedisse a matrícula. Isso não aconteceu e, para melhorar a sua situação, a Câmara Municipal decidiu custear seus estudos. A vida na escola parecia boa, pelo relato de Benedita, com exceção da presença do diretor, sempre temida. Este lhe chamava atenção pelos atrasos diante de toda a classe dizendo que ela, como professora já em exercício, sendo também uma mulher casada, precisava ser um exemplo para as outras alunas. Numa outra situação, Benedita achou graça na forma como a professora de Música a argüiu, tendo sido mal interpretada pela professora que disse:

O Diretor deu-me ordem para não ter a mínima condescendência com a Senhora. Êle disse que a Senhora está aqui tomando o lugar de outra que precisa, está fazendo o Curso só por vaidade: além de tudo, por conta do Município. Por isso, cumprindo as suas ordens, a Senhora ficará presa... (Dell'Isola,1970, p. 26)

Ao final da aula, as alunas todas se retiraram e Benedita permaneceu na classe. A lembrança dos filhos em casa à sua espera e a sensação de ter sofrido uma injustiça a fizeram cair em prantos. A professora de Música, vindo à sala, a encontrou e disse não achar que a aluna tivesse levado tão a sério as suas palavras. Pediu desculpas e a liberou para voltar para casa.

Outra vez, em estado adiantado de gestação, foi obrigada a participar de uma excursão a um local distante e o esforço fez com que ela tivesse a criança, logo na volta do passeio $^{262}$. Um farmacêutico e político local avisou ao diretor da Escola Normal que foi imediatamente visitá-la e pedir desculpas pelo excesso de exigências. Apesar de todas essas dificuldades, recebeu, ao final do curso, uma caderneta apresentando suas qualidades, assinada pela professora de Metodologia e pelo diretor, o que lhe fez mudar sua opinião em relação a este. Já morando e trabalhando em Belo Horizonte, como estagiária no Grupo Escolar Flávio dos Santos, a situação com outra diretora não foi muito diferente. Embora percebendo-na como uma amiga e emérita educadora, Benedita

\footnotetext{
${ }^{262}$ Ela diz que teve uma "délivrance", termo que no dicionário Houaiss está definido como parto, dar a luz, parir.
} 
afirma que a diretora reinava absoluta no Grupo, desconsiderando opiniões e mesmo críticas publicadas nos jornais sobre suas atitudes:

A Diretora era D. Margarida Praxedes Tôrres, educadora emérita, muito amiga das professôras, mas de uma energia tremenda. Sempre deu preferência aos alunos e aos pais, naturalmente, depois às professôras. Nunca admitia opiniões e sua palavra era a última. Nesta ocasião, o Ministro José Américo baixou uma lei que estabelecia a Hora de Verão. Os relógios deveriam ser adiantados uma hora. Mas acontece que D. Margarida não "aprovou" tal lei; portanto, o relógio do Grupo se conservava como antes e nós teríamos que segui-lo. (Dell’Isola, 1970, p. 31)

Além disso, a diretora ${ }^{263}$ não permitia que a orientadora técnica executasse o seu papel:

Nós tínhamos orientadora, mas só se seguia a orientação da Diretora que justificava sua posição:'_Estas moças chegam cheias de bobagem e não sabem nada'.

Eu quero é que ensinem o b-a:ba - dizia ela e nós nem pestanejávamos ao lhe obedecer. (Dell'Isola, 1970, p. 32)

Benedita salienta, entretanto, que a intenção da diretora era a melhor possível: aprovar os alunos. Com a aposentadoria de Margarida Praxedes Tôrres, Letícia Chaves assumiu seu lugar. Neste período, a matrícula no Grupo Escolar Flávio dos Santos havia crescido muito, sendo preciso criar mais duas seções: uma na Vila Renascença e outra na Rua Jacuí ${ }^{264}$. A diretora dirigia sozinha estes três estabelecimentos. Certo dia, sumiu um dinheiro da pasta da diretora e as suspeitas recaíram sobre as professoras, as únicas que trabalhavam no gabinete da diretoria. Um investigador foi chamado para interrogar, uma a uma, as professoras. Benedita conta sua indignação ao perceber que o investigador lhe cobrava encontrar o dinheiro que havia desaparecido num dia em que ela trabalhava em outro prédio, não estando sequer no estabelecimento. $\mathrm{O}$ investigador deixou escapar, então, que suspeitava da servente do Grupo que tinha o mesmo nome da professora e finalizou o interrogatório. Mais uma vez, Benedita se via na situação de ser confundida com uma servente e, além disso, a notícia chegou a outros Grupos que ficaram sabendo da situação constrangedora pela qual as professoras haviam passado.

\footnotetext{
${ }^{263}$ Curiosamente, a professora de canto, Jupira Dufles Barreto, entrevistada por Flávio Oliveira (2004) lecionou no Grupo Escolar Flávio dos Santos e também teve problemas com a diretora que, segundo ela, se chamava Nair Praxedes. A diretora não aceitava que os alunos se reunissem em grupos para cantar, exigindo que eles ficassem numa fila única, dizendo que o Grupo não era o Teatro Municipal, conforme lembranças da professora Jupira. Por este motivo, a professora teria pedido ao Secretário a sua remoção para a Escola de Aperfeiçoamento que lhe foi concedida.

${ }^{264}$ Onde funcionou posteriormente o Grupo Cristiano Machado.
} 
Com o desdobramento do Grupo Flávio dos Santos, Benedita foi trabalhar na Vila Renascença que passou a ter como diretora a sua ex-orientadora Edith Chaves.

D. Edith é um grande amiga, mas nunca estávamos de acôrdo em certos modos de agir. Quase diariamente eu era chamada ao seu gabinete, recebia um sermão daqueles... Mas que sermão! D. Edith falava tão alto, com tanta severidade... com tanta energia...

Na hora eu me calava ou procurava convencê-la de que ela estava errada, mas, em casa, no recesso de meu lar, sossegada, eu refletia sôbre tudo o que ouvira e concluía que era justa a sua nervosia. (Dell'Isola, 1970, p. 39)

Benedita Dell'Isola também teve problemas com a diretora do Grupo Escolar Tito Fulgêncio, Eulâmpia ${ }^{265}$, que a designou, com outras duas professoras, para irem até o Superintendente de Ensino pedir a transferência de sua auxiliar de Gabinete. Benedita não concordou com as justificativas dadas pela diretora e se recusou a cumprir a ordem, pedindo transferência para o Grupo Escolar Cristiano Machado.

Voltando à orientação de Edith Chaves, a professora passou por outras agruras. Segundo ela, a diretora elogiava quando achava uma coisa boa, mas também dava um bom sermão se visse algo errado. Certa vez, o médico do Grupo, Dr. Teófilo Pires, iria dar vermífugo aos alunos e as professoras deveriam pedir uma assinatura dos pais concordando com o procedimento e isentando as professoras e o Grupo da responsabilidade, caso houvesse algum problema. No entanto, a maioria dos alunos de Benedita confirmou apenas verbalmente a aceitação dos pais e a professora, sabendo da necessidade da confirmação por escrito, resolveu imitar a assinatura dos pais. Ao entregá-las à diretora, ela prontamente percebeu a fraude e fez com que a professora fosse atrás dos pais de cada um dos alunos e obtivesse a sua autorização por escrito imediatamente, para que o médico e a enfermeira pudessem aplicar o vermífugo.

As diretoras, não obtendo a solução para os problemas relacionados aos funcionários escolares, comunicavam-se diretamente com a Secretaria de Educação. Em 1939, por exemplo, a diretora do Grupo Escolar Olegário Maciel enviou um ofício ${ }^{266}$ ao Secretário comunicando que afastou, por cinco dias, uma das serventes do Grupo que, além de não cumprir seus deveres, estava provocando desordens e revolta entre as

\footnotetext{
${ }^{265}$ As Escolas da Vila Renascença e a da Rua Jacuí foram transformadas em Grupo. O da Renascença recebeu o nome de Grupo Escolar Tito Fulgêncio e o outro, de Grupo Escolar Cristiano Machado. Edith Chaves foi dirigir o Grupo Escolar Cristiano Machado e Dell'Isola ficou no Grupo Escolar Tito Fulgêncio, sob a orientação de Eulâmpia Ribeiro.

${ }^{266}$ Ofício enviado ao Secretário da Educação e Saúde Pública, em 14 de junho de 1939.
} 
outras funcionárias. Rotulando a servente de "elemento perigoso" e acusando-a de assinar o ponto para as companheiras impontuais, a diretora pedia que ela fosse imediatamente retirada do Grupo "a bem dos meus trabalhos, de ordem e disciplina, dentro do estabelecimento." Não foi possível saber se o pedido foi atendido.

Uma pesquisa realizada em 1932 pelo laboratório de Psicologia da Escola de Aperfeiçoamento indicava que não somente a direção do Grupo, mas também as professoras se mostravam reticentes às inovações pedagógicas implementadas. Os dados apresentados pelos 32 relatórios indicavam que a atitude destas em relação a vários temas. A respeito das inovações propostas, foram identificadas as seguintes reações entre os professores:

12) Hostil - 1 caso

13) Sem entusiasmo - 2 casos

14) Má vontade - 2 casos

15) Recusa em reger classe de retardados -1 caso

16) Incompreensão dos responsaveis diretos pelas classes - 1 caso

A) Decorrentes da sua formação pedagogica

17) Falta de habitos de leitura -3 casos

18) Habito de discussão não fundamentada -2 casos

B) Incompreensão no trabalho com crianças retardadas

19) Falta de preparo especializado ${ }^{267}$ [não há casos]

Se, como foi abordado, os relatos oficiais colocavam sobre os ombros dos professores, as mazelas do ensino no Estado, dentro da escola, o discurso permanecia o mesmo. Era preciso abnegação, envolvimento com as causas escolares, modernização das atividades pedagógicas e o cumprimento das normas impostas para $\mathrm{o}$ aprimoramento da educação dos alunos. Os dispositivos de disciplinarização das professoras eram intensos, mas os depoimentos revelam que elas também possuíam artimanhas para escapar a essa rede de controle e vigilância por parte do Estado. É interessante notar que as professoras questionavam as metodologias, os programas, as recomendações quanto ao ensino. Os depoimentos revelam as dificuldades enfrentadas pelas orientadoras técnicas, encarregadas de disseminar os novos métodos pedagógicos aprendidos na Escola de Aperfeiçoamento, no convencimento das professoras:

D. Erilda [orientadora] teve o maior trabalho de sua carreira para me convencer de como usar o Método Global. Eu achava-o difícil, não acreditava nos seus trabalhos.

${ }^{267}$ CUNHA, Maria Luiza de Almeida. Comentário geral sobre os relatórios referentes à homogeneização das classes escolares. Revista do Ensino, BH, ano VI [sic], n. 68, 69, 70, p.22-29, abr.maio.jun.1932. p.20 
Fazer a criança decorar uma história inteirinha, sem saber nada do que estava escrito, não podia dar certo.

Depois de um trabalho imenso que a orientadora teve comigo, comecei a ter um pouco de confiança com o tal Método Global e passei a usá-lo, embora com uma certa restrição. (Dell'Isola, 1970, p.33)

Benedita conclui que a energia da orientadora que exigia o cumprimento de suas normas fez com que ela se tornasse adepta do novo método, e sequer compreendia sua atitude conservadora de antes, que a fazia estar fechada ao progresso.

Em alguns momentos, a própria diretora parecia não estar certa do caminho a ser seguido. Uma professora do Grupo Escolar Mariano de Abreu, por exemplo, advertiu que o método global $^{268}$ não estava dado resultado em sua classe. A diretora imediatamente lhe permitiu usar outro método, desde que os alunos aprendessem.

Professoras, serventes, orientadoras técnicas e alunos ficavam sob os mandos e desmandos de alguns diretores e diretoras que não queriam perder o controle sobre o território escolar e dos que nele se inseriam. Por outro lado, as próprias diretoras estavam sendo pressionadas pelos superiores na hierarquia do ensino no Estado. As disputas por um lado e o respeito e a amizade por outro tornavam tensos e temerários os jogos de $\operatorname{poder}^{269}$ nos Grupos Escolares. Esta era, sem dúvida, uma situação que favorecia o controle por parte do Estado, já que os próprios funcionários e funcionárias do ensino se viam mais como concorrentes do que como colaboradores.

Arreguy, ao deixar a Escola de Aperfeiçoamento e voltar para o Grupo Escolar, mostra a sua difícil situação ao se defrontar com as antigas colegas, agora sob sua orientação:

Não me pareceu muito fácil orientar sobre métodos que eu conhecia apenas teòricamente, falar às mesmas colegas que me viram na escola antiga. Era preciso muita conviç̧ão e um pouco de audácia para convence-las a modificar o sistema de trabalho. [...] crivaram-me de perguntas e a cada resposta eu via estampadas nas fisionomias as mais variadas expressões de incredulidade, desconfiança, desânimo, algum entusiasmo e muita curiosidade. (Arreguy, 1958, p. 94-95)

\footnotetext{
${ }^{268}$ De acordo com Maciel (2001), o método global marcou a história da alfabetização em Minas entre os anos 30 e 70, sendo utilizado praticamente em todas as escolas.

${ }^{269}$ O poder, segundo Foucault (1990, p. 183), "não é algo que se possa dividir entre aqueles que o possuem e o detêm exclusivamente e aqueles que não o possuem e lhe são submetidos. O poder deve ser analisado como algo que circula, ou melhor, como algo que só funciona em cadeia. Nunca está localizado aqui ou ali, nunca está nas mãos de alguns, nunca é apropriado como uma riqueza ou um bem. O poder funciona e se exerce em rede. Nas suas malhas os indivíduos não só circulam, mas estão sempre em posição de exercer este poder e de sofrer sua ação; nunca são o alvo inerte ou consentido do poder, são sempre centros de transmissão. Em outros termos, o poder não se aplica aos indivíduos, passa por eles."
} 
A revista Educando e a Revista do Ensino publicaram, durante todo o período investigado, relatórios, cartas, depoimentos de professoras, orientadoras e assistentes técnicas mostrando como estavam lidando com as mudanças na educação. Boa parte desses artigos era escrito por professoras que haviam cursado a Escola de Aperfeiçoamento e voltado para suas escolas com o compromisso de modernizarem o ensino. Todos os artigos, sem exceção, faziam um relato das dificuldades sempre mostrando que era possível superá-las e que, lentamente, isso vinha acontecendo. Algumas professoras também escreviam para contar que haviam recebido as mudanças com desconfiança e receio e que haviam mudado de opinião, defendendo o uso dos testes psicológicos, do Método Global, da homogeneização das classes, das excursões, enfim, de todas as novidades introduzidas pelas Reformas. Também é possível que outras opiniões existissem, mas certamente não foram enviadas aos editores das revistas ou não foram publicadas. Um desses artigos, transcrito abaixo, mostra de forma primorosa o papel de confirmação das técnicas modernas pelas professoras que publicavam suas experiências na Revista do Ensino:

Eu era das que não podiam crêr na eficiencia do ensino pela "escola ativa", considerando as condições atuais do ensino. Achava quasi nulo o esforço que se vem empregando quotidianamente com o fim de tornar, entre nós, realidade o que já o é em outros paises há longo tempo.

Como eu, talvez possa existir ainda quem assim pense e, por isso, cumpro um dever trazendo ao conhecimento de minhas colegas alguns pormenores colhidos em minha classe.

Trabalhando sob a direção técnica da professora D. Aida B. Coelho, comecei a aplicar os principios pedagogicos por ela aconselhados e confesso que fiquei supreendida com o resultado em minha classe. Meus alunos progridem a olhos vistos, e a disciplina, estabelecida naturalmente, nada deixa a desejar. É com prazer que entro para minha sala de aula, onde cada aluno se assemelha a um amiguinho sincero. Todos procuram auxiliar-me, e, o que é melhor, estão possuidos de verdadeiro entusiasmo pelo saber, tudo indagando, tudo estudando, e pedindo-me explicações tão oportunas como nunca más fizera aluno algum.

$[\ldots]$

Como se vë, há um largo horizonte que se expande diante da professora, acenando-lhe para o progresso e aperfeiçoamento de seus métodos. Saiba a professora trilhar esse caminho, embora ás vezes se lhe deparem magoadores alcantis, e conseguirá amoldar o caráter da juventude para ressurgimento da estremecida Patria, como a sonhamos todos - bela e grandiosa!

Itanhandú, Agosto de 1932,

Else Bittencourt. ${ }^{270}$

${ }^{270}$ BITTENCOURT, Else. A Escola Ativa em Itanhandú. Revista do Ensino, BH, ano VI, n.75, $1^{\mathrm{O}}$ de novembro de 1932, p. 16-17. 
Outro artigo publicado na mesma revista apresenta de forma bastante irônica a relação entre uma professora de um Grupo Escolar e uma professora técnica da cidade de Ubá no interior de Minas:

Reconheço perfeitamente a minha ignorância, e muito longe estou de pensar, de supôr por um instante, siquer, que as minhas aulas resumam em si um trabalho perfeito, ou cousa apresentavel.

Lutei com a Ruth, nossa m.d. professora técnica, para que ela desistisse do encargo que me conferiu, porém ela fez coração duro e não me atendeu.

Ruth, a quem todas somos obrigadas a admirar pelo trabalho tão inteligentemente dirigido no nosso Grupo, será que não vê que sou incompetente e que, além de nada saber, dotou-me Deus de timidez ao extremo, para ter coragem de demonstrar o método de ensino que tenho seguido, desde o principio do ano?

No entanto, quero sinceramente atender á ordem superior, quero ser simples; pois bem sei que cada um é obrigado a fazer apenas o que está ao seu alcance.

Bom, minhas colegas, permitam-me que eu trate neste instante do assunto para terminar este dever, que tanto me impressiona. ${ }^{271}$

Este relato revela as tensões entre as professoras técnicas e as professoras não formadas pela Escola de Aperfeiçoamento e as disputas e conflitos que existiam no interior das escolas e que podem ser ainda mais evidenciados a partir da leitura das atas das reuniões pedagógicas.

\subsection{REUNIÕES PEDAGÓGICAS}

São principalmente as atas das reuniões que deixam transparecer os embates e impasses das práticas educacionais porque são especialmente as professoras que vivenciaram e colocaram em marcha as atividades cotidianas da escola. Ademais, eram elas, também, o alvo das intervenções feitas pelas Reformas, inspeções, orientações, visitas dos assistentes e cobranças das diretoras. A partir destes documentos, é possível rastrear as impressões e atitudes das professoras diante das mudanças que se anunciavam no cenário escolar mineiro. Alguns dos seus temores, dúvidas e hesitações, mesmo que timidamente anunciados, ficaram registrados nestes documentos. Também é possível detectar alguns conflitos entre as prescrições escolares e a conversão destas em práticas efetivas dentro dos muros dos Grupos Escolares.

É curioso que a Escola Nova mineira, ao mesmo tempo em que divulgava a necessidade de um ensino livre, baseado no interesse e na atividade aos alunos, desse

${ }^{271}$ TRABALHO de uma quinta-feira realizado a 25 de Agosto de 1932. Revista do Ensino, BH, ano VII, n. 81, p.17-19, $1^{\circ}$ de fevereiro de 1933. Agradeço a Maurilane Biccas por esta indicação preciosa. 
tão pouca liberdade e autonomia às professoras. A relação autoritária que permeava as reuniões escolares, as exigências de que as professoras transformassem as suas práticas pedagógicas e disciplinares almejavam, simultaneamente, formar sujeitos livres, ativos e capazes de agir autonomamente. Tais contradições permeavam não somente as reuniões escolares, mas todo o universo educativo, desde as legislações, os periódicos, as inspeções, as visitas, as Reformas educativas de maneira geral.

Havia duas reuniões pedagógicas semanalmente. Uma aos sábados e outra às quintas-feiras $^{272}$. Em cada Grupo Escolar as reuniões se organizavam de uma maneira. As reuniões de quinta-feira eram destinadas à leitura do professorado, entretanto, em alguns Grupos, o horário reservado às leituras destinava-se também a reuniões de caráter pedagógico. Às vezes, as professoras faziam leituras coletivas e comentavamnas. Em outros momentos, uma professora era sorteada para, na semana seguinte, apresentar por escrito e oralmente uma leitura realizada. Ao final da apresentação, a diretora e orientadora faziam um comentário sobre a adequação do tema e da exposição realizada. Às vezes, mais de uma professora era sorteada. Era, por exemplo, o que se fazia no Grupo Escolar Tomaz Brandão e os resumos apresentados ficavam arquivados no $\mathrm{Grupo}^{273}$.

As reuniões, em geral, eram conduzidas pelas diretoras e professoras técnicas que determinavam a pauta. Na maior parte das vezes, as reuniões eram utilizadas para informar exigências, planos e orientar as atividades escolares. As diretoras repassavam avisos da Secretaria, faziam recomendações sobre horários de saída e chegada, sobre atividades pedagógicas e aconselhavam as professoras a manterem um comportamento adequado dentro e fora do ambiente escolar, ressaltando a importância do seu exemplo diante da classe e da sociedade. A participação das professoras técnicas nas reuniões enfatizava o ensino propriamente dito, orientando as formas de melhor aplicar as orientações prescritas no Programa de ensino. Apesar disso, nem sempre os papéis das professoras técnicas e diretoras eram tão delimitados nas reuniões. De uma maneira geral, a função de disciplinamento cabia à diretora. Era esta que freqüentemente recomendava mais atenção, interesse e entusiasmo nas atividades; que corrigia os erros,

\footnotetext{
272 Através do decreto n. 2.455, de 14 de abril de 1947, no governo de Milton Campos e do Secretário Augusto Mário Caldeira Brant, se restabeleceu o descanso semanal aos sábados nos estabelecimentos de ensino.

${ }^{273}$ Essa foi uma informação recolhida de uma reunião de professoras, mas estes resumos não foram encontrados.
} 
falhas e equívocos nas apresentações de temas feitas pelas professoras; que apontava os atrasos na entrada, os descuidos na apresentação dos auditórios e a necessidade de empenho e dedicação ao ensino.

Analisando as atas de reuniões de professores pode-se ter uma idéia de como se dava esta intervenção. Não obstante, as atas, muito freqüentemente, trazem apenas uma síntese do ocorrido e, em diversos momentos, os assuntos são tratados superficialmente, registrando, por exemplo, que a diretora falou sobre a disciplina dos alunos ou que a diretora fez um comentário dos testes aplicados. Por essas assertivas, não é possível identificar como o assunto foi abordado, se houve ou não manifestações das professoras, se era uma crítica ao trabalho destas ou um elogio, etc. Direta e indiretamente, as professoras eram cobradas e exortadas a exercerem seu papel de acordo com as normas da educação pública no Estado.

Algumas atas de reuniões do Grupo Escolar Tomaz Brandão revelam as tensões e disputas entre professoras e diretoras. Numa delas, ocorrida em 1938, a diretora afirmara que os alunos estavam apresentando dificuldades em aritmética e talvez isto se devesse ao pouco entusiasmo das professoras. Imediatamente estas reagiram afirmando que elas se esforçavam, mas, mesmo assim, as crianças não estavam alcançando um bom índice de aprendizagem. Outra professora afirmou que o resultado ruim nas classes mais adiantadas devia-se a falhas nos primeiros anos do ensino, causando, obviamente, reações entre as professoras das classes iniciais.

Em 1943, as professoras do Grupo estavam sorteando quem redigiria a ata da reunião e a professora sorteada não quis fazê-lo. A própria diretora tomou a seu encargo a elaboração da referida ata, mas, após o "flagrante ato disciplinar", levou o fato ao conhecimento do Chefe do Departamento de Educação. Ele, então, quis saber por que a diretora não havia admoestado e suspendido a professora como instruía o Regulamento e ordenou que a professora comparecesse ao seu gabinete no dia seguinte. Como a diretora ia tratar com o Secretário da Educação assuntos pertinentes ao Grupo, resolveu abordar o assunto também com ele. O Secretário afirmou que, se fosse comunicado do fato imediatamente após a reunião, teria dado uma medida de suspensão à professora. A diretora justificou que o descumprimento do Regulamento não era um recuo nem um desconhecimento deste, mas ela o teria feito apenas para evitar o prolongamento do incidente. O Secretário apoiou sua decisão e pediu que fosse elaborada uma ata com o 
assunto e enviada à Secretaria. A diretora, na reunião, relatou o pesar com que constatava a desarmonia no Grupo, havendo algumas professoras que estariam cometendo faltas e atrapalhando o bom andamento dos trabalhos.

Cinco anos depois, numa outra reunião no mesmo Grupo, uma professora não havia acatado a ordem da diretora de esperar as crianças do terceiro turno ${ }^{274}$ no alpendre, ou seja, do lado externo do prédio, e outra professora afirmava também que não cumpriria tal ordem, que percebia como absurda. Como a diretora, no momento anterior da reunião, elogiara o trabalho das professoras do primeiro e segundo turnos em comparação ao terceiro, deixava a impressão de que tudo não passava de um castigo dado às últimas, embora isso não fosse dito claramente. A diretora limitou-se a dizer que não exigia o cumprimento da ordem, apenas comunicaria o seu não cumprimento ao Secretário da Educação. Neste momento, a professora que havia iniciado a discussão disse sentir-se sem liberdade no Grupo, e a diretora retrucou que não tolhia a liberdade de ninguém, mas que a verdadeira liberdade não propiciaria a desordem e a anarquia. Embora outras professoras compartilhassem a idéia de que a ordem era absurda, não se manifestaram com a mesma veemência que as duas citadas anteriormente. Além disso, duas professoras afirmaram que cumpririam a ordem, apesar de não justificarem tal posição. Ao final, a diretora disse que o que motivava a sua ordem, era o fato de as professoras do segundo turno reclamarem que o vozerio das professoras do último turno atrapalhava as aulas. E, para não atrapalhar as atividades pedagógicas, ela tinha tomado a referida decisão. Com tal argumento, ela conseguiu retirar a aparência de arbitrariedade da ordem e ainda colocou a origem do problema nas próprias professoras, tocando num aspecto crucial para a representação de professoras consideradas incompetentes: as vozes altas. Com grande habilidade, ela aproveitou a discussão para enfatizar que as professoras não deveriam se sentir humilhadas ao estarem na rua, afirmando que: “A presença das mestras diante dos alunos, nas salas de aula, na rua ou em qualquer outro lugar, nunca humilha, antes, pelo contrário, enobrece".

Em 1949, ainda no mesmo Grupo Escolar, uma professora reclamou que a diretora estava corrigindo os cadernos de ponto diário com tinta vermelha ${ }^{275}$. A diretora argumentou que somente não corrigiria com caneta vermelha, quando o engano

\footnotetext{
${ }^{274}$ Por motivo de falta de salas de aula e grande número de alunos, alguns Grupos da capital funcionavam com três turnos diurnos.

${ }^{275}$ Reunião de 04 de junho de 1949.
} 
ocorresse uma única vez, mas, quando este se repetisse, ela também voltaria a usá-la. Em outra reunião, a diretora avisou que só entraria para a sala de aula quem apresentasse antes o caderno de ponto diário. Alguns meses depois ${ }^{276}$, houve um atrito entre uma professora e a auxiliar da diretora. A professora teria afirmado que a auxiliar era "injusta, parcial e até malquista entre as colegas por seus atos de intolerância e de ruindade". A diretora disse que a auxiliar podia até estar errada, mas que a professora “desacatando publicamente uma superiora diante de alunos, professoras e serventes, deu um péssimo exemplo de rebeldia e de falta de educação" e que ela deveria ter conversado reservadamente com a auxiliar. A professora não se retratou e a diretora disse que, caso a cena se repetisse, ela tomaria "providências mais enérgicas cabíveis ao caso", já que se tratava de "um ato de flagrante indisciplina e desrespeito a uma autoridade constituída".

Numa reunião em agosto de $1952^{277}$ houve novo embate entre a opinião da diretora e das professoras. A diretora deu vários avisos sobre a ordem interna no Grupo: as professoras não estavam se preocupando com a disciplina escolar, deixando as classes em completo abandono sem acompanhá-las até o portão; o auditório estava sendo realizado sem entusiasmo e interesse e os números acabavam ficando mal apresentados; o jornalzinho estava sendo feito sem correção, aparentando ter sido feito apenas para cumprimento do dever. Quando a ata foi lida, na reunião seguinte ${ }^{278}$, duas professoras fizeram objeções afirmando que seus números de auditório eram bem preparados e a ata passava uma impressão negativa do Grupo. A diretora afirmou, então, que a ata não fugia da realidade do estabelecimento, mas ela não havia se referido em particular a uma ou outra professora, falando no geral.

Nota-se que as atas das reuniões do Grupo Escolar Tomaz Brandão são as que mais evidenciam as disputas e tensões no cotidiano escolar. Pode-se pensar em duas hipóteses: ou nos outros Grupos não existiam estas tensões ou elas não eram registradas nas atas escolares. É pouco provável que a primeira hipótese prevalecesse, já que outras fontes, como as memórias e as entrevistas, revelam que, mesmo nos Grupos modelares da capital, havia disputas e divergências. Tomando-se a segunda hipótese, pode-se supor que, pelo fato de localizar-se na periferia, com alunos de um meio social menos

\footnotetext{
${ }^{276}$ Reunião de 20 de agosto de 1949.

${ }^{277}$ Reunião de 30 de agosto de 1952.

${ }^{278}$ Reunião de 20 de setembro de 1952.
} 
favorecido, o Tomaz Brandão, bem como seus profissionais, não se constituíam como o protótipo do ideal de escola e, por este motivo, os conflitos podiam ser evidenciados nas atas escolares sem maiores reservas.

\subsection{OS TERMOS DE VISITA}

Os Termos de Visitas podiam ser assinados por pessoas que visitavam o Grupo Escolar, como o arcebispo, professoras de outras regiões e pessoas da comunidade, mas a maior parte é de inspetores e assistentes técnicos que traçavam um pequeno relatório das atividades escolares presenciadas. Alguns Termos de Visitas de inspetores tratam em detalhes as aulas ministradas, os problemas e as orientações dadas. A tentativa era sempre a de tornar as aulas mais dinâmicas, participativas, incentivar as excursões, relacionar os trabalhos manuais ao conteúdo trabalhado em classe, variar as atividades, verificar o funcionamento das instituições escolares como clubes de leitura, museus, jornais, entre outras. Os inspetores não se preocupavam apenas com as atividades pedagógicas desenvolvidas pelas professoras, eles verificavam a documentação do Grupo, a freqüência dos alunos, o número de consultas de alunos e professoras na biblioteca, recomendando alterações, maior empenho e dedicação das educadoras.

Os inspetores escolares sempre tiveram o papel de fiscalizar o trabalho realizado nas escolas e comunicar sua eficiência ou não aos órgãos mais altos da hierarquia educacional do Estado. Seu papel fiscalizador se misturava à função de orientação, objetivando modernizar as práticas escolares, sugerindo e incentivando atividades, lembrando as normas a serem seguidas e observando a aplicação dos regulamentos e legislações sobre o ensino.

As professoras ficavam sujeitas à entrada na classe de autoridades políticas e pedagógicas, que freqüentemente apareciam sem avisar, à vigilância de diretoras e inspetoras sobre o trabalho realizado, ao registro das observações dos inspetores nos Termos de Visita, às análises dos Cadernos de Preparo das Lições que, vez por outra, podiam ser inspecionados por todas as autoridades já citadas. Todos esses instrumentos constituíam-se em mecanismos de vigilância e exame aos quais as professoras deveriam se submeter. 
Segundo dados obtidos nestes relatos, é possível observar que algumas professoras desconheciam como trabalhar com algumas disciplinas. Em 1930 ${ }^{279}$, por exemplo, a inspetora do Grupo Pedro II, Maria Luísa de Almeida Cunha, precisou dizer a uma professora que era indispensável utilizar materiais para observação, adquiridos pelos alunos ou por ela mesma, para a disciplina Noções de Coisas. A professora estaria dando aulas teóricas da referida disciplina.

Estes documentos são uma fonte muita rica porque permitem uma maior aproximação com o cotidiano dos Grupos Escolares. Apesar disso, muitos devem ser os cuidados tomados na sua análise. Em primeiro lugar, tais documentos trazem uma visão parcial da realidade escolar, sendo um ponto de vista daqueles que ocasionalmente visitavam a escola. Além disso, os Termos de Visita eram públicos, ficavam registrados num livro ao alcance de todos os interessados. Tal publicidade talvez seja um dos motivos pelo qual, com bastante freqüência, os Termos tragam referências elogiosas ao Grupo e ao trabalho neste realizado. A maioria evidenciava os aspectos positivos encontrados na escola, elogiando nominalmente algumas professoras ou a diretora, ressaltando suas virtudes e contribuições para o bom andamento escolar. Quanto às falhas, havia sempre muito receio em apresentá-las. Inspetores e assistentes preferiam não dizer os problemas encontrados valendo-se de outro expediente, qual seja, o de enumerar uma série de sugestões e recomendações às professoras, sem afirmar quem não as estariam seguindo. Mas também foram encontrados Termos com referências depreciativas ao trabalho realizado no Grupo Escolar.

Um deles foi encontrado no Grupo Escolar Pedro II. Este Termo foi escrito num papel à parte e colado no caderno e havia, ao lado, uma anotação da diretora afirmando que, com autorização do Secretário da Educação, declarava aquele Termo de Visitas sem validade, já que havia sido lançado por uma pessoa com problemas mentais e que não tinha credenciais para inspecionar os trabalhos do Grupo ${ }^{280}$. Seu autor não era assistente técnico e não foi possível detectar o motivo de sua visita ao Grupo. Ele deixou registrado que nenhum aluno do Grupo havia sido capaz de responder às suas perguntas com segurança e ainda criticava sutilmente a diretora que teria feito tudo para agradá-lo, inclusive mostrando os diversos cartazes colocados nas paredes do Grupo.

\footnotetext{
${ }^{279}$ Termo de Assistência Técnica de 31 de julho de 1930.

${ }^{280}$ Este Termo de Visitas está registrado no livro do Grupo Escolar Pedro II, na data de 15 de março de 1938.
} 
Irônico, o visitante chamava de deliciosos os momentos que passou lendo os cartazes recomendando amor e carinho às árvores.

No Grupo Escolar Assis das Chagas também foi encontrado um Termo de Visitas criticando o trabalho de algumas professoras.

Chamo a atttenção da directoria e da docencia para o seguinte: a) a professora de $3^{\circ}$ anno, d. Josina Motta, cuja classe não prima pela ordem e disciplina, não faz ensino simultaneo efficiente; b) a professora d. Maria da Conceição Ferraz do $1^{\circ}$ anno, tem sua classe indisciplinada, porque ainda se não convenceu de que ordem, disciplina e attenção dos alumnos se não conseguem com o esbravejar da professora na classse e de tal modo que perturba o leccionamento nas classes visinhas. Impacientar-se, perder a calma a professora em aula é descomedir-se e perder toda autoridade moral sobre os discipulos. A professora d. Joanna Navarro precisa mais intensificar a efficiencia do ensino em sua classe, empregando maiores e melhores esforços pelo adeantamento dos proprios alumnos. ${ }^{281}$

Segundo um Termo de Visitas deixado por Leonilda Montandon no Grupo Escolar Bernardo Monteiro, quase todo o corpo docente era esforçado e buscava por progredir, no entanto, havia algumas que precisavam melhorar:

Não impressiona bem, ouvir dos labios de uma educadora, palavras de desanimo e pessimismo! Saibam agir, saibam trabalhar, saibam vencer! Para tudo isso conseguir, não é necessario grande sacrificio! Apenas o cumprimento exacto de seus deveres. Comecem por tomar a resolução firme de se interessarem pela classe e faze-la progredir. Attendam ainda ao seguinte: a) organisem o trabalho de classe, de modo a dar somente cousas proveitosas;

b) occupem bem o tempo, destinado ás lições;

c) não se esqueçam de que o exercicio é a principal garantia de aprendisagem.

d) vigiem sempre para que o interesse e a attenção dominem em todas as aulas.

e) garantam a disciplina com o trabalho bem dosado, bem escolhido e bem dirigido.

f) verifiquem sempre se os seus ensinamentos estão sendo aprendidos.

g) sejam prodigas de palavras e actos que estimulem os alunos ao trabalho.

h) não faltem ás aulas por qualquer motivo, lembrando-se do grande prejuiso que causam. (Que algumas profas. meditem sobre esse ponto).

i) finalmente, procurem exercer o seu cargo com consciencia, tendo sempre em mente, a sua responsabilidade não só perante os paes, o governo, mas, sobretudo, perante Deus! $!^{282}$

$\mathrm{Na}$ visita realizada às Escolas Beneficentes Italianas, posteriormente, Grupo Escolar Pandiá Calógeras, Irene Silveira deixava a seguinte impressão no ano de 1938:

${ }^{281}$ Termo de Visitas de Ernesto C. Santiago em 14 de junho de 1928.
${ }^{282}$ Termo de Visita de 13 de maio de 1936. 
Não posso compreender como os mestres, que a todo o instante ouvem falar na reforma do ensino, nas realisações, nas transformações porque têm passado o nosso ensino primario, continuem de braços cruzados, sem procurar o caminho verdadeiro, que somente depende de querer, de investigar, observar e sobretudo estudar, para que ele seja palmilhado rapida e suavemente, com os melhores e maiores resultados. ${ }^{283}$

Para garantir que todos os professores tivessem conhecimento do Regulamento e do Programa do ensino primário que deveria ser utilizado em classe, Irene realizou uma reunião com todas as professoras do Grupo, o diretor e a fiscal da Sociedade Italiana. A assistente ainda deu inúmeras explicações sobre diversos pontos do Regulamento de forma que não houvesse dúvidas na sua aplicação.

\subsection{DAS PRESCRIÇÕES ÀS PRÁTICAS: A PARTICIPAÇÃO DOS EDUCADORES}

Com as alterações na hierarquia educacional do Estado, criou-se uma fragmentação entre os educadores que facilitavam o controle sobre o trabalho destes, na medida em que eram colegas, mas também fiscais uns do trabalho dos outros. Dessa forma ficava mais fácil impor as mudanças e exigir o cumprimento das Reformas. Se, muitas vezes, os educadores foram pegos por esta armadilha, em algumas outras, entretanto, enfrentavam os superiores e faziam valer suas próprias crenças e convicções. Embora os professores fossem diretamente atingidos por estas mudanças, as fontes apontam também como se tornou instável e problemática a atuação das diretoras escolares, pressionadas por mostrar um trabalho eficaz e competente na administração dos Grupos. Pela primeira vez, tendo que compartilhar seu trabalho com as orientadoras não foi simples conciliar as exigências que se fazia sobre o trabalho das diretoras com a fiscalização que se implantava nos Grupos Escolares.

As atas das reuniões pedagógicas põem em evidência o conturbado cotidiano escolar, as disputas de poder, os jogos de representações, as exigências e ameaças. Por estes documentos, é nítida a impressão que as exigências burocráticas faziam com que os educadores entrassem em antagonismos, discussões e disputas quando, na verdade, esta era mais uma forma de exercer controle e vigilância, feita agora pelos próprios colegas instaurados nos aparelhos burocráticos do Estado.

${ }^{283}$ Termo de Visita de 30 de abril de 1938. 
Nos Termos de Visitas ficam mais diluídas as disputas, na medida em que se baseavam num olhar externo e pontual acerca das atividades desenvolvidas nas escolas. Além disso, é possível que as recomendações consideradas necessárias fossem feitas verbalmente, mas não anotadas nos Termos de Visitas, justamente para não expor os educadores do Grupo.

De diversas formas, portanto, procurava o governo do Estado implementar dispositivos de controle sobre o trabalho realizado nos Grupos Escolares. Apesar deste controle quase onipresente, é possível perceber que havia resistências e que nem tudo o que se fazia na escola coincidia com as prescrições e intenções dos reformadores. A cultura escolar, embora esteja imbuída das mudanças ocorridas de uma maneira geral, nas legislações e normas, podem sofrer novas configurações no espaço escolar que nem sempre coincidem com o esperado, desejado, imaginado. Os educadores sempre tiveram possibilidades, ainda que cada vez mais restritas, de elaborar táticas reveladoras de suas interpretações pessoais das legislações, normas e prescrições que, às vezes, se baseavam em princípios outros, obtidos a partir da cultura familiar, religiosa, social mais do que embasados pela cultura propriamente pedagógica. 


\section{CAPÍTULO 4 \\ NAS CARTEIRAS DOS GRUPOS ESCOLARES}

Pois memória e profundidade são o mesmo, ou antes, a profundidade não pode ser alcançada pelo homem, a não ser através da recordação.

(Hannah Arendt, 1954/1972, p.131)

O final do século XIX e início do século XX foi cenário para significativas mudanças que estavam em curso nas propostas educacionais. Tratava-se de uma nova concepção de infância e de relação com a aprendizagem que dava ensejo à criação de diversos métodos pedagógicos que pretendiam colocar os alunos como agentes do processo educacional ${ }^{284}$. A chegada dessas inovações ao Brasil, que passava nesse momento por transições políticas cruciais (de Colônia a Império e de Império a República em menos de um século), fomentava as discussões sobre a importância da educação para as definições do destino do país, como indica Faria Filho:

Os recentes estudos a respeito da educação brasileira no século XIX, particularmente no período imperial, têm demonstrado que havia, em várias Províncias, uma intensa discussão acerca da necessidade de escolarização da população, sobretudo das chamadas "camadas inferiores da sociedade" questões como a necessidade e a pertinência ou não da instrução dos negros (livres, libertos ou escravos), índios e mulheres eram amplamente debatidas e intensa foi a atividade legislativa das Assembléias Provinciais em busca do ordenamento legal da educação escolar. (Faria Filho, 2.000, p. 135)

Além de uma situação política e social que requeria mudanças na organização da sociedade, tiveram repercussão no Brasil diversas teorias que buscavam explicar e organizar a sociedade da época como o Positivismo, as concepções de um darwinismo social, as teorias eugenistas, o Higienismo e os princípios racionais de organização do trabalho, como o Taylorismo e Fordismo, entre outras. Todas essas concepções teóricas, de uma maneira ou de outra, de forma mais ou menos intensa, davam sustentação a uma série de medidas de modernização do país, mas em moldes bastante conservadores. Por outro lado, também as idéias comunistas e anarquistas que chegavam ao país, especialmente por parte dos imigrantes que vinham substituir a mão-de-obra escrava em fins do século XIX, vinham sendo abraçadas por setores urbanos nativos. Estas últimas ${ }^{284}$ Podemos citar algumas dessas inovações como o método mútuo (lancasteriano ou monitorial), o
método intuitivo e ainda a passagem do ensino individual para o ensino simultâneo. 
povoavam e ameaçavam o imaginário de uma elite que desejava o progresso e o desenvolvimento do país sem perder as regalias e o conforto da sua posição social.

Especialmente na segunda década do século XX a educação foi constituída como a redentora dos problemas nacionais, como nos indica Marta M.C.Carvalho:

Perpassava fortemente o imaginário desses entusiastas da educação o tema da amorfia. Referido ao país, marcava-o como nacionalidade em ser a demandar o trabalho conformador e homogeneizador da educação. Referido às populações brasileiras, proliferava em signos da doença, do vício, da falta de vitalidade, da degradação e da degenerescência. O trabalho, nessas figurações, elemento ausente da vida nacional. As imagens de populações doentes, indolentes e improdutivas, vagando vegetativamente pelo país, somam-se às de uma população urbana resistente ao que era entendido como trabalho adequado, remunerador e salutar. Imigrantes a fermentar de anarquia o caráter nacional e populações pobres perdidas na vadiagem impunham sua presença incômoda nas cidades e comprometiam o que se propunha como "organização do trabalho nacional".

Regenerar as populações brasileiras, núcleo da nacionalidade, tornando-as saudáveis, disciplinadas e produtivas, eis o que se esperava da educação. Regenerar o brasileiro era dívida republicana a ser resgatada pelas novas gerações. (1989, p.20-21)

A dívida republicana implicava, principalmente, educar, no sentido de moralizar, conformar, disciplinar a população pobre, mais do que em instruí-la. O conhecimento sempre foi um bem precioso e caro às elites. A escola pública disseminada para as massas deveria ter por objetivo formar o cidadão e conformá-lo a uma estrutura social cuja desigualdade era explicada pelo viés da meritocracia. As novas gerações tinham um papel primordial neste momento, a infância compreendida, pela sua plasticidade, como o momento crucial para a tarefa de moldagem a ser exercida pela educação, como mostra Lourenço Filho:

Quaisquer que sejam as concepções filosóficas e sociais da educação, ou qualquer que seja a visão dos fins possíveis ou julgados possíveis na formação humana, um denominador comum existe: é o de que podemos alterar, fazer variar ou modificar o comportamento e a experiência do educando, no sentido de objetivos que tenhamos como úteis, justos ou necessários. (1978, p. 61)

Construiu-se, então, a imagem da escola pública primária como a regeneradora da sociedade a partir da infância. As crianças, tornadas alunos, eram o alvo principal da intervenção dos "missionários do progresso" 285 na família e na sociedade, pela mediação da escola. Os alunos passaram a constituir não apenas o centro do processo de

\footnotetext{
${ }^{285}$ Título de uma obra organizada por Micael Herschamnn, Simone Kropf e Clarice Nunes (1996).
} 
ensino-aprendizagem, mas de um projeto de transformação social pela via da escola pública primária:

Quando seguimos as pegadas do que se disse sobre a escola estamos trabalhando com memórias agarradas a um contexto de infância que se remete a uma doxa urbana mutável, recortada pelas lembranças envolvidas na escrita, na escuta, no momento e nos costumes. As memórias dos ex-alunos das escolas públicas, dos poetas e dos cronistas da cidade em seus textos compõem de maneira anamórfica (formas sempre em mudança) o que chamaríamos de "realidade" da escola e os sentimentos e as opiniões que sobre ela se forjam. (Nunes, 1996, p.160)

Acompanhar os rastros do que foi a experiência da escola para essas gerações, implica ouvir os alunos e alunas das escolas públicas e vasculhar os recantos de suas memórias, resgatando as lembranças que ficaram do primeiro dia da escola, da convivência com os colegas, das brincadeiras no pátio, das relações com as professoras até o dia esperado da entrega do diploma. Essas lembranças permitem iluminar um pouco mais os territórios escolares, colorindo os espaços cinzentos com as emoções e as recordações de quem ali viveu parte de sua vida.

\subsection{CRIANÇAS DE OUTRORA}

Nas carteiras dos Grupos Escolares dos anos vinte aos cinqüenta estiveram crianças de diversas etnias, religiões e classes sociais. Nem sempre, porém, essa diversidade era respeitada, já que a homogeneidade é que era a "febre" do momento. Eram meninos e meninas que viveram um tempo em que o acesso à escola se tornava mais democrático e que o investimento em educação era a marca de um governo que se pretendia progressista. Hoje senhores e senhoras que, convidados a rememorar passagens da sua meninice nos bancos da escola, trazem à tona as vivências do cotidiano dos Grupos Escolares da capital mineira.

Foram realizadas para a pesquisa quatro entrevistas, com duas ex-alunas e dois ex-alunos de Grupos Escolares da capital. Utilizou-se, ainda, o depoimento de Berenice Menegale, aluna das classes anexas à Escola de Aperfeiçoamento e que registrou algumas de suas lembranças desse período numa entrevista concedida ao Centro de Referência do Professor. 
4.1.1. ARACY ABREU PINTO nasceu em Belo Horizonte em 1937, entrou para a escola aos sete anos e fez todo o curso primário no Grupo Escolar Mariano de Abreu, estudou, posteriormente, no Colégio Imaco, mas não concluiu o científico porque se casou muito nova. Durante 21 anos, trabalhou vendendo roupas em loja e em domicílio. Atualmente está aposentada.

4.1.2. BERENICE MENEGALE, que deixou registrada sua entrevista no Centro de Memória do Professor em Belo Horizonte, nasceu nesta mesma cidade no ano de $1934^{286}$ e fez o curso primário nas classes primárias anexas à Escola de Aperfeiçoamento. Após o curso primário, fez exame de admissão no Colégio Santa Maria, onde estudou por dois anos. Aos quinze anos, foi realizar um curso no Conservatório Nacional em Paris, permanecendo lá por um ano. Ainda voltou duas vezes para estudar na Europa e, em 1960, foi diplomada pela Academia de Viena. Foi professora da Escola de Música da UFMG e criou a Fundação de Educação Artística de Minas Gerais.

4.1.3. GERALDO FÉLIX DE JESUS atualmente é vereador em Belo Horizonte e possui quatro cursos superiores: Direito, Administração, Ciências Econômicas e Ciências Contábeis ${ }^{287}$. Trabalhou como alfaiate, camelô, jogador de futebol, foi militar e Procurador da Câmara de Vereadores de Belo Horizonte. Fez o curso primário no Grupo Escolar Tomaz Brandão, terminou o $1^{\circ}$ grau e estudou o $2^{\circ}$ grau pelo sistema madureza, entrando para a Universidade já casado e com 35 anos, após ter perdido as divisas como sargento da Aeronáutica, durante a ditadura militar. Depois disso, passou num concurso para Procurador da Câmara de Vereadores de Belo Horizonte e, desde 1992, tem sido eleito vereador em todos os pleitos eleitorais.

4.1.4. JOSÉ FERNAL BICALHO nasceu em Carmo da Mata, interior de Minas Gerais, em 1926. Mudou-se com a família em 1931 para Belo Horizonte e, aos

\footnotetext{
${ }^{286}$ Sua entrevista foi realizada em Belo Horizonte em 16 de maio de 2000 e teve, aproximadamente, 1 hora de duração. Tinha 66 anos de idade na data da entrevista. O vídeo com a entrevista está no Centro de Referência do Professor da Secretaria do Estado da Educação de Minas Gerais.

${ }^{287} \mathrm{O}$ curso de Direito foi feito na Universidade Federal de Minas Gerais, os outros foram cursados na Pontifícia Universidade Católica de Belo Horizonte e se chamava Curso Integrado de Ciências Econômicas que, na verdade, continha três cursos em um, já que dava direito a três diplomas nos cursos superiores, acima referidos.
} 
sete anos, foi matriculado no Grupo Escolar Olegário Maciel onde a mãe lecionava à noite, quando funcionava o Grupo Escolar Assis das Chagas. Fez o secundário no Colégio Anchieta e ingressou na Faculdade de Medicina da UFMG, concluindo o curso em 1951 como cirurgião e obstetra. Trabalhou em Ouro Preto na Alcan e em uma clínica particular. Depois de sete anos, mudou-se para os Estados Unidos onde estudou ortopedia, voltou ao Brasil, retornou novamente aos Estados Unidos e lá trabalhou até a aposentadoria. Atualmente, leciona para médicos residentes nos Estados Unidos e vem ao Brasil com freqüência.

4.1.5. NORMA LÚCIA CLEMENTE nasceu em Belo Horizonte, estudou no Grupo Escolar Barão de Macaúbas ${ }^{288}$, fez o secundário no Colégio São José e depois estudou na Escola Profissional Feminina. Segundo ela, era um curso de normalista profissional, mas não era reconhecido pelo governo federal. Ela só descobriu isso quando foi impedida de se matricular no Instituto de Educação. Em 1954, começou a trabalhar no Jardim de Infância da Creche Menino Jesus. No ano seguinte, este deixou de funcionar e ela foi trabalhar no Jardim de Infância da Escola Nossa Senhora de Fátima. Em 1956, trabalhou no Largo da Tia Célia que, a partir da metade do ano, passou a se chamar Educandário Estrela Matutina. De abril de 1958 a julho de 1959 trabalhou no Instituto Santo Antônio, colégio no bairro Sagrada Família. Parou de trabalhar como professora e, em 1961, conseguiu um emprego na Telemig, empresa na qual permaneceu durante trinta anos até se aposentar.

Algumas alunas como Alaíde Lisboa, Elza de Moura, Terezinha Casasanta ${ }^{289}$ e Berenice Menegale afirmaram que a passagem pela escola foi muito prazerosa e tranqüila, já que a mesma disciplina e as mesmas regras a que estavam acostumadas em casa serviam para a escola. Por outro lado, para algumas crianças, especialmente das classes menos favorecidas, a escola era um mundo completamente diferente da vida cotidiana, o que provocava uma grande angústia. Geraldo Félix comentou que seu

\footnotetext{
${ }^{288}$ No arquivo deste Grupo não há nada do período estudado. Segundo informações de uma visita realizada na escola, todos os documentos foram perdidos.

${ }^{289}$ Como as professoras entrevistas foram alunas em Grupos Escolares mineiros, suas lembranças deste período também foram utilizadas.
} 
primeiro dia de aula foi assustador, porque ele não estava preparado e nem sabia o que era uma escola. Um fato vivenciado neste dia contribuiu para aumentar os seus temores:

GF: Tem um fato aí, que você pergunta, do $1^{\circ}$ dia de aula que me marcou e está marcando até hoje. A minha professora chamava dona Maria da Conceição, a gente a chamava de dona Conceição e como entrou aquela turma, tudo, cada um mais caipira do que o outro, cada um mais cismado, porque a família levou. Não sabia o que era escola, a família levou, chegou lá e nos deixou lá dentro. Aí depois levaram a gente pra sala, a gente todo desconfiado e quando a professora foi tentar iniciar uma conversa para amaciar os meninos, ela chegou perto duma menina e começou a conversar com ela querendo saber nome, querendo saber, brincando com ela. A menina não respondia nada, ela apertou: "Mais que coisa você não está respondendo". A menina voou nela com as mãos no pescoço, coitada, era frágil, a menina agarrou no pescoço dela e para tirar foi uma dificuldade. Mas a menina também não sabe por que, "nervo", não tinha motivo, não tinha nada não, fato estranho. A professora começou a tossir, nós ajudamos a socorrer. Nós puxamos a professora e ela ficou lá. [Imita a tosse da professora] $\mathrm{R}$ : E a menina sofreu alguma punição depois?

GF: Não lembro, foi o $1^{\circ}$ dia, lá na sala de aula, não. Eu acho que não porque eu nunca vi um fato deste. A pessoa vai brincar com outra, quer conhecer a pessoa e acontece um fato deste. Um fato que marcou, né? E acabou assustando mais a gente. Gente, mas o que que é isso, o negócio aqui é feio! [risos]

Se, para o ex-aluno, a entrada na escola constituía-se numa novidade assustadora, o ocorrido revela, no entanto, que seus temores eram partilhados por outros colegas que se sentiam ameaçados diante das mais simples perguntas feitas pela professora. Também no Grupo Escolar Olegário Maciel uma aluna chegou a ser eliminada porque chorava o dia todo, perturbando as aulas. Para Geraldo Félix, esse completo desconhecimento acerca da escola dificultava a sua passagem por aquele espaço, sendo responsável mesmo por alguns de seus fracassos escolares:

R: Como foi a impressão do senhor quando o senhor passou por esta situação no $1^{\circ}$ dia da escola?

GF: Passei assustado, custei. Custei a compreender o que que era aquilo. Por isso que a gente repete, acho que eu fiquei assustado o tempo todo, não sabia para o que que servia aquilo. Ensinando uns negócios lá, não tinha preparo antecipado. Você ia como se você estivesse indo, como se pega esses bois aí e leva lá, eles não estão sabendo nada do que vai acontecer .... Isto me ajudou a repetir 2 anos para fazer o $1^{\circ}, 2$ anos para fazer o $2^{\circ}$, 2 anos para fazer o $3^{\circ}$, este com justificativa. Os outros era despreparo para entrar.

$\mathrm{R}$ : O sentimento que o senhor tinha, que o senhor lembra era de medo durante todo tempo?

GF: Assustado. Isso. Assustado. Você está num ambiente, você não tem protetor ali dentro, quem é que vai te proteger? Mamãe não está aqui, papai não está aqui, qualquer coisa aqui eu estou ferrado [risos]. Esse era o pensamento de infância do menino. 
Todos os entrevistados passaram pela escola sem repetência, com exceção de Elza de Moura que repetiu duas vezes a quarta série não por reprovação, mas para atingir a idade que lhe permitisse a inscrição na Escola Normal, e Geraldo Félix que levou sete anos para concluir o ensino primário. Além das reprovações, uma doença lhe teria tirado da escola algum tempo, prejudicando as atividades escolares.

G.F.: Eu fiquei sete anos na escola. Tirei meu diploma em 1948. Depois eu voltei para fazer o terceiro, tumultuado, e depois o quarto. Fiquei 2 anos no $1^{\circ}$ ano e conto uma coisa muito pitoresca do $1^{\circ}$ ano. As professoras não falavam pro aluno que ele tomou bomba, então a gente ia depois da prova saber se passou. Eu cheguei e perguntei: "passei?" Ela falou: "Nome?" Eu falei: "Geraldo Félix". Ela olhou na lista e falou: "Olha. Passou. Parabéns. Passou, você agora vai para o $1^{\circ}$ ano adiantado". Eu desci a rua Vassoura, a rua Escorrega, correndo para dar notícia lá em casa. E minha mãe chegou e falou: "Como é que foi?" Eu falei: "Passei, mãe, eu agora vou para o $1^{\circ}$ ano adiantado!" Que técnica deles, né? É assim, uai.

Sobre a questão da realização da $1^{\mathrm{a}}$ série do curso primário em dois anos, um artigo na Revista do Ensino afirmava:

Os resultados dos testes iniciais aplicados nos Grupos Escolares do Estado, a fim de se dar às classes organização mais homogênea, bem como os resultados dos testes de promoção levaram o D.E. [Departamento de Educação] a se convencer de que um grupo de crianças menos dotadas, ou melhor, menos desenvolvidas mentalmente, não poderia vencer a $1^{\mathrm{a}}$ série do curso em um ano apenas. ${ }^{290}$

Segundo o artigo, no início de 1945, em caráter experimental, seria exigido das crianças classificadas nestas classes tidas como mais lentas apenas o programa do $1^{\mathrm{o}}$ semestre do $1^{\circ}$ ano. No entanto, ainda nos anos vinte, nos Termos de Ata e Promoção do Grupo Olegário Maciel apareciam vários casos em que, ao final do ano, as turmas mais lentas tinham cumprido apenas metade do programa. Por esse motivo, continuariam, no ano seguinte, no $1^{\circ}$ ano para finalizar o programa. Talvez o que estava sendo experimentado em 1945 já fosse uma prática comum nos Grupos Escolares mineiros e, provavelmente, Geraldo Félix, que tinha se matriculado no Grupo em 1942, tivesse sido incluído neste caso.

Norma Lúcia, pelo contrário, antes de ser matriculada no Grupo, teve algumas aulas particulares com uma senhora que lhe ensinara a ler, escrever e somar. Segundo ela, na turma de novatos, ela estava mais adiantada que os outros alunos, então

${ }^{290}$ FROTA, Zilá.Estudo do Teste P.S. de 1945. Revista do Ensino, BH, ano XIV, n. 181, p. 28-51. jul.1946, p. 28. 
decidiram colocá-la numa sala de alunos repetentes, o que lhe trouxe muito sofrimento, porque ela não sabia subtração. A partir do segundo ano, ela foi colocada numa turma de alunos melhores e sentiu menos dificuldades. Entretanto, houve uma desavença inicial com a professora do segundo ano. Norma conta que esta não permitia o uso de borracha, queria que os alunos apenas riscassem os erros. Mas ela não queria o caderno cheio de erros e passou o dedo no exercício errado, manchando a folha. Feito isso, teve medo de ficar de castigo e não queria entregar o caderno à professora. Ela então lhe perguntou "Você quer mandar mais do que eu?" e a colocou de castigo sentada na mesa da professora, enquanto ela foi marchar com os alunos no pátio. Outros alunos ficaram de castigo com ela na sala. Quando os colegas retornaram, ela já tinha voltado para sua carteira, então novamente a professora lhe puxou e mandou que ficasse sentada na mesa da professora já que ela queria mandar tanto quanto ela. Essa situação, no entanto, não se repetiu e a relação com a professora, que foi a mesma até o final do curso primário, melhorou muito, e Norma chegou a ganhar muitos prêmios dados por ela. A ex-aluna lembra-se, ainda, dos problemas que teve que enfrentar com as duas professoras de bordado que já eram mais velhas, "estavam em final de carreira, acho que não tinham mais paciência para lidar com as meninas”. Segundo ela, suas mãos transpiravam muito, o suor escorria e apagava o risco do bordado. Para evitar transtornos, sua mãe fez um envelope com amido para ela passar as mãos.

A relação com as professoras envolvia sentimentos de medo e amizade e as crianças, auxiliadas pela família, tentavam encontrar formas de melhor se adaptarem ao cotidiano escolar. A convivência com os colegas no Grupo Escolar revela um pouco mais desse universo e das relações disciplinares nele imbricadas.

\subsection{ENTRE MENINOS E MENINAS}

A co-educação é um princípio caro ao movimento escolanovista. A concepção de que a escola deve se aproximar da realidade e da vida quotidiana implicava preparar meninos e meninas para a vida em comum desde os bancos escolares. Entretanto, essa era uma novidade vista como ameaçadora para a moral da época, principalmente, num Estado com forte cunho conservador como Minas Gerais. A Igreja católica, 
principalmente, não via com bons olhos a convivência de meninos e meninas nos espaços escolares.

Vários artigos ${ }^{291}$ publicados no jornal $O$ Horizonte expunham os motivos pelos quais esta prática era condenável pela Igreja. Num deles, o Padre Álvaro Negromonte ${ }^{292}$, que tinha livre trânsito entre os educadores mineiros, afirmava que homens e mulheres possuem naturezas distintas, não podendo receber a mesma educação, além disso, ela prejudicaria a formação moral das crianças e diminuiria o número de casamentos. Ele concluía com um trecho da Encíclica publicada pelo Papa Pio $\mathrm{XI}^{293}$ a respeito da educação da juventude, afirmando que a Igreja não temia o progresso nem a modernidade, mas aliava os seus princípios e valores às conclusões da ciência.

Como era de se esperar, introduzir a co-educação nos Grupos Escolares de Belo Horizonte foi um processo lento e repleto de precauções. Meninos e meninas partilhavam as mesmas salas escolares no período estudado, mas a proximidade física não garantia uma verdadeira possibilidade de entrosamento entre eles. Tinham recreios separados, espaços distintos nas carteiras e filas separadas à entrada e saída da escola. Curiosamente, até nos cadernos de matrícula e outras anotações escolares é comum que estivessem sempre discriminados os grupos de acordo com o sexo dos alunos.

A solução para o problema seria conciliatória numa sociedade que exigia uma maior interação entre os sexos, especialmente com a saída das mulheres para a cena

291 NEGROMONTE, Álvaro. Coeducação na Escola. O Horizonte, Belo Horizonte, n.863, 6 out. 1932, p.2-3 e OLIVEIRA, Mons. J.R. Da Coeducação. O Horizonte. Belo Horizonte, 25 nov.1934, ano XII, n.1.164, p.1. (Domingo). O jornal trazia, ainda, vários artigos de Gonzaga Júnior discorrendo sobre Educação e Catolicismo.

${ }^{292}$ Segundo Prates (1989, p. 133), o Padre Álvaro Negromonte, vigário da Igreja da Boa Viagem em Belo Horizonte, era o principal crítico dos trabalhos da professora Helena Antipoff. Uma pesquisa realizada por Helena Antipoff em 1929 com os alunos do $4^{\circ}$ ano primário dos Grupos Escolares de Belo Horizonte (publicada no Boletim n. 6 da Secretaria de Educação) revelou que o catecismo ficava em último lugar na preferência acerca das matérias escolares, para os alunos de ambos os sexos. As análises destes resultados indicavam que este desinteresse talvez fosse conseqüência dos métodos utilizados para o ensino desta disciplina. A partir dessa constatação, o Padre Álvaro Negromonte teria começado a investigar os processos ativos de educação e chegou a diversos livros que incorporavam os princípios renovadores ao ensino de religião. O único que foi encontrado destinava-se ao ensino de catecismo para alunos do quarto ano primário e trazia textos curtos, com ilustrações, espaços para desenhos e exercícios revelando o quanto o autor tinha se imbuído da proposta do ensino ativo. Além disso, o Padre Álvaro se tornou o vicepresidente da Sociedade Pestalozzi, criada por Antipoff. Helena Antipoff habilmente conseguiu vencer todas as suspeitas que uma professora russa de religião ortodoxa-grega sozinha em Belo Horizonte, tendo deixado na Europa seu marido e único filho, despertava nos redutos conservadores do Estado naquele período.

293 “Divini illius Magistri”de 31 de dezembro de 1929. 
pública, mas permanecendo a concepção de que o relacionamento entre homens e mulheres deveria guardar uma certa distância. A própria disposição arquitetônica dos espaços escolares revelava essa concepção:

O espaço escolar era calculado de forma a evitar possíveis encontros entre os dois sexos que não pudessem ser atentamente observados e vigiados pelos educadores. $\mathrm{O}$ Regulamento previa pátios distintos e, ainda, entrada separada para meninos e meninas. Outro cuidado previsto era com os banheiros, que deveriam ser completamente separados e com as entradas distantes, o mais possível, umas das outras. (Souza, 2001, p.210)

Imene Guimarães, que estudou num período anterior às Reformas da década de vinte, conta que o Grupo Escolar Barão do Rio Branco ${ }^{294}$ era exclusivo para meninas, e os meninos estudavam em outros Grupos. Todos os outros entrevistados estudaram em classes mistas. No entanto, havia uma separação na sala de aula. Algumas filas de carteiras eram para meninos, outras para meninas. Quanto à entrada, nem todos se lembram se era separada e, com relação ao recreio, Geraldo Félix foi o único a afirmar que não se lembrava se havia pátios distintos ${ }^{295}$.

Para Alaíde Lisboa, a diferenciação entre os dois sexos começava em casa e os meninos tinham mais liberdade até mesmo na leitura de livros. Segundo ela, seus irmãos liam os livros e faziam uma seleção do que as irmãs podiam ler. A censura era não somente de livros inteiros, mas também de partes consideradas impróprias, sendo as páginas que não deveriam ser lidas devidamente identificadas pelos irmãos. Alaíde disse, ainda, que seguia à risca a recomendação. Livros de Olavo Bilac e Monteiro Lobato eram sempre lidos antes pelos irmãos. Mais tarde, ela leu o que seu irmão lhe havia barrado e era uma parte da história em que a moça fugia de casa. Além disso, a consulta a dicionários também não era aprovada, pois, ao procurar uma palavra qualquer, a menina podia acabar encontrando uma palavra "feia".

A co-educação começava a ser uma realidade nos Grupos Escolares, entretanto, a sociedade certificava-se que, com o avanço da idade, os destinos demarcariam espaços muito distintos para os meninos e as meninas.

\footnotetext{
${ }^{294}$ Imene Guimarães estudou lá entre 1920 e 1923.

295 Em 1929, Theodore Simon visitou alguns Grupos em Belo Horizonte e observou que, no Grupo Escolar Barão do Rio Branco, os pátios eram separados para meninos e meninas. SIMON, Theodore. Dois mezes em Bello Horizonte. Minas Gerais, 05 abr. 1930.
} 
Nos Grupos noturnos, como os alunos apresentavam idades mais avançadas, a proximidade entre eles era percebida como inadequada e a separação entre as classes se manteve por mais tempo. No Grupo Escolar Afrânio de Melo Franco, por exemplo, havia muito receio em se aceitar a co-educação. Uma observação no livro de ocorrências do Grupo revela que uma única professora lecionava em quatro classes do sexo feminino que não poderiam ser fundidas às classes masculinas "por questões de ordem interna e disciplinar". Também não haveria professoras suficientes para se desdobrar as classes, concluindo-se que: "A situação dessa classe é lastimável, não podendo a professora, por mais que se esforce, apresentar resultado satisfactorio, devido a esses senões, aggravados ainda, pela escassez do tempo." 296

No Grupo Escolar Assis das Chagas, também noturno, havia o mesmo problema. Em fevereiro de 1930, Helena Pena, assistente técnica, recomendava que as alunas meninas e mocinhas - fossem colocadas em classes à parte ou pelo menos com os meninos menores. Quatro anos depois, Ernesto Santiago, inspetor escolar, comentava que a divisão do Grupo em seção feminina e masculina resultou em melhorias da ordem, da disciplina, das condições técnicas e até mesmo econômicas do Grupo ${ }^{297}$.

Não obstante, para as crianças menores, havia uma maior aceitação de que partilhassem o mesmo espaço escolar. Até porque se acreditava que não havia grande interesse por parte deles próprios de se misturarem uns aos outros. Manuel Casasanta, por exemplo, em artigo publicado na Revista do Ensino em 1946, argumentava que não se deveria temer a colocação dos alunos e alunas no mesmo pátio durante os recreios, já que eles próprios mantinham distância entre si:

O problema do recreio em comum a meninos e meninas permanece na ordem do dia. Alguns diretores o resolvem de plano, sumariamente: meninos e meninas, cada qual para o seu lado. Se houver muro separando os páteos, tanto melhor. Outros o consideram de maneira diversa: afinal de contas, trata-se de crianças e não vai mal que fiquem juntas, juntas satisfazendo ao impulso de brincar, correr, crescer.

Estou que os pais, se consultados, adotariam a primeira solução: - para as meninas a companhia das meninas e para os meninos a dos meninos.

E, note-se, com fundamento, pelo menos de certo ponto em diante. Aí, por volta dos nove anos, emquanto os meninos dão de preferir atividades, os exercícios que demandam força, necessários à formação do futuro homem, as meninas escolhem jogos ou brinquedos mais próprios da fragilidade e graça femininas.

A meu ver, o problema está mal colocado. Observem-se as crianças na hora do recreio. Em regra, os meninos ganham um canto do páteo, agrupando-se, à distância, as

\footnotetext{
${ }^{296}$ Livro de ocorrências de 1937.

${ }^{297}$ Termo de Visitas de 14 de fevereiro de 1930 e 08 de março de 1934.
} 
meninas, movidos uns e outros por sentimentos e pensamentos que nem sempre conferem com o pensamento e o sentimento adultos. ${ }^{298}$

Apesar disso, os meninos e as meninas chegavam até a escola por entradas distintas, eram separados nas filas, nas carteiras, nos recreios e também na hora da saída. As professoras contribuíam para manter esse distanciamento, especialmente em relação aos meninos. Temendo a ousadia deles em se aproximarem de suas colegas, as professoras criaram uma forma de castigo muito interessante. Caso os alunos fizessem qualquer travessura dentro da sala, eram colocados para assentar nas carteiras, que eram duplas, junto com uma menina. O castigo realçava a desonra para um menino que se via obrigado a aproximar-se de uma colega do sexo oposto. Vários depoimentos comentam este tipo de castigo, no entanto, e, segundo os(as) entrevistados(as), com exceção de Aracy Abreu, as meninas não eram colocadas ao lado dos meninos por castigo, o que confirma a hipótese de que o aluno indisciplinado era rebaixado à suposta inferioridade feminina ao ser colocado para se sentar a seu lado. Norma Lúcia comenta que sua professora colocava um colega mais indisciplinado para se assentar com ela, o que o enchia de vergonha.

N.L.: No primeiro ano, eu tinha um colega chamado Amâncio, ele era muito levado, de vez em quando ele vinha sentar perto de mim, a carteira era de dois lugares. A professora punha para sentar perto pra envergonhá-lo. Porque sentar com uma menina era uma vergonha, então freqüentemente esse Amâncio vinha sentar perto de mim como castigo.

R: E sentar perto dos meninos também era uma vergonha?

N.L.: Eu nunca me lembro de colega minha ir sentar perto de menino não.

R: As meninas levavam outro tipo de castigo?

N.L: As meninas eram muito mais comportadas, talvez por medo de castigo elas não faziam antes essas coisas assim. Este Amâncio que virava e mexia ele vinha sentar do meu lado. Os meninos ficavam mexendo com ele. Diziam assim: vai sentar perto da Norma, oh gente!

R: E ele, como ele se sentia?

N.L: Ele ficava envergonhado, ficava de cabeça baixa. E não era grande coisa o que ele fazia não, ele ria ou virava pra traz pra conversar com o colega. Isso era motivo pra ele vir sentar perto de mim.

Segundo Aracy Abreu, a única entre os entrevistados que afirmou se lembrar das meninas sendo colocadas para se sentar junto aos seus colegas do sexo masculino, este podia até ser um castigo bem-vindo:

${ }^{298}$ CASASANTA, Manuel. Instantâneos da escolar. Revista do Ensino, BH, n.177, p.103-104, mar.1946. p. 104 . 
Quando se dava este castigo, pra menina sentar com menino, ela falava: Ah, que bom, vou sentar com fulano de tal. [risos] Então não achava que aquilo era um castigo, achava que aquilo era bom, mas não fazia também com a intenção de ter o castigo. Era quando coincidia que dava isso, elas não achavam ruim não.

Pesquisas realizadas pelo Laboratório de Psicologia da Escola de Aperfeiçoamento buscavam atestar as "naturais" diferenças entre os dois sexos, detectando a distinção de interesses através dos livros escolhidos para leitura ${ }^{299}$, sobre as matérias preferidas no curso primário ${ }^{300}$ e quanto às escolhas profissionais ${ }^{301}$. Em uma das pesquisas realizada em 1934, com alunos do quarto ano primário de Belo Horizonte, por exemplo, os resultados mostravam que a maioria dos meninos e das meninas almejava uma profissão liberal. Os meninos desejavam ser aviadores, médicos, engenheiros e padres. As meninas preferiam ser professoras, pianistas ou ainda religiosas, ao que se conclui: "os dois sexos, educados, tanto na familia, como na escola, juntos, seguem nos seus gostos e suas aspirações caminhos distinctos, revelando nestas diferenças como que duas especies biológicas"302.

As estatísticas mostram que as meninas, embora entrassem em menor número no ensino primário, eram a maioria que chegava a concluí-lo. Uma pesquisa realizada por Helena Antipoff em Belo Horizonte atestava que as meninas seriam intelectualmente superiores aos meninos até a idade de nove anos. No entanto, a partir desse momento, haveria uma inversão nos resultados dos testes $\operatorname{cognitivos}^{303}$.

A distinção entre meninas e meninos não se restringia ao aspecto cognitivo. Os entrevistados foram unânimes ao afirmar que as meninas eram mais dóceis que os meninos, embora, como nos afirma Elza de Moura, elas também fizessem travessuras. Geraldo Félix concorda que os meninos eram muito mais indisciplinados do que as meninas: "Nós era periferia brava, nós era tudo pé no chão, casca grossa".

\footnotetext{
${ }^{299}$ Uma dessas pesquisas foi publicada na Revista do Ensino. LUSTOSA, Irene. Interesses infantis revelados por um catálogo de livros. Revista do Ensino, BH, ano VIII, n. 102, p.46-61, maio. 1934.

300 ANTIPOFF, Helena. Ideaes e interesses das creanças de Bello Horizonte e algumas sugestões pedagógicas. Revista do Ensino, BH, ano X, n.128-133, p.278-325, jul.dez.1936.

${ }^{301}$ ANTIPOFF, Helena. Iniciação a orientação profissional. Revista do Ensino, BH, ano XIII [sic], n.170172, p. 76-79, jan.mar.1940.

${ }^{302}$ CASTRO, Maria Angélica de; ANTIPOFF, Helena. Ideaes e interesses das creanças de Bello Horizonte no intervalo de cinco annos. Boletim n. 17. Belo Horizonte: Secretaria da Educação e Saúde Pública: $1935.57 \mathrm{p}$.

${ }^{303}$ ANTIPOFF, Helena. O desenvolvimento mental das crianças de Belo Horizonte. Revista do Ensino, BH, ano XI, n. 134-136, p.278-325, jan.mar.1937.
} 
R: E tinha outros castigos diferentes, o senhor acha que as meninas eram menos indisciplinadas...

GF: Menos, mas tinha umas de vez em quando do capeta também, mas a maior parte era pacífica, as meninas eram diferentes, outra criação. Nós éramos, toda a região, era tudo pivete, hoje a gente encontra velho um com o outro, começamos a lembrar de coisa, das brigas lá fora, quem eram os valentes. Eu era justiceiro, terrível justiceiro. Não agüentava ver covardia, todo mundo que fazia covardia tinha que acertar comigo lá fora. Tinha briga todo dia. [Conta de uma briga dele com um outro menino que havia dito que amansou a aula da tarde e ia amansar a aula da manhã. Ele bateu na turma da tarde e ia bater na turma da manhã. E Geraldo Félix brigou com o menino fora da escola.]

Segundo Norma Lúcia, o recreio era em pátios separados para meninos e para meninas, e a professora vigiava o recreio dos meninos e deixava as meninas livres porque elas eram mais bem comportadas:

N.L.: Pátios separados. Os meninos do lado de baixo e as meninas do lado de cima. Sendo que a minha professora nos ameaçou, que o dia que ela tivesse de passar pro nosso lado era castigo na certa. E foi num desses dias, que ela cismou de levar pra nós uma coleção de "Viagem através do Brasil" pra gente folhear durante o recreio, que nós assustamos quando ela chegou perto da gente. Aí pensamos que já vinha castigo e não era, era pra gente ler os livros, que aliás eu até tenho dois, ele era dividido em séries. Eu tenho um de Pernambuco e um de Minas Gerais, eu tenho dessa coleção.

É curioso o aviso da professora porque, como se esperava que as meninas fossem mais comportadas, suas travessuras eram castigadas, e os meninos, reconhecidamente mais levados, poderiam sofrer maior vigilância, mas, por outro lado, pareciam não receber tantos castigos.

Uma pesquisa do Laboratório de Psicologia atesta o fato de as professoras considerarem as meninas mais disciplinadas. $\mathrm{O}$ estudo consistia em um inquérito feito às professoras de 233 classes de $1^{\circ}$ ano de 35 Grupos Escolares sobre o estado de saúde, conduta e caráter dos 7.560 escolares de Minas Gerais (3.923 eram meninos e 3.637 meninas). $\mathrm{O}$ único item em que as meninas tiveram um índice mais alto que os meninos foi a bondade. Na opinião das professoras, a maioria das características, boa parte delas bastante negativas, como a mentira, o roubo e a falta de pudor, era mais intensa nos meninos. Curiosamente, os meninos foram classificados como os mais agitados, agressivos, mas também mais sonolentos e apáticos. 
QUADRO 7

Estado de saúde, conduta e caráter dos(as) alunos(as) de Grupos Escolares de Minas Gerais, segundo as professoras, em 1936 (Continua)

\begin{tabular}{cccccccccc}
\hline $\begin{array}{c}\text { Conducta } \\
\text { moral }\end{array}$ & Total & Masc. & Fem. & Total \% & Actividade & Total & Masc. & Fem & $\begin{array}{c}\text { Total } \\
\%\end{array}$ \\
\hline Agressivos & 7,5 & 11,1 & 3,7 & 20,0 & Somnolencia & 4,3 & 5,8 & 2,8 & 8,0 \\
Mentirosos & 7,9 & 9,5 & 6,1 & 18,0 & Apathicos & 10,6 & 11,8 & 9,4 & 19,0 \\
Impudicos & 2,1 & 3,5 & 0,6 & 7,0 & Agitados & 9,8 & 13,4 & 6,3 & 24,0 \\
Roubam & 1,7 & 2,0 & 1,4 & 7,0 & & & & & \\
\hline $\begin{array}{c}\text { Desobedie } \\
\text { ntes }\end{array}$ & 12,6 & 15,8 & 9,4 & 29,0 & & & & & \\
Bondosos & 22,9 & 18,6 & 24,2 & 22,0 & & & & & \\
\hline
\end{tabular}

Fonte: REZENDE, Naytres Maria de. Inquerito sobre o estado de saude, conducta e caracter dos escolares de Minas. Boletim n.20. Belo Horizonte: Secretaria da Educação e Saúde Pública: 1937. p. 25.

Este quadro nos indica quais as representações que as professoras tinham dos alunos e alunas do curso primário, uma imagem nem sempre cândida e pura. Talvez por este motivo se temesse tanto a proximidade entre meninos e meninas, principalmente porque, como o número de repetências era muito alto, estes entrassem na adolescência ainda no curso primário. Este fato fazia com que a necessidade de uma educação sexual não pudesse ser desconsiderada.

\subsection{EDUCAÇÃO SEXUAL}

A afirmação da Psicanálise de que as manifestações sexuais já se faziam presentes na infância ${ }^{304}$ trouxe para o campo educacional a discussão a respeito da sexualidade infantil. Essa era uma realidade a qual educadores e educadoras não podiam mais desprezar. Como afirma Maria Cecília C.C. Souza, a Psicanálise contribuiu para criar a necessidade de se informar a criança sobre questões sexuais:

Entretanto, a informação sobre o sexo destinada à criança, por meio dos manuais de educação sexual, se apóia na fisiologia do aparelho genital, de forma tal que qualquer criança percebe que um livro educativo explica tudo, menos (felizmente) o prazer (ou a angústia) do exercício da sexualidade. (1997, p. 20)

Tomar conhecimento dessas tendências era condição essencial para intervir de maneira adequada na educação da criança ${ }^{305}$. Essa intervenção consistia, quase sempre, em desviar o interesse de natureza sexual para outras áreas.

\footnotetext{
304 Freud desenvolveu sua teoria sobre a sexualidade infantil no segundo dos Três ensaios sobre sexualidade publicado em 1905. Este texto sofreu modificações até 1925, última edição publicada com Freud ainda vivo.

305 Segundo Diana Vidal (2003), a introdução da Psicanálise teria contribuído para o despertar da discussão sobre sexualidade entre os educadores. Em 1933, fora criado o Círculo Brasileiro de Educação Sexual no Rio de Janeiro que chegou a editar 47 Boletins sobre a temática. O tema preocupava não
} 
Começo por afirmar-lhe que a criança é apenas inocente, mas não o ser perfeito como pregava Rousseau. Nela já se manifesta, desde tenra idade, o instinto sexual procurando satisfazer as suas exigencias.

$[\ldots]$

O instinto sexual, que se manifesta na criancinha de berço, cada vez mais se define, à medida que o organismo se desenvolve. Quando o jovem atinge um certo crescimento físico, notamos um fato curioso: se deu expansão ao sexo, sofre as conseqüências de uma grande diminuição da sua capacidade intelectual, de atividade no trabalho e, sobretudo, de empobrecimento moral, pelo esgotamento das suas energias. Se agiu em sentido contrário, lucra em desenvolvimento intelectual, em capacidade para o trabalho e enriquece-se moralmente. ${ }^{306}$

O trecho acima faz parte de um artigo publicado na Revista do Ensino, cujo título Traçando um destino demarca a importância dada à questão sexual. A necessidade de conter os impulsos e a curiosidade revela que ambos eram percebidos nos alunos dos Grupos Escolares e que era preciso preparar as professoras para lidar com tais demandas. Numa das reuniões no Grupo Escolar Tomaz Brandão, a diretora pedia maior atenção durante o recreio porque estavam surgindo cartinhas e bilhetes amorosos entre os alunos. Outro artigo da Revista do Ensino trazia um folheto com sete capítulos no qual a mãe ensinava ao filho a reprodução de espécies vegetais e animais, incluindo a humana, de uma forma muito delicada, obviamente, sem tratar da relação sexual. A idéia subjacente era que tais explicações poderiam tamponar a curiosidade e direcionála para outros interesses. Além disso, o adulto priorizaria alguns aspectos ocultando outros. Daí a importância de que este conhecimento fosse passado por uma pessoa devidamente preparada ${ }^{307}$.

Só a educação sexual bem orientada será capaz de evitar êsse excesso de curiosidade que nasce na criança desde os mais tenros anos, pelo próprio instinto, pelo que êle vê no

somente os leigos. Dois religiosos que atuaram em Minas Gerais produziram textos sobre o assunto: o Padre Leonel Franca e Álvaro Negromonte. Este último chegou a publicar um livro, em 1939, intitulado A educação sexual. Franca repudiava a educação coletiva, bem como o ensino da educação sexual nas escolas, Negromonte considerava o confessor a maior autoridade sobre o assunto, em condição de superioridade sobre o médico e o professor. Leigos e católicos concordavam em muitos aspectos. Alguns deles eram o repúdio à masturbação, quase sempre discutida como própria apenas do sexo masculino, bem como a orientação distinta para cada sexo e sempre oferecida por familiares e professores do mesmo sexo da criança a quem cabia orientar. Parecia muito claro que a orientação para meninos e meninas deveria ser distinta, por isso a separação.

${ }^{306}$ FONSECA, Viriato. Traçando um destino. Revista do Ensino, BH, ano XII, n. 149-151, p. 185-189 abr.jun.1938, p.188.

${ }^{307}$ Não se encontraram referências a práticas de masturbação nas fontes consultadas. Essa passou a ser, como indica Foucault (2001), especialmente a partir do século XVIII, um indício de anormalidade. Podese supor, portanto, que as crianças que apresentassem tais práticas eram enviadas para as classes especiais. 
mundo dos seres vivos que palpitam ao seu redor; e mais do que tudo, pelas fitas de cinema onde, sem nenhuma escôlha prévia, as crianças são levadas e em cujos enredos na maioria das vezes o sensualismo impera em toda sua plenitude.

$[\ldots]$

A curiosidade só pode ser saciada pelo conhecimento exato dos fatos.

$[\ldots]$

O hábito da masturbação, freqüente nos meninos desde os mais verdes anos e que tantos inconvenientes traz através da vida àqueles que se entregam a êsse vício, pode bem ser evitado pela educação sexual, e severa vigilância.

Dando uma vida ativa cheia de ocupações variadas, e que cansem a criança tanto mental como fisicamente, trará a solução para o contrôle sôbre tendências para vícios. Esportes, jardinagens, jogos ao ar livre e finalmente brinquedos e estudos bem orientados dão resultados para ambos os sexos. ${ }^{308}$

O conhecimento não dispensava a vigilância sobre o comportamento das crianças. Além da vigilância, outro dispositivo de controle: o cansaço. Inúmeras atividades físicas, como os jogos e esportes fatigariam o corpo, e as atividades intelectuais desviariam o interesse para outros assuntos. E, assim como no quadro mostrado anteriormente, eram os meninos que demandavam maior atenção:

a) - Problema sexual propriamente dito - É menor na adolescente pela simples razão de que a sua fórmula é bem simples: "não fazer nem deixar que façam", ao passo que a do adolescente se apresenta: "fazer e deixar que façam".

Sempre é mais simples a atitude conservadora que a empreendedora. A virtude da adolescente é a "pureza", que simboliza a mera "resistência", a do varão, ao invés, tem de se a "firmeza", que simboliza uma boa capacidade ofensivo-defensiva. ${ }^{309}$

A citação acima foi retirada de uma conferência de Mira y Lopes em Belo Horizonte para professores em Curso de Férias tratando da Psicologia do adolescente. Dentre as diversas questões apresentadas, o "problema sexual", como é colocado, era muito mais iminente entre os alunos do sexo masculino. Separar os meninos das meninas, embora minimizasse, certamente não resolvia o problema. Talvez por isso, a professora de Norma Lúcia vigiasse exclusivamente o recreio dos meninos.

As poucas informações sobre a sexualidade encontradas nos documentos investigados não nos deve fazer supor que não houvesse interesse pela temática, nem que se considerasse as crianças isentas da questão. Havia, sim, preocupação com a sexualidade na escola, especialmente entre os alunos do sexo masculino. $\mathrm{O}$

\footnotetext{
${ }^{308}$ WEAVER, Eunice. A História maravilhosa da vida. Revista do Ensino, BH, ano XVI, n. 186, p. 56-72, jul.set. 1947, p.56-7.

${ }_{309}$ MIRA Y LOPES. A Psicologia do adolescente. Revista do Ensino, BH, ano XVI, n. 191[sic], p.14-33, jan.jun.1949, p.21.
} 
silenciamento do tema nas reuniões pedagógicas e nos conteúdos escolares se contrapunha a um discurso que se permitia aparecer nas revistas, nas palestras como uma discussão que se aproximava mais da cientificidade controladora e normalizadora das atividades infantis do que em ações concretas dos escolares. O não-dizer, o como e quando dizer, quem pode e quem não pode tratar desses assuntos devem ser tão ou mais importantes para o pesquisador que a sexualidade em si mesma. Tendo visto como os discursos científicos, professoras e diretoras tratavam o tema, resta saber como os alunos percebiam as relações com seus colegas, meninos e meninas, e em que medida as questões disciplinares e sexuais estiveram presentes nos Grupos Escolares de Belo Horizonte, pela ótica dos ex-alunos e ex-alunas.

\subsection{COLEGAS DE GRUPO ESCOLAR OU OS ALUNOS SOBRE ELES MESMOS}

As lembranças dos colegas do Grupo Escolar são recheadas de saudosimo e, para os ex-alunos e as ex-alunas entrevistados(as), não havia qualquer conotação de natureza sexual nas suas relações. Geraldo Félix conta que era comum os meninos perguntarem às colegas se poderiam conversar com elas e sempre recebiam uma resposta negativa. Certo dia, então, ele resolveu se arriscar na saída do Grupo. Perguntou a uma menina se poderia conversar com ela. Diante da resposta afirmativa, ele saiu cabisbaixo sem saber o que dizer.

Os(as) entrevistados(as) comentaram que foram crianças muito inocentes em relação à sexualidade. E apenas Norma Lúcia e Fernal Bicalho se lembraram dos namorinhos da escola:

F.B.: Eu tinha uma namoradinha, mas era assim, um flertizinho, não sei se naquela época de sete a dez anos se a gente chegava a ter um contato físico, pegar na mão, abraçar, alisar o cabelo, não tenho assim muita lembrança não. Mas que a gente tinha namorada tinha. Tanto é que eu tinha uma namorada que era loura, da minha classe e depois eu comecei a me interessar por uma outra que era morena e um dos meus colegas virou e falou assim: "Oh, Zé Bicalho, você acha que você pode namorar com a Sali? Nunca. Ela é namorada do Maurício Matos e ele é coroinha e já deu comunhão pra ela; você nunca vai roubar ela dele!". [risos] Era coisa de menino ingênuo: "Você nunca vai ser namorado dela". 
Para o ex-aluno, no entanto, a coisa era tão sem importância que não despertava preocupações ou intervenções por parte das professoras. Apesar disso, Geraldo Félix lembrava-se de uma situação constrangedora vivida no Grupo:

Tem uma coisa estranha que aconteceu! Eu gostava de desenhar, até hoje eu não sei o que aconteceu. Eu desenhei, na minha opinião, eu estava desenhando um sujeito subindo numa árvore. A professora viu e vermelhou: moleque sem vergonha eu vou te levar na diretora, eu não sei o que elas enxergaram no desenho. Na minha cabeça eu tava desenhando um cara subindo numa árvore, ela viu uma imoralidade que eu nunca vi na minha vida, correu na minha cabeça.

$\mathrm{R}$ : E o senhor foi pra diretoria?

G.F.: Fui pra diretoria. Seríssimo, o negócio foi feio, e eu não sei. Até hoje eu não sei o que interpretaram do meu desenho. Coisa que tem que ter muito cuidado para não fazer isso, o cara pensando uma coisa e o outro pensando outra, coisa totalmente diferente. Eu não sei, eu estou desenhando um homem subindo numa árvore. Moleque! É indecente! Emília $^{310}$ : Mas o homem estava vestido? Vai ver que estava pelado?

G.F.: Que pelado o quê. Essa eu não sei até hoje. Fiquei de castigo lá na diretoria.

Esta lembrança mostra que, apesar de eles(as) se considerarem crianças muito ingênuas, não parecia ser esta a impressão das professoras. A situação de Geraldo Félix talvez fosse mais complicada devido às suas repetências, o que o tornava um aluno mais velho no Grupo Escolar. Entretanto, ele não afirma quando foi feito o desenho. De qualquer forma, era muito comum que as professoras se preocupassem com os alunos que despertavam para a sexualidade antes dos seus colegas de Grupo. Os documentos consultados mostravam um cuidado todo especial com os alunos dos Grupos noturnos pelo mesmo motivo.

Os pátios dos Grupos Escolares eram cenários para amizades e também para pequenos desentendimentos, cuja resolução ficava marcada para o espaço externo à escola, território neutro em que as professoras não atuavam. De acordo com Geraldo Félix, durante os momentos de recreio, os alunos provocavam brigas entre si que eram resolvidas após o término das aulas:

Os "atiçadores" de briga. O cara queria fazer os dois brigarem, fazia um risco no chão. Aqui está sua mãe e aqui está a mãe dele. Quero ver quem tem peito de pisar na mãe do outro! Nossa Senhora! O cara pisava... Nossa. Quando ele pisava, o outro voava nele.

\footnotetext{
${ }^{310}$ Emília é assessora do vereador e entrara na sala participando, naquele momento, da entrevista.
} 
Atiçador só gostava de atiçar briga, saía todo satisfeito. Sabia que os dois eram bravos, que eles não iam agüentar. Pau sujo. Sujava pau de cocô, fingia que tava discutindo com outro, mas com o pau. Não pode brigar porque você está com o pau. Não senhor, então segura aqui pra mim. Segura aqui pra mim que eu vou brigar na mão. $\mathrm{O}$ cara pegava e ficava sujo. Fazia e corria, né?

Provocar os colegas parecia ser um comportamento típico dos alunos e alunas. Geraldo Félix conta que chamava um colega de Grupo de Zé do Facão. Ele não suportava o apelido, reclamava com a diretora, ia com o pai à casa de Geraldo reclamar para sua família, mas nem todas as surras tomadas em casa e as repreensões na escola lhe impediram de continuar apelidando o colega.

Luciano Mendes Faria Filho (2001, p.77 e seguintes) comenta que uma professora do Instituto João Pinheiro pedia reiteradamente ao diretor, a prisão ${ }^{311}$, por quatro dias, de um dos alunos que havia cometido uma indisciplina. A seu ver, a não punição ao comportamento do menino faria com que ela perdesse a força necessária ao exercício de sua tarefa. Segundo Faria Filho, a professora, percebendo que um aluno havia mentido, o chamou de Judas e ordenou a todos os seus colegas que repetissem o apelido dado por ela. No entanto, um deles se recusara a chamar o colega pelo apelido dado pela professora, Judas. Era para este menino que a professora pedia punição. Pelos diversos depoimentos coletados pelo autor, pode-se notar que os alunos não queriam repetir o apelido, mas a professora ameaçou de punição aqueles que não a obedecessem. Uma testemunha afirmava que o aluno recusou peremptoriamente repetir o apelido porque a mesma professora já o havia chamado, outra vez, de "negro indecente". A conclusão do caso se deu com a prisão do aluno, conforme o pedido da professora, e outra testemunha acrescentou que o menino preso teve que escrever mil vezes a frase: "Devo obedecer a ordem da minha professora".

A situação relatada por Faria Filho mostra que os apelidos dados aos alunos poderiam funcionar como uma forma de punição. Buscou-se, nesta pesquisa, verificar se esta punição também seria encontrada nos Grupos Escolares da capital. Entretanto, esta

\footnotetext{
${ }^{311}$ Ficar preso no Instituto era uma prática punitiva para casos de indisciplina.
} 
não parece ter sido uma prática recorrente. Nenhuma das professoras comentou fatos parecidos e mesmo os(as) entrevistados(as), quando perguntados, não se lembraram de professoras que apelidavam os alunos, embora alguns comentassem que esta era uma prática comum entre os alunos:

F.B.: Apelido a gente punha muito. Ficava rindo, púnhamos apelidos, o outro ficava com raiva e quanto mais o menino rejeita o apelido, pegava mais ainda. Eu lembro que tinha um menino que não tinha os dois incisivos, ele perdeu, e nós chamávamos ele de 1001. Não sei se eles ainda chamam de 1001.

Aracy Abreu conta que, apesar da amizade entre as colegas, elas também apelidavam umas às outras. Segundo ela, por ter o cabelo bem curto, uma de suas amigas a chamava de "galinha sureca" e que isso podia provocar brigas no recreio, mas nada que fosse para além daquele espaço.

Benedita Dell'Isola comenta que, em sua escola em Uberabinha, um aluno chamou o outro de cabrito. Ela imediatamente interferiu dizendo não ser adequado chamar o colega de animal, acrescentando que "não devemos por apelido em ninguém, porque, às vezes, nos causa aborrecimento". Pouco depois, ela soube que cabrito era uma forma comum utilizada pelos moradores daquela região para denominar as pessoas morenas.

Mas apresentar os defeitos dos colegas não parecia ser de todo um problema para os alunos, tudo dependia da circunstância dessa apresentação. Um poema de uma aluna do quarto ano de um Grupo Escolar de Pedro Leopoldo, reparando em todos os detalhes do comportamento de seus colegas, mereceu ser apresentado no auditório do Grupo, transcrito no relatório entregue ao Corpo Técnico de Assistência ao Ensino e, finalmente, publicado na Revista do Ensino. 


\section{Os meus colegas ${ }^{312}$}

Raymunda Rodrigues de Jesus

A colega Conceição

Tem vontade de aprender

Mas quando chega a escola

Ela não presta atenção.

Ubiratan na escola

Fica só conversando

Na hora de dar lição

Hilda Dias, prá estudar

Ele fica gaguejando.

Tem má vontade e moleza;

Mas quando vamos jogar

Ela é cheia de esperteza.

Maria José e Cacilda

Tomam tempo em distração;

Quando chegar o novembro

Vai haver reclamação

O Lourival na escola

Fica na vadiação

Pois vai brincar com os outros,

Esquecendo da lição

Maria Alice é uma rosa

E também estudiosa

Mas quando vira para traz,

Não para nunca com a prosa

O Eraclydes e o Moacyr

Eles ficam só pintando

E quando chegam á sala

É só correndo e brincando
O Nadino e José Bahia

Não tem geito de estudar,

Pois nas horas de atenção

Ficam sempre a conversar

A Emilia e Maria de Jesus

São meninas conversadas;

Quando chegar o exame,

Ganharão bombas pesadas

Alayde Diniz Vianna

Leva o tempo a escrever

Qdo a professora vai dar notas

Ela quer notas bôas obter

Com o $4^{\circ}$ ano da tarde

Nós gostamos de jogar,

A Ignacia de boca aberta

Deixa a bola só passar

A Iracema é boazinha,

Mas tem fala exquisita

Quando eu a ouço na sala

Agora é Olga Mansur

Fico às vezes muito aflita

Aluna muito aplicada

Mas que á hora da lição

Parece um pouco atrazada

Agora meus coleguinhas

Queiram sim? Me desculpar

Sei que a bondade de todos

Vai aqui me perdoar

Pode se suspeitar que não foi a aluna a autora do poema, ou que talvez não o tivesse feito sozinha e sim com a ajuda de um adulto ou da própria professora. De qualquer forma, era uma menina que apresentava os seus colegas e algumas características não muito favoráveis a seu respeito. No entanto, as observações transformadas em poema mereciam ser lidas publicamente em auditório, chegando até mesmo às páginas da Revista do Ensino.

Embora se trate de um caso isolado, tal situação talvez possa indicar porque as meninas tinham um trânsito mais fácil pelo universo escolar. A capacidade de transformar as possíveis querelas entre os colegas em brincadeiras inocentes pode dar

${ }^{312}$ ATIVIDADES Escolares. Revista do Ensino, BH, ano VI [sic], n.71,72 e 73, p.57-82, jul.ago.set.1932. 
pistas acerca das representações de que as meninas eram mais bondosas e menos agressivas do que seus colegas do sexo masculino.

\subsection{REPRESENTAÇÕES ACERCA DOS ALUNOS E ALUNAS DOS GRUPOS ESCOLARES}

\section{Canção do garoto $^{313}$}

Garoto peralta, garoto vadio

Garoto que salta

De cima da ponte p'ra dentro de rio...

Garoto moleque, nascido no morro,

Garoto de gorro,

Que atira predadas nas casas vizinhas...

Garoto malandro, de blusa de gola, Que apanha e que embirra (bis)

P'ra ir para a escola...

Garoto que brinca com bola de meia,

No meio da rua até se fartar...

Que cata mariscos nas praias de areia,

$\mathrm{Na}$ areia das praias, nas praias do mar...

Garoto que sonha com lindos brinquedos,

Brinquedos de louça, quebrando nos dedos,

Tão frageis que são...

Que solta balão, que arma fogueira,

Que tem batalhão, com porta-bandeira...

Garoto peralta, garoto vadio,

Garoto que salta

De cima da ponte p'ra dentro de rio...

Garoto medroso, garoto teimoso,

Que fala tolice, tolice a valer...

Cuidado, garoto, não queira ser grande,

Garoto, cuidado, não queira crescer.

Na canção acima, a representação de uma criança, do sexo masculino, travesso, peralta e teimoso não é de indisciplina, mas, pelo contrário, de uma liberdade, inventividade e atuação sobre o mundo percebidos como positivos: "não queira crescer”. Uma das contribuições da Psicologia e da introdução do escolanovismo para o entendimento da infância é a concepção de que a criança precisa de atividade, de experimentar o mundo, agir sobre ele para conhecê-lo, como comenta Alaíde Lisboa:

313 THEVENARD, Salvador (Letra); LAMBERT, Levindo (Música). Canção do Garoto. Revista do Ensino, BH, ano VIII, no. 105, p. 51-52, ago.1934. 
A obediência era básica na Escola tradicional. Quer dizer, o pai falou, a mãe falou, a professora falou, o professor falou acabou. Seguir as ordens então era uma obrigação: leia a página tal, estude de tal ponto a tal ponto. Tudo assim mais ou menos discriminado, tinha que ser feito. $\mathrm{E}$ aqueles que não faziam, quer dizer, eram considerados desobedientes. [ri] E hoje a desobediência quase que é bonito, né? Já mostra uma reação espontânea. Há um tipo de desobediência hoje que é quase apreciado, né? Sobretudo, uma coisa também que era um pouco condenada: a curiosidade excessiva. Fazer perguntas não era ideal. E hoje quanto mais a criança perguntar, mais entendimento ela terá. ${ }^{314}$

A professora comenta que a obediência era muito cobrada também em casa. A

educação na escola e na família dava pouca liberdade à criança:

Eu me lembro, por exemplo, quando eu era pequena, não sei que idade eu teria, mas eu lembro da minha mãe conversando com uma amiga e ela disse: Interessante! A Alaíde era tão educadinha, agora deu pra fazer pergunta. Você vê: Fazer pergunta não era boa educação, né? Então eu ouvi, ela nem sabe se eu sabia, nem nada. E passei a perguntar menos. E comecei a perguntar para mim mesma. Eu mesma respondia mais ou menos, né?

Embora Alaíde afirme que a curiosidade passou a ser aceita como uma forma de aquisição de conhecimento, uma composição de um aluno, publicada no jornalzinho $O$ Escolar do Grupo Escolar Flávio dos Santos, mostrava que, ainda na década de cinqüenta, a curiosidade de uma criança podia ser avaliada como muito desastrosa. $\mathrm{Na}$ redação, "A menina curiosa" ouviu o som de um tambor e debruçou-se na janela de seu quarto para ver de onde vinha o barulho. Nesse instante, ela caiu da janela e quebrou a perna direita, ficando com um problema de locomoção irreversível, tendo que arrastar a perna ao andar ${ }^{315}$. Moral da história: a curiosidade desta criança lhe causou danos físicos para toda a vida. Pode-se observar que, embora a redação tenha sido produzida por um menino, ela abordava o quanto a curiosidade de uma menina poderia ser perigosa.

Apesar dessa história trágica que evidenciava o perigo da curiosidade entre as crianças, especialmente as meninas, é possível notar que, como afirma Alaíde, a infância passava a ser caracterizada como um período natural de peraltices. Elza Moura conta, por exemplo, que uma das travessuras dos alunos era furtar frutas do pomar da

\footnotetext{
${ }^{314}$ Entrevista concedida ao Centro de Referência do Professor.

${ }^{315}$ Segundo Piaget (1932/1984), é comum a criança passar por um período no desenvolvimento moral em que a justiça é vista como imanente, ou seja, quando se comete uma falta, algo acontecerá para que a justiça seja feita, mesmo que este acontecimento não tenha nenhuma relação com a falta. Neste caso, a perna quebrada serviria como uma "lição" para que a menina nunca mais fosse curiosa.
} 
escola, mesmo com os quintais cheios de árvores frutíferas e mesmo que, as professoras distribuíssem as frutas na saída das aulas.

Apesar dos escolanovistas advogarem a idéia de que a criança necessita de atividade, liberdade de expressão e atuação, para um desenvolvimento sadio, era muito comum que os Grupos Escolares limitassem essa expansão infantil. Exemplo disso é uma atividade realizada pela professora Maria da Glória. Ela organizara, junto com os alunos do Grupo Escolar, uma Feira de Amostras com os produtos de Itabirito e da região. Embora ela enfatizasse a participação dos alunos, o uso desta atividade para organização de excursões, elaboração de cartas, entre outras tarefas, no dia da abertura da exposição foram convidadas autoridades locais e da Secretaria de Educação, as famílias e os colaboradores na organização da Feira e as crianças foram levadas para brincarem no pátio, para que "não servissem de obstáculo ao trânsito dos convidados". É curioso que, após tanta participação e envolvimento na organização da Feira, os alunos fossem considerados obstáculos e não verdadeiros colaboradores na execução do projeto.

Uma outra professora, ao preparar um auditório com a visita de pessoas da comunidade ao Grupo Escolar da cidade de Alfenas, teve o cuidado de planejar antes com os alunos os mínimos detalhes do comportamento destes ao receberem os convidados:

Estando tudo prompto, motivou-se uma aula de socialização para habituar aos alumnos ao correcto comportamento durante a sessão. Foi lhes ensinado como proceder dignamente naquelle auditorio.

- $\quad$ A commissão de recepção ficará á entrada. Chegando um convidado, recebel-oá com delicadeza e respeito, levál-o-á até á sala da festa designar-lhe-á um lugar para se assentar. Em seguida pedirá licença e sahirá indo ficar a mesma commissão novamente a postos.

Emquanto isso, os outros alumnos permanecerão em classe, assentados, em silencio, ou proseando pouco e em voz abafada.

Ao entrar um convidado, todos se levantarão. (Dispenso as palmas na chegada dos convidados). Ninguém rirá, nem criticará; pois a critica é prova de pouca educação e além disso é um peccado. Emquanto o convidado permanecer de pé, todos estarão igualmente em pé, e só se assentarão depois que o recém-chegado se assentar.

Durante a festa ninguem proseará, e muito menos fará reflexões sobre o collega que desempenha o seu papel. Si um collega errar quando estiver recitando, ninguém rirá, pelo contrario, compadecer-se-á do collega que cahiu em falta pensando que o mesmo poderia acontecer a qualquer um.

As palmas serão curtas e leves; não se baterá palmas muito fortes ou prolongadas. 
Só assim todos os convidados ficarão contentes ao notarem que vocês são meninos dignos, bons e bem educados. ${ }^{316}$

Neste caso, portanto, a agitação e a espontaneidade infantis eram tidas como empecilho para o andamento de algumas atividades escolares. Numa redação de uma aluna do Grupo Escolar Bernardo Monteiro fica explícito que a exigência de silêncio e obediência ainda imperava nos espaços escolares:

Como devemos proceder

$\mathrm{Na}$ aula devemos proceder muito bem. Obedecer à diretora, às professoras, às serventes e ao sr. Versol. Quando formos beber água, devemos ir em ordem, não conversar na cantina, na privada, em sala ou biblioteca. Não devemos brincar com estupidez no recreio e nem brigar. Na escola não podemos falar nomes feios e também na rua e em qualquer parte. Não andar nos estribos dos bondes para não acontecer desastres. Obedecer nossas mestras como se fossem nossos pais. Dedicar-lhes todo o carinho e amizade. Sermos caprichosos e cumpridores de nossos deveres de aluno.

Judite Vaz, $3^{\circ}$ ano de d. Marieta Salomão ${ }^{317}$.

Uma das explicações para tamanha contenção da atividade dos alunos pode ser que as representações sobre a infância nem sempre eram tão belas e puras quanto se pode imaginar e esta hipótese é confirmada pelas fontes. Um artigo da Revista do Ensino, por exemplo, ressaltava que, não apenas as travessuras, mas também a agressividade e mesmo a maldade seriam naturais na infância.

Toda criança é um Átila em embrião. Seu gôzo é destruir.

E dessa tendência misteriosamente cataclítica pode advir um homem realmente pernicioso à sociedade se lhe não fôr tirado das mãos, desde cedo, o alfabeto perigoso onde êle aprende as primeiras noções de crueldade impune e de tirania sem remorsos.

Esse alfabeto aziago é o exercício da perseguição inconsciente e tonta aos pequenos seres indefesos e humildes - os pássaros, os insetos, os gatos, os cães e até mesmo outras crianças menores e mais fracas.

$[\ldots]$

É que a tendência natural da criança é para torturar os indivíduos mais fracos, perseguilos, extermina-los. ${ }^{318}$

Outro artigo, na mesma revista acrescentava:

Já nos primeiros meses de idade, a criança pode mostrar-se caprichosa. Muitas vêzes, chora sem motivo plausível, apenas para arrancar mimos da fraqueza maternal. Satisfazer tais caprichos é iniciar a deformação do caráter, o estrago de uma personalidade.

\footnotetext{
${ }^{316}$ OLIVEIRA, Maria do Rosário. Auditório (Realizado no $3^{\circ}$ anno mixto C. do Grupo Escolar "Minas Geraes" da cidade de Alfenas). Revista do Ensino, BH, ano IX, n. 114-115, p.169-172, maio jun.1935. p.172.

${ }^{317}$ VAZ, Judite. Como devemos proceder. Voz da criança. Ano II, n. 9, p. 2, jul.1951.

${ }^{318}$ DUTRA, Aimoré. As crianças e os animais. Revista do Ensino, BH, ano XIV, n.181 p. 5-7, jul.1946. p. 6-7.
} 
Quando maior, a criança manifesta defeitos como: gulodice, cólera, desobediência, vaidade, etc. Uma correção ligeira poderá conter essas desordens, por exemplo: recusa formal da guloseima solicitada, privação, privação de um brinquedo ou de um carinho... ${ }^{319}$

A idéia de que a criança pode apresentar uma tendência a ser mimada, paparicada em excesso tornando-se um pequeno tirano que exige a satisfação de todas as suas vontades convive com as imagens positivas acerca da infância. Talvez por isso o discurso da liberdade a ser concedida às crianças não se desvencilhasse da necessidade de que esta estivesse, ao mesmo tempo, sob constante vigilância, como preconizava Rousseau $^{320}$.

As representações sobre os alunos e alunas de Grupos Escolares mineiros, de uma forma geral, não eram muito boas. O Laboratório de Psicologia fazia pesquisas comparativas acerca do desenvolvimento das crianças em Minas Gerais e no exterior, obtendo sempre resultados inferiores. O teste de Goodenough ${ }^{321}$, por exemplo, foi aplicado em 1930 nas crianças mineiras. Os resultados, comparados aos das crianças americanas, foi inferior ${ }^{322}$. Com relação à aplicação do teste de Dearborn, os resultados das crianças brasileiras também foram inferiores às de Genebra ${ }^{323}$.

Outros testes apresentavam resultados semelhantes. Nos anos de 1929, 1934, 1939 e 1944, o Laboratório de Psicologia da Escola de Aperfeiçoamento promoveu uma pesquisa sobre os ideais e interesses das crianças do $4^{\circ}$ ano primário e uma das conclusões obtidas foi a seguinte:

De um modo geral, podemos dizer, como em 1939, que o horizonte espiritual dos alunos do último ano da escola primária é ainda bastante estreito. Assuntos mais elevados, mais espirituais, mais humanos, a preocupação intelectual com certos problemas de caráter moral, não constituem a orientação dominante em sua mentalidade. Muito e muito terá que fazer ainda a escola para que, ao deixar os bancos escolares primários já possua a criança um desenvolvimento capaz de permitir-lhe alguma independência de espírito, certo discernimento próprio na orientação a seguir. ${ }^{324}$

\footnotetext{
319 CASTRO, Maria Angélica de. Castigar para corrigir. Revista do Ensino, BH, n. 178, p. 189-196. abr.1946. p.192.

${ }^{320}$ Em sua obra, Emílio ou Da educação, de 1762, Rousseau defende a liberdade infantil, mas sempre orientada e conduzida pelo adulto.

321 Mais informações sobre estes testes encontram-se no último capítulo desta tese.

322 ANTIPOFF, Helena. O desenvolvimento mental das crianças de Belo Horizonte. Revista do Ensino, BH, ano XI, n. 134-136, p.127-203, jan.mar.1937.

323 ANTIPOFF, Helena. O desenvolvimento mental das crianças de Belo Horizonte. Revista do Ensino. BH, ano XI, n. 134-136. p.127-203, jan.mar.1937.

${ }^{324}$ LUSTOSA, Irene; CUNHA, Maria Augusta; MORAIS, Márcia. Os ideais e interesses das crianças de Belo Horizonte durante o período de 1929 a 1944. Revista do Ensino, BH, ano XIX, n. 198, p.150-195, abr.jun/1951, p.194.
} 
Diante de representações tão antagônicas sobre a infância tornava-se imperioso identificar, caso a caso, as características de cada criança com o objetivo de lhe oferecer um tratamento individualizado conforme suas necessidades. Conhecer para controlar. Um dos principais dispositivos disciplinares. A Psicologia, a Biologia, a Sociologia são ciências que, a partir desse momento, passavam a auxiliar o professor a lidar com as diferenças de maneira útil, proveitosa, canalizando as tendências pessoais sempre em direção a um melhor ordenamento social. Em 1932, a Revista do Ensino informava que estava em projeto a formação de um arquivo pedológico escolar no qual ficariam registrados, numa ficha-envelope-individual, todas as informações pessoais do aluno durante a escola primária. Tais registros se constituem num dos dispositivos disciplinares comentados por Foucault:

O exame faz também a individualidade entrar num campo documentário: Seu resultado é um arquivo inteiro com detalhes e minúcias que se constitui ao nível dos corpos e dos dias. O exame que coloca os indivíduos num campo de vigilância situa-os igualmente numa rede de anotações escritas; compromete-os em toda uma quantidade de documentos que os captam e os fixam. Os procedimentos de exame são acompanhados imediatamente de um sistema de registro intenso e de acumulação documentária. $(1975 / 1987$, p. 168)

Prevenir para não ter que remediar. Esta máxima, que pode ser perfeitamente relacionada às técnicas empreendidas para se conhecer, de antemão, o adulto que está sendo produzido na infância, revela que formar e moldar remetem a uma concepção de ortopedia física e mental no sentido de endireitar corpos e, por extensão, o caráter:

Observar, medir, classificar, prevenir, corrigir. Em todas essas operações, a remissão à norma é uma constante. A pedagogia científica, as práticas que a constituíam e as que derivavam dela, caracterizavam-se, assim, por essa remissão constante a cânones de normalidade produzidos, pelo avesso, pela leitura de sinais de anormalidade ou degenerescência que a ciência contemporânea colecionava em seu afã de justificar as desigualdades sociais e de explicar o progresso e o atraso dos povos pela existência de determinações inscritas na natureza dos homens. E é por referência a essa norma que a pedagogia se fazia, nas práticas aqui analisadas, ortopedia - arte da prevenção ou da correção da deformação. (Carvalho, 2001, p.300)

Reunir todos os dados relativos aos alunos fazia parte de um mencanismo de controle que buscava assegurar a racionalidade e cientificidade das observações realizadas. Afinal, a classificação seria feita não a partir das impressões pessoais, subjetivas e sujeitas a incorreções, mas com base em dados objetivos e verificáveis que 
criavam a necessária aparência de objetividade. Mas, afinal, quem eram esses alunos indisciplinados? O que faziam para merecer esta denominação?

O parágrafo $4^{\circ}$ do artigo 435 do Regulamento do Ensino Primário de 1927 determinava que era dever dos diretores de Grupos Escolares e Escolas Reunidas organizar um Boletim Diário com as ocorrências, mencionando número de alunos, os faltosos, as faltas dos professores, os casos de indisciplina e outros aspectos importantes da rotina diária. Este documento foi exaustivamente procurado porque era precisamente nele que deveriam estar registrados os casos de indisciplina e os encaminhamentos dados. Ou porque foram destruídos, ou porque nunca chegaram a existir, ou ainda porque não foram disponibilizados para a pesquisa, o fato é que um único exemplar pertencente ao Grupo Escolar Afrânio de Melo Franco foi encontrado. Neste Boletim ficavam registrados os nomes de diversos alunos que foram para o gabinete da diretora levados pelas professoras. Somente em alguns casos está registrada a indisciplina cometida pelo aluno - todos os nomes são do sexo masculino. Nos casos registrados, aparecem os seguintes motivos: insubordinação, escrever palavras obscenas em um livro, fazer atos obscenos na sala de aula, falar palavrões aos transeuntes, soltar bombas no encanamento do Grupo - há três registros desse tipo. Nestes casos, ou o aluno ficava na sala da diretora por algum tempo ou era enviado para casa junto com o guarda.

Uma das páginas do livro de ponto dos professores no Grupo Afrânio de Melo Franco estava destinada ao assentamento do nome dos alunos insubordinados que não deveriam ser matriculados no ano de 1942. Há nomes de sete alunos e uma aluna e os motivos para não serem matriculados são: serem atrevidos, insubordinados, indisciplinados, não suportarem repreensões, faltarem muito às aulas, quererem se matricular em classes adiantadas, serem malcriados. Um dos avisos registrava que não somente o aluno não deveria ser matriculado como ninguém de sua família: "Raimundo Vianini e todos e qualquer Vianini que houver sido matriculados em qualquer epoca, porque são insubordinados e infrequentes e muito mal educados."

Como o movimento escolanovista defendia a idéia de que as atividades deveriam ser elaboradas para despertar o interesse das crianças ditas normais, a indisciplina, o desinteresse ou a falta de atenção, eram explicados por duas únicas causas: uma escola e/ou professor ainda não sintonizado com as novas propostas educacionais ou a 
anormalidade da criança. Para a primeira dessas causas, a exposição de motivos do Regulamento do Ensino Primário em 1927 adiantava:

E certo que grande numero de alumnos que passam como retardados devem o seu atrazo, em boa parte, na a uma constituição psychica defeituosa, mas a methodos de ensino irracionaes e a processos de instrucção que não solicitam os seus interesses, nem appelam para as tendências instictivas da infância, collaboradores indispensaveis na obra da educação primaria. ${ }^{325}$

Para o segundo caso, diversos artigos da Revista do Ensino tratavam da temática, auxiliando os professores a detectarem, entre seus alunos, os "anormais". Às vezes, os artigos destinavam-se aos pais das crianças e a preocupação consistia sempre em contemplar o máximo possível de casos que levassem a uma suspeita de anormalidade:

Quais os fatos que podem motivar a suposição de que há um desequilibrio nervoso na criança?

Vou enumerar os principais, os mais espetaculosos, e estou persuadido de que o seu simples conhecimento esclarecerá os pais, tornando-os aptos a não permitir que escapem os mais esquecidos.

Deve-se dividi-los em duas categorias: uma, refere-se às manifestações do caráter, á maneira de portar-se a criança nas suas relações com o meio; a outra refere-se aos vicios de conformação do corpo ou ás anomalias fisicas.

Na primeira estão incluidas as crianças:

- $\quad$ que são insaciáveis;

- $\quad$ as que choram sem motivo;

- $\quad$ as que têm o sono agitado;

- $\quad$ as que têm insonia;

- $\quad$ as que são desobedientes;

- $\quad$ as que são timidas;

- $\quad$ as que são preguiçosas;

- $\quad$ as que urinam involuntariamente de noite ou de dia (enurese);

- $\quad$ as que são muito sensíveis (emotivas);

- $\quad$ as que são más;

- $\quad$ as que são viciosas (amoralidade);

- $\quad$ as que são indiferentes aos brincos próprios da idade;

- $\quad$ as que são rixentas;

- $\quad$ as que têm crises de sufocação ou perdem o choro, (espasmofilia);

- $\quad$ as que são arrebatadas (impulsivas);

- $\quad$ as que são mentirosas;

- $\quad$ as que não acompanham a classe a que pertencem na escola;

$[\ldots]$

Tais manifestações não se apresentam em estado de natureza sózinha, associando-se habitualmente duas, três e mais.

[...]

${ }^{325}$ Exposição de motivos. Regulamento de instrução primária, 1927, p. 1137. 
$\mathrm{Na}$ segunda categoria que se refere aos vicios e anomalias físicas, estão incluidas crianças:

- $\quad$ que são vesgas;

- $\quad$ as que são peludas;

- $\quad$ as que tem os cabêlos irregularmente implantados;

- $\quad$ as que têm a cabeça deforme;

- $\quad$ as que têm um lado do rosto diferente do outro (assimetria facial);

- $\quad$ as que têm papo (tiroideas);

as que têm os órgãos genitais com qualquer anormalidade (no menino os testículos não desceram ás bolsas; o penis é muito pequeno ou muito grande ou não sai urina pelo ureto)

- $\quad$ as que têm o peito de pombo;

- $\quad$ as que são obesas;

- $\quad$ as que têm o nariz arrebitado;

- $\quad$ as que respiram fungando (adenoides)

- $\quad$ as que crescem exageradamente;

- $\quad$ as que param de crescer,;

O que impressiona no artigo é a variedade e a amplitude de características, o que certamente inclui a imensa maioria das crianças, se não todas. Outro artigo tentava alertar os professores sobre quais comportamentos apresentados pelos alunos poderiam indicar uma anormalidade:

Os senhores têm na sua classe um alumno que frequenta a escola há quatro annos com regularidade; mostra-se, pelo menos apparentemente, com attenção durante as aulas e, apezar disso, ainda não passou da $2^{\mathrm{a}}$ classe. $\mathrm{O}$ professor, interessado pelo seu alumno, chama-o repetidas vezes á lição, estimula-o nos estudos, e a creança mantem-se com fraco aproveitamento. Este conjuncto de factos deve levar o professor a suspeitar de anormalidade.

Um outro alumno mostra-se cuidadoso no desenho; faz nesta disciplina os progressos dos companheiros, ou mesmo excedel-os, mas não consegue apprender a ler, ou a escrever, ou a contar. Deve recahir egualmente sobre elle a suspeita de anormalidade. Aquelleoutro não consegue estar quieto, sossegado, na classe; ri para os companheiros, fala, levanta-se do logar, isto apezar das admoestações do professor; é caso para ser tido da mesma suspeição. ${ }^{327}$

Estas representações estavam vinculadas às teorias eugenistas em voga na época.

A crença de que a herança genética influenciava o caráter das novas gerações não impedia que o meio fosse considerado de fundamental importância para o afloramento ou o desvio de determinadas tendências, como comenta Peixoto:

${ }^{326}$ MARQUES, Hugo Vianna. Crianças nervosas (Conferência de divulgação científica na Colônia de Psicopatas de Engenho de Dentro) Revista do Ensino, BH, n. 92. p. 26-31,set. 1933. p. 28-29.

${ }^{327}$ FONTES, Victor. Ensino das creanças anormaes. Revista do Ensino, BH, ano X, n.125-126-127, p.95101, abr.maio jun. 1936, p. 97-98. 
No caso das [crianças] normais, a educação é vista como um processo de desenvolvimento dos dons, dos quais são naturalmente portadoras. Quando se trata de crianças excepcionais, o objetivo da educação já não é mais desenvolver, mas impedir o desenvolvimento de traços e comportamentos considerados indesejáveis. (2003, p.202)

A concepção de que o meio influencia na formação do caráter das crianças às vezes suplantava as teorias eugenistas, como indica Artur Ramos:

As crianças "caudas de classe" nas Escolas, insubordinadas, desobedientes, instáveis, mentirosas, fujonas ... na sua grande maioria não são portadoras de nenhuma "anomalia" moral, no sentido constitucional do têrmo. Elas foram "anormalizadas" pelo meio. Como o homem primitivo cuja "selvageria" foi uma criação dos civilizados também na criança, o conceito de "anormal", foi, antes de tudo, o ponto de vista adulto, a conseqüência de um enorme sadismo inconsciente de pais e educadores... ${ }^{328}$ (s.d, p. 18)

Embora Ramos opte pela expressão "criança-problema”, buscando retirar o atributo "anormal" conferido às crianças indisciplinadas, a questão da indisciplina era fortemente associada à questão médica e, por extensão, à idéia de anormalidade.

Uma vez tendo sido traçadas as características das crianças suspeitas de anormalidade, é preciso saber como as professoras apuravam tais suspeitas no cotidiano escolar. A primeira recomendação escolanovista era reunir tais crianças em classes especiais, partindo do princípio da homogeneidade, chamadas classes C ou D, dependendo da organização das turmas, conforme sugestão de Helena Antipoff:

As crianças que desde a entrada na escola apresentam nos tests quocientes intelectuais bem inferiores à media, como as crianças cujo estagio anterior revelou a insuficiencia mental ou o desequilibrio psíquico fazem doravante parte das classes especiais C e D.

As primeiras, chamadas classes fracas, recebem as crianças de desenvolvimento retardado, com um atrazo mental até cerca de tres anos, as crianças de espírito adormecido, ou turbulentas, mas sem defeitos notaveis no fisico como no moral. As classes D são criadas em beneficio das crianças cujo atrazo mental é consideravel, como as que oferecem particularidades fisicas ou psiquicas fora do comum e que reclamam condições escolares especiais. ${ }^{329}$

Embora se buscasse uma maior padronização, a distribuição dos alunos por classes nem sempre é muito clara. Em alguns momentos, por exemplo, eles são distribuídos em quatro classes: A, B, C e D. Em outros aparece também a classe E. Não

${ }^{328}$ RAMOS, Arthur. A criança problema. 4 ed. revista. Rio de Janeiro: Livraria-editora Casa do Estudante, [s.d.] 396p.

${ }^{329}$ ANTIPOFF, Helene. A Pedagogia nas classes especiais (C-D) (Introdução). Revista do Ensino, BH, ano VI, n. 56, 57, 58, p. 24-52, abr.maio. jun. 1931, p.24. 
somente o coeficiente intelectual era considerado para a organização de tais classes. Junto a este eram avaliados, ainda, a idade das crianças e o fato de serem novatos ou repetentes, como indica Antipoff:

Num total de cerca de 200 crianças novatas do $1^{\circ}$ ano de um grande grupo escolar, pode-se, assim, levando-se em conta a idade real e o desenvolvimento intelectual delas, formar as cinco classes seguintes: a) a de crianças mais moças: classe A, de crianças de Q.I. mais elevados; classe B, de Q.I. médios; classe C, de Q.I. inferior. B) crianças mais idosas e menos numerosas que as primeiras formarão a classe $\mathrm{AB}$, dos melhores Q.I., e classe BC, de Q.I. mais baixos.

As crianças repetentes serão agrupadas em classes, tendo em conta o grau de adiantamento escolar, de uma parte, e o desenvolvimento mental de outra. Nas três classes dos repetentes, haverá vantagem em grupar juntamente as crianças de melhor escolaridade e que poderão atingir o nível escolar do $2^{\circ}$ ano no fim do primeiro semestre - classe B (r); as crianças menos alfabetizadas formarão a classe C (r), em que serão reunidas as crianças pedagogicamente retardadas e de inteligência mais lenta; enfim, a classe D será formada pelo restante das crianças que apresentem um retardamento mental notável e anomalias sensório-motores, toleráveis na escola pública comum. ${ }^{330}$

Antipoff recomendava, ainda, uma separação entre as classes D e E, estas últimas formadas a partir da reunião de alunos de diversos Grupos Escolares, já que atenderiam a um grupo pequeno de alunos. Para a composição das classes, indicava:

Prevêem-se facilmente três grupos de classe D: 1) débeis mentais e com perturbações de visão e de audição; 2) débeis mentais com perturbações de motricidade e de palavra; 30 débeis mentais com perturbações nervosas diversas.

As classes E igualmente poderiam formar três unidades distintas: 1) para os indisciplinados de origem mesológica, sobretudo; 2) para os neuróticos; 3) as crianças com defeitos de ordem moral. ${ }^{331}$

Fica claro que as crianças que causavam tumulto, transtorno ou qualquer dificuldade no ambiente escolar seriam transferidas para tais turmas, e o trabalho com estas era considerado extremamente desgastante pelas professoras que as evitavam a todo custo. Maria da Glória, por exemplo, conta que, certa vez, ao tomar posse em um Grupo Escolar na cidade de Abre Campo, a diretora lhe designou para uma turma composta de "retalhos" das outras classes. Estas "sobras" tinham que ser "desbravadas" pela professora. No entanto, o inspetor, ao visitar a classe, afirmou que ela, sendo

\footnotetext{
${ }^{330}$ ANTIPOFF, Helena. Progressos escolares de cada tipo de classe e meios de controla-las. In: CENTRO DE Documentação e Pesquisa Helena Antipoff. Coletânea das obras escritas de Helena Antipoff. Belo Horizonte: Imprensa Oficial, 1992, vol. III. "Educação do excepcional". p.58.

${ }^{331}$ ANTIPOFF, Helena. Progressos escolares de cada tipo de classe e meios de controla-las. In: CENTRO DE Documentação e Pesquisa Helena Antipoff. Coletânea das obras escritas de Helena Antipoff. Belo Horizonte: Imprensa Oficial, 1992, vol. III. "Educação do excepcional". p.59.
} 
estagiária, não podia assumir uma classe, mas apenas auxiliar as outras professoras, e os alunos foram devolvidos às suas professoras de antes, para sua sorte, como ela comenta.

Benedita realizou um curso intensivo no Instituto Pestalozzi para atender alunos da classe An3, supostamente alunos com três anos de atraso cognitivo. Apesar da satisfação em realizar o curso e da boa aprovação, o trabalho com os alunos foi percebido como sendo muito difícil, especialmente pelo fato de estar acostumado às turmas An1, consideradas melhores:

Achei dificílimo lidar com aquêles, quase anormais, e não tive o menor entusiasmo para o trabalho; cheguei a me arrepender de ter feito o Curso. Por mais que esforçasse, não encontrava ressonância; as crianças eram impossíveis. Sabendo, pelos exemplos recebidos no Curso que acabara de fazer, que o educando teria mais prazer nos estudos ouvindo da professôra contos que lhe prendessem a atenção, eu, com imenso desejo de ajuda-los, dando-lhes um ambiente de amor, conforto e segurança, procurava o melhor modo possível de melhorar o seu raciocínio, contando-lhes fatos instrutivos e morais.

Contava histórias, dramatizava, falava de seus brinquedos, dos seus pais, seus amigos, mas nada os interessava. Continuava lutando desesperadamente, até que, enfim, consegui a promoção de seis alunos... Fiquei tão contente, tão contente que nem sei descrever. $(1970$, p.53)

O contentamento com a aprovação de um número tão diminuto de alunos pareceu à professora que esta teria sido uma conquista exclusivamente sua, que lutara bravamente para obter resultado de quem não esperava sucesso algum. Ficava evidente que, não podendo contar com o auxílio dos alunos, percebidos como incompetentes e incapazes, as professoras se sentiam, freqüentemente, sobrecarregadas e sem ânimo, como demonstra uma professora do $3^{\circ}$ ano do Grupo Escolar Tomaz Brandão, ao trabalhar com uma turma de alunos considerados mais difíceis:

Com o decorrer dos dias, no entanto, notei ter assumido a direção de uma classe pesada. $[\ldots]$

Era impossível dar uma aula. Si interessante ou não, êles não podiam saber, pois brigavam, mudavam de lugar e gritavam desde que entravam em aula até a hora em que saiam. Havia dias em que eu não ouvia o sinal da mudança de aula ou para terminar, tal era a balbúrdia. ${ }^{332}$

A professora dizia que, a princípio, culpava a implantação do ideário escolanovista nas escolas pela liberdade que a classe estava tendo, pois os seus propagadores, como Mário Casasanta, não tinham idéia de que haveria uma classe como

\footnotetext{
${ }^{332}$ CATHOUD, Odette. O que se tem feito no Grupo Escolar "Thomaz Brandão" (Relatório). Revista do Ensino, BH, ano VI [sic], n. 68, 69 e 79, p. 78-104, abr. maio jun. 1932.
} 
a dela. Ela passou então a buscar conhecer os alunos e tentar educá-los, valendo-se, ainda, da ajuda da diretora e da orientadora para conseguir a disciplina na classe. A professora descreveu um dos seus piores alunos: J.L.Per. "Era um menino retardado, sem proposito. Não ficava em sua carteira nem 5 minutos. Mexia com todos os alunos, batia, era um terror". A professora então diz que buscou observa-lo e conquistá-lo pelo carinho e ele se tornou um bom aluno: asseado, sendo o primeiro a fazer seus exercícios, trazendo todos os materiais escolares em dia. Já o segundo aluno, ela o descreve como: "retardado, sem nenhum adiantamento em nenhuma das disciplinas. Voluntarioso, malcriado, enfim um pessimo elemento para a classe". Como forma de resolver o problema, a professora e a diretora resolveram lhe dar uns dias de suspensão. Ele voltou um pouco melhor, ainda assim não melhorou a higiene corporal e, segundo ela, seu progresso era pouco animador, podendo ser promovido ao $4^{\circ}$ ano de alunos medíocres. Neste caso a professora parece querer demonstrar que, apesar de todo o seu empenho, alguns alunos eram mesmo pouco susceptíveis a esses esforços, reforçando a tese da incapacidade destes.

Num caso semelhante, uma professora da cidade de Conceição descreveu, em 1933, os trabalhos realizados numa classe D de alunos "retardados repetentes", alguns com diversas reprovações, tendo sido matriculados em 1926. A professora avaliou os alunos, concluindo que nada ou pouco sabiam: "Porém, digo com sinceridade, que cheguei ao desanimo: - nada lhes chamava a attenção; a frequencia era diminuta; não conseguia a menor disciplina; inquietos, não attendiam ás minhas observações". A solução encontrada foi apelar ao espírito de mãe, furtando a seus próprios filhos, para dedicar-se às crianças:

Conhecendo-os profundamente, applico os meus trabalhos na classe, com paciencia e carinho, para os que delles necessitam; com severidade para os que não comprehendem o dever, obrigando-os a isto. Após o castigo permittido, procuro convencel-os de que eu os estimo com a devida sinceridade, para que não conservem rancores e a vida escolar lhes seja sempre agradavel. E muito tenho conseguido na disciplina: de modo que a conversa e o barulho que em dado momento ainda existem na classe se deve a não terem esses meninos força bastante para reagir contra a natureza inquieta e barulhenta que as domina ${ }^{333}$.

333 CURSO para professores districtaes e ruraes. Revista do Ensino, BH, ano VIII, n. 105, p.1-24, ago.1934, p.16. 
Mais um relato de professora reiterando a imagem desalentadora dos alunos das classes especiais:

Em 1929, recebi uma classe de $1^{\circ}$ anno, que me causou pavor. Era uma classe masculina, que contava com quase 50 alumnos. Os elementos eram os mais hecterogeneos. Eram meninos differentes, sob todos os pontos de vista: em edade, tamanho, costumes, procedimento e escolaridade.

Havia crianças franzinas, de 7 annos, e meninos crescidos, robustos, já quasi rapazes. Alguns eram bem educados e de bôa indole, outros mal afamados na escola e na rua...

Havia os analphabetos - e repetentes do $1^{\circ}$ anno, duas, tres e cinco vezes!

$\mathrm{O}$ aspecto da classe era desolador: algumas creanças, filhas de pais abastados, apresentavam-se convenientemente vestidas. A maioria, porém, trazia o estigma da pobreza, da miseria, da falta de asseio e educação no lar. ${ }^{334}$

A professora afirmava que, apesar das inúmeras dificuldades, conseguiu realizar um bom trabalho. Os alunos da classe D eram considerados difíceis por diversos motivos, um deles era o meio social, já que as crianças eram quase todas vindas de famílias pobres. Os Grupos noturnos também eram percebidos como locais que demandavam maiores cuidados. Sendo seus alunos mais velhos, já trabalhadores, vindos de famílias com menos recursos financeiros reuniam condições vistas como desfavoráveis sendo alvo de preocupações. Segundo Maria da Glória, ao vir trabalhar no Grupo Escolar Noturno Diogo de Vasconcelos em Belo Horizonte no ano de 1934, recebeu a advertência:

... ela [a diretora] declarou que naquele meio escolar talvez eu nada pudesse fazer como técnica da escola nova. Os alunos eram na maioria adultos: operários, militares, guardas civis, caixeiros, etc., que não queriam saber de atividades nem de modernismos... Limitavam-se às lições de leitura, das quatro contas e da escrita mecânica. (Arreguy, 1958, p.113)

É interessante notar que, se para as crianças, o argumento de que as técnicas modernas de ensino despertavam a atenção, interesse e atividade, melhorando a freqüência e o aprendizado, no caso dos alunos do curso noturno esse argumento parecia não valer. Benedita, por exemplo, comenta que trabalhou numa escola noturna chamada Santa Catarina regida pelas freiras Dominicanas. Embora não se tratasse de uma escola estadual, a referência feita pela professora às alunas, todas empregadas domésticas, talvez se aplique aos alunos de cursos noturnos oferecidos pelo Estado. Para Dell'Isola,

${ }^{334}$ SANTIAGO, Alice de Andrade. Lições da experiência. Revista do Ensino, BH, ano VIII, n. 109, p. 4952, dez.1934. 
as alunas, mesmo sendo idosas, mais velhas do que ela, eram vistas como muito ingênuas e atrasadas porque gostavam de filmes e histórias infantis. Embora dissesse que fossem alunas aplicadas, assíduas, com ótima disciplina "durante a leitura das histórias, podia-se ouvir a respiração das alunas na classe", mesmo após um dia inteiro de trabalho, também havia problemas. Num caso apresentado pela professora, uma de suas alunas não se convencia de que seus argumentos estavam errados, sendo preciso que a diretora fosse chamada à classe e, com voz alterada, levasse a jovem a compreender seus equívocos. A partir deste caso, a professora conclui: "Essa foi uma das maiores dificuldades que encontrei: ensinar a adultos, tipo Pestalozzi, presunçosos e arrogantes..." (1970, p.77).

Considerando-se que as professoras resistiam ao máximo em trabalhar com as turmas especiais devido à reprovação quase unânime dos alunos, Helena Antipoff tentava salientar que a associação das aprovações ao bom trabalho pedagógico nem sempre estaria correta:

Logo que o professor obtém uma promoção suficiente ele se considera a si próprio e é considerado pelo diretor e pelos colegas como um professor "competente e hábil". Mas pode bem acontecer que esse professor competente nada mais seja que um puro empírico e um psicólogo medíocre, isto é, alguém que desempenha a uma tarefa de modo superficial, sem se importar com os problemas que surgem a cada momento, não aproveitando absolutamente as aptidões individuais de seus alunos, indiferentes às particularidades de caráter de cada criança, e que o leva não raro a cometer graves erros educativos, apesar de todo o seu êxito final que se traduz unicamente pela percentagem mais ou menos elevada das promoções. ${ }^{335}$

Não sendo suficientes as advertências que nem sempre a reprovação sinalizava para a incompetência docente, um artigo na Revista do Ensino sugeria que as diretoras e orientadoras fizessem com que lecionar em tais turmas se constituísse em um verdadeiro prêmio. Uma assistente técnica ${ }^{336}$ tentou uma outra alternativa. Ela assumiu a classe D por três meses. Segundo ela, os alunos desta classe eram já bem conhecidos das professoras e, além da dificuldade em trabalhar com eles, elas se sentiam humilhadas por não obterem a mesma taxa de promoção alcançada pelas colegas. A assistente intentava mostrar, na prática, como era possível trabalhar com tais alunos cujas idades

${ }^{335}$ ANTIPOFF, Helena. A pedagogia nas classes especiais (C.D.). In: CENTRO DE Documentação e Pesquisa Helena Antipoff. Coletânea das obras escritas de Helena Antipoff. Belo Horizonte: Imprensa Oficial, 1992, vol. I. "Psicologia Experimental". p.158.

${ }^{336}$ MELLO, Benedita. Experiências em uma classe de educação especial (cl.D). Revista do Ensino, BH, ano, VI [sic], n. 71,72 e 73, p.110-124, jul.ago.set.1932. 
variavam entre oito a quatorze, tendo alguns sete anos de repetência escolar. Todos eram do sexo masculino e provinham de um meio social com poucos recursos. Quase metade dos alunos não possuía os mínimos meios de subsistência. Eles foram assim classificados: sete seriam retardados pedagógicos, treze retardados pedagógicos e indisciplinados, quatro débeis mentais excitados e dois débeis mentais passivos. Dos vinte e seis alunos classificados, dezesseis podem ser considerados indisciplinados, já que a excitação também pode ser entendida como indisciplina. Esta classificação atesta que os alunos indisciplinados, freqüentemente, eram matriculados nas classes especiais. A assistente comentava as dificuldades do trabalho, principalmente em seu início. Os alunos, além de indisciplinados, apresentavam baixo índice mental. Segundo ela, embora alguns tivessem familiaridade com a aritmética, pois vendiam doces e verduras, não conseguiam aplicá-la na escola. A solução encontrada foi estudar os alunos, oferecer atividades novas e utilizar os exercícios de ortopedia mental sugeridos na Revista do Ensino. Dessa forma, ela afirmava estar conseguindo melhorar os hábitos e a disciplina dos alunos.

Uma vez convencidos os professores a lecionar nas classes especiais, era preciso prepará-los para esta tarefa. Em primeiro lugar, ficava claro que o conhecimento não era algo tão importante para tais classes, como atestava a exposição de motivos do Regulamento do Ensino de 1927:

São os anormaes propriamente ditos, condemnados ao atrazo pedagógico por defeitos de percepção, debilidade de attenção, instabilidade intellectual e emocional e outros índices de incapacidade para o esforço mental. A este resíduo das escolas primarias é necessário, para que seja convenientemente aproveitado e transformado em valores úteis, applicar um tratamento especial. [...] O ensino, nesses casos, deverá reduzir-se ao minimo, assenhoreando-se o trabalho do professor, recommendados os trabahos manuaes, não sómente pelo seu valor educativo, como também como preparação profissional a indivíduos que sómente com o trabalho das suas mãos poderão contar para viver. ${ }^{337}$

Em 1947, vinte anos após a publicação do Regulamento, uma Circular enviada ao Grupo Escolar Tomaz Brandão e, certamente, a outros Grupos Escolares confirmava a especificidade do atendimento dos alunos mais fracos, tipo $\mathrm{An}^{3}$, que teriam um atraso de três anos de idade mental.

\footnotetext{
${ }^{337}$ Exposição de motivos. Regulamento do Ensino Primário. 1927, p.1137-8.
} 
Feita a seleção dos alunos e organizadas as classes, deve a professora interessar-se pelo aluno, individualmente, e procurar conhecer-lhes as condições físicas, o meio social e a personalidade - ponto, aliás, indispensável ao trabalho em qualquer classe. $\underline{\text { Com }}$ crianças mentalmente fracas, a parte educativa deve predominar sôbre a instrução propriamente dita.

Conforme a circular, as crianças classificadas como $\mathrm{An}^{3}$ apresentariam deficiências de memória, de atenção, de observação, de controle muscular, etc., deficiências estas que deveriam ser sanadas pouco a pouco. Para isso, elas não deveriam ser submetidas a uma disciplina muito rígida, tendo necessidade de realizar diversas atividades: manuais, esportivas e intelectuais, com bastante material ilustrativo e jogos.

A título de sugestão e em caráter experimental, adaptamos o programa e horário abaixo, para serem usados nas classes $\mathrm{An}^{3}$ no corrente ano.

Educação dos sentidos 50 minutos por semana

Educação da atenção .50 minutos por semana

1- Trabalhos manuais 2 horas por semana

2- $\quad$ Exercício de desenho 1 hora e 15 minutos por semana

3- $\quad$ Ginástica 1 hora por semana

4- Canto 1 hora e 15 minutos por semana

5- $\quad$ Excursão

6- Linguagem oral 1 hora e 40 minutos por semana

$7-$

Leitura 2 horas e 30 minutos por semana

8- Escrita 50 minutos por semana 9- Ortografia 40 minutos por semana $10-$ Aritmética 2 horas por semana $11-$ Ciências Naturais. 1 hora por semana

As sugestões demonstram que, nestas classes, o essencial era educar e, se possível, instruir. Entre as atividades consideradas educativas estavam os exercícios de ortopedia mental, propostos por Helena Antipoff para serem utilizados nas classes $\mathrm{C}$ e D:

As crianças retardadas são seres inadaptados antes de tudo. Os sentidos a motricidade, a afetividade, o pensamento, a vontade se desencadeiam sem direção e sem ordem, de um modo caótico em umas, e inibido em outras. E é obrigação do educador ajudá-las, estimulando-as e organizando nelas os mecanismos psíquicos adequados aos fins.

A ortopedia mental visa precisamente este fim. Ela é uma ginástica psicológica cujos exercícios, variados e repetidos, vão por as faculdades em forma, adestra-las, uma por uma, tonificá-las e endireitá-las, se preciso. ${ }^{338}$

${ }^{338}$ ANTIPOFF, Helena. A pedagogia nas classes especiais (C.D.). In: CENTRO DE Documentação e Pesquisa Helena Antipoff. Coletânea das obras escritas de Helena Antipoff. Belo Horizonte: Imprensa Oficial, 1992, vol. I. "Psicologia Experimental". P.166 
Os alunos não ficavam alheios a esta classificação e nem mesmo aceitavam passivamente os exercícios propostos. Uma assistente técnica, em artigo publicado na Revista do Ensino informava que seus alunos mais "rebeldes" reclamavam dos exercícios de ortopedia mental a que eram obrigados a fazer: "Eu vim á escola pa[sic] aprendê lê" ou ainda "Esta escola é só de bobage"[sic] ${ }^{339}$. Por outro lado, um caso vivenciado por Benedita Dell'Isola ilustra o quanto os discentes incorporavam as representações que se faziam sobre eles. Segundo a professora, um de seus alunos veio lhe falar que pediria à sua mãe para levá-lo a um psiquiatra, já que ele detestava estudar, por mais que se esforçasse. Tal situação denota o quanto o aluno estava imbuído da idéia divulgada pela Psicologia e Medicina de que somente um aluno "anormal" não se interessaria pela escola moderna.

Não bastava, entretanto, convencer os professores e prepará-los para o trabalho nas classes especiais. Era preciso encontrar educadores que tivessem características adequadas ao exercício da função que, segundo as recomendações coletadas nas fontes, consistiam bem mais em disposição e interesse que propriamente de erudição:

Podemos dizer que a classe $\mathrm{D}$ requer um tratamento especial, metodos mais concretizados, regimen flexivel a mais atividades; que sua professora deverá ser dedicada, cumpridora dos deveres, calma, de maneira a manter na classe um ambiente sereno, próprio a essas crianças, e ministrar-lhes um ensino individual, diferencial; portanto, a uma professora que se recomende unicamente pela inteligência, é preferível aquela, cujos dotes de caráter e de coração, a façam amiga de seus alunos, pronta a se sacrificar por eles, pois é mais nobre, requer maior dose de abnegação cuidar daqueles que tudo esperam e pouco, relativamente pouco, poderão dar. ${ }^{340}$

\section{Helena Antipoff ${ }^{341}$ confirma essa recomendação:}

Se na escolha do professor para as classes dos bem-dotados a inteligência e a competência profissional desempenham o papel mais importante, a designação dos mestres para as classes dos retardados e dos instáveis deve obedecer aos critérios que fazem sobretudo realçar, ao lado da competência pedagógica, ainda as virtudes de caráter, tais como a afeição às crianças, o espírito altruísta e muitas vezes cheio de

\footnotetext{
${ }^{339}$ MELLO, Benedita. Experiências em uma classe de educação especial (cl.D). Revista do Ensino, BH, ano, VI [sic], n. 71,72 e 73, p.110-124, jul.ago.set.1932.

${ }^{340}$ MACHADO, Amélia Carlota da Mata. Organização das classes homogêneas de $1^{\circ}$ ano nos Grupos Escolares de Belo Horizonte. Revista do Ensino, BH, n.53,54 e 55, p.56-76, jan.fev.mar.1931, p. 70.

${ }^{341}$ Mais informações sobre o assunto cf. CENTRO DE Documentação e Pesquisa Helena Antipoff. Coletânea das obras escritas de Helena Antipoff. Belo Horizonte: Imprensa Oficial, 1992, vol. III. "Educação do excepcional". 336p.
} 
verdadeira abnegação, muito de paciência, e a busca incessante dos meios para tornar eficiente a educação dessas crianças. ${ }^{342}$

Essa observação deixa claro que a homogeneização não se restringia aos alunos, mas estendia-se aos professores: para alunos inteligentes, professores inteligentes; para alunos medíocres, professores que também não se destacassem pela inteligência. $\mathrm{Na}$ prática, entretanto, muitas vezes eram as professoras menos experientes que recebiam as classes ditas especiais. O primeiro trabalho de Terezinha Casasanta foi como substituta nos Grupos Escolares Bueno Brandão e Barão do Rio Branco, onde se efetivou. Segundo ela, as piores classes ficavam com as professoras recém-formadas. Eram as crianças com menos possibilidade de aproveitamento. As professoras mais famosas ficavam com as salas melhores, de alunos de nível social mais alto. Imene Guimarães confirma o procedimento de colocar as professoras menos experientes nas classes mais difíceis. Ao concluir seus estudos na Escola Normal, ela foi convidada para trabalhar no Grupo Escolar Barão do Rio Branco onde havia estudado. Neste momento, as salas já eram mistas. Ela recebera uma turma intitulada como muito difícil, que funcionava no porão da escola, com alunos de quarto ano repetente, vários moradores de favela e alguns maiores do que ela ${ }^{343}$. Era uma classe pequena, com quinze alunos. A diretora lhe disse para não se preocupar e que se ela passasse cinco estava bom. No fim do ano, doze alunos foram aprovados.

Não se esperava que essas classes fossem mesmo aprovadas e por isso também não havia grande interesse em oferecer-lhes professoras experientes e bons espaços de trabalho. No Grupo Escolar Tomaz Brandão uma dessas turmas chegou a funcionar no alpendre. Embora o artigo 378 do Regulamento do Ensino Primário afirmasse que as classes D deveriam comportar no máximo quinze alunos, esse número nem sempre era respeitado, chegando a ter até quarenta matriculados. Além disso, segundo a diretora do Grupo Tomaz Brandão, o chefe do Departamento de Educação, Dr. Eliseu Laborne, teria afirmado que quanto mais numerosa a classe, melhor seria o resultado obtido.

As análises da utilização do espaço escolar podem revelar muito sobre a educação ali realizada. Um relato sobre uma classe D do Grupo Escolar Bernardo

${ }^{342}$ ANTIPOFF, Helena. Seleção dos professores para cada tipo de classes. In: CENTRO DE Documentação e Pesquisa Helena Antipoff. Coletânea das obras escritas de Helena Antipoff. Belo Horizonte: Imprensa Oficial, 1992, vol. I. "Psicologia Experimental".

${ }^{343}$ Os alunos eram tão grandes que, um certo dia, a servente confundiu Imene Guimarães com uma das alunas e prometeu contar para a diretora que ela estava sem uniforme. 
Monteiro, por exemplo, é bastante significativa do lugar que ocupava as classes ditas especiais nos Grupos:

A sala onde funciona a classe é de pequenas dimensões, cerca de 3,5x5 metros; não tem boa ventilação, nem recebe a luz necessária.

Sendo tão exíguas as suas dimensões, não poderia, por conseguinte, comportar mais de quinze alunos, assim mesmo distribuídas as carteiras como antigamente, em filas, cada uma das quais ocupada por dois alunos. Convem assinalar que, devido a grande freqüência atual, de vinte e um alunos, há necessidade de distribui-los, pelo menos alguns, três a três, pelas 10 carteiras existentes.

$[\ldots]$

Como a sala se acha localizada junto á cosinha, a proximidade desta perturba a atenção dos alunos e, assim, o curso normal das aulas; e, tal acontece, quer pelo calor irradiante, quer pela fumaça, entrada e saída de pessoas, conversações tantas vezes longas e sumamente importunas. ${ }^{344}$

A classe tinha mais de 21 alunos com idades entre oito e treze anos. A professora que fez a observação acreditava que o ideal do tratamento dos "anormais" deveria ser o internato "Desta forma não continuariam êles expostos aos desvios de direção em meio do mau ambiente social ou familiar".

Outro relato também de uma classe de $1^{\circ}$ ano D do Grupo Escolar Francisco Salles confirma a precariedade dos espaços destinados a tais alunos:

A sala de aula é muito pequena (antigo gabinete da diretora). Comporta, apenas, duas fileiras pequenas de carteiras, ficando, para o trânsito das crianças, um pequenino espaço, entre as mesmas. Ao lado há um pequeno alpendre onde os alunos colocam e cuidam dos seus vasos de flores. ${ }^{345}$

Estes relatos evidenciam o quanto as classes homogêneas segregavam os alunos, oferecendo aos considerados menos inteligentes os piores espaços, os professores menos experientes, os conhecimentos menos importantes. Ortopedia mental é um nome bem sugestivo, quando se pensa que a disciplinarização, a retidão do comportamento, a moralidade e o conformismo eram as principais características a serem desenvolvidas nos alunos considerados "anormais".

${ }^{344}$ TOLEDO, Alice Rosa. Do Relatório sobre a classe especial $-1^{\circ}$ ano D Grupo Escolar "Bernardo Monteiro". SOCIEDADE Pestalozzi. A infância excepcional (sub-normais). Boletim n. 12 - Fascículo I, Secretaria da Educação e Saúde Pública; Inspetoria Geral da Instrução. Belo Horizonte, p. 77-84, setembro de 1933, p.77.

${ }^{345}$ NASCIMENTO, Marieta. Do Relatório sobre a classe especial - $1^{\circ}$ ano D "Grupo Escolar Francisco Sales". SOCIEDADE Pestalozzi. A infância excepcional (sub-normais). Boletim n. 12 - Fascículo I, Secretaria da Educação e Saúde Pública; Inspetoria Geral da Instrução. Belo Horizonte, p. 85-89, setembro de 1933, p.85. 
Diante da vigência de representações tão díspares sobre a criança, talvez se pudesse suspeitar que a graça e beleza da infância só fossem possíveis e comuns às ditas normais. Para as consideradas "anormais" toda sorte de vícios e defeitos poderiam lhes ser atribuídos. Os ex-alunos e ex-alunas entrevistados na pesquisa, a despeito de todo o saudosismo e consideração pelas professoras dos Grupos Escolares, evidenciaram o quanto tais espaços eram, em alguns momentos, ameaçadores e repressores. Suas travessuras e indisciplinas talvez tivessem sido mecanismos desenvolvidos para lidar num ambiente nem sempre confortável e tranqüilo.

Não somente os castigos constituíam-se numa ameaça nos Grupos Escolares, a classificação no grupo dos retardados ou "anormais" poderia significar dor ainda maior. Os meninos e meninas dos Grupos Escolares pareciam ser cuidadosamente vigiados, de tal forma que supostas características negativas como a curiosidade, entre elas, a sexual, a espontaneidade, a atividade e a indisciplina fossem previamente notadas e decodificadas e que pudessem ser controladas, antes mesmo de sua manifestação.

Os educadores eram instigados a observar, inspecionar, detectar, avaliar, tratar e corrigir com atenção todos os detalhes do comportamento dos alunos. A anormalidade se constitui como um problema para a escola que precisava alijar de diversas formas as crianças que não se enquadravam no padrão da normalidade. Aliás, o próprio sucesso do escolanovismo só seria possível com a seleção e exclusão dos alunos, a quem se atribuía a razão pelo seu próprio insucesso. A anormalidade foi uma das principais formas de exclusão por carregar o estatuto de cientificidade de ciências com grande aceitação social como a Medicina e a Psicologia.

Este projeto, entretanto, revelou-se um fracasso. As fontes denunciam que a indisciplina não era banida da escola, embora fosse violentamente empurrada para as classes especiais que funcionavam nos fundos, nos porões, em locais em que não ameaçassem a boa ordem das atividades escolares. Apesar disso, não apenas os alunos pareciam vítimas dessas práticas de segregação. Também as professoras, a contra-gosto, eram designadas para assumir tais classes. É curioso e ao mesmo tempo terrível perceber o quanto os pressupostos da liberdade e da atividade do aluno no processo de aprendizagem eram desconsiderados por essa classificação dos alunos e pelo uso de punições que davam uma roupagem científica e moderna aos velhos preconceitos e castigos escolares. 
Ao classificar algumas de suas crianças como "anormais", as escolas identificavam, como já foi dito, dois motivos principais que justificavam a anormalidade do aluno. Um era a sua própria constituição física e/ou psíquica que o predestinavam a apresentar aquelas características. Outro era o meio social no qual os alunos estavam inseridos. A pobreza, a miséria, a falta de escolaridade familiar favoreceriam a desnutrição, o aparecimento de doenças, a fraqueza física, mental e intelectual, a indisciplina e a revolta. Por este motivo, o projeto educativo da escola primária não devia se restringir apenas aos alunos. Entre os educandos, encontravam-se também as famílias e a própria sociedade, especialmente a menos favorecida pela fortuna e pela educação formal. No capítulo seguinte será discutido de que forma os dispositivos disciplinares saltavam os muros escolares e atingiam suas casas, seus familiares e a sociedade de uma maneira geral. 


\section{EIXO II}

CULTURA ESCOLAR \& DISPOSITIVOS DISCIPLINARES 


\section{CAPÍTULO 5}

\section{REPRESENTAÇÕES SOBRE A FAMÍLIA E A ESCOLA}

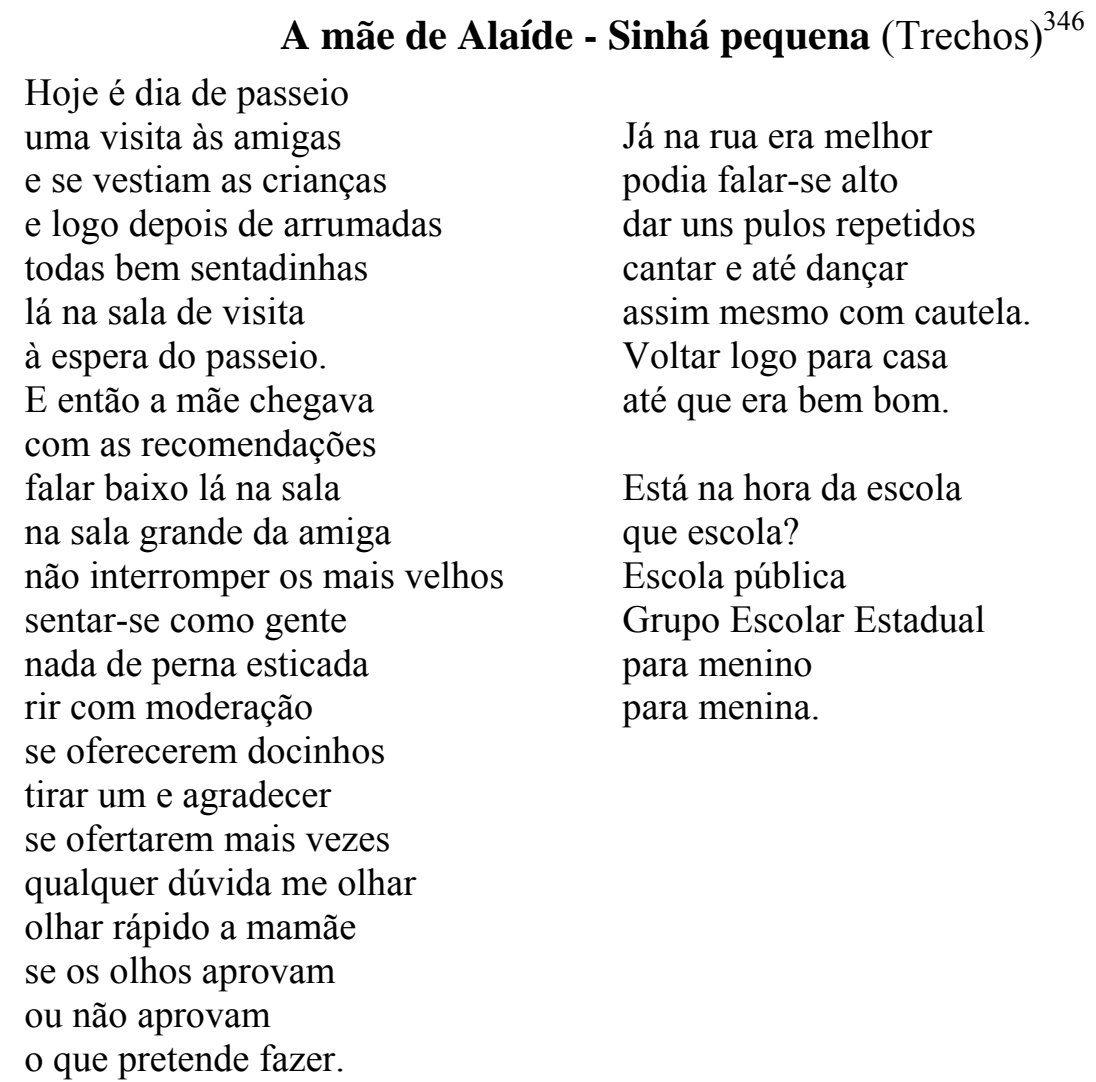

O poema acima, de Alaíde Lisboa de Oliveira, trata da educação regrada recebida na família, da convivência social, da liberdade das ruas e da ida para o Grupo Escolar. Todos os(as) entrevistados(as) foram unânimes em afirmar que a educação recebida da família era bastante rígida e de muito respeito. Alguns chegaram a dizer que não se espantavam com a disciplina escolar, porque já estavam acostumados às imposições da família. A obediência era um valor, conta Alaíde, e não se dava muita liberdade à criança:

Eu me lembro, por exemplo, quando eu era pequena, não sei que idade eu teria, mas eu lembro da minha mãe conversando com uma amiga e ela disse: Interessante! A Alaíde era tão educadinha, agora deu pra fazer pergunta. Você vê: Fazer pergunta não era boa educação, né? Então eu ouvi, ela nem sabe se eu sabia, nem nada. E passei a perguntar menos. E comecei a perguntar para mim mesma. Eu mesma respondia mais ou menos, né? ${ }^{347}$

\footnotetext{
${ }^{346}$ OLIVEIRA, 2000, p.36-37.

${ }^{347}$ Entrevista concedida ao Museu da Escola do Centro de Referência do Professor.
} 
Segundo Alaíde, a Escola Nova introduziu uma inovação: permitir e valorizar a curiosidade da criança, antes limitada tanto pela família quanto pela escola. Na sua infância, bonito era ser obediente e, segundo ela, atualmente este valor se inverteu: a ousadia, a coragem e, por extensão, a desobediência são valorizadas na educação da criança, comenta a professora. Quanto às relações entre família e escola, encontram-se momentos de convergência de idéias, de ajuda mútua e também de tensões e rupturas. Pode-se perceber que, quanto melhor a situação financeira das famílias, mais elas eram consideradas colaboradoras da tarefa escolar e, inversamente, as famílias pobres eram vistas como obstáculos ao trabalho pedagógico realizado na escola.

Um dos artigos da Revista do Ensino atestava que família e escola estavam sempre em lados opostos:

A escola, tem-se dito, é a continuação do lar. E, na verdade, a escola é a negação do lar, não só porque ela é uma coletividade muito mais ampla do que a família, como porque ela é um ponto neutro, onde côr, fortuna, títulos, posições, crenças, pouco valem: o filho do magistrado e do capitalista se sentam ao lado do filho da lavadeira e do carreiro, sujeitam-se aos mesmos mandamentos e sofrem idênticas restrições.

Não raro, a escola abre luta contra o lar, condenando genéricamente, sua organização interna, suas condições de salubridade, e até os vícios das pessoas da família. Eis porque a familia quase sempre nega à escola a colaboração que esta não apenas lhe pede, mas até lhe mendiga. ${ }^{348}$

Trata-se, obviamente, de uma idealização, não se pode dizer, como afirma o artigo, que a escola fosse neutra, supondo uma igualdade no tratamento das crianças. Todos os documentos analisados confirmam o quanto a cor, a fortuna, os títulos, as posições e crenças eram significativos na escola pública mineira. Certamente os Grupos Escolares eram um espaço democrático, mas a própria homogeneização das classes contribuía para dividir este espaço sob uma aparência racional e científica que ocultava as distinções subjacentes. Mas pode-se concordar com o fato de que escola e família foram colocadas histórica e culturalmente em condições de oposição uma a outra, como salienta Marcus Vinícius da Cunha:

Todos já ouvimos a expressão "a escola é o segundo lar" como se a instituição formal de ensino fosse uma extensão pública dos cuidados maternos. Nada mais falso! A escola jamais foi norteada pelos mesmos princípios educacionais vigentes no lar.

\footnotetext{
${ }^{348}$ O PRÊMIO maior. Revista do Ensino, BH, ano XI, n. 140-142, p.3-5, jul.set. 1937, p.3-4.
} 
Paulatinamente, ao longo da história, foi incorporando saberes científicos em oposição aos saberes domésticos tradicionais. (2000, p.450)

Segundo o autor, a escola, desde a sua origem, se colocou contra a família, especialmente as famílias pobres. Pode-se perceber, nos casos aqui analisados que, ao mesmo tempo em que as famílias são convidadas a colaborar e apoiar o trabalho pedagógico da escola, são acusadas de dificultar a atuação das professoras. Tratava-se de uma limitação do poder do pai e da família em geral por parte do Estado que vinha assumindo uma função educativa mais incisiva e minorando o poder familiar sobre a educação das crianças. Considerando tal movimento, pretende-se analisar que representações tinham as famílias a respeito da escola.

\subsection{A ESCOLA A PARTIR DE REPRESENTAÇÕES FAMILIARES}

Eram diversas as formas pelas quais as famílias se relacionavam com a escola. Algumas sem muito contato ou à distância. Segundo Elza de Moura, os pais eram muito ocupados e não iam à escola. Eles tinham confiança no trabalho realizado e não interferiam. Norma Lúcia conta, no entanto, que a sua mãe ia até a casa da professora saber como era o comportamento da filha na escola. Algumas famílias se interessavam pelo trabalho escolar, visitando as exposições pedagógicas, acompanhando os filhos e algumas delas chegavam a pedir auxílio para os problemas familiares. Imene Guimarães, por exemplo, comenta que era comum os pais procurarem as professoras para discutir problemas particulares por considerá-las pessoas cultas e dispostas a ajudar. Num caso transcrito num livro de Registro de Advertências do Grupo Escolar Olegário Maciel, pode-se perceber como os problemas familiares chegavam até a escola, na expectativa de uma solução. Em uma carta enviada a Helena Antipoff, provavelmente pela diretora do Grupo, solicitava-se a colocação de um aluno na GranjaEscola Pestalozzi:

Trata-se de uma criança sem mãe, que deixou a companhia de seu pai, por não poder morar com a madrasta, achando-se só, entregue a si, na possibilidade de futuramente prejudicar-se. 
É um menino forte, sadio e promete ser para o futuro um bom elemento para esta instituição. Seu pai [incompreensível] se compromete à contribuição de $30 \$ 000$ mensais, de acordo com suas posses. ${ }^{349}$

Trata-se, evidentemente, de um caso bastante delicado, já que a criança estava sendo abandonada pelo pai que se comprometia a pagar para manter o filho fora de sua residência. Não se pôde saber se a solicitação foi ou não atendida, percebe-se, todavia, o empenho da escola em resolver a situação do aluno, atendendo, possivelmente, a pedido feito pelo próprio pai.

Mas se as famílias iam até a escola pedir auxílio para a resolução de problemas particulares, elas também questionavam o trabalho escolar e, nem sempre aceitavam de forma pacífica e resignada os castigos aplicados aos alunos. Numa reunião de professoras do Grupo Escolar Tomaz Brandão a diretora fez a seguinte ressalva:

b) Nenhum castigo físico póde ser ministrado as crianças.

A boa professora conhece os meios que a pedagogia the faculta para corrigir os seus alunos e nunca deve lançar mão do castigo físico.

c) As familias estão acompanhando o trabalho das professoras; frequentemente comparecem ao gabinete do grupo, algumas vezes para elogiar, mas a maioria para reclamar e em certos casos, com muita razão. ${ }^{350}$

O fato de avisar às professoras da proibição ao uso de castigos nos revela indícios de que eles existiam na escola. Como a diretora chegou a dar razão aos familiares pode-se supor, mais uma vez, que o Regulamento havia sido ferido. O relato mostra ainda que pelo menos algumas famílias estavam atentas ao cotidiano escolar e davam as suas opiniões, ora elogiando, ora reclamando. Assim como algumas famílias poderiam se insurgir contra os castigos físicos, também existiam aquelas que orientavam as professoras no sentido de castigarem fisicamente as crianças, autorizando-as a fazê-lo; e ainda aquelas que não se intrometiam nos assuntos escolares ou fortaleciam as práticas punitivas, ao aceitarem resignadamente as suas aplicações. Em outro momento, a diretora:

... falou sobre o modo de educar as crianças, fazendo ver as docentes que a maioria dos alunos dado a educação falha dos pais, não pode se explandir [sic] em casa, aproveitando portanto da estadia escolar para dar expansão ao seu instinto irriquieto

\footnotetext{
${ }^{349}$ Carta enviada a Helena Antipoff, diretora da Sociedade Pestalozzi em abril de 1940.

${ }^{350}$ Ata $n^{\circ} 47$ do dia 25 de outubro de 1947.
} 
sendo então necessário toda a atenção da professora para observar a indole de cada um. Observar que tem aparecido escritos nas paredes das salas de aula que ficam fora do grupo e que, ao seu ver esta falta é partida dos alunos que já sairam deste estabelecimento, mas não obstante isto, é necessário vigilancia das docentes para sanar esta irregularidade. ${ }^{351}$

Percebia-se que o espaço escolar poderia oferecer maior liberdade e expansão aos alunos que não possuíam uma boa educação familiar, sendo necessária atenção redobrada por parte das professoras. Imene Guimarães comentou que dava uma sugestão interessante para as professoras não castigarem fisicamente os alunos. Ela lhes recomendava que mantivessem distância toda vez que fossem repreender um aluno indisciplinado, o que as impediria de tocá-los ou puni-los fisicamente. Apesar disso, quando se deparou com uma situação em que uma professora estava sendo acusada de bater num dos alunos, ela acabou defendendo o uso de castigos físicos porque, no seu entender, a criança bem os merecia.

D.I.: Houve um caso lá no grupo quando eu era diretora. Foi um caso muito sério. Um dia eu estava no meu gabinete que ficava logo na entrada, quando ouvi um barulho e vozes altas. Eu saí e fui ver o que era. Era um casal, e o marido gritava em voz alta que queria bater numa professora.

R: Estava dentro da escola?

D.I.: Dentro da escola, eu saí de lá e disse: "Se quiser bater na professora, então você bata em mim, que eu sou a Diretora do Grupo, eu recebo". Ele: "Deus me livre!" Ele era meu conhecido. "Você é muito boa, você trata muito bem meu filho, mas a tal professora... eu quero ir na sala de D. Fulana". Aí eu falei: "Se você der um passo mais aqui, eu chamo a polícia e se você quiser bater na professora, bata em mim, eu sou a diretora". Então ele se desarmou totalmente. Aí eu falei: "Mas o que que é?" Ele falou: "Ela bateu no meu filho". Eu falei: "Eu não acredito que ela tenha batido no seu filho, apesar dele merecer muito, porque seu filho é muito indisciplinado e muito malcriado".

Imene Guimarães, ao dizer ao pai que o filho merecia apanhar e que estava sendo mal criado, indiretamente sugeriu que ele o fizesse. Os castigos físicos proibidos na escola eram práticas aceitáveis nas famílias. Segundo Geraldo Félix, quando a família era chamada à escola não podia ser sinal de coisa boa. Seis meses após a conclusão do curso primário, sua família recebeu um recado para comparecer ao Grupo, o que o deixou apavorado: “... eu fiquei doido. Meu Deus, a bomba estourou agora.

${ }^{351}$ Ata $^{\circ} 52$ de 21 de agosto de 1948. 
Efeito retardado. Eu tô ferrado". As expectativas do ex-aluno não se confirmaram, já que o motivo do chamado não se referia ao seu comportamento, mas era para entregar um resultado de exame de saúde feito por ele, quando aluno do Grupo.

R: O senhor estava falando o tipo de punições. A família não reclamava, por exemplo, os alunos apanhavam de vara de marmelo...

GF: Se chegasse em casa uma notícia que pintou na sala de aula, o cara não quer saber, o pau ia comer em casa, em casa. Mas batia mesmo, as famílias batiam nos filhos, todos.

R: E não reclamava do professor...

GF: Nunca reclamava do professor, autorizava. Tinha o prazer de falar. Todo pai achava que era o maior prazer falar: "Se precisar, corrige ele aí pra mim, corrige ele". Era autorizado, não tinha isso não. Aquilo era rotina. Interessante, tinha os alunos da época, quando crescem, todo acham que aquilo ajudou, botou eles no eixo mesmo. A turma não era mole não. A turma não era mole não.

Segundo Geraldo Félix, além das punições recebidas na escola, o que acontecia no Grupo poderia gerar ainda mais punições em casa, embora os comportamentos do pai e da mãe fossem diferentes ao aplicar a punição. "A mãe tentava segurar. Só pai que batia, mãe não usava bater. Mãe é pra não deixar o pai saber. Ah, se seu pai ficar sabendo que o porteiro veio aqui”.

Se os castigos, especialmente físicos, vinham sofrendo cada vez mais críticas no âmbito escolar, havendo um rígido controle na sua utilização, os mesmos, quando aplicados pela família, não pareciam se constituir em problemas. As fontes mostram que a família era autorizada a utilizar punições, sem que a escola visse nisso qualquer inadequação. Pelo contrário, as punições eram um direito atribuído aos pais e familiares ao corrigirem as crianças, sendo até mesmo tema de poesias a serem utilizadas na escola: 


\section{As ruguinhas do papai ${ }^{352}$}

J. Didier Filho

Papai tem duas ruguinhas

Bem no alto do nariz: -pequeninas, franzidinhas, que se cortam como um xis...

Quando arranjo uma das minhas

travessuras de petiz

e ... vejo aquelas ruguinhas

desisto de fazer ... bis!

Desisto de puro mêdo

porque num xis, em segrêdo, as ruguinhas dizem tudo:

dizem que eu apresse o passo, pois vem aí pelo espaço

um formidável cascudo.

No caso da disciplina escolar, primordialmente, as famílias eram convidadas a auxiliar o trabalho escolar, até porque, embora se criticassem os castigos físicos aplicados pelas professoras, não havia nenhuma crítica aos castigos aplicados pelas famílias, ou outros adultos que fossem.

Nas composições escolares publicadas no jornal "Sandoval de Azevedo", por exemplo, várias são histórias de crianças que, por diversos motivos, levavam surras do pai ou da mãe. Essas são composições interessantes porque mostram como as próprias crianças retratavam o direito das famílias e/ou dos adultos de castigá-las e bater-lhes. Em todas as histórias, o castigo havia sido merecido porque o castigado, a criança ou mesmo um animalzinho de estimação, fora desobediente. Desobedecer aos adultos deveria ser motivo para castigo. Caso este não fosse aplicado pelos mais velhos, a vida se encarregaria de fazer justiça. $\mathrm{O}$ castigo levaria a uma mudança no comportamento dos rebeldes. Um fato significativo é que algumas crianças desobedientes em diversas histórias recebiam o nome de Tisiu, denominação dada a um pássaro preto e também muito utilizada para crianças negras. Ser negro e ser moleque estavam freqüentemente associados nas histórias. Uma das composições é bastante significativa porque permite verificar estes elementos aqui discutidos:

Morava numa cidade distante daquí um menino muito levado chamado Tisiu.

Um dia Tisiu foi à casa de uma preta velha chamada Chica Maria.

\footnotetext{
${ }^{352}$ M.L. Duas poesias [Extraídas do livro "A poesia no curso primário" de Alaíde Lisboa de Oliveira, Zilá Frota e Marieta Leite]. Educando, BH, ano I, n. 5, jul. 1940, p. 31-32.
} 
Ele chegou à janela e disse: D. Chica, a senhora quer parar um pouco de varrer e me dar um pouco de atenção?

Ela disse: _ Não posso. Eu estou varrendo e não vou parar por sua causa.

O menino então jogou-lhe uma boa quantidade de besouros que êle tinha trazido nos bolsos.

D. Chica Maria ficou com muita raiva e quis bater no menino levado mas não foi preciso. Tisiu foi castigado. Ele se afastou fazendo fiau... para D. Chica, mas êle foi infeliz por que não viu uma tina cheia d'agua e caiu bem dentro dela.

Tisiu se molhou todo e nunca mais quis ser travesso. ${ }^{353}$

O menino da história havia pedido a atenção da senhora que lhe foi negada. Mesmo não recebendo a surra, o menino foi castigado. Embora cair na tina de água nada tivesse a ver com o ocorrido, isso o fez associar imediatamente à molecagem com a velha preta. A lição fez com que cessassem todas as travessuras do menino. $\mathrm{O}$ fato de ser negro não é um mero acaso. Numa pesquisa realizada pelo Laboratório de Psicologia pedia-se que as professoras fizessem uma classificação dos alunos a partir da cor da pele para o Serviço de Orientação e Seleção Profissional. Um jornalista do Estado de Minas ironizava a pesquisa afirmando que, num regime democrático, não se deveria considerar a cor da pele dos alunos:

A iniciativa pertence ao sr. Mira y Lopes, consagrado psicólogo, psicanalista, psicotécnico e psicastenico. Ainda não conheço todos os títulos do eminente educador. Em um regime democrático, o recenseamento dos alunos deveria ser feito pelo processo daltônico, isto é, sem discriminação de cores. O professor Myra y Lopes não correrá grande perigo, por não ser muito conhecido entre nós. Há o receio de que o pai de algum preto ou mulato não goste da historia. Qualquer dia um pai negro dará um tiro na professora. ${ }^{354}$

As teorias eugenistas em voga no país e no mundo naquele momento evidenciam que a discriminação existia na sociedade e nas escolas, por extensão. Prova disso é a ampla análise realizada por Júlia Viotti sobre a herança racial das alunas da Escola de Aperfeiçoamento $^{355}$. Sobre a discriminação racial, acrescentava-se, ainda, a discriminação de classes. Ficava claro que das crianças vindas dos meios sócio-

\footnotetext{
${ }^{353}$ BARRETO E SILVA, William. (Aluno da $2^{\mathrm{a}}$ série da professora Maria Antonieta Moreira) Como é travesso o Tisiu. Sandoval de Azevedo, Belo Horizonte, ano I, n. 4, setembro de 1952, p.1.

${ }^{354}$ SILVA, Jair. Oropa, França e Bahia. Estado de Minas. 15/05/1949 - N. 9.017

${ }^{355}$ VIOTTI, Julia de Magalhães. Contribuição à antropologia da moça mineira. Boletim n. 13. Belo Horizonte: Secretaria da Educação e Saúde Pública; Inspetoria Geral da Instrução, 1933.73p. Uma análise sobre esta questão pode ser vista em: VEIGA, Cynthia Greive. Manifesto dos pioneiros de 1932: o direito biológico à educação e a invenção de uma nova hierarquia social. In: XAVIER, Maria do Carmo (org.) Manifesto dos pioneiros da educação: um legado educacional em debate. Rio de Janeiro: ed. FGV, 2004. p.67-88.
} 
econômicos mais desfavorecidos não se deveria esperar muitos talentos, e o mesmo se poderia dizer de suas famílias.

Uma outra composição publicada no jornal Voz da criança reitera a concepção de que algumas famílias contribuíam para manter, no espaço doméstico, imposições e restrições relacionadas ao comportamento dos alunos no espaço escolar. A composição abaixo tem o sugestivo nome Deus abençõe meus pais e revela como a sombra da escola acompanhava a criança até mesmo durante as férias:

Durante as férias de Julho não passei [sic] nada, devido ao meu boletim e às minhas más notas em procedimento!

No dia 29 de julho, dia do meu aniversário fui a Lagôa Santa porque todos lá de casa foram e eu não podia ficar sozinho em casa.

Brinquei só em casa com meu irmão Oscar, não fui às matinées. Papai e mamãe disseram que eu poderia ir à matinée só quando melhorar de procedimento na escola. Estudei muito todos os pontos, passei-os a limpo. Fiz o álbum que D. Carmem pediu.

No dia 17 entraram as aulas, estou com muita disposição para estudar, pois, quero tirar o diploma êste ano. Também quero proceder muito bem para que papai e mamãe fiquem contentes. Não quero dar desgosto a d. Carmem que é uma bôa mestra e, para que ela não fique descontente, prometo proceder bem, durante as aulas.

Pedro Paulo Tibúrcio, $4^{\circ}$ ano de d. Carmem Parreiras. ${ }^{356}$

Quando não se chamavam as famílias à escola, se levavam os alunos infreqüentes, atrasados ou indisciplinados para suas casas, a fim de que os pais fossem comunicados a respeito daquele comportamento, mesmo no caso de alunos e alunas dos Grupos Noturnos. No Grupo Afrânio de Melo Franco, por exemplo, a diretora enviou à casa de um dos alunos o guarda e o próprio aluno para esclarecer o motivo pelo qual ele sempre saía mais cedo da escola. O pai do aluno disse que ele não tinha motivos para deixar a escola antes dos outros colegas e o fazia para "vagabundar", por este motivo, ele pedia à diretora que não o autorizasse a sair mais cedo.

Em outros casos, as famílias demonstravam se preocupar também com a qualidade do ensino ministrado na escola. Numa das reuniões do Grupo Escolar Mariano de Abreu, a diretora leu uma carta de um pai de um aluno dirigida a uma professora, corrigindo-a sobre a ortografia da palavra "chuchú". O pai afirmava que o aluno havia escrito com " $\mathrm{x}$ " e a professora corrigiu colocando "ch", o que teria sido um erro. A diretora confirmou que a professora estava certa segundo o decreto-lei de 1943 que realizara uma Reforma ortográfica. Ainda assim, utilizou o caso para pedir mais

${ }^{356}$ TIBURCIO, Pedro Paulo. Deus abençoe meus pais. Voz da criança. Ano II, n.9, p.1, julho 1951. 
atenção das professoras na correção dos cadernos dos alunos. Percebe-se, portanto, que as escolas estavam preocupadas com a repercussão de seus atos no meio familiar.

\subsection{A FAMÍLIA A PARTIR DAS REPRESENTAÇÕES ESCOLARES}

Em primeiro lugar, pode-se destacar que, diante das dificuldades financeiras de alguns alunos e alunas e das próprias escolas, as famílias e a sociedade de maneira geral eram compreendidas como parceiras que deveriam auxiliar os trabalhos escolares de diversas formas, especialmente no tocante a ajuda monetária. Mas a família também deveria se interessar pelos trabalhos pedagógicos desenvolvidos nos Grupos Escolares, como recomendava um artigo da Revista do Ensino:

$1^{\circ}$ - A cooperação dos pais impõe-se para a eficiência da obra educativa da Escola.

$2^{\circ}$ - Para obter, pedagògicamente, a colaboração dos pais é necessário interessá-lo na vida normal da escola, perfeitamente integrada como deverá estar a técnica educacional moderna.

$3^{0}$ - Por serem de responsabilidade direta do professor os métodos de ensino e a administração geral da escola, não cabe aos pais procurar intervir em tais questões de natureza especializada e completamente independentes das atribuições da família. ${ }^{357}$

Os itens colocados no artigo deixam claro que a tarefa colaborativa da família era limitada, já que não lhes cabia intervir nos assuntos pedagógicos por lhes faltar os requisitos para julgar a atuação da escola. No caso, por exemplo, relativo à homogeneização das classes, era comum as famílias quererem escolher a professora para os filhos, pleitearem a colocação de parentes e amigos na mesma classe ou ainda não aceitarem a classificação realizada pela escola. Em todos esses casos, buscava-se persuadir as famílias de que a organização "racional" das crianças seria benéfica ao aprendizado.

A Associação das Mães de Família, embora já existisse em algumas escolas, foi incluída no Regulamento do Ensino Primário na Reforma Francisco Campos. Buscou-se verificar como era a atuação de tais associações no dia-a-dia escolar. Foram poucos os documentos encontrados que tratavam da existência desta Associação e, na maioria dos Grupos, ela parece nem ter existido. Um artigo publicado em 1936 na Revista do Ensino ${ }^{357}$ BACKHEUSER, Alcina. A cooperação dos pais na obra educativa da escola. Revista do Ensino, BH,
n.202, p.157-164, abr.jun.1952, p.164. 
afirmava que 90\% das Caixas Escolares e Associações de Mães de Família eram inoperantes $^{358}$.

No Grupo Escolar Olegário Maciel funcionava uma Associação das Mães de Família. No entanto, não foi possível verificar qual o tempo de sua duração. A primeira ata de 1929 tratava da eleição da nova diretoria, o que indica, portanto, que havia uma diretoria anterior. Afirmava-se ainda que a Presidente eleita era a vice no mandato anterior. Foram eleitas uma presidente, uma vice-presidente e uma secretária. Vinte e duas mulheres assinaram a ata, muitas delas, professoras do Grupo. A ata seguinte tratava da posse da nova diretoria e não há mais nada registrado no caderno. Após a segunda ata, vinha um esboço do Estatuto da Associação:

\section{Capitulo I}

Da denominação, fins e séde da Associação

Art. $1^{\circ}$ - Sob a denominação de Associação das Mães de Familia fica creada neste logar que lhe serve de séde, uma associação de senhoras, com os fins seguintes:

a) promover o progresso moral e mental do povo, agindo especialmente nas escolas;

b) estabelecer uma collaboração intima entre o professorado e as mães de familia, como base indispensavel para a consecução do fim principal da sociedade;

c) prestigiar os professores, acompanhando com attenção e carinho o trabalho escolar, prestando-lhes todo o auxilio possivel no caso de difficuldades e molestia;

d) cooperar para o augmento da matricula e da frequencia nas escolas;

e) velar pela moralidade das creanças quanto á frequencia aos cinemas, á leitura de livros e jornaes, á pratica de vicios como o alcool, o fumo, o jogo etc...

f) cultivar o sentimento patriotico e o civismo do povo;

g) cuidar da hygiene escolar e da assistencia ás creanças pobres, especialmente os orphãos e abandonados.

Art. $2^{\circ}$ - Como meios de instrumentos de que se servirá a Associação podem ser indicados, entre outros, os seguintes:

a) espalhar impressos e boletins de estimulo, informações e conselhos ás mães e aos professores, para melhor direcção da infancia, em todos os pontos de vista;

b) promover propaganda em favor da bôa imprensa, pela censura nos cinemas, pela prohibição da entrada de menores em tabernas, casas de jogos etc., pondo-se a sociedade em relação com as outras que collinem os mesmos objectos;

c) propor ao governo as medidas que julgar convenientes ao desenvolvimento do ensino e prestar ao mesmo as informações que solicitar;

d) auxiliar as Caixas Escolares;

e) fornecer vestimenta e livros, organizar cantinas escolares e instituições como a sopa escolar ou com o copo de leite escolar, para os alumnos pobres etc., etc., por meio das Caixas Escolares;

f) promover a acquisição de premios para serrem dados aos alumnos nos exames, por meio das Caixas Escolares;

\footnotetext{
${ }^{358}$ FAGUNDES, Abel. Lar e escola. Revista do Ensino, BH, ano X, n. 122-123, p.68-70, jan.fev.1936.
} 
g) collaborar com os professores na organização das festas civicas ou em beneficio das Caixas Escolares;

h) empregar quaesquer outros meios proprios para a realização dos fins da sociedade ${ }^{359}$.

O capítulo II do Estatuto evidenciava a importância financeira da instituição que deveria arrecadar fundos para as Caixas Escolares, as cantinas e tudo mais que os Grupos Escolares estivessem necessitando, notadamente, para o atendimento de seus alunos mais humildes. Não havia cobrança de mensalidade e os fundos da Associação eram adquiridos com festas e donativos de pessoas internas ou não à Associação. Apesar disso, para fazer parte da Associação, as senhoras deveriam apresentar bons requisitos morais e recursos financeiros. Não os tendo, deveriam ter boa vontade e disposição para obtê-los. Provavelmente, mesmo com as festas, eram os donativos que contavam para o funcionamento da Associação, por isso a exigência de recursos para as associadas. Em 1932, o Relatório do Grupo Escolar denunciava:

Existe no estabelecimento a Associação das Mães de Família, cuja diretoria é a mesma do ano passado. Esta Associação não tem eficiência nenhuma com relação á finalidade para que foi fundada. Quando se convoca uma reunião, ninguém comparece, a não ser a diretoria, cujos membros, às vezes, faltam também ${ }^{360}$.

É possível perceber, portanto, que tais Associações não conseguiam se manter por muito tempo, talvez porque faziam concorrência às próprias Caixas Escolares que também eram instituições de auxílio aos escolares e, cuja presença de associados do sexo masculino, favorecesse a obtenção de recursos mais abundantes que as Associações. Nem sempre este dinheiro arrecadado pelas Caixas e Associações era suficiente, e as professoras promoviam diversas atividades como quermesses, sessões de chá, de cinema, festas dançantes, entre outros, para conseguir recursos financeiros para os Grupos. Carlos Drummond de Andrade comenta, em suas crônicas, sobre estas atividades promovidas dessas associações beneficentes:

Pessoas inclinadas ao vício da estatística informam que, de janeiro até esta data, já se beberam e dançaram em Belo Horizonte nada menos do que quarenta e cinco chás dançantes, com quarenta e cinco fins diferentes, mas todos altamente simpáticos e meritórios. Eu não freqüento as estatísticas nem os chás, mas acredito em ambos. E do

\footnotetext{
359 Primeira ata do livro de atas das reuniões da Associação das Mães de Família do Grupo Escolar Olegário Maciel, datada de 18 de maio de 1929.

360 Relatório de 1932 encontrado no livro para o registro de relatórios enviados à Secretaria. A data do livro é 10 de dezembro de 1931.
} 
que me revela agora a voz fria dos algarismos, tiro conclusões altamente otimistas e consoladoras.

Quarenta e cinco chás dançantes em benefício de quarenta e cinco instituições de caridade ou de civismo são bem um índice de aperfeiçoamento da humanidade. ${ }^{361}$

Apesar da boa vontade da sociedade em contribuir com as escolas, não faltavam as críticas nos jornais. Em 1934, o jornal O debate anunciava: “A pobreza das Caixas Escolares - que se reserve alguma cousa dos banquetes politicos para soccorer a infancia necessitada ${ }^{, 362}$. O artigo na primeira página afirmava que, quase diariamente, o jornal recebia queixas de pessoas afirmando que as Caixas escolares não providenciavam roupas para os mais necessitados, mesmo tendo dinheiro. O jornal foi então ao Grupo Escolar Lúcio dos Santos no bairro Carlos Prates. A diretora Conceição Pinto afirmou que, no seu Grupo, a Caixa contava com a ajuda de menos de trinta sócios para atender a quase mil alunos que estudavam no Grupo, a maior parte deles pobres. Ela afirmava que retirava do seu próprio salário para ajudar a Caixa, além de promover festivais para auxiliar nas despesas. Segundo ela, a Caixa fornecia diariamente pão aos alunos e alunas pobres, na hora do recreio. Estas crianças passavam por comissões de sindicância, para apurar a real necessidade de receberem o pão. $O$ jornalista pediu para ver o movimento da Caixa, mas a diretora disse que a tesoureira estava doente, mas assegurava que era com muitas dificuldades que a Caixa do Grupo oferecia remédios, roupas e mantimentos aos pobres.

Outra publicação ${ }^{363}$, no dia seguinte, trazia uma carta recebida pelo jornal e enviada por José Antunes Rodrigues, atestando que as Caixas viviam em dificuldades porque dependiam de recursos próprios, enquanto o governo gastava a maior parte das verbas em “patuscadas regadas a 'champaggne' e enfumaçadas de havanas, nos amplos salões governamentais", salientando o descaso do governo por estas instituições.

Para conquistar as famílias e a comunidade para o trabalho escolar, estas eram convidadas para participar em auditórios especiais, nas festas religiosas, exposições de trabalhos pedagógicos entre outras atividades. No relatório de 1932 do Grupo Escolar Olegário Maciel, a diretora afirmava que, para conseguir a colaboração dos pais, organizava trimestralmente, em cada classe, uma exposição dos trabalhos dos alunos em

\footnotetext{
361 A crônica "Caminho do Céu” foi publicada no Minas Gerais em 24 de maio de 1931 na página 12 apud ANDRADE (1987, p. 122).

${ }^{362}$ O debate. 03 out. 1934 , ano I, n. 173. p. 1-2.

363 BANQUETES regados a champagne e estumados a havanas enquanto nos grupos escolares creanças desmaiam de fome. O debate. 04 out. 1934, anno I, n. 174. p.1.
} 
suas próprias carteiras. As crianças escreviam cartas aos pais, convidando-os a comparecerem ao Grupo, sendo o papel de carta e o respectivo envelope confeccionados pelos alunos na aula de trabalhos manuais. Segundo a diretora, esta medida proporcionou bons resultados, porque muitos pais compareceram ao Grupo e muitos alunos dos diversos anos que estavam muito fracos em todas as matérias no mês de setembro conseguiram se recuperar. Com a visita dos pais, eles tomavam conhecimento do fato e se empenhavam na melhora dos filhos. A diretora acrescentava que todos aqueles cujos pais compareciam às exposições progrediam muito e conseguiam a promoção ao ano seguinte.

Certamente, muitos pais e mães que trabalhassem no horário letivo não podiam comparecer à escola, podendo deixar frustrados os alunos e ainda ser responsabilizados pela escola por não auxiliarem na promoção dos seus filhos. Também nos casos de infreqüência e de indisciplina escolar, as famílias eram responsabilizadas, mesmo nos Grupos noturnos cuja clientela já tinha um pouco mais de idade, como se pode ver em um aviso no Grupo Escolar Assis das Chagas:

Recommendei à $\mathrm{Exm}^{\mathrm{a}} \mathrm{Snr}^{\mathrm{a}}$ Diretora que remettesse aos paes ou responsaveis pelos alumnos infrequentes cartões de aviso, tendo impresso, no verso dos mesmos, os arts. do regulamento que preceituam multas e que, ainda como meio de elevar a frequencia, instituisse, com auxilio da caixa escolar, premios bons, mensaes ou trimestraes, aos alumnos assiduos.

$[\ldots]$

Bello Horizonte, 30 de julho de 1928

Helena Penna, assistente technica, em commissão ${ }^{364}$.

Em alguns números no jornal Estado de Minas foram publicados nomes de responsáveis pelos alunos de Grupos Escolares de Belo Horizonte e do interior multados pela infreqüência destes nos Grupos Escolares, o que mostra que o Regulamento era cumprido no sentido de obrigar as famílias a enviar seus filhos à escola. Os pais deveriam se comprometer não apenas com a freqüência escolar, mas ficar cientes de todo o percurso dos alunos pela escola. Eram enviados boletins ${ }^{365} \mathrm{com}$ notas, avisos sobre o comportamento dos alunos e, nos casos indisciplinares mais

\footnotetext{
${ }^{364}$ Retirado do livro destinado aos Termos de Visitas em 14 de fevereiro de 1921.

${ }^{365}$ Em 1938, no Grupo Escolar Tomaz Brandão, noticiou-se que os alunos teriam registrados em seus boletins mensais não apenas a nota, mas também o cuidado pessoal e com os objetos escolares. Estes boletins não foram encontrados.
} 
graves, também os pais eram convidados a ir à escola para tomarem ciência e providências sobre o comportamento dos filhos.

\subsection{REPRESENTAÇÕES ACERCA DO MEIO SOCIAL DOS ESCOLARES E DE SUAS FAMÍLIAS}

Conhecer a infância tornava-se condição sine qua non para moldá-la segundo os interesses da sociedade. As famílias, especialmente as famílias pobres, eram percebidas como ignorantes, superticiosas, possuidoras de vícios e costumes anti-higiênicos que impediam-nas de oferecer um espaço sadio e adequado para a educação das crianças. "A instituição familiar naquela época era caracterizada como em permanente estado de mal funcionamento, era dada como incompetente, incapaz, sem qualidades para educar as crianças. Fazia-se urgente inseri-la nos padrões da normalidade" (Cunha, 2000, p.452$3)$.

As fontes pesquisadas indicam que havia uma grande preocupação relativa ao meio social dos alunos e de suas famílias, acreditando-se que a influência deste era crucial para a vida escolar dos alunos. Todos os documentos indicam que a crença era de que um ambiente mais rico levaria a uma vida escolar com maior sucesso e viceversa. A escola não se colocava em nenhum momento como uma instituição que pudesse alterar esta ordem dos fatores. Pelo contrário, acreditava-se que conhecer esse determinismo social era uma maneira de a escola contribuir para a sua manutenção, inclusive não despertando nos alunos ambições para além de suas condições sociais. Geraldo Félix comenta, por exemplo que, por estar a escola localizada num bairro da periferia da cidade naquela época, não se esperava dos alunos que continuassem a estudar:

E eu quero te contar uma coisa inédita. Tirei o meu diploma de $4^{\mathrm{a}}$ série e não sabia que existia mais estudo, eu tava convicto de que tinha acabado, encerrado a carreira de estudante. Não falavam isso. Não sei por que, porque nós éramos de periferia, o estilo de época. Eles nunca contavam que o estudo era importante, só diziam que tinha que formar, tirar o diploma porque nós íamos ser os soldados, nós íamos ser os operários e os soldados de amanhã. Se não estudasse não tinha condições de ser operário e soldado.Não falava nada além disso, eu ouvia falar longe que tinha um tal de admissão, mas nunca me explicaram o que era aquilo. Eu fiquei com minha $4^{a}$, depois que eu fui tomar consciência, já tava aprendendo pela vida. Eu entrei para a aeronáutica com a minha $4^{a}$ série. Fui ser soldado .... 
A necessidade de melhorar na carreira militar o teria levado a estudar continuamente, como ele afirma "apanhei uma fome de estudar...", chegando a estudar escondido em horário de trabalho. Mesmo assim, acredita que a escola o ajudou: “Tornei sargento com $4^{\mathrm{a}}$ série do Tomaz Brandão. Isso eu devo muito à escola. Eu não sei se essa demora também em formar, o cara repetente, firma mais, não sei o que que é..."

A constatação de Geraldo Félix de que as professoras não esperavam que os alunos chegassem a ter profissões mais valorizadas pode ser constatada nas reuniões do Grupo Escolar Tomaz Brandão em que, por diversas vezes, a questão do meio social pobre dos alunos vinha à tona. Este meio era tido como tendo influências perniciosas sobre os alunos. Já se precavendo da situação a ser enfrentada, estas eram as "animadoras palavras" da diretora do Grupo:

...como cristãs verdadeiras devemos subir as rampas do "Tomaz Brandão" com espirito de sacrificio e de caridade, pois aí vamos encontrar elemento humano paupérrimo, cujo meio de vida mais comum é catar papel.

Vê-se que a mentalidade destas crianças não póde ser normal, devido ao tratamento fisico que recebem.

A noção de que os alunos deste Grupo eram mais pobres não era baseada em suposições. Pesquisas realizadas pelo Laboratório de Psicologia da Escola de Aperfeiçoamento mostravam que as condições sócio-econômicas dos alunos do Tomaz Brandão eram das mais difíceis de todos os Grupos Escolares. Estas pesquisas contribuíam para dar um aspecto científico às diferenças sociais. Em 1934, o Boletim $n$. 15 publicou uma pesquisa sobre o coeficiente social dos alunos de dezesseis Grupos Escolares de Belo Horizonte, a partir da profissão dos pais. O resultado final foi:

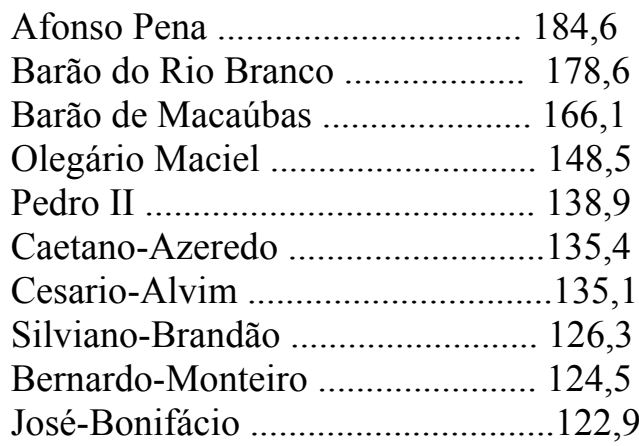


Lucio dos Santos .............................119,4

Francisco-Sales .............................. 109,9

Henrique-Diniz ..............................108,4

Sandoval-Azevedo ...........................104,1

João-Pessoa ....................................... 92,8

Tomaz-Brandão ................................ 86,0

Flavio dos Santos ............................... 81,6

Mariano de Abreu ................................ 77, $6^{366}$

Fazendo uma comparação entre os resultados apresentados pelos coeficientes sociais e os coeficientes mentais -os alunos foram submetidos ao Teste L.A. ${ }^{367}$ concluiu-se que havia uma relação entre estes dois índices, já que os maiores resultados no coeficiente mental dos alunos foram justamente apresentados pelos cinco Grupos com alunos advindos de melhores condições sociais. Pesquisas de Antipoff mostravam que eram os alunos das classes mais baixas que mais repetiam o ano e que havia uma forte relação entre os quocientes intelectuais e o nível sócio-econômico dos alunos ${ }^{368}$. Tais pesquisas justificavam que a reprovação se explicava pela incapacidade, incompetência e falta de talentos dos alunos mais pobres ${ }^{369}$.

... a ocorrência de crianças muito inteligentes é cerca de 3 vezes maior que a das pouco inteligentes, no meio privilegiado; no meio modesto, nas famílias dos operários e artífices, a relação é justamente inversa e muito mais acentuada do que no primeiro grupo. Em 58 crianças desse meio encontramos apenas 4 muito inteligentes contra 54 de inteligencia inferior. Póde-se ainda interpretar esse quadro da seguinte maneira: em um meio pobre, tem-se menos probabilidade de encontrar crianças inteligentes do que de encontrar crianças pouco inteligentes em um meio abastado e culto. ${ }^{370}$

${ }^{366}$ CASTRO, Maria Angelica. As classes do $1^{\circ}$ ano em 1933. Boletim n. 15. Belo Horizonte: Secretaria da Educação e Saúde Pública: 1934, p. 102-103

${ }^{367}$ Não foi possível identificar qual era o teste L.A., talvez se tratasse do teste E.A. apresentado no capítulo 06 .

${ }^{368}$ Essa relação não era nova. Daniel Antipoff comenta na biografia da mãe que, ao deixar a Rússia, Helena teve problemas com as autoridades soviéticas, pois suas pesquisas indicavam que "os filhos de intelectuais e nobres eram mais capazes do que os de proletários, partidários da Revolução". (1996, p. 83)

${ }^{369} \mathrm{Em}$ outras pesquisas utilizando os testes Ballard e de Dearborn. Antipoff indica claramente tal correlação, tratando dos Grupos Francisco Sales e Bernardo Monteiro com resultados inferiores; Olegário Maciel e Pedro II, resultados medianos; Barão do Rio Branco com um melhor resultado e, em melhor condição de todos, o Grupo escolar Affonso Penna. Cf. ANTIPOFF, Hélène. O desenvolvimento mental das creanças de Bello Horizonte segundo alguns tests de intelligencia geral. Boletim n. 7. Bello Horizonte: Secretaria da Educação e Saúde Pública; Inspectoria Geral da Instrucção, 1931, p.38. No ano seguinte, a aplicação do Teste Prime provocou algumas alterações nos resultados obtidos pelos grupos, com exceção para os Grupos Afonso Pena, Mariano de Abreu e Francisco Sales que mantiveram suas posições, respectivamente, $1^{\circ}, 11^{\circ}$ e $12^{\circ}$ lugares.

370 ANTIPOFF, Helena. O desenvolvimento mental das crianças de Belo Horizonte. Revista do Ensino., BH, n. 134-136, p.127-203, jan.mar.1937 ou ANTIPOFF, Hélène. O desenvolvimento mental das creanças de Bello Horizonte segundo alguns tests de intelligencia geral. Boletim n. 7. Bello Horizonte: Secretaria da Educação e Saúde Pública; Inspectoria Geral da Instrucção, 1931, p.192-193. 
Considerando que as crianças mais pobres eram percebidas como menos inteligentes, era preciso que a escola as preparassem para não ambicionar níveis sociais mais elevados e nem qualificações profissionais que não conseguiriam atingir. Em 1940, a Revista do Ensino publicou uma discussão de Helena Antipoff sobre sua pesquisa realizada em 1929 sobre a orientação profissional dos alunos do $4^{\circ}$ ano primário. A questão era "Quando você for grande, que deseja ser?". Segundo ela, as profissões de engenheiro, médico e advogado foram as mais escolhidas pelos meninos. As meninas escolheram ser professora e pianista. A autora então observava que tais escolhas não estavam relacionadas às atividades familiares e era preciso haver equilíbrio entre estas preferências, para haver equilíbrio social. As crianças deveriam suceder os pais nas suas respectivas profissões, não almejando alcançar níveis sociais mais elevados e à escola cabia a tarefa de selecioná-los segundo estes fatores. Em outro momento, Antipoff retoma o problema buscando auxiliar a orientação profissional no ensino primário. Com a mesma questão anterior, obteve os seguintes resultados:

QUADRO 8

Ocupações profissionais escolhidas por alunos(as) de Grupos Escolares

\begin{tabular}{lccc}
\hline Ocupações escolhidas pelas crianças & 1929 & 1934 & 1939 \\
\hline Liberais & $51,3 \%$ & $52,7 \%$ & $51,9 \%$ \\
Intermediários & $22,3 \%$ & $23,5 \%$ & $22,5 \%$ \\
Manuais & $18,9 \%$ & $18,5 \%$ & $17,5 \%$ \\
Outras & $7,4 \%$ & $3,8 \%$ & $8,3 \%$ \\
\hline
\end{tabular}

Fonte: ANTIPOFF, Helena. Iniciação à orientação profissional. In: CENTRO DE Documentação e Pesquisa Helena Antipoff. Coletânea das obras escritas de Helena Antipoff. Belo Horizonte: Imprensa Oficial, 1992, vol. I. "Psicologia Experimental", p. 265-278.

Entretanto, o confronto com o meio social obtido por meio de uma pesquisa feita em 1937 com 13.500 alunos de Grupos Escolares de Belo Horizonte revelava que eles ambicionavam profissões bem distintas daquelas que eram comuns em seu grupo social:

QUADRO 9

Relações ente o grupo social dos escolares e as profissões escolhidas

\begin{tabular}{ccc}
\hline Grupo Social & Meio Social & Profissões ambicionadas \\
\hline $1^{\circ}$ & $10 \%$ & $59 \%$ \\
$2^{\circ}$ & $20 \%$ & $13 \%$ \\
$3^{\circ}$ & $36 \%$ & $19 \%$ \\
$4^{\circ}$ & $34 \%$ & $8 \%$ \\
\hline
\end{tabular}

Fonte: ANTIPOFF, Helena. Iniciação à orientação profissional. In: CENTRO DE Documentação e Pesquisa Helena Antipoff. Coletânea das obras escritas de Helena Antipoff. Belo Horizonte: Imprensa Oficial, 1992, vol. I. "Psicologia Experimental". 
Os números revelam que $70 \%$ da população dos Grupos Escolares que participaram da pesquisa estavam no $3^{\circ}$ e $4^{\circ}$ grupos sociais. Pode-se supor que, de uma maneira geral, estava assim distribuída socialmente a clientela atendida pelos Grupos Escolares de Belo Horizonte. Como a maioria dos alunos provinha de meios sociais menos favorecidos, pode-se inferir que este era um dos motivos para a constante preocupação com o futuro profissional de tais crianças. Para Antipoff, a falta de uma orientação profissional adequada causaria o nomadismo - mudanças constantes de trabalho - e os acidentes e, em sua opinião, a escola primária teria como dever a orientação dos alunos segundo suas aptidões. Para auxiliar nesta tarefa, ela indicava os caminhos a seguir conforme as habilidades dos alunos:

Quanto aos indivíduos mediocremente dotados, o papel da escola é prevenir os futuros fracassos, aconselhando os pais, os próprios adolescentes a não visarem carreiras altas demais para a sua inteligência e aptidões. Convém acostumá-los a considerar, de maneira objetiva, seus dotes, sem entretanto criar neles o sentimento maléfico de inferioridade. Educar o caráter, insinuar tais virtudes como a modéstia, a prudência, a paciência aos pais como aos filhos, é prestar grandes serviços no seu futuro campo profissional. A regra para com estes alunos sem brilho e vigor intelectual é não procurar caminhos que levam para lugares altos demais. ${ }^{371}$

Para os talentosos, entretanto, Antipoff recomendava apenas "acompanhar, com maior atenção, a sorte destes alunos", como se o seu brilhantismo, reconhecido nas escolas, fosse também naturalmente reconhecido pela sociedade que, automaticamente, o encaminharia para funções adequadas para utilização dos seus dotes.

Por outro lado, também havia um estranhamento quando crianças de níveis sociais mais elevados escolhiam profissões manuais, como se pode perceber num relatório de uma classe de um Grupo Escolar em Belo Horizonte:

Dois meninos estão aprendendo oficio: um pretende ser alfaiate, o de n.7; e outro pensa em ser sapateiro.

Interessante! - Este ultimo menino, o de n.34, é filho único; o pai tem uma profissão muito diferente da de sapateiro, e a familia parece viver comodamente ${ }^{372}$.

${ }^{371}$ ANTIPOFF, Helena. Iniciação à orientação profissional. In: CENTRO DE Documentação e Pesquisa Helena Antipoff. Coletânea das obras escritas de Helena Antipoff. Belo Horizonte: Imprensa Oficial, 1992, vol. I. "Psicologia Experimental", p.277.

${ }^{372}$ MONOGRAFIA de um [sic] classe escolar de Belo Horizonte: estudo escolologico de 1931. Boletim n. 9. Belo Horizonte: 1931, p.22. 
Assim como os Grupos Escolares de periferia, também os Grupos noturnos atendiam a crianças de estratos sociais mais baixos. Por isso mesmo, as atenções dos inspetores e professores eram muito mais sobre os aspectos disciplinares do que propriamente pedagógicos.

As condições economicas dos alumnos e de suas familias, de proletarios, impedem uma frequencia normal. Em todas as classes prestei assistencia technica às professoras. No estabelecimento, quanto possivel, há ordem e disciplina e asseio. O conjuncto da docencia não é homogeneo quanto ao poder didactico, dahi não ser efficiencia do ensino egual em todas as classes. As professoras são geralmente dedicadas á sua ardua profissão e disciplinadas. É entretanto de justiça reconhecer que há aproveitamento geral dos alumnos. Chamo a attenção da esforçada directora e de algumas professoras para as seguintes instrucções: a) as professoras devem ser para os discipulos paradigmas de compostura e correcção em suas attitudes, gestos e actos; b) falar muito e gritando em aula é gravíssimo erro pedagógico, porque irrita os alumnos, dá ensejo á desattenção delles e consequentemente à indisciplina ....

[...]

Bello Horizonte, 13 de outubro de 1927

Ernesto C. Santiago, inspector regional e municipal",373

O Regulamento do Ensino Primário de 1927 reiterava a idéia de que, para os menos capazes, a escola deveria se comprometer mais com a educação que com a instrução, inserindo "sem choques e desarmonias" as crianças na sociedade vigente. A tarefa da escola consistia, portanto, em conformar, disciplinar e adaptar sem jamais se comprometer com uma transformação social.

A figura representando a Escola Moderna publicada na Revista do Ensino ${ }^{374}$ é bastante sugestiva sobre o tratamento dado pela escola às crianças dos meios mais pobres. Na figura, a criança que aparece resolvendo o problema aritmético colocado no quadro está muito bem vestida, talvez uniformizada, já que era costume que o uniforme escolar apresentasse golas tipo marinheiro ${ }^{375}$. Ao lado da professora, uma criança pobre - com roupas remendadas - assiste a cena, mas não parece participar ativamente do exercício. A professora, num gesto muito sugestivo, "passava a mão na cabeça” da criança pobre.

\footnotetext{
${ }^{373}$ Retirado do Termo de Visitas do Grupo Escolar Assis das Chagas.

${ }^{374}$ Cf. Capítulo 2.

${ }^{375}$ É interessante que este mesmo uniforme era utilizado também na Escola Normal de Belo Horizonte, como se pode conferir nas fotografias, anexas à tese, de Luíza Travassos Ribeiro Campos. Norma Lúcia conta também que seu uniforme no Grupo Escolar era assim.
} 
A instrução era considerada perigosa para as classes mais desfavorecidas, justamente porque criava o desejo de exercer ofícios mais intelectualizados, o que prejudicaria a ordem social estabelecida. Diversos artigos na Revista do Ensino, principalmente da Sociedade dos Amigos de Alberto Torres, enfatizavam a importância de se manter o homem no campo e criticavam a oferta de escolas primárias no meio rural.

O analfabeto não fez ao Brasil, até hoje, nenhum mal. Todas as nossas desgraças, isto é, toda a nossa desorganização política, não é obra do homem do povo, na sua ignorancia; mas do bacharel, do homem diplomado, dos que fazem as leis e dos que as fazem cumprir, isto é, da "élite" letrada, á qual tem estado entregues os destinos nacionais.

$[\ldots]$

Nucleos de trabalho rural do sertão, que produziam a farinha, o feijão e o milho, foram completamente destruidos por meia duzia de escolas primarias. Brasileiro que sabe lêr nome não péga mais no cabo da enxada: abandona a lavoura e vem para a cidade ${ }^{376}$.

Benedita comenta que o sucesso de sua classe no Grupo em Uberabinha lhe rendeu um convite para trabalhar com uma turma de $4^{\mathrm{a}}$ série no Ginásio. No ano seguinte, como estava em turmas de $3^{\circ}$ ano no Grupo e no Ginásio, ela achou que pudesse trabalhar com o mesmo programa. No entanto, constata “...pela experiência, que as diferenças individuais são um fato e que a professôra jamais poderá desconhecêlas ou fingir ignora-las". Entretanto, o que Benedita nota a respeito das diferenças individuais, nos parece relacionar mais diretamente com as diferenças sociais. Ela comenta que os alunos da $4^{\mathrm{a}}$ série tinham um nível intelectual admirável, vindo de um meio excelente, fazendo perguntas que levavam a professora a consultar livros para poder dar a resposta. Benedita comenta que não gostava de declarar o meio social de seus alunos, não fazendo distinção entre eles, mas, ao assumir as classes do Ginásio, tinha certeza de que aqueles alunos "prometiam ser a glória de Minas", citando alguns nomes que confirmaram a sua previsão.

As crianças mais favorecidas economicamente tinham melhores condições escolares e até mesmo maior oportunidade de leitura. No Grupo Escolar Olegário Maciel, por exemplo, os livros da Biblioteca Infantil eram alugados aos alunos que quisessem fazer sua leitura em casa. Embora os alunos pobres também tivessem o direito de levar os livros para casa, tudo dependeria de uma rigorosa avaliação e da boa-

${ }^{376}$ CAMPOS, Humberto de. O elogio ao analfabeto. Revista do Ensino, BH, ano VII, n.86, p.22-24, abr.1933, p. 22-23. 
vontade da escola. Este fato mostra que o melhor desempenho escolar das crianças das classes ricas pode ser explicado também pelo maior acesso que a escola lhe facultava à leitura de livros da biblioteca e também à participação de eventos pedagógicos e sociais.

Quando as classes anexas à Escola de Aperfeiçoamento foram criadas, foi preciso reunir às pressas diversos alunos de outros Grupos Escolares e, por isso, não houve seleção. A primeira turma, de acordo com Imene Guimarães, uma de suas primeiras professoras, era de favelados, depois disso, os alunos passaram a ser selecionados, sendo da classe alta e muito inteligentes. Olga Ullman também confirma que as crianças das classes anexas eram todas de nível social muito bom. Para tais classes, pertencentes à Escola que era o símbolo maior do investimento do governo na educação primária, era preciso reunir as crianças mais inteligentes e também mais ricas que servissem de modelo e propaganda dos escolares mineiros.

É muito provável que os alunos líderes e mais participativos nas atividades e associações escolares fossem sempre de estratos sociais mais elevados. Uma aluna do $3^{\circ}$ ano do Grupo Escolar Sandoval de Azevedo comenta num texto sobre o Clube de Leitura publicado no jornalzinho: "Foi escolhida a diretoria do nosso Clube de Leitura. Os meninos que ganharam votos são muito bons e estudiosos. Apresentam-se bem vestidos, limpos e são inteligentes". Se a inteligência e a limpeza não são atributos exclusivos dos alunos mais ricos, o mesmo não se pode dizer do fato de apresentarem-se bem-vestidos.

Diversas festas, eventos e atividades escolares terminavam por prestigiar sempre os alunos com maiores recursos financeiros. Numa festa em comemoração à Semana das Crianças no Grupo Escolar Flávio dos Santos, foi apresentado um desfile de “bonecas”, em que as meninas do Grupo representavam a França, Portugal, Espanha, Rússia, Japão e Holanda. Apesar da justificativa para a festa ter sido a Semana da Criança e ter sido "dedicada aos pequeninos do nosso amado Brasil", nenhuma criança o representou. As meninas escolhidas para representar os países certamente deveriam ter condições para comprar roupas apropriadas para a afesta. Além de já serem selecionadas para comporem a apresentação, ainda seria coroada aquela que melhor tivesse feito a representação.

Se as crianças belas, brancas, sadias, robustas e ricas eram sempre as escolhidas para fazer parte das festas escolares e estar à frente nas fotografias, nos desfiles, nas 
apresentações e outras atividades, existiam também aquelas que, desafortunadamente, eram o oposto dessa imagem de saúde e beleza: crianças que iam descalças, as de pele negra e, desse modo, consideradas feias, as que não podiam adquirir roupas para os desfiles, mesmo que trajassem decentemente, as famintas e as doentes que preenchiam os pátios escolares com suas dificuldades, fraquezas, sofrimentos e feiúras. E selecionálas, ocultá-las, colocá-las nos porões, no fundo da classe, com as professoras menos experientes e também menos famosas não parecia ser suficiente para ocultar a fome, as doenças, a pobreza que as suas presenças traziam para o ambiente escolar. Por este motivo, algo precisava ser feito. Dotar essas crianças de condições mínimas para freqüentar o ambiente escolar era uma forma de minorar as diferenças sociais entre as crianças ou de tornar possível e menos doloroso o trabalho pedagógico e disciplinador. Além disso, sabe-se que muitas das crianças pobres eram estigmatizadas como feias, pela suas características sociais e raciais, pela ausência de um vestuário melhor e sofriam diversas formas de preconceito e exclusão na escola. Oferecer uniformes, cuidados médicos e higiênicos, melhores condições alimentares era fundamental para tornar a convivência com estes grupos sociais menos ameaçadora e incômoda, embora, de modo algum, extinguisse o estigma do preconceito.

\subsection{DISPOSITIVOS DISCIPLINARES: ENTRE A ESCOLA E A FAMÍLIA}

\subsubsection{O UNIFORME ESCOLAR}

Um dos mais evidentes símbolos da condição social é o vestuário. Talvez por este motivo, escolarizar as crianças e dotá-las de um uniforme desse a ver o investimento do governo estadual na educação primária e reunisse as crianças de diferentes estratos sociais numa classe única: a de alunos dos Grupos Escolares. Embora o Regulamento do Ensino Primário de 1927 afirmasse que o uniforme não deveria ser obrigatório para não impedir o acesso à escola daqueles que não pudessem providenciálo, na prática, este parecia ser sempre exigido. Benedita Dell'Isola afirma que os uniformes dos alunos do Grupo Cristiano Machado eram muito brancos e essa era uma exigência da diretora que excluía das excursões os alunos que não estivessem rigorosamente uniformizados. Numa reunião do Grupo Escolar Tomaz Brandão, a 
diretora recomendava às professoras que ficassem atentas ao estado de conservação dos uniformes dos alunos que iriam à procissão da Semana Eucarística, devendo escolher ainda os alunos de melhor comportamento. Em outra reunião, se esclarecia que, se os meninos que não tivessem terno e as meninas, vestido branco, não poderiam participar da cerimônia de formatura no Estádio Benedito Valadares, ocorrida em 1941.

Tarcísio Mauro Vago salienta o quanto a cor branca funcionava como disciplinadora dos corpos infantis, especialmente para as meninas:

O uso do branco por meninas e professoras não parece ter sido escolha casual como cor predominante no uniforme. Além da impressão da limpeza que dessa cor emana, a destinação e o uso de roupas brancas pelas meninas podem revelar também um desejo de conter seus movimentos e práticas corporais, que provocariam sujeiras facilmente visíveis. A exposição ao vexame por desmazelo e a conseqüente repreensão seriam iminentes. Imagine-se o esforço das meninas para evitá-las. Ao contrário, a maioria dos meninos usa roupas escuras, o que também parece proposital, antecipando cuidados para esconder por mais tempo impurezas contraídas na movimentação deles pelos espaços escolares. A maneira de vestir as crianças é evidência de que a imposição de bons modos e o controle dos deslocamentos não eram iguais para meninos e meninas, aparecendo, aqui também cuidados diferenciados que interferem na produção do feminino e do masculino nas práticas escolares. (2002, p.162-163).

Embora não tendo se constatado nesta investigação se havia essa diferença no uso das cores nos Grupos Escolares pesquisados, é notável que os uniformes, a despeito de constituírem uma tentativa de apagamento das diferenças sociais, não conseguiam fazê-lo com eficácia, tanto em termos de classe social como em termos de gênero. A cor escura do traje era uma característica da moda masculina do período, mas é evidente que o uso da roupa branca exigia da mulher e da menina um comportamento mais contido para evitar mostrar excessivamente o corpo. Os laços, fitas, babados, as saias (as mulheres não usavam calças neste período) e a roupa branca exigiam todo um cuidado ao se sentar, ao se levantar, ao correr, ao caminhar. Norma Lúcia comenta que, ao entrar no Grupo, os alunos tinham que esperar assentados o sinal para fazer as filas, não podiam correr ou brincar neste período. Ainda que pudessem fazê-lo, as roupas das meninas exigiam sempre movimentos mais lentos e delicados. Os laços, por exemplo, colocados no alto da cabeça das escolares, além de distinguir socialmente as que tinham um laço maior e feito com tecidos mais nobres, demandavam atenção e maior imobilidade por parte das meninas. Luíza Travassos esclarece todo o cuidado na produção e manutenção dos laços: 
L.T.: Ah! Tinha uniforme, era obrigado a ir de uniforme, era uma saia toda pregueada, uma blusinha e tinha um laço de fita de organdi. Comprava uns $5 \mathrm{~cm}$ de largura mais ou menos, mandava picotar, fazer ponto ajour e fazia aquele laço e tinha que ser engomado, aquilo era bonito todos com aquela borboleta na cabecinha das meninas. A gente não dava o laço na hora não, tinha que fazer, armava o laço, prendia e aí colocava um grampo ou pregava um pouco do cabelo pra por a fita senão ela caía, se fosse largo saía, incomodava. E era um laço só. A gente fazia com cuidado, ainda dava pra quinze dias, mas se não tivesse, se sujasse. Naquele tempo tinha muita poeira, as ruas nem todas eram calçadas. Mas aquele laço de fita que era o horror do uniforme porque dava trabalho, tinha que engomar, porque o organdi só arma engomando. Aí abria, ficava aquilo bonito. As quatro partes do laço.

A maioria dos entrevistados afirmou que o uso do uniforme era obrigatório e os alunos iam uniformizados para as escolas. Aqueles que não podiam providenciá-lo, ganhavam o tecido com o dinheiro da Caixa Escolar e, em alguns casos, as próprias professoras confeccionavam-no.

Segundo Norma Lúcia, as crianças da Caixa Escolar ganhavam um uniforme diferente das outras crianças e o seu uso era obrigatório. Geraldo Félix conta que, no Grupo Escolar Tomaz Brandão, as famílias pobres não ganhavam ajuda para a compra do uniforme e tinham que "se virar". As aulas de Educação Física, por exemplo, só eram feitas por quem tivesse uniforme específico, por isso, ele nunca participou dessas aulas. O decreto n. 11.411 de 1934, que discorria sobre a Inspetoria de Educação Física no Estado, tratava em detalhes do uniforme dos alunos:

Art. 17. A indumentária para as actividades da Educação Physica deve ser apropriada e uniforme,tanto para o aluno como para o professor.

$\S 1^{\circ}$. Para os alumnos do sexo feminino, o uniforme constará de uma saia-calção, azul, preta, cinzenta ou branca, e blusa branca; sapatos com sola de borracha ou alpercatas; meias compridas ou curtas, segundo a edade.

$\S 2^{\circ}$. Para os alumnos do sexo masculino - calção á altura dos joelhos, camiseta sem mangas e sapatos de sola de borracha ou alpercatas. [...]

Embora Geraldo Félix confirmasse a exigência do uniforme, acrescentou que esta não se estendia aos calçados e os alunos pobres iam descalço para a escola. Segundo ele, para conseguir que todos fossem uniformizados, a escola não exigia um único padrão. Tinha que ser uma camisa branca e uma calça azul. Mas cada família fazia as roupas com os recursos disponíveis. As mais pobres faziam o uniforme com saco de farinha de trigo e, para as calças, as mães faziam uma tinta caseira e tingiam o 
tecido de azul e estes uniformes ficavam verdadeiras "marmotas",377, segundo suas lembranças.

Marmotas ou não, o que se pode perceber é que os alunos tinham mesmo que estar uniformizados não apenas para assistir as aulas, mas principalmente para participarem de cerimônias que dariam visibilidade aos Grupos Escolares. Para conseguir esta padronização e para auxiliar os alunos em outras necessidades imprescindíveis para o bom andamento da vida escolar, foram criadas as Caixas Escolares.

\subsubsection{CAIXAS ESCOLARES}

Os Grupos Escolares deparavam-se com a necessidade de auxiliar os alunos pobres que vinham sem uniforme e sem alimentação para as aulas. As Caixas Escolares valiam-se da contribuição mensal dos sócios e benfeitores, entre eles os próprios alunos com melhor condição social, da organização de festas, rifas, sessões de cinema e tudo quanto fosse possível para arrecadar ajuda para as crianças. A merenda escolar só era distribuída gratuitamente aos alunos inscritos na Caixa e era vendida aos outros, cujo dinheiro retornava para a Caixa. O art. 54 do decreto n. 10.362 de 1932 determinava que: "Em favor das caixas escolares reverterá o que os professores e funcionários do ensino de cada estabelecimento perderem de seus vencimentos, qualquer que seja o motivo, e que não tenha sido aplicado no pagamento de seus substitutos". Por isso, os funcionários que chegassem atrasados ou perdessem o dia de trabalho tinham um desconto salarial que ia para a Caixa Escolar. No Grupo Escolar Tomaz Brandão as professoras, com exceção das substitutas, eram obrigadas a contribuir para a Caixa e, quem não pudesse contribuir, tinha que procurar alguém para fazê-lo ${ }^{378}$. Também os alunos dos Grupos Escolares eram convidados ou convencidos a contribuírem mensalmente para a Caixa como mostra um recado deixado às professoras no livro de ponto do Grupo noturno Afrânio de Melo Franco:

\footnotetext{
${ }^{377}$ Um dos significados atribuídos à palavra "marmota", segundo Houaiss é: "pessoa mal-ajambrada, desengonçada, deselegante; espantalho".

${ }^{378} \mathrm{Na}$ reunião de 03 de abril de 1943 , as professoras foram "convidadas" a participar das Caixas Escolares, quem não quisesse fazê-lo, "poderia" colocar outro sócio em seu lugar. A diretora afirmava, ainda, que as professoras substitutas ficavam isentas da contribuição para a Caixa, o que deixa claro que o convite era mais do que um simples convite, mas uma obrigação. No entanto, em outra reunião, de 25 de março de 1944, se diz que a única fonte de renda da Caixa Escolar era as faltas das professoras.
} 
Peço a todas as professoras fazerem uma lista de todos os alunos que quizerem contribuir, mensalmente com esmola para a Caixa Escolar. Quem puder ser socio efetivo dando 2 cruzeiros para auxilio dos companheiros mais pobres, receberá um talãozinho cada vez que pagar. Esses socios efetivos ter o direito de na ocasião do beneficio a ser distribuido - tem o direito de avisar quais os que mais precisam do auxilio. Cada socio que tiver 5 recibos de dois cruzeiros, pode indicar o candidato de sua preferencia, desde que esse candidato seja aluno do grupo e seja pobre.

Essa lista, se possivel, será organisada ainda esta semana, até o dia 15 - para que na proxima reunião da Caixa - este mês, possamos ler o nome de todos os alunos caridosos. Quem não puder dar dois cruzeiros, mas quizer fazer a caridade, dê o que as posses permitirem e Deus o recompensará.

Peço às professoras leiam em voz alta e expliquem aos seus alunos o que acima escrevi, e agradeço pessoalmente a todas o esforço para esse fim. ${ }^{379}$

Em 1940, no governo de Benedito Valadares e do Secretário Cristiano Machado, o decreto-lei n. 734 tornava obrigatória a existência das Caixas Escolares nos estabelecimentos públicos de ensino primário com as seguintes finalidades:

a) fornecer merenda, roupa e calçado aos alunos pobres do estabelecimento;

b) adquirir e distribuir livros didáticos e material escolar entre os alunos a que se refere a alínea anterior, e conferir prêmios escolares aos alunos que se distinguirem nos cursos;

c) prestar assistência médico-farmacêutica e dentária aos alunos que não possam tê-la à custa dos pais ou responsáveis. ${ }^{380}$

Conforme o decreto, eram protetores da Caixa professores, funcionários e alunos do estabelecimento e benfeitores as pessoas de fora do estabelecimento que contribuíssem mensalmente com qualquer quantia e aqueles que pagassem a taxa escolar $^{381}$.

As rendas para a Caixa Escolar vinham de uma taxa estadual específica ${ }^{382}$, outras taxas e contribuições do Estado e Município, festas organizadas em seu benefício, doações, valores descontados dos professores e funcionários do ensino e não aplicados no pagamento de substitutos, mensalidades e taxas escolares. O decreto advertia, ainda, que os materiais escolares seriam cedidos aos alunos como empréstimo, durante o ano letivo, e que as Caixas deveriam ter o nome do estabelecimento no qual estava inserida.

\footnotetext{
${ }^{379}$ Aviso deixado pela diretora Maria Araci Lessa provavelmente em fevereiro de 1947.

${ }^{380}$ MINAS GERAIS. Decreto-lei n. 734 de 17 set. 1940. Dispõe sobre Caixas escolares.

${ }^{381}$ A taxa escolar fora criada pelo art. 48, do decreto-lei n. 67 de 20 de janeiro de 1938. Em 1939, o decreto-lei n. 164 definia que a taxa escolar seris arrecadada em dinheiro entregues às Caixas Escolares.

${ }^{382}$ Taxa destinada à Caixa Escolar pelo decreto-lei estadual n.164, de 7 de janeiro de 1939.
} 
A idéia cristã da caridade estava presente nessas Associações que eram uma forma de o governo dividir o custo pela oferta de educação com a própria sociedade. Uma notícia curiosa publicada num jornalzinho escolar de uma escola em Pedro Leopoldo mostrava que a idéia da caridade era de diminuir o incômodo causado pela pobreza, mas jamais acabar com ela própria:

Banco dos Pobres

Brevemente vai-se inaugurar nesta cidade uma casa que vai chamar-se Banco dos Pobres.

Esta casa deve ser muito útil. A primeira cousa que ela vai fazer é proibir os pobres de esmolarem de porta em porta. Todos desta cidade que quiserem, vão pagar ao Banco dos Pobres, mensalmente, de $2 \$ 000$ para cima. A casa que der esta quantia, terá uma placa com a inscrição: B.P.

Os pobres não vão assim pedir esmolas nessas casas, mas vão buscar no Banco. ${ }^{383}$

A idéia de buscar a esmola no banco pode ser associada à idéia de buscar algum conforto material também na escola, e isso se fazia principalmente através do auxílio das Caixas Escolares. O dinheiro arrecadado pelas Caixas era gasto com a distribuição de merenda aos alunos pobres, a compra de tecidos para os uniformes de alunos, para a roupa da formatura, para a confecção de agasalhos, a compra de medicamentos, materiais didáticos e também para a distribuição de prêmios entre os alunos.

Com a ampliação do atendimento escolar um problema que até então estava circunscrito às famílias torna se público: a alimentação dos alunos pobres. Uma das formas de minimizar esta dificuldade era oferecendo alimentação através das cantinas, já que alguns alunos não tinham o que comer durante todo o período escolar.

\subsubsection{CANTINAS ESCOLARES}

A alimentação dos alunos era um problema também escolar pois, como não havia merenda oferecida pelo próprio Estado e muitos não tinham alimentação garantida pelas famílias, os Grupos Escolares se deparavam com a situação de alunos famintos durante todo o período de aulas. Geraldo Félix diz que, logo na chegada à escola, os alunos recebiam um copo de leite gelado: "Tinha leite gelado, de manhã cedo. Abria

\footnotetext{
${ }^{383}$ ATIVIDADES Escolares. Revista do Ensino, BH, ano VI [sic], n. 71,72 e 73, jul.ago.set.1932, p.69. [Notícia publicada no jornalzinho do Grupo Escolar de Pedro Leopoldo no dia 24 de julho de 1931, pelo aluno José Baia]
} 
com leite gelado, se não desse aquilo, nós estávamos perdidos. Não é toda hora que tinha coisa nas casas, não". Esse leite garantia que as crianças já se alimentassem antes do início das aulas e no recreio era sempre servido um mingau, uma sopa, lembra o exaluno.

A idéia de que a alimentação iria auxiliar nos trabalhos escolares levava os Grupos a se empenharem na construção de cantinas. No histórico do Grupo Escolar Bernardo Monteiro também se fala no "copo de leite" que teria sido inaugurado em 1927:

Desde 1926, inicio deste grupo escolar, era distribuido pão entre as crianças pobres; logo depois, por iniciativa da então diretora D. Guiomar Vaz de Melo, improvisaram um fogareiro, onde se preparava mingau de fubá, o qual era servido em canequinhas, levadas ás salas em taboleiros. Cozinhavam com serragem trazida de uma lenharia proxima. Tinham apenas uma lata de banha grande, algum tempo depois passou a ser servido em um dos corredores, onde colocaram uma mesa. ${ }^{384}$

A cantina se mantinha com a venda de sopas para os alunos que pudessem pagar, com as frutas colhidas na horta do Grupo e com os donativos de professores. Em 1948, por iniciativa de várias professoras, foi conseguido com o Secretário de Agricultura o fornecimento de trinta litros de leite durante três dias na semana. Além disso, contava-se com a ajuda do Banco do Brasil, de um representante da Companhia Força e Luz e de um dono de bar da região.

Este relato revela as dificuldades encontradas pelas escolas para oferecer alimentação aos alunos. Apesar disso, os Grupos se esforçavam. Em 1933, a Revista do Ensino informava que sete Grupos Escolares em Belo Horizonte possuíam cantina: Silviano Brandão, Bernardo Monteiro, João Pessoa, Flávio dos Santos, Mariano de Abreu, Henrique Diniz e Tomaz Brandão ${ }^{385}$. Eram justamente aqueles que atendiam aos bairros menos favorecidos e cujas crianças eram mais necessitadas.

Em janeiro de 1935 foi criada a "Associação das Cantinas Escolares", cujos objetivos foram detalhados em um regulamento:

Art. $1^{\circ}$ - A Associação das Cantinas Escolares tem por fim:

\footnotetext{
${ }^{384}$ Histórico da Cantina "Dr. Teofilo Santos” 08 de outubro de 1948. São duas páginas coladas entre as páginas 27 e 28 do livro que traz o Histórico da Escola Estadual Bernardo Monteiro.

${ }^{385}$ CASTILHO JUNIOR, J. Cantinas escolares. Revista do Ensino, BH, ano VII, n. 95, p.81-82, out.1933.
} 
$1^{\circ}$ ) Promover alimentação racional às crianças que freqüentam as escolas primárias estaduais.

$2^{\circ}$ ) Educar as crianças no que respeita à higiene alimentar.

$3^{\circ}$ ) Servir de centro de estudos e observações sôbre a alimentação em geral e particularmente nas escolas.

Art. $2^{\circ}$ - As refeições e merendas serão gratuitas para as crianças pobres e cedidas por preço módico às que possam pagá-las.

Art. $3^{\circ}$ - A Associação terá sua sede nesta Capital, podendo ter filiais em qualquer ponto do Estado.

Parágrafo único - Os estatutos destas serão submetidos à aprovação da Associação central, para fins de filiação.

Art. $4^{\mathrm{O}}-\mathrm{A}$ Associação terá duração indeterminada. ${ }^{386}$

Oferecer alimento às crianças pobres dos Grupos Escolares era não somente uma forma de caridade que diminuiria o sofrimento destas, mas também uma forma de evitar que a convivência com outras crianças de estratos mais elevados criasse revolta e inconformismo. Alimentar, neste caso, era também uma forma de conformar e disciplinar as crianças mais pobres.

Conseqüentemente, a fome é cúmplice da indisciplina.

A falta de alimento leva a criança à rebeldia, à inveja e até ao roubo.

O pobrezinho que não almoçou e não tem um tostão no bolso para comprar a merenda é tentado a roubar o tostão ou a merenda do seu colega.

No recreio, quando os outros comem, gulosos, doces ou frutas, o infeliz pequeno rala-se de inveja, lançando um olhar cubiçoso aos petiscos que ele gostaria tanto de saborear.

Daí, quantas vezes não nasce o despeito, o ódio contra os colegas mais favorecidos da fortuna...

A criança definha-se, e na sua almazinha frágil de degenerado vão se aninhando hábitos e impulsos que the formarão o caráter e que a levarão ... sabe Deus onde! $!^{387}$

Uma boa alimentação poderia contribuir, segundo a diretora do Grupo Escolar Olegário Maciel, para diminuir a falta de atenção dos alunos. Em 1944, o Grupo informava que havia alunos que pagavam mensalidades para utilizar a cantina e que eles recebiam cartões de cores diferenciadas, segundo o grau de nutrição e o tipo de alimento que deveriam receber, sentando em mesas diferentes, segundo a cor do cartão recebido. Não foi possível saber como esses alunos eram selecionados, provavelmente com o auxílio do médico e da enfermeira escolar. Também na ata de uma reunião no Grupo Escolar Tomaz Brandão está registrada a necessidade de uma melhor distribuição dos cartões de sopa, mas não se esclarece como isto era feito.

${ }^{386}$ CANTINAS escolares. Educando, BH, ano I, n. 4, p. 3-5, jun. 1940, p. 4-5.

387 SANTIAGO, Alice de Andrade. A merenda e as caixas escolares. Revista do Ensino, BH, ano VIII, n.101, p.28-30, abr. 1934, p.29. 
Essa separação dos alunos pelas cores é bastante sugestiva. Sabendo que os alunos com melhor situação financeira compravam a merenda e que esta renda era revertida para as Caixas Escolares fica a dúvida: os cartões eram para oferecer uma alimentação segundo o grau de nutrição dos alunos ou segundo o pagamento efetuado? É de se duvidar que às crianças mais ricas, que custeavam a merenda, fosse oferecida uma sopa com menos ingredientes, já que elas eram mais bem nutridas e; para as mais pobres, a sopa mais rica em proteínas e vitaminas sendo elas as mais necessitadas. No entanto, não foi possível averiguar como era dada esta diferença. Apesar disso, é preciso notar que, mesmo não havendo uma diferença na alimentação oferecida para as crianças, somente a existência de cartões de cores distintas já poderia ser um indício de humilhação para as crianças mais pobres.

Em agosto de 1940, a revista Educando informava que a Associação das Cantinas Escolares instalara duas cozinhas nos Grupos Cesário Alvim e Vila Celeste Império $^{388}$. A notícia acrescentava que, depois disso, a freqüência do Grupo Vila Celeste Império subira a 100\%, havendo, diariamente, pedidos de pais para matricular os filhos.

Se a alimentação dos alunos era garantida, os adoecimentos infantis eram outro problema a ser encarado pelas escolas e, para isso, o auxílio da Medicina era imprescindível.

\subsection{MEDICINA, HIGIENE E SAÚDE NA ESCOLA: PRODUZINDO UM CORPO DISCIPLINADO}

A atuação da Medicina está sempre condicionada ao que é compreendido como sendo doença e saúde em um determinado contexto sócio-histórico. Para compreender qual a importância da atuação dos médicos na escola é preciso decifrar estas concepções e suas implicações para a educação naquele momento.

Helena Antipoff, maior representante da Psicologia em Minas Gerais no período, nos adianta o que ela compreendia como doença. Em uma carta enviada aos alunos do Grupo Escolar Sandoval de Azevedo justificando sua ausência em uma reunião do Clube de Leitura do qual havia sido eleita como patronnesse, ela afirmava não merecer a homenagem e sugeria outros nomes como o da professora falecida Naitres Maria de Rezende que teria dedicado a sua vida em prol da educação das crianças. Segundo

\footnotetext{
${ }^{388}$ O decreto municipal n. 3.235 de 20 de abril de 1978 alterou, para Bairro Celeste Império, a denominação da Vila Celeste Império.
} 
Antipoff, a referida professora e psicóloga, já havia trabalhado no Grupo, sendo capaz até de ensinar crianças surdas-mudas a falar. Ela atendia "crianças doentes que não progrediam nos estudos, porque lhes faltava alguma capacidade de inteligência, de memória ou de carater".

Ao comentar o trabalho da professora, chama a atenção o qualificativo de doentes para crianças que tinham dificuldades de aprendizagem. $\mathrm{O}$ adoecimento, nas suas palavras, se caracterizaria pela falta de atributos necessários à aprendizagem como a inteligência e a memória. O fato de Helena Antipoff, pioneira na inserção da psicologia na educação mineira, atribuir os problemas de aprendizagem à falta de caráter dos alunos numa carta endereçada a estes revela o quanto se imputava aos próprios alunos a responsabilidade pelo atraso escolar, além da concepção de doença que estava em voga no período.

São diversos os documentos consultados que produzem uma estreita vinculação entre as doenças de origem física e as manifestações de ordem psíquica. Um artigo da Revista do Ensino intitulado A criança e o crime, por exemplo, defendia a idéia de que na infância poderiam ser detectados os primeiros sinais de tendências e predisposições para a criminalidade, o que possibilitaria uma intervenção a tempo de tais tendências serem tratadas e de se impedir seu avanço.

Citaremos certos exemplos de distúrbios físicos da infância que podem ser reconhecidos desde logo, por médicos psiquiatras especializados, a fim de surpreender e corrigir as tendências e predisposições naturais de certas crianças para o crime. Aqui é preciso destacar, desde logo, a contribuição decisiva da herança. Os filhos dos sifilíticos, tuberculosos e alcoólatras, são os que pagam maior tributo e as estatísticas neste ponto, são uniformes e eloqüentes.

Duas são as doenças que devem ser referidas, como fatôres do desenvolvimento do fenômeno da criminalidade infantil. A primeira delas é a epilepsia. [...]Êstes doentes são obrigados a abandonar as classes comuns e, não podendo ser internados em estabelecimentos pedagógicos especiais, vão para as ruas, tornando-se vagabundos, para acabar no vício e na prática de pequenos delitos que os levam, afinal, à criminalidade habitual.

As encefalites infantis também devem ser estudadas como elemento freqüente na história dos menores fadados ao crime. Em tôdas as infecções agudas da infância, podem aparecer sintomas de encefalite, especialmente na disenteria, tifo, coqueluche, sarampo, gripe e difteria, síndrome grave que chega a lesar os centros nervosos, deixando lesões e vestígios, tais como movimentos coréicos, enfraquecimento intelectual progressivo cuja evolução é sempre caprichosa e imprevisível.

O crime está na dependência imediata das condições íntimas da personalidade de cada indivíduo. Existe estreita correlação entre a delinqüência infantil e certas anomalias e doenças mentais. A enurese noturna, quando se prolonga depois dos cinco anos de idade, os fenômenos de sonambulismo, os terrores noturnos, são sinais que explicam 
certas manifestações anormais do comportamento da criança. Nas prisões de França, as estatísticas demonstram que trinta e quarenta por cento dos menores criminosos urinam na cama, de noite, até a idade da adolescência e da puberdade.

[...]

Estas crianças perversas, mentirosas, insubordinadas, violentas, impulsivas, intrigantes, caluniadoras, que fogem de casa e abandonam a escola, para viver na rua e na vagabundagem, entregando-se à prática de pequenos roubos e outros delitos é que vão constituir a massa de onde saem os criminosos incorrigíveis que enchem as prisões. ${ }^{389}$

Tanto as doenças de ordem biológicas como os traços de personalidade e mesmo os comportamentos apresentados pelas crianças eram computados nesse afã de se impedir o desenvolvimento das tendências criminosas. Para isso, se pedia o auxílio de pais e educadores de forma que se descobrisse o criminoso antes mesmo do próprio crime.

A atuação das professoras deveria ser minimamente calculada para preservar e fomentar a saúde física e mental dos alunos, a partir da higiene e dos cuidados com a própria forma de abordar os alunos, evitando traumatizá-los e provocar o aparecimento de doenças psíquicas.

Quando não haja pelotões de saude, é necessario que a professora faça uma inspecção diaria dos alumnos: ao entrar na sala, revista de asseio das mãos, unhas, cabellos e roupa; á hora da merenda, no que constitue esta, no modo de acondicionamento e na maneira pela qual a criança come (mastigando bem, de mãos limpas, etc.).

$[\ldots]$

Desde os primeiros dias de trabalho, o professor deve observar attenta, constante, porém discretamente, as creanças, afim de verificar si há creanças "problemas" ou creanças "dificeis", na classe. Neste grupo encontram-se os preguiçosos, os desobedientes, os deshonestos, os incorrigiveis, os repetentes, os retardados, em summa - todas as creanças cuja conducta differe da que geralmente se acceita e se espera da creança normal.

[...]

Si houver, merecerão ellas cuidados especiaes: serão submetidas a exame medico para se verificar si há ou não causa organica que determine a anomalia manifestada. Em caso afirmativo, o medico decidirá sobre a providencia a ser tomada. Si não, o professor e a familia terão de trabalhar conjunctamente para o fim de "curar" os pequenos desajustados. P. 123

Nunca se deve amedrontar as creanças: um susto na infancia póde tornar-se a base para psychose de um adulto.

As creanças não devem ser ridicularizadas, envergonhadas, nem perturbadas; o medo do ridiculo numa creança póde ser tão intenso que paralyse a acção. Deve haver na escola uma calma atmosphera de ordem para evitar o constrangimento exaggerado que paralyse a acção. ${ }^{390}$

${ }^{389}$ RIBEIRO, Leonídio. A criança e o crime. Revista do Ensino, BH, ano XX, n. 202, p. 142-146, abr.jun.1952, p. 143-144.

${ }^{390}$ GUIMARÃES, Ignacia Ferreira. Introducção ao programma de Educação e Saúde. Revista do Ensino, BH, ano IX, n. 116-117. p. 113-144, jul.ago. 1935, p. 119, 122, 123 e 126. 
A higiene bucal, bem como a saúde dos dentes e da boca se somavam nessa busca pela saúde física e mental dos alunos. Por isso, o atendimento dentário também era importante para a educação escolar:

Estes resultados [doenças causadas pela má higiene bucal] são aggravados pelas manifestações psychologicas, que attingem o caracter: falsidade, incorrigibilidade, degenerescencias, etc.

Os dentes têm intima relação com as glandulas endocrinas, que actuam sobre o desenvolvimento do individuo, bem como sobre o seu temperamento e caracter. ${ }^{391}$

A concepção de que a indisciplina infantil tinha suas causas em problemas orgânicos favorecia a defesa de uma atuação a nível corporal tanto por parte dos educadores, quanto de médicos, enfermeiros e dentistas.

$2^{\circ}$ ) A cooperação eficaz entre o medico e o educador, pois, muitas vezes, a suposta indisciplina, as aparentes deficiencias fisicas mentais e sociais, têm sua origem nas molestias infantis: vegetações adenoides, verminose, deficiencia da acuidade auditiva e da visual etc. etc. as quais devem ser combatidas para que a criança possa atingir o seu maximo desenvolvimento. ${ }^{392}$

Não foi possível detectar em detalhes a atuação dos médicos no espaço escolar. Os alunos não se lembram muito e os documentos abordam pouco essas atividades, mas, com certeza, havia este tipo de assistência. Luíza Travassos afirmou que havia um Centro Médico e Dentário que funcionava na rua Rio de Janeiro, onde eram atendidos os alunos dos Grupos Escolares.

No Grupo Escolar Olegário Maciel foram encontradas as receitas do médico para os alunos do Grupo e uma reclamação de que não havia um local adequado de trabalho deste profissional no estabelecimento. Não fica claro se os remédios eram dados pelo Grupo. Parece que, para os mais necessitados, a Caixa Escolar providenciava a sua compra. Mesmo quanto a uma vacina BCG aplicada aos alunos do Grupo em 1954, aparecem valores monetários que, ao que tudo indica, devem ter sido o custo da aplicação da vacina, pagos pelos alunos.

${ }^{391}$ SANTIAGO, Alice de Andrade. A hygiene dentaria nas escolas, Revista do Ensino, BH, ano IX, n.113. p.21-24, abr.1935, p.22.

${ }^{392}$ ALMEIDA, Philocelina C. Mattos. Que é a Escola Moderna? Quais são os característicos e a finalidade da Escola Ativa? Revista do Ensino, BH, ano VI, n. 56, 57 e 58, p. 90-97, abr.maio.jun.1931. 
Entre 1938 e 1960, o Grupo Escolar Pedro II tinha serviços de um médico e uma enfermeira escolar que lá trabalhou todos esses anos. Foram registradas algumas atividades realizadas nesse período que incluem exames, medicações, palestras, encaminhamentos para outros tratamentos médicos, vacinação, entrevistas com pais dos alunos, cadastro físico das crianças. As palestras versavam sobre diversos temas como regras de trânsito, higiene, o perigo do uso de giletes. Também as professoras de puericultura e higiene passavam por exames médicos no Grupo. Embora não tenha sido encontrada referência a dentistas, entre as atividades realizadas, aparece a correção dentária.

Em agosto de 1948, uma informação no Grupo Escolar Tomaz Brandão anunciava que o governo federal estava fazendo uma pesquisa sobre verminoses entre os alunos. Este era o último ano de Geraldo Félix no Grupo e, certamente, ele participou da pesquisa. Segundo ele, seis meses após a conclusão do primário, seus pais foram convidados a comparecer no Grupo. Ele então se desesperou achando que iam tratar das suas travessuras na escola. No entanto, era para dar o resultado do exame que acusava quatro vermes. O menino foi levado até a Escola de Medicina e internado imediatamente. Geraldo Félix atribui à escola a salvação da sua vida por causa do exame realizado.

R: E sempre se faziam exames na escola, o médico ia?

GF: De vez em quando fazia. Lá tinha, eles recolhiam, faziam exame.

$\mathrm{R}$ : Tinha assistência médica, dentária?

GF: Não, dente de jeito nenhum. Médico lá dentro não, só exame de fezes. Eles colhiam e mandavam fazer.

R: Lá tem duas salinhas com plaquinhas de dentista e gabinete médico. Mas na época do senhor não tinha?

GF: Não tinha isso não. Eu sou hoje sem dente. A maior covardia acontecia naquela época. Você não sabe o que se passou naquela época, que que eles fizeram com os meus dentes. Época danada. Você tinha qualquer problema de dente, eles arrancavam. Eu fui no Hospital da Prefeitura pra arrancar um dente. O sujeito aplicou a anestesia. Eu falei: "Ô doutor não tá aquele negócio..." Ele falou: "Não, anestesia é pra não doer quando chegar em casa" e arrancou sem pegar. Depois eu fui fazer um outro dente. Eu chego a tremer. $\mathrm{O}$ médico tentou arrancar e o dente não saía. $\mathrm{O}$ médico ficou uma meia hora, ele virava e mexia e o dente não saia. Aí o médico falou: "Esse dente tá é bom, ele tá firme". Eu morri de dor depois, porque ele abalou o dente todo. Um dentista ruim também. Eu tremia. Eu estava na aeronáutica e tremia por causa de um dente.

Embora Geraldo Félix afirme que não havia atendimento médico e dentário no Grupo Escolar Tomaz Brandão, existem registros de pedidos do médico e da enfermeira 
para que a Caixa Escolar fornecesse remédios às crianças mais carentes. Em 1946, a diretora afirmava, entretanto, que era uma servente quem fazia os curativos nas crianças que se machucava. Em fins de 1949, a diretora do Grupo avisava que seriam inaugurados um lactário e um gabinete dentário próximos ao Grupo.

Geraldo Félix lembra-se de que os professores contavam a história do Jeca Tatu que tomou "Biotônico Fontoura" e mudou de vida. Ele disse que a história era distribuída entre os alunos. Também a "Kolynos", certa vez, havia levado à escola pasta de dente para os discentes. No entanto, a maioria deles comia a pasta e não escovava os dentes com ela.

Alguns médicos escolares sugeriam premiar os alunos com utensílios de higiene. A partir do caso relatado pelo ex-aluno pode-se afirmar, no entanto, que tais prêmios não garantiam que as crianças fariam o uso apropriado dos objetos.

Em 1952, o jornal do Grupo Escolar Sandoval de Azevedo anunciava a inauguração de um Gabinete Dentário para assistência aos meninos pobres, e a composição de uma aluna relata o trabalho realizado pela enfermeira do Grupo:

Nós estamos muito satisfeitas com a nossa enfermeira. Ela nos presta grandes serviços. A nossa enfermeira se chama Florentina. É uma criatura muito meiga, bôa e delicada. Ela faz tudo para o nosso bem: aplica-nos vacina contra a febre amarela, contra varíola, etc.

Se um menino se machuca ela acode logo fazendo os curativos necessários; consolando a criança doente, dando conselhos sôbre higiene a nossa querida D. Florentina vai espalhando o bem seu [sic] olhar a quem. É Justo pois que falemos nela nêste número do jornal.

A ela a gratidão dos alunos do Grupo "Sandoval de Azevedo". ${ }^{393}$

O jornal traz vários comentários a respeito do bonde que parecia ser um problema para a segurança das crianças no período. Os acidentes foram relatados em vários documentos.

No jornalzinho do Grupo Escolar Sandoval de Avezedo, algumas composições de alunos publicadas enfatizavam o perigo desses veículos, nem sempre respeitados pelas crianças. No jornal, havia notícias de que o inspetor de trânsito teria feito uma palestra aos alunos sobre o perigo das ruas. Para os autores das composições publicadas no jornal, as crianças se acidentavam porque eram imprudentes e teimosas, não

\footnotetext{
${ }^{393}$ Notícia publicada pela aluna Antonia da Piedade Lima, intitulada "A nossa Ana Nery" no jornal $O$ Sandoval de Azevedo, Belo Horizonte, ano I, abril de 1953, n 9, p. 3.
} 
obedeciam aos pais e à professora e não ouviam o conselho dos colegas mais cautelosos.

Tal problema não era exclusivo desta escola. No Grupo Escolar Bernardo Monteiro, um aluno perdera as duas pernas sob as rodas de um bonde, ao salvar um colega de ser apanhado por outro veículo. A escola fez uma campanha na comunidade, envolvendo alunos, professores e a paróquia, e conseguiu pernas ortopédicas para o menino.

Geraldo Félix comenta que um dos lados do bonde era muito perigoso e as pessoas não deviam ficar naquele lado. Havia um aviso. No entanto, era o lado do perigo que alguns preferiam. Segundo ele, não havia nenhuma campanha na escola sobre o assunto: “... bater a cabeça no poste, cair lá rachado com a cabeça, aquilo era normal."

Não eram apenas os bondes próximos aos Grupos Escolares que preocupavam a sociedade. No jornal Estado de Minas publicou-se uma notícia de que um aluno do Grupo Escolar Lúcio dos Santos havia se machucado durante o recreio e que as professoras teriam levado mais de uma hora para levar a criança de bonde ao prontosocorro, depois de o farmacêutico ter feito tal recomendação. Dias depois, era publicada uma carta de Aberico Ribeiro Guimarães afirmando que o menino caíra durante o recreio na escola havia sido levado para a farmácia próxima e depois para a Santa Casa com a servente do Grupo e estava passando bem. A carta desmentia a notícia de que o menino teria ficado esperando uma hora sem as devidas providências da diretora. Não foi possível saber quem é o autor da carta, talvez o pai de um aluno. Como se tratava de um nome masculino, pode-se supor que fosse alguém externo à escola, o que dava mais confiabilidade à carta já que, provavelmente, era alguém da comunidade que vinha em defesa da instituição.

\subsection{PRÊMIOS: DISPOSITIVOS DISCIPLINARES DE EXEMPLARIDADE}

Uma das formas mais conhecidas e utilizadas para disciplinar o comportamento dos alunos consiste na distribuição de prêmios. Nas avaliações realizadas pelas professoras, era comum se destacar o nome daqueles que obtiveram melhores notas ou melhor comportamento. A assiduidade também era premiada, objetivando-se despertar 
nos colegas o desejo por obter também a premiação. Embora esta seja uma atividade sempre excludente, na medida em que os prêmios são para um ou alguns dos alunos, objetivam melhorar o comportamento, a dedicação e a assiduidade de todos.

Os prêmios eram os mais variados e poderiam ser elogios públicos, dinheiro, bolsa de estudos, o ingresso em instituições de ensino secundário e até mesmo a aprovação escolar, entre outros. Como premiação também pode-se identificar os atributos conferidos aos alunos segundo as notas obtidas nos exames escolares. Os alunos poderiam ser aprovados com distinção, plenamente ou simplesmente, de acordo com o resultado dos exames finais. Essas denominações eram colocadas nos diplomas e estes guardados com muito orgulho, especialmente pelos alunos que obtinham distinção ${ }^{394}$.

Os prêmios poderiam ser oferecidos pela professora, pelo Grupo Escolar ou pela comunidade. Sempre que possível, sua distribuição acontecia em cerimônias públicas para cumprir o objetivo de dar visibilidade aos seus ganhadores e, extensivamente, aos patrocinadores da premiação. Na Ata de Exames realizados em 1928 nas Escolas Reunidas de Cachoeirinha, posteriormente Grupo Escolar Mariano de Abreu, um aluno recebeu um prêmio em dinheiro oferecido por alguém da comunidade:

[...]Findo o trabalho, a Dra. Mieta Santiago dirigiu palavras de animação aos alumnos, concitando-os a continuarem os estudos e dando-lhes os parabens pelo resultado bom que colheram dos seus esforços. Foi especialmente elogiado o alumno Renato de Souza, julgado pela commissão, merecedor do $1^{\circ}$ premio, instituido e offerecido gentilmente pelo Dr. Vicente Assumpção, premio este constante da importancia de cincoenta mil reis em dinheiro. A commissão examinadora deixou consignada impressão satisfatoria sobre o resultados dos exames da classe que julgou proficientemente dirigida pela professora Edith Nunes. Aos exames compareceram somente os quatorze alumnos approvados. Para constar lavrou-se a presente acta, que vae assignada pela commissão examinadora e mais pêssoas presentes. ${ }^{395}$

Durante a sessão de encerramento do ano letivo, foram distribuídos solenemente, perante os pais dos alunos e pessoas da localidade, diversos prêmios aos alunos: o primeiro prêmio, oferecido pelo Dr. Vicente Assumpção ${ }^{396}$, coube ao aluno Renato de

\footnotetext{
${ }^{394}$ É o caso de Imene Guimarães que fez questão de apresentar o seu diploma do Grupo Escolar Barão do Rio Branco constando que fôra aprovada com distinção em dezembro de 1923, como consta dos anexos. ${ }^{395}$ Ata dos exames do $3^{\circ}$ ano misto das escolas reunidas de Cachoeirinha de $1^{\circ}$ de dezembro de 1928.

396 Nesta ata não fica claro quem é Vicente Assumpção. No ano seguinte, entretanto, ele ofereceu novamente um dinheiro para premiar os melhores alunos não mais em nome próprio, mas como Superintendente Geral Companhia Mineira de Fiação e Tecelagem que se localizava no bairro.
} 
Souza $^{397}$, que obteve nota dez de comportamento e aproveitamento e ainda o louvor da comissão examinadora; o primeiro e segundo prêmios foram oferecidos pela professora da classe ao mesmo aluno anterior e também à aluna Altamira Procópio, o terceiro e quarto prêmios couberam a duas outras alunas. Dos alunos do segundo ano, seis obtiveram nota dez de procedimento e aproveitamento e, entre eles, três prêmios foram sorteados. Portanto, mesmo a obtenção de nota máxima não garantia a conquista dos prêmios, que eram sorteados. A todos os estudantes houve distribuição de biscoitos oferecidos pelo coronel Joaquim Machado.

Os Ginásios Afonso Arinos e Anchieta, em 1936, ofereceram ao Grupo Escolar Olegário Maciel cinco vagas gratuitas aos alunos de bom comportamento. $\mathrm{O}$ oferecimento repetiu-se no ano seguinte, quando a diretora do Grupo enviou ao diretor do Ginásio Anchieta o nome de seis alunos - sexo masculino - que mereceram o prêmio oferecido pelo estabelecimento. Possivelmente, tratava-se de uma bolsa de estudos. Em 1938, outra correspondência foi enviada a uma freira, afirmando que uma das alunas "menina bôa, aplicada, bem procedida, e notadamente pobre" era merecedora do prêmio "Presidente Getúlio Vargas", não especificando que prêmio seria. Como algumas das justificativas para a obtenção do prêmio era a falta de recursos financeiros do aluno, pode-se supor que este fosse um dos critérios estabelecidos por aqueles que ofereceram a premiação. Também no Grupo Escolar Olegário Maciel, segundo um relatório do movimento na Biblioteca Infantil Vitália Campos, foram criadas diversas formas de premiar as salas que mais retiravam livros da biblioteca. Elas ganhavam a oportunidade de brincar com brinquedos novos, preferência no aluguel de livros novos e a retirada gratuita de livros. Entretanto, como os livros da biblioteca eram alugados para os alunos os levarem para casa, provavelmente, as classes mais premiadas deveriam ser também aquelas de alunos com melhores condições econômicas e que podiam alugar com mais freqüência os livros do Grupo.

Em 1942, numa carta enviada ao Diretor da Academia de Comércio, provavelmente pela diretora do Grupo Escolar Olegário Maciel, havia a indicação de um aluno para um curso na referida instituição:

\footnotetext{
${ }^{397} \mathrm{O}$ aluno passou, em presença das professoras, um recibo do valor recebido, em duas vias, visadas pela professora da classe, pela diretora das escolas reunidas e pelo Dr. Vicente Assumpção, que ofereceu o prêmio. Uma via ficaria no arquivo da escola e outra seria remetida à Secretaria de Educação.
} 
Tenho o prazer de apresentar a V. Excia, José Marques Sanches, indicado para fazer o curso nesse modelar estabelecimento de ensino, preenchendo a vaga que, com tanta generosidade, ofereceu ao Grupo E. "Olegario Maciel”.

Trata-se de um menino pobre, sem recursos, que naturalmente deixaria de continuar os estudos, não fora a sua valiosa oferta. Possue, no entanto, qualidades excelentes que fizeram dele um aluno distinto durante todo o seu curso primario. A sua boa inteligencia, aliada á sua aplicação e bom procedimento e, principalmente, á sua otima classificação nos testes finais de $4^{\circ}$ ano foram fatores que influiram poderosamente na sua escolha. Estou certa de que o meu indicado saberá, pela sua educação e amor aos estudos, fazer jús a honra que lhe coube. ${ }^{398}$

Um relatório do Grupo Escolar Olegário Maciel, de 1932, afirmava que o médico escolar havia criado um concurso sobre questões de higiene que premiaria as duas melhores provas. Como vários alunos foram classificados em $1^{\circ}$ lugar, foi preciso sortear o prêmio oferecido entre os vencedores. No Grupo Escolar Bernardo Monteiro, o médico escolar sugeriu que os alunos fossem premiados com toalhas de rosto, guardanapos, escovas, dentifrícios, sabonetes e pentes para melhorarem a sua higiene, mas não foi possível saber se esta idéia foi implementada e aqueles que tiraram nota dez de procedimento, no período de fevereiro a setembro de 1948, ganharam cadernetas de poupança na Caixa Econômica Federal.

No ano de 1955, a diplomação dos alunos da $4^{\mathrm{a}}$ série de Grupos Escolares de Belo Horizonte ocorreu no Teatro Francisco Nunes, e receberam bolsas de estudo os melhores alunos do Grupo Escolar Olegário Maciel e Barão de Macaúbas. Ao melhor aluno do Grupo Escolar Olegário Maciel foi entregue, ainda, uma medalha de ouro.

As professoras também distribuíam prêmios aos alunos. Norma Lúcia contou que estes ganhavam livros e brinquedos em função dos trabalhos escolares realizados. Segundo ela, havia o "bom ponto" que eram pedacinhos de papel distribuídos pela professora. Os valores variavam com a cor do papel e, ao final de um certo tempo, a professora recolhia os "bons pontos" somando os valores obtidos pelos alunos. Quem conseguisse o valor maior ganhava algum prêmio.

Apesar dessas indicações de que havia distribuição de prêmios aos alunos das escolas primárias, a Revista do Ensino divulgava uma série de artigos que criticavam

\footnotetext{
${ }^{398}$ Esta carta, de 31 de dezembro de 1942, está no Livro de registro de advertências com anotações de 1927 a 1953.
} 
esta prática $^{399}$, entre eles, a máxima que intitula esta tese. Nenhum artigo encontrado defendia as premiações, mesmo as mais simbólicas. Os autores afirmavam que o maior prêmio a ser obtido pelos escolares devia ser a satisfação do trabalho realizado e que essa era a recompensa mais natural e adequada para os trabalhos escolares. A questão das premiações é bastante sugestiva por evidenciar as apropriações contraditórias em relação à Escola Nova e à heterogeneidade de concepções que buscavam dar sustentação à modernização escolar. Se os artigos da Revista do Ensino, órgão oficial do Estado, criticavam o uso das punições, as legislações escolares, por sua vez, defendiam e recomendavam a utilização dos prêmios. O decreto-lei n. 734 de 1940, por exemplo, determinava que a Caixa Escolar tinha por finalidade distribuir prêmios aos alunos que se distinguissem no curso primário.

Deve-se salientar que a premiação não se restringia aos alunos. Fica claro que a aprovação dos alunos se constituía em uma maior valorização dos professores que recebiam elogios dos colegas, diretores, inspetores e examinadores nas provas. No Grupo Escolar Assis das Chagas foram realizadas, em 1952, 1953 e 1954, eleições para uma rainha e duas princesas entre as professoras. Para obter os títulos, era preciso obter as maiores vendagens no número de votos, cuja arrecadação era direcionada à Caixa Escolar do Grupo. Em 1954 também recebeu premiação a professora mais assídua do Grupo.

\subsection{ENTRE ESTRATÉGIAS E TÁTICAS DE DISCIPLINARIZAÇÃO}

As estratégias e táticas disciplinadoras permeavam toda a vida escolar, estendendo-se para além dos seus muros e atingindo não somente as famílias dos estudantes, mas a sociedade como um todo. Algumas famílias pareciam representar as escolas e seus educadores como portadores da verdade e corrigiam, em casa, os comportamentos dos filhos na escola. Outras, no entanto, questionavam a escola e defendiam os filhos, exigindo melhores formas de tratamento e melhor nível educacional. A sociedade também não estava alheia ao que se passava nos pátios escolares. Os jornais mostram que esta era uma realidade discutida no meio social e buscava-se conformar a escola e seus educadores às exigências da própria sociedade.

${ }^{399}$ A maioria deles era de autoria de Manuel Casasanta. 
Por outro lado, a escola conferia aos familiares dos alunos e à sociedade como um todo o papel de auxiliares nas atividades pedagógicas, culturais e sociais desenvolvidas por esta. A partir das representações sobre a família dos alunos e alunas, a escola organizava uma série de estratégias disciplinares que envolviam desde o corpo dos escolares, sua alimentação, vestuário, higiene até as relações entre pais e filhos fora do ambiente escolar. $O$ trabalho a ser realizado nas escolas contava com o apoio e a participação da sociedade de uma maneira geral que, entre outras coisas, custeava as despesas com os "benefícios" concedidos aos estudantes pobres.

Com a criação dos Grupos Escolares públicos, as contingências familiares deixaram de estar circunscritas ao espaço privado das casas das crianças e ganharam visibilidade no meio social. A fome, o frio, as doenças, as verminoses iam junto com as crianças para o ambiente escolar e passaram a incomodar os olhos da sociedade em seu entorno. Propiciar condições menos desfavoráveis a essas crianças significava não somente minimizar o incômodo de ver o sofrimento destas, mas ainda evitar que as desigualdades sociais que se descortinavam nos Grupos Escolares gerassem revoltas que, mais tarde, poderiam desencadear em movimentos exigindo transformações sociais.

Minimizar o sofrimento das crianças pobres e torná-las mais higienizadas e saudáveis aos olhos da sociedade não era, entretanto, o suficiente para discipliná-las. Era essencial conhecer quem eram essas crianças, quais as suas características, habilidades, necessidades. As avaliações e exames cumpriam este papel de diagnosticar a situação escolar e permitir intervenções adequadas. No caso das avaliações escolares, tema do próximo capítulo, tratava-se também de selecionar aqueles mais capazes, únicos a merecerem os diplomas do ensino primário ou ainda, no caso das meninas, o diploma do Curso Normal e da Escola de Aperfeiçoamento.

Se os Grupos Escolares de Belo Horizonte visavam atender ao maior número de crianças, oferecendo condições básicas essenciais para a realização do ensino, as avaliações escolares exerciam o papel selecionador, minimizando o número daqueles que conseguiriam deixar os bancos da escola munidos do diploma do curso primário. 


\section{CAPÍTULO 6 \\ AVALIAÇÕES E TESTES ESCOLARES COMO DISPOSITIVOS CIENTÍFICOS DE SELEÇÃO E DISCIPLINAMENTO}

A avaliação, desde muito tempo, tem se constituído num dos momentos mais dramáticos da vida escolar. Nas memórias de alunos e professores sempre há espaço para lembranças as mais diversas relacionadas aos exames, especialmente aqueles mais temidos dos finais de ano ou das matérias mais difíceis. Pode-se afirmar que a avaliação constitui-se como um momento crucial na escolarização de diversos alunos e alunas e que demonstra, de maneira mais nítida, as representações acerca do ensino e da aprendizagem subjacentes a esses processos.

De uma maneira geral, os escolanovistas concebiam a avaliação como um importante artefato para auxiliar o professor na organização das classes, elaboração dos programas escolares e definição das atividades a se realizar. A concepção meritocrática de que os postos superiores na sociedade deviam ser ocupados pelos indivíduos melhor preparados e mais capacitados sustentava uma imagem da escola como o espaço mais adequado para realizar esta seleção social, como indica o próprio Programa do Ensino Primário: “A Sociedade não eguala todos os homens. Ella serve ao contrario d'isso para salientar-lhes a diferença dos merecimentos" ${ }{ }^{400}$. Nesse sentido, manter a ordem social era uma tarefa da escola, incutindo nos alunos a crença de que a sua inabilidade, incapacidade ou pouca dedicação eram as responsáveis por ocuparem um estrato social menos favorecido ${ }^{401}$.

As proposições escolanovistas valem-se do rótulo da cientificidade para ocultar quaisquer intervenções subjetivas nessa seleção entre os mais e os menos capacitados. $\mathrm{O}$ exame constitui-se, tanto para a ciência, quanto para a escola, um símbolo de objetividade e precisão: “... a era da escola 'examinatória’ marcou o início de uma pedagogia que funciona como ciência”. Segundo Foucault (1987, p. 170), o exame faz de todo indivíduo um "caso", demarcando a sua individualidade e ainda permitindo criar um arquivo documentado que o expõe e o delimita como único e perfeitamente identificável.

\footnotetext{
${ }^{400}$ MINAS GERAIS, 1927, p. 1660.

${ }^{401}$ O Manifesto dos Pioneiros, redigido em 1932 por Fernando de Azevedo, por exemplo, definia: "Se o problema fundamental das democracias é a educação das massas populares, os melhores e os mais capazes, por selecção, devem formar o vértice de uma pyramide de base immensa".
} 
Se a cientificidade era a marca da escola moderna em Minas, o cuidado com os exames escolares evidenciava essa busca de objetividade. As avaliações são dramas presentes nas memórias das professoras e dos alunos.

\subsection{AVALIAÇÕES DAS NORMALISTAS \& PROFESSORAS}

No período estudado, a formação para professoras no Estado sofrera diversas alterações. Em março de 1925, o decreto n. 6.831 definia que os estabelecimentos que ofereceriam o Curso Normal seriam: a Escola Normal Modelo, em Belo Horizonte, escolas regionais oficiais e escolas particulares equiparadas, além de criar uma Escola Normal Superior que não viera a se implantar. O Curso seria feito em seis anos, em duas etapas. A primeira, chamada Curso Fundamental, teria duração de dois anos e seria propedêutico para a entrada das alunas do Curso Normal, que teria duração de quatro anos.

QUADRO 10

Duração do Curso Normal pelo decreto n. 6.831/25

\begin{tabular}{cc}
\hline & 6 anos \\
\hline 2 anos & 4 anos \\
Fundamental & Normal \\
\hline
\end{tabular}

Fonte: Decreto n. 6.831 de 1925

A Reforma no Ensino Normal organizada por Francisco Campos também dividia o Curso Normal em dois: o Curso de $1^{\circ}$ grau seria realizado por instituições particulares, com um currículo menor e teria duração de cinco anos, sendo os dois primeiros anos, de adaptação, e os três finais, de preparação. O curso de $2^{\circ}$ grau seria fornecido, exclusivamente, por escolas mantidas pelo Estado e tinha um currículo mais extenso, com sete anos de duração: os dois primeiros de adaptação, três de curso preparatório e dois de aplicação. Entretanto, havia possibilidade de se realizar apenas parte do curso, bastava fazer um exame de admissão e tentar o ingresso no Curso Preparatório ou no último nível, no Curso de Aplicação. Foi criado, ainda, um curso de formação de professores para as escolas rurais, oferecido por Grupos Escolares de $1^{\mathrm{a}}$ e $2^{\mathrm{a}}$ categorias $^{402}$.

${ }^{402}$ O Regulamento do Ensino Primário - Decreto n. 7.970-A de 15 de outubro de 1927 - definia que os Grupos Escolares seriam divididos em três categorias: na $1^{\mathrm{a}}$, os que tivessem quinze ou mais classes, na 
QUADRO 11

Divisão do Curso Normal a partir da Reforma de 1927

\begin{tabular}{|c|c|c|c|c|}
\hline \multicolumn{2}{|c|}{$1^{\circ}$ grau (5 anos) } & \multicolumn{3}{|c|}{$2^{\circ}$ grau (7 anos) } \\
\hline 2 anos & $\begin{array}{c}3 \text { anos } \\
\text { Pronãon }\end{array}$ & 2 anos & $\begin{array}{c}3 \text { anos } \\
\text { Prónario }\end{array}$ & 2 anos \\
\hline
\end{tabular}

Fonte: Decreto n. 7.970-A de 15 de outubro de 1927

Em 1932, Noraldino Lima, como Secretário da Educação, deu uma nova organização às escolas normais do Estado:

Art. 68. As escolas normais de segundo grau, com exceção das de Belo-Horizonte e Juiz de Fora, que continuam a ter a atual organização, conferirão diplomas de normalistas do primeiro e do segundo grau.

$\S 1^{\circ}$ Para esse fim, as referidas escolas terão seus cursos preparatórios transformados em cursos normais, iguais, bem como os cursos de adaptação, aos das escolas de primeiro grau, observando em tais cursos os mesmos programas e horários destas e concedendo diplomas de normalistas do primeiro e do segundo gráu.

$\S 2^{\circ} \mathrm{O}$ curso de aplicação das mencionadas escolas conservará a mesma organização atual e dará diplomas do segundo grau, de acordo com o art. 17 do Regulamento do Ensino Normal. ${ }^{403}$

QUADRO 12

$\frac{\text { Divisão do Curso Normal a partir do decreto n. } 10.362 \text { de } 1932^{404}}{3 \text { and }}$

\begin{tabular}{ccc}
\hline 2 anos & 3 anos & 2 anos \\
\hline Adaptação & Normal & Aplicação \\
\hline & & \\
\hline $1^{\circ}$ grau (5 anos) & \\
\hline & \\
\hline
\end{tabular}

Fonte: Decreto n. 10.352

Em 1934, novamente Noraldino Lima reformulava o decreto n. 10.362 através do decreto n. 11.501 e esclarecia que as escolas normais de $1^{\circ}$ grau ofereceriam o Curso de Adaptação e o Curso Normal. O Curso de Aplicação seria oferecido apenas nas escolas de $2^{\circ}$ grau e poderiam se candidatar a ele alunos formados nas escolas de $1^{\circ}$ grau e alunos que tivessem concluído o Curso Preparatório nas Escolas Normais Oficiais de Belo Horizonte e Juiz de Fora, que não tiveram seu programa alterado.

$2^{\mathrm{a}}$ os que tivessem entre oito e quatorze e na $3^{\mathrm{a}}$ os com menor número de classes. Em abril de $1934 \mathrm{o}$ governo passou para os municípios o custeio com o ensino primário rural, através do decreto n. 11.297.

${ }^{403}$ MINAS GERAIS. Decreto n. 10.362 de 31 maio 1932. Aprova modificações aos regulamentos que baixaram com os decretos ns. 7.970-A, e 9.450, de 18 de fevereiro de 1930.

${ }^{404}$ As escolas normais de Belo Horizonte e Juiz de Fora mantinham a divisão anterior. 
Em 1943, Benedito Valadares e Cristiano Machado autorizavam as escolas normais de $2^{\circ}$ grau que tivessem Curso Ginasial reconhecido a funcionarem apenas com o Curso de Aplicação ${ }^{405}$.

Nas memórias das professoras sempre há lembranças, freqüentemente desagradáveis, acerca das avaliações escolares. Benedita Dell'Isola, por exemplo, tendo apenas o curso primário, tinha que passar por um exame de suficiência para poder lecionar. A situação do exame lhe causava muitas dificuldades. Em sua cidade, poucos acreditavam que ela conseguisse ser aprovada na Escola Normal Regional de Ouro Fino, considerado um estabelecimento de ensino muito sério e exigente. Mesmo assim, Benedita foi para lá com o seu pai e uma filha de seis meses de idade. Em suas memórias, as provas são contadas em minúcias e a professora revela o sentimento de desamparo diante de uma banca que ela classificou como "estranhos de fisionomias austeras e tristes; melhor: severas e autoritárias". Apesar de ser a única candidata e se preparar com antecedência, Benedita não dispensou o auxílio político. Levou à banca uma carta de apresentação, mas o diretor disse-lhe que esta só seria aberta após a realização da prova. Neste período, nem sempre era a competência que determinava a conquista de cargos públicos, como atesta Maria Cecília C. C. Souza:

Muitas vezes, o apadrinhamento era a única forma de conseguir direitos que estavam instituídos de forma parcial ou indefinida, ou mesmo de forma clara. Assim, os critérios se superpunham - os professores necessitavam de apadrinhamento para fazer valer os resultados de concursos que os tinham beneficiado pelo mérito. $(2000$, p.78)

Uma vez entregue a carta, era preciso passar aos exames. A argüição envolvia as seguintes matérias: Português, Matemática, Ciências Naturais, Desenho, Geografia, Francês e História. Nesta última, foi sorteado o ponto de História do Brasil e ela deveria falar tudo que sabia sobre a descoberta deste território pelos portugueses. A professora conta que discorreu todo o ponto, sem mudar uma vírgula, já que naquele tempo, o estudo consistia em decorar. Apresentou o assunto, embora nem sempre soubesse o que estava falando. Parece que um dos examinadores percebeu que a candidata não tinha muito conhecimento sobre o que apresentava e pediu para ela explicar o que significava

\footnotetext{
${ }^{405}$ MINAS GERAIS. Decreto-lei n. 970 de $1^{\circ}$ de dezembro de 1943 que se colocava em conformidade com o Decreto-lei federal n. 1.202, de 8 de abril de 1939.
} 
"calmaria", uma das palavras utilizadas na apresentação. Benedita respondeu sem titubear: "É vento". O professor pensou um pouco, mas a aprovou.

O jornal de Ouro Fino noticiou a aprovação e a professora levou uma série de exemplares para sua cidade, buscando comprovar o fato entre seus conterrâneos, embora muitos ainda afirmassem que a conquista se devia à política, desmerecendo o esforço e a capacidade da professora.

Anos depois, Benedita matriculou-se na Escola Normal de Uberlândia, onde viveu uma situação bem desagradável no que se refere aos exames realizados. $\mathrm{O}$ professor passava os resultados de uma prova escrita de Ciências. Quando falou o nome dela, a terceira na chamada, disse que tinha tirado zero. As alunas se mobilizaram para saber o que havia acontecido. O professor justificou então que a aluna havia colado, o que todas duvidaram, exigindo que ela fosse submetida a uma outra prova. Depois de muitas manifestações das colegas, a professora foi submetida a um novo exame, tendo sido aprovada. Essa, entretanto, parece ter sido uma situação isolada, já que, ao final do Curso, Benedita recebeu sua Caderneta Escolar assinada pela professora de Metodologia e pelo diretor da Escola, destacando suas qualidades profissionais:

A portadora desta caderneta possui acentuada aptidão para o magistério, pois é carinhosa para com os alunos e se esforça para manter uma disciplina de doçura e energia nas aulas. As suas lições de prática foram sempre bem preparadas, com antecedência, zêlo e asseio. É portadora de boa inteligência e preparo. O seu trato pessoal é ótimo: carinhosa com os alunos e atenciosa com as demais pessoas, sejam colegas ou pais de alunos.

Conduta moral

Aplicação ótima.

Aproveitamento ótima.

Assiduidade ótima. boa. (Dell'Isola, 1970, p. 28)

A declaração de que a professora tinha ótima conduta moral parece confirmar que a acusação de haver colado nos exames havia sido mesmo um engano.

Ao vir para Belo Horizonte, Benedita trabalhou como substituta e, na primeira oportunidade, fez um concurso para professora. O concurso constava de provas de Português, Metodologia e Psicologia. A situação de prova era temerária para a professora, especialmente pelos anos de trabalho, era difícil admitir a possibilidade de reprovação: "A sensação de ter que ser submetida a uma prova foi terrível, mas persisti. O Dr. Maurício Murgel seria um dos examinadores e eu sabia o quanto era exigente. E se eu fôsse reprovada? Que vergonha..." (Dell'Isola, 1970, p.30) 
Segundo Benedita, aos domingos, o jornal Estado de Minas publicava uma coluna do jornalista Jair Silva que, às vezes, tratava de questões escolares, o que significava um olhar da própria sociedade para o interior das escolas:

Tudo que eu fazia na classe, era com um medo enorme de ser criticada em público. Que angústia eu sentia quando fazia um auditório, uma excursão ou uma reunião do Clube de Leitura! Esperava ansiosamente, dias e dias, com o maior medo, na dúvida: se haveria ou não uma crítica do ilustre jornalista. Eu bem que desejava que estas atividades fossem divulgadas, mas ... e o mêdo de merecer críticas. (Dell'Isolla, 1970, p. 32)

Quando professora do Grupo Cristiano Machado, Dell'Isola fez um Curso de Aplicação de Testes na Escola de Aperfeiçoamento. Embora estivesse entusiasmada, tendo sido uma aluna pontual e aplicada, foi reprovada. Mais tarde, descobriu que sua reprovação foi motivada por não ter uma boa entonação de voz, além de trocar a letra "l" pela letra "r".

Outra professora, Marta Nair Monteiro, fora presidente do Conselho de Administração Escolar da Escola de Aperfeiçoamento, quando aluna da instituição. Terminado o curso e mesmo já não estando mais vinculada ao Conselho e à própria Escola, resolveu iniciar uma batalha por seis colegas que não tiveram direito ao diploma nem mesmo à repetência ${ }^{406}$. Marta Nair, considerando o regimento interno rigoroso e autoritário, pediu ao Secretário da Educação, Cristiano Machado, uma nova chance para suas colegas. Elas então tiveram a oportunidade de fazer novos exames finalizando, desse modo, o curso ${ }^{407}$.

Se durante a vida escolar no Curso Primário, Normal ${ }^{408}$ e na Escola de Aperfeiçoamento as professoras passavam por duras situações de exame, durante o exercício profissional estes também não deixavam de existir.

Imene Guimarães conta de uma fase difícil ao trabalhar nas classes anexas da Escola de Aperfeiçoamento, após a conclusão do Curso Normal. Segundo ela, só depois de dois anos de experiência como professora é que poderia cursar a Escola de

\footnotetext{
${ }^{406}$ Ela não esclarece por que motivo as alunas seriam reprovadas.

${ }^{407}$ Segundo Coelho et al. (s.d.), a Escola de Aperfeiçoamento caracterizava-se não somente pela rigidez na seleção das alunas, mas ainda pelas inúmeras exigências para a realização do curso, que tornava seletiva também a permanência nele. Bom aproveitamento e comportamento eram condições necessárias para a realização dos cursos. A qualquer momento, alunas que não conseguissem atingir tais metas poderiam ser desligadas da instituição.

${ }^{408} \mathrm{O}$ decreto-lei n. 668 de 23 de abril de 1940 introduzia modificações na apuração das notas nas Escolas Normais de Minas Gerais, adequando-se ao regime de provas estabelecido pelo governo federal para o ensino secundário.
} 
Aperfeiçoamento. Neste período, suas aulas eram assistidas por alunas e professoras da Escola que faziam críticas ao seu trabalho, para que ela melhorasse.

\subsubsection{FICHAS PROFISSIONAIS}

Em maio de 1934, durante dois dias consecutivos, o diretor do jornal O debate, Paulo Pinheiro Chagas publicava, na primeira página, uma crítica ferina à implementação das fichas pedagógicas ${ }^{409}$. Neste artigo e em outro publicado no dia seguinte, ambos na primeira página do jornal, o seu diretor, Paulo Pinheiro Chagas, que ocupava aquele espaço da publicação para fazer um comentário pessoal sobre acontecimentos importantes do momento, fazia uma crítica ferina às fichas profissionais, como se depreende do texto transcrito integralmente abaixo:

O tal regime das fichas, "dernier cri" da Secretaria da Educação, vem causando especie no seio da laboriosa e mal recompensada classe dos nossos pedagogos. Ainda hontem, O DEBATE teve opportunidade de publicar a carta-protesto de uma professora, onde a signataria mostrava os absurdos da medida.

A nova é, em verdade, esdrúxula. Daqui por diante o professorado será fichado. A "ficha profissional", organizada por assistentes technicos, professoras technicas e directores de casas de ensino, dará conta da capacidade pedagógica de cada professora. tanto?

Uma preliminar se impõe. Os fichadores têm a necessaria competência para

Eu não ignoro o heroismo e o animo de servir que caracterizam o professorado mineiro. Sei da obra de notavel reerguimento do ensino que, apezar dos máos secretarios, vae sendo realizada, com abnegação e renuncia, por esses campeões anonymos da nossa civilização.

Assistentes technicos, professoras technicas e directoras estão, em geral, nesse caso. Mas em particular, ha muita excepção a fazer. Culpa de quem? Dos máos governos que introduziram o empenho politico nas nomeações, outrora feitas por concurso. Nessas condições, há muito assistente, muita professora technica, muita directora devendo a nomeação não ao criterio elevado das selecções do concurso, mas, tão apenas, á praxe perniciosa da protecção politica. de outrem?

Assim sendo, quem subiu por esse preço terá aptidão para fichar a capacidade

As instrucções para a organização da ficha profissional, entre outras exigencias, prescrevem a maneira de ser investigado o "preparo pedagogico muito superior". O fichador deve observar se a fichanda tem conhecimentos pedagogicas [sic] relacionados com assumptos de psychologia, sociologia e philosophia.

\footnotetext{
${ }^{409}$ A sua crítica teria sido desencadeada por uma carta na qual uma professora reclamava da introdução das fichas pedagógicas nas escolas. A carta fôra publicada na edição anterior de 25 de maio de 1934, entretanto, esta edição não foi localizada.
} 

hierarchicos?

E o fichador terá esses conhecimentos para os observar em seus inferiores

Evidentemente, não! Se nas nomeações da Secretaria da Educação prevalecesse o criterio do merecimento, poder-se-iam exigir esses requisitos aos fichadores. Mas se é a politica, a mais novica das politicalhas, que alli impera, como querer esse objectivo?

Qual! Só a má fé, phantasiada de virtude, engendraria coisas desse jaez! Porque quem não observa o criterio da capacidade em seus actos de governo, não tem o direito de fichal-o em seus subaternos!

O fichador terá, porventura, desembaraço bastante para catalogar como mediana ou inferior a capacidade de uma professora parenta ou protegida do chefe politico local? Só se for ingenuo e ignorar as tremendas perseguições que a Secretaria da Educação, por intermedio do sr. Lima, desencadeará sobre esse insensato...

$* * *$

Desse regime de fichas vae nascer uma nova forma de oppressão. A ficha será, no futuro, a desculpa para as preterições, remoções e omissões de ordem politica. Sempre que o governo se vir ante uma accusação dessa natureza, o pretexto será facil:

- A ficha da professora era má. E essas fichas são organizadas pelo proprio professorado. Portanto, foi justa a medida tomada!

A opinião de hoje pode ser o erro de amanhã. Todos têm opportunidade de melhorar, de progredir. Mas as fichas fatidicas lá estarão, na Secretaria, expostas á eterna fama de incultura e incapacidade. Haverá o desalento por parte de quem obtiver ficha ruim. E a experiencia, que modifica e orienta a conducta humana, será a bem dizer, relegada ao plano das coisas inuteis. Porque, acima da experiencia, existirá a ficha, que se poderá eternizar, injustamente.

Depois, não é só isso. A interpretação dos factos é coisa subjectiva. Varia de individuo para individuo. "Cada cabeça, uma sentença". Um mesmo facto póde ser diversamente interpretado. "Julgar e julgar com acerto é o que há de mais difficil". Exige o discernimento, a imparcialidade e a critica, factores não accessiveis a todos.

$$
* * *
$$

A desconfiança vae penetrar o ambiente educacional. Para longe a escola moderna! Para longe aquelle espirito de colaboração e de amizade que, numa escola, deve reinar entre superiores e inferiores hierarchicos!

Os fichadores terão qualquer coisa de policial. Serão temidos e o professorado não mais se manifestará expontaneamente. A reserva substituirá a camaradagem. $\mathrm{O}$ receio tomará o logar da confiança. Porque já não haverá cooperadores de um ideal commum, mas, juízes e réos do crime, pelo menos, de recíproca incomprehensão...

E ahi está em que consiste o famigerado fichario que a Secretaria de Educação vem de conceber.

Professorado livre de Minas tremei! Acautelai-vos! Dentro em breve um regime inquisitorial estará implantado vosso meio! E vós, assistentes technicos, professoras technicas e directores de casas escolares, e vós, os futuros fichadores, estareis collocados na tragica posição de novos Torquemadas de vossos companheiros de trabalho! $!^{410}$

${ }^{410}$ CHAGAS, Paulo Pinheiro. Ainda as "fichas profissionaes". O debate. Anno I, n. 64, 28 maio 1934. p. 1 
Não se satisfazendo com a primeira discussão, o diretor do jornal continua a investida na edição seguinte, também transcrita na íntegra:

O sr. Floriano de Paulo, chefe do Corpo Technico do Ensino, em entrevista á imprensa, teceu considerações em torno das "fichas profissionaes", com que se pretende, daqui por diante, catalogar os meritos e as capacidades de cada professor.

Falou longamente. Defendeu a nova praxe com calôr. E terminou assim: "Desta forma, nos casos de promoções, commissões ou duvidas relativas ao professor, concorrem as tres opiniões(da assistente technica, da professora technica e da directora da casa de ensino) para formar um juizo, mais ou menos seguro, do valor deste".

Quem ler estas palavras talvez se incline a acreditar na pureza do novo regime estabelecido na Secretaria da Educação. Mas ninguém se iluda! Tudo isso não passa de verbosidade theorica!

$\mathrm{Na}$ pratica, as coisas assim não acontecem. Concretizemos a affirmativa.

Houve, dias atrás, uma vaga de assistente technico, com o commissionamento do sr. João Baptista Santiago na direcção da Revista do Ensino. Qual o criterio de que se lançou mão para o provimento do seu logar?

Nenhum! Não se buscaram professoras, com o curso da Escola de Aperfeiçoamento; não se procurou indagar da somma de serviços prestados ao ensino por educadores encanecidos nessa faina, gloriosa mas ingrata, de civilizar a nossa gente. Nada disso! O criterio adoptado foi, exclusivamente, o de não haver nenhum criterio!

E foi commissionado naquella vaga, o sr. Jacaúna de Paula, pessôa inteiramente desconhecida nos meios educacionais de Minas. E sabem quem é o sr. Jacaúna? Precizamente o irmão do sr. Floriano de Paula que, nas suas falações á imprensa, pretende organizar "juizos, mais ou menos seguros, ácerca de cada professor, nos casos de promoções ou commissões"...

Essa questão de "fichas profissionaes" nada resolverá, portanto. Não há praxes, por melhor que sejam, capazes de moralizar os actos de governo, quando os seus detentores não são possuidos daquelle espirito publico que define a sinceridade das intenções puras.

As fichas, já o commentámos, nesta columna, constituem uma innovação absurda. Mais ainda que sejam bem organizadas e desmintam os prognosticos pessimistas, serão, pelo menos, improficuas. Porque, na hora das promoções, o criterio não se baseará, como não se baseia, sob a administração do sr. Lima, no aproveitamento dos valores. Os contemplados não serão os mais aptos; mas os felizes que tiverem fortes empenhos politicos ou, então, os parentes das altas auctoridades da Educação. Esta a verdade.

Os incumbidos de fichar as professoras são os assistentes technicos, os professores technicos e os directores de casas de ensino. Eis os encarrregados de aquilatar a cultura e a capacidade pedagogica de professores que cursaram, com afinco, a Escola de Aperfeiçoamento, ou, então, de professoras com muitos annos de pratica escolar.

Esses fichadores terão a necessaria competencia para isso?

Não! Pelo menos, em face do nenhum criterio que preside, em geral, as nomeações desses "fichadores", póde-se affirmar: não! Porque, se existem assistentes capazes, seleccionados em concurso, acontece que muitos devem a nomeação á politica e não ao proprio valor.

O irmão do chefe do Corpo Technico é um exemplo recente, que vem a calhar. Futuro fichador, futuro julgador da capacidade alheia, o sr. Jacaúna de Paula é 
inteiramente desconhecido nos nossos meios pedagogicos. Seu merito é uma hypothese. Seus conhecimentos, relacionados ao ensino, uma interrogação.

O sr. Jacaúna de Paula nem siquer professor primario foi, aqui em Minas. Inteiramente extranho a essas labutas, coube-lhe entretanto, o alto logar de assistente technico do ensino. Sua nomeação é, porisso, uma injustiça feita á laboriosa classe dos nossos professores.

Quanto fervor, quanto idealismo, quanto merecimento, quanta capacidade o sr. Jacaúna, irmão do chefe do Corpo Technico, veiu preterir!

Depois disso, como levar a sério as novidades da Secretaria da Educação? Para que as "fichas profissionaes"? Para que, se o sr. Lima se curva ás injunções da politica e não ás do valor individual?

Qual! Este sr. Lima só se póde definir com aquelle conceito de Mendes Fradique: "cada vez mais sempre o mesmo". 411

No primeiro artigo, o diretor do jornal fez uma análise que, além de política, voltava-se também para a organização interna à escola, analisando o preparo pedagógico - ou a falta de - dos técnicos da educação que "fichariam" os seus colegas, instaurando uma situação de desconfiança e vigilância entre os educadores. Na edição seguinte, no entanto, o autor se delimitou à questão política, não poupando as autoridades educacionais do Estado e revelando, com nomes e exemplos, a interferência da "politicalha" na seleção de profissionais para a educação no Estado ${ }^{412}$, enfatizando o uso político que se poderia fazer das fichas profissionais para beneficiar os interessados ou prejudicar os desafetos políticos. Suas observações deixam claro que, em momento algum, as fichas pedagógicas poderiam ser consideradas instrumentos neutros de avaliação docente, já que, em Minas Gerais, era a política que determinava a contratação de profissionais para as escolas públicas.

Certamente em resposta a tais ataques, a Revista do Ensino ${ }^{413}$ do mês de junho dedicou as suas dez primeiras páginas às fichas profissionais. $\mathrm{O}$ artigo intentava mostrar que as fichas não eram uma inovação, já existindo nas escolas mineiras desde o início do século XX e que teriam se oficializado através do decreto n. 3.191, de 1911 que, no art. 41, parágrafo 18, atribuía aos inspetores regionais a obrigação de remeter à

\footnotetext{
${ }^{411}$ CHAGAS, Paulo Pinheiro. Ainda as "fichas profissionaes". O debate. Anno I, n. 64, 28 maio 1934. p.1 ${ }^{412}$ Segundo Peixoto (1992, p. 9), o cargo de Assistente Técnico deveria ser preenchido por meio de concurso entre os diplomados pela Escola de Aperfeiçoamento, no entanto, era, geralmente, confiado a pessoas de indicação direta do Secretário da Educação.

${ }^{413}$ AS FICHAS profissionais. Revista do Ensino, BH, n. 103, p.1-10, jun.1934.
} 
Secretaria um boletim reservado a respeito de cada um dos professores ou diretores dos estabelecimentos inspecionados. Nestes constariam a inteligência, o preparo, a aptidão didática, a moralidade e impressões de pessoas da região sobre o avaliado, tratando ainda dos métodos de ensino utilizados. .

O Regulamento de 1924 criava um "Registro de Notas" que ficaria na Diretoria de Instrução, onde seriam lançadas, por despacho do Secretário do Interior, informações sobre os funcionários do ensino, depois de apurada a veracidade das mesmas.

Segundo o artigo, até 1927, as notas eram fornecidas à Secretaria pelos assistentes técnicos, em impressos com a denominação "Boletim Reservado" e, a partir daquele ano, haveria os "Boletins de nota", já sem o caráter reservado. Entretanto, os Regulamentos de 1924 e 1927 são idênticos no que tange a esse assunto.

A Revista do Ensino assegurava que a Secretaria de Educação não estava criando as fichas profissionais, mas aperfeiçoando um procedimento já existente, as antigas "notas reservadas". Tais "Fichas" seriam organizadas de acordo com informações fornecidas pelos assistentes técnicos, pelas técnicas orientadoras e pelos diretores dos estabelecimentos de ensino. Cada um deles informava, em separado e em papel impresso pela Secretaria, os seguintes dados sobre o professor: cultura geral; preparo pedagógico; capacidade de ensinar; capacidade de educar; trato social e sua contribuição para o ensino. Seriam então atribuídas notas referentes a cada um desses valores podendo ser: "muito superior", "superior", "media", "inferior" e "muito inferior".

Em 1932, um concurso para selecionar diretoras para Grupos Escolares na capital e nos distritos teria se baseado nas notas existentes na Secretaria e de documentos comprovando a idoneidade moral e profissional dos candidatos. 
QUADRO 13

Comportamentos dos professores do Ensino Primário a serem reunidos no Registro de Notas em 1924 e 1927

\begin{tabular}{l|l}
\hline \multicolumn{1}{c|}{1924} & \multicolumn{1}{c}{1927} \\
\hline “a)aptidão para o ensino, revelada na & "a) aptidão para o ensino, revelada na \\
cultura pedagogica e na boa transmissão & cultura geral, nos methodos e processos de \\
daquelle; & instrucção e educação recommendados por \\
b) assiduidade aos trabalhos escolares e & comprehumento, no modo de \\
dedicação profissional; & disciplina e os meios de organizal-a de \\
c) disciplina mantida no estabelecimento ou & maneira que ella seja um instrumento de \\
na classe, ordem, asseio, conservação do & formação social e de educação moral e \\
predio e material escolares; & civica; \\
d) criterio na applicação dos processos de & b) assiduidade aos trabalhos escolares e \\
ensino; & grau de frequencia dos alumnos; \\
e) dom de tornar sua escola frequentada por & c) aproveitamento dos alumnos; \\
maior número de alumnos; & d) esforços tendentes a organizar e manter \\
f) resultado nos exames finaes e de & as instituições escolares e complementares \\
promoção; & e auxiliares da escola; \\
g) organização das caixas escolares ou & e) procedimento social; \\
esforço pela prosperidade destas; & f) collaboração na Revista do Ensino; \\
h) estima em que é tido pelos alumnos e & g) participação ás conferencias das \\
paes dos mesmos; & professoras, ás reuniões do Auditorium e ao \\
i) procedimento social; & dia da leitura; \\
j) elaboração de livros didacticos, reputados & h) elaboração de livros didacticos reputados \\
uteis pelo Conselho Superior de & uteis pela Secção Technica do Conselho \\
Instrucção.” & Superior de Instrucção." \\
\hline
\end{tabular}

Fonte: MINAS GERAIS. Decreto n. 6.555 de 19 ago.1924, p. 316 (Regulamento do Ensino Primário) e MINAS GERAIS. Decreto n. 7.970 de 15 out.1927, p. 1271 e 1272 (Regulamento do Ensino Primário).

No mês de agosto de 1934, a assistente técnica, Zélia C. Rabello, iniciou uma reunião ${ }^{414}$ no Grupo Escolar Assis das Chagas, abordando as fichas pedagógicas. Segundo ela, as fichas registrariam os dados de todos os professores, assistentes, diretores e orientadores na Secretaria de Educação e teriam por objetivo auxiliar na seleção das alunas que iriam cursar a Escola de Aperfeiçoamento, além de servir de estímulo às professoras. A resistência das professoras foi imediata. Uma delas questionou se o Caderno de Plano de Lições não seria o bastante para avaliar a competência das docentes. A assistente retrucou que, como os Cadernos não eram feitos na sua presença, ela não podia garantir que fossem realmente feitos pelas professoras. Houve pedidos de que elas tomassem conhecimento do que seria colocado nas fichas. Além desta, houve ainda uma discussão sobre a aplicação de testes de inteligência e

\footnotetext{
${ }^{414}$ Ata da reunião de 23 de agosto 1934 do Grupo Escolar Assis das Chagas.
} 
cultura geral entre as professoras, mas não há mais nada anotado nas atas seguintes sobre tais assuntos.

Em 1936, numa outra reunião ${ }^{415}$ de professoras no Grupo Escolar Olegário Maciel, a assistente técnica, Irene Silveira, afirmava que a nota da professora sempre havia existido e que o Boletim de Notas era constituído de algumas perguntas respondidas apenas com sim ou não.

No mesmo ano, a assistente do ensino, Zembla Soares de Sá, deixava a seguinte anotação no livro de Termos de Visitas do Grupo Escolar Pedro II:

A todo corpo docente recommendo a organização de fichas bibliographicas de todos os livros que lerem, sobre todos os assumptos, fichas essas que irei recolher no fim do anno, bem como as palestras que fizerem, cadernos de planos [verso] de aula, publicações etc., emfim, todo trabalho escripto que realizarem, além de informações sobre o typo de classe recebida e a porcentagem de promoção ou approvação obtida; a assiduidade ao trabalho; a disciplina em classe; assistencia aos alumnos; interesse pela vida do grupo, etc., finalmente, tudo quanto me puder servir de elemento para poder levantar a ficha profissional de cada uma, ficha essa que tenho o dever de apresentar à Secretaria. ${ }^{416}$

As fichas bibliográficas solicitadas pela assistente técnica deveriam ser entregues ao final do ano para a organização da "Ficha Pedagógica do Professor". Além das informações anteriores, Zembla recomendava um melhor desenvolvimento dos planos de lição, com uma apresentação detalhada das matérias, dos exercícios e do material utilizado. A avaliação destes planos constaria da ficha profissional da professora. Zembla afirmava, ainda, que os testes aplicados aos alunos seriam baseados nos Cadernos de Preparos das Lições, por isso, estes deveriam ser sinceros para evitar fracassos. Esta recomendação deixa subentendida a desconfiança de que as professoras nem sempre pautavam suas aulas no que apresentavam nos Cadernos.

Em 1943, numa reunião ${ }^{417}$ de professoras no Grupo Escolar Tomaz Brandão, a diretora e as técnicas avisavam que haviam organizado um livro onde seriam anotados os dias do mês, os nomes das professoras, as faltas, a disciplina e as atitudes das mesmas e trabalhos como planos, recreios, entre outros. Este livro lhes ajudaria a ter "com clareza e justiça a medida exata do trabalho de cada professora". Em 1948, em outra reunião neste Grupo, foi dito que seria organizado um fichário no qual se

\footnotetext{
${ }^{415}$ Ata da reunião de 13 de agosto de 1936 do Grupo Escolar Olegário Maciel.

416 Termo de Visita de 26 de outubro de 1937 do Grupo Escolar Pedro II.

${ }^{417}$ Ata de 7 de agosto de 1943 da reunião de professoras do Grupo Escolar Tomaz Brandão.
} 
anotariam os dados referentes à vida da professora no Grupo, destacando-se os seguintes:

Pontualidade: Está no grupo á hora exata? Falha em demasia? Pede licença por qualquer cousa?

Disciplina: Nas fileiras, á entrada, á saida. Maneira de consegui-la.

Auditórios e atividades extra-programa: Clubes, Horas de História - Excursões - Horas cívicas

Critério - Frequência á Biblioteca Pedagógica

Urbanidade no trato - com as colegas e os alunos.

Colaboração com a diretoria na solução de problemas tais como: aumento da renda da Caixa Escolar; organização de festivais, missões sociais.

Préstimos - Oferecimento expontâneo para trabalhos extraordinários.

Cooperação - Acatamento ás ordens dadas, não sendo permitido sublevar as companheiras contra as ordens recebidas. Cooperação nas reuniões - Atitude nas mesmas: de atenção e participação nos debates pedagógicos.

Abstenção de merenda durante as reuniões e de palestras nas portas das classes vizinhas e nas varandas, em horário escolar. ${ }^{418}$

Uma boa professora, segundo estes dados, deveria ser pontual, colaborar com a diretora e as outras professoras, organizar atividades escolares como auditórios e excursões, freqüentar a biblioteca, não manter conversas com as colegas em horário escolar e, quanto à disciplina, não bastava mantê-la, era preciso que esta fosse obtida de maneira adequada. Os dados parecem apontar que as representações sobre uma boa professora indicavam mais para alguém prestativo e de boa vontade do que com competência pedagógica.

Em 1948, no livro de ponto do Grupo Escolar Afrânio de Melo Franco, estava colado um pedaço recortado de jornal com o seguinte pedido: "leiam com atenção este aviso" em que se apresentam alguns critérios para a avaliação dos professores, bem como a pontuação que deveria ser atribuída. $\mathrm{O}$ aviso continha a seguinte informação:

\section{Departamento de Educação}

AVISO

O Departamento de Educação apresenta as seguintes sugestões para servirem ao critério de julgamento do trabalho dos docentes, regentes de classe e especializadas, de acordo com as instruções n.3, de 11 de março de 1947:

As notas serão avaliadas de 1 a 10 , atendendo aos seguintes tópicos:

1- Assiduidade e pontualidade -2 pontos

2- Interesse e entusiasmo pelo ensino - 1 ponto

3- Cultura geral e pedagógica -2 pontos

4- Iniciativa -1 ponto

\footnotetext{
${ }^{418}$ Ata de 7 de fevereiro de 1948 da reunião de professoras do Grupo Escolar Tomaz Brandão.
} 
5- Cooperação - 1 ponto

6- Interesse pelas instituições escolares e atividades do programa - 1 ponto

7- Capacidade de educar:

a) devotamento aos alunos (1);

b) paciencia - (1);

c) capacidade de manter a disciplina sem coagir nem atemorizar os alunos - (1);

d) justiça (1);

e) tacto (1) -5 pontos.

8 - Eficiência didática:

a) organização e execução dos planos de lições (1);

b) clareza nos ensinamentos (1);

c) bons métodos e processos de ensino (1);

d) hábito de correção dos exercícios escolares e verificação da aprendizagem;(1)

e) atenção às diferenças individuais (1) - 5 pontos.

9- Prontidão, capricho e exatidão na escrita da classe.

Total -20 pontos

Obtém-se a nota de merecimento da professora, dividindo-se por 2 o total de pontos apurados.

As notas serão conferidas trimestralmente, ou seja, nos boletins dos meses de abril, agosto e novembro.

Os diretores devem dar conhecimento aos professores deste critério de avaliação do trabalho escolar. ${ }^{419}$

Estes critérios, diferentemente dos anteriores, incluíam aspectos pedagógicos, como eficiência didática. Mesmo assim, em vinte pontos distribuídos, apenas sete podem ser contabilizados como se referindo às questões mais diretamente relacionadas à capacidade pedagógica: dois pontos para cultura geral e pedagógica e cinco para eficiência didática.

Em 1951, a diretora do Grupo Escolar Assis das Chagas, numa reunião ${ }^{420}$ com as professoras, disse que havia recebido da Secretaria de Educação questionários individuais referentes às fichas das professoras. Ela leu e comentou cada quesito que deveria ser avaliado, concluindo que gostaria de dar nota máxima a todas e elas deveriam contribuir para isto acontecer.

Estas fontes revelam que, apesar das críticas feitas em 1934, as tentativas de “fichar" os professores se estenderam pelo menos até a década de cinqüenta. Não foram encontradas tais fichas e é difícil avaliar se elas realmente foram instituídas.

Ainda que esta tentativa de classificar os educadores não tenha se generalizado, outras formas eram utilizadas para se extraírem informações sobre as práticas nos

${ }^{419}$ O aviso era dado pelo superintendente do Departamento de Educação, em 30 de abril de 1948.

${ }^{420}$ Ata de 2 de agosto de 1951 da reunião de professoras do Grupo Escolar Assis das Chagas. 
Grupos Escolares bem como os Termos de Visitas dos inspetores e assistentes técnicos que deixavam registradas as impressões do Grupo, das docentes e da diretora; os Cadernos de Preparo das Lições $^{421}$ em que as professoras registravam, com antecedência, o plano de aula que era visado pela diretora, pelos inspetores, professoras técnicas e assistentes, se possível, com antecedência e as Fichas Bibliográficas nas quais deveriam constar as leituras realizadas pelas professoras durante o período letivo. Tais meios de fiscalizar e vigiar os espaços escolares faziam parte de uma tentativa de disciplinamento que enredava todo o universo escolar, da mais alta hierarquia de administração dos Grupos até os alunos. Classificar consiste em uma forma de penalizar, hierarquizar e, principalmente, disciplinar.

\subsubsection{AVALIAÇÕES DE ALUNOS E ALUNAS EM GRUPOS ESCOLARES}

A reprovação era a marca registrada dessa Escola Moderna mineira. Antes um aluno reprovado que aprovado sem apresentar as condições esperadas. A assistente técnica do ensino, Leonilda Montandon, no Grupo Escolar Bernardo Monteiro recomendava:

Sejam bem criteriosas no trabalho de promoções, lembrando-se que um alumno mal preparado sendo promovido, constituirá um pessimo elemento na classe onde for colocado. No proximo anno, adoptem o criterio de nota, que tive a opportunidade de lhos aconselhar. Sejam ellas objetivas, quanto possivel, baseadas nas provas e testes de verificação. $^{422}$

Apesar dessas constantes recomendações, parece ter existido expedientes outros que permitissem burlar os exames realizados, especialmente nos Grupos noturnos ${ }^{423}$. Num livro de ponto do Grupo Escolar Afrânio de Melo Franco havia um aviso para não matricular um aluno porque este sempre se matriculava num ano superior ao seu. Segundo a professora, ele só podia freqüentar o $2^{\circ}$ ano adiantado. Apesar disso, ele havia cursado clandestinamente o $3^{\circ}$ ano, tendo vindo do $4^{\circ}$ dispensado pela professora.

${ }^{421}$ O Caderno de Preparo de Lições foi criado na Reforma de 1927. O Regulamento de 1924 tratava do Diário de Classe que parecia ter o mesmo sentido e objetivo, sendo visado pelas diretoras antes do início das aulas.

${ }^{422}$ Recomendação feita no livro de Termos de Visitas do Grupo Escolar Bernardo Monteiro na visita do dia 29 de outubro de 1935.

${ }^{423}$ Como parecia não haver homogeneização das classes nos Grupos noturnos, não foi possível saber se estes alunos também eram submetidos aos testes psicológicos aplicados pelo Laboratório de Psicologia e se a padronização dos testes finais também se aplicava a estes Grupos. 
O aviso descrevia o aluno como malcriado, que não sabia tabuada, escrevia e lia mal. Os procedimentos utilizados pelo referido aluno indiciam que, apesar das tentativas de se padronizarem e objetivarem as aprovações escolares, não se dispensava outros esforços para a obtenção de um adiantamento escolar.

No mesmo Grupo Escolar, um outro aluno procurou a diretora pedindo para voltar à classe do $4^{\circ}$ ano, pois a professora o havia rebaixado ao $3^{\circ}$. A professora, chamada para explicar o caso, afirmou que este era fraco até para o $3^{\circ}$ ano e não se esforçava para aprender, assim como seu irmão. A diretora pediu ao aluno que se esforçasse, chegasse cedo às aulas e fosse mais assíduo. Caso ele mudasse seu comportamento e tivesse condições de realizar os exames ao final do ano, ela se comprometia a incluí-lo. Caso contrário, permaneceria no $3^{\circ}$ ano. Não fica claro, mas parece que o aluno cursaria o $3^{\circ}$ ano com a possibilidade de realizar os exames finais junto com os do $4^{\circ}$ ano. Mesmo que isso acontecesse, é improvável que ele conseguisse ser aprovado num exame que exigia conhecimentos de uma série a qual não havia cursado.

Como as professoras definiam, a partir das notas obtidas durante o ano, quais os alunos podiam ou não fazer os exames finais, havia uma série de pedidos para que fossem criteriosas nessa escolha, já que algumas eram muito rigorosas nas avaliações e outras não. Eram tentativas de se padronizarem as avaliações escolares. Com a aplicação do teste E.A. (Escola de Aperfeiçoamento) em 1931, Helena Antipoff afirmava: “... os Grupos de Belo-Horizonte estão longe de adotar um único critério para a promoção das crianças do $1^{\circ}$ e do $2^{\circ}$ ano escolares. Há alguns que são relativamente muito mais severos que os outros..."424

Maria da Glória Arreguy comenta que, certa vez, foi examinadora de uma classe e que, na soma final das notas, uma professora não queria aprovar um aluno alegando seu péssimo procedimento durante o ano, embora tivesse nota 8 na prova escrita e feito muito boa prova oral. Maria da Glória tentou convencer a professora de que o menino havia tido um bom aproveitamento e que, se ela não o queria promover, não deveria têlo incluído na lista de chamada, já que seu nome constava com a média necessária para a prova final. No entanto, a professora não se convenceu e, ao fazer a leitura dos

${ }^{424}$ ANTIPOFF, Hélène. Organização das classes nos grupos escolares de Bello Horizonte e o control dos tests. Boletim n. 8. Bello Horizonte: Secretaria do Interior de Minas Gerais; Inspectoria Geral da Instrucção, 1932. p.36. 
aprovados, omitiu o nome do aluno. Maria da Glória, no dia seguinte, prometeu à professora conversar com o menino e obter dele o compromisso de se comportar melhor no quarto ano, colocando-se como sua madrinha. Quanto à omissão do nome deste aluno, Maria da Glória sugeriu que fosse justificado como uma confusão do momento da leitura, concluindo, dessa forma, ter remediado uma injustiça.

O curioso na história, que parece ter ocorrido em 1928 na cidade de Itabirito, é constatar que o mau procedimento do aluno podia implicar na sua reprovação. Além disso, a própria Maria da Glória afirma que a professora poderia não incluí-lo na chamada para a prova final, mesmo tendo média suficiente para aprovação. Casos semelhantes poderiam acontecer em outras escolas. Em 1935, Leonilda Montandon, assistente técnica do ensino, deixava a seguinte recomendação nas páginas do Termo de Visitas do Grupo Escolar Bernardo Monteiro: "Não confundam a nota de applicação com a de aproveitamento. Para o comportamento, continuem a adoptar o systhema de pontos perdidos e de pontos de honra" ${ }^{\text {,25 }}$. Tal recomendação às professoras sugere que nem sempre elas faziam distinção entre procedimento e as notas conseguidas nos exames escolares. Pode-se depreender destes fatos, o quanto as avaliações deveriam ser utilizadas para punir alunos indisciplinados, já que, ainda que tivessem boas notas, poderiam ser reprovados por apresentarem comportamentos pouco aceitáveis para suas professoras. Além disso, a própria concepção de que a escola deveria, mais do instruir, educar, poderia fazer com que as professoras cometessem tais arbitrariedades, privilegiando o comportamento dos alunos em detrimento do aproveitamento escolar.

As avaliações de final do ano dos alunos do $4^{\circ}$ ano dos Grupos Escolares de Belo Horizonte eram realizadas por uma banca composta de professores de outras escolas e da diretora do estabelecimento. Os exames eram escritos e orais e, às vezes, levavam dois dias para serem concluídos. No exame oral, havia sorteio de pontos. Nem todos os alunos compareciam a estes exames, apenas aqueles que, durante o ano letivo, tivessem obtido notas suficientes para a sua realização. Parece que o resultado dos exames era dado tão logo se finalizavam as provas orais.

Por este motivo, as professoras não tinham a oportunidade de interferir na nota final obtida pelos alunos e, às vezes, os resultados surpreendiam-nas. Um ex-aluno de Benedita Dell'Isola, ao formar na Faculdade de Engenharia da UFMG, a procurou

${ }^{425}$ Termo de Visitas do dia 29 de outubro de 1935. 
convidando-a para a solenidade. Ele havia sido um dos melhores alunos de sua classe e ela havia garantido a seus pais sua aprovação. Após a realização dos testes feitos pela Secretaria de Educação, soube que o aluno havia sido reprovado, enquanto a sua mais fraca aluna, uma "pretinha", havia sido aprovada com nota máxima. Era a diretora quem informava aos pais os resultados dos alunos. Dell'Isola acreditava que houvera um engano com relação aos testes e procurou ver as provas realizadas pelo menino, confirmando a prova péssima que ele havia feito. Esse não foi o único caso. Também outra aluna que era considerada pela professora como muito adiantada foi reprovada no exame da Secretaria. A reprovação de ambos os alunos, no entanto, não significou fracasso posterior. O menino tornara-se engenheiro e a aluna, professora de um dos Grupos da capital. É sugestivo pensar, entretanto, que nem sempre os alunos adiantados, na avaliação das professoras, eram os que se saíam bem nos testes da Secretaria e que, caso fossem avaliados por estas, poderiam apresentar resultados muito diferentes do que o revelado pelos testes.

É impressionante o número de reprovações encontradas nos arquivos dos Grupos Escolares. Como era de se esperar, a reprovação é compatível com o quoeficiente intelectual dos alunos, ou seja, as turmas classificadas como melhores tinham maiores índices de aprovação e estes índices decresciam proporcionalmente entre as turmas rotuladas como menos inteligentes. Obviamente, a explicação para estes casos estava na incompetência dos próprios alunos. Existem casos em que o Grupo, por excesso de matrícula, dividia o horário escolar em três turnos e alguns alunos chegavam a ter apenas duas horas de aulas diárias, o que levava a reprovação por não ser possível cumprir todo o programa escolar. Com a aplicação do teste E.A., em 1931, Helena Antipoff chegava à seguinte conclusão: “Os numeros mostram que os resultados das crianças que frequentam os Grupos de 3 turnos são sensivelmente inferiores aos que frequentam de $2 . . . " 426$, mas considerando ainda que os Grupos de 3 turnos eram aqueles localizados nos meios mais desfavorecidos, isto também pode ter influenciado o resultado.

\footnotetext{
${ }^{426}$ ANTIPOFF, Hélène. Organização das classes nos grupos escolares de Bello Horizonte e o control dos tests. Boletim n. 8. Bello Horizonte: Secretaria do Interior de Minas Gerais; Inspectoria Geral da Instrucção, 1932. p. 46. Essa observação oi confirmada pelo teste B. Hor. aplicado em 1932. Cf. CASTRO, Maria Angélica de. Formação das classes e o controle da sua homogeneidade em 1932. Boletim n. 11. Belo Horizonte: Secretaria de Educação e Saúde Publica; Inspetoria Geral da Instrução, 1933.69p.
} 
Diversas vezes salas inteiras eram reprovadas. No livro de Ata de Exames e Termos de Promoção do Grupo Escolar Olegário Maciel, existem alguns casos deste tipo. Em 1927, uma classe de $1^{\circ}$ ano foi reprovada, justificando-se que os alunos tiveram somente duas horas diárias de aula e não estavam "bastante firmes nas materias basicas", apesar da "competencia e dedicação das professoras". As fontes indicam que a turma havia passado por quatro professoras durante o ano. Em 1930, a turma de $4^{\circ}$ ano também foi reprovada, porque a estagiária que estava com eles teria ficado doente. A partir de setembro, as aulas teriam se regularizado, mas como a professora só teve tempo de executar o programa do $1^{\circ}$ semestre, "os alunos revelaram bastante aproveitamento, provando o esforço e a dedicação da actual professora", mas foram reprovados. Em 1932, quatro classes do Grupo Escolar Olegário Maciel tiveram reprovação total. As justificativas apontavam para o baixo índice mental dos alunos, afirmando-se que estes precisavam de dois a três anos para assimilar o que os alunos normais fariam em um ano. Três destas professoras eram estagiárias. Em 1934, uma classe de $1^{\circ}$ ano misto foi reprovada, por apresentar "indice mental fraco" e, em 1935, uma classe de $1^{\circ}$ ano de alunos com “indice mental C D" regida por uma estagiária foi reprovada, incluindo-se sempre o comentário: "apezar do esforço e dedicação da respectiva estagiaria".

O fato de, no Grupo Escolar Olegário Maciel, os examinadores terem o cuidado de ressaltar as qualidades da professora revela que elas também eram responsabilizadas, juntamente com os alunos, pelos altos índices de reprovação. Um relatório de alunos da Escola de Aperfeiçoamento sobre uma classe de $3^{\circ}$ ano de um Grupo Escolar da capital reafirmava tal compreensão:

Boa vontade, entusiasmo, optimismo, energia fisica e moral - são cousas que não the faltam [à professora]. Mais não progridem os seus alunos, por não serem "grande cousa", intelectualmente falando; por não ter ela, por falta de conhecimento dos novos metodos, habilidade para bem dirigir o seu material de ensino para os fins que deseja alcançar $^{427}$.

No relatório afirmava-se que a professora não tinha muitos conhecimentos sobre os modernos métodos de ensino e justificava que: "O meio familiar e as condições economicas não favorecem o desenvolvimento da classe. Quasi todas as crianças são

${ }^{427}$ MONOGRAFIA de um [sic] classe escolar de Belo Horizonte: estudo escolologico de 1931. Boletim n. 9. Belo Horizonte: 1931, p.71. 
filhas de operarios e habitam os bairros mais modestos da cidade". Talvez por este motivo se explicasse que o nível intelectual da classe não fosse bom, ficando os alunos abaixo da média nos testes psicológicos e pedagógicos.

Segundo a diretora do Grupo Escolar Tomaz Brandão, numa reunião do Departamento de Educação, o chefe do Departamento, Dr. Laborne Vale, teria afirmado que a percentagem das promoções revelava a capacidade da professora. A diretora e as professoras do Grupo não concordaram com esta afirmativa, mas este fato pode indicar outro motivo pelo qual as professoras resistiam tanto em reger as classes classificadas como mais fracas.

É importante frisar que já se esperava altos índices de reprovação, especialmente nas classes mais fracas. A reprovação era a constatação objetiva da incapacidade dos alunos de aprender. Helena Antipoff afirmava que as classes A deveriam ter uma promoção de $100 \%$ dos alunos; as classes B também poderiam ter aprovação total depois de 1 ano e meio de estudos e as classes C e D eram mais lentas, sendo aqueles que repetiam o ano. A expectativa de aprovação de Antipoff era bem mais alta que as divulgadas pela Secretaria de Educação e, apesar dessa baixa expectativa, nem mesmo ela conseguia ser alcançada, tanto nas classes ditas fortes como nas consideradas fracas.

Em 1933, Maria Angélica de Castro apresentava o resultado obtido nas classes A, B, C e D obtendo as promoções de respectivamente $96,63,58$ e 18\% dos alunos do $1^{\mathrm{o}}$ ano dos Grupos Escolares de Belo Horizonte, exaltando a homogeneização das classes obtida com o uso de testes: “... o agrupamento dos alunos de acordo com o desenvolvimento mental, é medida de alcance para o progresso do ensino e maior êxito dos bem dotados" ${ }^{\prime 428}$. Seu comentário deixa claro que o progresso do ensino atrelava-se ao bom desempenho dos considerados bem dotados.

\section{QUADRO 14}

Porcentagens esperadas e obtidas de aprovação em 1934 e 1938

\begin{tabular}{cccc}
\hline Tipo da classe & Porcentagem esperada & $\begin{array}{c}\text { Percentagem obtida } \\
\text { em } 1934\end{array}$ & $\begin{array}{c}\text { Percentagem obtida } \\
\text { em 1938 }\end{array}$ \\
\hline Forte & $86 \%$ & $61 \%$ & $72,2 \%$ \\
Média forte & $57 \%$ & $42 \%$ & $46,5 \%$ \\
Média fraca & $27 \%$ & $26 \%$ & $30,6 \%$ \\
Fraca & $12 \%$ & $2 \%$ & $8,62 \%$ \\
\hline
\end{tabular}

Fonte: A HOMOGENEISAÇÃO das classes e os resultados escolares em quatro anos. Revista do Ensino, BH, n.173, p.99-175, abr.1940.

${ }^{428}$ CASTRO, Maria Angélica de. Formação das classes e o controle da sua homogeneidade em 1932. Boletim n. 11. Belo Horizonte: Secretaria de Educação e Saúde Publica; Inspetoria Geral da Instrução, 1933. p. 68. 
Apesar destes dados alarmantes, uma pesquisa feita pela Escola de Aperfeiçoamento mostrava que a aprovação estava crescendo ao longo dos anos.

QUADRO 15

Alunos matriculados e aprovados entre 1938 e 1944

\begin{tabular}{lccc}
\hline & Matriculados & Aprovação geral & $\%$ \\
\hline $1938 \ldots \ldots .$. & 13.748 & 7.711 & 56 \\
$1939 \ldots \ldots$ & 17.129 & 10.227 & 59,7 \\
$1940 \ldots \ldots$ & 18.019 & 11.504 & 63,8 \\
$1941 \ldots \ldots$. & 19.625 & 12.350 & 62,9 \\
$1942 \ldots \ldots$. & 20.302 & 12.210 & 60,1 \\
$1943 \ldots \ldots$ & 20.756 & 13.212 & 63,6 \\
$1944 \ldots \ldots$ & 21.134 & 14.103 & 66,7 \\
\hline
\end{tabular}

Fonte: O RENDIMENTO do trabalho: problemas de medidas. Revista do Ensino. BH, n.176, p. 9-17, jan. fev. 1946.

Nem mesmo os Grupos Escolares escapavam de ser avaliados. Em maio de 1947, o Grupo Escolar Tomaz Brandão recebeu uma avaliação negativa do Departamento de Educação porque os resultados dos alunos da $1^{\mathrm{a}}, 2^{\mathrm{a}}$ e $3^{\mathrm{a}}$ série haviam sido bem inferiores à média geral dos Grupos da capital. Embora considerando as condições materiais do prédio e o meio social e econômico dos alunos, o relatório do Superintendente do Departamento de Educação afirmava que o Grupo já havia apresentado resultados melhores em idênticas condições. $\mathrm{O}$ relatório indicava quais os problemas identificados e sugeria algumas mudanças.

Os alunos mais fracos eram, já no segundo semestre letivo, deixados de lado pelas professoras, segundo recomendações das próprias diretoras. Numa reunião de quinta-feira, no Grupo Escolar Mariano de Abreu, a diretora apresentou o resultados dos alunos em algumas avaliações, dizendo: “... os nomes dos mais fortes e dos mais fracos, para que haja mais esforço, das professoras, sobre os fortes" ${ }^{429}$. Em outra reunião, a diretora:

Frisou ainda, que agora não devemos nos preoccupar mais com aquelles alumnos que até agora não alcançaram um desenvolvimento capaz de serem promovidos e sim, devemos destacar o grupo mais forte e trabalharmos mais com elle.

$[\ldots]$

A directora disse que devemos ser muito rigorosas nas notas, para que não passem, para o anno seguinte, alumnos de pouco desenvolvimento. A não ser com aquelles maiores do $4^{\circ}$ anno, como há na classe de Celia. Com esses não devemos ser muito rigorosas

${ }^{429}$ Reunião do dia 12 de setembro de 1935. 
porque elles em casa já levam uma vida de adulto e por isso não devem ter convivencia com as crianças menores. ${ }^{430}$

Estas observações mostram claramente o quanto os critérios utilizados para a avaliação dos alunos e alunas dos Grupos Escolares eram subjetivos e pessoais, derrubando o mito da neutralidade científica e da objetividade implantados com a introdução do escolanovismo. Era preciso fazer seleções rigorosas, deixando de lado as crianças com dificuldades de aprendizado que deveriam ser preteridos em função das mais talentosas. Por outro lado, era preciso se desfazer dos escolares maiores que, pelas constantes reprovações, chegavam à adolescência freqüentando os bancos da escola primária. Nestes casos, a aprovação era, mais do que um atestado de aquisição de conhecimentos, uma forma de liberar a escola do encargo de lidar com as vicissitudes desta fase do desenvolvimento, entre elas, certamente, o aparecimento mais incisivo de questões envolvendo a sexualidade.

Maria Angélica de Castro, ao fazer uma análise dos resultados da aplicação do teste B. Hor., em 1932, nos alunos repetentes dos Grupos Escolares de Belo Horizonte, identificava como possíveis causas para um número tão alto de reprovações, acima da média estrangeira: a infreqüência dos alunos, as falhas e licenças retiradas pelas professoras, as poucas horas de trabalho na escola e até mesmo a modernização dos métodos de ensino:

A tudo isto podemos acrescentar o inexito dos métodos novos que, adotados por professores que desconhecem suas verdadeiras teoria e técnica, não têm produzido ainda os resultados esperados. Todavia era de se esperar por esta deficiência no ensino, pois as nossas escolas experimentam atualmente um período de transição, o que não póde deixar de prejudicar os resultados. ${ }^{431}$

Quanto à modernização do ensino, a crítica não era atribuída a possíveis equívocos dos novos métodos instituídos, mas à falta de preparo e experiência dos educadores ao lidarem com as novas exigências. Em um aviso no Grupo Escolar Tomaz Brandão, por exemplo, havia uma afirmação de que as substitutas que não realizassem um trabalho igual ao das efetivas e mostrassem desinteresse pelo trabalho deveriam ser

\footnotetext{
${ }^{430}$ Atas da reunião de quinta-feira do dia 10 de novembro de 1935 do Grupo Escolar Mariano de Abreu.

${ }^{431}$ CASTRO, Maria Angélica de. Formação das classes e o controle da sua homogeneidade em 1932. Boletim n. 11. Belo Horizonte: Secretaria de Educação e Saúde Publica; Inspetoria Geral da Instrução, 1933.p. 68.
} 
suspensas, deixando subentendida a idéia de que as substitutas não se dedicavam, satisfatoriamente, ao trabalho. Mas também as efetivas eram responsabilizadas pelo fracasso escolar dos alunos.

Certamente pelo grande número de evasão e repetências, a conclusão do curso primário em Minas Gerais nesse período merecia uma grande solenidade, tanto para os alunos, vencedores de grandes obstáculos, tanto para as autoridades políticas que tinham a oportunidade de divulgar o seu investimento no setor educacional. Embora alguns entrevistados comentem não se lembrar de solenidade alguma, há registros de que, pelo menos em alguns Grupos Escolares, as solenidades eram sempre muito preparadas, com a participação da comunidade, apresentação de números artísticos e com a exposição dos trabalhos realizados durante o ano letivo como os cadernos de exercícios, os centros de interesse, os cadernos de desenho e cartografia e as provas mensais dos alunos de todas as classes. Em certos momentos, todos os formandos dos Grupos Escolares se reuniam em locais especiais como num grande estádio ou teatro onde havia o comparecimento das mais altas autoridades do Estado.

\subsection{AVALIAÇÕES E PREMIAÇÕES: DISPOSITIVOS DISCIPLINARES DE SELEÇÃO E EXCLUSÃO}

É bastante curioso e sugestivo que a Escola Nova se acercasse de tantas avaliações em todos os níveis escolares. As avaliações tinham início já na chegada dos alunos na escola, quando eram submetidos a diversos testes direcionados à homogeneização escolar. A passagem pelo Grupo, pela Escola Normal e de Aperfeiçoamento é lembrada pelos entrevistados como repleta de mecanismos avaliativos que se colocavam como obstáculos para a conquista do diploma e davam destaque à capacidade daqueles que foram capazes de enfrentar e vencer tantas barreiras.

Na representação dos entrevistados fica nítida a concepção de que escola boa é também exigente. As avaliações pareciam ser vistas como o momento fundamental para que os alunos aprendessem. Apesar disso, e da tentativa de objetividade da qual se tentava cercar os exames escolares, as fontes indicam que não foi possível eliminar a subjetividade das avaliações apresentadas aos alunos. As professoras tinham uma larga 
margem de manobra para definir quem ia ou não fazer os exames, embora não fossem elas as examinadoras e, às vezes, se surpreendessem com os resultados obtidos que podiam se distanciar muito das suas expectativas.

A seleção e a exclusão que marcaram todos os níveis escolares da educação mineira contribuíram para fomentar a idéia de que a escola era boa e de que seus exalunos, vencedores de tantas artimanhas e armadilhas, eram mais competentes e capazes do que os que se perderam no caminho. Aspectos como a pobreza, a fome, a miséria, a falta de materiais escolares, o menor acesso ao conhecimento formal, a livros, jornais, as condições de vida dos alunos reprovados eram desconsiderados ou utilizados para salientar, mais uma vez, sua incompetência pessoal e a de seus familiares que se mantinham em tal situação. Toda a justificativa pela reprovação escolar, ainda que passassem pelos educadores, tocassem os problemas sociais ou até mesmo indicassem a modernização escolar, recaiam, ao final, com toda força e convicção nos próprios alunos e o pensamento científico, especialmente a Psicologia, respaldava esta convicção.

A despeito dos inúmeros prêmios conferidos nas escolas, certamente o mais almejado e de árdua conquista era o diploma escolar. Boa parte dos alunos não conseguiu obtê-lo, "apesar dos esforços do Estado e dos educadores". Excluídos e segregados na escola primária iam se acostumando, desde cedo, ao que certamente a sociedade havia previsto para eles.

Os Grupos contavam com o apoio fundamental do conhecimento científico mais moderno e atualizado do período e, sem dúvida, a Psicologia tornou-se um saber crucial entre aqueles que pretendiam conhecer a criança para, então, controlá-la. A Escola Nova tinha um estatuto de cientificidade, alegando valer-se de conhecimentos considerados neutros e técnicos para fundamentar suas prescrições. Em Belo Horizonte não foi diferente. A Psicologia foi um instrumento fundamental para a renovação do ensino e a capital tornou-se um centro irradiador de pesquisas acerca dos escolares e da educação em todo o Estado.

\subsection{A PSICOLOGIA EM BELO HORIZONTE: PRODUZINDO A ESCOLA MODERNA \& EXPLICANDO O FRACASSO ESCOLAR}


As décadas de vinte e trinta inauguraram um momento em que a Psicologia entrava de maneira triunfal no cenário pedagógico mineiro ${ }^{432}$. Se em 1925, o ensino de Pedagogia e Psicologia Infantil já constava do Programa de Ensino nas Escolas Normais do Estado, a partir da Reforma de 1927, instituiu-se a Psicologia Educacional apresentando o programa e a bibliografia mais extensos de todo o Curso Normal. Professores estrangeiros de destaque internacional na área foram contratados para dar cursos e palestras aos educadores do Estado, como Leon Walther, Edouard Claparéde $^{433}$, Theodore Simon ${ }^{434}$ e Helena Antipoff. Os artigos relacionados à Psicologia tinham ampla divulgação na Revista do Ensino e Educando, nos Boletins publicados pela Secretaria do Interior e, posteriormente, da Educação e, em alguns momentos, eram nítidas as tentativas de formação do professorado, ensinando-se testes de fácil execução para aplicação nas escolas. O Laboratório de Psicologia da Escola de Aperfeiçoamento tinha, ainda, uma publicação própria: os Boletins que divulgavam as pesquisas realizadas nos Grupos Escolares mineiros. A Psicologia constituiu-se, nesse momento, como uma ciência primordial para uma ação científica e moderna dos educadores. $\mathrm{O}$ trabalho realizado na capital mineira foi registrado por Lourenço Filho:

Em Belo Horizonte, logo após, surgia uma organização a que muito deve a Psicologia Educacional no país, e que, desde o início, contou com a colaboração de especialistas estrangeiros. Tratava-se do "Laboratório de Psicologia da Escola de Aperfeiçoamento Pedagógico", de Minas Gerais, cujos trabalhos iniciais datam de março de 1929, sob a orientação de Th. Simon (1873), companheiro de Binet em suas investigações pioneira, e Leon Walther (1889), assistente de Claparède. Logo ao fim dêsse ano, a direção dos trabalhos passava a Helena Antipoff (1892) também antiga assistente de Claparède, e que se devia radicar no Brasil, para aqui prosseguir fecunda obra de caráter científico e alcance social. Até a extinção do Laboratório, em 1946, realizou êle, sob a chefia de Antipoff, acuradas investigações sobre inteligência geral e biótipo; inteligência, meio social e escolaridade; inteligência e vocabulário; orientação e seleção profissional; homogeneização de classes escolares; personalidade e tipos de crianças; memória,

432 Cf. Assunção, 2002; Boschi, 2000; Goulart, 1985 para maiores informações sobre a Psicologia em Minas Gerais no período aqui estudado.

${ }^{433}$ Claparéde esteve em Belo Horizonte em outubro de 1930, e promoveu uma conferência publicada no jornal Estado de Minas. No entanto, foi justamente quando os Estados do Rio Grande do Sul, Minas Gerais e Paraíba se rebelaram contra o governo Washington Luís. Assustado com os conflitos instaurados na capital mineira, deixou a cidade.

${ }^{434}$ No ano de 1929, o Theodore Simon esteve em Belo Horizonte e também em algumas cidades do interior do Estado. Na capital, realizou uma série de conferências sobre testes no Grupo Escolar Barão do Rio Branco reunindo entre 300 e 500 professores, além de fazer uma série de demonstrações na Escola de Aperfeiçoamento para cerca de 150 alunas-professoras. Em alguns Grupos da capital, submeteu alunos a exames e inquéritos que foram modificados e corrigidos também por ele, visando uma adaptação à realidade do Estado. Os testes eram mimeografados na Secretaria do Interior ou impressos nas oficinas do Estado e foram aplicados em todos os alunos do Grupo Escolar Pedro II submetidos a testes de leitura, ortografia, cálculo e inteligência. Também as crianças do Jardim de Infância e alunas e professoras do Curso Normal foram submetidas a testes de inteligência. 
aprendizagem e testemunho; motricidade e fadiga; julgamento moral e julgamento social. Além disso, procedeu à adaptação e à revisão de numerosos testes de inteligência e aptidão, havendo preparado testes originais, para medida psicológica e verificação do rendimento do ensino. (s.d., p.277)

Helena Antipoff foi a principal divulgadora da Psicologia no Estado nesse período, ficando responsável por lecionar Psicologia Experimental e Pedologia na Escola de Aperfeiçoamento, além de criar e organizar o Laboratório de Psicologia, o Museu da Criança e aplicar testes visando homogeneizar as classes dos Grupos Escolares mineiros. As discussões a respeito da organização das classes, do conhecimento dos alunos, da seleção, do self-government são essenciais na compreensão da disciplina escolar implantada no período. Dessa forma, faz-se necessário compreender as práticas punitivas e disciplinares utilizadas na escola a partir das análises da divulgação da Psicologia no Estado e da sua utilização no dia-a-dia das salas de aula, já que, segundo o Regulamento do Ensino Normal, a introdução dessa ciência na formação de professores tinha a função exclusiva de instrumentalizá-los para o trabalho pedagógico.

Os testes escolares aproximavam os esforços do médico, do educador e do estatístico, promovendo um minucioso reconhecimento das possibilidades e limites da aprendizagem da criança e o estudo dos casos isolados para correção adequada. Daí sua ênfase na perspectiva individualizante, mesmo quando focaliza o perfil da classe. Por analogia, através de respostas provocadas pela reação da criança aos estímulos do aplicador, seria revelado seu retrato do ponto de vista da maturidade ou não para a aprendizagem da leitura e da escrita. Os testes escolares (assim como os testes de encaminhamento profissional) tornaram-se a coqueluche dos educadores, em vários estados brasileiros, por várias décadas, nas escolas públicas e particulares do país. (Nunes, 1996, p.208)

Todas essas mudanças que se pretendia realizar no espaço da escola fundamentavam-se em alguns conceitos e instrumentais fornecidos pela Psicologia que enfatizavam a importância de se conhecer para prevenir.

A possibilidade de traçar as características, aptidões e tendências dos alunos, classificá-los, organizá-los, oferecer-lhes um ensino adequado às suas capacidades eram algumas das vantagens apregoadas aos professores, na busca por convencê-los da importância do conhecimento dessa ciência. A Psicologia suavizaria o trabalho docente, dando-lhe bases científicas e contribuindo para a eliminação dos problemas disciplinares, índice de algum grau de "anormalidade" apresentado pelo aluno. 
A Reforma do Ensino de 1927 instaurava definitivamente o uso da Psicologia entre os educadores mineiros. Os testes de inteligência para organização das classes foram utilizados pela primeira vez no Grupo Escolar Barão de Macaúbas em 1928. No ano seguinte, sob a direção de Theodore Simon, foram aplicados testes nos Grupos Escolares Barão do Rio Branco e Pedro II. Em 1930, foi a vez do Grupo Escolar Olegário Maciel. A partir de 1931, a aplicação foi sistematizada e ampliada, sendo realizada também em cidades do interior por ex-alunas da Escola de Aperfeiçoamento.

Com a criação da referida escola, mais testes puderam ser traduzidos. Além disso, alguns deles eram adaptados ao contexto e à realidade mineira do período. $\mathrm{O}$ trabalho de adaptação dos testes fazia com que Antipoff e suas alunas se orgulhassem de não estar apenas repetindo a aplicação dos testes, mas recriando-os e buscando novas formas de aplicação.

\subsubsection{DISPOSITIVOS DE CONTROLE: OS TESTES PSICOLÓGICOS E PEDAGÓGICOS ${ }^{435}$}

Durante o período em que Helena Antipoff esteve à frente do Laboratório de Psicologia da Escola de Aperfeiçoamento, foram identificados os seguintes os testes ${ }^{436}$ :

6.3.1.1. DEARBORN ${ }^{437}$ : teste de inteligência geral criado por um americano de mesmo nome. O nome original do teste é Games and Pictures Puzzles. São 17 grupos de desenhos aplicados coletivamente. As crianças recebem uma folha com desenhos e têm algumas atividades a fazer. As orientações são dadas pelo examinador e não se exige

\footnotetext{
${ }^{435}$ As informações sobre estes variam muito, portanto, alguns dados estão mais completos, outros menos. ${ }^{436}$ O decreto-lei n. 1.666 de 28 de janeiro de 1946, que transformou a Escola de Aperfeiçoamento em Curso de Administração Escolar, previa a continuidade do funcionamento do Laboratório de Psicologia. Entretanto, com a saída de Helena Antipoff, parece que o laboratório ou não foi adiante ou não teve a mesma visibilidade anterior. Somente em 1949, com a implantação do SOSP, a Psicologia voltou a ter espaço reconhecido na educação mineira do período.

${ }^{437} \mathrm{O}$ teste de Dearborn foi aplicado pelas professoras-alunas da Escola de Aperfeiçoamento a 2.464 crianças de Belo Horizonte, na idade de 6 a 16 anos no jardim de infância, nas escolas primárias e em alunas da Escola Normal, entre os meses de novembro de 1929 e abril de 1930. Os resultados aqui encontrados foram muito menores do que as crianças de Genebra, especialmente entre as crianças de 11 anos. Antipoff atribui este resultado à repetência, ao meio miserável de algumas crianças, bem como a uma possível irregularidade de freqüência à escola. Quanto ao gênero, meninos e meninas entre 7 e 9 anos tiveram resultados muito semelhantes, com resultados melhores apresentados pelos meninos entre 10 e 13 anos. Certamente não foi possível fazer uma comparação com alunos maiores, já que a pesquisa havia sido feita na Escola Normal que só aceitava meninas.
} 
conhecimento da leitura e da escrita. Vejamos a descrição do teste dada por Helena Antipoff:

Sem entrar nos pormenores das dezessete provas de Dearborn, diremos brevemente do que se trata: a creança, com o auxílio de seu lápis, terá que executar na sua folha de papel desenhos que consistirão ora em reproducção dos desenhos dados, ora na escolha de um algarismo em uma serie que vá de 0 a 12 , correspondendo a sua idade e que deverá ser contornado com um circulo; ou então terá que resolver um pequeno problema dos trajectos, seguindo com o lápis o mais curto dos dois caminhos; ou ainda,desenhada uma certa quantidade de bolas, deverá desenhar ao lado a metade dessas bolas. Ahi ella verá ainda o desenho da mão esquerda, mandando-se-lhe desenhar a mão direita, depois contar o numero dos dedos das duas mãos e escrever o algarismo num pequeno quadrado ao lado. Deverá ainda identificar as dimensões dos círculos com a de um nickel de cem réis, cujo modelo é desenhado na folha; fará também o calculo e inscreverá a somma do valor de todas as moedas identificadas com o tostão ou os dois tostões. Terá que achar e marcar com uma cruz ou com um circulo, conforme sejam mais caros ou mais baratos, os sellos de 100 e 200 réis e calcular a somma de dinheiro que tiver necessidade para compra-los todos etc., etc. (Antipoff, 1931, p. 29) (33 $^{438}$

6.3.1.2. GOODENOUGH ${ }^{439}$ : teste de inteligência geral a partir do desenho, criado pela psicóloga americana Florence Goodenough. Consiste em uma única prova (o desenho da figura humana), sendo necessário apenas uma folha de papel e um lápis, podendo ser aplicado coletivamente. O experimentador pede para se desenhar um homem, e a criança deve fazê-lo do melhor modo possível e sem pressa. Depois, o experimentador solicita um segundo desenho ainda melhor que o primeiro, sendo aproveitado o que for considerado melhor entre os dois. No julgamento da prova, não se analisa o valor estético, a avaliação é feita por meio de pontos que são dados conforme a presença de elementos como nariz, olhos, pernas, braços e outros e sua colocação nos devidos lugares. O máximo de pontos obtido é 51 , e uma tabela indica o número de pontos esperado desde uma criança de 3 anos e 6 meses ( 2 pontos) até um adolescente de 13 anos e 6 meses (42 pontos). Segundo Antipoff, o desenho poderia auxiliar na compreensão do desenvolvimento intelectual da criança:

\footnotetext{
${ }^{438}$ ANTIPOFF, Hélène. O desenvolvimento mental das creanças de Bello Horizonte segundo alguns tests de intelligencia geral. Boletim n. 7. Bello Horizonte: Secretaria da Educação e Saúde Pública; Inspectoria Geral da Instrucção, $1931.74 p$.

${ }^{439}$ O teste de Goodenough foi aplicado em 1930 em 32 classes de seis Grupos Escolares de Belo Horizonte, totalizando cerca de 900 desenhos em dois dias. Os resultados obtidos, comparados com os resultados apresentados por crianças dos Estados Unidos e de Genebra, mostraram-se inferiores para as crianças brasileiras. $\mathrm{O}$ resultado mostrava, ainda, que as meninas investigadas foram superiores aos meninos de idades entre 7 a 9 anos e que, a partir dos 10, 11 anos, os meninos passariam a levar vantagem. Antipoff comenta que, nos resultados encontrados pela própria Goodenough, as meninas de 6 a 12 anos foram superiores aos meninos.
} 
Realizando-se parallelamente com o desenvolvimento intelectual da creança o desenvolvimento do desenho, pode-se inferir o primeiro, servindo-se do ultimo, como de um symptoma. Esse desenvolvimento interior, exteriorizado em signaes materiaes, tem a vantagem de poder ser estudado e analysado pelos methodos das sciencias naturaes, que são: observação, comparação, interpretação, e pode ser submettido a uma investigação numérica, estatística.(Antipoff, 1931) ${ }^{440}$

6.3.1.3. BALLARD ${ }^{441}$ : teste de inteligência geral composto por 100 questões aplicadas coletivamente aos alunos que devem respondê-las numa folha. Exige, portanto, conhecimento da escrita ${ }^{442}$. As razões para a utilização do teste seriam as seguintes:

Escolhemo-nos por varias razões: primeiro, porque esse test nos pareceu, effectivamente, prescrutar o desenvolvimento mental geral, tendo-nos dado aliás (em Genebra) resultados comprovantes; segundo, porque elle se dirige à edade das creanças para as quaes o test de Dearborn (em sua primeira parte) não dava mais resultados tão seguros como faz para as mais jovens. Podendo as creanças, na edade de 9 a 10 annos, dar bem as suas respostas por escripto, era-nos possível applica-lo com proveito nos dois últimos annos escolares; $3^{\circ}$ ) porque a technica do test é relativamente simpes; e que por esse facto pode ser accessível a qualquer pessôa um pouco treinada no methodo dos tests. $4^{\circ}$ ) porque é um test economico, por excellencia, não exigindo formulários impressos, como o Dearborn, por exemplo. E, $5^{\circ}$ ) utilizamo-lo afim de comparar os nossos resultados com os de outros psychologos, de diversos paises.

$\mathrm{O}$ test compõe-se de 100 questões variadas que o auctor apresenta ás creanças como sendo "questões de bom senso". Ao lado dellas, há bom numero que faz appello á discriminação da analogia, á das diferenças, á synthese (palavras dadas desordenadamente que cumpre reduzir a uma phrase), ao vocabulário, á informação geral, á memória, á inducção mathematica (achar a lei segundo a qual é dada uma serie de números).(Antipoff, 1931, p.56-7). ${ }^{433}$

\footnotetext{
${ }^{440}$ ANTIPOFF, Hélène. O desenvolvimento mental das creanças de Bello Horizonte segundo alguns tests de intelligencia geral. Boletim n. 7. Bello Horizonte: Secretaria da Educação e Saúde Pública; Inspectoria Geral da Instrucção, 1931. 74p.

${ }^{441}$ O teste de Ballard foi aplicado a 953 examinandos em abril de 1930, e a 428 em novembro deste mesmo ano, totalizando 1.381 alunos. Destes, 1.025 cursavam os Grupos Escolares entre o $2^{\circ}$ e $4^{\circ}$ anos e 356 eram alunas da Escola Normal de Belo Horizonte. Comparando os resultados deste teste e os encontrados pelo de Dearborn, Antipoff encontra uma alta correlação com o meio social dos alunos. Cf. Antipoff, H. O desenvolvimento mental e o meio social. In: ANTIPOFF, Hélène. O desenvolvimento mental das creanças de Bello Horizonte segundo alguns tests de intelligencia geral. Boletim $n$. 7. Bello Horizonte: Secretaria da Educação e Saúde Pública; Inspectoria Geral da Instrucção, 1931. p. 62-65. ${ }^{442} \mathrm{~A}$ criança recebe uma folha numerada de 1 a 100 na qual responde às questões.

${ }^{443}$ ANTIPOFF, Hélène. O desenvolvimento mental das creanças de Bello Horizonte segundo alguns tests de intelligencia geral. Boletim n. 7. Bello Horizonte: Secretaria da Educação e Saúde Pública; Inspectoria Geral da Instrucção, 1931. 74p.
} 
Segundo Iago Pimentel (1955), este teste foi elaborado para crianças de 10 a 14 $\operatorname{anos}^{444}$ e exige controle rigoroso do experimentador, pois cada atividade deve ser realizada dentro de um determinado tempo, pré-estipulado.

\subsubsection{TESTE DE VOCABULÁRIO E INTELIGÊNCIA DE THEODORE}

SIMON: teste individual aplicado em 1931 nas crianças do $1^{\circ}$ ano.

6.3.1.5. TESTE PRIME OU T.P. ${ }^{445}$ : adaptado do Teste de Vocabulário e Inteligência de Theodore Simon, a partir das observações colhidas com a sua primeira aplicação e revisão feita em 1931 pelo Laboratório de Psicologia da Escola de Aperfeiçoamento. O impresso apresenta um cabeçalho para o preenchimento dos dados da criança e da escola, bem como algumas observações referentes ao teste - tempo da aplicação, horário, pontos obtidos -, trinta questões e alguns desenhos. Para sua aplicação, são necessários alguns materiais simples: uma pena velha e uma pena nova, presas a um cordão, um palito de fósforos, um pedaço de tecido grosso como flanela ou casimira, um tecido fino como seda, ambos, se possível, da mesma cor. Como o teste é preenchido pelo experimentador, pode ser aplicado a crianças não alfabetizadas. A aplicação do teste permitia, entre outras observações, que Antipoff indicasse que: "É provavelmente entre os jovens e precoces que vai ser recrutada a futura elite escolar do Grupo e talvez mesmo da futura sociedade". ${ }^{446}$ A professora apontava, ainda, que o teste deveria servir para se reconhecer "o material humano que ele [o Grupo] recolhe" de tal forma que utilizasse o tratamento adequado às capacidades infantis:

Com que cuidado o mestre vai amparar os fracos, os pobres, os ingênuos e com que generosidade ele vai procurar aumentar o magro domínio de coisas sabidas, pensadas, sentidas nessas crianças. A atitude do mestre será já bem diferente para as crianças que vieram para o grupo de mãos cheias, com espírito bem formado, com firmeza no julgamento, reto e sagaz. Este tesouro inicial crescerá na escola certamente como

\footnotetext{
${ }^{444} \mathrm{O}$ número de respostas acertadas esperado seria, para cada idade respectiva, o seguinte: 32 acertos para crianças de 10 anos, 42 para de 11, 50 para de 12,55 para 13 e 58 para crianças de 14 anos.

${ }^{445} \mathrm{O}$ Teste Prime foi aplicado em fevereiro de 1932 a todas as crianças novatas de primeiro ano de Belo Horizonte, cerca de 1.606 alunos. De Grupos Escolares de 24 cidades do interior chegaram ao Laboratório de Psicologia dados referentes à aplicação de 2.741 testes. Sobre 5.000 impressos mandados a pedido, foram recebidos 4.347 testes aplicados diretamente ou sob imediata direção das professoras técnicas, diplomadas pela Escola de Aperfeiçoamento. No entanto, nem todos puderam ser analisados porque nem todos traziam dados confiáveis sobre a data de nascimento da criança.

${ }^{446}$ ANTIPOFF, Hélène; CUNHA, Maria Luiza de Almeida. Teste Prime. Boletim n. 10. Belo Horizonte: Secretaria de Educação e Saúde Publica; Inspetoria Geral da Instrução, 1932.p 22.
} 
crescem as riquezas confiadas a um banco poderoso. Si não for assim, o país e o povo deveriam julgar a escola pública bem seriamente ${ }^{447}$. $(1932$, p. 22)

6.3.1.6. TESTE E.A. (ESCOLA DE APERFEIÇOAMENTO): teste coletivo criado pela Escola de Aperfeiçoamento e aplicado, em outubro de 1931, nos alunos repetentes das classes de $1^{\circ}$ ano de 13 Grupos da capital. O teste, com 31 questões, teria sido aplicado a 2.680 crianças.

6.3.1.7. TESTE B. HOR.: teste coletivo composto de 34 questões, 19 relativas à língua-pátria e 15 à aritmética. Sua aplicação foi feita na segunda quinzena de outubro de 1932 a 140 classes do $1^{\circ}$ ano de 18 Grupos de Belo Horizonte. Foram examinados 3.396 alunos (1.192 novatos e 2.204 repetentes). Não fica claro se o teste foi produzido também pela Escola de Aperfeiçoamento, mas é possível que sim e que B.Hor. signifique Belo Horizonte. A sua utilização possibilitava comparações com os resultados obtidos com a aplicação do teste E.A. no ano anterior.

6.3.1.8. TESTE DO LIMIAR ${ }^{448}$ : aplicado em 1934, para substituir o Teste Prime.

6.3.1.9. TESTE P.S.: este teste fora aplicado para promover uma divisão entre os alunos que poderiam realizar a primeira série do curso primário em um único ano e aqueles que não poderiam fazê-lo. Embora não se tenha certeza, pode-se supor que P.S. fosse uma sigla para Primeira Série.

6.3.1.10 TESTE INICIAL: organizado pelo Laboratório de Psicologia e aplicado, sucessivamente, em 1937,1938 e 1939.

6.3.1.11. TESTE DOS PRINCIPIANTES: preparado para a homogeneização das classes dos novatos em 1940;

6.3.1.12. TESTE DOS NOVATOS: aplicado em 1942 e 1943.

${ }^{447}$ ANTIPOFF, Hélène; CUNHA, Maria Luiza de Almeida. Teste Prime. Boletim n. 10. Belo Horizonte: Secretaria de Educação e Saúde Publica; Inspetoria Geral da Instrução, 1932.63p.

${ }_{448}$ Os resultados acham-se publicados no Boletim n. 19, da Secretaria de Educação, por Maria Angélica de Castro, então assistente do Laboratório de Psicologia da Escola de Aperfeiçoamento. 
6.3.1.13. TESTE MM OU “MINHAS MÃOS”: criado por Helena Antipoff, teve seus resultados publicados pela primeira vez em 1943 e na década de setenta e foi, após muitas pesquisas efetuadas pela própria autora e colaboradores, publicado pelo CEPA Centro Editor de Psicologia Aplicada. Consiste em uma redação intitulada "As minhas mãos" que objetivava traçar o perfil psicológico do examinando, investigando a utilização do espaço no papel, o conteúdo da redação, a fluência gráfica e outros $\operatorname{aspectos}^{449}$.

Os testes eram utilizados não apenas para se conhecerem as crianças mineiras, pois, freqüentemente, os resultados eram comparados com os apresentados por crianças de outros países. Numa comparação com os resultados obtidos no teste de Ballard, por exemplo, as crianças mineiras mostraram algumas semelhanças com os resultados apresentados pelas de Londres e Bruxelas. As crianças de Genebra foram superiores a todos as outras e as de Recife, testadas por Ulisses Pernambucano e pela senhora Paes Barreto, tiveram os índices mais baixos de todos ${ }^{450}$. Antipoff afirma que tais resultados são de difícil análise, sendo necessário criar uma maior homogeneidade na própria aplicação dos testes.

Um ofício expedido pelo Departamento de Educação em outubro de 1947 ao Grupo Escolar Tomaz Brandão definia os testes a serem aplicados em cada classe:

$$
\begin{aligned}
& 1^{\text {a }} \text { série - P.S. } \\
& 1^{\text {a }} \text { série - T.P. } \\
& 2^{\text {a }} \text { série - L.P e G.H.B. }{ }^{451} \\
& 2^{\text {a }} \text { série - A.G }{ }^{452} \text {. e C.N. }{ }^{453} \\
& 3^{\text {a }} \text { série - L.P. e G.H.B. } \\
& 3^{\text {a }} \text { série - A.G. e C.N. } \\
& 4^{\text {a }} \text { série - L.P. e G.H.B. } \\
& 4^{\text {a }} \text { série - A.G. e C.N. }
\end{aligned}
$$

\footnotetext{
${ }^{449}$ Mais informações sobre o teste podem ser encontradas em: CENTRO DE Documentação e Pesquisa Helena Antipoff. Coletânea das obras escritas de Helena Antipoff. Belo Horizonte: Imprensa Oficial, 1992, vol. I. "Psicologia Experimental".

${ }^{450}$ ANTIPOFF, Hélène. O desenvolvimento mental das creanças de Bello Horizonte segundo alguns tests de intelligencia geral. Boletim n. 7. Bello Horizonte: Secretaria da Educação e Saúde Pública; Inspectoria Geral da Instrucção, 1931. 74p.

${ }^{451}$ Supostamente sigla utilizada para Geografia e História do Brasil.

${ }^{452}$ Não foi possível decifrar qual seria este teste, mas, provavelmente, tais siglas se refiram à Aritmética e Geometria.

${ }^{453}$ Provavelmente Ciências Naturais.
} 
Não se pode afirmar ao certo qual o significado dessas abreviações. Pode-se inferir, no entanto, que se referiam a testes psicológicos como o Teste Prime que avaliava a inteligência e a testes pedagógicos avaliando conhecimentos escolares tais como Língua Pátria e Ciências Naturais.

A partir da aplicação dos testes, as classes eram divididas em:

Tipo A - A melhor classe, alunos portadores dos mais elevados Q.I. Classe de responsabilidade, destinada a uma promoção de 100\%. Com trabalho escolar intensificado.

Tipo B - Classe intermediaria, Q.I. medios.

Tipo C - Classe de crianças fracas, lentas, retardadas.

Tipo D - Classe de crianças visivelmente diferentes das comuns, apresentando grande atraso ou qualquer anomalia mental ou física, que impedisse seu desenvolvimento natural. $^{454}$

QUADRO 16

Classificação dos alunos, segundo os resultados obtidos no $1^{\circ}$ ano do Grupo Escolar T.P. ${ }^{455} 1946-1^{\circ}$ ano

\begin{tabular}{|c|c|c|c|c|}
\hline & Percentis & L.P. ${ }^{456}$ & Art. & Classificação \\
\hline Promovidos & 100 & 45 & 58 & $2^{\circ}$ ano de escolaridade $\left(\mathrm{An}^{1}\right)$ \\
\hline à & 90 & 43 & 54 & $3^{\circ}$ ano de escolaridade $\left(\mathrm{Bn}^{1}\right)$ \\
\hline \multirow[t]{2}{*}{$2^{\mathrm{a}}$ série } & 80 & 41 & 52 & $4^{\circ}$ ano de escolaridade $\left(\mathrm{Cn}^{1}\right)$ \\
\hline & 75 & 40 & 51 & $5^{\circ}$ ano de escolaridade (Dn) \\
\hline & 70 & 39 & 48 & $2^{\circ}$ ano de escolaridade $\left(\mathrm{An}^{2}\right)$ \\
\hline Promovidos & 60 & 36 & 43 & $3^{\circ}$ ano de escolaridade $\left(\mathrm{Bn}^{2}\right)$ \\
\hline à & 50 & 33 & 39 & $4^{\circ}$ ano de escolaridade $\left(\mathrm{Cn}^{2}\right)$ \\
\hline \multirow[t]{2}{*}{$2^{\mathrm{a}}$ série } & 40 & 30 & 35 & $5^{\circ}$ ano de escolaridade (Dn) \\
\hline & 30 & 25 & 32 & \\
\hline Promovidos & 25 & 23 & 27 & $2^{\circ}$ ano de escolaridade $(\mathrm{Br})$ \\
\hline ao $2^{\circ}$ período & 20 & 20 & 22 & $3^{\circ}$ ano de escolaridade $(\mathrm{Cr})$ \\
\hline da $1^{\mathrm{a}}$ série & & & & $4^{\circ}$ ou $5^{\circ}$ ano de escolaridade (Dr) \\
\hline Repetentes da & 10 & 15 & 18 & $2^{\circ}$ ano de escolaridade $\left(\mathrm{Br}^{1}\right)$ \\
\hline \multirow[t]{2}{*}{$1^{\mathrm{a}}$ série } & 0 & 0 & 0 & $3^{\circ}$ ano de escolaridade $\left(\mathrm{Cr}^{1}\right)$ \\
\hline & & & & $4^{\circ}$ ou $5^{\circ}$ ano de escolaridade $\left(\operatorname{Dr}^{1}\right)$ \\
\hline
\end{tabular}

Fonte: Ofício do Departamento de Educação enviado ao Grupo Escolar Tomaz Brandão em 10 de janeiro de 1947.

${ }^{454}$ MACHADO, Amélia Carlota da Mata. Organização das classes homogêneas de $1^{\circ}$ ano nos Grupos Escolares de Belo Horizonte. Revista do Ensino, BH, ano VI, n. 53, 54 e 55, p.56-76, jan. fev.mar.1931, p. 69.

${ }_{455}$ Supostamente o teste utilizado.

${ }^{456}$ L.P. e Art. devem ser abreviaturas para provas de Língua Pátria e Aritmética. 
QUADRO 17

Classificação dos alunos, segundo os resultados obtidos no $2^{\circ}$ ano do Grupo Escolar T.P. $1946-2^{\circ}$ ano

\begin{tabular}{ccccc}
\hline & Percentis & L.P. & Art. & Classificação \\
\hline Promovidos & 100 & 54 & 45 & $3^{\circ}$ ano de escolaridade $\left(\mathrm{An}^{1}\right)$ \\
à & 90 & 43 & 40 & $4^{\circ}$ ano de escolaridade $\left(\mathrm{Bn}^{1}\right)$ \\
$3^{\mathrm{a}}$ série & 80 & 40 & 38 & $5^{\circ}$ ano de escolaridade $\left(\mathrm{Cn}^{1}\right)$ \\
& 75 & 38 & 36 & $6^{\circ}$ ou $7^{\circ}$ ano de escolaridade $(\mathrm{Dn})$ \\
\hline & 70 & 37 & 35 & $3^{\circ}$ ano de escolaridade $\left(\mathrm{An}^{2}\right)$ \\
Promovidos & 60 & 35 & 33 & $4^{\circ}$ ano de escolaridade $\left(\mathrm{Bn}^{2}\right)$ \\
à & 50 & 32 & 30 & $5^{\circ}$ ano de escolaridade $\left(\mathrm{Cn}^{2}\right)$ \\
$3^{\mathrm{a}}$ série & 40 & 30 & 27 & $6^{\circ}$ ou $7^{\circ}$ ano de escolaridade $(\mathrm{Dn})$ \\
& 30 & 27 & 24 & \\
\hline Repetentes da & 25 & 26 & 22 & \\
$2^{\circ}$ série & 20 & 24 & 20 & $3^{\circ}$ ano de escolaridade $(\mathrm{Br})$ \\
& 10 & 19 & 15 & $4^{\circ}$ ano de escolaridade $(\mathrm{Cr})$ \\
\hline
\end{tabular}

Fonte: Ofício do Departamento de Educação enviado ao Grupo Escolar Tomaz Brandão em 10 de janeiro de 1947.

QUADRO 18

Classificação dos alunos, segundo os resultados obtidos no $3^{\circ}$ ano do Grupo Escolar T.P. $1946-3^{\circ}$ ano

\begin{tabular}{ccccc}
\hline & Percentis & L.P. & Art. & Classificação \\
\hline Promovidos & 100 & 56 & 45 & $4^{\circ}$ ano de escolaridade $\left(\mathrm{An}^{1}\right)$ \\
à & 90 & 42 & 39 & $5^{\circ}$ ano de escolaridade $\left(\mathrm{Bn}^{1}\right)$ \\
$4^{\text {a }}$ série & 80 & 38 & 37 & $6^{\circ}$ ano de escolaridade $\left(\mathrm{Cn}^{1}\right)$ \\
& 75 & 37 & 36 & $7^{\circ}$ ou $8^{\circ}$ ano de escolaridade $(\mathrm{Dn})$ \\
\hline \multirow{2}{*}{ Promovidos } & 70 & 35 & 35 & $4^{\circ}$ ano de escolaridade $\left(\mathrm{An}^{2}\right)$ \\
à & 60 & 33 & 33 & $5^{\circ}$ ano de escolaridade $\left(\mathrm{Bn}^{2}\right)$ \\
$4^{\text {a }}$ série & 50 & 31 & 31 & $6^{\circ}$ ano de escolaridade $\left(\mathrm{Cn}^{2}\right)$ \\
& 40 & 28 & 29 & $7^{\circ}$ ou $8^{\circ}$ ano de escolaridade $(\mathrm{Dn})$ \\
& 30 & 26 & 26 & \\
\hline Repetentes da & 25 & 24 & 23 & \\
$3^{\circ}$ série & 10 & 23 & 22 & $4^{\circ}$ ano de escolaridade $(\mathrm{Br})$ \\
& 0 & 2 & 4 & $5^{\circ}$ ano de escolaridade $(\mathrm{Cr})$ \\
\hline
\end{tabular}

Fonte: Ofício do Departamento de Educação enviado ao Grupo Escolar Tomaz Brandão em 10 de janeiro de 1947.

A seleção e organização dos alunos em classes homogêneas criavam, portanto, para uma única série escolar, diversas subdivisões que iam de A a D e, em alguns casos também a E, e ainda recebiam a letra $n$, caso fossem novatos naquela série, ou $r$, caso fossem repetentes. Entre os novatos, havia, ainda, uma classificação entre os de nível 1, com percentil acima de 80 e nível 2, com percentil entre 50 e 70 . A trama formada por esses diversos níveis escolares permitia um controle minucioso sobre os alunos, demarcando, de antemão, as expectativas em torno deles. 
Com exceção de Berenice Menegale e Terezinha Casasanta que falam das pesquisas de Helena Antipoff nas classes anexas à Escola de Aperfeiçoamento, nenhum dos alunos entrevistados se lembrou de ter sido submetido à aplicação de testes no curso primário. As professoras, como cursaram o primário num período anterior à Reforma Francisco Campos, foram unânimes em dizer que não havia aplicação de testes. Os alunos como Geraldo Félix e Norma Lúcia, disseram não haver Psicologia nos Grupos Escolares naquele momento. Provavelmente, porque a Psicologia, como eles a conhecem hoje, não é reconhecida no seu curso primário. Certamente, eles passaram por testes psicológicos, embora não tenham consciência disso. A orientação era para que os alunos não fossem comunicados da classificação das turmas, o que não significa que estes não soubessem quais as turmas consideradas melhores e piores e em qual delas estavam incluídos. É provável que não fossem alertados de que estivessem sendo submetidos a testes psicológicos já que não se desejava a divulgação dos resultados. Além disso, vários testes não eram propriamente psicológicos, mas a padronização de provas sobre as matérias escolares.

\subsection{HOMOGENEIZAÇÃO: PRODUZINDO O FRACASSO ESCOLAR}

Se a defesa da homogeneização das classes parece ser um dos principais aspectos do escolanovismo em Minas Gerais, pode-se afirmar, entretanto, que nem sobre este assunto havia uma unanimidade. Como foi tratado anteriormente, os Grupos Escolares noturnos eram alvo de preocupações por atenderem alunos de meios sociais mais desfavorecidos e com idades mais avançadas. Por este motivo, a co-educação se tornava um problema e diversos orientadores preferiam manter as turmas conforme a idade dos alunos do que optar pela homogeneização. Era o caso de Ernesto Santiago que não concordava com a homogeneização das classes e com a co-educação, argumentando acerca das especificidades do Grupo noturno. Em sua opinião, as propostas escolanovistas implantadas nos Grupos Escolares diurnos da capital e do interior não eram adequadas aos alunos que constituíam a maior parte da clientela das escolas noturnas. 
Helena Penna, assistente técnica do ensino, realizou ${ }^{457}$ no Grupo Escolar Assis das Chagas em 1932 uma redistribuição dos alunos do $1^{\circ}$ ao $4^{\circ}$ ano, organizando-os em classes fortes, médias e fracas já que, na organização anterior, não havia uniformidade nas classes. A nova organização, no entanto, parece ter provocado dificuldades e quatro meses depois, Ernesto Santiago, inspetor escolar municipal deixava a seguinte nota no mesmo Termo de Visitas: "As condições especialissimas e economicas deste instituto de ensino não permitem seleção ou nivelamento de classes. O proprio programa de ensino, para ser eficiente, precisa adaptar-se às condições economicas e mentais dos alunos".

Os Grupos noturnos não eram os únicos obstáculos para a homogeneização das classes. Algumas famílias, acostumadas a escolher a professora para seus filhos, a colocar na mesma classe irmãos ou primos, não se satisfaziam com a organização feita a partir dos testes. Leonilda Montandon registrou no Termo de Visitas do Grupo Escolar Bernardo Monteiro que era necessário realizar uma melhor organização das classes que reuniam "elementos hecterojeneos, [sic] que não deixam de perturbar o trabalho da mestra e a disciplina da classe". Segundo ela, os pais obrigariam as professoras a colocarem seus filhos em classes de nível mental superior, mesmo quando estes não apresentavam as devidas condições para essa classificação. A assistente recomendava que as exigências dos pais não se sobrepusessem aos interesses da comunidade escolar, prejudicando o trabalho das professoras e dificultando o rendimento dos alunos ${ }^{458}$. Confirmando este dado, uma professora de Brasópolis, num artigo para a Revista do Ensino, afirmava que chegou a trabalhar um uma classe heterogênea, a pedido dos pais.

No Grupo Escolar Olegário Maciel havia casos de alunos que evadiram porque não se sujeitaram à classificação, o que indica que as famílias ficavam sabendo qual a classificação obtida pelos seus filhos, por meios diretos ou indiretos, e resistiam à esta forma de organização dos alunos. Num desses casos, a aluna foi transferida para o Grupo Escolar Pedro II. Fica a dúvida se lá ela estaria melhor classificada.

Uma outra dificuldade para se realizar a homogeneização das classes consistia na obtenção de dados verídicos sobre os alunos. Como não se exigia certidão de

\footnotetext{
${ }^{457}$ Anotação feita no dia 15 de abril de 1932 no Termo de Visitas do Grupo Escolar Assis das Chagas da assistente técnica regional Helena Penna.

${ }^{458}$ Termo de inspeção de Leonilda Montandon, no dia 11 de junho de 1937.
} 
nascimento para a matrícula, as famílias podiam alterar as informações sobre a criança, conforme os seus interesses ou mesmo pela imprecisão da memória ${ }^{459}$.

A professora Maria da Glória revela um fato significativo que demonstra o cuidado que se deve ter ao se fazerem inferências sobre os documentos encontrados nas escolas. Retornando ao Grupo Escolar de Itabirito, após a formação na Escola de Aperfeiçoamento, ela iniciou o trabalho de organização dos livros de matrícula. Para dividir os alunos, era preciso conhecer a filiação, idade, escolaridade e meio social destes, dados que se encontravam totalmente desordenados:

É bom esclarecer que o livro de matrícula apresentava um verdadeiro labirinto. Iniciado para instalação do grupo em 1927, conservava todos os nomes dos alunos, sem baixas de espécie alguma, nem mesmo por morte. As idades não se alteraram como o decorrer do tempo, a filiação era um quebra-cabeça legítimo, pois, na transcrição dos nomes dos alunos em coluna, ao passar a "coluna dos pais" houve omissão do primeiro e todos os pais foram trocados sem a menor preocupação...(Arreguy, 1958, p. 95)

Benedita Dell'Isola informa também a respeito da dificuldade em precisar algumas informações acerca dos alunos. Embora afirme que tais dados tinham que ser lançados com exatidão nos livros de matrícula, isso nem sempre acontecia. Segundo ela, uma professora novata, cansada de procurar a data de nascimento de um aluno, queixouse a ela dessa dificuldade. Dell'Isola, procurando auxiliar a colega, recomendou-lhe que colocasse a data de nascimento de Jesus. A novata ainda lhe pediu a confirmação se poderia mesmo fazê-lo, ao que ela respondeu que sim. Alguns dias depois, Dell'Isola foi chamada ao gabinete da diretora que a recebeu de "cara fechada". Seguindo a recomendação dela, a professora havia colocado a mesma data de nascimento, 25 de dezembro, para cerca de vinte alunos e ainda argumentou que o havia feito por orientação da colega. Benedita justificou-se dizendo que só havia recomendado à colega colocar a data para um único aluno e não esperava que isso chegasse aos ouvidos da diretora. Ela recebeu uma suspensão que não se efetivou já que, no dia seguinte, a diretora não se lembrou mais do ocorrido.

Buscando solucionar o problema, o governo do Estado passou a exigir o registro de nascimento ${ }^{460}$ como documento indispensável para a matrícula, o que não garantia a

459 Segundo Clarice Nunes (2000), no Rio de Janeiro, os alunos que não apresentavam certidão de nascimento eram matriculados pelo exame dos dentes. A troca dos dentes de leite sinalizava o momento de entrar na escola. 
veracidade dos dados obtidos a partir do documento, feito exclusivamente para obter a vaga nos Grupos Escolares. Tal exigência teria provocado uma diminuição na matrícula dos novatos no $1^{\circ}$ ano em 1932:

Acreditamos que esta baixa já é um efeito do decreto 10.133, que exige a apresentação do certificado de nascimento para a matricula, não permitindo a entrada em nossos grupos de crianças que não tenham atingido a idade escolar. E si fôr esta a verdadeira causa da diminuição de alunos nestas classes, devemos aceitá-la como um benefício prestado à infância que só tinha a se prejudicar, indo para a escola antes de ter alcançado o desenvolvimento necessário para o trabalho que a esperava e prejudicar os outros em idade escolar, superlotando as classes, dificultando o trabalho das professoras e tomando o tempo dos colegas. (Castro, 1933, p. 14) ${ }^{461}$.

O que a autora não considera é que as crianças em idade escolar também poderiam estar sendo excluídas das matrículas nos Grupos Escolares, a partir da exigência da documentação.

Em 1935, para Oscar Guimarães, ainda eram poucas as escolas que haviam conseguido realmente obter a homogeneização dos alunos:

Confessemos que não estamos ainda apparelhados para generalizar em nossas escolas a pratica dos tests, que permitte a classificação dos alumnos em turmas homogeneas, sob aspecto cientifico.

Tal confissão, porém, não sirva de pretexto para que se cruzem os braços á espera de que nos venha do céo o remedio de que carecemos. ${ }^{462}$

Apesar de tal constatação, ele atestava que, mesmo sem os testes, o professor deveria organizar racionalmente seus alunos nas classes, buscando uma maior homogeneidade.

Outro problema consiste em detectar o que, afinal de contas, as professoras compreendiam como homogeneização. Numa reunião do Grupo Escolar Tomaz Brandão a técnica afirmou que os alunos que apresentavam percentil elevado nem

\footnotetext{
${ }^{460}$ Desde 1929, quando visitara Minas Gerais, Theodore Simon havia chamado a atenção para o fato de que os pais alteravam a idade das crianças para matriculá-las nos Grupos, que exigiam uma idade mínima de 7 anos. O governo mineiro, através do decreto n. 10.133 de 17 de novembro de 1931, passou a exigir apresentação obrigatória da certidão de nascimento para a matrícula escolar.

${ }_{461}$ CASTRO, Maria Angélica de. Formação das classes e o controle da sua homogeneidade em 1932. Boletim n. 11. Belo Horizonte: Secretaria de Educação e Saúde Publica; Inspetoria Geral da Instrução, 1933.69p.

${ }_{462}$ GUIMARÃES, Oscar Artur. Notas semanaes. Revista do Ensino, BH, ano IX, n.111. p. 11-116. fev.1935, p. 112.
} 
sempre eram "bons elementos", sendo preciso que a professora verificasse a tabela e a nota dos testes para conhecer os pontos fracos dos alunos. Resta a dúvida do porquê esses alunos, considerados maus elementos, não haviam sido colocados nas classes especiais, destinadas também aos alunos inadaptados. Uma outra professora, ao relatar na Revista do Ensino sua experiência com uma classe difícil, assegurava ter obtido a homogeneização da sua classe. Curiosamente, ela não a obteve com a aplicação de testes, até porque ela permaneceu com a mesma classe. A homogeneização, segundo ela, foi obtida com a sua dedicação e amizade aos alunos. Conseguindo isso, em três meses, a classe se homogeneizara: os alunos iam limpos para a escola, uma criança negra havia comprado uma escova de dentes com o dinheiro da venda de lenha e uma criança órfã passou a lavar, ela mesma, as próprias roupas.

Um outro problema acerca da homogeneização era que, tão logo ela era realizada, as professoras se davam conta de que as classes continuavam reunindo elementos heterogêneos e que precisavam atender às diferenças individuais que não se nivelariam por testes psicológicos.

Embora os testes analisados pela Escola de Aperfeiçoamento fossem somente os aplicados por suas alunas e ex-alunas, a divulgação em detalhes dos testes, da forma de aplicação, dos cuidados sugeridos na sua aplicação, do material utilizado bem como a análise dos resultados apresentando gráficos dos índices obtidos, em alguns números da Revista do Ensino, Educando e alguns dos Boletins publicados pela Secretaria da Educação tornavam possível aos leitores reaplicá-los, especialmente os mais simples, não sendo fácil controlar a forma de sua aplicação, que poderia sofrer as mais diversas alterações. Além disso, também as análises ficavam completamente fora de controle. Essa facilitação no acesso aos testes poderia ter como objetivo permitir que professoras que não tinham passado pela Escola de Aperfeiçoamento conhecessem-nos, talvez diminuindo o receio e a preocupação que estes despertavam entre elas. No entanto, tal acessibilidade permitia também usos indevidos deste conhecimento. Era o caso, por exemplo, de alguns professores que ensinavam a fazer os testes, treinando os alunos antecipadamente ou auxiliando a resolver as atividades, conforme denunciava Oscar Artur Guimarães ${ }^{463}$. Segundo ele, os motivos para que os professores assim procedessem eram má-fé, ignorância ou por vaidade tola. Em 1938, por exemplo, a

${ }^{463}$ GUIMARÃES, Oscar Artur. Homogeneização das classes. Revista do Ensino, BH, ano VII, n. 85, p.14-15, $1^{\circ}$ abr. 1933 . 
diretora do Grupo Escolar Tomaz Brandão afirmou que daria provas para os alunos do $2^{\circ}, 3^{\circ}$ e $4^{\circ}$ ano para que estes ficassem treinados para a realização dos testes, ao final do ano letivo. Certamente, ela estava falando em treiná-los não para realizar os testes, mas para se adaptarem à situação, ao contexto de aplicação destes. No entanto, este treinamento já podia tornar a situação daqueles alunos distinta dos que não estivessem acostumados ao ambiente dos testes. Esta poderia ser, no entanto, uma sugestão feita pelo próprio Departamento de Educação já que o mesmo aviso foi dado numa reunião no Grupo Escolar Olegário Maciel em que a assistente técnica afirmava que as professoras precisavam preparar os alunos para se sairem bem nos testes. A recomendação era de que estes não se limitassem à avaliação do final do ano, mas que fizessem parte do dia-a-dia escolar:

[D. Alba, diretora] Falou ainda sobre a importancia dos testes de escolaridade e sobre a necessidade de se applical-os ao menos uma vez por mes para se avaliar o rendimento da classe. Salientou ainda a necessidade de se registrar o resultado nos cadernos de plano, por meio dos graphicos que mostram tão claramente o perfil da classe, facilitando o controle.

Mostrou em seguida os graphicos levantados de accordo com o resultado das ultimas provas feitas nas diversas classes do $2^{\circ}$ anno. Commentou com as professoras os resultados, fixando os pontos fortes e fracos de cada classe e os erros mais frequentes da maioria. Terminou pedindo às professoras o melhor de seu empenho no sentido de combaterem com energia os pontos debeis, para que se melhore neste ano, a porcentagem de promoções. ${ }^{464}$

Tamanha preocupação em preparar os alunos para a realização dos testes se justifica pelo fato de que havia todo um cuidado para este momento. As recomendações detalhavam o ambiente, a colocação dos alunos e a atuação das professoras. As provas deveriam ser realizadas num ambiente adequado, os alunos deveriam sentar-se individualmente nas carteiras, não havendo comunicação entre eles, nem entrada de pessoas estranhas à classe. As professoras não poderiam dar nenhuma explicação, além das instruções necessárias para a realização dos testes. A aplicação seria feita pela diretora técnica, orientadora ou professora técnica regente de classe e professoras regentes treinadas para o trabalho. Cada classe teria uma professora do Grupo, que não fosse a própria regente da classe, para acompanhar os trabalhos. Esta deveria ter uma atitude discreta para auxiliar a aplicadora. Todo esse ritual, diferente da rotina cotidiana

464 Ata de 03 de novembro de 1935 das sessões de $5^{\text {a }}$ feira do Grupo Escolar Tomaz Brandão. 
da escola, resultava por amedrontar educandos e educadores que se sentiam, ambos, ameaçados e inseguros.

A correção das provas seria feita por duas ou mais professoras indicadas pela professora técnica, seguindo-se rigorosamente as instruções do Departamento de Educação. A correção seria feita no próprio Grupo e, uma vez concluídas as correções, era preciso entregar imediatamente ao Departamento os quadros com os resultados finais $^{465}$. Todas essas precauções dificultavam à professora da classe influenciar o resultado de seus alunos e provocavam objeções por parte destas, como se pode perceber numa reunião do Grupo Escolar Tomaz Brandão:

Foi motivo de debate entre a inspetora técnica e a orientadora, a correção dos testes. Esta aprovava a correção pela própria professora, tendo como argumento um meio seguro e eficaz de dar o teste a conhecer os êrros de cada criança; que a professora da classe corrigindo se interessará muito mais, e, que é também, de grande vantágem, porque á medida que ela for encontrando êrros poderá anotá-los e verificar no final a parte onde as crianças mais erraram.

Da sua vez a inspetora nos fez ver que não é necessário corrigir-se um teste para melhor-se conhecer um aluno. ${ }^{466}$

A argumentação de que a professora tivesse acesso aos dados obtidos pelos seus alunos nos testes não foi aceita. Isso não significa que os docentes não tivessem nenhum poder sobre os testes. Eram elas que definiam, de acordo com a média obtida durante o ano pelos alunos, quem iria ou não realizar os testes finais. Em 1947, uma circular do Departamento de Educação encontrada no Grupo Escolar Tomaz Brandão esclarecia algumas regras para a realização dos testes. Nesta se pedia que todos os alunos comparecessem no dia da aplicação. Apesar disso, na primeira série, a professora deveria definir os alunos que estivessem em condições de ser promovidos para realizarem o teste que envolvia todo o programa do curso. Os demais alunos que fossem julgados incapazes de ser aprovados realizaram um teste apenas sobre a primeira parte do Programa.

A tentativa de tornar a observação, análise e classificação dos alunos o mais objetivas possível deparava com algumas teorias nem sempre aceitas cientificamente. No Grupo Escolar Tomaz Brandão, por exemplo, em uma reunião de professoras, houve

${ }^{465}$ Curiosamente, um livro de movimento da Caixa Escolar do Grupo Assis das Chagas indica venda de testes, mas não esclarece se eram testes pedagógicos ou psicológicos e se eram vendidos para os alunos ou para os professores.

${ }^{466}$ Reunião no Grupo Escolar Tomaz Brandão em 24 de maio de 1941. 
uma discussão sobre as fases da lua e sua influência "nas plantações, na parte emocional e destino do indivíduo". Apesar da discussão e talvez por saber o caráter não científico da mesma, a diretora recomendou às professoras que não comentassem sobre tais influências entre si e não afirmassem tal influência, caso os alunos tocassem no assunto.

Curiosamente, apesar de todas as dificuldades em se lidar com os testes e da constatação da impossibilidade em se homogeneizarem os alunos, as professoras acabavam sempre reiterando a idéia de que tais testes eram a melhor forma de se organizarem as classes. Não foi encontrado nenhum tipo de repúdio a eles, a não ser quando elas próprias se depararam com a possibilidade de serem submetidas aos testes. Se, por um lado, eles eram valorizados para se obter maior conhecimento sobre os alunos, facilitar o trabalho do professor e, em última instância, retirar dos professores o peso pela reprovação dos discentes, a simples possibilidade de também serem submetidas aos testes, fazia com que elas questionassem seus resultados.

Na reunião de agosto de 1934, no Grupo Escolar Assis das Chagas ${ }^{467}$, houve uma discussão acerca das Fichas Profissionais, tratando-se, ainda, da possibilidade de as professoras serem submetidas a testes de inteligência e cultura pedagógica. Pela primeira vez, então, em todas as fontes consultadas, as docentes fizeram questionamentos aos testes, dizendo que eram instrumentos falhos e imperfeitos. Elas temiam ficarem nervosas e se atrapalharem, enquanto a assistente técnica, Zélia C. Rabelo, assinalava que o pavor existente em relação aos testes era infundado e precisava acabar. As professoras perguntavam sobre como estes seriam feitos, se seriam orais ou escritos, afirmando preferirem os escritos. Diante do pedido de uma professora, a assistente se comprometeu a levar alguns modelos na próxima reunião. Nas atas seguintes, o assunto não foi tratado novamente, e não foi possível saber se foram ou não aplicados às professoras, embora seja mais certo que não tenham sido, já que a polêmica de sua aplicação não foi encontrada em outros documentos.

Um único artigo na Revista do Ensino denunciava a pouca cientificidade dessas iniciativas:

...a ciencia não fornece, pelo menos na hora atual, os materiais suficientes para que se possa instituir uma pedagogia que tivesse o direito de se valer dela, que pudesse

\footnotetext{
${ }^{467}$ Ata da reunião de 23 de agosto 1934 do Grupo Escolar Assis das Chagas.
} 
prescrever em seu nome. [...] ... é preciso desconfiar de inovações audaciosas que pretendam revolucionar a pedagogia em nome da ciencia. Porque essa ciencia é muitas vezes uma pseudo-ciencia, que não merece nenhuma confiança. ${ }^{468}$

As professoras, pelo menos aquelas que passavam pela Escola de Aperfeiçoamento, também eram submetidas a testes. Maria da Glória conta que, em 1930, já no segundo ano da Escola de Aperfeiçoamento, as professoras-alunas foram divididas em duas turmas, o que provocou muitas discussões:

Julgavam umas [alunas] que a divisão era devido ao número, ao passo que outras atestavam que obedecia ao critério das médias obtidas dos trabalhos do primeiro ano. Houve até um palpite de que fôramos divididas pela ordem do Q.I. (quociente intelectual).(Arreguy, 1958, p. 87)

A impressão que se tem, ao ler as memórias da professora, é que essa dúvida não fôra esclarecida. As próprias colegas aplicavam testes umas nas outras na Escola de Aperfeiçoamento. Imene Guimarães conta que, após ser submetida à aplicação do Teste de Cores, fora chamada à sala de Helena Antipoff que lhe repreendeu por haver demorado a concluir o teste e cometer muitos erros. Antipoff suspeitava que ela havia brincado durante a aplicação. Foi quando descobriu que a aluna não se saíra bem no teste por ser daltônica. Apesar disso, num depoimento dado a Daniel Antipoff, Imene revelou que as suspeitas da professora de que as alunas deturpavam os testes não eram infundadas. Segundo ela, Helena Antipoff aplicava testes de personalidade baseados na preferência por determinadas cores, e as alunas, buscando se esquivarem de tais avaliações, inventavam preferências. Imene afirma que a sagacidade de Helena era tanta que ela "percebia a nossa farsa com a maior facilidade". ${ }^{469}$

Os testes psicológicos contribuíram para isentar escolas e professoras pela reprovação dos alunos. Esperava-se, de antemão, que alguns destes não se saíssem bem nos exames finais e tal acontecimento não provocava nenhuma surpresa. $\mathrm{O}$ "atraso mental" dos alunos justificava até mesmo a infreqüência escolar, como está registrado no livro de Relatórios Mensais do Grupo Escolar Olegário Maciel em setembro de 1928: "a classe não tem a freqüência mensal obrigatória por ser de alunos retardados".

\footnotetext{
${ }^{468}$ FAUCONNET, Paul. Pedagogia e ciência da educação. Revista do Ensino, BH, ano VII, n. 82, p. 2629, n. 81,15 fev.1933.

${ }^{469}$ Cf. Daniel Antipoff (1996, p. 120)
} 
Sugestivamente, em outra pesquisa realizada pelo Laboratório de Psicologia, chegava-se à conclusão de que o agrupamento dos alunos segundo o desenvolvimento mental "é medida de alcance para o progresso do ensino e maior êxito dos bem dotados". Se a homogeneização era fator de êxito para os alunos bem dotados, não o deveria ser para os considerados menos dotados que tinham altíssimos índices de reprovação.

Tal conclusão reforça a idéia de que a implantação do escolanovismo facilitou o processo de disciplinarização e a exclusão dos alunos, como confirma Maria Cecília C.C. Souza:

É importante frisar esse ponto: a Psicologia foi chamada a resolver problemas da nascente escolarização brasileira, não porque a escola estava fadada ao fracasso, mas porque estava fadada ao sucesso. Era preciso "conter" o sucesso, colocando a população brasileira no lugar onde a pedagogia iluminista francesa havia colocado as exceções: os "fracos de espírito", os "preguiçosos, etc. (Souza, 1998, p.66)

Dentre os fadados ao insucesso escolar, a Psicologia mineira acrescentava os “anormais", os pobres, os negros, os indisciplinados e até mesmo os alunos muito comportados, muito bonzinhos:

Não o é tanto, porém, lembrar-se que a influência transformadora da escola não visa tão sómente aos alunos considerados irrequietos, rebeldes e inadaptáveis, mas também aos anormalmente bem comportados, apáticos, não raro apontados como exemplos a seguir. Ao educador vigilante não passa despercebido o problema pedagógico sugerido pelo aspecto psicológico dêsses "bonzinhos" que se deixam ficar nas classes ou nos cantos do pátio à hora do recreio, fugindo, sistematicamemnte, aos folguedos e à movimentação do recreio. Não há dúvida de que essas crianças, sempre muito tímidas, desconfiadas e tristes, irredutíveis no seu mutismo habitual podem reagir sôbre si mesmas e modificar-se, maxime em consequência do convívio natural ou da socialização conforme os métodos tão empregados em nossas escolas.

$[\ldots]$

Algumas vezes esses tipos de alunos são casos que se enquadram na clínica psiquiátrica e exigem tratamento médico-pedagógico especializado, serviço que já não é estranho ao aparelhamento escolar do Estado. [p.43] $]^{470}$

${ }^{470}$ COSTA, Raul de Almeida. Os alunos "bonzinhos" e os incorrigíveis. Educando, BH, ano II, n. 10, p. 43-44, mar.1941. 
É difícil localizar as impressões que a sociedade tinha dos testes psicológicos, mas Carlos Drummond de Andrade se referiu a eles numa crônica publicada no Minas Gerais com pitadas de ironia:

O ensino mudou. Vieram uns senhores de nomes estranhos mais simpáticos - o dr. Decroly, o dr. Kerchensteiner, o dr. Dewey - que substituíram com vantagem as barbas do Barão de Macaúbas e ao cavanhaque severo de Felisberto de Carvalho. Veio também uma palavra nova, rápida e feliz, uma palavra que a gente apenas começa a pronunciar e já acabou: teste. Há testes de tudo: de aritmética, de linguagem, de geografia e de inteligência. A escola ficou interessantíssima. Os alunos são testados pelas professoras e estas, por sua vez, se deixam testar pelo dr. Simon, aquele doce e grave dr. Simon, que achou as professoras mais adiantadas do que as estagiárias e as diretoras mais adiantadas do que as professoras: exatamente na ordem hierárquica ${ }^{471}$. Depois de tudo isso, testar é um prazer, e eu testo, você testa, ele testa.

$\mathrm{O}$ último exercício desse gênero a que me foi dado assistir foi um teste de absurdos. A professora dizia uma frase absurda e, de relógio na mão, esperava a classe corrigir. Por exemplo: "Na rua São Paulo, um homem caiu de bicicleta, de cabeça para baixo, e morreu instantaneamente. Foi conduzido ao hospital mas há receio de que ele não fique bom". Todo mundo viu logo que isso não podia ser e que o sujeito estava morto mesmo. O segundo exemplo foi mais trágico: "Acharam no mato o corpo de um rapaz cortado em 18 pedaços. Dizem que ele suicidou. Será exato?” A maioria repeliu imediatamente essa hipótese, mas um garoto a admitiu, lembrando que o rapaz podia ter obtido aquela porção de pedaços cortando os dedos. Com que? Indagou outro. Ele não respondeu e a classe passou-lhe um trote.

Deixei para o fim a terceira pergunta, não propriamente porque ela envolva uma anedota engraçada - e não envolve - mas porque faz pensar. A professora disse que tinha sete irmãos: "Pedro, Arthur, Joaquina, Janjão, Romualdo e eu". Certo? Houve um momento amargo de indecisão. Afinal, uma garotinha de sete anos descobriu: "Errado! A gente não pode ser irmão de si mesmo".

Sussurro de aprovação do auditório. Mas um menino experimentado e de óculos, ruga precoce na testa, levantou-se para protestar: "Está errado. Onde já se viu ter tanto irmão num tempo desses?" ${ }^{472}$

Até o final do contrato de Helena Antipoff com o governo do Estado de Minas

Gerais na década de quarenta, os alunos dos Grupos Escolares mineiros na capital e no interior foram submetidos a diversos testes aplicados pelas professoras técnicas, exalunas da Escola de Aperfeiçoamento. Com o fim do contrato, mas para dar continuidade aos estudos e à prática clínico-pedagógica nos moldes do trabalho de Helena Antipoff, em 1949, no governo de Milton Campos e do Secretário Abgar

\footnotetext{
${ }^{471}$ Carlos Drummond de Andrade referia-se a um comentário feito pelo próprio Theodore Simon: "Também as professoras das classes em que operamos se prestaram gentilmente à prova, e devo acrescentar logo que se saíram como fora de se esperar, ou mesmo melhor, pois respeitaram sempre a hierarquia: as diretoras apresentaram os melhores resultados, e as professoras fizeram mais do que as estagiárias" (Simon, 1930).

${ }^{472}$ ANDRADE, Carlos Drummond de. Crônicas 1930-1934. Crônica publicada no jornal Minas Gerais na Coluna "Notas Sociais" em 24/04/1930 na página 11.
} 
Renault, foi criado o $\operatorname{SOSP}^{473}$, Serviço de Orientação e Seleção Profissional ${ }^{474}$ vinculado ao Instituto de Educação, antiga Escola Normal Modelo. O objetivo era orientar vocações no meio escolar e estabelecer critérios para a seleção de pessoal destinado à administração pública e a organizações particulares ${ }^{475}$.

Como se pode perceber, os dispositivos disciplinadores utilizados em Grupos Escolares de Belo Horizonte eram variados e, por vezes, ambíguos. A necessidade de transformar a escola num espaço de menos punição e mais disciplina, no entanto, parecia ser um consenso. A palmatória, as varadas, as orelhas de burro cediam o lugar para as classificações científicas de anormalidade, as reprovações, as classes especiais, as exclusões e seleções escolares. No capítulo seguinte, a temática a ser discutida é justamente essa transição de uma escola que pune para uma que disciplina, ainda que a existência de uma não signifique a extinção da outra.

\footnotetext{
${ }^{473}$ MINAS GERAIS, Lei n. 482 - 11 nov. 1949. Cria, no Instituto de Educação, o Serviço de Orientação e Seleção Profissional.

${ }^{474}$ O serviço planejado por Pedro Parafita de Bessa e Mira y López, repetia, em princípio, a metodologia psicotécnica que praticava o ISOP - Instituto de Orientação e Seleção Profissional - criado em 1947 na Fundação Getúlio Vargas no Rio de Janeiro que aplicava exames de orientação profissional e educacional, serviços de seleção de pessoal para empresas e exames psicotécnicos para motoristas de automóveis. Criado por lei estadual e, em sua origem, pertencente ao Instituto de Educação de Minas Gerais, o SOSP foi posteriormente federalizado e absorvido pela Faculdade de Filosofia. Em 1950, Emílio Mira y Lopes, professor espanhol que havia sido colega de Helena Antipoff no Instituto Jean Jacques Rousseau em Genebra nos anos vinte, ministrou um curso para professoras em Belo Horizonte.

${ }^{475}$ A colaboração com organizações particulares era feita de forma remunerada.
} 


\title{
CAPÍTULO 7
}

\section{DA ESCOLA PUNITIVA À ESCOLA DISCIPLINADORA: NOS RASTROS DE UMA TRANSIÇÃO}

\begin{abstract}
O capricho da criança não é nunca obra da natureza e sim de uma má disciplina: terá obedecido ou mandado e já disse cem vezes que não deve ocorrer nem uma coisa nem outra. Vosso aluno não terá portanto senão os caprichos que lhe tiverdes dado: é justo que carregueis o fardo de vossos erros. (Rousseau, 1762/1973, p. 115-6)
\end{abstract}

Foucault mostra na obra Vigiar e Punir $^{476}$ como as punições públicas, dramáticas e comoventes, até o século XVIII, envolviam a população européia, dando visibilidade à aplicação da justiça. O espetáculo contribuía para horrorizar, visando desestimular, entre os espectadores, qualquer pretensão de ferir a lei. Entretanto, segundo o autor, no fim do século XVIII e começo do XIX, dois processos marcaram mudanças importantes na execução penal. O primeiro foi a supressão do espetáculo punitivo que passou a ser cada vez menos honroso e tornou-se apenas tolerável. Por outro lado, a supressão da dor e um maior repúdio às punições corporais, que passam a dar lugar às prisões, aos trabalhos forçados, à deportação, entre outros.

$\mathrm{Na}$ transição de uma sociedade punitiva para a disciplinar, os castigos saem do domínio público e buscam se tornar menos visíveis e incisivos. As punições corporais vão perdendo espaço para a privação de direitos, como a liberdade ou a aquisição do diploma escolar. Esta transição nunca é absoluta, ou seja, as punições físicas permanecem existindo; entretanto, na sociedade disciplinar, quando se aplica um castigo, ele deve ficar confinado aos interessados e ter, se possível, uma atuação muito mais psíquica do que física. Por outro lado, o comportamento desejado deve ser motivo de muita publicidade para instigar os outros a imitá-lo. No ambiente escolar, expor publicamente crianças indisciplinadas passou a ser duramente criticado, especialmente a partir do final do século $\mathrm{XIX}^{477}$. As punições, quando utilizadas, deveriam ficar entre

\footnotetext{
${ }^{476}$ Cf. Foucault, 1975/1987, p. 14 a 17.

477 Em diversas pesquisas pode-se flagrar, ainda que indiretamente, o tratamento dado à punição e à disciplina nas escolas. Cf. Oliveira, 2001; Camargo, 2000; Galvão, 1998; Lima, 1999; Alencar, 1996. Ana Laura Godinho Lima (1999) apresentou um estudo sobre a disciplina escolar em revistas direcionadas aos professores paulistas, bem como em Manuais didáticos para a formação desses professores entre os anos
} 
aluno e professor, no máximo envolvendo a diretoria e familiares. Por outro lado, os comportamentos desejáveis mereceriam publicidade, daí, as cerimônias públicas de premiação, as exposições dos trabalhos dos alunos, os elogios aos trabalhos realizados.

Os castigos físicos, embora não tenham desaparecido completamente dos espaços escolares, vêm, ao longo do tempo, se tornado cada vez menos admitidos nas escolas $^{478}$. No entanto, dificilmente se pode dizer que fossem muito bem aceitos, por mais que se tolerasse o seu uso com resignação ou, pelo menos, sem grandes contestações. Era, talvez, considerado um mal necessário, quando se tratava de o professor ensinar o que não sabia e de o aluno aprender o que não entendia, como Maria Cecília C.C. Souza (1998, p. 88) adverte ao tratar da memorização. O que não entrasse pelo entendimento, haveria de entrar pelas pancadas.

Heloísa Villela, ao tratar dos temas publicados no jornal A Instrução Publica entre 1872 e 1875, em um jornal pedagógico lançado na Corte em 1872 por José Carlos de Alambary Luz, traz informações acerca das discussões sobre os castigos físicos daquele período:

Quanto ao item - castigos corporais - a pequena incidência de artigos (quatro no ano de 1872 e dois, em 1874) pode sugerir a falsa idéia de que o tema não era muito discutido na época, o que não é verdade, já que a seleção foi feita apenas em relação aos artigos que trataram diretamente desse assunto, pois de forma indireta ele estava presente em inúmeras matérias de vários tipos nos editoriais de Alambary, nos discursos comemorativos, nas apresentações das conferências literárias, etc. Fica evidente a existência de uma forte corrente contrária a tal prática, que nesse momento começava a parecer repugnante, embora no cotidiano os professores a utilizassem bastante, alguns desconhecendo mesmo como conseguir a disciplina sem recorrer à violência física. (2002, p.64)

Segundo a autora, neste mesmo jornal apareceu uma questão de um professor perguntando se os castigos poderiam ser banidos da escola e como fazer então para substituí-los. Outros artigos, neste mesmo ano, condenavam o uso dos castigos, mas a pergunta feita pelo professor evidencia o seu despreparo para lidar com tal situação. Outro incidente discutido pela autora situa como os castigos físicos, se não eram raros

de 1944 e 1965. Atualmente, este vem sendo um tema bastante debatido em dissertações e teses tanto nos cursos de Educação, quanto nos de Psicologia, e é o tema principal de diversos livros destinados a pais, mães e profissionais da educação.

${ }^{478}$ Em 1995, a Folha de São Paulo publicou uma reportagem sobre um professor do ensino primário do sertão paraibano que utilizava a palmatória em seus alunos. Apesar do fato ser certamente uma exceção, é significativo por revelar o quanto a palmatória e outros métodos punitivos podem configurar práticas punitivas escolares ainda nos dias atuais. Cf. BARBOSA, Adelson. Professor usa palmatória em alunos. Folha de São Paulo, 14 de março de 1995. Caderno Via Brasil, p. 3 
nas escolas, criavam uma situação bastante desconfortável entre os educadores. Em 1874, na abertura de uma Conferência Pedagógica no Rio de Janeiro, “um professor declarou publicamente que usava a palmatória, causando um clima tão desagradável que a sessão teve que ser suspensa". Na semana seguinte, foi expedida uma circular da Corte que instruía os delegados a punirem os professores que usassem palmatórias. No entanto, a circular da Corte, segundo a informação de Villela, nada sinalizava quanto ao uso de outros castigos físicos. A palmatória, naquele momento, já parecia representar uma imagem de autoritarismo, violência e terror que a tornaram um símbolo da escola ruim e do professor incompetente. Entretanto, foram as alternativas criadas e/ou divulgadas pelo método intuitivo e, posteriormente, a Escola Nova e Escola Ativa que possibilitaram a percepção de uma escola agradável, interessante e sem necessidade de punições. No entanto, mesmo com a introdução dessas novas concepções de educação, nem sempre era possível controlar as inúmeras e variadas formas de punição, cuja inventividade parece não conhecer limites, como denuncia Artur Ramos em 1944, num artigo em que enumera uma série de castigos utilizados pelos professores:

...bolos por palmatória, com várias modalidades (palmatória furada, bolos com milho na mão...), cascudos, puxões de orelhas, ajoelhar em cima do milho ou feijão, ficar de pé na classe, de pé em cima do banco, orelha de burro, pedra ou caderno pendurado ao pescoço com exercício errado, lavar a boca tantas vezes quanto as sílabas da palavra "feia" dita pela criança, ficar de pé com uma cadeira na cabeça, privar a criança de internato de dormir, quando já com sono, pregar caderno às costas e fazer passar por toda a escola ... que sei mais? (Ramos, 1944, p. 457)

Ramos advertia, ainda, para outros castigos usados no Rio de Janeiro daquele período:

... ficar de joelhos (observação de 1938); por de joelhos embaixo da mesa; por a criança de joelho com a cesta de papéis na cabeça (numa escola particular); um superintendente da sétima circunscrição encontrou, em 1934, uma professora que levava milho para castigar os alunos; puxões de orelhas, cascudos... (Ramos, 1944, p. 457)

$\mathrm{O}$ autor ressalta que os castigos físicos em algumas escolas estavam sendo substituídos pelos castigos morais que, para ele, seriam de "conseqüência tão desastrosa como os primeiros". Seriam estes castigos: 
... retenção na hora do recreio; retenção na hora da saída; humilhar a criança perante os colegas; retirar a criança da classe para a turma de outra professora; retirar a criança da aula para o gabinete da diretora; suspensão por tempo limitado; expulsão; nome na "lista negra". (1944, p. 457)

Talvez a maior inovação das Reformas mineiras no campo da disciplina escolar tenha sido, não a proibição dos castigos físicos em voga desde o século XIX, mas a preparação do professorado para proporcionar aos alunos atividades mais estimulantes, divertidas e que ocupassem todo o tempo destinado aos trabalhos escolares. A constituição de uma série de dispositivos disciplinares como a construção arquitetônica dos edifícios, a organização das carteiras, as fílas dos alunos, o sem-número de atividades a serem realizadas, as leituras, os auditórios, as festas cívicas e religiosas faziam parte de uma rede disciplinar em que todos os personagens escolares estavam envolvidos. Afinal, a disciplina dos educandos só aconteceria a partir da disciplinarização também dos educadores.

Nenhum entrevistado nem mesmo as professoras mais antigas disseram ter visto uma palmatória em uso nas escolas. Em um livro lançado em comemoração ao cinqüentenário da cidade de Belo Horizonte, seu autor, Djalma Andrade, tratava do enterro da palmatória:

Em 1926, a Secretaria da Educação baixou uma ordem terminante, abolindo o uso da palmatória nos estabelecimentos de Ensino de todo o Estado. Em muitos lugarejos do interior, as professoras, cumprindo as determinações do governo e imbuídas dos novos métodos pedagógicos, instituíram uma solenidade pitoresca - o "enterro da palmatória". Essa estranha festa escolar consistia no seguinte: a velha palmatória de cabiúna, que havia disciplinado várias gerações, era encerrada em uma caixa artisticamente trabalhada. O aluno mais adiantado do grupo, à frente dos seus colegas e ladeado pelas professoras, levava o "esquife" até ao largo da matriz da vila. Ali era aberta uma cova de um metro de profundidade.

Vários oradores, professores, alunos, homens importantes do arraial, exaltavam os novos sistemas de ensino e injuriavam acremente a palmatória.

Findos os discursos, punha-se a caixa no fundo da cova e os alunos voltavam satisfeitos para casa, porque, em regra, era considerado de férias o dia em que se realizava essa cerimônia tão grata às crianças das escolas. (Andrade, 1947, p.31-32)

Esta história do enterro da palmatória já havia aparecido na Revista do Ensino ${ }^{479}$ em 1927, mas, segundo o autor desta versão, na escola antiga, a palmatória era enterrada no início das férias e ressuscitava no retorno do período letivo. Não foi possível

\footnotetext{
${ }^{479}$ PEREIRA, Leopoldo. A escola antiga. Revista do Ensino, BH, ano III, n.23, p.524-525, out.1927.
} 
encontrar essa ordem de que a palmatória fosse banida dos estabelecimentos, embora ela não constasse das punições admitidas pelo Regulamento. De qualquer forma, a entrada dos princípios escolanovistas no ensino em Minas Gerais condenava a palmatória à obsolescência, embora não se possa afirmar com precisão em que momento ela deixou de ser utilizada, especialmente nas escolas localizadas em regiões mais distantes da capital. Por outro lado, é evidente que as chamadas formas científicas de homogeneização das classes, as avaliações de todo tipo, a aplicação e categorização dos alunos por meio de testes e a própria reprovação escolar não deixavam de ter um caráter punitivo, embora fosse menos evidente e incisivo quanto o uso da palmatória.

Como a disciplina encontra-se sutilmente espraiada pelo ambiente escolar, não é fácil detectar a sua existência, sendo preciso percorrer os indícios deixados em todos os segmentos escolares. Uma das formas de educar e disciplinar é a partir da ordenação dos espaços, como nos mostrou Cynthia Greive (2000) ao tratar das reformas na cidade de Belo Horizonte. O espaço escolar, por sua vez, também exerce um caráter disciplinador. Desde a implantação em Minas Gerais dos Grupos Escolares, através da Reforma João Pinheiro realizada em 1906, toda uma forma escolar foi instituída configurando novos espaços, novas atribuições a professores e alunos, enfim, uma nova cultura escolar. Pode-se considerar que na estrutura arquitetônica, na disposição das salas, dos pátios, na existência ou não de jardins, de hortas, de gabinetes médicos, dentários, enfim, em toda a organização predial da escola, existe um projeto e uma concepção de como deve ser o processo educativo ali realizado. Nesse sentido, o prédio também educa e é daí ele também pode vir a ter uma função disciplinar.

\subsection{NO INTERIOR DOS PRÉDIOS ESCOLARES}

A princípio, esperava-se analisar os dispositivos disciplinares dispostos na estrutura arquitetônica dos prédios ${ }^{480}$. Para isso, seria preciso encontrar a planta original

\footnotetext{
${ }^{480}$ Cláudio Fonseca $(2004$, p.20) realizou uma pesquisa sobre a arquitetura das escolas públicas primárias construídas em Belo Horizonte desde 1892 até 1930. Conforme salienta Faria Filho (2002, p.112), o espaço escolar é também um componente da educação: "Nesta perspectiva, a ocupação do espaço escolar, sua divisão interna, suas aberturas para o espaço exterior, a delimitação de fronteiras entre o interno e o externo, e, mais que isso, a disposição e a diferenciação dos sujeitos (alunos e professores, sobretudo) e dos objetos no espaço, na sala de aula, tudo isso cumpre um papel educativo da maior importância".
} 
dos edifícios e as mudanças efetuadas no decorrer do tempo. No entanto, tais plantas não foram encontradas. Além disso, foram diversas as reformas pelas quais passaram os prédios escolares em todos esses anos. Além de pequenas mudanças para manutenção, instalação de novas salas, cantinas, bibliotecas que todos os Grupos sofreram, na década de sessenta, os Grupos da capital passaram por reformas feitas pela CARPE ${ }^{481}$. Esta buscava padronizar esses edifícios que haviam sofrido uma série de ajustes e adaptações nem sempre respeitando as normas adequadas para tais espaços.

O Grupo Escolar Tomaz Brandão, por exemplo, passou por drásticas reformas. Segundo Geraldo Félix, como o espaço não comportava todas as classes, algumas aulas aconteciam em casas alugadas próximas ao edifício. O Grupo tinha apenas um pavimento que, segundo ele, ficava ao nível da rua. Posteriormente, o morro foi aplainado e a escola ficou num nível mais alto. Assim ele descreve a escola no período em que estudou:

G.F.: No nível da rua, lá em cima. Com um pavimento só, tipo uma ferradura, a frente da escola era parte curva da ferradura, tinha salas de um lado e salas de outro, o corredor fazia a volta na ferradura. No meio certinho dessa ferradura era coberto de vidro onde era auditório e sala de lanches, de refeição, coberto de vidro, e no fundo da ferradura, onde está lá solto, era a área pro recreio, sem andar. Como tinha muito aluno e a escola não era grande porque não tinha andar, ela tinha anexos fora, tinha 3 ou 4 casas que funcionavam muitas salas fora.

Elza de Moura também recorda de um espaço bem mais amplo para o funcionamento do Grupo Escolar Henrique Diniz, onde estudou:

E.M.: Que saudade! Até a construção do meu antigo Grupo Escolar foi modificada e aquele ar de fazenda velha foi modernizado. A chácara encolheu, dividida, ruas abertas no lugar do arvoredo. Um país com tanto espaço não precisava mutilar o terreno das escolas, que se tornaram apertadas, sem jardins, sem pátios arborizados. E as brincadeiras, próprias de grandes espaços, tornaram-se impraticáveis. ${ }^{482}$

\footnotetext{
${ }^{481}$ Segundo informações de Nelma Marçal Lacerda Fonseca, a CARPE - Campanha de Aperfeiçoamento e Recuperação de Prédios Escolares - foi criada no Governo Magalhães Pinto (1961-1966) e perdurou até a década de 80. Seu responsável era Paulo Diniz Chagas que atuou como substituto do Secretário da Educação, Antônio Aureliano Chaves de Mendonça (que exerceu o cargo entre 07 de fevereiro de1964 e 01 de julho de1975). De acordo com Fonseca (2004, p.20) a CARRPE significava Campanha de Reparo e Restauração dos Prédios Escolares do Estado e que, no final dos anos 70, passaria a ser denominada de CARPE - Comissão de Construção, Ampliação e Reconstrução dos Prédios Escolares do Estado.

${ }^{482}$ MOURA, Elza de. Saudades do meu grupo escolar. Estado de Minas, 19/03/2001.
} 
Outra entrevistada, Norma Lúcia, se lembra de poucas alterações no Grupo Escolar Barão de Macaúbas:

N.L.:[O Grupo Escolar] É como hoje. Só que eles aumentaram. No pátio onde tem um pequeno galpão foi lá, inclusive, que o meu sobrinho Humberto tirou o diploma de préprimário. A última turma de pré-primário foi a dele, onde é este galpão hoje era um pátio de terra e tinha umas armações de gangorras, mas no nosso tempo já não tinha mais gangorra não. Então era um pátio de terra do lado do Grupo, sabe? Mas o galpão central onde nós tínhamos recreio era do mesmo jeito que é hoje não mudou quase nada, nada, nada.

Outros Grupos Escolares foram completamente demolidos e, em seu lugar, foram construídos prédios considerados mais modernos ${ }^{483}$. Entretanto, não foi possível identificar qual o alcance dessas mudanças arquitetônicas nos Grupos Escolares já que não foram encontradas as plantas dos Grupos sendo difícil precisar as reformas efetuadas.

Segundo Elza de Moura, até mesmo a amplitude dos espaços escolares davam à criança liberdade de ação e expansão que as tornavam menos indisciplinadas e, na sua opinião, as crianças de antes eram mais disciplinados justamente porque tinham mais liberdade:

E.M: A nossa vida de Grupo Escolar era muito tranqüila, havia disciplina que a diretora e a professora exigiam, mas a gente nem percebia porque a gente já era disciplinado, a começar pela casa. Nós tínhamos liberdade, eu nasci aqui; onde é o Novo São Lucas era mato. Então nós tínhamos liberdade de brinquedo. Então a gente era disciplinado porque tinha liberdade. É uma coisa muito importante a questão da liberdade do brinquedo. Hoje a criança está confinada entre quatro paredes e fica na televisão, então ela tem que ser violenta. Nós tínhamos espaço, quintais, ruas tranqüilas, sem pivete, sem trânsito, então uma liberdade total. Isto refletia na escola.

R: A senhora acha que maior espaço, maior possibilidade de brincadeira, fazia com que a criança ficasse mais disciplinada?

E.M: Sim. Ela tinha liberdade em casa, tinha espaço, brinquedos, nada de clubes nos fins de semana, nada disso. A casa da gente era um clube.

Essa liberdade de se movimentar pelo espaço, segundo Elza de Moura tornava a criança menos violenta. Num artigo publicado no jornal Estado de Minas ${ }^{484}$, Elza

\footnotetext{
483 As reformas para modernização do prédio podiam ser mais ou menos drásticas. O Grupo Escolar Bernardo Monteiro, por exemplo, foi totalmente demolido e reconstruído novamente. É difícil saber quais foram as alterações até porque não foram encontradas plantas dos prédios nem antes nem após as reformas. Alguns entrevistados comentaram sobre mudanças realizadas nos prédios, mas não se pode afirmar que sejam datadas na década de 60 . O Grupo Escolar Sandoval de Azevedo ficou fechado de setembro de 1959 a janeiro de 1961 para reforma.

${ }^{484}$ MOURA, Elza de. Saudades do meu grupo escolar. Estado de Minas, 19 de março de 2001.
} 
reclama: "Um país com tanto espaço não precisava mutilar o terreno das escolas". Mas tal liberdade não parecia ser a mesma no que tange ao contato com os adultos: “... havia muito respeito à hierarquia que hoje não existe. A gente respeitava a diretora, respeitava as professoras, o porteiro, as serventes e os pais em casa". Esse profundo respeito pelos adultos não impedia, contudo, a realização de algumas travessuras como colher frutas na chácara do Grupo Escolar sem o devido consentimento da direção. Para Elza, isso não é indisciplina, mas seriam "levadezas" próprias da infância.

A concepção de que a criança deveria ter espaços livres de movimentação para desenvolver brincadeiras era a justificativa para a existência dos recreios escolares que descansariam as crianças das exigentes tarefas intelectuais. Assim também a Educação Física e até mesmo as excursões poderiam servir como válvulas de escape para a energia infantil que se prendia nas carteiras escolares.

Elza afirma, também, que os casos de indisciplina eram resolvidos pela professora e que, não sendo possível resolvê-los, chamava-se a diretora e, para casos ainda mais graves, a família. Ir para o gabinete da diretora e ficar retido na escola após a aula eram, segundo suas memórias do Grupo Escolar Henrique Diniz, os castigos mais comuns.

Apesar da liberdade concedida nos recreios, não se descuidava da vigilância que era sempre cobrada das professoras nas reuniões escolares. A própria construção escolar deveria favorecer a vigilância, e determinados espaços escolares eram carregados de simbolismos acerca das punições, como a frente da sala de aula, onde ficavam os alunos castigados e a sala da diretora, para onde eram encaminhados. Das paredes e dos espaços escolares emanavam dispositivos de disciplinarização que envolviam não apenas os alunos, mas também os educadores cuja circulação e comportamento podiam sofrer constante vigilância por parte dos colegas.

\subsection{DISPOSITIVOS DISCIPLINARES NOS GRUPOS ESCOLARES DE BELO HORIZONTE}

Benedita Dell'Isola revela que sentia pavor e ficava contrariada quando recebia autoridades escolares em sua sala-de-aula. Certo dia, o Inspetor-Escolar Guerino Casasanta entrou em sua sala junto com a diretora e a encontrou castigando um aluno. 
Ela o tinha colocado de pé no meio da sala. A professora começou a tremer e, quando o Inspetor lhe perguntou o motivo do castigo, ela afirmou que o aluno estava arrancando desnecessariamente folhas do caderno e fazendo pirraça. O inspetor pediu licença à professora, ordenou que a criança voltasse ao seu lugar, retirando-a do castigo, e fez um sermão sobre a importância de se economizar mesmo os materiais mais simples, tendo sido aplaudido por todos ao final de sua fala. Esta atitude mostra o quanto é pouco clara a definição do que seria ou não uma punição aceitável, já que colocar um aluno de pé era menos aceito do que fazer um sermão para o alunos diante de todos os colegas de classe.

A não punição do comportamento da professora que castigou o aluno dentro da escola fornece indícios de que este não era um procedimento tão raro assim ou que não merecesse maior atenção. Fato é que, segundo suas memórias, não se falou mais no assunto. É curioso notar, portanto, como o próprio Inspetor Geral do Ensino pôde relativizar o fato e aceitar que a professora não seguisse tão à risca as normas do não uso do castigo. Por outro lado, a própria exposição da professora diante de uma autoridade do Estado e da escola talvez pudesse ser considerada punição e humilhação suficientes para fazê-la rever a atitude do castigo.

Em outro momento, Dell'Isola conta que o guarda do Grupo Cristiano Machado pegou um menino que a diretora havia mandado castigar por indisciplina e mau procedimento dentro da sala de aula, mas que conseguiu escapar do disciplinário. Correu a notícia de que o referido aluno era filho dela e a professora deu ordem ao guarda para buscar o menino onde este estivesse, apesar de suas colegas recomendarem que nada dissesse à diretora e que somente o castigasse em casa. Dell'Isola não concordou. Achava que o seu filho deveria ser tratado como os demais alunos do Grupo. O porteiro e o guarda foram atrás do menino que já recebia mais uma acusação: a de furtar dinheiro de um colega. Quando encontraram a criança debaixo da cama em sua casa, o policial percebeu que não era ele quem havia lhe escapado dos braços. Mesmo assim, queria saber por que ele estava tentando fugir. O menino explicou que seus colegas o haviam informado de que ele estava sendo procurado e então fugiu. $\mathrm{O}$ guarda o liberou dizendo que, no dia seguinte, pegaria o verdadeiro culpado.

Perguntada pelas colegas sobre a sua atitude, Benedita afirmou que, caso seu filho fosse culpado, a diretora deveria lhe castigar em dobro, pois filho de professora 
deveria dar exemplo aos colegas, voltando atrás na afirmação anterior de que os filhos das professoras deveriam ter o mesmo tratamento dado aos outros alunos do Grupo. Certamente, a diretora concordava com Dell'Isola, já que elogiou o comportamento desta e fez o elogio constar da ata da reunião escolar.

Este foi o único caso encontrado em que o guarda e o porteiro do Grupo atuaram como disciplinários dos alunos mesmo que a indisciplina, como conta a professora, tenha ocorrido dentro da classe. Mas é possível que estes fossem chamados a exercer este papel disciplinador, mesmo porque, deveriam ser os únicos homens que atuavam no espaço da escola primária naquele momento.

Dell'Isola comenta que a disciplina no Grupo Escolar Cristiano Machado era muito boa, porque os alunos marchavam com muita elegância nas filas para entrar e sair das salas de aula. A professora disse que as pessoas das imediações do Grupo ficavam impressionadas com o bom comportamento dos alunos, mas não sabiam que mais de uma professora ficava responsável pela disciplina. Ela comenta que uma de suas alunas que veio do interior contou que ficava com as mãozinhas inchadas porque o professor lhe batia com a palmatória cada vez que não sabia a tabuada. Também ficava ajoelhada em grãos de milho, quando não levava a lição. Tais castigos teriam deixado a menina traumatizada: chorava e tremia quando tinha que responder alguma pergunta e falava muito baixo, evitando olhar para a professora, tendo levado muito tempo para se livrar dessas lembranças.

Elza de Moura contou que, às vezes, as professoras davam uma "sacudidela" ou puxavam as orelhas dos alunos, aplicavam beliscões, tapas e reguadas que, segundo ela, existiam em qualquer escola, mas ressaltou que as punições físicas eram mais para advertir do que para machucar. Outro castigo revelado pelos entrevistados era colocar o aluno indisciplinado para assentar numa carteira com uma menina, já que as carteiras eram duplas ${ }^{485}$ e somente Aracy Abreu lembrou-se de que as meninas que cometessem alguma indisciplina também eram colocadas para assentar-se com os meninos. Na fotografia abaixo pode-se ver como as crianças eram dispostas na sala de aula:

\footnotetext{
${ }^{485}$ A confirmação das carteiras duplas foi feita por todos os entrevistados. Estas carteiras deveriam substituir os bancos-carteiras múltiplos em que se assentavam vários alunos que haviam sido "definitivamente banidos das escolas" pelo art. 164 do Regulamento do Ensino Primário de 1927.
} 


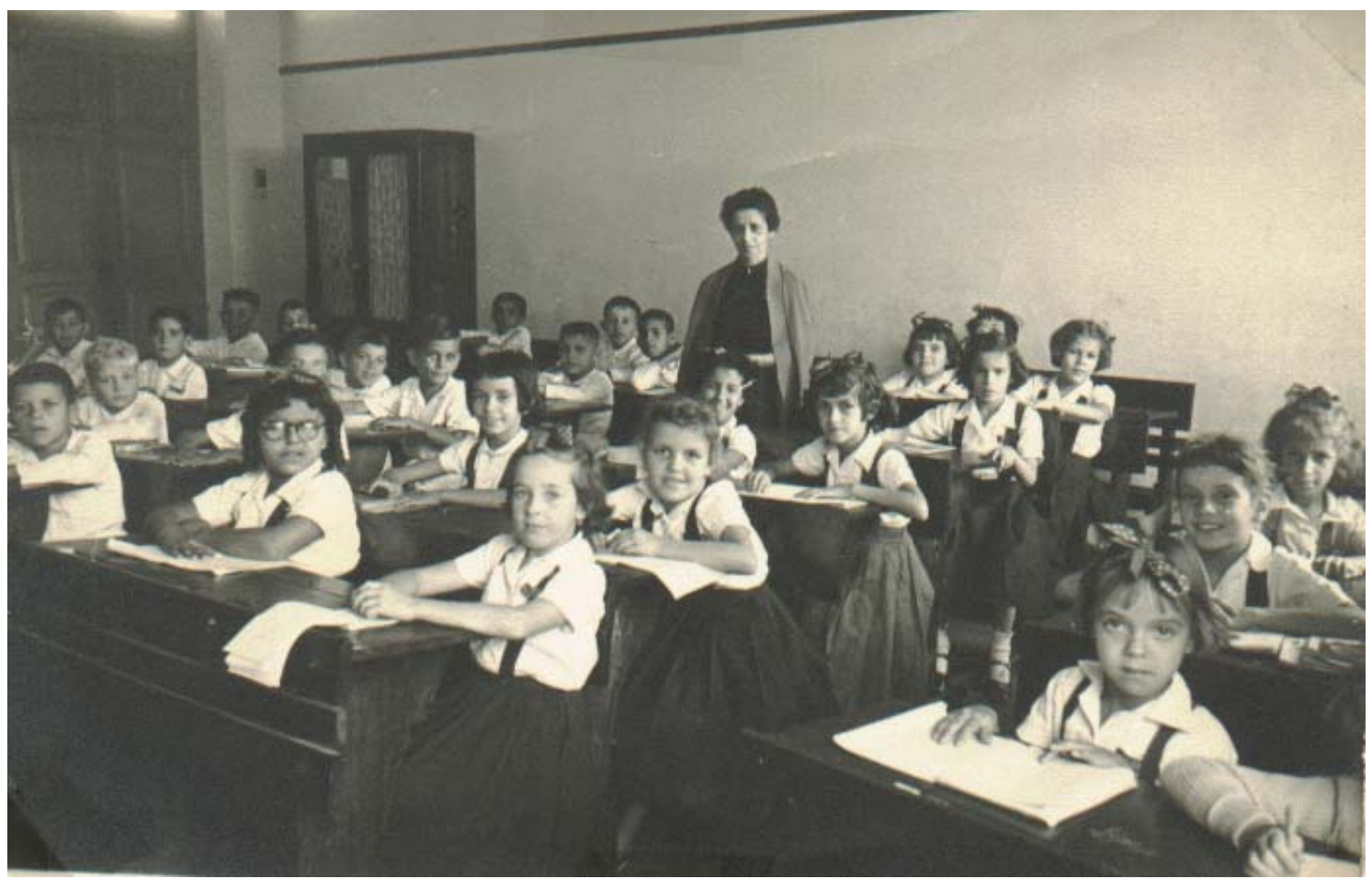

Foto 17: Sala de aula do G.E. Sandoval de Azevedo com a professora Luíza Travassos Ribeiro Campos (s.d.)

Fonte: Álbum de fotografias de Luíza Travassos Ribeiro Campos.

Segundo Geraldo Félix, normalmente os meninos mais indisciplinados tinham que sentar à frente, senão a perturbação da aula seria maior. A professora queria estar perto para dar o castigo se precisasse. Além disso, os alunos indisciplinados gostavam de dar tapas na nuca daqueles que estivessem à sua frente e, estando na primeira carteira, não teriam como fazê-lo.

GF: Vou te contar o meu caso. O que que eu fazia. Eu não sei por que cargas d'água achava graça nas coisas demais e na minha sala de aula, já era $3^{\circ}$ ou $4^{\circ}$ ano, tinha um aluno que se chamava José Mansueto e outro chamava José Timóteo, eu não concebia isso. Eu achava tão engraçado isto, todo dia na hora que ia fazer a chamada, gritava: José Mansueto eu caía ... [dá uma gargalhada]. Eu achava mesmo uma graça naquilo, e disparou. Sabe quando dá uma risada disparada? Ai começava todo mundo a rir.

R: Era o nome?

GF: Era o nome dele. Eu achava engraçado aquilo. Aí parava, sarava. Custava a controlar, já tinha tomado umas varadas de vara de marmelo. Aí parava. Voltava a chamada, chamava Zé Timóteo, outra vez, mas não tinha jeito, mas não tinha jeito. Esse é um exemplo. Não era uma maldade. Uma indisciplina danada, não tem como dar aula deste jeito, não tinha como dar aula desse jeito, mas não tinha como segurar.

$\mathrm{R}$ : O senhor sentava lá na frente?

GF: Muitas vezes, muitas vezes, muitas vezes. E depois virei palhaço. Tinha um outro castigo que elas davam. Nossa senhora. Não podia ter jeito. Dá remorso depois, a cara cresce, fica com dó da professora porque eu ria demais e não tinha jeito. E a professora então, ela usava, primeiro, por pra frente, mas não tinha jeito, eu não segurava aquilo. 
Punha em pé, lá na frente em pé, mas não tem jeito d'eu segurar, nunca vi um negócio desse, parecia uma doença. Aí, braço aberto, usava, mas não tem jeito e os alunos... um dia ela me pôs pra fora.

R: Por outros tipos de indisciplina também se colocavam os alunos de braços abertos?

GF: De braços abertos era muito comum do lado da porta.

R: Muito tempo?

GF: Muito comum. Ficava lá um tempão até ele sentir, depois mandava embora. Eu já estava mais, já estava baixo, não agüentava mais. Varinha de marmelo comia solto. Beliscão no braço ou puxão de orelha. Mas a turma era muito encapetada, à medida que ia avançando. Nós éramos os pivetes de hoje, só que era pivete sem maldade, não agredia, mais brigava muito, nunca brigava dentro de sala de aula, mas na saída pelo amor de Deus, a gente já acertava, acertava que lá fora vai ter.

No ano de 1978, os ex-alunos do Grupo Escolar Lúcio dos Santos voltaram à escola para uma comemoração dos 30 anos de formatura. Na solenidade, eles reviveram um dia na escola. A descrição do roteiro é interessante porque mostra como era organizado o cotidiano escolar, quando eles estudaram. Fizeram a fila das meninas e dos meninos no pátio, entraram para a sala e ocuparam os devidos lugares. Foram feitas a oração e a chamada. Na encenação, um dos alunos deveria ficar de castigo na frente porque não trouxe todos os colegas para a festa, outro pediu à professora para "ir à casinha”, o que ela não permitiu. Houve também a observação de que Dona Geralda não fica claro quem é, talvez uma professora - fez um discurso aos alunos sem a vara de marmelo. Pode-se supor, portanto, que ela estivesse sempre acompanhada da vara.

No Grupo Escolar Tomaz Brandão, a diretora, em diversas reuniões, avisava às professoras para não aplicarem castigos físicos, que eram proibidos. Apesar disso, Geraldo Félix disse haver castigos físicos aplicados pelas professoras. Elas pediam às meninas que trouxessem uma vara de marmelo de casa e, com isto, os alunos passavam a ter mais raiva da colega que trazia a vara do que da própria professora que a utilizava: "Um ódio que dá da menina, toda varada que você tinha, você queria virar na menina depois".

Estes dois relatos revelam que, se a palmatória tinha perdido o espaço privilegiado na mesa do professor, a vara de marmelo continuava reinando nas salas de aula. Os castigos, entretanto, não significavam que o comportamento indesejado estava banido para sempre. Pelo contrário, a própria situação dos castigos poderia provocar nova indisciplina, como relata Geraldo Félix:

R: O senhor se lembra de outros casos de indisciplina, além do riso? 
GF: Eu lembro do riso, que no riso ela me pôs para fora da sala. Só que tinha a sala, e logo na janela, tinha um lote baldio e alto.Você acredita que eu fui pro lote baldio? R: Então o senhor saía da escola?

GF: Era no anexo, ela me pôs fora da sala. Que que eu fiz? Eu saí, arrumei uma madeira, amarrei uma trouxinha e fiquei fazendo gracinha do lado de fora. Os meninos, tudo, todo mundo... ela dando aula aqui, mais não tinha jeito, não tinha jeito. Mas eu era considerado aluno adiantado, gozado, repetia, não sei se por causa disso, sabia mais porque estava no segundo ano adiantado. E perturbava, se esquentasse mais, a professora também não relevasse, levava para a diretoria. O pavor dos alunos era ir para a diretoria.

R: Por que era o pavor?

GF: Porque a diretora sempre tinha a fama de brava. Lá era a última instância, ali o sujeito ia ter que se explicar. Ali a gente tinha medo porque a diretoria mandava o porteiro levar o sujeito em casa como um indisciplinado, entregar para os pais, suspensão. Então tinha medo porque os pais batiam demais. Naquele tempo o pau comia em casa. Pancadaria em casa. Se chegasse em casa levado pelo porteiro, dizendo que você estava pego por indisciplina o negócio ficava feio.

O porteiro também era alvo de críticas já que ele representava uma autoridade nada amigável na escola. Os alunos do Grupo Escolar Tomaz Brandão, para se vingar, apelidaram-no de "bigodinho", apelido que ele, como era de se esperar, detestava.

R: O senhor se lembra de mais punições que eram utilizadas?

GF: Lembro das varinhas. Agora, tinham as professoras tidas como boazinhas que usava menos, usava, mas tinha umas professoras que eles temiam. Tinha uma tal de D. Carmem lá que todo mundo tinha pavor dela, por causa do tamanho da unha.

R: Por causa dos beliscões? [risos indicando que sim] E a diretora aplicava castigos físicos?

GF: Na diretoria usava levar o cara muito esquisito este de ficar em pé, mas deixava ficar em pé até quase derreter lá, acabava a aula e o cara ficava lá. Avisava pra turma da tarde para mantê-lo lá em pé. Nestas alturas o porteiro já tinha ido em casa avisar que o mau elemento tava lá. Quando o cara chegasse em casa o cara tava no pau.

Não só o guarda recebia apelidos. Segundo Fernal Bicalho, a prática dos alunos de apelidarem estendia-se também às professoras e diretoras. Ele conta, por exemplo, que a vice-diretora do Grupo Escolar Olegário Maciel era muito gorda e tinha uma cara muito fechada, segundo suas lembranças. Os alunos chamavam-na Dona Carmem Bolão, porque a consideravam muito rígida e áspera, mas jamais faziam isso para que ela ouvisse. Nas memórias deste ex-aluno, as travessuras dos meninos e meninas de sua época eram inocentes e pouco sérias:

R: E, na época, como eram as meninas?

F.B.: Tinha umas briguinhas também. Puxar a saia, se ela tinha um laço na cintura, puxava o laço, ela te dava um tapa, laçava de novo, coisa de menino, mas nada violento 
ou que prejudicasse a integridade delas. Nome feio praticamente não existia; a gente tinha medo de falar nome feio, se falasse nome feio era problema, a professora inclusive chamava os pais, se a criança estava com uma língua abusiva. Mas de um modo geral não lembro assim...

Por outro lado, Geraldo Félix atribui às crianças uma certa irresponsabilidade e inconseqüência que demandam observação e cuidados por parte dos adultos, já que suas traquinagens poderiam ter efeitos mais desastrosos que as próprias crianças não conseguiriam antecipar:

GF: A pessoa tem que analisar menino, muito bem analisado. Menino que é dos infernos, quando é menino, pode não ser quando vira adulto. Eu fui com o meu pai num comício. Tinha um sujeito soltando bomba e foguete forte. Tinha um guarda de trânsito tomando conta. Eu passei debaixo da perna dele, peguei um, tipo dinamite, mas não era dinamite, era uma bomba forte. Eu peguei um negócio daquele e levei, mostrei para o meu amigo. No dia que terminou a aula, nós íamos entrar de férias, joguei pelo muro, joguei na escola, não tinha ninguém e corri. Desci a rua "Escorrega" correndo, quando eu estava lá embaixo nós ouvimos. Nunca pensamos: "E se alguém visse aquilo e fosse chegar perto?" Quebrou o vidro do banheiro, nós não pensamos que podia ter alguém. Já tinha saído todo mundo, mas podia ter um atrasado. O espírito não é de destruição, é de molecagem [risos]. Não imagina o que pode acontecer. Quando nós ouvimos a gente estava cá embaixo.

R: Descobriram?

GF: Não, até hoje eles não sabem.

Geraldo Félix conta que, uma vez, um colega seu lhe mostrou que estava levando uma garrucha de pólvora feita em casa, dizendo que quem o provocasse "ia levar tiro". Mas, segundo ele, não era costume os alunos levarem arma para a escola e nunca aconteceu nenhum incidente com esse menino na instituição. Conta também de um colega seu que recentemente lhe disse ter quebrado o braço de um outro colega "folgado" dentro da escola, embora Geraldo afirme não ter ficado sabendo do ocorrido na época.

Numa outra situação, o ex-aluno comenta que derrubou uma panela de canjica porque não conseguia obter a sua parte na distribuição:

GF: Muitos fatos aconteceram e comigo aconteceu um fato lá até esquisito, mas é bom pra conhecer menino, tem que ter muito cuidado. Nós estávamos no recreio e era período de festa junina e eles resolveram distribuir canjica para os meninos na escola, lá no pátio. E não sei por que cargas d'agua tinha que entrar na fila e eu entrei na fila e foi distribuindo, foi distribuindo, foi distribuindo, foi distribuindo e a turma naquele empurra-empurra, eles tinham mania de empurrar na fila, os detrás empurrando, 
tumultuando, empurra, não empurra. Quando chega na minha hora de pegar canjica a servente falou: "Chega, chega, chega. Tá muito bagunçado". Aí dispensou tudo. Daí uns 5 minutos falou: "Faz a fila de novo". Eu já estou de novo lá atrás e está distribuindo, está distribuindo e o safado começa a empurrar, chega na minha hora, acabou. "Tá muito bagunçado". Pararam. Vem a terceira vez, e não tem jeito de ser o primeiro e aconteceu a mesma coisa, ela falou: "Acabou, acabou". Eu não agüentei, eu peguei o caldeirão cheio de canjica e despejei no chão. Eu não agüentei, eu tava possesso de raiva. Coisa que você tem que ter cuidado com isso, menino não é dele. Cismei que aquilo era comigo.

Emília ${ }^{486}:$ Teve punição?

GF: Eu já tinha voltado do meu problema, eles começaram a relevar, ele tá meio doido. Só pode estar meio doido.

R: Aí, ninguém mais comeu canjica. Nem o senhor, nem ninguém!

GF: Acabou. Não querem que eu coma canjica, ninguém vai comer canjica nessa escola. Uma panela ainda quase pela metade, só tombei ela. Menino é perigoso, veio do hospital, cheio de cicatriz na cabeça. Não deu nada, punição não.

Geraldo Félix havia ficado muitos dias internado em um hospital depois de sofrer uma osteomielite e todos achavam que não se curaria mais. Ele conta até que os colegas foram visitá-lo em casa e pediam para "mandar lembranças ao Papai do céu". Quando voltou para a escola, suas ações eram minimizadas, na medida em que achavam que ele não estava mais dentro da normalidade.

Para Elza Moura, as professoras são responsáveis pela disciplina na sala de aula. Ela conta que, uma vez, uma aluna muito tímida foi ao seu gabinete e lhe disse que ela não deveria mandar mais a professora de trabalhos manuais substituir a professora da classe, porque a menina que não gostava de fazer travessuras, acabava fazendo.

E.M.: Esse foi um fato interessante da minha vida como professora escolar. Então menino gosta de professora exigente. Eu tenho uma experiência no meu Grupo Escolar. Uma professora termina aos 25 anos, não quer aposentar e fica lá amolando. Quando sobra uma classe pra ela, dana. Então essa professora, sabe o que ela fazia? Ela sentava na porta, punha a sombrinha no joelho e deixava a meninada pintando. Quer dizer, menino não gosta de professora malandra. Pelo menos as crianças de Grupo Escolar do meu tempo gostavam da professora exigente.

R: Então a senhora acha que o comportamento da professora pode fazer com que os alunos fiquem indisciplinados?

E.M: Ô se... Isso, minha filha, é coisa que você vê nas escolas. Até nós, eu como diretora de Grupo, nós tivemos um curso do PABAEE. Nós fomos fazer esse curso tão ruim, tão ruim que nós começamos a fazer indisciplina. Nós diretoras. Se adulto não agüenta, imagina criança.

R: A senhora acha também que um bom curso torna os alunos mais disciplinados?

E.M.: Tem razão. Uma coisa desinteressante que quê você faz? Você vai embora, pega sua pasta ou então você conversa com o outro. Disciplina é uma coisa divina e depois o interesse. Se o curso é bom tem interesse e tem disciplina. O Claparède na Educação Funcional dele é que fala. Ele estuda muito bem o interesse que é uma questão

\footnotetext{
${ }^{486}$ Emília é a assessora do vereador que nesse momento havia entrado na sala e participava da entrevista.
} 
biológica, psicológica. Hoje ninguém estuda mais. Precisava voltar ao Claparède, ao Dewey.

Na entrevista concedida ao Museu da Escola, Elza de Moura confirma:

Interessante! Os alunos gostam de professor exigente. O professor relaxado não. Que elas sentem: o professor relaxado não gosta delas, ao passo que o professor exigente tem amor à classe. [...] Toda classe desorganizada, indisciplinada, o problema está no professor.

Imene Guimarães confirma a opinião de Elza de Moura de que a professora é a responsável pela disciplina escolar. Entretanto, Imene ressalta não a exigência, mas a produção de aulas interessantes. Ambas revelam que internalizaram as atribuições que eram feitas pelas Reformas do Ensino, que as responsabilizavam pela disciplina escolar. Entretanto, Elza de Moura, apesar de se dizer "100\% escolanovista", alia ao interesse a necessidade da exigência dos professores. Num aviso colocado no Livro de Ponto dos funcionários do Grupo Noturno Afrânio de Melo Franco, as professoras eram diretamente responsabilizadas pelo comportamento dos alunos:

\begin{abstract}
Aviso
As professoras que vigiem as salas durante as aulas, para que os alunos não as sujem com pedaços de papel, cascas de frutas, aparas de lapis etc.

De hoje em diante responsabiliso diretamente as professoras por essa irregularidade, pois compete tambem à professora ensinar as regras de higiene e boa sivilidade [sic] aos alunos. Não vejam nesse meu aviso o menor intuito de ofendel-as, mas a boa ordem dos serviços escolares. Se as salas ficarem muito sujas, como têm ficado algumas, (felizmente poucas) as serventes só poderão terminar o serviço muito tarde, o que não é justo, visto que as mesmas chegam 1 hora antes das professoras e são senhoras respeitaves que têm direito de chegar mais cedo em casa.

Araci Lessa, diretora. ${ }^{487}$
\end{abstract}

Geraldo Félix diz que se arrepende do comportamento tido com relação às antigas professoras. Perguntado sobre o que queria acrescentar à entrevista, respondeu justamente sobre o tratamento dado a uma delas:

GF: Nossas professoras... Eu encontrei com essa Alaíde, essa professora vive ainda. Ela me chamou, me deu um remorso... um dia, a Maria Amélia, minha última professora, me pôs pra fora da sala de aula, por causa de molecagem, de gargalhada na sala de aula, eu fiz um troço imperdoável. Eu peguei um carvão e escrevi no muro da escola: D. Maria Amélia - Péssima professora. Ela chorou.

${ }^{487}$ Aviso deixado no Livro de ponto de 1947. 
No entanto, ele afirma que ela era uma das melhores professoras que havia e que ele estava perturbando a sala com as risadas e, por isso, ela o pôs para fora. Apesar do choro da professora, ele não sofreu punição, porque, tendo saído do hospital, seu comportamento era sempre desculpado.

No recreio, as professoras não estavam desobrigadas de vigiar os alunos e, novamente, podiam ser responsabilizadas pela indisciplina cometida pelas crianças nos pátios escolares:

Geralmente, cuida-se do recreio por escalas e plantões. As professoras encarregadas da vigilância dêsse mundo efêmero e barulhento acompanham, disciplicentemente, os seus movimentos com a atenção dispersa em outros problemas distantes ou então retida na preocupação formal de policiá-lo.

Entretanto, o recreio não pede apenas tal atitude - é um campo variado de observações e pede estudo demorado e consciencioso. É uma sociedade que se agita, embrionária embora, mas trazendo os delineamentos mais ou menos positivos do futuro. Ali, podem ser avaliadas tôdas as reações das diversas personalidades sob a ação da escola e, conseqüentemente, o que a escola está conseguindo como força educadora.

Sim, como fôrça educadora - porque o recreio, livrando o aluno das peias artificiais da classe, precipita todos os resíduos nocivos da sua personalidade real e desata os recalques da alma em explosões sinceras que denunciam logo os lados incoercíveis da índole do educando. ${ }^{488}$

Durante o recreio, eram freqüentes os pedidos para que os alunos não ficassem sem vigilância, como está registrado no caderno de advertências do Grupo Olegário Maciel:

A vigilancia da professora, mais do que em aula, é imprescindivel durante os recreios sobre os alumnos. É justamente durante os recreios que os alumnos, em relativa liberdade têm constantes ensejos de infringir a ordem e a disciplina. Na pedagogia norte-americana, a vigilancia do preceptor sobre os discipulos é recomendada e feita com tal cuidado e solicitude, que nas escolas daquelle paiz super-civilisado essa vigilancia instituiu o seguinte postulado para os mestres: "Em aula o professor sempre defrontando a classe e dominando-a com o olhar; no recreio o professor sempre junto ao alumno."

Neste Grupo Escolar, a vigilancia semanal dos recreios será feita por duas ou mais professoras designadas semanalmente pelo director do estabelecimento. Ellas, terminados os recreios, communicarão ao director quaesquer infracções da ordem e da disciplina.

488 DUTRA, Aimoré. Lições do recreio. Revista do Ensino, BH, ano XVIII, n. 194, p. 168-171. jan.mar.1950, p. 168. 
Em um relatório de Mariana Jofrina Mourão de Miranda, de outubro de 1955, ela afirmava que era preciso que as crianças fizessem filas para entrar e sair do Grupo, para ir à biblioteca, etc., não apenas para a disciplina escolar mas "para evitar conseqüências mais sérias, mesmo da parte moral."

As solicitaçõs para que os alunos entrassem e saíssem dos Grupos em silêncio, em filas, sem provocar gritarias ou desordens eram constantes. A presença das professoras neste momento era sempre requerida. Incansáveis pedidos eram feitos pelas diretoras para que as professoras levassem seus alunos em filas até a saída do Grupo e vigiassem esta saída. Várias reuniões discutiam a ordem da saída das classes para não haver confusão. Segundo Geraldo Félix, no entanto, o que se fazia para além dos portões escolares não era levado em consideração pelos funcionários do Grupo. As brigas ocorridas na saída da escola podiam até mesmo ser presenciadas pelas professoras que não tomavam parte na questão, já que ali não era mais espaço escolar. Numa reunião em 1939, a diretora do Grupo Escolar Olegário Maciel pedia para que as professoras aconselhassem os alunos a evitarem brigas, durante a saída da escola, com alunos do Grupo Escolar vizinho.

Responsabilizar as professoras pela indisciplina escolar, tomando o interesse e dedicação dos alunos como índices de competência pedagógica de suas mestras, era lugar-comum na Escola Nova mineira. Entretanto, não bastava obter a participação e um comportamento adequado dos alunos. Era preciso que isso fosse feito sem se recorrer a punições ou, pelo menos, sem uso de recursos mais drásticos e visíveis como os castigos físicos. No discurso das diretoras, inspetores e assistentes técnicas a responsabilização das professoras era constante. Para isso, eram freqüentes as recomendações disciplinares indicando quando e como obter um bom comportamento das crianças dos Grupos Escolares.

\subsection{ESTRATÉGIAS DISCIPLINARES}

As professoras dos Grupos Escolares de Belo Horizonte estavam em situação oposta à do professor do Rio de Janeiro que, no século XIX, escreveu ao jornal perguntando como poderiam ser banidos os castigos físicos na escola, já que eram 
diversas e constantes as recomendações de que utilizassem dispositivos disciplinares, abandonando ou usando menos freqüentemente e menos incisivamente as punições.

A assistente técnica Leonilda Montandon, visitando o Grupo Escolar Bernardo Monteiro, deixou algumas recomendações a professoras e dirigentes:

1.) Sejam assiduas. Na classe cujo professor constantemente falta, não há trabalho proficuo e muito menos resultados satisfatorios. A disciplina torna-se dificil, os bons habitos não se formam e a educação, no seu verdadeiro sentido, não se realiza.

Que nenhum pretexto, seja bastante forte para afastar o mestre do cumprimento de seu dever, lembrando-se ele sempre, da grande responsabilidade contrahida, ao assumir a direção das alunas que lhe foram confiadas.

2.) Sejam energicos nessa direção, guiando seus alunos com serena autoridade, habituando-os ao cumprimento de seus deveres e não permitindo que a desordem ahi se implante, com o nome de "liberdade". Procurem fazer se respeitados e queridos pela sua atitude energica, carinhosa, imparcial e prudente, não se servindo nunca da autoridade de segundos, para manter em sua classe a disciplina. Existem certos castigos que não corrigem e aos quaes as creanças se habituam e até desejam, um por $\mathrm{ex}^{\circ}$ : mandar fóra da classe, prisão na diretoria, posição de pé, etc e etc.

Mais eficiente talvez seja a reclusão durante o recreio, dando porem, ao castigado, algum trabalho que lhe aproveite: uma copia, algumas contas, trechos ou poesias a decorar, etc, etc. De preferencia, entretanto, usem os meios estimulantes, a [incompreensível] conselho, a palavra amiga que revele ao aluno a amizade que the dedica o mestre. ${ }^{489}$

Numa reunião realizada no Grupo Escolar Tomaz Brandão, a diretora substituta enumerou uma série de cuidados que a professora deveria ter para manter a disciplina dos alunos:

a) Conservar os alunos sempre ocupados com interessantes trabalhos. b) Não exigir silêncio absoluto ou completa passividade dos alunos; c) Permitir a livre troca de idéias ou impressões entre os colegas, sempre em voz natural e sem provocar desordens.

d) As professoras devem evitar que as crianças sintam-se constrangidas diante delas favorecendo-lhes ambiente de razoavel liberdade de movimentos e principalmente de confiança e afeição.

e) Não usar o quadro-negro para o registro dos nomes dos alunos de mau comportamento.

f) Nunca revelar aos alunos desagrado pela vida escolar, antes demonstrar-lhes que vive satisfeita entre eles.

g) Não manifestar predileções acentuadas.

Para conseguir praticar estas recomendações apresenta varias sugestões às professoras:

Falar pouco, em tom de voz médio e agradavel. Não gritar nunca, nem para repreender.

Não infantilizar demais a linguagem e os gestos.

Deve andar entre as carteiras para prevenir erros e apontar faltas.

Ser assídua e pontual.

${ }^{489}$ Extraído do Termo de Visitas do Grupo Escolar Bernardo Monteiro do dia 9 de novembro de 1934. 
Dar exemplos com mais frequência do que conselhos; os primeiros são observados, presenciados e por isso, mais eficientes do que os segundos.

Preparar sempre materiais novos, interessantes. ${ }^{490}$

A diretora recomendava, ainda, que, além de orientar as crianças para o "bom caminho", era necessário reprimir "com amor e doçura suas más tendências e inclinações".

Conforme as lembranças de Terezinha Casasanta, que fez o curso primário nas classes anexas à Escola de Aperfeiçoamento, havia muita liberdade nessa escola e ela sentiu uma grande mudança, especialmente no que se refere à disciplina escolar, quando foi cursar o ensino ginasial num colégio de freiras em Belo Horizonte:

Estranhei bastante porque a minha escola era uma escola, como você diz, moderna, diferente, totalmente diferente do comum. Então o colégio me pareceu bastante rigoroso, muito rigoroso. Era a escola do não. Nada mais a gente podia fazer, não tinha liberdade para nada, a sensação que eu tinha era que estavam sempre, que as irmãs estavam sempre pensando o pior de nós. Sempre nos vigiando. Tudo era pecado, usar esmaltes era pecado, usar batom era pecado. Não que usasse naquela época. Naquela época, criança não fazia isto. ${ }^{491}$

Segundo a ex-aluna, o colégio the tirara até o prazer e o entusiasmo por aprender. Em entrevista, Alaíde Lisboa também confirma a sensação de vigilância constante nos colégios. Uma vigilância que atingia até os pensamentos das alunas:

Não fazia muito tempo eu estava no colégio. Eu me lembro, eu estava...., de repente eu parei e levantei os olhos assim [faz o gesto] olhando. A professora bateu [ela bate forte do lado]: Alaíde, o que você está pensando? [voz firme] [ela ri]. Então eu falei assim: Em mamãe. E realmente estava pensando em mamãe. Ela quis sorrir mas não chegou a esboçar bem. E escreveu ali, pôs a nota em francês porque o colégio era tudo em francês, mas eu vou falar em português mesmo: Alaíde estava distraída, mas não pensava nada de mal. ${ }^{492}$

Entretanto, Alaíde percebe como bela a atitude das freiras que zelavam até mesmo por seus pensamentos para que nada as aproximasse do mau. Ela ainda lembra que é possível pecar em pensamentos como o mandamento que determina que não se deve desejar a mulher do próximo ou cobiçar as coisas alheias.

\footnotetext{
${ }^{490}$ Reunião do dia 04 de maio de 1946.

${ }^{491}$ Entrevista concedida ao Centro de Referência do Professor.

${ }^{492}$ Entrevista concedida ao Centro de Referência do Professor.
} 
Se a rigidez e a disciplina já não eram as mesmas da escola antiga, não se pode dizer que tenham perdido a importância na escola moderna.

Um aviso da diretora colocado no Livro de Ocorrências do Grupo Escolar Afrânio de Melo Franco confirma a existência de castigos físicos, inclusive nos Grupos noturnos em que os alunos costumavam ser mais velhos:

Rogo às professoras o obsequio de nunca mandar chamar pae algum de qualquer aluno, sem a minha autorização. Caso haja qualquer caso de indisciplina na sua sala, mande chamar-me pelo guarda, que providenciarei, immediatamente. Castigos corporaes são absolutamente prohibidos em qualquer estabelecimento, e, principalmente, neste de homens e rapases.

Maria Aracy Lessa, directora commissionada.

Ps. Este meu aviso é feito sem nenhuma má intenção, apenas para evitar dissabores para mim e para as Snras. professoras. ${ }^{493}$

Por que a diretora salienta que o uso de castigos físicos era ainda menos aceitável num estabelecimento que atende homens e rapazes? Seria por causa da idade dos alunos? Ou por serem eles do sexo masculino?

Talvez por ser um Grupo noturno, o Assis das Chagas merecesse especial atenção para com a disciplina. Por isso, Ernesto C. Santiago, inspetor regional, deixava registrada uma série de recomendações, das quais algumas foram transcritas abaixo:

"f) findo o tempo escolar do dia, deverão sair alumnos em forma, em ordem e disciplina e cada classe acompanhada pela respectiva professora até a esquina do predio, dispersando-se então sem assuadas e tropelias; g) entre a saida das classes deverá intervalar o tempo pelo menos de um minuto; $h$ ) cada professora, pelo menos uma vez semanalmente, fará a revista de asseio individual na sua classe; h) o canto em cada classe, dirigido pela professora, deverá ser executado, como determina o programma; i) attentas as condições moraes e economicas dos alumnos dos grupos nocturnos, a educação civica e moral, os ensinamentos de urbanidade e civilidade devem merecer especial solicitude das professoras; $j$ ) sendo forçosamente o tempo exíguo nos grupos nocturnos, deverá elle ser aproveitado intelligemente e criteriosamente; ${ }^{494}$

As recomendações do inspetor, minuciosamente detalhadas, revelam o tratamento dado aos alunos dos Grupos Escolares noturnos e às suas professoras. Para se garantir um bom uso do tempo escolar, o bom comportamento dos alunos, sua higiene, e até mesmo definir quais os conhecimentos mais importantes para este ensino - urbanidade e civilidade -, era preciso explicar às professoras sua função e as formas de

${ }^{493}$ Aviso deixado no dia 01 de abril de 1937.

${ }^{494}$ Termo de Visitas do Grupo Escolar Assis das Chagas de 28 de abril de 1927. 
obter os objetivos desejados. No caso dos Grupos Escolares noturnos, no entanto, era comum que a responsabilização pela indisciplina dos alunos não recaísse somente nas professoras, mas também neles próprios que, em algumas escolas, deveriam pagar os danos materiais que causassem ao estabelecimento, já que trabalhavam e, portanto, deveriam ter recursos para tal.

...todo o aluno que quebrar vidros de armarios, cadeiras etc sera responsabilisado pelo seu conserto, visto que, é do regulamento do ensino a obrigação de consertar o que estragou, sob pena de ter-se que comunicar a Secretaria da Educação, que tomará providencias necessarias no caso da recusa, por parte do responsavel pelo dano, a reparar o estrago. ${ }^{495}$

A exigência de um comportamento disciplinado, como se pode perceber, não se restringia aos alunos, os inspetores faziam também uma série de recomendações às professoras e à diretora do Grupo.

Uma hipótese da pesquisa era a de que alguns alunos mais indisciplinados poderiam ter sido expulsos dos Grupos Escolares. No Livro de Matrícula, havia uma coluna onde se anotava o motivo pelo qual os alunos eram eliminados do Grupo. Dentre estes, estavam registrados: doença, falecimento, mudança de cidade, de bairro, transferência para outros Grupos, infreqüência, conseguir emprego, ir estudar em casa, não ter idade suficiente ou ainda, chorar demais. Curiosamente, um aluno que deixava o Grupo Escolar Olegário Maciel por falta de idade tinha $8 \operatorname{anos}^{496}$.

Em alguns casos, encontra-se apenas a palavra "eliminado", não se explicando a causa. No Grupo Escolar Pedro II encontram-se casos de exclusão do aluno por medida disciplinar, mas sem esclarecer o que havia ocorrido. Um aluno que havia estudado no Grupo Escolar Pandiá Calógeras comentou, por telefone, que a diretora o havia expulsado de lá, embora o pai dele auxiliasse muito o Grupo, até financeiramente. Entretanto, este ex-aluno não quis participar da pesquisa, disse não se lembrar de nada, não ter nada a dizer e não esclareceu o motivo de sua expulsão, considerando-a uma injustiça cometida pela diretora.

O número de alunos eliminados nos Grupos Escolares era bastante alto, não foi feita uma análise cuidadosa dessa questão por não se tratar de um objetivo da pesquisa, mas, para se ter uma idéia, em um único mês, o Grupo Escolar Olegário Maciel chegou

\footnotetext{
${ }^{495}$ Consta no Livro de ponto das professoras do Grupo Escolar Afrânio de Melo Franco de 1941.

${ }^{496}$ Neste mesmo Grupo, uma menina de 12 anos saíra para ser entregue ao Juizado de Menores.
} 
a ter 38 alunos eliminados. Em 1953, o Grupo iniciou o funcionamento com 923 discentes e terminou com 712, havendo uma redução de $23 \%$ no número de matriculados.

Pode-se concluir, portanto, que o destino das crianças indisciplinadas nos Grupos Escolares de Belo Horizonte poderiam ser as classes especiais, o envio para instituições que tratassem de crianças consideradas "anormais", a recusa de sua matrícula ou a expulsão da escola. O que faziam essas crianças para obter tais punições? $\mathrm{O}$ que se percebia como sendo indisciplina? O que levava os alunos a sofrerem castigos?

\subsection{TÁTICAS DA INDISCIPLINA}

Os castigos na escola eram motivados, segundo Elza de Moura, pela falta de estudos, pela má criação, briga entre colegas e por conversar no horário de aulas. Perguntada sobre a questão do uso de giletes na escola, a professora afirmou que nunca passou por este tipo de problema. No entanto, em 1951, numa palestra dada no Grupo Escolar Pedro II, o médico e a enfermeira escolar alertavam sobre o perigo dos acidentes com giletes. Três anos depois, numa reunião com as professoras do Grupo Escolar Olegário Maciel, a diretora pedia atenção destas para com o uso de giletes. No ano seguinte, ela proibiu o uso destes na escola.

No Grupo Escolar Olegário Maciel, a professora de ginástica era também disciplinária. Em outras escolas, essa função parece ter sido exercida pelo porteiro, ou pelo guarda. Os guardas tinham, ainda, a função de proteger os escolares dos veículos nas ruas próximas e de ataques de meninos estranhos ao Grupo Escolar. Fernal Bicalho, ex-aluno do Grupo, lembra-se das rixas que existiam entre eles e os alunos do Grupo Escolar Cesário Alvim que funciona no mesmo quarteirão:

F.B.: Eu me lembro uma vez que veio um aluno do Grupo Cesário Alvim, que era de costas para o Olegário Maciel, e a gente éramos rivais. A gente falava: Grupo Cesário Alvim, comeu "b" com capim. E eles falavam: Grupo Olegário Maciel: comeu "b" com pastel. [risos].

A diretora do Olegário Maciel, por exemplo, justificava o pedido de um guarda na escola, afirmando que moleques jogavam frutas estragadas e objetos encontrados na 
rua, para dentro do prédio. Comentou, inclusive, que uma professora fôra alvejada no rosto e, certa vez, um tijolo quase acertou a cabeça de um aluno. Mesmo quando o Grupo Escolar estivesse sem aulas, era solicitado ao guarda que protegesse o edifício da "acção malefica dos garotos desoccupados, nos dias e horas em que não há funccionamento das aulas".

Em 1949, a diretora do Grupo Escolar Pedro II enviou uma correspondência ao Superintendente da Guarda Civil com o seguinte pedido:

Venho solicitar a V. Excia especial atenção no sentido de prestar o seu valioso auxílio na disciplina dos escolares que, às 7,30 e 12 horas dos dias uteis, fogem das aulas do Grupo Escolar "Pedro II", à Avenida Mantiqueira, para o Parque Municipal.

Seria de grande vantagem a permanência de um guarda nas imediações do referido Grupo, evitando, deste modo, não só semelhante irregularidade, como outras "demonstrações" de travessuras: tomada de bondes em movimento, jogos de futebol na avenida e ruas fronteiriças, lutas com exibição de nomes inconvenientes, apedrejamentos, etc.

Desejo esclarecer a V. Excia que, ainda agora, o Estado acaba de autorizar a colocação de vidros, apenas nas janelas, despendendo com tal serviço, a apreciavel importancia de Cr\$2.580,00. ${ }^{497}$

Em 1951, 1954 e 1955 novos pedidos foram feitos ao Superintendente da Guarda Civil para que auxiliasse na manutenção da ordem e da disciplina nas imediações do Grupo. Estas fontes revelam, portanto, que o que acontecia fora dos muros escolares, especialmente no seu entorno, também sofria vigilância por parte das escolas que se valiam de profissionais como os guardas ${ }^{498}$ para manter a ordem nestes espaços em que a autoridade de professoras e diretoras pareciam não mais alcançar. Em um Grupo Escolar da cidade de São Tomás de Aquino foram os próprios alunos transformados em Polícia do Grupo, verificando e registrando o procedimento inadequado dos colegas ${ }^{499}$ dentro e fora da escola.

\footnotetext{
${ }^{497}$ Carta enviada pela diretora Antonieta Faleiro de Oliveira Faria em 29 de agosto de 1949 para Helvécio Horta Arantes, Superintendente da Guarda Civil.

${ }^{498}$ Segundo Geraldo Félix, não apenas o guarda apenas amedrontava os alunos ou os levava até suas casas, também os policiais comuns poderiam levar as crianças para ficarem presas na delegacia por algum tempo. Ele conta que, certa vez, havia roubado jambo num quintal e perdeu o boné. No dia seguinte, a dona da casa chamou a polícia e ele foi levado para a delegacia. Ele devia ter entre 9 e 10 anos. Na delegacia eles passaram um escovão na cabeça dele que doía muito e os pais ainda diziam que era bem feito.

${ }^{499}$ SANTANA, Tomaz. Pelotão de saúde e polícia do Grupo Escolar de São Tomás de Aquino. Revista do Ensino, BH, ano VII, n.92, p.67-68, 15 set. 1933.
} 
Os indisciplinados eram também transferidos de classe. Nas listas de promoção dos alunos havia um item que indicava a nota de procedimento. Essa nota era, em geral, alta para a maioria dos alunos. É difícil saber que critérios eram utilizados para a atribuição deste valor. Um caso encontrado no Grupo Escolar Flávio dos Santos pode nos indicar o perfil desses alunos-problema nas escolas. Eram dois meninos e uma menina que foram transferidos de classe por motivo disciplinar. Todos eles vinham de meio social baixo, sendo, às vezes, os mais pobres da classe, segundo uma classificação do próprio Grupo. Eram também repetentes e, por isso, mais velhos que os outros alunos.

Numa reunião do Grupo Escolar Tomaz Brandão, após a leitura do trecho "Os prêmios e os castigos", do livro Didática da Escola Nova, de A. M. Aguayo, a diretora fez os seguintes esclarecimentos sobre os castigos:

O menino que todo o dia merece o mesmo castigo, relaxa. Precisamos ter muita prudência em dar castigos; lembrou-nos ter avisado diversas vezes para termos o máximo cuidado, várias professoras já procuraram-na com lágrimas nos olhos, falando sôbre a deficiência alimentar das crianças. Evitar, pois, o castigo de priva-las da sopa. Não mandar a criança para outra sala como castigo e nem pô-la fora da sala, pois essa medida não resolve. Ficando retido; deve ter exercícios para fazer. Quando o aluno chegar a ponto de não obedecer à professora, vamos então chamar os pais ou pessoa que se responsabilisa por êle. ${ }^{500}$

Numa reunião do Grupo Escolar Tomaz Brandão, a diretora pediu a uma professora cuja classe, segundo ela, não possuía "bons elementos", para que explicasse o que havia feito para conseguir a disciplina. Ela informou que exigia silêncio durante as aulas, interrompendo-as todas as vezes que notava conversa entre os alunos. As professoras discutiam os motivos da indisciplina, afirmando que, para muitos, faltava uma melhor educação no lar. Em outra reunião, a diretora proibiu as brincadeiras durante o recreio, afirmando que o espaço era muito pequeno. Acrescentou que os guardas não se interessavam pelo Grupo e que não se podia contar com a ajuda deles. Em outra reunião, a professora técnica pediu às professoras que mantivessem seus alunos sempre em atividade durante as aulas para que a disciplina não ficasse prejudicada, recomendando, ainda, a divisão do quadro em duas partes anotando os nomes dos alunos em dois grupos: dos mais atrasados e dos mais adiantados.

${ }^{500}$ Ata $^{\circ} 9$ de 04 de outubro de 1952. 
Os recorrentes avisos de que as crianças não poderiam ficar após a aula sozinhas, com as serventes ou sob a vigilância de outros colegas mostra que estas eram práticas constantemente utilizadas pelas professoras.

Em 1931, Mário Casasanta publicou, com o pseudônimo ABC, uma série de artigos na Revista do Ensino e no jornal Minas Gerais. Em um deles, o ex-Inspetor Geral da Instrução trazia a sua concepção de disciplina: “...disciplina nada mais é do que a manutenção da ordem, por bem ou por mal. Escola disciplinada é escola ordenada, quer seja pelo premio, quer seja pelo castigo. O tipo mais comum é a disciplina imposta pelo castigo" ${ }^{\circ 01}$. Casasanta afirmava, então, que era preciso que os professores deixassem de associar a disciplina a castigo e associá-la a governo, discorrendo sobre quatro tipos de disciplina:

a) O que conduz a anarquia. Constitui um mau uso da liberdade, os alunos fazem o quer querem o que traz sérios prejuízos à educação.

b) O professor é ditador. Segundo ele, é o tipo mais comum. O professor dita as regras e vigia para que sejam obedecidas. Tais ditadores são apreciados pelos pais e também podem o ser pelos próprios alunos, sobretudo se forem justos, trabalhando com critério e moderação. Entretanto, o professor se esgota na vigilância aos alunos que só se comportam bem se estiverem sob o olhar do professor. Além disso, torna os alunos passivos e autômatos.

c) Prepondera a decisão do grupo. Os próprios alunos estabelecem regras de trabalho e defendem sua aplicação.

d) Os alunos agem espontaneamente em benefício da escola, colocando em segundo plano seus interesses particulares.

Para Casasanta, os dois últimos tipos de disciplina é que possibilitam a formação de cidadãos, sendo o último o mais elevado deles. Tais discussões deveriam deixar bastante confusas as professoras que, por um lado, eram diretamente responsabilizadas pela disciplina escolar e, por outro, recebiam a recomendação de deixarem os alunos estabelecerem as próprias regras. Há aqui uma crença de que os alunos, por si mesmos, seriam capazes de instaurar um sistema disciplinar eficaz. De certa forma, nessa concepção, os professores seriam os responsáveis não mais pela disciplina que poderia ser alcançada espontaneamente pelos alunos, mas sim pela tirania ou pela anarquia nas escolas.

${ }^{501}$ ABC (CASASANTA, Mário). O problema da disciplina. Revista do Ensino, BH, ano VI, n. 53,54 e 55, p. 32-43, jan.fev.mar.1931. 
A Escola Nova instituía diversos mecanismos de controle capazes de disciplinar. Por esse motivo, ela possibilitava dispensar ou pelo menos reduzir a necessidade das punições. É precisamente esta a discussão apresentada por um dos artigos da Revista do Ensino:

A disciplina é o problema maximo da Escola.

$[\ldots]$

A Escola Nova deve ser traduzida como a Escola da Disciplina!

[...]

Deve, pois, o professor ter em consciência que a ordem da classe está directamente ligada á sua reputação profissional, é o seu nome que está em jogo.

$[\ldots]$

Entre os factos que, positivamente, cooperam para a má disciplina da classe, destacamse:

a) Heterogeneidade da classe $[\ldots]$

b) A falta de plano bem organizado [...]

c) A falta de firmeza nas advertencias [...]

d) Os complexos de inferioridade e superioridade de alguns alunos [...]

e) A personalidade do professor [...]

f) Ausencia de ambiente de confiança. $[\ldots]^{502}$

Se a Escola Nova era seguramente a escola da disciplina, ela não conseguia, por mais que tentasse, banir o estigma das punições. Uma das soluções para o problema era culpabilizar os educadores e/ou os educandos pela existência da indisciplina. Apesar de todos os dispositivos: os testes, a homogeneização das classes, o atendimento nas classes especiais, as excursões, os auditórios, o atendimento médico aos alunos, a catequização, e outros tantos recursos utilizados, a indisciplina persistia. Até porque, na trama estruturada dos dispositivos disciplinares, sempre é possível encontrar falhas e aberturas. Por mais que se busque abarcar todos os espaços e possibilidades de ação, a infinitude de resistências criativas e saídas tangenciais jamais pode ser contida. Por este motivo, poucos eram aqueles que admitiam a existência da punição nas escolas como recurso último, mas indispensável. Era mais simples admitir a incompetência dos educadores, especialmente para quem não exercia tal função. Por outro lado, alguns autores da Revista do Ensino acabaram se rendendo à convicção de que a punição, se não era a melhor saída para a educação dos alunos, também não podia ser de todo banida do processo educacional. Obviamente, não se tratava mais das punições físicas,

${ }^{502}$ STARLING, Nair. O problema da indisciplina. Revista do Ensino, BH, ano X, n.122-123, p. 57-60. jan.fev.1936, p. 57, 58, 59 e 60. 
vistas como inadmissíveis na escola moderna, mas dos castigos aplicados naqueles que conseguiam burlar todo o conjunto da estratégia disciplinar. O próprio Foucault revela que "na essência de todos os sistemas disciplinares, funciona um pequeno mecanismo penal” (1977/1987, p. 159) o que demonstra que, de forma mais sutil e menos visível, funcionam o que ele denomina as "micro-penalidades".

Entre estas micro-penalidades talvez se possa incluir a severidade dos estudos, dos exames e das avaliações que excluíam radicalmente aqueles que não se adequassem às exigências escolares. O bom professor, como Elza Moura e outros afirmavam, deveria ser exigente:

A firmeza é uma das características do bom professor. Ser firme é prova de ter caráter, de não ter hipocrisia, de ser sincero e leal. Esta firmeza, porém, baseia-se no tríplice princípio: a) jamais desprezar o mestre o seu direito; b) nunca enfraquecer na ação; c) nunca ceder por fraqueza aos caprichos dos alunos.

Nós, professores, temos o direito de perdoar uma leviandade, uma inadvertência, mas uma falta de respeito, nunca, meus jovens e amigos. Quando o aluno não respeita e venera o seu mestre, perde todo o direito à consideração do mestre que, muitas vezes e a contragosto, se vê na dura contingência de se fazer respeitado.

A nós não é permitido deixar passar uma falta, perdoavel que seja, sem uma palavra de censura, sem um gesto, sem um olhar, cumpre-nos exigir o respeito, a obediência, sobretudo ao regulamento da Casa e, caso contrário, punir.

[...]

Nada de tibieza e enfraquecimento, quando fôr preciso o castigo, nada de hesitações, quando a opinião se faz mister. ${ }^{503}$

Ser firme, portanto, implicava corrigir e castigar quando isto fosse necessário, como salientava Maria Angélica de Castro num artigo publicado na Revista do Ensino:

Corrigir a criança, torná-la um ser educado para a felicidade própria, satisfação de seus pais, enriquecimento do tesouro humano e glorificação de Deus, eis a grande tarefa dos que têm a seu cargo a educação da infância e da adolescência. Avulta-se a extensão e acentua-se a complexidade de tão relevante problema quando consideramos os requisitos que o homem educado deve apresentar:

a) Correção e precisão na linguagem [...]

b) Modos finos e cortezes [...]

c) Capacidade de hábitos de reflexão [...]

d) Capacidade de desenvolvimento [...]

e) Eficiência na atividade que desenvolve [...]

[...]

Como corrigir, a partir do uso da razão:

a) instruindo;

${ }^{503}$ MULLER, Christiano. Dignidade, austeridade, firmeza e doçura do mestre. Revista do Ensino, BH, ano XI, n. 137-139, p.100-104, abr. jun. 1937, p. 103 e 104. 
b) repreendendo ou incitando;

c) ameaçando;

d) castigando ou recompensando;

$[\ldots]$

Os castigos, por outro lado, nem sempre oferecem grandes vantagens, como corretivos da conduta. De aplicação difícil e delicada, exigem de quem os executa muita habilidade.

São apontados, como melhores meios de correção, os castigos que derivam diretamente das infrações cometidas.

$[\ldots]$

Outra condição do castigo é que seja raro para ser eficiente. "Uma punição corporal bem dada preserva a criança de vinte palmadas, dispensa cem ameaças, suprime mil repreensões". É o abade René quem o diz.

$[\ldots]$

Outra condição a ser observar, na aplicação de um castigo, é que seja proporcional à falta cometida deliberada.

$[\ldots]$

Outra regra a seguir: Nunca inflingir um castigo a quem não foi reconhecido como culpado.

$[\ldots]$

Por último, esquecer tudo, uma vez aplicado o castigo. ${ }^{504}$

Se o castigo não podia ser, pelo menos para alguns autores e professores, completamente banido, não se duvida de que se exigia uma complexa atuação de quem aplicava a punição. Era preciso levar em conta uma série de detalhes. A habilidade em aplicar o castigo era tão ou mais importante quanto a de evitar a indisciplina. Diversos deveriam ser os fatores considerados para tornar o castigo válido e, principalmente, evitar se cometer uma injustiça.

Tarcísio Mauro Vago, embora tratando de um período imediatamente anterior a esta pesquisa, mostra que a disciplina era sinônimo de um bom Grupo Escolar. Representação esta que certamente se manteve por muitos anos:

As práticas disciplinares contribuíram para o reconhecimento público dos Grupos Escolares. Bom Grupo era aquele em que reinava uma disciplina considerada exemplar. Isso valia também para a Diretora, representada como competente quanto mais enérgica e disciplinadora fosse. Nos relatórios, elas sempre fazem alusão a uma ótima disciplina em seus respectivos Grupos, porque, afinal, estavam escrevendo ao Secretário do Interior, autoridade máxima em instrução pública, inclusive com poderes para indicar ao Presidente do Estado a permanência ou a destituição de diretoras dos Grupos. (2002, p.132)

${ }^{504}$ CASTRO, Maria Angélica de. Castigar para corrigir. Revista do Ensino, BH, ano XIV, n. 178, p. 189196, abr. 1946, p.189, 193, 195 e 196. 
Uma outra discussão muito comum em todos os documentos consultados era em torno da liberdade e da disciplina. Se a escola moderna deveria proporcionar liberdade aos alunos, era necessário deixar muito claro o que se entendia como liberdade:

A liberdade que as crianças têm na Escola Ativa não é só a liberdade de ação. Antes de tudo, a liberdade do pensamento. Não é a liberdade de correr, saltar, "fazer o que quer". Assim, estariamos deseducando a criança, deixando-a agir unicamente de conformidade com os instintos, o que seria uma coisa deploravel. ${ }^{505}$

A associação entre Escola Nova e indisciplina escolar era feita por alguns professores que diziam que a excessiva liberdade concedida aos alunos provocava anarquias. No entanto, não era este o espírito das Reformas. Pelo contrário, a Escola Nova é que instaurava a disciplina escolar no sentido proposto por Foucault. Para este autor, a punição, bem como os castigos físicos e humilhações só podem acontecer após o comportamento faltoso. Os métodos disciplinares, por sua vez, têm por objetivo prevenir as faltas, moldando de antemão os sujeitos e criando técnicas que diminuam a possibilidade de ser a falta novamente cometida. Para Foucault (1975/1987, p.126), as disciplinas são métodos que permitem controlar minuciosamente as operações do corpo, impondo uma relação de docilidade-utilidade. O poder disciplinar encontra-se espraiado pelo ambiente escolar sem uma localização pontual e é daí, precisamente, que decorre sua funcionalidade. Tal poder se exerceria de forma micro, sutil e se faria presente nos gestos, nos olhares e em diversos objetos e comportamentos, constituindo-se numa tecnologia que reúne instrumentos, técnicas, procedimentos e alvos que previnem o aparecimento da indisciplina.

Guerino Casasanta conseguiu resumir sabiamente o que se entendia como liberdade na escola da disciplina instaurada pela Escola Nova: “A verdadeira liberdade está em obedecer" ${ }^{, 506}$. Nesse processo de transição das punições à disciplina era fundamental não apenas a concepção de liberdade, mas também de ocupação do tempo livre. A obediência seria garantida com o uso de atividades e instituições escolares que pretendiam, para além de instruir, disciplinar e moralizar, direcionando as crianças para a realização de atividades consideradas sadias e adequadas e ocupando o seu tempo livre, como será visto no próximo capítulo.

\footnotetext{
${ }^{505}$ LUCAS, Geralda. A Escola Ativa estudada através dos seus característicos. Revista do Ensino, BH, ano VI, n. 56,57 e 58, p.86-89, abr. maio jun.1931, p. 88.

${ }^{506}$ CASASANTA, Guerino. A disciplina que nos convém. Revista do Ensino, BH, ano VII, n. 97, p.2846, dez. 1933.
} 


\section{CAPÍTULO 8 \\ ATIVIDADES E INSTITUIÇÕES ESCOLARES: OCUPANDO E DISCIPLINANDO ALUNOS}

Uma das características mais importantes da Escola Nova era a efetiva participação dos educandos no processo de aprendizagem. Para que isto acontecesse, novos métodos de ensino foram incorporados ao sistema escolar, introduzindo-se as excursões, os auditórios, a ginástica, e também algumas "instituições escolares"507 como os Clubes de Leitura, os Clubes Agrícolas e os Pelotões de Saúde. Os educadores eram sempre exortados a promover tais atividades, incentivar e promover as instituições entre os alunos, não somente com o objetivo de reforçar o aprendizado, mas principalmente, como forma de provocar o interesse dos alunos, formá-los para o exercício da cidadania, ocupar o tempo ocioso, ensinando-lhes valores cívicos e morais, ou seja, disciplinar. Como defendia Mário Casasanta, formar o cidadão era muito mais importante que instruí-lo:

É certo que o aluno saberá menos fatos da história ou menos nomes de geografia. Mas que é isso, afinal, senão uma bagaceira, diante da aquisição de virtudes civicas, importantes e essenciais, para o bem do indivíduo e da coletividade, tais como a lealdade, a exatidão, o desassombro, o desinteresse, o respeito à personalidade alheia, $\mathrm{o}$ devotamento ao bem publico? ? $^{508}$

Muitas eram as recomendações para que as escolas inovassem nas maneiras de ensinar, transformando o ensino excessivamente livresco a partir da incorporação de atividades físicas e manuais e incentivando a participação dos alunos. Obviamente, todas tinham um caráter disciplinador mais ou menos explícito, e um dos objetivos da pesquisa consistia em analisar se as escolas realmente conseguiram realizar tais atividades e se elas cumpriam ou não o seu papel.

Um dos documentos interessantes para se obterem informações sobre tais práticas são os Boletim $\mathrm{M}$, nos quais se registravam todas as atividades realizadas

\footnotetext{
${ }^{507}$ O termo "instituições" fazia parte do Regulamento do Ensino Primário de 1927 que diferenciava as instituições escolares e as complementares à escola, como as Associações das Mães de Família e a Caixa Escolar, já discutidas no capítulo 05.

${ }^{508}$ ABC (CASASANTA, Mário). O problema da disciplina. Revista do Ensino, BH, n. 53,54 e 55, p. $32-$ 43, jan.fev.mar.1931, p. 43.
} 
durante o mês nos Grupos Escolares. Este documento trazia impressos diversos itens a serem preenchidos: Hora da Leitura, Clubes de Leitura, Auditórios, Horta escolar, Pelotão de Saúde, entre outros. Por ele, é possível acompanhar como as escolas declaravam estar ou não cumprindo tais exigências. Pode-se perceber que as escolas buscavam incansavelmente cumpri-las, embora nem sempre conseguissem com a devida eficácia.

O tempo livre era considerado um perigo. As ruas e os quintais ${ }^{509}$ eram percebidos como espaços maléficos e prejudicais, podendo destruir o trabalho formativo levado a cabo pela escola. Por esse motivo, a ação desta deveria se estender para os espaços onde se encontrassem as crianças, ocupando-lhes o máximo possível de seu tempo livre. Helena Antipoff propunha, por exemplo, que às quintas-feiras, dia destinado às reuniões pedagógicas, as escolas oferecessem atividades de recreação para os alunos. Segundo ela, se era importante o contato das crianças com a vida externa à escola, tal não devia ser feito sem a mediação de um adulto experiente que fosse capaz de dar método e direção às experiências vividas. Numa reunião do Grupo Escolar Olegário Maciel, a diretora salientava a importância de que as professoras acompanhassem seus alunos durante o recreio, momento visto como propício para que as crianças revelassem com maior desembaraço seus defeitos. Desta forma, observá-los neste contexto de maior liberdade, poderia fornecer novas informações sobre as características e os comportamentos dos alunos. Além disso, em diversas reuniões, solicitava-se que não se deixassem os alunos retidos durante o recreio como castigo, mas somente após o término das aulas. Esta recomendação revela o quanto era importante este momento para o extravasamento das energias das crianças. É possível que uma criança muito agitada, ficando presa durante o horário de recreio, tivesse piorado o seu comportamento de agitação após o castigo. Além disso, a retenção após a aula tinha mais chances de chegar ao conhecimento das famílias dos alunos que poderiam tomar outras providências para punir seu comportamento.

Outras recomendações eram para que as professoras realizassem jogos e atividades durante o recreio, não deixando os alunos inteiramente livres e, freqüentemente, as professoras se revezavam no cuidado destes durante este momento. Em uma reunião do Grupo Escolar Tomaz Brandão, a diretora afirmou que a professora

509 Título de um trabalho de Cynthia Greive Veiga (1998). 
designada para este trabalho seria responsável por tudo que acontecesse durante o recreio.

Além das atividades e da vigilância exercida durante o recreio, outras atividades e instituições escolares permitiam ocupar os alunos, tendo ainda a possibilidade de moralizá-los, conforme nos revela Anita Fonseca:

Sendo missão da escola não sòmente formar, mas também reformar, devem as instituições escolares ser conduzidas com tato e vigilante atenção, a fim de que as características negativas manifestadas pelas crianças, como o egoísmo, a vaidade, a presunção, a rivalidade, etc, cedam o lugar à solidariedade, à cooperação, ao respeito e mútua estima, etc., para que haja unidade no grupo e progresso de todos. Tais virtudes, adquiridas desde a escola primária, hão de guiar os educandos em suas atuações futuras como cidadãos.

As instituições escolares tomaram maior incremento em nosso Estado com a reforma Francisco Campos e as técnicas de sua organização foram divulgadas pela antiga Escola de Aperfeiçoamento, mediante as aulas ministradas na cadeira de Socialização pela ilustre professôra Amélia de Castro Monteiro.

As instituições escolares mais comuns em nossas escolas são as seguintes: Clubes de Leitura, Pelotão de Saúde, Auditório, Jornal, Excursão, Caixa Escolar, Biblioteca Infantil e Clube Agrícola.

Funcionam nas escolas mineiras, segundo as últimas estatísticas, 208 clubes de leitura, 16.189 sessões de auditórios, 140 pelotões de saúde, 198 clubes agrícolas, 208 jornais, escolares, etc. (Fonseca, 1950, p.6-7)

A autora esclarece quais deveriam ser os objetivos das instituições escolares e deixa bem claro o caráter disciplinador de tais atividades:

Tôda instituição escolar deve favorecer a socialização do aluno, isto é, deve ensina-lo a viver em sociedade, dando-lhe hábitos de cooperação, de iniciativa, de disciplina, de cortesia, despertando-lhe sentimentos de lei e de ordem, de responsabilidade, de tolerancia e respeito à personalidade alheia, etc. etc. (Fonseca, 1950, p. 7)

As instituições escolares também deveriam ser utilizadas pelas escolas noturnas com o objetivo principal de formação moral dos alunos, como recomendava o decreto $\mathrm{n}$. 10.897 de 1933:

Ministrando aos moços êsses poucos conhecimentos indispensáveis á vida, procure dar, ao mesmo tempo, de modo disfarçado, sem discursos inúteis e nem narrações de fatos inverossímeis, a educação de maneiras e a orientação moral, que muitos deles nunca acharam quem lhes desse, e cujo valor sabem muito bem apreciar. Utilize, para isso, as instituições escolares (perfeitamente adaptadas á mocidade, por servirem admiravelmente para lhes canalizar certas tendências e instintos) cujos estatutos organizados pelos alunos, com a hábil orientação da professora, exigirão o cumprimento 
de deveres próprios a lhes proporcionar, pela repetição e pelo exercício, hábitos e atitudes, que a educação dificilmente obteria por outros processos. ${ }^{510}$

Estas diversas atividades e instituições escolares intentavam disciplinar, higienizar e moralizar. Formar cidadãos limpos, ordeiros e trabalhadores era o ideal da Escola Nova, e as práticas proporcionadas pelas escolas não deveriam perder tais objetivos de vista.

Os dispositivos disciplinares dispersos pelos Grupos Escolares de Belo Horizonte são inúmeros e sua invisibilidade torna mais difícil a sua localização. Alguns deles, entretanto, são bem mais nítidos e revelam claramente a função disciplinadora da Escola Nova aqui estudada. Exemplos claros são as atividades e instituições promovidas pelos Grupos Escolares.

Nas fontes consultadas, foram localizadas algumas instituições que deixam evidente de que forma se realizava a função disciplinadora, já que apresentavam um discurso mais explícito nesse sentido. Pode-se classificar em dois momentos essas estratégias. No primeiro, tratava-se de formar o corpo e, por extensão, a mente das crianças. Um corpo saudável e robusto sinalizava a presença de uma mente idem. As teorias eugenistas em voga na época enfatizavam a concepção de que uma nação forte era formada por um povo sadio e era preciso preparar o corpo desde a infância, preservando a saúde e prevenindo as doenças. O Pelotão de Saúde e a Educação Física são os exemplos mais claros de como se buscava não somente garantir a saúde das crianças, mas tornar, elas próprias, defensoras deste modelo.

Mas não bastava a existência de um corpo sadio, era preciso que ele fosse, antes de tudo, disciplinado. Daí que ocupar o tempo livre com atividades educativas era fundamental. Para tanto, foram desenvolvidas diversas situações em que as crianças poderiam ir se habituando a um trabalho considerado honesto (loja, produção agrícola, jornal) e a um lazer visto como adequado (cinema, música, leitura, desenho). Esperavase que tais atividades não apenas afastassem as crianças do vício e da vagabundagem, mas desenvolvessem a moralidade, o civismo, a ordem, a higiene, a disciplina não apenas enquanto alunos dos Grupos Escolares, mas também e, principalmente, como futuros cidadãos.

${ }^{510}$ MINAS GERAIS. Decreto n. 10.897 de 14 jun. 1933. Aprova programas do ensino. 


\subsection{PELOTÃO DE SAÚDE}

O cuidado com a Medicina e a Higiene na educação demandava a atuação de todos os personagens do universo escolar auxiliados por especialistas como médicos dentistas e enfermeiras ${ }^{511}$. Na impossibilidade destes, eram as diretoras, as professoras, as serventes e até os próprios alunos que se incumbiam da tarefa de inspecionar a higiene, fazer curativos e medicar os escolares. Dividir essas responsabilidades com os alunos era uma forma de cooptá-los para a função de vigiar e medicalizar o próprio corpo e de seus colegas.

Os Pelotões de Saúde eram instituições escolares compostas, em geral, por alunos da quarta série que inspecionavam a higiene dos colegas, auxiliavam a fazer curativos e todos os demais trabalhos relativos à saúde. Eles foram criados em vários Grupos Escolares de Belo Horizonte e, em alguns deles, o Pelotão era composto por dois representantes de cada classe, como no Grupo Escolar Tomaz Brandão e Olegário Maciel. Neste último, o Dr. João dos Santos, médico escolar, fundou o Pelotão de Saúde “Oswaldo Cruz". Este Pelotão fazia inspeções diárias nos alunos, mas havia reclamações de que estas tomavam muito tempo das aulas, devendo ficar restritas a apenas um dia da semana. Em 1951, no Livro de Boletins e Ocorrências, afirmava-se que o Pelotão de Saúde "Dr. Waldemar Batista" - nome do médico do Grupo -, havia promovido concursos, dramatizações e inspecionado a saúde e higiene dos alunos.

No Grupo Escolar Tomaz Brandão, em 1951, inaugurou-se o Pelotão de Saúde chamado "Pronto-Socorro Dr. Laureano". Todas as classes tinham representantes, chamadas Assistentes Sanitaristas que faziam curativo e limpeza nos colegas. O médico, dentista e enfermeira escolar iam ocasionalmente às escolas.

Luíza Travassos afirmou que os alunos do Pelotão carregavam uma maletinha pintada com uma cruz vermelha onde havia algodão, bicarbonato, uma cera para passar no dente ${ }^{512}$ e outros pequenos utensílios para fazer curativos.

Grupos do interior também noticiavam a existência destes Pelotões. Um artigo da Revista do Ensino de autoria de um aluno do $3^{\circ}$ ano do Grupo Escolar de São Tomás de Aquino mostrava um dia de funcionamento do Pelotão de Saúde e Polícia em sua

\footnotetext{
511 A Lei n. 305 de 15 de dezembro de 1948 criou um curso de educadoras sanitárias; em 1950, as professoras primárias foram autorizadas a realizar este curso conforme o decreto n. 3.432.

512 Essa cera se chamava "Cera Dr. Lustosa" e tinha um efeito analgésico.
} 
escola. No dia do relato, haviam sido fiscalizados as unhas, a roupa, a cabeça, os dentes, a canequinha e a freqüência dos alunos. Duas enfermeiras, que provavelmente eram alunas, medicaram as crianças ${ }^{513}$. Curiosamente, este Pelotão de Saúde cuidava não apenas da questão médica, mas também disciplinar, já que exercia concomitantemente a função de Polícia do Grupo. No artigo do aluno, se afirmava que a patrulha nada teve a registrar naquele dia porque as crianças haviam ido para casa, sem transtornos. Esta observação é interessante porque sugere que a atuação da Polícia do Grupo estendia-se para além dos muros escolares, acompanhando também o trajeto dos alunos na volta para casa. Além disso, é muito curiosa e sugestiva essa associação entre saúde e disciplina escolar. O policiamento do corpo e da alma estavam interligados nesta instituição escolar, revelando, claramente, a relação entre o cuidado com a aparência física e a disciplina.

\subsection{EDUCAÇÃO FÍSICA}

Os Pelotões de Saúde e o ensino de Educação Física constituíam-se em dispositivos para formar, desde os bancos escolares, cidadãos saudáveis, fortes, com corpos limpos e resistentes. Em 1927 foi criada a Inspetoria de Educação Física com os seguintes objetivos:

a) organizar programmas e horários de exercícios, jogos, gymnastica, etc., de accordo com as estações e circumstancias locaes, edade e desenvolvimento physico das creanças;

b) organizar instrucções para a orientação dos professores de educação physica e inspeccionar as respectivas aulas;

c) ministrar na Capital um curso especial para formação e aperfeiçoamento do pessoal docente destinado ao ensino da educação physica;

d) organizar, de accordo com a Inspectoria Medica, classes especiaes de educação physica para creanças mal constituídas, débeis orgânicos, defectivos mentaes e portadores de defeitos orthopedicos;

e) collaborar nos programmas e na organização das excursões escolares, prescrevendo e recommendando os jogos e exercícios physicos adequados;

f) propor a acquisição dos aparelhos e materiaes apropriados ás diversas classes de educação physica;

g) estabelecer na Capital nas outras cidades praças de exercícios physicos convenientemente localizadas para que possam concorrer a ellas todos os alumnos das

513 SANTANA, Tomaz. Pelotão de saúde e polícia do Grupo Escolar de São Tomás de Aquino. Revista do Ensino, BH, ano VII, n.92, p.67-68, 15 set. 1933. 
escolas publicas, devendo cada praça ser dirigida por um dos auxiliares, designados pelo inspector;

h) incentivar e orientar a organização do escoteirismo nas escolas publicas, formando e preparando o necessário corpo de instrutores. ${ }^{514}$

A Educação Física, portanto, não poderia ser uma tarefa efetuada por leigos. Criava-se uma nova hierarquia das funções escolares, devendo haver técnicos responsáveis pela definição dos exercícios e horários mais adequados, e as aulas serem ministradas, preferencialmente, por professoras especializadas no assunto. Por este motivo, em 1933, foi aberto um curso intensivo de Educação Física com representantes de 79 municípios.

Em 1934, o decreto n. 11.411 aprovava um novo Regulamento para a Inspetoria de Educação Física, trazendo bem delimitados os seus objetivos nos estabelecimentos de ensino que deveriam ser:

a) organizar, dirigir e inspeccionar a Educação Physica escolar do Estado e, eventualmente, em cooperação com a Directoria da Saúde Publica, traçar, regulamentar e fiscalizar as praticas esportivas, levadas a effeito pelos clubes desportivos, centros de cultura physica etc., reconhecidos pelo Governo e que mantenham actividades para menores de 18 annos;

b) ministrar na Capital cursos intensivos destinados á formação e aperfeiçoamento do pessoal docente em exercício do ensino da Educação Phyisica.

c) organizar, de acordo com a Inspetoria Medica, classes especiaes de Educação Physica para ás crenças mal constituídas, débeis orgânicas, defectivas mentaes e portadoras de deffeitos orthopedicos;

d) propor a acquisição dos apparelhos e materiaes apropriados às diversas classes de Educação Physica;

e) estabelecer na Capital e nas outras cidades praças de jogos convenientemente localizadas, devendo cada praça ser dirigida por funccionario designado pelo Secretario da Educação;

f) organizar, incentivar e orientar o escoteirismo nas escolas publicas e praças de jogos, formando e preparando o necessario corpo de instructores honorários.

Estes novos objetivos, mais condensados, incluíam a higiene e a prevenção de doenças futuras, embora não tratassem diretamente da hierarquia instaurada na legislação anterior.

Nas memórias de Alaíde Lisboa, na escola em que estudou, os alunos ficavam quietos o tempo todo, porque sempre havia trabalho. Havia posição para sentar-se e levantar-se e a postura era muito exigida, especialmente quanto à posição das pernas. As

${ }^{514}$ MINAS GERAIS. Decreto n. 7.970-A de 15 out. 1927. Aprova o Regulamento do Ensino Primário. 
mãos ficavam cruzadas em cima da carteira. Havia uma vigilância nesse sentido. A Escola Nova, por sua vez, criticava a imobilidade da escola, afirmando que as atividades físicas não apenas eram essenciais à saúde, mas também ao desenvolvimento infantil.

O marido de Alaíde, José Lourenço de Oliveira, era um dos defensores da atividade física nas escolas: "A educação physica vai ajudar-nos na nossa preservação contra o vicio, o alcoolismo e a depravação. Ella é a melhor escola de sobriedade, de ensino da defesa do corpo contra os agentes desgastadores da saude" ${ }^{\not 15}$.

$\mathrm{O}$ estímulo à Educação Física não se restringia à escola. O governo incentivava essas atividades também com a criação de praças de esportes, clubes e realização de torneios no Estado.

Segundo a recomendação de Zembla Soares de Sá, a Educação Física não tinha por objetivo apenas cuidar da parte física dos alunos, ela devia estar relacionada aos conteúdos trabalhados em classe, objetivando reforçar seu aprendizado:

Recomendo, ás professoras de Educação Física, associarem, o mais possivel, os jogos menores ás disciplinas escolares, afim de que as atividades da Educação Física não apareçam como que isoladas do conjunto educacional, o que hoje não podemos permitir na escola nova. Assim, se a classe está estudando as combinações da multiplicação, deve a professora de Educação Fisica procurar um jogo em que as creanças tenham que aplicar os seus conhecimentos, em tal ramo, pelo que fixarão melhor a materia dada, um ambiente agradavel e expontaneamente aceito. 516

Por este motivo, era importante que as apresentações não fugissem às exigências morais, como afirma a diretora do Grupo Escolar Olegário Maciel em 1936:

As professoras, a quem cumpre zelar de modo efficaz, pela completa educação moral e intellectual das crianças, jamaes devem consentir em que se representem, cantem ou dansem numeros cuja conveniencia, nos moldes da sã moral, deixe algo a desejar. Isso vem a proposito, pois, ainda há pouco the foi dado assistir uma dessas praticas instructivas, em nosso proprio Grupo, onde verificou haver grande infelicidade na escolha do programma, justamente nos pontos visados. Assim, acha de bom alvitre que as professoras sempre collaborem com os alumnos nos seus preparativos, visando corrigir esse descaso. ${ }^{517}$

515 OLIVEIRA, José Lourenço. Educação physica e futura raça brasileira. In: INSPECTORIA DE EDUCAÇÃO FÍSICA. Educação Physica (Jogos e callisthenia). Boletim n. 18. Belo Horizonte: Secretaria da Educação e Saúde Pública: 1935. p.18.

${ }_{516}$ Termo de Visita assinado em 24 de julho de 1934 no Grupo Escolar Pedro II.

${ }^{517}$ Ata da reunião de 15/10/1936. 
A liberdade concedida aos alunos não poderia permitir, entretanto, que as apresentações pudessem acontecer sem uma prévia censura por parte das professoras. Além disso, as atividades físicas deveriam ser adequadas às necessidades específicas das crianças, conforme o discurso escolanovista. Por este motivo, elas deveriam ser diferenciadas para as distintas classes do Grupo Escolar, ou seja, a homogeneidade das classes supunha uma diferenciação não somente nas atividades cognitivas destinadas às crianças, mas também aos exercícios físicos. Outra preocupação era a respeito da especificidade dos exercícios destinados aos meninos e às meninas:

A moça não precisa desenvolver seu instincto de combatividade. Ella não está ou não deveria estar interessada, primariamente, em levantar ou bater records. Deve interessarse em typos de actividade que lhe dêem graça, equilibrio, flexibilidade, velocidade, agilidade, destreza, esthetica, belleza, vigor geral e resistencia. ${ }^{518}$

Embora se afirmasse, reiteradamente, que as atividades físicas se adequassem aos interesses e necessidades dos alunos, como todas as outras atividades pedagógicas, não se encontrou nenhum documento que buscasse analisar quais os interesses dos alunos, inquirindo a eles próprios. A distinção dos exercícios parecia se dar, de forma mais evidente, entre atividades consideradas próprias para cada sexo. As danças, as atividades que envolvessem mais o ritmo, com delicadeza, leveza e elegância eram preconizadas para as meninas. Os esportes que exigiam maior competitividade e força eram prescritos apenas aos meninos. Por outro lado, o futebol, que parecia ser uma atividade esportiva de grande interesse por parte dos meninos, não era percebida como adequada pela psicóloga Helena Antipoff:

Tomemos uma das nossas observações inequívocas: a paixão dos meninos de Belo Horizonte pelo futebol. O exagero, a exclusividade desse jogo nos alarma; e o bom senso nos aconselha a sustar essa paixão, sugerindo outras ocupações: leituras, trabalhos manuais, coleções, etc... Em suma, quiseramos atuar sobre a criança num sentido oposto à sua paixão. Desejaríamos distraí-la do seu interesse demasiado absorvente. E presumimos não errar procedendo assim ${ }^{519}$. (1930?, p.97)

${ }^{518}$ SÁ, Zembla Soares de. A educação physica applicada ao sexo feminino. In: INSPECTORIA DE EDUCAÇÃO FÍSICA. Educação Physica (Jogos e callisthenia). Boletim n. 18. Belo Horizonte: Secretaria da Educação e Saúde Pública: 1935.p.22.

519 ANTIPOFF, Helena. Ideais e interesses das crianças de Belo Horizonte. In: CENTRO DE Documentação e Pesquisa Helena Antipoff. Coletânea das obras escritas de Helena Antipoff. Belo Horizonte: Imprensa Oficial, 1992, vol. II. "Fundamentos da Educação". No texto a autora afirma que era a primeira publicação do Museu da Criança que havia sido criado em outubro de 1929 na Escola de Aperfeiçoamento, por isso, a suposição de que o texto tratasse de 1930. 
A autora, entretanto, não recomenda a pura e simples proibição do futebol ${ }^{520}$, já que tal feito provocaria o fechamento de uma válvula de escape e as tendências físicas e psíquicas, não tendo como se manifestar, ficariam retidas "sob forte pressão prestes a explodir". Recomenda-se, assim o uso de sublimações, canalizações e desvios que, segundo elas, seriam mais eficazes que a repressão.

Educação e Saúde reuniam-se num único Ministério inaugurado por Francisco Campos em 1930. Estes eram considerados os pilares de uma sociedade moderna que precisava de um povo forte, saudável e educado. A vida numa sociedade que se urbanizava e industrializava exigia a formação de cidadãos que soubessem se comportar no espaço urbano, e de trabalhadores que se adaptassem ao trabalho fabril. O valor do tempo, da dedicação, os bons costumes, bons modos e boa disciplina eram requisitos essenciais para a formação de trabalhadores urbanos.

\subsection{TRABALHOS MANUAIS}

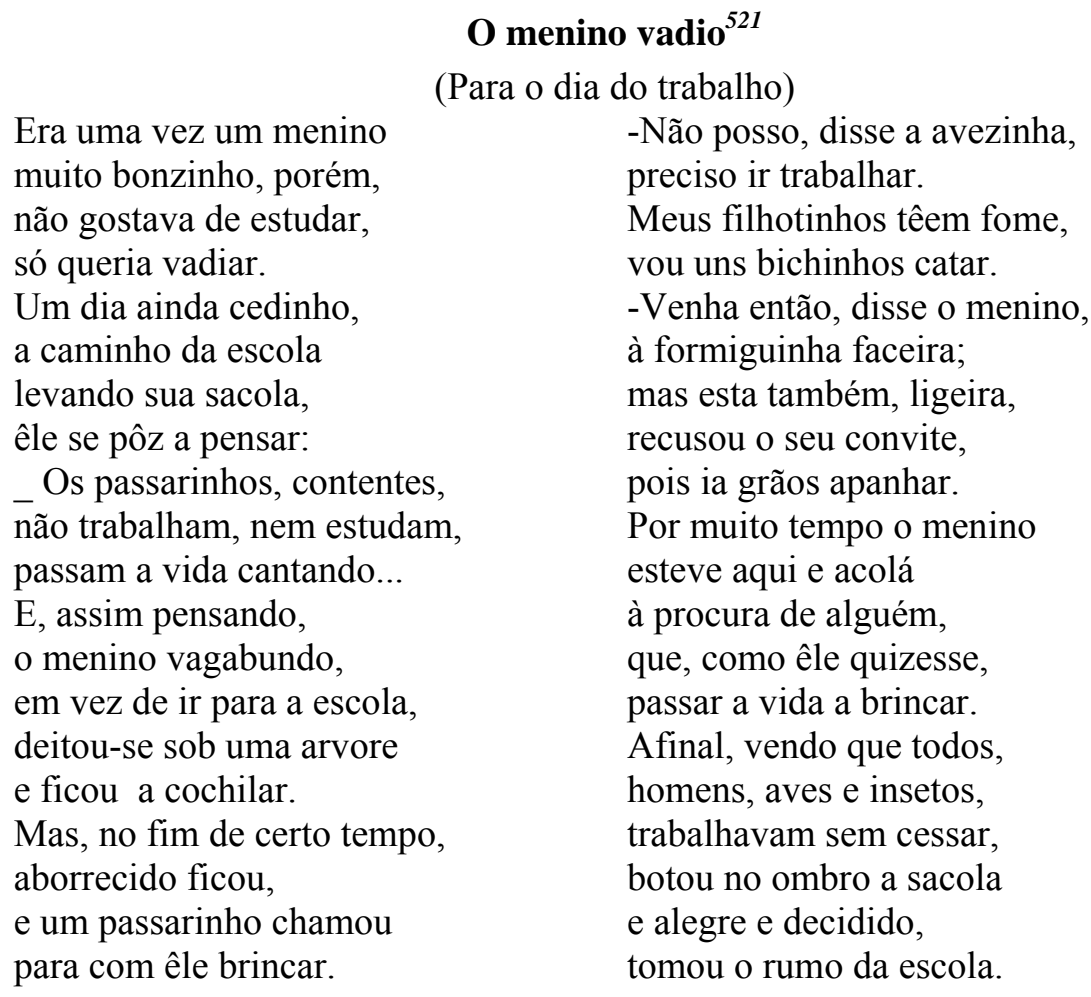

\footnotetext{
520 Sobre o futebol, ela elaborou um questionário sobre o assunto a ser aplicado em escolares. Provavelmente seria mais uma de suas pesquisas, no entanto, não foi possível identificar se ela foi realizada e os resultados obtidos. Sobre o questionário, cf. ANTIPOFF, Helena. Questionário sobre futebol. In: CENTRO DE Documentação e Pesquisa Helena Antipoff. Coletânea das obras escritas de Helena Antipoff. Belo Horizonte: Imprensa Oficial, 1992, vol. I. "Psicologia Experimental". P.71-72

${ }^{521}$ ÁUREA, Maria. O menino vadio. Educando, BH, ano I, n. 4, junho. 1940, p. 33-34.
} 
O poema acima mostra a importância da inserção do valor do trabalho na escola primária $^{522}$. A imagem do trabalho como uma atividade que dignifica o ser humano era recorrente na revista Educando e na Revista do Ensino. A preguiça, a vadiagem e a inatividade eram males a ser banidos da sociedade capitalista e desenvolvida que se pretendia implantar no país. Incutir o valor do trabalho, do bom aproveitamento do tempo em atividades produtivas era uma das tarefas da escola. Manter os alunos em atividade constituía-se numa forma de criar um horror à ociosidade, além de evitar atitudes que pudessem distrair a classe ou provocar comportamentos indisciplinados entre os alunos. Embora não se possa afirmar que a questão da preparação para o trabalho estivesse ausente no período anterior, durante todo o governo de Getúlio Vargas, se incentivou a formação de uma massa trabalhadora que teve na escola uma de suas alavancas ${ }^{523}$.

Tarcísio Mauro Vago, ao abordar a Reforma do Ensino Primário realizada em 1906, comenta:

A presença de "trabalhos manuaes" no programa de ensino pode ser compreendida a partir de pelo menos três sentidos. O primeiro deles, de caráter moral, era o cultivar nas crianças um sentimento de amor ao trabalho. Outro, de caráter profissionalizante, tinha em vista promover mesmo um aprendizado técnico por meio de práticas iniciáticas a ofícios diversos. E o terceiro sentido, que afinal aglutina os anteriores, o de realizar, como já o ordenamento legal revela, uma "educação physica" das crianças - a modelagem de seus corpos, no trabalho de suas mãos. (2002, p. 197)

Certamente, tais sentidos não se perderam. Pelo contrário, foram, possivelmente por eles, que os trabalhos manuais continuaram existindo nas escolas auxiliando, ainda, na disciplinarização infantil.

\footnotetext{
522 Outro poema referente ao valor do trabalho fora publicado na Revista do Ensino, edição de n. 11, de fevereiro de 1926 e o mesmo poema intitulado "Canto do Trabalho" apareceu também na revista Educando.

${ }^{523}$ Como exemplos da valorização do trabalho neste período pode-se citar: em 1930 a criação do Ministério do Trabalho, Indústria e Comércio; no ano seguinte a criação do IDORT (Instituto de Organização e Racionalização do Trabalho) que buscava o aumento da produtividade sustentada no pensamento de Taylor e tinha Lourenço Filho como um dos fundadores. Em 1932 foi criada a Carteira de Trabalho e da Previdência Social e garantidas a licença maternidade, jornada de 8 horas e férias anuais. Nos anos quarenta, o Ministro da Educação Gustavo Capanema realizou diversas Reformas no ensino através de decretos-lei. Em 1942 a Lei Orgânica do Ensino industrial criava o Serviço Nacional de Aprendizagem dos Industriários, mais tarde, Serviço Nacional de Aprendizagem Industrial (SENAI) e, em 1943, a Lei Orgânica do Ensino Comercial criava o Serviço Nacional de Aprendizagem Comercial (SENAC), neste ano ainda organizou-se a CLT - Consolidação das Leis do Trabalho. Na própria revista Educando foram publicadas várias frases de Getúlio Vargas exaltando o trabalho.
} 
Como forma de não desperdiçar o tempo, uma professora do Grupo Escolar Sandoval de Azevedo criou um Caderno de Fichas a serem preenchidas pelos alunos à medida que finalizavam seus trabalhos. Dessa forma, manteria em atividade, principalmente, aqueles alunos mais ágeis nos exercícios escolares. Norma Lúcia conta que, enquanto as meninas faziam aulas de bordado, os meninos, para não ficarem sem atividades, copiavam fichas com a matéria dada, para eles e para as suas colegas. É curioso que, enquanto as meninas realizavam trabalhos manuais, os meninos - para quem deveria ser mais difícil oferecer trabalhos manuais pela exigência de ferramentas mais caras, sofisticadas e até mesmo pela necessidade de ter professores do sexo masculino - também não podiam ocupar o tempo com atividades espontâneas.

Além de ocupar o tempo ocioso, o trabalho manual era enfatizado nas classes de alunos classificados como mais difíceis ou menos inteligentes, devendo ser "usado como meio educativo e não com o fim de fazer da criança um escultor ou um marceneiro." ${ }^{524}$ Apesar dessa recomendação, esperava-se não que a escola fosse formar para o trabalho manual, mas que apurasse algumas tendências dos alunos de forma a lhes indicar um caminho profissional mais adequado, assim como salienta Marta Carvalho, ao mostrar como o assunto era tratado pela Associação Brasileira de Educação:

As propostas de implantação de uma "escola do trabalho oscilavam entre expectativas distintas: valorizar o trabalho, enfatizando o princípio da "atividade" caro à "moderna pedagogia", educando pelo trabalho ou educar para o trabalho formando hábitos e preparando para profissões de acordo com "necessidades do meio". Em nenhuma dessas acepções ela se reduzia ao que se entendia como profissionalização do ensino. (1998, p.230)

A tradução de um artigo publicado na revista Educando enfatiza a importância da formação do hábito do trabalho na Escola Primária:

Máu sinal, ao contrário, para uma criança é a displicência e a impontualidade. O máu escolar começa mal a sua vida; êle a começa com defeitos que o levarão a vícios indestrutíveis. Desconfiemos de quem não ama o trabalho, de quem se recusa a trabalhar ou o faz quando se lhe dá na fantazia; êle tem em si o germem de um máu individuo, de um homem inútil. Quem não trabalha, palmila as ruas, rumina más ações, se perverte e toma um caminho perigoso. Opôr a isso a alegria do aluno laborioso que

\footnotetext{
${ }^{524}$ Frase da professora Aurora Lambert na ata da $4^{\mathrm{a}}$ sessão de $5^{\text {a }}$ feira, no dia 19 de julho de 1934 , no Grupo Escolar Tomaz Brandão em julho de 1934.
} 
estuda, que se sente progredir, que sente seu espírito se abrir, eis como deve agir o professor. ${ }^{525}$

A importância dos trabalhos manuais era tanta que foram criados os inspetores escolares desta disciplina que tinham, por objetivo exclusivo, incentivar e avaliar o desenvolvimento desta nos Grupos Escolares. Havia professoras especializadas ${ }^{526}$ para este trabalho e pedia-se sempre que a professora da classe estivesse presente nas aulas da docente especializada para que contribuísse com o trabalho, já que tais aulas não deveriam ser um passatempo, mas deveriam estar intimamente relacionadas com as discussões teóricas realizadas em classe. $\mathrm{O}$ mesmo se afirmava nas aulas de Educação Física que deveriam ser ministradas por professoras especializadas, mas que deveriam contar sempre com a presença da professora da classe, justificando-se a necessidade de que esta auxiliasse no controle da disciplina dos alunos. No entanto, pode-se perceber que esta era uma forma de ocupar também as professoras que não ficariam com tempo livre no momento em que os alunos tivessem aulas especializadas.

Havia ainda uma assistente técnica especializada em trabalhos manuais que visitava as escolas orientando e organizando o trabalho das professoras, além de um inspetor de ensino de desenho. Esta burocracia criada em torno dos trabalhos manuais revela a importância dada a este ensino. Tais aulas pareciam ter também o objetivo de desviar alguns alunos de carreiras mais intelectuais, como nos informa o trecho abaixo, retirado de um relatório de visita ao Grupo Escolar Pedro II de Zembla Soares de Sá, em 1932:

Não posso silenciar sobre a exposição apresentada, onde se destacava com brilho a parte pedagógica e pre-profissional, aquela demonstrando o quanto de desenvolvimento intelectual e social se conseguira, dando ensejo a que se acompanhasse o trabalho do ano; esta descobrindo e analisando tendencias, que evitarão por certo os famosos erros de vocações; impostos pela incompreensão e egoísmo dos pais, em desejar ter um filho doutor, quando a sua eficiencia social seria numa oficina. Tal exposição, pois, constituiu uma prova publica de como se encara o atual e complexo problema da educação. ${ }^{527}$

\footnotetext{
525 ANGEL, L. Os bons hábitos na escola. Tradução de um artigo da Revista Manuel General L'Instruction Primaire. Educando, BH, ano I, n. 7, p.40-41, set. 1940, p.40.

526 Em 1933, segundo um Termo de Visitas, o Grupo Escolar Pedro II tinha quatro professoras especializadas em "Trabalhos Manuais" trabalhando no mesmo período.

${ }^{527}$ Termo de Visitas de 24 de novembro de 1932.
} 
Além da encadernação de livros da biblioteca e da produção de materiais didáticos, eram muito comuns os trabalhos de modelagem em argila, especialmente no Grupo Escolar Pedro II e sempre merecedores de muitos elogios pelos inspetores. Segundo Zembla Soares de Sá: "O barro coordena a moral, coordena actividade de pensamento e actividade muscular, melhora a intelligencia, etc, tendo ainda a grande vantagem de satisfazer as preferencias da criança". 528

$\mathrm{O}$ envolvimento dos alunos nas atividades propostas deveria parecer natural e partir da iniciativa deles próprios. Por isso, tornava-se essencial que a professora criasse o desejo nos alunos de realizar alguma atividade, como nos mostra o relatório de um Termo de Visita no Grupo Pedro II, em 1933:

A professora conduziu-os, habilmente, de maneira que eles mesmos se propuzessem a reencadernar esses livros. E assim motivou-se uma das mais belas atividades manuais a que já assisti. Eles mesmos raciocinaram, agiram de tal maneira que era evidente a atividade de pensamento e das mãos ao mesmo tempo. E de tam maneira estavam encantados com suas atividades que, chegando a hora do recreio, pediam insistentemente a professora permissão para deixarem de goza-lo, continuando o seu interessante trabalho. E esforçavam-se e venciam as pequenas e grandes dificuldades, $o$ que garante evolução, melhora da capacidade de pensar e de agir, objetivo maximo da escola porque e ele garante o sucesso individual e o sucesso coletivo. ${ }^{529}$

Para a assistente técnica deste ensino, Mariana Noronha Horta, os trabalhos manuais deveriam ser a preocupação primordial dos Grupos Escolares: "Já se tem dito muitas vezes que será preferivel que uma criança deixe a escola, analfabeta, mas levando uma bela noção do bem e uma bela capacidade de trabalho, do que uma inteligencia por demais esclarecida e a conciencia ás escuras e braços cruzados". 530

Eram comuns as exposições de trabalhos manuais organizadas pelos Grupos Escolares, abertas à visitação da comunidade, e cujas aberturas eram sempre muito solenes com apresentações musicais, poesias e discursos.

O Regulamento do Ensino de 1924 demarcava uma rígida separação entre os trabalhos a serem feitos pelas meninas (costura, bordados, culinária) e os oferecidos aos meninos (carpintaria, agricultura). No Programa do Ensino Primário de 1927, Francisco

\footnotetext{
${ }^{528}$ De um Termo de Visitas no Grupo Escolar Tomaz Brandão em 24 de abril de 1937.

${ }^{529}$ Termo de Visitas de 25 de outubro de 1933. Embora não esteja assinado, é provável que seja Mariana Noronha Horta devido à caligrafia.

${ }^{530}$ HORTA, Mariana Noronha. O trabalho manual em nossas escolas. Revista do Ensino, BH, n. 87-88, p.3-8, maio. 1933 .
} 
Campos defendia que as aulas poderiam ser feitas conjuntamente, já que o menino poderia freqüentar a costura porque talvez quisesse tornar-se alfaiate, bem como a menina poderia ir para a marcenaria, a jardinagem ou a horticultura, dependendo exclusivamente do seu interesse. Entretanto, esta recomendação não parece ter sido seguida.

Elza de Moura conta que, enquanto aluna do Grupo Escolar Henrique Diniz, os meninos tinham aula com um professor de carpintaria. As meninas faziam aulas de bordados, bainhas, pontos de cruz, ráfia. O material utilizado para a confecção dos trabalhos era levado pelas alunas e os estes não eram comercializados, ficando com as alunas. As aulas de bordado foram comentadas por várias entrevistadas. A educação doméstica foi uma das discussões de uma reunião de professoras no Grupo Escolar Olegário Maciel em 1936:

O afan do trabalho, affastando do lar a mulher, atirando-a no turbilhão vertiginoso da actividade mundial; a febre de diversões, aos que se enquadram todas as modalidades dos esportes e por fim o flagelo do divorcio, contribuindo para a desaggregação da familia, vêm lançar ao abandono milhares de crianças, necessitadas do melhor amparo social. $^{531}$

A escola deveria preocupar-se em ensinar o valor do trabalho doméstico, relegado a um plano inferior, segundo as professoras. Além disso, a participação da mulher nas diversões, entre elas os esportes, era vista como prejudicial à formação feminina, que não deveria desviar-se da sua mais nobre missão: a maternidade e o cuidado da casa e da família.

Em uma reunião de 1940, no Grupo Escolar Tomaz Brandão discutiu-se sobre as aulas de trabalhos manuais e as vantagens de se montar um curso de costura para as meninas:

... afim de preparar as alunas para os seus futuros misteres de donas de casa, e, se possivel, e evitá-las do convívio nem sempre sadio das fabricas e estabelecimentos congêneres; mas que este seu ato não visava pôr seu nome em evidencia, mas tão somente facultar das mocinhas uma aprendizagem útil, debaixo dos ensinamentos morais e bons exemplos das professoras. ${ }^{532}$

\footnotetext{
531 Ata da reunião de 05 de novembro de 1936.

${ }^{532}$ Reunião de 30 de abril de 1940.
} 
Uma professora sugeriu que as docentes pagassem pelos trabalhos realizados pelas alunas do Grupo para custear o pagamento da máquina de costura. Pelo visto, portanto, o pagamento não era para as alunas, mas para o próprio Grupo. Chegou a se propor um valor máximo para este pagamento, mas não um valor mínimo, o que revela que o trabalho das alunas, no momento da comercialização, nem sempre era considerado um verdadeiro trabalho, mas apenas uma atividade de aprendizado.

Em outra reunião em 1944, a diretora afirmava que os Cursos de Puericultura e Culinária destinados às ex-alunas seriam ampliados, atendendo também às alunas e se transformariam em sessões de Culinária, Costura e Puericultura, sendo oferecidos por professoras especializadas. Houve, ainda, ampliação no número de horas do curso.

Além dos cursos, a diretora do Grupo Escolar Tomaz Brandão fez uma interessante sugestão durante uma das reuniões: que as professoras deixassem uma ou duas meninas encarregadas da limpeza da classe. Sendo o Grupo situado num dos mais pobres bairros de Belo Horizonte, pode-se deduzir a importância de oferecer cursos profissionalizantes para as alunas, desviando-as, o mais cedo possível, das carreiras intelectuais. Tanto que não foram encontrados registros de outros cursos deste tipo nos outros Grupos pesquisados. É de se imaginar, ainda, que uma proposta de que as alunas ficassem responsáveis pela limpeza da classe não seria feita nos Grupos que atendiam a uma clientela com melhores condições financeiras.

Geraldo Félix, ex-aluno do Grupo Escolar Tomaz Brandão, não se lembrou de nenhuma atividade manual ou profissional desenvolvida no Grupo. Ele disse que se tornou alfaiate auxiliando um primo que exercia a profissão e afirma que não tinha aula de trabalhos manuais: "Não. Não tinha ensino nenhum. Não tinha nada. Nunca falaram disso. Só falava que nós ia ser operário ou soldado. Aí eu procurei logo a aeronáutica: soldado". Talvez o seu comentário seja porque os cursos de Puericultura e Culinária oferecidos pelo Grupo pareciam destinar-se exclusivamente a um público feminino. Ou talvez porque as aulas de trabalhos manuais freqüentadas por ele fossem menos profissionalizantes, como as aulas com argila, dobraduras ou encapamento de livros da biblioteca como se fazia em diversas escolas.

O decreto n. 10.897 de 14 de junho de 1933 definia o programa de ensino para o Curso Técnico Complementar de dois anos, justificando: 
Estes programas, destinados ao ensino manual nos cursos técnicos complementares, não se referem exclusivamente ao trabalho manual educativo, sem caráter de ofício "slojd" propriamente dito - que constitue hoje o relevo mais saliente da escola nova. Nem tão somente ao ensino profissional verdadeiro, que prepara o indivíduo em uma especialidade qualquer, que the garanta um meio de subsistência honesto e independente: êles se colocam, por assim dizer, entre ambos, articulando-se em um sistema único, que se poderá chamar técnico-educativo, cujo fim principal é dar aos adolescentes certos conhecimentos práticos, firmados em princípios teóricos, que constituem a base de iniciação para a generalidade das profissões.

Quer isto dizer, que com o preparo de acordo com estes programas, o aluno fica apto para se especializar, com rapidez, em um ofício escolhido, para que tenha decidida vocação, sem que isto possa prejudicar a marcha de seus estudos intelectuais destinados á conquista de outros títulos para uma profissão liberal. ${ }^{533}$

O decreto revela que não se tratava de um ensino para os pobres, já que ele não deveria ser unicamente profissionalizante, possuindo um papel educativo importante que não deveria obstaculizar a carreira liberal de alguns alunos. O programa previa o ensino de trabalhos em madeira, em vime (cestaria), em metal e latoaria (com folha de flandres, latão, chumbo, estanho, etc).

Parece que um curso desse tipo fora instalado imediatamente no Grupo Escolar Lúcio dos Santos porque, em abril de 1934, o jornal O debate publicou uma notícia de que o referido Grupo tinha um curso complementar para os alunos. As aulas duravam quatro horas e eram freqüentadas por discentes de todos os anos, divididos em dois turnos. O curso estaria em funcionamento desde julho de 1933 e aceitava encomendas de particulares, revertendo o dinheiro para o próprio curso e para a compra de materiais $^{534}$. Em 1946, a diretora do Grupo Escolar Olegário Maciel encaminhou, ao Secretário da Educação, um pedido de que se fizesse a montagem de uma oficina com ferramentas e máquinas, para a realização do trabalho de um professor de ensino técnico profissional designado para trabalhar no Grupo, mas não foi possível verificar se o curso realmente aconteceu.

\footnotetext{
${ }_{533}^{533}$ MINAS GERAIS. Decreto n. 10.897 de 14 jun. 1933. Aprova programas do ensino.

${ }^{534}$ Numa conferência realizada por Theodore Simon sobre os dois meses de sua estadia em Belo Horizonte, ele conta que no Grupo Escolar Afonso Pena funcionava, do outro lado da rua, um curso técnico em que os alunos trabalhavam com madeira. SIMON, Theodore. Dois mezes em Bello Horizonte. Minas Gerais, 05 abr. 1930. O mesmo texto foi publicado na Revista do Ensino, BH, n. 44, p. 102-113, abr. 1930.
} 


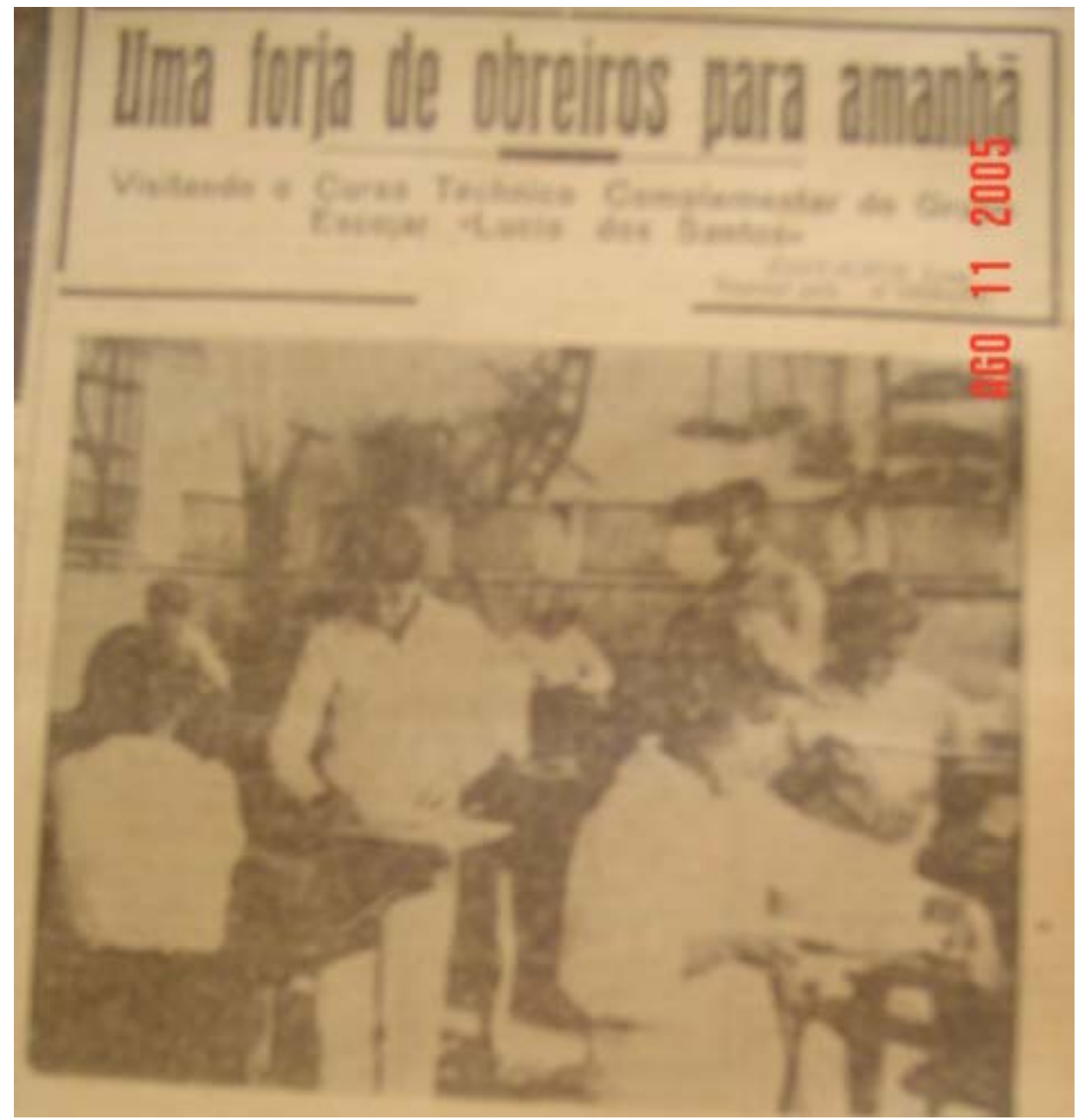

Foto 18: Instrutor e alunos num curso no Grupo Escolar Lúcio dos Santos. A data na fotografia é a da digitalização feita pela pesquisadora.

Fonte: UMA FORJA de obreiros para amanhã. Visitando o curso complementar do Grupo Escolar "Lucio dos Santos". O debate. Anno I, n. 34, 23 abr. 1934, p. 1 e 3.

Em 1931, como Ministro, Francisco Campos promoveu Reformas no ensino nacional, organizando o ensino comercial nos níveis médio e superior (para a formação do profissional de contabilidade ${ }^{535}$ ) e também o ensino secundário ${ }^{536}$ e superior $^{537}$.

${ }^{535}$ O decreto n. 20.158 , de 30 de julho de 1931, organizava o ensino comercial e regulamentava a profissão de contador.

536 Até o fim da década de vinte, o ensino secundário no Brasil se restringia a cursos preparatórios para o ensino superior e o curso seriado, quando existente, era pouco procurado. Em 1931, Francisco Campos, como Ministro da Educação e Saúde, promoveu uma Reforma que implantou o currículo seriado e a freqüência obrigatória no ensino secundário criando dois ciclos: o primeiro, fundamental, durava 5 anos e propunha uma formação básica geral e o complementar com 2 anos de formação propedêutica para o ensino superior. O decreto n. 19.890, de 18 de abril de 1931, dispunha sobre a organização do ensino secundário e o decreto $n$. 21.241 consolidava as disposições sobre o ensino secundário.

537 O decreto n. 19.851, de 11 de abril de 1931, instituía o Estatuto das Universidades Brasileiras dispondo sobre a organização do ensino superior no Brasil com a adoção do regime universitário. $\mathrm{O}$ decreto n. 19.852, também de 11 de abril de 1931, dispunha sobre a organização da Universidade do Rio de Janeiro. 
Como os cursos profissionalizantes não davam acesso ao nível superior, pode-se afirmar que tais mudanças favoreceram a educação da elite.

A década de quarenta foi um período de importantes iniciativas com relação ao ensino profissionalizante, em nível federal ${ }^{538}$. Em 1942, o Ministro Gustavo Capanema realizou diversas Reformas no ensino através de decreto-lei: a Lei Orgânica da Aprendizagem Industrial que criava o Serviço Nacional de Aprendizagem dos Industriários, mais tarde, Serviço Nacional de Aprendizagem Industrial (SENAI) e Lei Orgânica do Ensino Secundário, criando o $1^{\circ}$ ciclo, chamado ginasial, com duração de quatro anos e o $2^{\circ}$ ciclo, com os cursos científico e clássico, que preparavam para o ingresso no curso superior e eram realizados em três anos.

Em 1943, a Lei Orgânica do Ensino Comercial dava origem ao Serviço Nacional de Aprendizagem Comercial, o SENAC. Em 1946, novas legislações tratavam do ensino agrícola, primário e normal.

O ensino primário teve uma primeira lei nacional em 15 de outubro de 1827 que durou pouco tempo, pois o ato adicional de 1834, que alterava a legislação anterior, descentralizou a instrução primária, tornando-a uma responsabilidade das províncias. Em 02 de janeiro de 1946, somente após 118 anos, portanto, o Brasil teria novamente uma lei nacional do ensino primário através do decreto-lei n. 8.529 $9^{539}$. Esta lei criou o curso primário supletivo de dois anos para adolescentes e adultos e organizou o ensino primário regular em quatro anos complementado por mais um ano como preparatório para admissão nos níveis posteriores.

No caso de Minas Gerais, foi através do decreto n. 2.576, de 19 de janeiro de 1948, que o governo tornava possível a realização do curso primário em cinco anos onde fosse necessário articulá-lo com o ensino secundário, fosse ele industrial, ginasial ou agrícola. As disciplinas oferecidas revelam não somente o caráter propedêutico desse ano complementar, mas principalmente, a profissionalização. As disciplinas para o $5^{\circ}$ ano eram: leitura e linguagem; aritmética e noções de geometria; geografia e história do Brasil e noções de geografia geral; ciências naturais e higiene; conhecimento das

\footnotetext{
${ }^{538} \mathrm{Um}$ dos decretos, por exemplo, dispunha sobre a obrigação dos estabelecimentos industriais empregarem aprendizes e menores num total de $8 \%$ do número de seus operários, priorizando filhos, os órfãos e os irmãos de seus empregados. Pela primeira vez o governo não apenas subsidiava escolas para formação de mão-de-obra, mas também imputava aos empresários a responsabilidade pela formação de seus novos quadros.

${ }^{539}$ Lei Orgânica do ensino primário.
} 
atividades econômicas da região; desenho; trabalhos manuais e práticas educativas relacionadas com as atividades econômicas da região; canto orfeônico; educação física, noções de economia doméstica e puericultura (para os estudantes do sexo feminino ${ }^{540}$ ).

As Hortas e Clubes Agrícolas instaladas nos Grupos Escolares constituíam-se como importantes dispositivos para inculcar nas crianças o valor do trabalho e das atividades manuais, indicando-lhes formas outras de trabalho que não somente as intelectuais. Ampliar o acesso à escola primária não deveria significar uma ampliação também nas oportunidades profissionais, em cursos percebidos como mais nobres e vantajosos. Os trabalhos manuais eram utilizados como mecanismo disciplinador de um grupo social que tinha acesso pela primeira vez aos bancos escolares, mas cuja escolarização não deveria ser associada a maiores expectativas sociais e profissionais.

\subsection{CLUBES AGRÍCOLAS E HORTA ESCOLAR}

A Sociedade dos Amigos de Alberto Torres ${ }^{541}$ teve vários artigos publicados na Revista do Ensino, defendendo a importância do trabalho agrícola. Vários desses artigos criticavam o acesso das crianças, principalmente as moradoras da zona rural, à escola, afirmando que esta lhes retirava o desejo de trabalhar no campo e permitia que os alunos, uma vez alfabetizados, aspirassem à realização de trabalhos intelectuais.

O Brasil, para alguns intelectuais, tinha uma tradição agrícola que não deveria ser alterada. Além disso, as levas de imigrantes rurais eram vistas como um perigo para o meio urbano, provocando inchaço nas cidades, a proliferação de cortiços e favelas e a oferta excessiva de mão-de-obra, gerando desemprego e miséria. A oferta de escolas primárias poderia favorecer a migração e, desta forma, sua necessidade e importância era discutível no que se refere às crianças do meio rural.

Tratando dos Grupos Escolares de Belo Horizonte, não se pode dizer que as hortas tivessem por objetivo assegurar que os alunos se destinassem aos trabalhos

\footnotetext{
${ }^{540}$ A Lei Orgânica do ensino secundário recomendava que a educação das mulheres fosse feita em estabelecimento exclusivo.

${ }^{541}$ Alberto Torres (1865-1917) foi um intelectual, jurista e político fluminense. Em 1932, foi fundada, no Rio de Janeiro, a Sociedade dos Amigos de Alberto Torres, criada para promover estudos sobre o país. Tratava-se de uma sociedade civil ativa e organizada que promovia reuniões, palestras e debates sobre diversos temas como: educação, agricultura, imigração, nacionalidade, trabalho, conservação da natureza, todos considerados questões importantes para a nação brasileira.
} 
agrícolas, pelo menos, de uma maneira geral ${ }^{542}$. As hortas eram importantes para o trabalho manual com a terra, para oferecer ajuda às Caixas Escolares seja com a venda de produtos, seja com o fornecimento destes para a merenda. Além disso, a Escola Nova sempre enfatizou o equilíbrio entre o trabalho intelectual e o manual e a importância de se valorizar a produção feita pelos alunos. Por outro lado, a escola, fosse rural ou urbana, deveria ter sensibilidade para encaminhar os alunos mais pobres e/ou considerados menos inteligentes, para os ofícios manuais, como os agrícolas.

As fontes consultadas mostram que algumas escolas da capital realizavam tais atividades. No Grupo Escolar Olegário Maciel, os alunos trabalhavam tanto na horta como no jardim. No Grupo Escolar Tomaz Brandão criou-se o Clube Agrícola “José Anatólio Lima”, mas parecia haver muita dificuldade para colocá-lo em funcionamento. Há alguns registros de plantio de couve, batata doce e inglesa pelas turmas de $3^{\circ}$ e $4^{\circ}$ ano, que seriam utilizadas para enriquecer a sopa escolar. No entanto, na maior parte do tempo, o terreno ficava inutilizado pela falta de água no prédio. Nos demais Grupos Escolares não foi possível verificar se as hortas ou os Clubes Agrícolas realmente funcionavam. Entretanto, segundo informações obtidas na Revista do Ensino ${ }^{543}$, em 1935, havia 69 Clubes Agrícolas com 6.953 associados em 47 municípios e 10 em Belo Horizonte. Nestes Clubes, funcionavam 5 cooperativas para venda de produtos, 66 hortas, 28 pomares, 5 pequenas indústrias, 9 criações de aves, 3 criações de abelhas e 4 criações de bicho da seda.

\subsection{DESENHO}

O ensino de desenho era separado do ensino de trabalhos manuais, havendo um inspetor exclusivo para essa matéria. No entanto, este inspetor não parecia avaliar somente o ensino de desenho nas escolas. Numa única visita realizada a 18 de julho de 1934 no Grupo Escolar Pedro II, ele deixou registrado no Livro de Termo de Visitas uma observação de que haveria alunos na classe $\mathrm{D}$ do $1^{\circ}$ ano que poderiam ser promovidos a uma classe superior. Não fica claro se esta classe superior seria o $1^{\circ}$ ano $\mathrm{C}$

\footnotetext{
${ }^{542}$ Deve-se considerar, no entanto, que Belo Horizonte, no início do século XX, era uma cidade em desenvolvimento e que muitas casas tinham quintais; além disso, seus bairros não eram ainda tão urbanizados e a linha divisória entre o meio urbano e rural era bem menos evidente que nos dias atuais.

${ }_{543}$ COMUNICADOS do Serviço de Estatística da Secretaria de Educação. Revista do Ensino, BH, n.140142, p. 92, jul. set.1937.
} 
ou o $2^{\circ}$ ano. Pode-se observar, no entanto, que o inspetor de desenho ou não se restringia às análises apenas das aulas de sua especialidade, ou utilizava o desenho para definir qual o grau de adiantamento dos alunos ${ }^{544}$. Em 1934, este inspetor estava organizando um curso de aperfeiçoamento na Escola Normal Modelo para as professoras $^{545}$ e sugeria a construção, nos Grupos Escolares, de Centros Artísticos com as seguintes finalidades:

a) Difundir o gosto artistico nas escolas;

b) Para realizar esse objectivo promoverão:

c) conhecimento da personalidade de seu patrono;

d) $\mathrm{O}$ maior desenvolvimento do ensino das disciplinas que possam despertar o sentimento esthetico;

e) Promover a educação esthetica pela contemplação de obras de arte, originaes ou em reproduções de cunho artistico pelas audições de boa musica, recitaes, etc.;

f) Organizar as exposições dos trabalhos escolares e dar a todas as festas da escola um cunho de bom gosto e elegancia;

g) Zelar pela conservação do edificio escolar, salas de aula, cuidando dos meios de ornamenta-las, cultivando o jardim, tratar com carinho as plantas e as arvores, que ornamentam as dependencias da escola e os jardins publicos, manter asseio e boa ordem do mobiliario, etc.; tornando extensivos aos lares esses cuidados;

h) Despertar attenção para as belezas naturaes, respeito pelos monumentos publicos e amor pelo passado e pelas tradicções, promovendo para esse fim, passeios, excursões e a fixação em "croquis", dos aspectos mais interessantes desses trabalhos; palestras apropriadas exaltando o amor pela natureza, a beleza artistica e moral dos monumentos e a importancia social da historia. ${ }^{546}$

Os Centros Artísticos, segundo o inspetor, não se diferenciavam muito das outras associações escolares, mas ele não esclarecia como deveria ser a sua organização, afirmando apenas que, além da diretoria dos alunos, era preciso haver uma diretoria de professores. $\mathrm{O}$ inspetor dava algumas sugestões de nomes de diversos artistas brasileiros para patronos dos Centros. Recomendava, no entanto, que os próprios alunos escolhessem o patrono, a partir de uma lista indicada pelo professor. Ou seja, a escolha dos alunos era livre, desde que dentro da seleção prévia já realizada.

O decreto n. 10.362 de 1932 exigia que as professoras de Trabalhos Manuais dos Grupos Escolares fizessem um curso na Escola de Aperfeiçoamento sobre desenho e

\footnotetext{
${ }^{544}$ Essa última hipótese é plausível. No relatório de aulas de desenho, elaborado por uma professora do Grupo Escolar Olegário Maciel, ela avalia a idade mental dos alunos, a partir da análise de seus desenhos. ${ }^{545}$ Segundo Peixoto (2003, p. 119), o governo teria convocado, pela Inspetoria Geral de Instrução, 54 professores em exercício nos Grupos Escolares para o Curso de Desenho e Modelagem que seria realizado na Escola de Aperfeiçoamento.

${ }^{546}$ A sugestão para a organização dos Centros Artísticos nos Grupos Escolares foi publicada no jornal Minas Gerais.
} 
modelagem. O decreto n. 11.411 de 1934 passou a exigir que o curso de especialização com duração de um ano, feito na Escola de Aperfeiçoamento, fosse pré-condição para a contratação no cargo de professora especializada em Trabalhos Manuais. No entanto, Maria Aparecida (Dona Yá), professora desta disciplina no Grupo Olegário Maciel, afirmou não ter nenhum curso de especialização para tais aulas ${ }^{547}$ :

D. Yá: Eu dava aula assim, na sexta-feira quando não ia uma professora eu ia substituir. Ajudava também na escrita no gabinete, passando a matrícula. Fiquei com a alimentação, fui professora de desenho, de trabalhos manuais. Eu ia a aula, em conjunto com a professora, dava aula correlacionada com a aula.

$\mathrm{R}$ : A senhora fez algum curso específico?

D. Yá: Não é por intuição mesmo, porque eu acho que a aula intuitiva é muito melhor. Por exemplo, você está falando sobre o café, aí a professora dá aula, a gente entra com um trabalho, vamos fazer um trabalho correlacionado com o café, com o alimento. Fazia meu plano de lição sobre o café desenhava a xícara, o pires no pano e guardava o guardanapo, desenhava um bule, o açucareiro, era tudo intuitivo. Sobre tudo eu dava assim. Muito bonito, meu grupo era muito organizado.

Os desenhos eram utilizados não apenas para treinar a destreza, o controle, a concentração nas aulas, mas serviam, também, para avaliar a inteligência geral dos alunos, a partir dos testes psicológicos. Em alguns momentos, acreditava-se que se poderia melhorar o coeficiente intelectual dos alunos, como no caso da professora de desenho do Grupo Escolar Olegário Maciel. Em um relatório detalhado das aulas de desenho ${ }^{548}$, Maria Taranto afirmava ter sete anos de trabalho e suas aulas, segundo ela, "além de interessar vivamente a criança, mantém o entusiasmo e a disciplina". Este relatório é bastante interessante porque apresenta como se fazia a análise dos desenhos. A professora apresentou uma ficha de observação de um teste inicial da figura humana realizado por uma menina de nove anos. Fazendo uma análise do desenho apresentado pela garota, Maria Taranto concluía que a idade mental da menina era de seis anos, demonstrando um atraso de três anos. Logo na primeira aula, a partir de análises e correções do desenho do teste, a menina conseguiu evoluir para uma segunda etapa do desenho. Já na segunda aula, o desenho, bem mais elaborado, mostrava uma idade mental de 10 anos e 3 meses. O avanço dessa idade ocorreu em menos de um ano e a explicação para isso era que a professora lhe apontava os erros cometidos no desenho,

\footnotetext{
${ }^{547}$ Ela teria feito um curso de nutrição para auxiliar na merenda escolar.

${ }^{548}$ Este relatório encontra-se num Livro de pagamento de funcionários. No entanto, nos dias 01/08/1937 e 06/11/1937, encontra-se uma descrição pormenorizada de duas aulas de desenho.
} 
ensinando-a a desenhar corretamente, como ela própria explica: "De posse dos desenhos aproveito a primeira oportunidade para que o aluno compare e estude o natural, fazendo-o observar mais atentamente as falhas que o seu trabalho apresentar e pedindolhe novo desenho sobre o mesmo assunto e com a devida correção". Este caso mostra uma relação bastante peculiar entre a idade mental e o desenho. Bastava a professora ensinar a criança a desenhar melhor, para obter um avanço no índice mental dos alunos.

\subsection{LOJA ESCOLAR}

Existente em alguns Grupos, a Loja vendia materiais escolares aos próprios alunos, e uma descrição, feita em 1932, mostra o seu funcionamento, no Grupo Escolar Olegário Maciel. A Loja Escolar, chamada Carmem Silva, nome da professora auxiliar que a criou, era considerada uma fonte de ensinamentos pedagógicos, morais e sociais. A escrita diária era utilizada no desenvolvimento do ditado, da linguagem e da aritmética, especialmente entre os alunos do $3^{\circ}$ e $4^{\circ}$ anos. A prestação de contas desenvolveria nos alunos o senso de responsabilidade e honestidade.

Havia na Loja um gerente, um correntista, vinte caixeiros que trabalhavam durante um trimestre e vinte fiscais, comparecendo, por dia, em cada turno, somente dois: um caixeiro e um fiscal. O dever do caixeiro consistia em vender, registrar as vendas e entregar o dinheiro à professora encarregada de dirigir o movimento da Loja. O dever do fiscal era verificar se o caixeiro estaria vendendo de acordo com os preços marcados, se recebia corretamente o dinheiro das vendas, se dava o troco ao comprador, verificando também o registro das vendas efetuadas. O gerente, por sua vez, compareceria uma vez por semana, em cada turno, para observar o trabalho dos fiscais e caixeiros da semana, receber informações quanto à falta de material na Loja e verificar onde compraria artigos em melhores condições. Ele também determinava o horário de funcionamento da Loja e a relação dos preços. O correntista e o caixa, escolhidos pelos colegas, deveriam fazer o registro semanal das vendas, sob a direção da professora.

Em outros Grupos Escolares também foram encontrados registros da existência destas Lojas que eram uma forma de conseguir materiais escolares para os alunos que os estivessem deixado em casa e de arrecadar fundos para a Caixa Escolar. O seu 
funcionamento permitia ainda fornecer materiais escolares mais corriqueiros, como lápis e borracha, aos alunos que não tivessem condições.

As Lojas Escolares eram um interessante recurso para desenvolver nos alunos o senso da responsabilidade, de atenção e de valor ao trabalho. Além disso, já estabeleciam uma hierarquia de trabalho que preparava as crianças, desde cedo, para se submeterem aos processos de divisão e vigilância no trabalho.

\subsection{HORA DA HISTÓRIA \& CLUBES DE LEITURA}

Conforme Diana Vidal, a leitura silenciosa é de fundamental importância para a sociedade moderna que exige leitores rápidos, eficientes e cuja relação com o texto aconteça de forma individualizada ${ }^{549}$. Formar, a partir da leitura, era um dos objetivos da Escola Nova não só para os alunos, mas também para as professoras.

A importância da leitura na formação dos professores era crucial na Reforma Francisco Campos. Determinava-se que cada Grupo Escolar tivesse duas bibliotecas, pelo menos. Uma, infantil, para os alunos e outra, pedagógica, para os professores. As revistas do Ensino e Educando premiavam seus leitores com livros. Segundo um relato de Lúcia Casasanta ${ }^{550}$, dificilmente se encontraria, naquele, momento um acervo de livros técnicos comparável ao da Escola de Aperfeiçoamento o qual se queimara num incêndio ocorrido em 1953. Também a biblioteca infantil da referida escola teria sido, segundo ela, a primeira a ser criada no Brasil e estava organizada "nos moldes das melhores americanas do gênero" e ainda acrescenta:

Seus livros eram estudados em aulas de literatura infantil - curso também pioneiro em nosso país - e, bem catalogados, com indicação para os interesses da idade das crianças a que devia atender. Possuía equipamento simples mas funcional. E havia, finalmente, as fichas para controlar suas leituras. Uma das atividades ligadas à biblioteca infantil era a de contar histórias e graças a ela, ótimas "contadoras" se forjaram no curso. (1984, p.47)

As reuniões de quinta-feira destinadas à leitura das professoras se transformaram, ao longo do tempo, em reuniões pedagógicas nas quais elas deveriam

\footnotetext{
${ }^{549}$ Esta discussão foi feita por VIDAL, Diana. Escola Nova e Processo Educativo. In: LOPES, Eliane Marta Teixeira; FARIA FILHO, Luciano Mendes de; VEIGA, Cynthia Greive. 500 anos de educação no Brasil. 2 ed. Belo Horizonte: Autêntica, 2000. p 497-517.

${ }^{550}$ Cf. Ângela Souza, 1984, p. 47.
} 
apresentar, oralmente e por escrito, as leituras realizadas durante a semana. Nessas reuniões no Grupo Escolar Tomaz Brandão uma professora por semana ficava responsável por trazer um resumo de um texto, livro ou artigo para apresentar e que ficaria arquivado no Grupo ${ }^{551}$.

Se a falta de leitura era indesejável, ler em excesso também era perigoso. Um artigo na Revista do Ensino ${ }^{552}$ classificava os professores em três grupos: o primeiro era o dos gastrônomos caracterizado pelos que liam em excesso, vistos como devoradores de livros. O grupo dos jejuadores era composto pelos que não liam. Do terceiro grupo, mais moderado, faziam parte aqueles que liam algumas páginas diariamente e as aplicavam na escola. Somente os últimos, denominados sóbrios, teriam "o seu nome vinculado à grandiosa obra de educação da massa popular”. É curiosa tal proposição na medida em que, às mulheres daquele período, não era muito bem vista uma dedicação maior às atividades intelectuais, consideradas até mesmo perniciosas para suas frágeis inteligências. Também não se podia admitir que não lessem nada, até porque, elas eram responsáveis por formar leitores. Nesse sentido, o meio termo parece ter sido a saída encontrada para as mulheres que se tornavam professoras, mas que continuavam carregando todos os preconceitos associados à mulher, dentre eles, a incapacidade para os ofícios intelectuais.

Com relação aos discentes, foram criados os Clubes de Leitura para os alunos do $3^{\circ}$ e $4^{\circ}$ ano e a Hora da História para os mais novos que não tinham muita habilidade para a leitura. Os Clubes eram valorizados por tornar os alunos sujeitos de sua própria formação, acreditando-se que: "As crianças lendo muitos livros que cooperem para sua formação e personalidade suavisarão o trabalho pedagógico dos mestres."

Logo que chegou à Escola de Aperfeiçoamento, Helena Antipoff realizou uma pesquisa ${ }^{554}$, buscando conhecer a "natureza" das crianças belorizontinas. Com este intuito, ela, com o auxílio das alunas da Escola de Aperfeiçoamento, aplicou 760 inquéritos aos alunos do $4^{\circ}$ ano primário da capital mineira. A quarta questão

\footnotetext{
${ }^{551}$ Não foram encontrados estes resumos nos arquivos consultados.

${ }_{552}$ PRAZERES, Duntalmo. Gastrônomos, sóbrios e jejuadores. Revista do Ensino, BH, ano VII, n. 92, p. 14-16, jul. 1933.

${ }^{553}$ Citação retirada de uma ata de reunião de professoras no Grupo Escolar Tomaz Brandão em 16 de abril de 1946.

${ }^{554}$ ANTIPOFF, Hélène. Ideaes e interesses das creanças de Bello Horizonte e algumas suggestões pedagogicas. Boletim n. 6. Bello Horizonte: Secretaria do Interior de Minas Gerais; Inspectoria Geral da Instrucção, 1930.46p.
} 
apresentada era: "Qual o livro ou a história que você mais gosta?" Com os resultados obtidos, a professora fez uma comparação entre as crianças mineiras, as cariocas ${ }^{555} \mathrm{e}$ crianças de outras capitais como Paris, Berlim e Nova Iorque encontrando um atraso nas crianças mineiras. Ela atribuiu essa diferença ao meio social das crianças e concluiu ressaltando a gravidade da situação:

É difícil aceitar a idéia de que a criança, ao deixar a escola primária e tendo passado ali quatro anos de sua vida, na época em que justamente o cérebro apresenta tanta receptividade e os olhos se abrem com tanta curiosidade sobre o mundo e onde este cérebro é tão sensível a menor indicação, que lhe faz descobrir novos horizontes, é difícil, digo eu, acreditar que toda essa bagagem espiritual da criança não ultrapassa aquela dos contos de PELE DE ASNO e outros! Se, ao deixar a escola primária, o menino não sabe ler outra coisa, senão aqueles contos pueris; se, por outro lado esta criança não terá a sorte de poder continuar os estudos pode-se presumir que esta criança não conseguirá ler mais nada, e que provavelmente, esquecerá bem depressa o seu alfabeto. Então, não terá sido melhor, deixar a criança à vontade sem obrigação daquele estudo, já que tudo que lhe foi ensinado pode evaporar tão rapidamente? ${ }^{556}$

Antipoff salienta a importância das leituras: são elas que darão continuidade ao trabalho educacional da escola primária, especialmente entre aquelas crianças que não podem continuar os estudos, daí a necessidade de prepará-las para selecionar as leituras consideradas benéficas.

Era preciso limitar e vigiar o acesso aos livros de maneira que os alunos não escolhessem leituras tidas como perniciosas. Uma outra pesquisa realizada pelo Laboratório de Psicologia da Escola de Aperfeiçoamento consistia em apresentar aos alunos um catálogo com 100 livros de 20 categorias diferentes para sua escolha. Participaram do estudo 456 crianças do quarto ano escolar em Belo Horizonte, sendo 222 do sexo masculino e 234 do feminino. As crianças do sexo feminino escolheram, em $1^{\circ}$ lugar, livros sobre religião, família, amor, prazer orgânico ${ }^{557}$ e banditismo (nessa ordem) e do sexo masculino religião, banditismo, aventura, guerras e história universal. Interessante que o item beleza física foi o último colocado para os meninos e o $17^{\circ}$

\footnotetext{
${ }^{555}$ Testadas por Armanda Álvaro Alberto.

${ }^{556}$ Este trabalho foi publicado nos Archives de Psycologie, de Genebra, n. 86, p. 153-185, 1930 e está traduzido em: ANTIPOFF, Helena. Interesses e ideais das crianças brasileiras: Conclusões. In: CENTRO DE Documentação e Pesquisa Helena Antipoff. Coletânea das obras escritas de Helena Antipoff. Belo Horizonte: Imprensa Oficial, 1992, vol. I. p. 65-66.

${ }^{557}$ No interesse por prazer orgânico estavam relacionados livros referentes à saúde corporal, nutrição e outros temas relativos à "conservação do eu orgânico".
} 
(entre 20) para as meninas ${ }^{558}$. A partir dos resultados, recomendava-se maior vigilância sobre as leituras infantis, já que alguns livros classificados como impróprios "por encenarem más aventuras, crimes e cenas horripilantes" haviam sido indicados como preferidos pelas crianças.

Apesar dessas constatações, nem sempre os Grupos Escolares favoreciam a criação de um hábito de leitura entre os alunos, especialmente os mais pobres. No Grupo Escolar Olegário Maciel, por exemplo, nos relatórios sobre o movimento da biblioteca infantil Vitália Campos, ao final de cada mês, a classe que mais retirasse livros ganhava como prêmio o direito de todos da classe retirarem gratuitamente um livro. Como a retirada dos livros não era gratuita ${ }^{559}$, os alunos que recebiam a premiação eram, seguramente, os pertencentes às classes com maior poder aquisitivo que podiam sempre alugar os livros para levarem para casa. Em 1936, o relatório afirmava, ainda, que os alunos que alcançassem os três primeiros lugares em todo o segundo turno, poderiam retirar três, dois e um livro, respectivamente. Não ficava claro o que classificaria os alunos nesses três primeiros lugares. É muito provável que fosse novamente a maior retirada de livros da biblioteca o que, mais uma vez, privilegiava os alunos com melhor condição financeira. Os alunos pobres também tinham a oportunidade de ler os livros da biblioteca, uma concessão que dependia da boa vontade dos diretores da escola:

Contudo, aos alumnos reconhecidamente pobres é permittido retirarem livros gratuitamente depois de verificações severas sobre a sua conducta, sua applicação às aulas, gosto pela leitura, etc. Faz-se com que elles comprehendam o valor dessa concessão, que cessará desde que não correspondam à nossa bôa-vontade. ${ }^{560}$

Neste mesmo Grupo, as classes tinham, durante a semana, trinta minutos de leitura recreativa. Curiosamente, após a leitura, dita recreativa, os leitores tinham vinte minutos para resumir o que haviam lido. A bibliotecária corrigia os resumos, sendo os melhores transcritos pelo aluno no caderno “Álbum da biblioteca”. Os resumos também

\footnotetext{
${ }^{558}$ LUSTOSA, Irene. Interesses infantis revelados por um catálogo de livros. Revista do Ensino, BH, ano VIII, n. 102, p. 46-61, maio 1934.

${ }^{559}$ No Grupo Escolar Bernardo Monteiro, os alunos pagavam uma taxa de Cr $\$ 0,20$ de diária, caso quisessem levar os livros do Clube de Leitura para casa, e o mesmo valor era pago por multa de atraso na entrega do livro.

${ }^{560}$ Bibliotheca Infantil “Vitália Campos” em 1936.
} 
poderiam ser feitos a partir de histórias contadas pela bibliotecária. Em 1938, este caderno passou a se chamar "Livro de Ouro" da biblioteca, e no jornalzinho da escola havia uma "Coluna de Ouro" na qual eram publicados os trabalhos do "Livro de Ouro".

Um outro meio encontrado pelos professores do Grupo Escolar Olegário Maciel para promover um maior interesse pela Biblioteca Infantil era a produção de gráficos de classes que mais tinham alugado livros na biblioteca. A classe que alcançasse o primeiro lugar teria direito de alugar, primeiramente, os livros novos adquiridos para a coleção. Num outro momento, foram comprados três brinquedos novos, com recursos dos alunos, mas apenas as turmas que estavam classificadas nos três primeiros lugares no aluguel de livros da biblioteca, podiam utilizar os brinquedos durante o recreio. As outras turmas, conforme o relatório, utilizavam-nos em segundo lugar. Sendo o recreio um curto período de tempo, é difícil imaginar quando as outras turmas puderam usufruir o direito de brincar com os brinquedos, cuja compra havia sido custeada por todos. Tais brinquedos eram, segundo o relatório, jogos educativos.

Outra iniciativa muito original criada pelo Grupo foi a "Corrida do Livro", que pretendia estimular a leitura considerada muito fraca. As classes iriam percorrer uma estrada imaginária de Belo Horizonte até o Rio de Janeiro numa baratinha, veículo da época. A classe que mais tivesse lido livros da biblioteca chegaria simbolicamente à cidade do Rio de Janeiro e as outras iriam parando nas cidades do caminho. No dia da apresentação do resultado, foi feita a dramatização de uma transmissão radiofônica, e cada classe levou o seu representante para descrever a cidade a qual teria atingido na viagem.

A poesia abaixo, publicada no jornalzinho O Sandoval de Azevedo, resume a importância da leitura na educação infantil. Uma leitura que tanto poderia educar quanto “envenenar”. A recomendação de que esta se tornasse um hábito não se desvinculava do fato de que nem todas eram apreciadas e louváveis. Era preciso criar o hábito da leitura e, simultaneamente, combater os maus hábitos de ler o que não era percebido como formador. 


\author{
Ler \\ Raimunda Coelho \\ Lê, criança, com carinho \\ Lê, com amor, com alegria. \\ Seja o livro teu amiguinho. \\ Quer de noite, quer de dia! \\ Lendo, sintas a beleza \\ Sem sombra de negro véu. \\ Sejas como a natureza, \\ Fitando o azul do céu. \\ Muito cuidado, pequeno, \\ Não busques qualquer leitura. \\ Vê antes se tem veneno, \\ Que mate a tua candura. \\ Lê sempre, lê com afan, \\ Com zelo verdadeiro \\ E poderás amanhã, \\ Ser um grande brasileiro!
}

Guerino Casasanta (1934, p.197) conta de uma medida intrigante utilizada pelos alunos de um Grupo Escolar de Belo Horizonte para aumentar os volumes da biblioteca escolar. Eles separaram e encadernaram os contos de único livro e fizeram dele 50 volumes, cada volume contendo um conto. $\mathrm{O}$ autor comenta que, dessa forma, eles não apenas aumentaram os volumes da biblioteca como facilitaram o acesso aos livros. Certamente, essa seria uma forma muito pouco esperada de ampliação do acervo de uma biblioteca e da utilização da própria obra.

\title{
8.8. MÚSICA NA ESCOLA
}

Assim como a leitura, a música também consistia em um importante dispositivo de formação dos alunos. De acordo com Flávio Couto de Oliveira, a música foi um importante recurso escolar utilizado para a formação estética das crianças, auxiliada pelas danças e pela ginástica rítmica:

Em Minas Gerais, a partir de 1925, com a inauguração da Revista do Ensino e com a publicação do primeiro cancioneiro escolar oficial, esse repertório passou a ser amplamente difundido entre professores dos ensinos primário e normal. Essas publicações não só foram fundamentais para divulgar o repertório das canções 
escolares, como também para instruir os professores quanto à utilização das canções, a maneira de entoá-las, bem como os benefícios que o canto escolar traria para as crianças, sob diversos pontos de vista. O surgimento dessas publicações marcou a consolidação do canto coletivo enquanto disciplina escolar nas escolas primárias e normais do Estado, principalmente na capital, fazendo despontar também os primeiros especialistas mineiros na referida disciplina. $(2004$, p.9)

Acerca da utilização da música nas escolas no Brasil pode se retroceder até o ensino jesuítico que o utilizava para despertar a sensibilidade indígena para a religião dos colonizadores. A partir da independência e, posteriormente, da República, a música na escola passou a ter a importância de criar uma identidade nacional, civilizar e conferir sentimentos patrióticos ao povo brasileiro. Conforme Flávio Oliveira ${ }^{561}$ :

Em meio a esse contexto de transformações, que se estendeu pelas primeiras décadas do século XX, o canto escolar, entendido como um componente essencial na educação das crianças, cumpriria assim um papel especial na formação de novos cidadãos, chegando mesmo a ocupar um lugar central na cultura escolar do país durante o apogeu da política nacionalista na fase do Estado Novo (1937-1945). (2004, p.37)

O Regulamento do Ensino Primário de 1924 determinava a publicação de um cancioneiro escolar contendo a letra e a música dos hinos e cânticos patrióticos aprovados pelo Conselho Superior, para serem distribuídos a todas as escolas primárias do Estado. Arduíno Bolívar e Branca de Carvalho Vasconcelos, professores da Escola Normal Modelo, foram os encarregados de organizar o referido cancioneiro (Oliveira, 2004, p. 118). O cancioneiro e o hinário escolares eram enviados às escolas mineiras como forma de selecionar as músicas mais adequadas para a educação das crianças nos Grupos Escolares. Músicas como tangos, maxixes e sambas não eram consideradas educativas pelos temas que tratavam. Era importante selecionar a boa música e também a professora adequada para este ensino:

Principalmente nas escolas que não têm professora encarregada exclusivamente de musica, o canto faz-se cheio de constrangimento. A professora toma essa tarefa como um pesado encargo e espera, ansiosa, no toque da sineta, o fim do seu sacrificio. Os alunos, por sua vez, refletem o constrangimento e a má vontade da mestra: grande parte não canta. ${ }^{562}$

\footnotetext{
${ }^{561}$ No governo Mello Vianna (1922-1926), foi criada a primeira orquestra sinfônica e o primeiro conservatório de música de Belo Horizonte (Oliveira, 2004, p. 73).

${ }_{562}$ LAMBERT, Levindo. Cantos escolares. Revista do Ensino, BH, ano VII, n. 90-91. p. 38-47, jul. 1933, p.45-46.
} 
Sempre que possível, as aulas de música eram dadas por professoras especializadas neste ensino, não só pela necessidade de melhor formação técnica, mas também porque a emoção e o entusiasmo da professora empolgariam os alunos que tentariam imitá-la:

A musica alegre, feita de movimentos rapidos, de phrases brilhantes, sonoras e dansantes, retempera o espirito, renova o sangue, faz amar a vida e o trabalho, anima a escola; a musica triste, toca o coração, faz amar o proximo, corrige os habitos, provoca emoção, educa. ${ }^{563}$

O decreto n. 10.821 de 1933 aprovava, entre outras mudanças, alterações no ensino da disciplina de Música e Canto Coral nas Escolas Normais ${ }^{564}$. Segundo a exposição de motivos de Noraldino Lima:

Sem o intuito de formar artistas, tem a música, na escola, um fim todo educativo, como agente pedagógico de grande relevância. Além de desenvolver a memória auditiva e o senso rítmico, é de influência precípua e decisiva na formação do caráter e dos sentimentos... Cultivando e melhorando as vozes no canto de um hino ou uma canção, esquecem-se das desigualdades de condição e, vibrando à mesma emoção de alegria e de entusiasmo, sentem-se irmanados no mesmo afeto e no mesmo ideal. ${ }^{565}$

Segundo o decreto n. 11.411 de 1934, o governo poderia contratar professoras especiais de música e canto para os Grupos Escolares urbanos de mais de dez cadeiras. Eram exigências para o contrato das referidas professoras:

a) certificado do curso de piano, pelo menos até o $4^{\circ}$ anno inclusive, do Conservatório Mineiro de Música ou de institutos congêneres, de reconhecida idoneidade;

b) attestado de bom funccionamento dos órgãos da respiração, da phonação e da audição;

c) attestado de vaccinação contra a varíola e de que não soffre nenhuma das moléstias, anomalias e defeitos especificados pelo artigo 114 do Regulamento do Ensino Primário.

\footnotetext{
${ }^{563}$ CRUZ, Georgina Machado da. O canto nas escolas. Revista do Ensino, BH, ano IX, n. 110, p.5-9, jan. 1935, p.7

${ }^{564}$ Em 1934, a Secretaria de Educação promoveu um curso de canto para professores de grupos escolares de Belo Horizonte.

${ }^{565}$ LIMA, Noraldino. Decreto n. 10.821/33. Exposição de motivos. Belo Horizonte, Imprensa Oficial, Coleção de Leis e Decretos do Estado de Minas Gerais, v.1, p.160, 1934.
} 
A exigência de que tivessem certificado reconhecido de curso de piano, poderia ser substituída por um concurso mediante banca examinadora. Tinham preferência as normalistas, especialmente as de escolas de $2^{\circ}$ grau. $\mathrm{O}$ decreto exigia, ainda, que as professoras de música e canto já contratadas fossem efetivadas, mediante diploma de curso intensivo de Pedagogia da Música e Canto Orfeônico que seria oferecido pelo Conservatório Mineiro de Música.

Todas as escolas que fizeram parte da pesquisa tinham piano. Apesar disso, o canto orfeônico que se disseminou no governo Vargas não exigia acompanhamento por se tratar apenas das vozes que compunham o coro. Heitor Villa-Lobos (1887-1959), maestro e compositor brasileiro, teve grande importância na divulgação do canto orfeônico no país. Suas grandiosas apresentações regendo inúmeras vozes no Rio de Janeiro estão diretamente atreladas às apresentações públicas de exaltação nacionalista do governo Vargas. Em 1934, o canto orfeônico passou a ser disciplina obrigatória nas escolas primárias e secundárias do país.

O canto possui um forte caráter disciplinador: por um lado, pode transmitir diversos conteúdos importantes para o desenvolvimento moral e, por outro, exige uma postura, um ritmo, uma apresentação e a aquisição de um tempo próprio que disciplinam o corpo e a voz dos sujeitos envolvidos ${ }^{566}$. O canto orfeônico apresenta as vantagens de dispensar instrumentos musicais de acompanhamento, o que torna mais barata a sua utilização, além de permitir que esta aconteça em qualquer ambiente, apenas com a presença dos cantores. Os sentimentos de unidade, de força, de vigor, de identidade que as apresentações do canto orfeônico eram capazes de despertar causavam profunda impressão ao público e, por isso, esta apresentação artística se tornou tão importante no Estado Novo e na educação escolar deste período no país.

Apesar disso, não se pode afirmar que o canto tivesse tido importância apenas no período varguista. Flávio Oliveira (2004, p. 74) encontrou inúmeras apresentações musicais de escolares em Belo Horizonte, especialmente a partir da implantação dos Grupos Escolares, em 1906. As canções eram, especialmente, cívico-patrióticas e, às vezes, folclóricas. O autor informa que encontrou mais continuidades do que rupturas no ensino de música nas escolas primárias nos primeiros anos da República brasileira,

\footnotetext{
${ }^{566}$ Segundo Oliveira (2004, p. 90), tanto o conteúdo textual das canções, quanto da literatura infantil daquele período eram "repletos de ensinamentos de bons hábitos, de boa conduta, de amor à escola, ao trabalho, aos pais e à pátria".
} 
especificamente em relação às temáticas do civismo e patriotismo. No entanto, o fim do Estado Novo teria representado uma diminuição do incentivo ao canto orfeônico no país:

É interessante observar que com o fim do Governo Vargas em 1945, o canto orfeônico perdeu grande parte de seu apoio institucional que, juntamente com a falta de uma política sistemática de capacitação de professores para essa disciplina e com a emergência de outras correntes teóricas tais como a arte-educação, pode ter contribuído para um lento e gradual processo de desarticulação dessa disciplina escolar. Contudo, o canto orfeônico ainda se manteve nos currículos das escolas brasileiras até a promulgação da Lei 5692/71, quando somente então passou a ser substituído por uma disciplina mais genérica, a Educação Artística. Essa pretendia englobar conhecimentos de música, artes plásticas, teatro e dança. Assim, por serem epistemologicamente distintas, todas essas áreas do conhecimento sintetizadas em uma só disciplina, acabaram por sofrer grandes prejuízos quanto ao seu conteúdo e aproveitamento. Entretanto, algumas fontes levantadas nessa pesquisa, tais como a Revista do Ensino e os depoimentos orais dos professores entrevistados, apontam para a existência bem sucedida, após o fim da década de 40, de orfeões escolares em Belo Horizonte, tais como o Orfeão do Instituto de Educação, dirigido pela professora Maria Amorim Ferrara, o qual participava regularmente de canto orfeônico na cidade. (2004, p.176-7)

Apesar dessa constatação, o autor também comenta que a professora Maria Ferrara que trabalhou durante trinta anos no Instituto de Educação levou a frente o canto orfeônico até a sua aposentadoria ${ }^{567}$. Nos anos cinqüenta, a professora teria sido responsável por diversas apresentações públicas de canto orfeônico na cidade de Belo Horizonte, estendendo a sua influência para além do período estadonovista.

Apesar disso, com exceção dos auditórios, não foram encontrados, nas fontes pesquisadas, indícios da participação dos Grupos Escolares de Belo Horizonte nessas grandes festas, com exceção da festa de formatura que, em 1941, parece ter reunido vários alunos de Grupos no Estádio Benedito Valadares, mas mesmo nesse caso, não se faz menção às apresentações musicais. No entanto, nas festas no interior escolar, a música estava sempre presente e, assim como outras instituições escolares, tinha por objetivo moldar, formar e conformar o caráter e ainda revelar à sociedade a ordem e a disciplina desenvolvidas nos alunos dos Grupos Escolares.

${ }^{567}$ Que parece ter acontecido nos anos 70. 


\subsection{AUDITÓRIOS}

Os auditórios eram apresentações realizadas nas escolas que tinham por objetivo dar visibilidade ao trabalho efetivado nas salas de aula. Diversos eram os motivos para a realização desses auditórios até porque, por exigência do Regulamento do Ensino de 1927, eles deveriam ser quinzenais: aniversários de alunos e professores, inauguração de retratos de autoridades escolares, homenagem a colaboradores da Caixa Escolar, datas cívicas e religiosas entre outros.

Os relatos dos alunos sobre os auditórios são variados. Uns se lembram de peças teatrais que foram encenadas para toda a comunidade escolar e familiares. Outros se lembram de apresentações reservadas, no fundo do Grupo Escolar exclusivamente para a classe. O fato é que os auditórios aconteciam e encenações, declamações de poemas, músicas, ginástica e dança faziam parte destas atividades. Uma outra presença constante nos auditórios escolares era a religiosidade. As coroações, as festas de Maria, as primeiras comunhões, Páscoa e outros eventos eram todos integrados aos auditórios escolares.

\subsection{ATIVIDADES CÍVICAS}

Dois conteúdos importantíssimos para a disciplina escolar eram o ensino da Moral e do Civismo. O primeiro era incluído no dia-a-dia escolar, nas prescrições disciplinares, nos conteúdos tratados em classe e revelados nas composições escolares como as publicadas nos jornaizinhos escolares - nos auditórios, nas aulas de catecismo e conteúdo religioso. O civismo também estava presente em diversos momentos da vida escolar. Fazia parte do ensino de música, dos auditórios, dos jornaizinhos, dos conteúdos trabalhados e estavam presentes até mesmo nas capas dos cadernos escolares. 


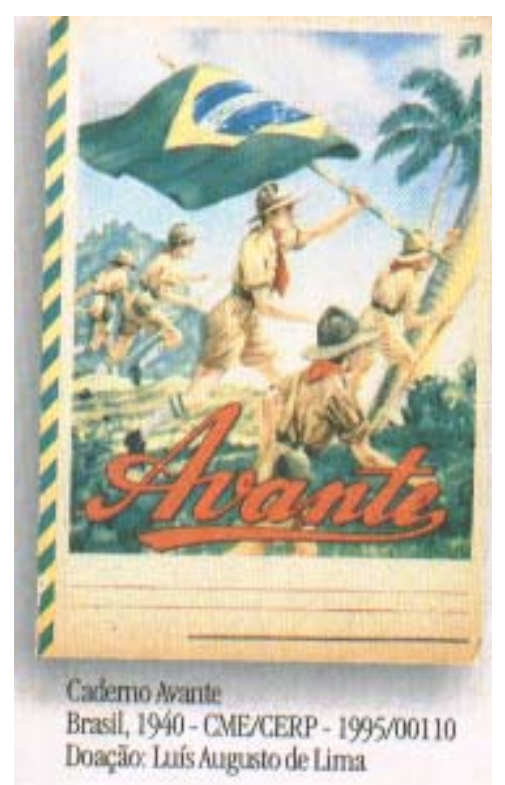

Figura 19: Capa de Caderno Escolar de 1940.

Fonte: Folder do Museu da Escola de Minas Gerais

Curiosamente, apesar de ter sido um período em que o nacionalismo exacerbado e as manifestações militares eram grandiosas como no Estado Novo, não se pode afirmar que houve grande mudança com relação ao início do século XX. Tanto Alaíde Lisboa, quanto Elza de Moura e Imene Guimarães, professoras que estudaram antes da década de vinte nos Grupos Escolares mineiros, foram incisivas ao afirmar que o civismo, o amor à Pátria eram temas constantes tratados pelas professoras. O que se percebeu como diferente durante o Estado Novo foram as comemorações pelo aniversário de Getúlio Vargas. As fontes consultadas não mostraram paradas militares, desfiles e outras apresentações cívicas que fossem realizadas para além dos espaços escolares. Se os alunos não participavam de desfiles e paradas cívicas na cidade, não significa que esses estivessem restritos ao espaço escolar. Através das excursões, tornavam-se espaços educativos também as ruas, prédios, parques, igrejas e praças que compunham o cenário citadino.

\subsection{EXCURSÕES}

Fortemente preconizadas pela Escola Nova, as excursões faziam parte do dia-adia escolar, sendo para Aracy Abreu Pinto uma das melhores recordações da escola. Nos Grupos Escolares foram encontrados diversos registros de excursões. Os alunos 
iam ao Parque Municipal, à Pampulha ${ }^{568}$, participavam de eventos religiosos, entre outros passeios.

Esta prática foi também introduzida na Escola de Aperfeiçoamento por Helena Antipoff que já estava acostumada a realizar excursões com os alunos do Instituto Jean Jacques Rousseau em Genebra. Pequenos grupos de alunas-professoras visitaram Sabará, Caeté, Santa Luzia, Nova Lima, Barbacena e Viçosa ${ }^{569}$.

As excursões proporcionavam aos alunos e alunas um novo olhar sobre a cidade. Através delas, as escolas orientavam quais os melhores espaços para circular, o que olhar, quais os espaços de lazer adequados, sadios, benéficos. As excursões jamais foram pensadas como momentos de puro lazer, os objetivos de formação deveriam ficar bem claros aos educadores, educandos e sociedade, de maneira geral.

\subsection{CINEMA ESCOLAR}

O acesso das crianças a novas tecnologias, como os filmes exibidos pelos cinemas, trazia constantes preocupações aos educadores. De um lado, considerava-se que o cinema poderia auxiliar a aprendizagem utilizando-se filmes educativos, além de render lucros para as Caixas Escolares. Por outro, temia-se o efeito pernicioso que as fitas apresentadas nas salas de cinema da cidade pudessem provocar nas crianças. Em julho de 1932, o decreto n. 10.414 regulamentava como deveria ser utilizado o cinema educativo no Estado, definindo que:

Art. $1^{\circ}$. As escolas normais, grupos escolares e escolas reunidas que desejarem fazer uso do cinema em suas aulas, auditórios ou reuniões recreativas, uma vez que não disponham de outros meios, poderão realizar semanalmente, ou quando julgarem conveniente, sem prejuízo dos trabalhos regulares do estabelecimento, sessões recreativas cinematográficas, afim de adquirirem, com o produto das entradas, o aparelho projetor. [...]

$\S 2^{\circ}$. As caixas escolares, que dispuzerem do fundo necessário, poderão auxiliar a compra do aparelho de projeção, mediante autorização expressa de sua assembléa geral. $[\ldots]$

Art. $5^{\circ}$. Nenhum estabelecimento de ensino poderá adquirir aparelho projetor sem prévia consulta á Comissão Central.

Art. $6^{\circ}$. Os estabelecimentos de ensino só poderão adquirir ou exibir filmes que tenham sido submetidos á censura da Comissão Central.

[...]

\footnotetext{
${ }^{568}$ Pontos turísticos da capital mineira.
}

${ }^{569}$ Cf. Daniel Antipoff (1996, p. 121) 
Art. 10. Á Comissão Central compete:

$[\ldots]$

b) Publicar quinzenalmente no "Minas Gerais", um relatorio pormenorizado do movimento da filmoteca e uma lista dos filmes adquiridos e dos que se encontrarem disponíveis no arquivo.

A utilização do cinema como recurso educativo era uma das defesas dos escolanovistas, desde que as fitas escolhidas atendessem bem aos objetivos educacionais. Muitos filmes exibidos nas salas de projeção da cidade eram considerados extremamente nocivos à educação. No entanto, a utilização dessa moderna tecnologia, no período, em prol da educação escolar parecia ser muito bem-vinda.

Apesar disso, poucos foram os registros encontrados da existência desse recurso nos Grupos Escolares da capital, talvez porque em escolas nas quais os alunos não tinham roupas adequadas, alimentação, calçados, acesso a serviços de saúde, entre outros, o investimento em aparelhos caros de projeção fosse um luxo impensável.

O único Grupo no qual se encontraram registros de haver um aparelho cinematográfico em funcionamento dentro da própria escola foi o Olegário Maciel. Este cine-infantil funcionava com o auxílio de um ex-aluno, Newton Velloso, sendo organizado pelos próprios alunos. Uns eram "fiscais da ordem e disciplina no cinema", outros buscavam e levavam as fitas nas empresas de filmes - as fitas eram alugadas - e outros manuseavam o projetor, havendo até um concurso para identificar quem melhor lidava com o aparelho sem danificá-lo. As sessões eram feitas aos domingos e o rendimento repassado à Caixa Escolar. Entretanto, pela dificuldade de se encontrarem fitas mudas, foi necessário adquirir um aparelho novo, dessa forma, o lucro das sessões de cinema não iriam mais para a Caixa, mas para o pagamento da máquina Kodach adquirida pelo Grupo. No entanto, as fontes não deixam claro se o cinema era um recurso para as aulas ou se seu uso se limitava às apresentações aos domingos. Uma dúvida, por exemplo, era se os alunos pagavam para assistir aos filmes. É provável que sim, já que o Grupo cobrava, inclusive, aluguel dos livros da Biblioteca, para aqueles que quisessem levá-los para casa.

No Grupo Escolar Tomaz Brandão uma professora afirmava, em uma das reuniões, que o cinema era um recurso muito interessante para o ensino de Geografia, mas que era preciso combater o perigo do cinema não educativo. Em 1932, teria havido uma sessão de cinema no Grupo, no entanto, fôra a única encontrada, e também não foi 
possível saber se era destinada aos alunos. Talvez não, porque havia um agradecimento pela sessão que teria sido oferecida em benefício do Grupo, seja porque foi oferecida aos alunos, seja porque o filme foi apresentado à comunidade para arrecadar lucros para a Caixa Escolar.

Embora o cinema fosse uma atividade que envolvia a participação dos alunos, nada se comparava a outras nas quais eles eram muito mais do que espectadores. Em relação aos jornais escolares, por exemplo, eram os alunos os principais responsáveis pela sua produção, escrevendo artigos, charadas, enviando desenhos e gerenciando a produção do periódico.

\subsection{JORNAIS ESCOLARES}

Havia uma constante cobrança a respeito da criação e manutenção dos jornais escolares. A cobrança era feita nas reuniões pedagógicas, por parte dos inspetores e diretores, e os Grupos esforçavam-se sempre para cumprir tais demandas. Há muitas referências nas fontes consultadas acerca da existência de jornais impressos ou manuscritos ${ }^{570}$.

A questão dos jornais escolares era um tema recorrente tanto na Revista do Ensino como na imprensa local. Em novembro de 1933, a Revista do Ensino informava que a Inspetoria Geral de Instrução contava 380 jornais escolares de 143 municípios mineiros. Em muitos Grupos foi possível perceber que esses jornais realmente existiam, no entanto, eles não foram guardados pela maior parte das escolas e nenhum dos alunos entrevistados tinha algum exemplar.

Em 1939, Guerino Casasanta lançou um livro intitulado Jornais Escolares que trazia uma pesquisa realizada em 1934 em Minas Gerais e inúmeras sugestões para a organização do Jornal Escolar. Em novembro de 1933, o autor teria enviado a diversas professoras um inquérito sobre a produção de jornais nas escolas, suas vantagens e

\footnotetext{
570 Somente no Grupo Escolar Sandoval de Azevedo foram encontrados alguns números do jornal $O$ Sandoval de Azevedo. Na Hemeroteca de Belo Horizonte estão alguns jornais escolares e de lá foi utilizado o jornal O Escolar do Grupo Flávio dos Santos. Na coleção de Joaquim Nabuco Linhares, doada à biblioteca da UFMG, há muitas edições de jornais entre 1895 e 1954, entre eles vários jornais escolares. Podem ser encontrados jornais de estudantes de diversos níveis, desde o ensino primário ao superior, além de jornais de colégios particulares da capital e do Estado. Para esta pesquisa foram selecionados apenas os jornais do ensino primário dos grupos escolares da capital que tinham outros documentos localizados. (Cf. Linhares, 1995)
} 
formas de organização. Apesar de transcrever algumas respostas dadas pelas professoras, ele não esclarece quantas foram as participantes da pesquisa. $\mathrm{O}$ autor descreve vários tipos de jornais escolares: os lidos, falados, manuscritos, datilografados e impressos que poderiam ser produzidos pela própria escola ou publicados em jornais da cidade, numa seção específica. O autor trata das vantagens e desvantagens de cada um e orienta como se deve dar a organização de um bom jornal escolar. Era importante, por exemplo, que os alunos participassem ativamente da sua elaboração e construção, que este não fosse uma imposição da diretoria ou da professora e que surgisse do desejo dos alunos, motivados pelo professor. Recomendava-se que o nome do jornal fosse infantil, demonstrando ser realmente uma produção dos alunos. Também a diretoria e a redação do jornal deveriam ser ocupadas pelas crianças. $\mathrm{O}$ autor sugere diversas formas de eleição dessa diretoria e de como escolher os temas para publicação no periódico, bem como orientar os alunos para buscar notícias e escrevê-las. A obra traz muitas gravuras de jornais recolhidos, certamente para mostrar ao professor como fazê-los.

As orientações dadas pelo autor são muito curiosas e, às vezes contraditórias. Mesmo reafirmando a importância do jornal surgir por uma motivação dos alunos, ele elogiava nominalmente dois assistentes técnicos que fundaram, nas respectivas circunscrições, jornais dedicados às escolas de sua região. Além disso, o livro traz exemplos claros de assuntos que não deviam constar no jornal. Um desses assuntos era a indisciplina dos alunos. Apesar disso, o autor achava muito infantil e natural a seguinte frase: "Na hora do recreio, escreve um aluno, Sebastião estava montado a cavalo na torneira" (1934, p.138). Guerino Casasanta recomendava, ainda, um humorismo leve nos jornais. Para mostrar a leveza do humorismo, transcreveu a seguinte história de um Grupo Escolar noturno:

Quem será?

É de boa altura, cabelos pretos repartidos de lado, moreno, simpático, nariz afilado, um tanto convencido, andar elegante e, no Grupo é ótimo aluno e colega, distinguindo-se sempre pelo seu desenvolvimento intelectual. Entende de "musica", "pintura" e até de "arquitetura"!

Há pouco tempo fez um trabalho, verdadeiro "mimo de arte", que até hoje provoca os maiores elogios possíveis.

Mas ... a-pesar-de tudo isso, descontentou-se com a vida e resolver pôr fim á monotonia lírica dos seus aplausos.

Fui encontrá-lo certa vez, em plena mata virgem, com a fisionomia cadavérica e numa atitude que me fez instintivamente recuar: jazia inerte, pendente de uma arvore; com um grosso cipó atado pela cintura. 
Eu, então, vencido o primeiro susto e recobrando o animo me fugira, aproximei-me devagarinho e perguntei-lhe num tom quase de suplica: _ Que é que você faz aí dependurado pelas cadeiras, homem?

E ele, com a voz sumida, como si estivesse de muito longe, disse: - "Tô injuado de vivê e vim se matá".

- $\quad$ Mas, não é dependurado pelas cadeiras que a gente se enforca! Devia ter passado a laçada do cipó do pescoço.

- Já experimentei desse jeito, mas me deu tanta falta de ar!... J.A. (1939, p. 106-7)

O quadro abaixo, transcrito do livro, revela o alcance dos jornais escolares de Minas Gerais. Não constam do quadro jornais de Escolas Normais, Ginásios e estabelecimentos de assistência social.

QUADRO 19

Jornais escolares em Minas Gerais nos anos 1934 e 1935 (Continua)

\begin{tabular}{|c|c|c|}
\hline Especificação & 1934 & 1935 \\
\hline Total & 328 & 409 \\
\hline \multicolumn{3}{|l|}{ Segundo o sistema de impressão: } \\
\hline Em tipografia & 192 & 183 \\
\hline Em mimeografo & 15 & 16 \\
\hline Em datilografia & 12 & 7 \\
\hline Manuscrito & 109 & 203 \\
\hline Pertencente a todo estabelecimento & 176 & 208 \\
\hline Pertencente a uma só classe & 152 & 201 \\
\hline Mantendo intercambio & & 258 \\
\hline \multicolumn{3}{|l|}{ Segundo a tiragem media: } \\
\hline Até 200 & 236 & 59 \\
\hline 201 a 300 & 42 & 26 \\
\hline 301 a 400 & 17 & 4 \\
\hline 401 a 500 & 12 & 5 \\
\hline Mais de 500 & 6 & 6 \\
\hline Indeterminada & 15 & 309 \\
\hline De assinatura paga & 195 & 199 \\
\hline De assinatura gratuita & 133 & 210 \\
\hline \multicolumn{3}{|l|}{ Segundo a periodicidade } \\
\hline Semanal & 57 & 33 \\
\hline Quinzenal & & 32 \\
\hline Mensal & 241 & 289 \\
\hline Anual & 5 & 8 \\
\hline Indeterminada & 25 & 47 \\
\hline \multicolumn{3}{|l|}{ Segundo o numero de paginas } \\
\hline 4 paginas & 297 & 333 \\
\hline 6 paginas & 12 & 10 \\
\hline Mais de 6 paginas & 7 & 3 \\
\hline Indeterminado & 12 & 63 \\
\hline \multicolumn{3}{|l|}{ Segundo a manutenção } \\
\hline Recursos da Caixa Escolar & 45 & 53 \\
\hline Recursos internos & $\bar{T}$ & 254 \\
\hline Recursos externos & - & 54 \\
\hline
\end{tabular}

QUADRO 19 


\begin{tabular}{lcc}
\multicolumn{3}{c}{ Jornais escolares em Minas Gerais nos anos 1934 e 1935 (Conclusão) } \\
\hline \multicolumn{1}{c}{ Especificação } & 1934 & 1935 \\
\hline Recursos internos e externos & $\overline{283}$ & 48 \\
Outros recursos & & - \\
Segundo o tempo de existência & 158 & 157 \\
Menos de 1 ano & 88 & 106 \\
Mais de 1 a 2 anos & 31 & 98 \\
Mais de 2 a 3 anos & 51 & 48 \\
Mais de 3 anos &
\end{tabular}

Fonte: Casasanta (1939, p. 230-1)

O quadro revela que, apesar do grande número de jornais, muitos eram precariamente produzidos, sendo datilografados e manuscritos. Justamente por isso, a tiragem não podia ser muito alta. A periodicidade da maioria dos jornais era mensal, com poucas páginas e mantidos com recursos internos e outros (possivelmente festivais e doações) com pouco tempo de existência, menos de um ano. Uma mensagem do Interventor Benedito Valadares Ribeiro em 1937 afirmava existirem 409 jornais escolares no Estado com tiragem superior a 600.000 exemplares $^{571}$.

Em 1949, o jornal Estado de Minas anunciava um concurso de jornais escolares realizado pela Secretaria de Educação. Neste concurso concorreram 108 jornais, havendo 28 vencedores, mas apenas os cinco primeiros colocados receberam premiações. Foram critérios do concurso: tempo de circulação, regularidade na publicação, indicações essenciais, cabeçalho, ilustração, apresentação, variedade, interesse e linguagem. O Grupo Escolar Tomaz Brandão ganhou um desses prêmios, mas não foi possível localizar qual era o seu jornal e por que obteve a premiação.

Para esta pesquisa foram localizados e consultados os seguintes jornais escolares:

\subsubsection{O SANDOVAL DE AZEVEDO}

No próprio Grupo Escolar Sandoval de Azevedo foram encontrados exemplares do referido jornal entre os anos de 1952 e 1956, desde a primeira edição até a trigésima sétima. Impresso pelo jornal Tribuna de Minas, tinha um diretor, um redator-chefe e um gerente, todos alunos. O jornal possuía quatro páginas e trazia notícias de visitas,

${ }^{571}$ Cf. Minas Gerais, 1937 
professoras novas, estagiárias, aposentadorias de funcionários, excursões, auditórios, festas religiosas, trabalhos de ciências, notícias do Clube de Leitura, Clube Agrícola, composições de alunos, cartas enviadas e recebidas, aulas, entregas de uniformes, filmes e teatros assistidos, biografias, comemoração de datas como Tiradentes, dia do soldado, etc. Trazia, também, fotos de atividades na escola e de alguns alunos. O jornal era vendido a $\mathrm{Cr} \$ 1,00$ e apresentava propagandas de algumas empresas como casas de materiais escolares, lojas Pernambucanas, entre outras, podendo-se supor que a renda obtida auxiliasse no custo de impressão.

O jornal escolar O Sandoval de Azevedo era um meio de comunicação da escola com a comunidade externa. Além disso, tinha a vantagem de não ser diretamente produzido pelas professoras. Era a fala das professoras traduzidas na linguagem infantil. Não há dúvidas de que as matérias publicadas no jornal estavam em inteira consonância com o pensamento da direção da escola. As composições e as notícias revelavam o que a escola tinha de mais importante para apresentar à sociedade. O espaço era utilizado para veicular informações consideradas necessárias tanto às crianças como a seus familiares. As composições dos alunos tinham sempre um conteúdo moralizador enfatizando a importância da obediência, do estudo, da dedicação, do trabalho, do bom comportamento, tudo vindo em palavras, recursos e expressões infantis. O adulto por detrás das histórias moralizantes não estava visível, mas sem dúvida, era quem autorizava, selecionava, aprimorava toda a produção do jornal, seja no conteúdo ou diagramação. O público alvo não se restringia aos alunos. Algumas reportagens, como uma que trata do sono na infância e também alguns apelos para o pagamento de Tributos ao Estado, importantes para a manutenção das escolas e das estradas, eram claramente direcionadas aos adultos, pessoas externas à escola.

Nos casos do Grupo Sandoval de Azevedo e Bernardo Monteiro o jornal era de todo o Grupo Escolar. Em outras escolas, principalmente quando os jornais eram manuscritos, havia um para cada classe. 


\subsubsection{VOZ INFANTIL}

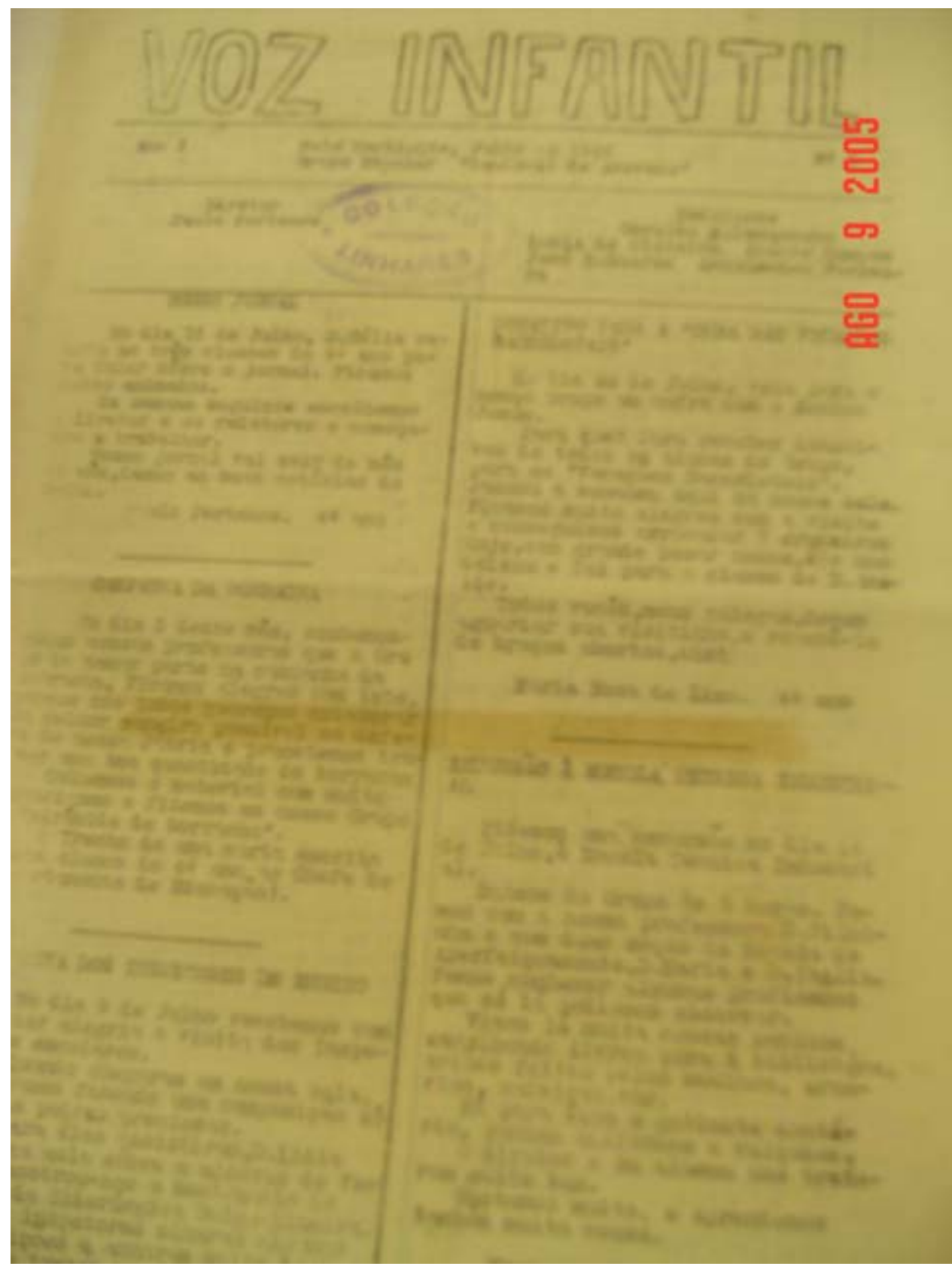

Figura 20: Imagem do Jornal Voz Infantil

Fonte: Jornal da Coleção Linhares - UFMG [A data na imagem é da digitalização feita pela pesquisadora]

Também do Grupo Escolar Sandoval de Azevedo, foram encontrados os números $1,2,3$ e $5^{572}$. Os números 1 e 2 foram publicados nos meses de julho de 1943, o número 3 era referente aos meses de setembro e outubro de 1943 e a edição de número 5 correspondia aos meses de maio e junho do ano seguinte.

${ }^{572} \mathrm{Na}$ Coleção Linhares na Biblioteca da UFMG. 
É um jornal mimeografado elaborado pelas classes do $4^{\circ}$ ano e vendido aos alunos. Trazia composições, poesias, excursões, nomes de alunos aniversariantes, entre outras notícias. Diferentemente de todos os outros jornaizinhos, um número trazia um desenho para as crianças colorirem.

Segundo Linhares (1995, p. 17), este jornal passou a ser impresso a partir do número 17 de 18 de dezembro de 1947. Entretanto, tais números não foram encontrados.

\subsubsection{A INFÂNCIA MODERNA}

O jornalzinho do Grupo Escolar Lúcio dos Santos era impresso, exceto a última edição que foi mimeografada. Para a presente pesquisa, foram encontradas as edições 1 , 3 e $9^{573}$. Todas possuem formato e cabeçalhos distintos tendo também diretores, redatores e gerentes específicos. Na primeira edição, que não traz o valor do jornal, encontram-se alguns anúncios comerciais. Nas seguintes, não existem anúncios e, na primeira página, consta que o jornalzinho custava duzentos réis. Na edição de número 2 encontra-se a tiragem do jornal: 150 exemplares. É um número muito pequeno se considerarmos toda a população escolar. Provavelmente, a vendagem do jornal diminuía muito o número de leitores que pudessem pagar pela publicação.

As edições têm quatro páginas e versam sobre acontecimentos vividos pelos alunos como excursões, Primeira Comunhão, datas comemorativas, aniversários. Traz composições, charadas e poemas dos alunos e também um desenho realizado por uma criança do primeiro ano.

\footnotetext{
573 As edições 1, 3 e 9 correspondem às seguintes datas, respectivamente: 15/08/1930, 03/08/1939 e 31/10/1940
} 


\subsubsection{O ESCOLAR}

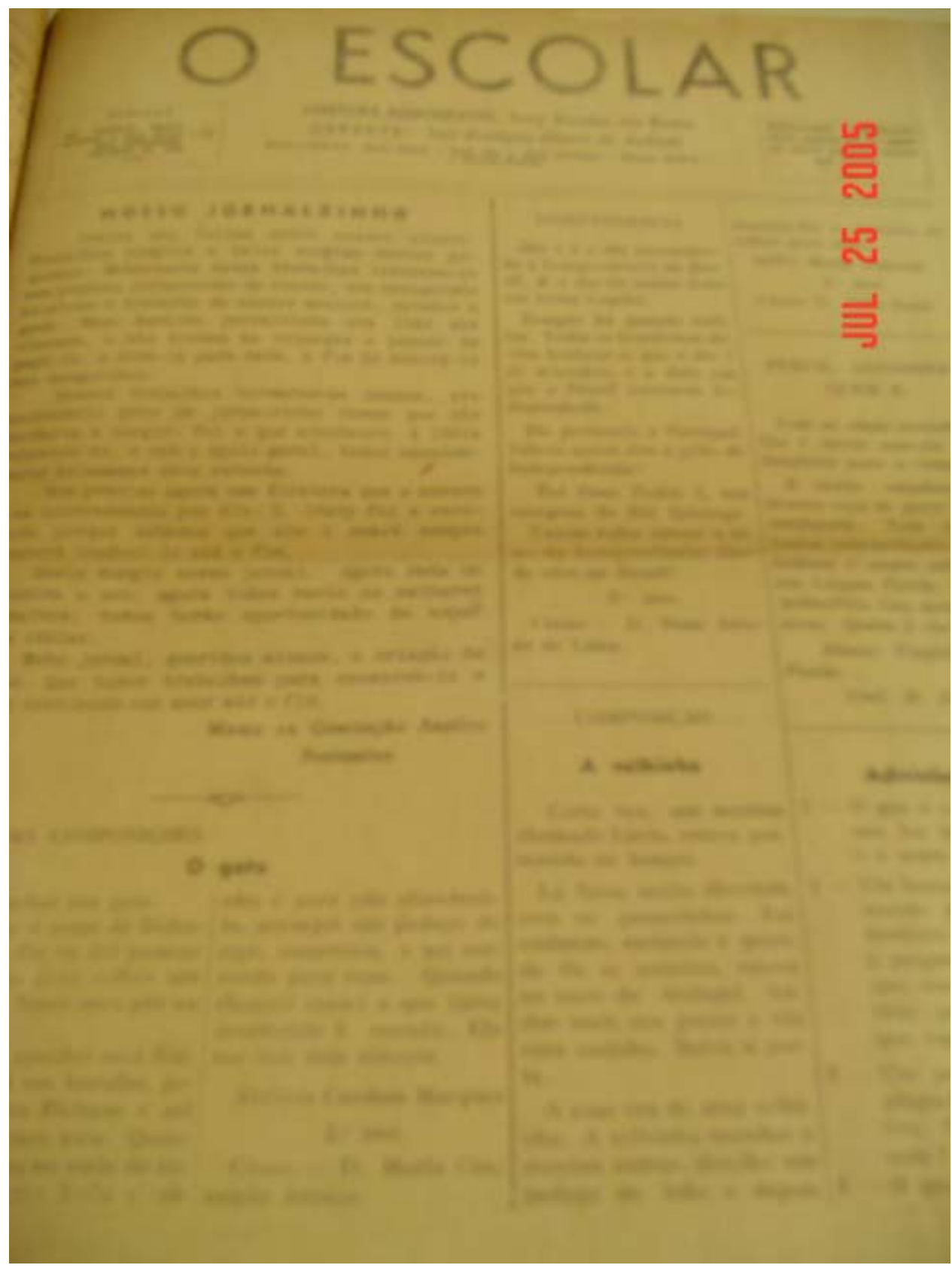

Figura 21: Jornal O Escolar

Fonte: Jornal da Coleção Linhares -UFMG

Trata-se de um jornalzinho dos alunos do terceiro turno do Grupo Escolar Flávio dos Santos, do qual foi encontrada apenas uma única edição, de outubro de 1955. Segundo artigo da professora Maria da Conceição Araújo, este já era produzido anteriormente, mas de maneira artesanal e os alunos não podiam levá-lo para casa. $\mathrm{O}$ jornal consultado era impresso pela Imprensa Oficial, possuía duas folhas frente e verso 
e trazia composições de alunos, charadas, aniversários, versos, artigos sobre hábitos de higiene, vestuário, alimentação e textos sobre a Semana da Criança.

\subsubsection{VOZ DA CRIANÇA}

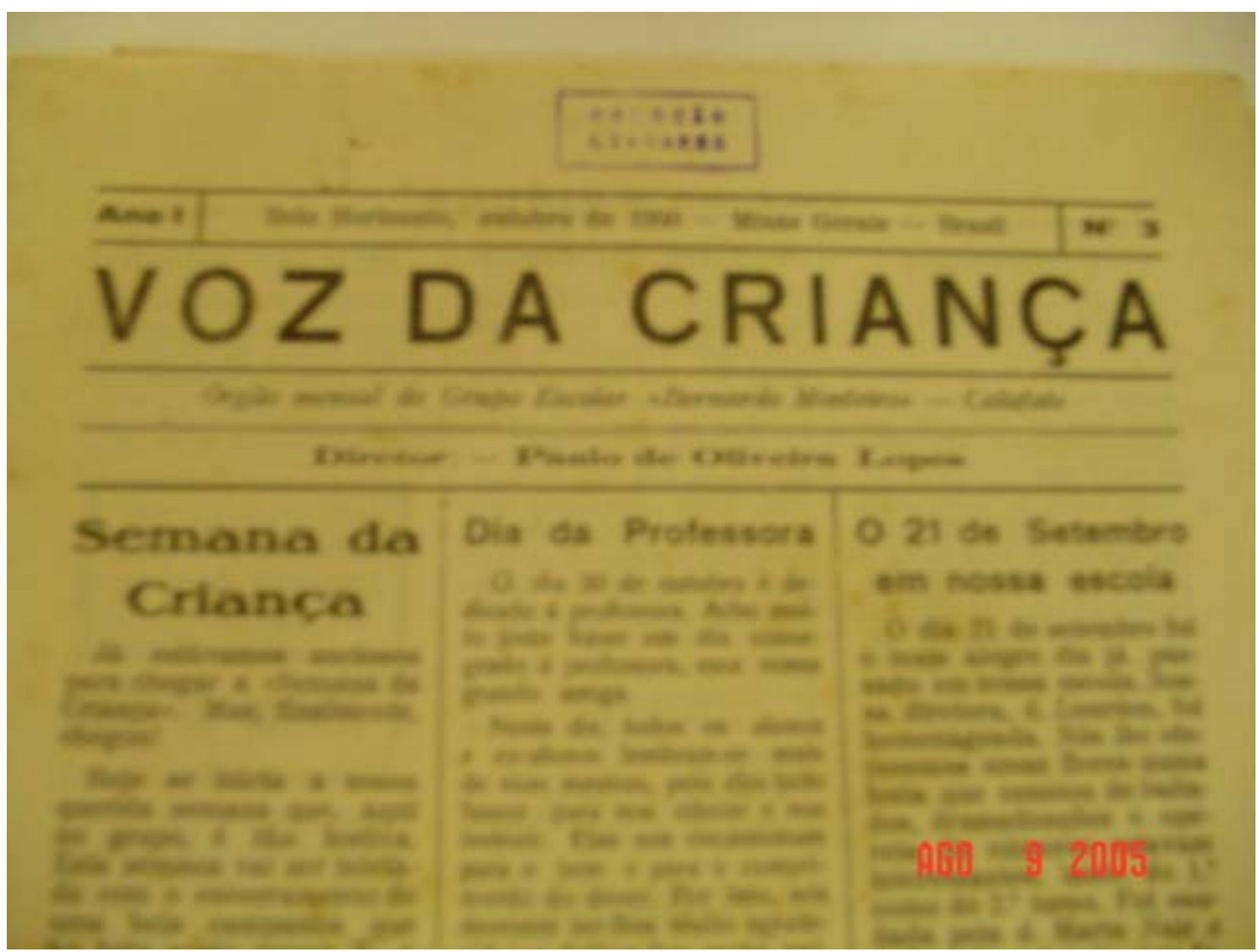

Figura 22: Jornal Voz da Criança

Fonte: Jornal da Coleção Linhares - UFMG

Este jornalzinho pertencia aos estudantes do Grupo Escolar Bernardo Monteiro. Foram encontrados os números 3 (de 1950), 6, 7, 8, 9 e 10 de 1951. O jornal era impresso na tipografia Marly, da cidade de Campo Belo, interior de Minas Gerais e apresentava quatro páginas.

Os artigos eram assinados pelos alunos e alunas ou por uma classe inteira. A primeira edição consultada foi a única que trazia algumas propagandas e em nenhuma das edições aparece o preço do jornal e não se diz se ele era vendido ou doado aos alunos. Como diversas edições traziam os seguintes comentários: "É dever de todo aluno dêste Grupo auxiliar a manutenção deste jornal” e "Cooperem com a manutenção 
dêste jornalzinho", pode-se supor que este auxílio fosse em dinheiro para as despesas de impressão.

Uma característica do referido jornal são as suas notícias religiosas e a introdução do tema em diversos artigos. Há artigos sobre missões, Páscoa, Primeira Comunhão, missa, visita do padre à escola, aula de religião, Natal e festas religiosas. Além disso, são comuns os nomes dos aniversariantes do mês, a apresentação de charadas, pensamentos e poesias dos alunos e alunas.

Embora os textos apresentados sejam, em sua maioria, assinados pelos alunos, é difícil delimitar até que ponto as produções eram espontâneas e até que ponto havia a participação dos adultos na seleção das informações, na elaboração da escrita, na sugestão de temas, entre outras possíveis intervenções. No texto abaixo, por exemplo, publicado no jornal Voz da criança é pouco provável que a criança tenha sido a única autora da missiva, como se pode depreender da sofisticação da linguagem utilizada:

Carta Aberta

Campo Belo, 16-4-51

Prezada e gentil amiguinha Leila Parreira Tavares, $3^{\circ}$ ano de dona Hilda Cruz,

Mui sensibilizada, venho, em nome do papai e do meu próprio coração, trazerlhe o manifesto sincero de nossa imorredoura gratidão pelas referências elogiáveis feitas a minha obscura pessoa, na última edição do "Voz da Criança".

Somente de uma nobre alma, como é a sua, pode-se esperar tanta bondade e tamanha gentileza. Sómente de corações afeitos à prática do bem, como são os de todos os seus coleguinhas e que se irradia generosidade, é que se pode receber gestos e atos altruísticos, do feitio dêste que você me presenteou ainda há pouco.

Somos-lhe grados no limite máximo da palavra, assim como também admiradora entusiástica eu continuarei sendo de suas qualidades estudantis.

Aqui permanecemos, ansiosos para ser-lhes úteis, certos de que os nossos entrelaços amistosos e escolares muito hão de perdurar.

Marly Leite Andrade, aluna do $3^{\circ}$ ano do Grupo Escolar "Cônego Ulisses"

Este foi o único jornal que trazia, em um dos artigos, a sua forma de $\operatorname{organização~}^{575}$ :

Como está organizado o nosso jornalzinho

O nome do Diretor do jornal de nosso Grupo é Edson Éden do Santos. Ele é do $4^{\circ}$ ano de d. Carmem Parreiras. Em todas as salas foi escolhido um menino para ser copiador e

\footnotetext{
${ }^{574}$ ANDRADE, Marly Leite. Carta aberta. Voz da criança. Ano 2, n. 6, p. 2, abril.1951. Não foi possível saber qual a homenagem feita à colega porque os números anteriores não foram localizados.

575 Quanto aos outros jornaizinhos pesquisados, não foi possível identificar quais os critérios para a publicação dos artigos, a seleção dos diretores, gerentes e redatores, a determinação do formato do jornal, a escolha da organização dos assuntos, bem como outras informações sobre sua produção e circulação.
} 
outro para ser revisor. Primeiro as professoras deram uma escrita para nós copiarmos. Depois fizeram um concurso para saber quem tinha a letra melhor. $\mathrm{O}$ que tirou o primeiro lugar foi escolhido copiador. Depois foram escolhidos os revisores. Só os que fazem composições melhores. Depois a Dona Elizeta nos chamou para irmos à sala onde ela fica. Aí foram todos os revisores. Escolhemos os melhores trabalhos do Grupo que deviam ir para o jornalzinho. Depois que nós escolhemos, os copiadores passaram a limpo para serem enviados a Campo Belo para ser impresso o jornal. ${ }^{576}$

A produção de um jornal semanal das escolas demandava bastante trabalho. A escolha dos temas, a seleção das composições, a formatação do jornal e, especialmente, arcar com os custos de sua impressão eram dificuldades com as quais as diretoras, professoras e alunos tinham que lidar constantemente. Se este era um trabalho que devia envolver os alunos, pode-se supor, no entanto, que uma minoria deles conseguia ter suas composições publicadas ou mesmo participar de sua elaboração e organização. Apesar disso, é notável o esforço das escolas para a produção de um jornal, especialmente um jornal impresso.

Uma prática comum na apresentação dos artigos dos jornaizinhos escolares era colocar, junto com o autor do texto, o nome da professora e da classe do aluno. Pode-se imaginar que tal prática auxiliava a identificação do autor, num Grupo com centenas de estudantes. Por outro lado, pode-se perceber que esta prática dava visibilidade à professora da classe e também podia ter por objetivo incentivar as docentes a enviarem a produção dos alunos para a publicação. Esta medida, sem dúvida, contribuía para dar a ver à comunidade uma escola em franco progresso, que oferecia um trabalho prático aos alunos, além de permitir à sociedade se inteirar do que se passava dentro dos muros escolares. Obviamente, não exatamente do que acontecia neste espaço, mas do que a comunidade deveria saber que acontecia.

\subsection{O ALCANCE DAS ATIVIDADES \& INSTITUIÇÕES ESCOLARES}

Esperava-se que as atividades e instituições escolares contribuíssem para o trabalho disciplinador do ensino primário. Em 1934, a Revista do Ensino divulgava que existiam nos Grupos Escolares de Minas Gerais as seguintes instituições:

\footnotetext{
${ }^{576}$ COMO está organizado o nosso jornalzinho. Voz da criança, ano 2, n.8, p.4, junho. 1951.
} 
Clubs de leitura .456

Auditoriuns

Pelotões de Saúde

Organizações de escotismo escolar .........................................

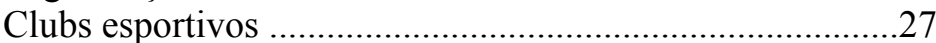

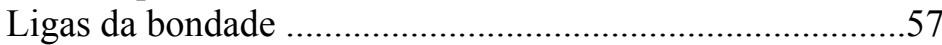

Associações de Pais e Professores .........................................80

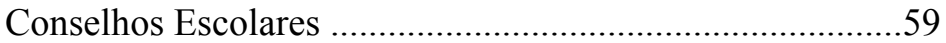

Fundos Escolares .........................................................59

Outros dados estatísticos de 1952 afirmavam a existência de 208 Clubes de Leitura, 16.189 sessões de auditórios, 140 Pelotões de Saúde, 198 Clubes Agrícolas, 208 jornais escolares em funcionamento nas escolas mineiras. As instituições escolares mais comuns nesse período segundo a Revista do Ensino eram: Clubes de Leitura, Pelotão de Saúde, auditório, jornal, excursão, Caixa Escolar, biblioteca infantil e pedagógica e Clube Agrícola. Pela consulta às fontes, pode se observar que realmente estas eram atividades importantes dentro das escolas. Com maior ou menor incidência em determinados Grupos Escolares, mas sempre presentes. Embora as professoras tivessem sido dispensadas das reuniões de quinta-feira para participar de um curso na Escola Normal sobre a organização de Museus Escolares, muito pouco se encontrou a respeito dessa atividade. Com relação ao escoteirismo, também não se encontraram indícios de sua existência nos Grupos Escolares pesquisados, embora alguns artigos na Revista do Ensino comentassem sobre o escotismo nas escolas.

As atividades e instituições constituíam-se num dos cernes da Escola Nova, ocupando e disciplinando os alunos. Apesar disso, em fevereiro de 1947, no governo de Alcides Lins, cujo Secretário da Educação era Ildefonso Mascarenhas da Silva, o decreto n. 2.399 impôs mudanças no ensino estabelecendo uma redução nas atividades educacionais extra-classe. Talvez pelo excesso de comemorações ocorridas no Estado Novo, o decreto seja tão duro, levantando uma suspeita de que os educadores não estavam cumprindo adequadamente as suas funções. Com relação às atividades escolares, o decreto asseverava:

Art. $1^{0}$ - Fica suspensa, durante os períodos letivos, a realização de excursões, congressos, semanas estudantis e outras manifestações, a fim de não serem perturbados os trabalhos escolares.

${ }^{577}$ O ENSINO no Brasil em 1933. Revista do Ensino, BH, n.137-139. p.122-134, abr.jun.1937, p.131. 
$\S 1^{\circ}$ - As excursões de estudantes têm sempre o objetivo de estudo, sendo obrigatória a apresentação de relatório, em duas vias, após a sua conclusão, uma das quais será enviada, com a apreciação do professor que a presidir, ao Departamento próprio da Secretaria de Educação.

$\S 2^{\circ}$ - As excursões dentro do Estado devem ser aprovadas, previamente, pelo diretor do estabelecimento escolar interessado ou por quem o substituir e, fora do Estado, pelo Secretário de Educação.

$\S 3^{\circ}-$ O Secretário de Educação pode autorizar ou proibir excursões ou quaisquer outras manifestações estudantis, notadamente as de finalidade escolar. ${ }^{578}$

O decreto continuava afirmando que os pontos facultativos estabelecidos durante o ano não seriam extensivos aos estabelecimentos de ensino de qualquer nível, que os dias de festas escolares não poderiam exceder de quatro mensais e que não haveria tolerância de horário para professores e funcionários do ensino. Os artigos determinavam, ainda, que os professores eram obrigados a comparecer às reuniões e a dar, no mínimo, nove horas semanais de aula e trabalhos escolares. Além disso, caso houvesse professor excedente, ele ficaria na escola à disposição dos alunos, podendo receber outras atribuições compatíveis com o exercício do cargo ou função pelo diretor ou pela Secretaria da Educação, sem receber remuneração extraordinária. Essas são apenas algumas regulamentações sobre o trabalho escolar que dão a ver a representação nada satisfatória do governo estadual ${ }^{579}$ sobre os profissionais da educação.

Pode-se perceber, portanto, divergências acerca da importância das atividades extra-classes. Para a Escola Nova, estas seriam oportunidades preciosas de os alunos se tornarem ativos no processo de aprendizado. Ressaltava-se o valor de cada uma dessas atividades para o desenvolvimento cognitivo, moral, social e físico dos escolares. Por outro lado, as recomendações de que tivessem sempre objetivos claros e definidos, deixavam a ver o temor de que tais atividades fossem utilizadas pelos educadores para relaxarem as exigências sobre os alunos e sobre si mesmos. Se as atividades e instituições tinham um caráter disciplinador, o decreto n. 2.399 parecia sê-lo ainda mais. Reduzir tais atividades constituía-se num recurso para aumentar o controle sobre o trabalho escolar, circunscrevendo-o ao espaço reduzido da sala de aula e dos prédios escolares, potencializando a vigilância sobre educandos e educadores.

\footnotetext{
${ }^{578}$ MINAS GERAIS. Decreto n. 2.399 de 07 fev. 1947. Determina providências em proveito do ensino. ${ }^{579} \mathrm{O}$ decreto foi assinado pelo Interventor Alcides Lins e por Ildefonso Mascarenhas Silva. Ambos estiveram no cargo por apenas três meses (21.12.1946 a 19.03.1947).
} 
De maneira mais ou menos direta, portanto, tais atividades e instituições visavam disciplinar e ocupar os alunos, preparando-os, desde os bancos escolares, para o exercício futuro como profissionais e cidadãos. A disciplinarização ia desde os cuidados higiênicos, com a saúde e com o corpo, os preparativos para o exercício do trabalho, como os trabalhos manuais, os clubes agrícolas e as hortas escolares, bem como as festas, as músicas, os auditórios, as excursões, o cinema que delineavam as formas sadias de lazer para as crianças e os adultos que estavam em formação. Os jornais escolares também realizavam um duplo objetivo: o de formar para o trabalho e o de colocar na fala dos alunos todo o discurso dos educadores. Nesse sentido, as atividades escolares permitiam não somente ocupar o tempo livre dos alunos e preparálos para a vida adulta, mas, ainda, disciplinar seus corpos e suas mentes de forma que fossem habituados, ativamente, ao sistema disciplinar que lhes era imposto. 


\section{CONSIDERAÇÕES FINAIS}

Mapear dispositivos disciplinares em voga em Grupos Escolares de Belo Horizonte não é uma tarefa simples, seja pelas características do próprio objeto, fugidio e fragmentado, pelas características do período escolhido, tão extenso e intenso, seja pelas características das fontes, dispersas e distintas. O desafio é, entretanto, fundamental para a realização de qualquer trabalho. E este pode se tornar bastante aconchegante e agradável, quando a tarefa envolve conhecer sujeitos, personagens de uma história de sucessos e fracassos, idas e vindas, que marcaram época na educação mineira.

As fotografias, as revistas, os jornais, os livros e cadernos antigos, empoeirados, amarelados e esquecidos no fundo dos armários e das gavetas foram fontes cruciais para a realização desta pesquisa. Aqui estão as legislações, as recomendações, os avisos, as sugestões, as exigências, as ameaças, as punições, mas estão também os sujeitos, seus temores, suas táticas, seus desejos, suas crenças, seus valores. Foram essas, sem dúvida, as fontes mais ricas e fundamentais: as conversas, a cumplicidade, a colaboração, o entendimento. A produção das fontes orais envolveu diversos momentos: a expectativa da pesquisadora e do entrevistado; a ansiedade diante do gravador, da filmadora, do questionário; o desejo de auxiliar a pesquisa, de contar os fatos considerados importantes e o desejo (que certamente houve) de ocultar fatos tidos como frugais ou inconvenientes; a alegria diante da rememoração e das lembranças vívidas, a frustração diante dos silêncios e esquecimentos (que às vezes dizem mais que as próprias palavras).

São, portanto, diversos os sujeitos que compõem esta tese. Suas vidas, lembranças, memórias, biografias, os registros deixados nas escolas, nos livros, nas atas, nos Termos de Visitas e nos mais diversos documentos pesquisados foram fios para a tessitura desta trama. Esta é, sem dúvida, uma versão da história. E muitas outras precisam ser descobertas e/ou produzidas. Esta versão procurou traçar o percurso de transformação da chamada "Escola Antiga" à produção da Escola Nova mineira especialmente no que seria o cerne dessa mudança: a disciplina escolar.

É preciso dizer que os dispositivos disciplinares se dispõem em rede e a organização do texto também. Por este motivo, muitos assuntos circulam por entre os 
capítulos e se prendem a temas já discutidos ou ainda por discutir. Esta configuração do próprio texto revela a teia que forma a disciplina escolar e foi, sem dúvida, influenciada pela dispersão das fontes, mas também e, sobretudo, pela sua aproximação e afinidade entre todos os temas tratados.

Como forma de desvendar a trama de todos esses temas e fontes, foram organizados dois eixos básicos para a produção do texto. Obviamente, não são dois eixos distintos e fragmentados. Eles se entrecruzam todo o tempo, as discussões se interceptam e a separação é muito mais didática do que efetiva. $\mathrm{O}$ primeiro deles relaciona-se diretamente com os personagens centrais dessa história: educadores e educandos. Entre os educadores estão diretores, inspetores, assistentes e orientadores técnicos e professores das escolas primárias, sendo este grupo composto, em sua maioria, por mulheres. Mulheres que se tornaram professoras cuja profissão foi escolhida ou imposta, quando ainda estavam na escola primária. Este percurso de alunas a professoras foi marcado por mudanças na legislação escolar, nas condições de vida das mulheres, na escolha por formar ou não uma família, pelas disputas e exigências entre ser esposa, mãe e professora. Nas memórias, biografias e entrevistas podem ser captadas as tensões, as angústias, mas também as recompensas e alegrias que envolviam o cumprimento desses papéis. Mulheres que eram cada vez mais disciplinadas para tornarem-se também disciplinadoras.

A liberdade, a autonomia, a expansão dos espaços nos quais a mulher circulava e intervinha nesse momento coexistiam com as estratégias disciplinadoras e conformadoras acerca da sua missão. À representação da mulher moderna e atualizada, agregavam-se a necessidade de uma aparência sempre jovem e bela, a maternidade estendida aos alunos do Grupo Escolar, a baixa remuneração condizente com a moral católica de que a caridade, a vocação e a missão é que sustentavam os trabalhos realmente dignos, especialmente os femininos. Dispositivos disciplinares que ofereceram à mulher novos espaços públicos, mas reiterando sua missão familiar e religiosa de mãe e catequizadora.

Os Grupos Escolares compõem um cenário riquíssimo para a investigação da atuação dos educadores. Disciplinados e disciplinadores de si mesmos e dos colegas, os inspetores, diretores, orientadores, assistentes e professores encarregados de efetivar as Reformas Escolares, ensinar e disciplinar os alunos. A burocracia estatal chegava até a 
escola com a implantação do serviço de orientação técnica, cujas professoras, formadas na Escola de Aperfeiçoamento, ficavam incumbidas de garantir a modernização do ensino. Além disso, essa burocracia tornava os educadores fiscais do trabalho pedagógico a ser realizado nas escolas. Tal situação provoca tensões visíveis nas reuniões pedagógicas e nos Termos de Visitas, embora sejam estas ainda fontes muito suspeitas de investigação, na medida em que podem ter ocultado as principais disputas e informações do universo escolar. Ainda assim, constituíram-se importantes documentos para se mensurarem os conflitos, disputas e, principalmente, as estratégias e táticas dos educadores para lidarem com a nova disciplina que se implantava nas escolas.

Os educandos são a razão de ser de todo projeto pedagógico. Em última medida, é para eles e por eles que se fazem as Reformas Educacionais, se pensam os currículos, os métodos, os horários, os espaços e os objetivos escolares. Foram elas, as crianças de outrora, suas lembranças, de meninos e meninas que estiveram nas carteiras, nos pátios, nas excursões, na ginástica, nos recreios dos Grupos Escolares que permitiram vislumbrar de que forma a modernidade pedagógica chegava aos alunos e alunas. As representações acerca do que era ser criança, do que se esperava dos estudantes dos Grupos Escolares de Belo Horizonte, do que era ser disciplinado, do que era ser normal e ou anormal foram fundamentais para se compreenderem as vivências infantis e escolares destes sujeitos, cuja infância foi produzida e reinventada também pela escola primária. Recuperar as vozes dos educandos é um trabalho sempre árduo, entretanto, fundamental para se identificar de que forma estes se apropriaram das Reformas Escolares e, no caso da pesquisa, rastrear as lembranças das punições e dos dispositivos disciplinares a que estiveram submetidos. Apesar disso, fica claro, que, por mais que se buscasse recuperar suas memórias, os educandos ainda ocuparam um espaço muito restrito na pesquisa, já que as fontes consultadas forneciam preferencialmente a visão dos educadores.

Quanto aos educadores, as fontes consultadas revelam que pouca margem de liberdade e discussão se dava a estes no que tange aos novos métodos educacionais. Os cursos que eram realizados, a própria Escola de Aperfeiçoamento, os periódicos destinados a esta classe como a Revista do Ensino e a Educando e os Boletins publicados pela Secretaria de Educação revelam que o discurso da Escola Nova, embora fosse bastante contraditório, tentava ser o único possível para educadores modernos e 
baseados nos preceitos científicos. No cotidiano escolar, a vigilância constante da diretora que revia, pelo menos mensalmente, os cadernos de preparos das lições; a presença dos inspetores escolares dentro das salas de aulas; o esforço de convencimento das professoras técnicas, tudo isso fazia parte de um projeto de formação dos professores em exercício que buscava a conformação às regras estabelecidas. A clara tentativa de silenciar os conflitos e os confrontos revela que eles existiam e que, a despeito de toda a vigilância, os educadores usavam diversas táticas para conformar as novas regras às suas próprias crenças e expectativas.

Os educandos, por sua vez, convivem com o saudosismo e a idealização da escola, com bons professores, bons colegas, bons ensinamentos e as lembranças de que nem tudo foram flores e que muitas tensões, injustiças e tristezas foram vividas também na escola.

O segundo eixo do trabalho envolve a cultura escolar e os dispositivos disciplinares nela instaurados. Uma das saídas utilizadas pela escola era convocar familiares dos alunos e a própria sociedade para auxiliarem a tarefa educacional. A infância, ora exaltada como pura, ingênua e feliz, ora ressaltada como período de vícios, berço dos criminosos e "anormais", exigia constante atenção e intervenção dos educadores que convocavam a sociedade nessa empreitada de moralizar crianças e suas famílias. Estas nem sempre eram bem vistas pela escola, mas ainda assim eram exortadas a participar do projeto pedagógico e disciplinador das escolas primárias. Nesse sentido, oferecer aos alunos alimentação, vestuário, vacinas, remédios, tratamento médico e odontológico era uma forma de minimizar a miséria que muitos expunham nos pátios da escola, mas também uma forma de evitar que as desigualdades sociais ficassem por demais evidentes e gerassem revoltas entre os menos favorecidos pela fortuna.

O espaço dos Grupos Escolares de Belo Horizonte foi o palco no qual educadores e educandos encenaram a história da educação aqui estudada. Uma das marcas mais importantes e significativas da escola formal instituída desde o ensino seriado é a avaliação escolar. Avaliação que segrega e exclui, que provoca tantos conflitos e traumas, que envolve, sem dúvida, os momentos mais tensos do cotidiano escolar. Pois bem, a Escola Nova não somente intensifica o uso das avaliações como pretende alcançar ao máximo a sua objetivação. Estas são utilizadas desde a matrícula 
do aluno na escola, na medida em que os testes devem classificá-lo de acordo com a classe em que irá freqüentar, até o exame final do quarto ano, feito, algumas vezes, com pompa e circunstância, contando com a presença de professores de outras escolas e com a distribuição de títulos e prêmios após a solene divulgação das notas.

A Escola Nova em Minas Gerais era fundamentalmente seletiva. Incluía para excluir. A conquista do diploma de curso primário significava árdua batalha para muitos alunos e alunas. Cursar a Escola Normal e a temida Escola de Aperfeiçoamento não parecia ser muito diferente. Os exames médicos, físicos, psicológicos, pedagógicos se somavam e complementavam. Mas não apenas os educandos eram vítimas dessa avalanche avaliativa, também os educadores estavam a elas sujeitos, através das fichas profissionais, dos cadernos de preparo das lições, das constantes visitas dos inspetores, da assistência dos orientadores e diretores que fiscalizavam as salas de aula. Eram os sinais de uma escola que punia cada vez menos ou, cada vez mais disfarçadamente, mas cujos dispositivos disciplinares cresciam de forma avassaladora.

A Psicologia era uma parceira fundamental na tarefa disciplinadora. $\mathrm{O}$ trabalho de Helena Antipoff e do Laboratório de Psicologia ganhou reconhecimento nacional e internacional. Os testes aplicados e criados em Belo Horizonte deram aos mecanismos de homogeneização reconhecimento científico, produzindo um fracasso escolar que nunca se justificava pelas técnicas utilizadas, mas sempre pela incapacidade e anormalidade dos alunos.

Algumas contradições ficaram bastante claras durante a realização da pesquisa. A primeira refere-se ao papel da mulher-professora que devia promover a liberdade e a autonomia dos alunos, sendo constantemente constrangida no seu espaço de trabalho. A conquista de um espaço público e da profisssionalização se deu sem se romper as relações de autoritarismo e de vigilância sobre as mulheres. Não somente suas práticas pedagógicas eram alvo de discussão e regulamentações, mas ainda o seu vestuário, postura, comportamento e até mesmo a sua sexualidade e religiosidade.

A transição da punição à disciplina era fundamental na escola moderna e inúmeros os dispositivos disciplinares utilizados nessa empreitada. As fontes demonstram, no entanto, o quanto essa transição se dava de maneira paradoxal e confusa, supondo mesmo que a liberdade estava em obedecer. Os educadores, como se pode constatar, não abandonaram tão fácil e rapidamente as punições escolares. Os 
alunos, embora não conhecessem palmatória, levavam varadas, ficavam de pé à frente da sala, eram presos durante o recreio e ao final das aulas, e até mesmo poderiam ser expulsos da escola. As professoras assumem que, a despeito de todas as proibições, davam reguadas, puxões de orelha e colocavam os alunos de castigos, às vezes, em situações humilhantes. Apesar disso, outras formas de punição menos visíveis também estavam em uso nos Grupos Escolares, como a segregação dos alunos indisciplinados; o oferecimento de atividades menos relevantes pedagogicamente como os exercícios de ortopedia mental, de professores novatos e freqüentemente insatisfeitos com a classe que lhes foi designada; os espaços menos agradáveis do edifício escolar e, principalmente, a reprovação. Esta parecia ser o destino mais comum dos alunos das classes especiais e este era, sem dúvida, o destino dos indisciplinados. Com o aval da Psicologia e o estatuto de neutralidade científica, ficavam estes alunos anos a fio depositados nos porões das escolas e atingindo a adolescência ainda nos bancos dos Grupos Escolares. Tais práticas demonstram o quanto o entendimento de punição e disciplina era vago, elástico e impreciso. Além disso, a cientificidade, supostamente inaugurada pela Escola Nova, em novos formatos e contextos, mantinha os preconceitos que sustentavam não somente a escola, mas a sociedade do período. A palmatória, as reguadas, os puxões de orelha eram os demonstrativos mais espetaculares da antiga tradição dos castigos físicos; entretanto, não se pode dizer que a substituição destes pela exclusão, pela denominação de retardados, incapazes e menos inteligentes tenha significado grande progresso para os alunos.

Diante da necessidade de trabalhar, muitos alunos faziam o curso primário nos Grupos noturnos. Mesmo tendo pouca idade, as representações sobre estes eram tão soturnas quanto as noites em que estudavam. Considerando-se que a situação financeira de seus familiares exigia que estes chegassem ainda crianças no mercado de trabalho, as escolas pareciam compreender que não seria prudente ou recomendável oferecer a mesma liberdade e os mesmos conteúdos dos Grupos Escolares diurnos. Para tais alunos, priorizavam-se a moralização e o disciplinamento, assim como nas classes especiais. No caso dos alunos dos Grupos noturnos, entretanto, a segregação não se dava a partir de critérios científicos e psicológicos, mas, primordialmente, por critérios sociais e econômicos. 
Uma vez estando os alunos na escola, cabia então lhes oferecer um ensino condizente com suas características, detectadas a partir dos testes psicológicos, mas também que lhes fomentasse a participação ativa no processo de ensino aprendizagem. Nesse sentido, foram desenvolvidas então as atividades e instituições criadas pela própria Escola Nova que objetivavam ocupar e disciplinar os alunos, visando, principalmente, o cidadão em gérmen nos bancos escolares.

As fontes consultadas indicam que as práticas pedagógicas em Grupos Escolares de Belo Horizonte, fundamentadas na moderna concepção educacional no período, baseadas em técnicas avançadas, em preceitos científicos, faziam parte de um projeto disciplinador que partia da escola primária, mas almejava alcançar toda a sociedade. A fundamentação científica era o cerne da Escola Nova em Minas, embora não se possa desconsiderar que essa mesma ciência teve que se adequar aos preceitos da Igreja Católica cuja força se mostrou algumas vezes maior do que a própria administração política do Estado.

Com as vissicitudes do Estado de Minas Gerais, do avanço técnico e científico dos anos vinte aos cinqüenta, com as características da própria cidade de Belo Horizonte, os Grupos Escolares e a educação neles implementada ia, certamente, muito além do que essa pesquisa conseguiu apurar. O longo período estudado envolve contextos políticos, econômicos, sociais e culturais muito diversos. A República Velha, o período Vargas, Estado Novo, a Segunda Guerra Mundial, a Guerra Fria, o início da industrialização, o fenômeno das massas, o crescimento das cidades e a demanda por maior escolarização. Belo Horizonte, cidade extremamente jovem, teve um crescimento espantoso no período e as exigências por uma escolarização pública foram gradualmente se ampliando. Muitos momentos delicados e aspectos significativos precisam ser melhor abordados em outras pesquisas sobre a história da educação mineira, entre eles: Como os reformadores ao mesmo tempo que alteravam as legislações, buscavam manter a mística da Reforma Francisco Campos? De que forma se deu este embate entre as mudanças e a preservação do mito? Como se travava o combate entre Igreja e Reformadores? Havia combate ou conciliação? Como a imprensa tratava a educação em Minas? Como a imprensa era utilizada como uma proposta educativa na escola? Acerca da produção dos jornaizinhos escolares, como era a sua montagem, realização, divulgação e venda? Enfim, são ainda muitas fontes e objetos da 
história da educação mineira que merecem maior investigação. Neste caleidoscópio de normas, regimentos, decretos, exigências, sentimentos, temores, sujeitos, tarefas e atividades a serem realizadas muitas podem ser as composições formadas e percebidas. O olhar do investigador acaba por realçar alguns ângulos e ocultar outros. Vários olhares serão então necessários para se obter uma imagem mais completa e complexa desse processo.

As principais conclusões da pesquisa ressaltam que não se pode tratar de disciplina escolar sem buscar seus múltiplos disfarces e formas dispersas de atuação e, principalmente, deixando de lado os principais protagonistas desse processo: educadores e educandos. São eles que irão dar vida aos regulamentos e programas e, nesse sentido, que, efetivamente, colocam em funcionamento a escola e seus dispositivos disciplinares aos quais são também submetidos. Nesse processo, muitos são os caminhos e descaminhos, os meandros que circulam as informações escolares, e captar as diversas composições deste cenário exige uma investigação minuciosa e complexa que necessita de diferentes pontos de vista e olhares múltiplos sobre os eventos. Esta tese descortina apenas alguns desses ângulos.

Uma outra conclusão é a de que a Escola Nova em Minas está envolta em muitos enigmas, um deles é o de que talvez, não tenha sido tão nova e tão moderna assim, como suspeita Alaíde Lisboa:

A Escola Nova abriu os olhos do professor para uma porção de problemas. Talvez muitas dessas situações da Escola Nova já fossem usadas pelos professores mais hábeis. Não foi uma coisa inventada de uma hora para outra, são coisas existentes que vieram à tona. Então, talvez houvesse Escola Nova antigamente, talvez haja Escola Antiga ainda hoje. ${ }^{580}$

Assim como a implantação do escolanovismo não tenha sido tão inovadora quanto se propunha, a escola atual talvez não esteja tão distante dos Grupos de cinqüenta anos atrás. Visitar a história dos Grupos Escolares de Belo Horizonte, os personagens que fizeram parte desta trama, os prédios que compuseram este cenário e, principalmente, as propostas pedagógicas e disciplinares ali encenadas é fundamental para reconhecer o legado deixado pelos nossos antepassados. Segundo Hanna Arendt, ao contrário do que se usualmente se pensa é o futuro que nos impele ao passado:

${ }^{580}$ Trecho de entrevista concedida ao Centro de Referência do Professor. 
Assim, a perda inegável da tradição no mundo moderno não acarreta absolutamente a perda do passado, pois passado e tradição não são a mesma coisa, como os que acreditam na tradição, de um lado, e os que acreditam no progresso, de outro, nos teriam feito crer - pelo que não faz muita diferença que os primeiros deplorem esse estado de coisas e os últimos estendam-lhe suas congratulações. Com a perda da tradição, perdemos o fío que nos guiou com segurança através dos vastos domínios do passado; esse fio, porém, foi também a cadeia que aguilhou cada sucessiva geração a um aspecto predeterminado do passado. Poderia ocorrer que somente agora o passado se abrisse a nós com inesperada novidade e nos dissesse coisas que ninguém teve ainda ouvidos para ouvir. Mas não se pode negar que, sem uma tradição firmemente ancorada - e a perda dessa firmeza ocorreu muitos séculos atrás -, toda a dimensão do passado foi também posta em perigo. Estamos ameaçados de esquecimento, e um tal olvido - ponto inteiramente de parte os conteúdos que se poderiam perder - significaria que, humanamente falando, nos teríamos privado de uma dimensão de profundidade na existência humana. Pois memória e profundidade são o mesmo, ou antes, a profundidade não pode ser alcançada pelo homem a não ser através da recordação. $(1954 / 1972$, p. 131)

Inventariar os dispositivos disciplinares em uso em Grupos Escolares de Belo Horizonte nos anos vinte aos cinqüenta, mais do que dar visibilidade a uma história que, para muitos, consistiu no tempo áureo da educação mineira, implica decifrar enigmas de uma tradição que precisa ser explorada e ressignificada. É preciso considerar que não se trata de julgar os antepassados, suas falhas e equívocos, mas reconhecer que estes nos deixaram um legado que precisa ser conhecido e reconhecido. Não há linearidade na história, a não ser por artifícios didáticos. Esta continua em processo de constituição e os capítulos que se desdobram nesta história da educação em Minas Gerais e de Belo Horizonte estão em contínua construção com novos personagens, novos cenários e, quiçá, novos temas, mas sempre dando continuidade a um passado que, antes de tudo, permanece em nós e em nossa história. 


\section{FONTES}

\section{ACERVOS PESQUISADOS}

Acervo Helena Antipoff - Biblioteca Central da Universidade Federal de Minas Gerais Arquivo Municipal de Belo Horizonte

Arquivo Público Mineiro

Biblioteca Pública Estadual Luiz de Bessa

Biblioteca da Faculdade de Pedagogia da Universidade do Estado de Minas Gerais.

Biblioteca da Faculdade de Direito da Universidade Federal de Minas Gerais.

Biblioteca do Centro de Referência do Professor

Coleção Joaquim Nabuco Linhares - Biblioteca Central da Universidade Federal de Minas Gerais

CPDOC- Biblioteca da Faculdade de Educação da UFMG

Escola Estadual Bernardo Monteiro

Escola Estadual Benjamim Guimarães

Escola Estadual Lúcio dos Santos

Escola Estadual Mariano de Abreu

Escola Estadual Olegário Maciel

Escola Estadual Pandiá Calógeras

Escola Estadual Pedro II

Escola Estadual Sandoval de Azevedo

Escola Estadual Tomaz Brandão

Hemeroteca do Estado de Minas Gerais

Museu Histórico Abílio Barreto

Museu da Escola - Centro de Referência do Professor

\section{MEMÓRIAS}

ARREGUY, Maria da Glória d'Avila. Memórias de uma professora. Belo Horizonte: Carneiro \& Cia editora, 1958. 151p.

DELL'ISOLA, Benedita. Memórias de uma professora primária. Belo Horizonte: Imprensa Oficial, p. 1970. 127p.

MONTEIRO, Marta Nair. Meu mundo. Belo Horizonte: Imprensa Oficial, 1991, 235p.

OLIVEIRA, Alaíde Lisboa de. Se bem me lembro... Belo Horizonte: Mazza, 2000. 216p. 


\section{BIOGRAFIAS}

ANTIPOFF, Daniel I. Helena Antipoff: sua vida, sua obra. Belo Horizonte: ed. Itatiaia, 1996.198 p. $^{581}$

SOUZA, Angela Leite de. Lúcia Casasanta, uma janela para a vida. Belo Horizonte: Imprensa Oficial, 1984. 87 p.

\section{PUBLICAÇÕES DE HELENA ANTIPOFF ${ }^{582}$}

CENTRO DE Documentação e Pesquisa Helena Antipoff. Coletânea das obras escritas de Helena Antipoff. Belo Horizonte: Imprensa Oficial, 1992, vol. I. "Psicologia Experimental". 369p.

CENTRO DE Documentação e Pesquisa Helena Antipoff. Coletânea das obras escritas de Helena Antipoff. Belo Horizonte: Imprensa Oficial, 1992, vol. II. "Fundamentos da Educação". 414p.

CENTRO DE Documentação e Pesquisa Helena Antipoff. Coletânea das obras escritas de Helena Antipoff. Belo Horizonte: Imprensa Oficial, 1992, vol. III. "Educação do excepcional". 336p.

CENTRO DE Documentação e Pesquisa Helena Antipoff. Coletânea das obras escritas de Helena Antipoff. Belo Horizonte: Imprensa Oficial, 1992, vol. IV. "Educação rural" 209 p.

\section{LEGISLAÇÕES}

MINAS GERAIS. Decreto n. 6.655 de 19 ago. 1924. Aprova o Regulamento do Ensino Primário. Collecção das Leis e Decretos do Estado de Minas Gerais. Belo Horizonte: Imprensa Oficial, 1924.

MINAS GERAIS. Decreto n. 6.758 de 01 jan. 1925. Aprova o Programa do Ensino Primário. Collecção das Leis e Decretos do Estado de Minas Gerais. Belo Horizonte: Imprensa Oficial, 1925.

MINAS GERAIS. Decreto n. 6.831 de 20 mar. 1925. Aprova o Regulamento do Ensino nas Escolas Normais. Collecção das Leis e Decretos do Estado de Minas Gerais. Belo Horizonte: Imprensa Oficial, 1926.

\footnotetext{
${ }^{581}$ A obra foi publicada em 1975 pela editora José Olympio. Entretanto a obra consultada é de 1996, publicada por outra editora.

${ }_{582}$ Nessa coletânea encontram-se muitos textos repetidos, publicados na Revista do Ensino e nos Boletins da Secretaria de Educação.
} 
MINAS GERAIS. Decreto n. 6.832 de 20 mar. 1925. Aprova os Programas do Ensino nas Escolas Normais. Collecção das Leis e Decretos do Estado de Minas Gerais. Belo Horizonte: Imprensa Oficial, 1926.

MINAS GERAIS. Decreto n. 7.970-A de 15 out. 1927. Aprova o Regulamento do Ensino Primário. Collecção das Leis e Decretos do Estado de Minas Gerais. Vol III. Belo Horizonte: Imprensa Oficial, 1928.

MINAS GERAIS. Decreto n. 8.094 de 22 dez. 1927. Aprova os Programas do Ensino Primário. Collecção das Leis e Decretos do Estado de Minas Gerais. Vol III. Belo Horizonte: Imprensa Oficial, 1928.

MINAS GERAIS. Decreto n. 8.162 de 20 jan. 1928. Aprova o Regulamento do Ensino nas Escolas Normais. Collecção das Leis e Decretos do Estado de Minas Gerais. Belo Horizonte: Imprensa Oficial, 1929.

MINAS GERAIS. Decreto n. 8.225 de 11 fev. 1928. Aprova os Programas do Ensino Normal. Collecção das Leis e Decretos do Estado de Minas Gerais. Belo Horizonte: Imprensa Oficial, 1929.

MINAS GERAIS. Lei n. 1.036 de 25 set. 1928. Aprova os Regulamentos do Ensino Normal e Primário, expedidos, respectivamente, com os decretos n. 8.162, de 20 de janeiro de 1928, e 7.970-A, de 15 outubro de 1927, e contem outras disposições. Collecção das Leis e Decretos do Estado de Minas Gerais. Belo Horizonte: Imprensa Oficial, 1929.

MINAS GERAIS. Decreto n. 8.949 de 25 jan. 1929. Aprova modificações ao Regulamento do Ensino Normal. Collecção das Leis e Decretos do Estado de Minas Gerais. Belo Horizonte: Imprensa Oficial, 1930.

MINAS GERAIS. Decreto n. 8. 987 de 22 fev. 1929. Aprova o Regulamento da Escola de Aperfeiçoamento. Collecção das Leis e Decretos do Estado de Minas Gerais. Belo Horizonte: Imprensa Oficial, 1930.

MINAS GERAIS. Decreto n. 9.450 de 18 fev. 1930. Aprova o Regulamento do Ensino Normal, revisto e modificado. Collecção das Leis e Decretos do Estado de Minas Gerais. Belo Horizonte: Imprensa Oficial, 1930.

MINAS GERAIS. Decreto n. 9.653 de 30 ago. 1930. Aprova o Regulamento da Escola de Aperfeiçoamento. Collecção das Leis e Decretos do Estado de Minas Gerais. Belo Horizonte: Imprensa Oficial, 1930.

MINAS GERAIS. Decreto n. 9.892 de 18 mar. 1931. Estabelece categorias às escolas normaes officiaes, modifica tabellas de vencimentos, suspende o funccionamento de escolas primarias e toma outras providencias.

MINAS GERAIS. Decreto n. 10.133 de 17 nov. 1931. Contém disposições sobre matrícula em estabelecimentos de ensino primário. 
MINAS GERAIS. Decreto n. 10.362 de 31 maio 1932 - Aprova modificações aos regulamentos que baixaram com os decretos ns. 7.970-A, e 9.450, de 18 de fevereiro de 1930.

MINAS GERAIS. Decreto n. 10.414 de 15 jul.1932. Aprova o regulamento do cinema educativo.

MINAS GERAIS. Decreto n. 10.821 de 29 abr. 1933. Aprova programas do ensino normal.

MINAS GERAIS. Decreto n. 10.897 de 14 jun. 1933. Aprova programas do ensino.

MINAS GERAIS. Decreto n. 11.297 de 10 abr. 1934. Passa para os municípios o custeio dos serviços com o ensino primário rural, e contem outras disposições.

MINAS GERAIS. Decreto n. 11.411 de 30 jul. 1934. Approva o regulamento da Inspectoria de Educação Physica.

MINAS GERAIS. Decreto n. 11.501 de 31 ago. 1934. Approva modificações feitas no decreto n. 10.362, de 31 de maio de 1932.

MINAS GERAIS. Decreto n. 151 de 29 jul. 1935. Dispõe sobre o ensino religioso nos estabelecimentos officais de instrucção primaria, secundaria, profissional e normal.

MINAS GERAIS. Decreto n. 11.908 de 05 abr. 1935. Cria o Instituto Pestalozzi de Minas Gerais.

MINAS GERAIS. Decreto n. 887 de 30 jun. 1937. Aprova os programmas da Escola de Aperfeiçoamento.

MINAS GERAIS. Decreto n. 1.007 de 22 out. 1937. Nomeia uma comissão para formular sugestões no sentido de maior eficiência do ensino cívico e do combate ao comunismo em todas as escolas do Estado de minas Gerais.

MINAS GERAIS. Decreto n. 1.008 de 22 out. 1937. Nomeia uma comissão para orientar a propaganda anti-comunista, por meio de jornais, revistas e rádio-difusão, e fazer a censura a todas as obras de caráter didático, técnico, político, social ou simplesmente literário, que tenham por finalidade, direta ou indireta, propagar idéias comunistas.

MINAS GERAIS. Lei n. 212 de 30 out. 1937. Reorganiza os serviços da Secretaria da Educação e Saúde Pública.

MINAS GERAIS. Decreto-lei n. 38 de 03 jan. 1938. Cria a Inspetoria de Assistência Técnica do Ensino. 
MINAS GERAIS. Decreto-lei n. 63 de 15 jan. 1938. Suprime seis Escolas Normais Oficiais e revoga os artigos 157, 158, 159 e 160 do decreto n. 11.501 de 31 de agosto de 1934.

MINAS GERAIS. Decreto-lei n. 164 de 07 jan. 1939. Dispõe sobre arrecadação, nos estabelecimentos de ensino primário, da taxa escolar, que reverterá em benefício das respectivas caixas escolares.

MINAS GERAIS. Decreto n. 668 de 23 abr. 1940. Introduz modificações ao regime de apuração de notas nas Escolas Normais do Estado.

MINAS GERAIS. Decreto-lei n. 734 de 17 set.1940. Dispõe sobre Caixas escolares.

MINAS GERAIS. Decreto-lei n. 970 de $1^{\circ}$ dez. 1943. Dispõe sobre o funcionamento de Escolas Normais de $2^{\circ}$ grau.

MINAS GERAIS. Decreto-lei n. 1.666 de 28 jan. 1946. Transforma a Escola Normal de Belo Horizonte em Instituto de Educação de Minas Gerais.

MINAS GERAIS. Decreto n. 2.455 de 14 abr. 1947. Restabelece o descanso semanal aos sábados nos estabelecimentos de ensino.

MINAS GERAIS. Decreto n. 2.399 de 07 fev. 1947. Determina providências em proveito do ensino.

MINAS GERAIS. Decreto n. 2.576 de 19 jan. 1948. Dispõe sobre a duração do curso primário.

MINAS GERAIS. Lei n. 408 de 14 set. 1949. Dispõe sôbre plano de desenvolvimento do ensino primário, estabelece princípios para a criação de unidades escolares e escala de prioridade para construção de prédios destinados ao seu funcionamento e dá outras providências.

MINAS GERAIS, Lei n. 482 de 11 nov. 1949. Cria no Instituto de Educação o Serviço de Orientação e Seleção Profissional.

MINAS GERAIS. Decreto n. 3.432 de 29 set. 1950. Dispõe sobre o exercício das funções de educadoras sanitárias por professôras primárias e contem outras providências.

MINAS GERAIS. Decreto n.3.508 de 21 dez. 1950. Consolida as leis e decretos do ensino primário e contém outras disposições.

MINAS GERAIS. Decreto n. 1.127 de 13 nov. 1954. Considera de Magistério o cargo de Inspetor Regional do Ensino.

MINAS GERAIS. Decreto n. 4.565 de 28 abr. 1955. Dispõe sobre a admissão à carreira de inspetor regional do ensino. 


\section{BOLETINS DA SECRETARIA DO INTERIOR, POSTERIORMENTE SECRETARIA DE EDUCAÇÃO E SAÚDE}

SIMON, Dr. Th. Os methodos pedagogicos e a pedagogia experimental. Boletim n. 1. Bello Horizonte: Secretaria do Interior de Minas Gerais; Inspectoria Geral da Instrucação, 1929. 17p.

SIMON, Th. Exames de audição. Boletim n. 2. Bello Horizonte: Secretaria do Interior de Minas Gerais; Inspectoria Geral da Instrucção, 1929.9p.

SIMON, Th. Exames de visão. Boletim n. 3. Bello Horizonte: Secretaria do Interior de Minas Gerais; Inspectoria Geral da Instrucção, 1929.14p.

SIMON, Th. Anomalias de visão - crescimento. Boletim n. 4. Bello Horizonte: Secretaria do Interior de Minas Gerais; Inspectoria Geral da Instrucção, 1929.13p.

SIMON, Th. Desenvolvimento physico e desenvolvimento intelectual. Boletim n. 5. Bello Horizonte: Secretaria do Interior de Minas Gerais; Inspectoria Geral da Instrucção, 1930.15p.

ANTIPOFF, Hélène. Ideaes e interesses das creanças de Bello Horizonte e algumas suggestões pedagogicas. Boletim n. 6. Bello Horizonte: Secretaria do Interior de Minas Gerais; Inspectoria Geral da Instrucção, 1930. 46p.

ANTIPOFF, Hélène. O desenvolvimento mental das creanças de Bello Horizonte segundo alguns tests de intelligencia geral. Boletim n. 7. Bello Horizonte: Secretaria da Educação e Saúde Pública; Inspectoria Geral da Instrucção, 1931. 74p.

ANTIPOFF, Hélène. Organização das classes nos grupos escolares de Bello Horizonte e o control dos tests. Boletim n. 8. Bello Horizonte: Secretaria da Educação e Saúde Pública; Inspectoria Geral da Instrucção, 1932. 57p.

MONOGRAFIA de uma classe escolar de Belo Horizonte: estudo escolologico de 1931. por alunas da Escola de Aperfeiçoamento. Boletim n. 9. Belo Horizonte: Secretaria da Educação e Saúde Pública; Inspetoria Geral da Instrução, 1932. 99p.

ANTIPOFF, Hélène; CUNHA, Maria Luiza de Almeida. Teste Prime. Boletim n. 10. Belo Horizonte: Secretaria de Educação e Saúde Publica; Inspetoria Geral da Instrução, 1932.63p.

CASTRO, Maria Angélica de. Formação das classes e o controle da sua homogeneidade em 1932. Boletim n. 11. Belo Horizonte: Secretaria de Educação e Saúde Publica; Inspetoria Geral da Instrução, 1933.69p. 
SOCIEDADE Pestalozzi. A infância excepcional (sub-normais). Boletim n. 12 Fascículo I, Secretaria da Educação e Saúde Pública; Inspetoria Geral da Instrução. Belo Horizonte, setembro de 1933. 101p.

VIOTTI, Julia de Magalhães. Contribuição à antropologia da moça mineira. Boletim $n$. 13. Belo Horizonte: Secretaria da Educação e Saúde Pública; Inspetoria Geral da Instrução, 1933.73p.

ANTIPOFF, Helena; REZENDE, Naitres de. Ortopedia mental nas classes especiais. Boletim n. 14. Belo Horizonte: Secretaria da Educação e Saúde Pública, 1934.106p.

CASTRO, Maria Angelica. As classes do $1^{\circ}$ ano em 1933. Boletim n. 15. Belo Horizonte: Secretaria da Educação e Saúde Pública, 1934. 113p.

SOCIEDADE PESTALOZZI. Infancia Excepcional (sub-normaes e desamparados). Boletim n. 16. Belo Horizonte: Secretaria da Educação e Saúde Pública: dez. 1934. (Fasciculo II) 130p.

CASTRO, Maria Angélica de; ANTIPOFF, Helena. Ideaes e interesses das creanças de Bello Horizonte no intervalo de cinco annos. Boletim n. 17. Belo Horizonte: Secretaria da Educação e Saúde Pública: 1935.57p.

INSPECTORIA DE EDUCAÇÃO FÍSICA. Educação Physica (Jogos e callisthenia). Boletim n. 18. Belo Horizonte: Secretaria da Educação e Saúde Pública: 1935.86p.

CASTRO, Maria Angelica de; ANTIPOFF, Helena. A orientação das classes nos grupos escolares de Bello Horizonte. Boletim n. 19. Belo Horizonte: Secretaria da Educação e Saúde Pública: 1936.138p.

SOCIEDADE PESTALOZZI. Infancia excepcional. Boletim n. 20. Belo Horizonte: Secretaria da Educação e Saúde Pública: 1937.163p.

\section{REVISTAS}

EDUCANDO. Belo Horizonte: Associação dos Professores Primários de Minas Gerais, fev.1940 a jun. $1945^{583}$.

REVISTA DO ENSINO. Belo Horizonte: Secretaria do Interior/ Secretaria de Educação e Saúde Pública, jan. 1931 a dez. 1952. ${ }^{584}$

\footnotetext{
${ }^{583}$ Estão faltando os números 22 e 23 e 39 já que, segundo Prates (1998, p.24) e Biccas (2001, p. 101) foram publicados 39 edições da revista.

${ }^{584}$ Os anos de 1925 a 1930 fizeram parte da pesquisa de Mestrado: SOUZA, Rita de Cássia. Sujeitos da educação e práticas disciplinares: uma leitura das reformas educacionais mineiras a partir da Revista do Ensino (1925-1930). 2001. 355f. Dissertação (Mestrado em Educação). Faculdade de Educação da UFMG, Belo Horizonte, 2001. Nos anos de 1953, 1954 e 1955 a revista não foi publicada.
} 


\section{JORNAIS}

\section{ESTADO DE MINAS}

CLAPARÉDE chega hoje a Belo Horizonte. Estado de Minas. Belo Horizonte, 21 set. 1930, p. 1.

A ESTADIA, na Capital, do professor Claparède. Estado de Minas. Belo Horizonte, 23 set. 1930, p. 1.

PSYCHOLOGIA do Sentimento de Inferioridade. (Conferência do professor Claparède). Estado de Minas. Belo Horizonte, 24 set. 1930, p. 1.

UM ACCIDENTE no grupo escolar "Lúcio dos Santos". Estado de Minas. Belo Horizonte, 24 set. 1930, p. 8.

AINDA O ACCIDENTE occorido no grupo escolar "Lúcio dos Santos". Estado de Minas. Belo Horizonte, 26 set. 1930.

AS ALUMNAS da Escola Normal Modelo em auxilio das famílias dos soldados mineiros - o bando precatório de hontem à tarde. Minas Gerais, Belo Horizonte, 19 out.1930, p.4.

PSICOLOGIA da Educação. Estado de Minas. Belo Horizonte 02 nov. 1930.

AS ALUMNAS da Escola Normal Modelo em auxilio das famílias dos soldados mineiros. Estado de Minas. Belo Horizonte, 19 out. 1930, p.4.

SECRETARIA de Educação. Inspectoria Geral da Instrucção. Estado de Minas, Belo Horizonte, 04 dez.1930. p.5 e 7.

INSPECTORIA Geral da Instrucção. Estado de Minas, Belo Horizonte, 12 dez. 1930, p.7.

A SOLENNIDADE, hontem, de entrega de diplomas ás alumnas da Escola de Aperfeiçoamento. Estado de Minas, Belo Horizonte, 16 dez. 1930, p.2.

AS FESTAS de collação de grau das normalistas de 1930. Estado de Minas, Belo Horizonte, 19 dez.1930, p.3.

AS PROFESSORAS do Curso de Adaptação da Escola Normal pleiteam augmento de vencimentos. Uma commissão que se entendeu com o interventor federal e o secretário da Educação. Estado de Minas. Belo Horizonte, 01 ago. 1934. p.3.

GRAVE DENUNCIA contra a Escola de Aperfeiçoamento - Segundo informações que nos foram trazidas hontem, já se registraram naquelle estabelecimento casos de morte, loucura e cegueira - Aponta-se o methodo de ensino ali adoptado como causador desses males. Estado de Minas. Belo Horizonte, 16 ago. 1934, p.10. 
GRAVES DENUNCIAS contra a Escola de Aperfeiçoamento - Declarações do sr. Noraldino Lima, secretario da Educação, em torno do assumpto - Em palestra com o ESTADO DE MINAS, d. Amelia de Castro Monteiro, directora daquelle importante estabelecimento de ensino superior, destróe as accusações formuladas. Estado de Minas. Belo Horizonte, 17 ago. 1934. p.8

CONCURSO de jornais escolares. Estado de Minas. Belo Horizonte, 24 jun. 1949, p.7.

\section{FOLHA DE MINAS}

ESTA desabando o edificio do Grupo Escolar de Itapecerica. Folha de Minas. Belo Horizonte, 09 fev.1935. p.4.

OS PROFESSORES serão novamente sacrificados? Folha de Minas. Belo Horizonte, 22 set. 1935, p.3.

A INSUFICIENCIA dos grupos escolares. Folha de Minas 03 jan. 1936, p.3.

\section{MINAS GERAIS}

SECRETARIA do Interior. Minas Gerais. Belo Horizonte, 29 jan. 1928. Seção Pelo Ensino.

CASASANTA, Guerino. Ensino leigo nas escolas. Minas Gerais. Belo Horizonte, 05 jan. 1933. Seção Pelo Ensino.

SECRETARIA da Educação e Saúde Pública. Minas Gerais. Belo Horizonte, 18 jan. 1933. Seção Pelo Ensino.

RIBEIRO, Benedito Valadares. A nossa atividade escolar (Mensagem de 1937, p.243) Minas Gerais. Belo Horizonte, 12 out. 1937, p. 12.

\section{O DEBATE}

SANTACRUZ LIMA. Uma forja de obreiros para amanhã - visitando o Curso Technico Complementar do G. E. Lucio dos Santos. O debate. Belo Horizonte, 23 abr. 1934, anno I, n. 34. p.1 e 3.

CHAVES, Letícia. Mentores de uma geração: assuntos palpitantes do ensino primário, através a palavra de professores mineiros. O debate. Belo Horizonte, 27 abr. 1934, anno I, n. 38. p.1 e 3.

A POBREZA das Caixas Escolares. O debate. Belo Horizonte, 03 out. 1934, ano I, n. 173. p.1-2. 
BANQUETES regados a champagne e estumados a havanas enquanto nos grupos escolares creanças desmaiam de fome. O debate. Belo Horizonte, 04 out. 1934, anno I, n. 174. p.1.

\section{O HORIZONTE}

NEGROMONTE, Álvaro. Coeducação na escola. O horizonte. Belo Horizonte, 6 out. 1932 , n. 863 , p.2-3.

DEVE A Escola Nova renegar a Escola Tradicional?- (Conferência do exmo. D. Joaquim Silvério de Souza proferida na Escola de Aperfeiçoamento). O Horizonte, Belo Horizonte, 3 set. 1933, p. $3 .^{585}$

DEVE A Escola Nova renegar a Escola Tradicional?- (Conferência do exmo. D. Joaquim Silvério de Souza proferida na Escola de Aperfeiçoamento) - O Horizonte, Belo Horizonte, 7 set. 1933, p.3

DEVE A Escola Nova renegar a Escola Tradicional?- (Conferência do exmo. D. Joaquim Silvério de Souza proferida na Escola de Aperfeiçoamento) - Conclusão. $O$ Horizonte, Belo Horizonte, 10 set. 1933, p.2.

ORAÇÃO às novas professoras. Proferida pelo Revmo. Pe. Alvaro Negromonte, na missa de conclusão do curso. O Horizonte, Belo Horizonte, 24 dez. 1933, p.3-5

AS CONVICÇÕES religiosas do Dr. Noraldino Lima. O horizonte. Belo Horizonte, 09 out. 1934, ano XII, n.1.144, p.1.

TAVARES, Waldemar. As credenciais catholicas do Dr. Noraldino Lima. O horizonte. Belo Horizonte, 11 out.1934, ano XII, n.1.145, p.1.

LIMA, Noraldino. Telegrama. O horizonte. Belo Horizonte, 28 out.1934, ano XII, n.1.152, p.1.

CURSO de Aperfeiçoamento para religiosas. O horizonte. Belo Horizonte, 22 nov.1934, ano XII, n.1.163, p.1.

OLIVEIRA, Mons. J.R. Da Coeducação. O horizonte. Belo Horizonte, 25 nov.1934, ano XII, n.1.164, p.1.

${ }^{585}$ A Conferência era uma continuação da edição anterior que não foi encontrada na Hemeroteca. 


\section{VÍDEOS}

A ESCOLA agora é outra. Herbert Richers - Sino filmes. 1 fita de vídeo (10 min.) VHS, son., preto e branco, s.d.

LISTEN WELL, learn well. Coronet Films Education Collaborator. Viola/Theman, Ph.D. Associate Professor of Education, Northwestern Universit.(10 min.) VHS, son., preto e branco; s.d.

SKIPPY and the RRR'S. Direction: Irving Rusinow. Agrofilms Production. (32 min) VHS, son., color, s.d.

TEACHER Educational Series: The broader concept of method. New York: Caravel Films. VHS, son., preto e branco. Part I: Developing pupil interest. Correlated with schorlings "Student Teaching" (10min.); Part II: Teacher and Pupils Planning and working together - Correlated with schorlings "Student Teaching" (19min.); s.d.

THE FELTBOARD in teaching. Eduard Hoot: audio-visual materiais - Consultation Bureau - College of Education Wayne University. VHS, son., color, (10 min.); s.d.

\section{DADOS ESTATÍSTICOS}

ANNUARIO Estatistico - anno II (1922-1925). Secretaria da Agricultura - Serviço de Estatística Geral - Estado de Minas Geraes. Bello Horizonte: Imprensa Official, 1929.

ANUÁRIO Estatístico de Minas Gerais - ano III, 1949. Departamento Estadual de Estatística. (Órgão Regional do Instituto Brasileiro de Geografia e Estatística). Belo Horizonte: Oficinas Gráficas da Estatística, 1950.

ANUÁRIO Estatístico de Minas Gerais - ano IV, 1950. Departamento Estadual de Estatística. (Órgão regional do Instituto Brasileiro de Geografia e Estatística). Belo Horizonte: Oficinas Gráficas da Estatística, 1951.

ANUÁRIO Estatístico de Minas Gerais - ano VII, 1955. Departamento Estadual de Estatística. (Órgão regional do Instituto Brasileiro de Geografia e Estatística). Belo Horizonte: Oficinas Gráficas do Departamento Estadual de Estatística, 1957. 


\section{REFERÊNCIAS BIBLIOGRÁFICAS}

ADÃO, Áurea. A história da profissão docente em Portugal: balanço da investigação realizada nas últimas décadas. In: NÓVOA, A.; BERRIO, J.R. (eds.) A história da educação em Espanha e Portugal: investigações e actividades. Lisboa: Sociedade Portuguesa de Ciências da Educação, 1993. p. 123-135.

ALENCAR, Joelma Sampaio de. Flagrantes da vida escolar brasileira: final do século XIX e início do século XX (relatos autobiográficos). 1996. 267 f. Dissertação (Mestrado em Educação) - Faculdade de Educação, Universidade de São Paulo, São Paulo, 1996.

ANDRADE, Carlos Drummnod de. Crônicas 1930-1934. Secretaria de Estado da Cultura de Minas Gerais: Banco de Desenvolvimento de Minas Gerais, 1987. 227p.

. As moças da Escola de Aperfeiçoamento. Educação em Revista, Belo Horizonte (6):48-54, dez. 1987.

ANDRADE, Djalma. História alegre de Belo Horizonte. Belo Horizonte, Imprensa Oficial, 1947.

ANDRADE, Moacir. República Decroly. Belo Horizonte: edição Pindorama, 1935. $204 p$.

ARENDT, Hannah. Entre o passado e o futuro. 2 ed. São Paulo: Perspectiva, 1972. A primeira edição é de 1954.

ARIÉS, Philippe. História social da criança e da família. 2. ed. Rio de Janeiro: Zahar, 1991.

ASSUNÇÃO, Maria Madalena Silva de. A psicologia da educação e a construção da subjetividade feminina (Minas Gerais - 1920 -1960). 2002. 411f (Doutorado em Educação) - Faculdade de Educação, Universidade Federal de Minas Gerais, Belo Horizonte, 2002.

AZEVEDO NETO. 13 de dezembro. In: . Trechos. Belo Horizonte: Gráfica Queiroz Breiner Ltda, 1945. p. 240-242.

BARBOSA, Adelson. Professor usa palmatória em alunos. Folha de São Paulo, 14 de março de 1995. Caderno Via Brasil, p. 3

BASTOS, Maria Helena Câmara; FARIA FILHO, Luciano Mendes (org.). A escola elementar no século XIX: o método monitorial/mútuo. Passo Fundo: Ediupf, 1999

BICCAS, Maurilane de Souza. O impresso como estratégia de formação de professores(as) e de conformação do campo pedagógico em Minas Gerais: o caso da Revista do Ensino (1925-1940).2001. 3 vol. (Doutorado em Educação) - Faculdade de Educação, Universidade de São Paulo, São Paulo, 2001. 
BORGES, Vera Lúcia Abraão. A ideologia do caráter nacional da educação em Minas: Revista do Ensino (1925-1929). 1993. (Doutorado em Educação) - Faculdade de Educação, Universidade Estadual de Campinas, Campinas, SP, 1993.

BOSCHI, Maria de Fátima Lobo. A Psicologia na formação do professor. A Psicologia nos programas dos cursos normais em Belo Horizonte (1930-1940). 2000. $115 f$. (Mestrado em Psicologia Social) - Faculdade de Filosofia e Ciências Humanas, Universidade Federal de Minas Gerais, Belo Horizonte, MG, 2002.

BOSI, Eclea. Memória e sociedade: lembranças de velhos. 2 ed. São Paulo: T.A. Queiroz: ed. da Universidade de São Paulo, 1987.

BOURDIEU, Pierre. Contrafogos: táticas para enfrentar a invasão neoliberal. RJ: Zahar, 1998. 151p.

. A Escola Conservadora: as desigualdades frente à escola e à cultura. In: NOGUEIRA, Maria Alice e CATANI, Afrânio Mendes (org.). Escritos de educação. 4 ed. Petrópolis: Vozes, 2002. p.39-64

BURKE, Peter. Civilização, disciplina, desordem: estudos de caso em História e Teoria Social. Revista Teoria e Sociedade, Belo Horizonte: UFMG, n. 1, p. 74-86, 1997.

CAMARGO, Marilena A. Jorge Guedes de. Coisas velhas: um percurso de investigação sobre cultura escolar (1925-1928). São Paulo: Ed. da UNESP, 2000.

CAMPOS, Francisco. Pela civilização mineira. Belo Horizonte: Imprensa Oficial, 1931.

CAMPOS, Regina Helena de Freitas (org.) Helena Antipoff: textos escolhidos. São Paulo: Casa do Psicólogo e Brasília: Conselho Federal de Psicologia, 2002. 369p.

CARVALHO, Marta M. C. O território do consenso e a demarcação do perigo: política e memória no debate educacional dos anos 30. In: FREITAS, Marcos Cezar (org.). Memória intelectual da educação brasileira. 2 ed. Bragança Paulista: Edusf, 2002. p.13-26.

. Molde nacional e Fôrma Cívica: higiene, moral e trabalho no projeto da Associação Brasileira de Educação. Bragança Paulista, SP: EDUSF, 1998.

. A escola e a república. São Paulo: Brasiliense, 1989. 86p.

- O novo, o velho, o perigoso: relendo A cultura brasileira. Cadernos de Pesquisa, São Paulo, (71): 29-35, novembro 1989.

Educação e política nos anos 20: a desilusão com a República e o entusiasmo pela educação. In: LORENZO, Helena Carvalho de; COSTA, Wilma Peres 
(Org.) . A década de 1920 e as origens do Brasil moderno. São Paulo: Fundação Editora UNESP, 1997.

; VIDAL, Diana G. (Org.) Biblioteca e formação docente; percursos de leitura. Belo Horizonte: Autêntica, 2000.

; HANSEN, João Adolfo. Modelos culturais e representação: uma leitura de Roger Chartier. Varia História, Belo Horizonte, n. 16, p. 7-24, set. 1996.

- Quando a história da educação é a história da disciplina e da higienização das pessoas. In: FREITAS, Marcos César de (org.) História social da infância no Brasil. 3 ed. São Paulo: Cortez, 2001.

- Por uma história cultural dos saberes pedagógicos. In: SOUSA, Cynthia Pereira de; CATANI, Denice Bárbara (org). Práticas educativas, culturas escolares e profissão docente. São Paulo: Escrituras, 1998, p. 31-40.

CASASANTA, Guerino. Jornais escolares. São Paulo: Companhia Editora Nacional, 1939.234p.

CATANI, Denice. Estudos de história da profissão docente. In: FARIA FILHO, Luciano et al. 500 anos de educação no Brasil. Belo Horizonte: Autêntica, 2000.

. Memória e biografia: "o poder do relato e o relato do poder" na história da educação. Pesquisa histórica: retratos da educação no Brasil. Rio de Janeiro: UERJ, p. 73-80.

CERTEAU, Michel de. A invenção do cotidiano: 1.Artes de fazer. Petrópolis: Vozes, 1994.

CHAMON, Carla Simone. Maria Guilhermina Loureiro de Andrade: a trajetória profissional de uma educadora. 2005. 138 f. Tese (Doutorado em Educação) Faculdade de Educação, Universidade Federal de Minas Gerais, Belo Horizonte, 2005.

CHARTIER, Roger. A história cultural: entre práticas e representações. Rio de Janeiro: Bertrand Brasil, 1990.

O mundo como representação. Revista de Estudos Avançados. São Paulo, v. 11, n. 5, p. 173-191, 1991.

CHERVEL, André. Des disciplines scolaires à la culture scolaire. In: . $L a$ culture scolaire: une approche historique. Paris: Belin, 1998, p. 181-192.

COELHO, Maria Inês de Matos et al. (coord.) Escola Normal - Instituto de Educação: reconstrução da história da educação elementar (Minas Gerais 1906-1969) - Curso de Pedagogia do Instituto de Educação de Minas Gerais - Centro de Estudos e Pesquisas Educacionais de Minas Gerais. Apoio do Instituto Nacional de Estudos e Pesquisas Educacionais - INEP/MEC - Relatório de pesquisa (s.d.) 2 volumes. 466f. 
COUSINET, Roger. A Educação Nova. São Paulo: Companhia Ed. Nacional, 1930.

CUNHA, Jorge Luiz da; MACHADO, Alexsandro dos Santos. Sujeitos que lembram: história oral e histórias de vida. História da Educação. Pelotas, RS, n. 14, p. 63-96, set. 2003.

CUNHA, Marcus Vinicius da. A escola contra a família. In: LOPES, Eliane Marta Teixeira; FARIA FILHO, Luciano Mendes de; VIDAL, Diana. 500 anos de educação no Brasil. 2 ed. Belo Horizonte: Autêntica, 2000. p. 447-468.

DELLA CAVA, Ralph. Igreja e Estado no Brasil do século XX: sete monografias recentes sobre o catolicismo brasileiro, 1916/64. Revista Estudos Cebrap, n. 12, p.5-52, abr.jun.1975.

DEL PRIORE, Mary (Org.). História da criança no Brasil. São Paulo: Contexto, 1991. DUARTE, Marisa Ribeiro Teixeira. O trabalho de ensinar: pedagogia para a professora. 1988. 216f. (Mestrado em Educação) - Faculdade de Educação, Universidade Federal de Minas Gerais, Belo Horizonte, 1988.

DUARTE, Marisa Ribeiro Teixeira; LOPES, Ana Amélia Borges de Magalhães. Políticas públicas e a organização do sistema de ensino elementar: Minas Gerais década de 30 e 40. Belo Horizonte: Universidade do Estado de Minas Gerais. Relatório técnico de pesquisa encaminhado à Fundação de Amparo à Pesquisa de Minas Gerais. 1997. $120 \mathrm{f}$.

ESCOLANO Agustín Benito. Los profesores en la historia. In: MAGALHÃES, Justino; ESCOLANO, Agustín B. Os professores na História. Porto: Sociedade Portuguesa de Ciências da Educação, 1999, p. 15-28.

FARIA FILHO, Luciano Mendes. Escolarização, culturas e práticas escolares no Brasil: elementos teórico-metodológicos de um programa de pesquisa. [s.d.] (mimeo)

- Instrução elementar no século XIX. In: LOPES, Eliane Marta Teixeira; FARIA FILHO, Luciano Mendes de; VIDAL, Diana. 500 anos de educação no Brasil. 2 ed. Belo Horizonte: Autêntica, 2000. p. 135-150.

- República, trabalho e educação: a experiência do Instituto João Pinheiro (1909/1934). Bragança Paulista: Ed. da Universidade São Francisco, 2001.

- Dos pardieiros aos palácios: cultura escolar e urbana em Belo Horizonte na Primeira República. Passo Fundo: UPF, 2000. 213p.

. Cultura e práticas escolares: escrita, aluno e corporeidade. Cadernos de Pesquisa, São Paulo, n. 103, p. 136-149, mar.1998.

A legislação escolar como fonte para a História da Educação: uma tentativa de interpretação. In: FARIA FILHO, Luciano Mendes (org.) Educação, 
modernidade e civilização: fontes e perspectivas de análises para a história da educação oitocentista. Belo Horizonte: Autentica, 1998a, p. 89-125.

FAUSTO, Boris. História do Brasil. 10 ed. São Paulo: Editora da Universidade de São Paulo, 2002.

FÁVERO, Maria de Lourdes de Albuquerque e BRITTO, Jader de Medeiros (org.) Dicionário de educadores no Brasil. Rio de Janeiro: Editora UFRJ / MEC- Inep, 1999.

FERNANDES, Florestan. Notas sobre a educação na sociedade tupinambá. In: A investigação etnológica no Brasil e outros ensaios. Petrópolis: Vozes, 1975, p.33-83.

FONSECA, Anita. Clubes de leitura. Belo Horizonte: Secretaria da Educação de Minas Gerais, 1950. 69p.

FONSECA, Cláudio Lucio. Arquitetura das escolas públicas nas reformas educacionais mineiras (1892-1930). 2004. 184f. (Mestrado em Educação) - Faculdade de Educação, Universidade Federal de Minas Gerais, Belo Horizonte, 2004.

FOUCAULT, Michel. Microfísica do poder. 9. ed. Rio de Janeiro: Graal, 1990. A primeira edição brasileira é de 1979.

. História da sexualidade: a vontade de saber. 14 ed. Rio de Janeiro: Graal, 2001.vol.1. 152p. A primeira edição é de 1976.

. História da sexualidade: o cuidado de si. 6 ed. R.J.: Graal,2001. 246p. vol.3. A primeira edição é de 1984 .

Vigiar e Punir: História da violência nas prisões. 5. ed. Petrópolis: Vozes, 1987. A primeira edição é de 1975.

. Os anormais. São Paulo: Martins Fontes, 2001. 479p. (Curso dado pelo autor em 1974/1975). original é de 1970.

A ordem do discurso. 4 ed. São Paulo: Loyola. 1998. 79p. A obra FOULQUIÉ, Paul. As Escolas Novas. São Paulo: Companhia Ed. Nacional, 1951.

FRANÇA, Junia Lessa et alli. Manual para normalização de Publicações TécnicoCientíficas. 6 ed. Belo Horizonte: ed. UFMG, 2003.

FREUD. Freud, Sigmund. O mecanismo psíquico do esquecimento. In:

Obras Completas de Sigmund Freud. Vol.III. 2 ed. Rio de Janeiro: Imago, 1986. p.257270. Originalmente escrito em 1898. 
FREUD. Freud, Sigmund. Lembranças encobridoras. In: Obras Completas de Sigmund Freud. Vol.III. 2 ed. Rio de Janeiro: Imago, 1986. p.271-287. Originalmente escrito em 1899.

GINZBURG, Carlo. Mitos, emblemas, sinais: morfologia e história. São Paulo: Companhia das Letras, 1989.

GONÇALVES, Irlen Antonio. Cultura escolar, práticas e produção dos grupos escolares em Minas Gerais (1891-1918). 286 f. Tese. (Doutorado em Educação) Faculdade de Educação, Universidade Federal de Minas Gerais, Belo Horizonte, 2004.

GOULART, Íris Barbosa. Psicologia da Educação em Minas Gerais: histórias do vivido. 1985. 238f. Tese. (Doutorado em Educação) - Faculdade de Educação, Pontifícia Universidade Católica, São Paulo, 1985.

GOULEMONT, Jean Marie. As práticas literárias ou a publicidade do privado. In: ARIÈS, Philipe; DUBY, Georges. História da vida privada: do Renascimento às Luzes. São Paulo: Companhia das Letras, 1991. vol.3. A edição original é de 1986.

GOUVEA, Maria Cristina S. A construção de uma infância escolarizada: a escola na literatura infantil (1900-1935). Educação em Revista, Belo Horizonte, n. 29, p.97-107, jun. 1999.

; VAGO, Tarcísio Mauro (org.). Histórias da educação: histórias de escolarização. Belo Horizonte: Edições Horta Grande, 2004. 208p.

; ROSA, Walquíria Miranda. A escola normal em Minas Gerais. In: FARIA FILHO, Luciano Mendes; PEIXOTO, Ana Maria Casasanta (org.). Lições de Minas: 70 anos da Secretaria de Educação. Belo Horizonte: Secretaria do Estado da Educação de Minas Gerais, 2000, p. 18-31.

JATOBÁ, Carla Mercês da Rocha. Às sombras das escalas: um estudo sobre a concepção de anormalidade em Alfred Binet. 2002. 157f. Tese (Doutorado em Educação) Faculdade de Educação, Universidade de São Paulo, São Paulo, 2002.

JULIA, Dominique. A cultura escolar como objeto histórico. Revista Brasileira de História da Educação. SBHE, Campinas, SP, n.1, p. 9-43, 2001.

LANG, Alice Beatriz da Silva Gordo. Muitas dúvidas, poucas certeza e uma proposta. In: MEIHY, José Carlos Sebe Bom. (Re)introduzindo a História Oral no Brasil. São Paulo: Xamã, 1996. 342p. p.33-47.

LE GOFF, Jacques. História e memória. 4 ed. Campinas: ed. da UNICAMP, 1996.

LIMA, Ana Laura Godinho. De como ensinar o aluno a obedecer: um estudo dos discursos sobre a disciplina escolar entre 1944 e 1965. 198f. (Mestrado e m Educação) Faculdade de Educação, Universidade de São Paulo, São Paulo, 1999. 
LINHARES, Joaquim Nabuco. Itinerário da imprensa em Belo Horizonte: 1875-1954. Belo Horizonte: Fundação João Pinheiro, Centro de Estudos Históricos e Culturais, $1995^{586}, 612 p$.

LONGO, Cristiano da Silveira. A punição corporal doméstica de crianças e adolescentes em livros sobre educação familiar no Brasil (1981-2000). 2001. 215f. Dissertação (Mestrado em Psicologia). Instituto de Psicologia, Universidade de São Paulo, São Paulo, 2001.

LOPES, Ana Amélia Borges de Magalhães. A expansão/contenção do ensino em Minas Gerais (1931-1934): um jogo político. 1997. 101f. Dissertação (Mestrado em Educação) Faculdade de Educação, Universidade Federal do Rio de Janeiro, Rio de Janeiro, 1997.

LOPES, Eliane Marta Teixeira. Da sagrada missão pedagógica. Bragança Paulista: Edusf, 2003. 267p.

. Memória e estudos autobiográficos. História da Educação.

Pelotas, RS, n. 14, p. 47-62, set. 2003.

LOURENÇO FILHO, Manuel Bergstrom. Introdução ao estudo da Escola Nova. 13 ed. Sao Paulo: Melhoramentos, 1978.

. A Psicologia no Brasil. In: AZEVEDO, Fernando de. As ciências no Brasil. São Paulo: Melhoramentos, s.d. p. 263-296. (vol.II)

LOVISOLO, Hugo. A memória e a formação dos homens. Revista de Estudos Históricos. Rio de Janeiro, v.2, n. 3, p. 16-28, 1989.

MACIEL, Francisca Izabel Pereira. Lúcia Casasanta e o Método Global de Contos: uma contribuição à história da alfabetização em Minas Gerais. 180f. Tese (Doutorado em Educação) Faculdade de Educação, Universidade Federal de Minas Gerais, Belo Horizonte, 2001.

MARCONI, Marconi de Andrade; LAKATOS, Eva Maria. Técnicas de pesquisa. 3 ed. São Paulo: Atlas, p. 1996.

MARGOTTO, Lílian Rose. A Psicologia chega à escola: o saber psicológico nos periódicos educacionais. (São Paulo 1890-1930). 2000. 257 f. Tese (Doutorado em Educação) Faculdade de Educação, Universidade de São Paulo, São Paulo, 2000.

A Psicologia entre notas, cópias e citações: periódicos educacionais paulistas (1902/1930). In: CARVALHO, Marta Maria Chagas de; VIDAL, Diana Gonçalves. Biblioteca e formação docente: percursos de leitura (1902-1935). Belo Horizonte: Autêntica, 2000. p. 37-61.

\footnotetext{
${ }^{586}$ A obra trata de um trabalho de um colecionador de jornais mineiros que faleceu em 1956. Portanto, 1995 não é a data de produção do texto mas de publicação da obra.
} 
MARTINS, Lincoln Coimbra. Psicologia escolar: das práticas disciplinares ao discurso psicológico. 1989. 113f. Dissertação (Mestrado em Educação). Faculdade de Educação, Universidade Federal de Minas Gerais, 1989.

MEIHY, José Carlos Sebe Bom. (Re)introduzindo a História Oral no Brasil. São Paulo: Xamã, 1996. 342p.

MEIHY, José Carlos Sebe Bom. Manual de História Oral. São Paulo: Loyola, 1996. $78 \mathrm{p}$.

MINAS GERAIS. Governo Provincial. "Castigos Lancasterianos: em consequência da Resolução do Exmo. Conselho de Governo da Província de Minas Gerais, mandado executar pelos mestres e 1as. Letras e Grammatica Latina”. Ouro Preto: Typografia de Silva, 1829, p.3.

MONARCHA, Carlos. A invenção da cidade e da multidão - dimensões da modernidade brasileira: A Escola Nova. São Paulo: Autores Associados, 1989.

MORAES, Maria Célia Marcondes de. Educação, Política e Ideologia - Análise de algumas propostas educacionais de Francisco Campos. Educação em Revista, Belo Horizonte, (16): 5-11, dez. 1992.

MOURA, Elza de. Saudades do meu grupo escolar. Estado de Minas, 19 de março de 2001.

MOURÃO, Paulo Krüger Corrêa. O ensino em Minas Gerais no tempo da República (1889-1930). Belo Horizonte: Centro Regional de Pesquisas Educacionais de Minas Gerais, 1962. 608p.

NAGLE, Jorge. Educação e sociedade na Primeira República. 2 ed. Rio de Janeiro: DP\&A, 2001. 411p.

NARODOWSKY, Mariano. Infancia y poder: la conformación de la pedagogía moderna. Buenos Aires: Grupo editor AS, 1994.

A infância como construção pedagógica. In: COSTA, Marisa Vorraber. Escola básica na virada do século: cultura, política e currículo. São Paulo: Cortez, 1996. p.107-118.

NEGROMONTE, Padre Álvaro. Meu catecismo (para o $4^{\circ}$ ano primário). 7 ed. Rio de Janeiro: José Olympio, 1950, 181p.

NEVES, Maria de Fátima Rodrigues das. Infância de faces negras: a criança escrava brasileira no século XIX. 1993. 306 f. Dissertação (Mestrado em História) Faculdade de Filosofia, Letras e Ciências Humanas, Universidade de São Paulo, São Paulo, 1993. 
NÓVOA, Antônio. A reforma educativa portuguesa: questões passadas e presentes sobre a formação de professores. In: NOVOA, A; POPKEWITZ, Thomas S. (eds.) Reformas educativas e formação de professores. Lisboa: Educa, 1992. p. 57-69.

Do mestre-escola ao professor do ensino primário: subsídios para a história da profissão docente em Portugal (séculos XVI-XX). Lisboa: Instituto Superior de Educação Física, 1986. 64p.

NUNES, Clarice. Cultura escolar, modernidade pedagógica e política educacional no espaço urbano carioca. In: HERSCHAMNN, Micael; KROPF, Simone; NUNES, Clarice. Missionários do Progresso: médicos, engenheiros e educadores no Rio de Janeiro (1870-1937). Rio de Janeiro: Diadorim, 1996.

- (Des)encantos da modernidade pedagógica. In: FARIA FILHO, Luciano et al. 500 anos de educação no Brasil. Belo Horizonte: Autêntica, 2000.

O Estado Novo e o debate educacional nos anos 30. In: FREITAS, Marcos Cezar (org.). Memória intelectual da educação brasileira. 2 ed. Bragança Paulista: Edusf, 2002. p.27-40.

OLIVEIRA, Maria Helena Palma de. Lembranças do passado: a infância e a adolescência na vida escritores brasileiros. Bragança Paulista: EDUSF, 2001, 204p.

PATTO, Maria Helena Souza. A produção do fracasso escolar: histórias de submissão e rebeldia. São Paulo: Casa do Psicólogo, 1999. 458p.

PAIVA, Edil. V. de; PAIXÃO, Lea Pinheiro. PABAEE, o ensino primário com assistência internacional. In: FARIA FILHO, Luciano Mendes; PEIXOTO, Ana Maria Casasanta (org.). Lições de Minas: 70 anos da Secretaria de Educação. Belo Horizonte: Secretaria do Estado da Educação de Minas Gerais, 2000. p. 105-119.

PAIXÃO, Léa Pinheiro. Mulheres mineiras da República Velha - profissão: professora primária. Educação em Revista, Belo Horizonte, n. 1, p.12-25, jul. 1985.

PEIXOTO, Ana Maria Casasanta. Educação e Estado Novo em Minas Gerais. Bragança Paulista: EDUSF, 2003. 458p.

A luta dos católicos em Minas Gerais, anos 30. Educação em Revista, Belo Horizonte (17): 56-63, jun. 1993.

. Recessão e controle: a política educacional mineira na Era Vargas. Educação em Revista, Belo Horizonte (15): 5-13, 1992.

. A escola no projeto de construção do Brasil moderno - a reforma Francisco Campos em Minas Gerais. Educação em Revista, Belo Horizonte, (16): 1217, dez. 1992. 
. A escola no regime autoritário: o caso mineiro. Educação em Revista, Belo Horizonte (6): 3-10, dez. 1987. . Educação no Brasil nos anos vinte. São Paulo: Loyola, 1983. 180p.

(coord); PAIVA, Edil Vasconcellos; PAIXÃO, Lea Pinheiro; PRATES, Maria Helena de Oliveira. Projeto: Memória Histórica do ensino primário e normal em Minas Gerais. FAPEMIG, 1995, Relatório Final. 345p.

PETITAT, A. Produção da escola, produção da sociedade. Porto Alegre: Artes Médicas, 1994.

PIAGET, Jean. O juízo moral na criança. 2 ed. São Paulo: Sumus, 1984. 302p. A primeira edição é de 1932.

PIMENTEL, Iago. Noções de Psicologia aplicadas à educação. 9 ed. rev. São Paulo: Melhoramentos, 1955. 227p.

PINTO, Diana Couto; LEAL, Maria Cristina; PIMENTEL, Marília A. Lima. Trajetórias de liberais e radicais pela educação pública: Anísio Teixeira, Fernando de Azevedo, Florestan Fernandes e Darcy Ribeiro. São Paulo: Loyola, 2000. 150p.

POLLAK, Michel. Memória, esquecimento, silêncio. Revista de Estudos Históricos. Rio de Janeiro, v.2, n. 3, p. 3-15, 1989.

PRANDI, José Reginaldo. Catolicismo e família: transformação de uma ideologia. Cadernos do CEBRAP, Caderno 21, 1975.70p.

PRATES, Maria Helena de Oliveira. A introdução oficial do movimento de escola nova no ensino público de Minas Gerais: a Escola de Aperfeiçoamento. 1989. (Doutorado em Educação) Faculdade de Educação, Universidade Federal de Minas Gerais, 1989.

- Uma nova pedagogia para o professor mineiro: a escola de aperfeiçoamento. Educação em Revista, Belo Horizonte (11): 12-29, jul. 1990.

RAMOS, Arthur. A criança problema. 4 ed. revista. Rio de Janeiro: Livraria-editora Casa do Estudante, [s.d.] 396p. [1 ${ }^{\text {a }}$ edição: 1939?]

- Esplendor e decadência da palmatória. Revista Brasileira de Estudos Pedagógicos, 2(6): p. 454-457, dez.1944.

RELATÓRIO pelo fim das punições físicas contra as crianças. Comissão de Cidadania e Direitos Humanos da Assembléia Legislativa do Estado do Rio Grande do Sul, gestão 1995-1996. 103p.

ROCHA, Marlos Bessa Mendes da. Educação conformada: a política pública de educação no Brasil 1930-1945. Juiz de Fora: ed. da UFJF, 2000.180 p. 
ROLIM, Marcos. Apresentação. In: RELATÓRIO pelo fim das punições físicas contra as crianças. Comissão de Cidadania e Direitos Humanos da Assembléia Legislativa do Estado do Rio Grande do Sul, gestão 1995-1996. 103p.

ROUSSEAU, Jean Jacques. Emílio ou Da educação. 2 ed.São Paulo: Difusão européia do livro, 1973. A edição original é de 1762.

SCHWARTZMAN, Simon; BOMENY, Helena Maria Bousquet; COSTA, Vanda Maria Ribeiro. Tempos de Capanema. Rio de Janeiro: Paz e Terra; São Paulo: Ed. da USP, 1984. 388p.

SEVCENKO, Nicolau. Literatura como missão: tensões sociais e criação cultural na Primeira República. São Paulo: Brasiliense, 1999.

SIQUEIRA, Elizabeth Madureira. Luzes e sombras: modernidade e educação pública de Mato Grosso (1870-1889).1998. Tese (Doutorado em História da Educação) - Instituto de Educação, Universidade Federal de Mato Grosso, Cuiabá.

SOUZA, Maria Cecília Cortez Christiano de. Escola e memória. Bragança Paulista: IFAN-CEDAPH, EDUSF, 2000.

.Decorar, lembrar e repetir: o significado de práticas escolares na escola brasileira do final do século XIX. In: SOUSA, Cynthia Pereira. (Org.) História da Educação: processos, práticas e saberes. São Paulo: Escrituras, 1998. p.83-93.

Professores e professoras: retratos feitos de memória. In: GONDRA, José (Org.) Dos arquivos à escrita da história: a educação brasileira entre o império e a república no século XIX. Bragança Paulista: Ed. da Universidade de São Francisco, 2001.

À sombra do fracasso escolar: a psicologia e as práticas pedagógicas. Revista Estilos da Clínica, São Paulo, ano III, n. 5, p.63-83, $2^{\circ}$ sem.1998.

. A documentação judiciária e o estudo da família em São Paulo da primeira república, Cadernos ANPEd, n. 5, p. 119-137, set.1993.

Sob o silêncio da escola, a Memória. Revista Brasileira de História. São Paulo, v. 17, n. 33, p. 280-292, 1997.

Sexo é uma coisa natural? A contribuição da psicanálise para o debate sexualidade/escola. In: AQUINO, Julio Groppa (org.) Sexualidade na escola: alternativas teóricas e práticas. 2 ed. São Paulo: Summus, 1997. p.11-23.

século XIX (mimeo, s.d.).

Ensinar a ler pode ser faca de dois gumes: São Paulo, metade do 
SOUZA, Ricardo Luiz. Autoritarismo, cultura e identidade nacional (1930-1945). História da Educação. Pelotas, RS, n. 15, p. 89-127, abr. 2004.

SOUZA, Rita de Cássia. Sujeitos da educação e práticas disciplinares: uma leitura das reformas educacionais mineiras a partir da Revista do Ensino (1925-1930). 2001. 355f. Dissertação, (Mestrado em Educação). Faculdade de Educação da UFMG, Belo Horizonte, 2001.

THOMPSON, Paul. A voz do passado.2ed. Rio de Janeiro: Paz e Terra, 1998.

VAGO, Tarcísio Mauro. Cultura escolar, cultivo de corpos: educação physica e gymnastica como práticas constitutivas dos corpos das crianças no ensino público primário de Belo Horizonte (1906-1920). Bragança Paulista: EDUSF, 2002. 307p.

VARELA, Julia. Categorias espaço-temporais e socialização escolar: do individualismo ao narcisismo. In: COSTA, Marisa Vorraber. Escola básica na virada do século: cultura, política e currículo. São Paulo: Cortez, 1996. p. 73-106.

VEIGA, Cynthia Greive. Cidadania e educação na trama da cidade: a construção de Belo Horizonte em fins do século XIX. 1994. Bragança Paulista: EDUSF, 2002. 347p.

As ruas e os quintais: o rural e o urbano nas práticas pedagógicas destinadas à regeneração de meninos pobres (Belo Horizonte, décadas de 30 e 40). UFMG, Relatório Final de Pesquisa, 1998. 101p.

- Educação estética para o povo. In: In: LOPES, Eliane Marta Teixeira; FARIA FILHO, Luciano Mendes de; VIDAL, Diana. 500 anos de educação no Brasil. 2 ed. Belo Horizonte: Autêntica, 2000. p. 399-422.

VEIGA, Cynthia Greive. O movimento da Escola Nova em Minas Gerais - a introdução da rotina dos testes. [s.d.] (mimeo).

VIDAL, Diana Gonçalves. Educação sexual: produção de identidades de gênero na década de 30. In: SOUSA, Cynthia Pereira (org.) História da Educação: processos, práticas e saberes. 3 ed. São Paulo: Escrituras Editora, 2003. p.53-74.

SOUZA, Maria Cecília C.C. A memória e a sombra: a escola brasileira entre o império e a república. Belo Horizonte: Autêntica, 1999.

A fonte oral e a pesquisa em História da Educação: algumas considerações. Educação em Revista, Belo Horizonte, n.27, p. 7-16, jul./98.

; CARVAlHO, Marília Pinto de. Mulheres e magistério primário: tensões, ambigüidades e deslocamentos. In: VIDAL, Diana Gonçalves; HILSDORF, Maria Lúcia. Brasil: 500 anos: Tópicas em História da Educação. São Paulo: Editora da Universidade de São Paulo, 2001. 
VILLELA, Heloisa de Oliveira Santos. Da palmatória à lanterna mágica: a Escola Normal da Província do Rio de Janeiro entre o artesanato e a formação profissional (1868-1876). 2002. 291f. Tese, (Doutorado em Educação). Faculdade de Educação da USP. São Paulo, 2002.

VIÑAO FRAGO, Antonio. Historia de la educación e historia cultural: posibilidades, problemas, cuestiones. Revista Brasileira de Educação. ANPED, n.0, p.63-82, set.out.nov.dez. 1995.

VINCENT, Guy, LAHIRE, Bernard \& THIN, Daniel. Sobre a história e a teoria da forma escolar. Educação em Revista. Belo Horizonte, n. 33, p. 7-47, jun. 2001.

XAVIER, Maria do Carmo (org.) Manifesto dos pioneiros da educação: um legado educacional em debate. Rio de Janeiro: ed. FGV, 2004. 363p.

\section{SITES CONSULTADOS:}

http://www.fundacaohantipoff.mg.gov.br/origem fha.htm - Consultado em 06 de junho de 2005.

http://www.pestalozzi.org.br/ASPX/historia_helena.aspx - Consultado em 28 de julho de 2005

Constituições brasileiras

http://www.presidencia.gov.br/ccivil_03/Constituicao/Nova-consti/Main.htm Consultado em 17 de agosto de 2005 
RITA DE CÁSSIA DE SOUZA

"NÃO PREMIARÁS, NÃO CASTIGARÁS, NÃO RALHARÁS..." dispositivos disciplinares em Grupos Escolares de Belo Horizonte (1925-1955)

\section{ANEXOS}




\section{ENTREVISTAS}

Os(as) entrevistados(as) foram contactados e recebiam uma carta explicando a pesquisa, o roteiro e o ato de autorização. Tendo conhecimento de todo esse material, novamente eram contactados para confirmarem se gostariam ou não de conceder a entrevista. Após a confirmação do aceite, a entrevista era marcada no local e horário definidos pelos entrevistados. O roteiro para os(as) alunos(as) era menor, justamente porque contemplava apenas o período de formação do grupo escolar.

\section{MODELO DA CARTA ENVIADA}

Belo Horizonte, 20 de outubro de 2004

Sra. ou Sr. Xxxxxxxxx,

Estou lhe enviando o roteiro da entrevista e o ato de autorização. O roteiro é extenso, mas é somente um indicador do que pretendo saber. A senhora deve responder somente o que se lembrar e o que quiser. Não é necessário responder tudo.

O roteiro não deve ser respondido por escrito. Na verdade, é para a senhora ficar sabendo, mais ou menos, o que irei perguntar.

Ficarei aguardando a sua resposta, dizendo se concorda ou não em dar o depoimento e, se concordar, onde e quando podemos fazê-lo. Preciso saber também se a senhora concorda em filmarmos e/ou gravarmos o depoimento.

Estou à disposição para lhe esclarecer quaisquer dúvidas.

Agradeço-lhe a atenção e disponibilidade,

Rita de Cássia de Souza

Telefones para contato: $\mathrm{xxxxxxxx}$ 


\section{ROTEIRO DE ENTREVISTA ${ }^{587}$}

\section{PARTE I \\ ALUNOS \& ALUNAS}

\section{IDENTIFICAÇÃO}

- Nome completo

- Data e local de nascimento

- Estado civil

- Escolaridade

- Profissão

\section{A ESCOLA PRIMÁRIA}

- Idade em que entrou na escola

- Qual escola, quanto tempo ficou e nome dos professores

- Localização da escola

- Como era a escola - Espaço físico

- Impressão dos professores

- Um fato marcante acontecido na escola

- As classes eram mistas? E os recreios? Todas as aulas eram juntas ou havia separação entre meninos e meninas?

- Como era a organização das classes? Como eram distribuídas as carteiras? E os/as alunos? Sentavam juntos ou separados/as?

- Que materiais se utilizava nas escolas?

- Com quais livros estudou?

- Como era a rotina escolar?

- Havia uniforme escolar? Era obrigatório?

- Lembra-se do nome da diretora no período em que estudou?

- Como era a disciplina na escola

\section{Disciplina escolar}

- Como os professores lidavam com a questão disciplinar

- Que tipo de regras havia

- O que podia e o que não se podia fazer

- O que era bom e mau aluno

- O que era um aluno disciplinado e um indisciplinado (características)

- Que tipos de castigos eram aplicados

- Por que motivos eram aplicados os castigos

- Quem aplicava

- E a família? Ficava sabendo? Como reagia?

- Como a família participava da questão disciplinar na escola? Era convocada?

\footnotetext{
${ }^{587} \mathrm{O}$ roteiro foi dividido em duas partes. A primeira delas era destinada a todos (professoras e alunos/as) e tratava do curso primário. A segunda parte era específica para as professoras, tratando do período da Escola Normal, da Escola de Aperfeiçoamento (para aquelas que lá haviam estudado) e do percurso profissional.
} 
- Havia punições físicas?

- De que tipo?

- Já viu uma palmatória? Em que contexto?

- Sabia de outras escolas ou de alguma professora em que existiam punições físicas?

- Havia regras diferentes para meninos e meninas?

- Quem eram os mais levados, meninos ou meninas? Por que? Conte alguma indisciplina.

- As punições eram diferentes para meninos e meninas?

\section{Testes psicológicos}

- Como os alunos eram divididos em classes?

- $\quad$ Como era a colocação na sala de aula? Havia algum tipo de divisão? De que forma era realizada? (meninos/meninas, maiores/menores, etc)

- Havia testes? De que tipo? Quem aplicava? Como eram aplicados?

- Lembra-se de algum teste? Fale sobre.

- $\quad$ As famílias sabiam dos testes? Sabiam do resultado? O que achavam?

- Os alunos sabiam dos testes? Do resultado? O que achavam?

\section{Organizações escolares}

- Havia organizações escolares como Auditórios, Clubes de Leitura, Pelotão da Saúde?

- Como eram? O que faziam? Como eram compostos? E a participação dos/as alunos/as?

- Participou de algum? Em que período? Como foi?

- Na sua escola havia jornal feito pelos alunos? Como se chamava? Lembra da criação? Como era a participação dos alunos? Tem algum exemplar?

\section{Aulas de Educação Física ou Ginástica}

- Como eram as aulas?

- Havia professores especializados?

- Meninos e meninos faziam atividades conjuntas ou não?

- Havia diferenças entre as atividades para meninos e para meninas?

- Quais as atividades realizadas?

- Os alunos gostavam? Por que?

- Havia um uniforme específico?

- Como era?

$\bullet$

\section{Excursões}

- Havia excursões?

- Para onde?

- Como eram feitas?

- Os alunos iam com sua turma ou as turmas iam reunidas? 


\section{$\underline{\text { Religião }}$}

- Havia aulas de religião? Quem ministrava?

- Como eram as aulas?

- Havia alunos/as não-católicos? Como se lidava com a religião destes?

$\underline{\text { Avaliações }}$

- Como eram as avaliações?

- Havia muita reprovação?

- Como era a aplicação das provas?

$\underline{\text { Outras atividades }}$

- Havia aulas de trabalhos manuais?

- Como eram?

- O que faziam?

- Como eram feitos os objetos? De onde vinham os materiais?

- A produção era comercializada?

- Ouviu falar de Escola Nova? De que forma? O que era?

- E de Escola Ativa? Do que se tratava?

- Lembra dos livros utilizados? Quais?

- Como era a leitura e o acesso aos livros?

- De que forma esses livros influenciaram sua formação?

\section{ACRESCIMOS}

o Disciplinas mais importantes

o Disciplinas mais difíceis, mais fáceis, mais agradáveis.

o Professores mais difíceis e mais agradáveis.

Lembra-se de um fato marcante na Escola?

Conte sobre um fato ocorrido envolvendo o comportamento de alunos na escola. Você tem algum material deste período (fotos, cadernos, jornalzinho, livros deste período que você possa me mostrar).

\section{AUTORIZAÇÃO PARA USO MEU E DE OUTROS PESQUISADORES.}

O senhor tem algum tipo de restrição para a utilização desta entrevista?

Ela pode ser utilizada inteiramente ou em partes na pesquisa?

Ela pode ser utilizada em outras pesquisas minhas ou de outros pesquisadores?

As fitas podem ser disponibilizadas para outros pesquisadores? 


\section{PARTE II \\ COMPLEMENTAÇÃO DA ENTREVISTA PARA PROFESSORAS}

\section{ESCOLA NORMAL}

- Como você se tornou professor/a?

- Como foi para a Escola Normal?

- Tinha outra vocação?

- Como era a seleção?

- Em que escola estudou? Onde se localiza.

- Quanto tempo durava o curso?

- Quais foram os professores/as?

- Que impressão tem deles/as?

- Como era a convivência na Escola Normal? Com professores, diretores e colegas.

- Que disciplinas fazia?

- Era uma escola mista? Por que? Como era?

- Havia aulas práticas? Como? Quais? De que forma eram dadas?

- Ouviu falar de Escola Nova? De que forma? O que era?

- E de Escola Ativa? Do que se tratava?

- Lembra dos livros utilizados? Quais?

- Como era a leitura e o acesso aos livros?

- De que forma esses livros influenciaram sua formação?

Na prática

\section{Como era a disciplina na escola}

- Como os professores lidavam com a questão disciplinar?

- Que tipo de regras havia?

- O que podia e o que não se podia fazer?

- O que era bom e mau aluno?

- O que era um aluno disciplinado e um indisciplinado (características)?

- Que tipos de punições eram aplicadas?

- Por que motivos eram aplicadas punições?

- Quem aplicava?

$\mathrm{Na}$ teoria

- Como era discutida a questão da disciplina?

- O que se falava sobre?

- Em que disciplinas?

\section{Testes psicológicos}

- Como os alunos eram divididos em classes?

- Como era a colocação na sala de aula? Havia algum tipo de divisão? De que forma era realizada?

- Havia testes? De que tipo? Quem aplicava? Como eram aplicados? 
- $\quad$ Lembra-se de algum teste? Fale sobre.

- Os alunos sabiam dos testes? Do resultado? O que achavam?

Um fato marcante na Escola Normal.

Conte sobre uma questão da disciplina na Escola Normal.

\section{ESCOLA DE APERFEICOAMENTO}

- Como se deu a entrada na Escola? Concurso? Nomeação?

- $\quad$ Como era a seleção ?

- O que achava de ir para a Escola?

- $\quad$ Onde se localizava a escola?

- Quanto tempo durava o curso?

- Quais foram os professores/as?

- Que impressão tem deles/as?

- Como era a convivência? Com professores, diretores e colegas.

- Que disciplinas fazia?

- Era uma escola mista? Por que? Como era?

- Havia aulas práticas? Como? Quais? De que forma eram dadas?

- Ouviu falar de Escola Nova? De que forma? O que era?

- E de Escola Ativa? Do que se tratava?

- Lembra dos livros utilizados? Quais?

- Como era a leitura e o acesso aos livros?

- De que forma esses livros influenciaram sua formação?

Na prática

\section{Como era a disciplina na escola}

- Como os professores lidavam com a questão disciplinar

- Que tipo de regras havia

- O que podia e o que não se podia fazer

- O que era bom e mau aluno

- O que era um aluno disciplinado e um indisciplinado (características)

- Que tipos de punições eram aplicadas?

- Por que motivos eram aplicadas punições?

- Quem aplicava?

$\mathrm{Na}$ teoria

- Como era discutida a questão da disciplina?

- O que se falava sobre?

- Em que disciplinas?

\section{Testes psicológicos}

- Como os alunos eram divididos em classes?

- $\quad$ Como era a colocação na sala de aula? Havia algum tipo de divisão? De que forma era realizada?

- Havia testes? De que tipo? Quem aplicava? Como eram aplicados?

- Lembra-se de algum teste? Fale sobre. 
- Os alunos sabiam dos testes? Do resultado? O que achavam?

Um fato marcante na Escola Normal.

Conte sobre uma questão da disciplina na Escola normal.

\section{VIDA PROFISSIONAL}

- Quando e onde trabalhou?

- Cargos

- Escolas

- Houve mudanças na Escola Nova durante o Estado Novo?

- A questão da disciplina na escola

- Regulamentos escolares

- Relação com a família

- Como se lidava com crianças rebeldes?

- O que era considerado indisciplina?

- Algum professor usava de forma mais consistente da punição?

- Como eram punidos os comportamentos indesejáveis?

- A família era chamada?

- Com que objetivo?

- A família reclamava das punições aplicadas na escola?

- A escola era mista? Como era?

O uso dos testes escolares

- Que testes?

- Quem aplicava?

- Resultados. Quem os recebia? Família, alunos ou somente a escola?

\section{LEITURAS}

A Revista do Ensino

- Conheceu a Revista?

- Como ela circulava (era comprada em bancas, era entregue em casa, na escola?)

- Lia-se com freqüência? Que artigos? Havia uma seção mais importante, mais lida?

- Recomendava-se a leitura? Onde ela era feita? Em casa, na escola? De que forma?

- Utilizavam-se seus artigos na escola? De que forma?

- A Revista era importante? De que forma?

- Publicou na Revista?

Outras leituras

- Lia outras Revistas? Quais? Como era o acesso a elas? Eram compradas, consultadas em bibliotecas? Quais? De que forma?

- Livros lidos? Lembra-se de algum? Eram comprados ou retirados em biblioteca?

- Qual a importância dessas leituras? 


\section{ATO DE AUTORZZACÃO}

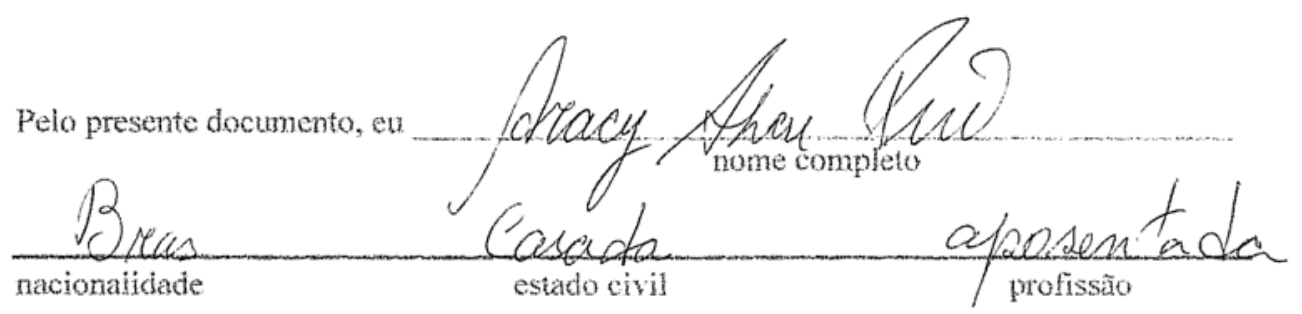

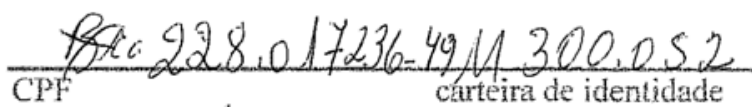
emitido por

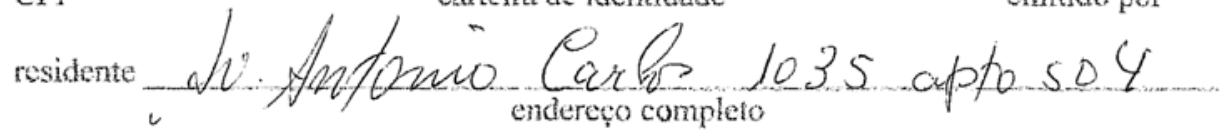

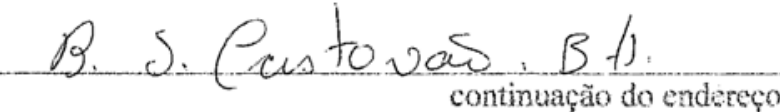

declaro ceder, sem quaisquer restrições quanto aos seus efeitos patrimoniais e financeiros, a plena propriedade e os direitos autorais do depoimento de caráter histórico e documental que prestei à pesquisadora Rita de Cássia de Souza, estudantó de doutorado da Faculdade de Educação da Universidade de São Paulo na cidade de Belo Horizonte, em $20-10-2064$ Autorizo a utilizar, divulgar e publicar o mencionado depoimento no todo ou em parte, bem como permito a terceiros o acesso ao mesmo para fins de pesquisa, resguardada sua integridede e a indicação da fonte e do autor.

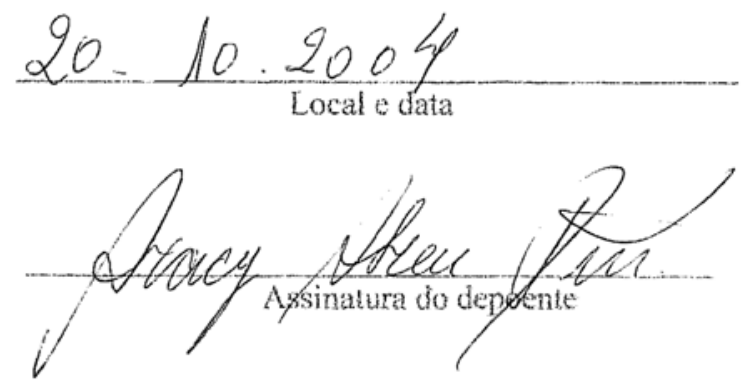




\section{ATO DE AUTORIZAÇÃo}

Pelo presente documento, eu Elza de Wioura nome completo

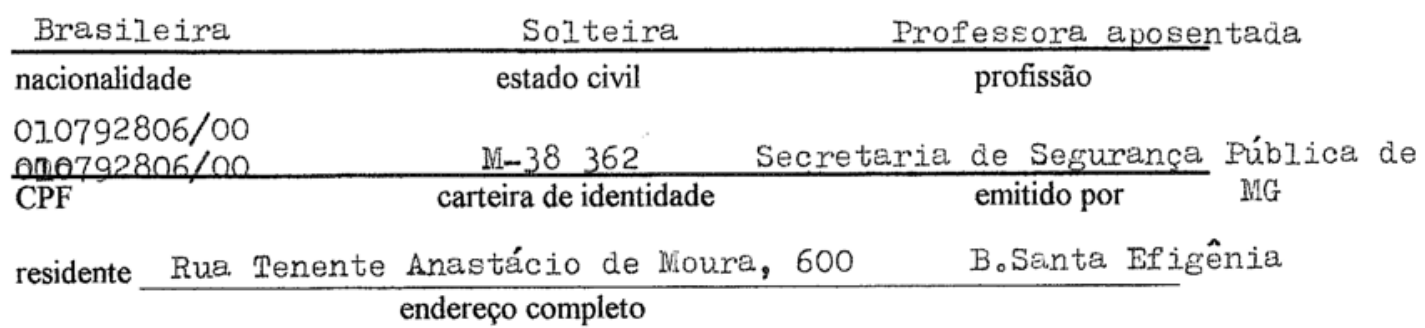
declaro ceder, sem quaisquer restrições quanto aos seus efeitos patrimoniais e financeiros, a plena propriedade e os direitos autorais do depoimento de caráter histórico e documental que prestei à pesquisadora Rita de Cássia de Souza, estudante de doutorado da Faculdade de Educação da Universidade de São Paulo na cidade de Belo Horizonte, em Autorizo a utilizar, divulgar e publicar o mencionado depoimento no todo ou em parte, bem como permito a terceiros o acesso ao mesmo para fins de pesquisa, resguardada sua integridade e a indicação da fonte e do autor.

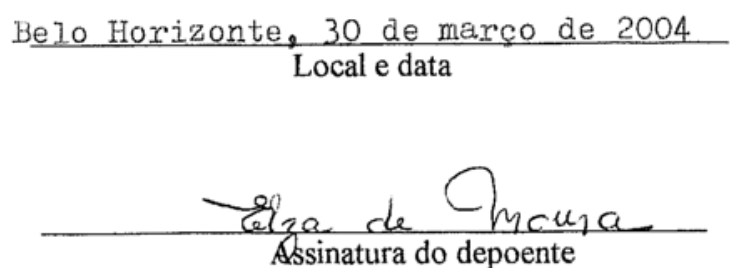




\section{ATO DE AUTORIZAÇ̃̃o}

Pelo presente documento, eu GERALDOFELIX DE TESUS

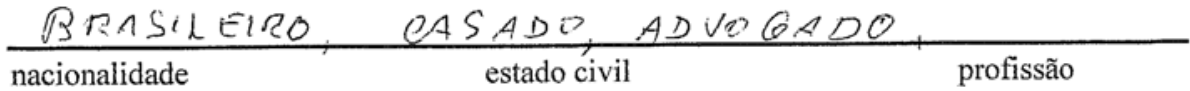

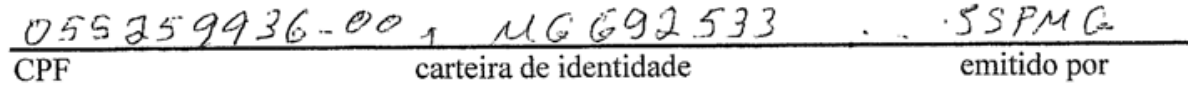

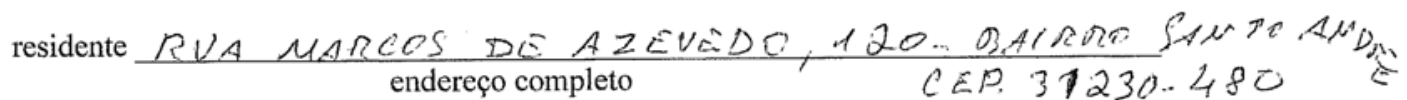
declaro ceder, sem quaisquer restrições quanto aos seus efeitos patrimoniais e financeiros, a plena propriedade e os direitos autorais do depoimento de caráter histórico e documental que prestei à pesquisadora Rita de Cássia de Souza, estudante de doutorado da Faculdade de Educação da Universidade de São Paulo na cidade de Belo Horizonte, em 1 DEABR/L DE 2004 . Autorizo a utilizar, divulgar e publicar o mencionado depoimento no todo ou em parte, bem como permito a terceiros o acesso ao mesmo para fins de pesquisa, resguardada sua integridade e a indicação da fonte e do autor.

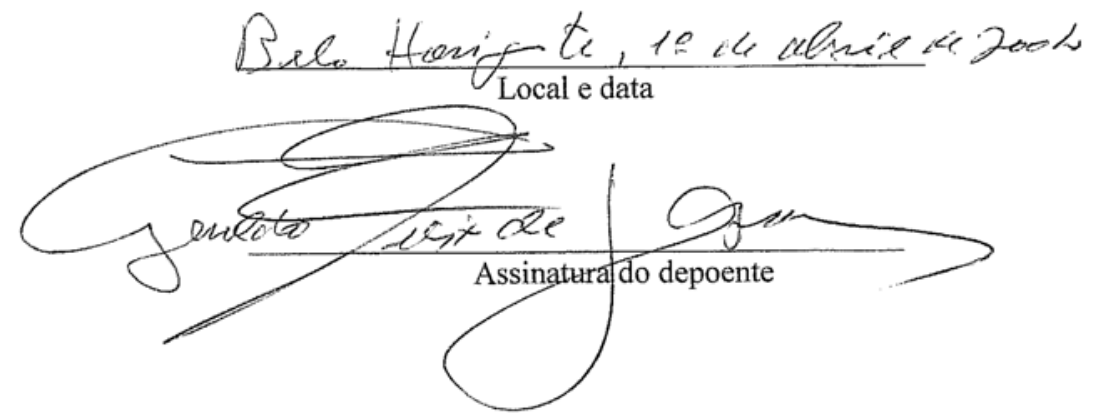




\section{ATO DE AUTORIZAÇ̃̃o}

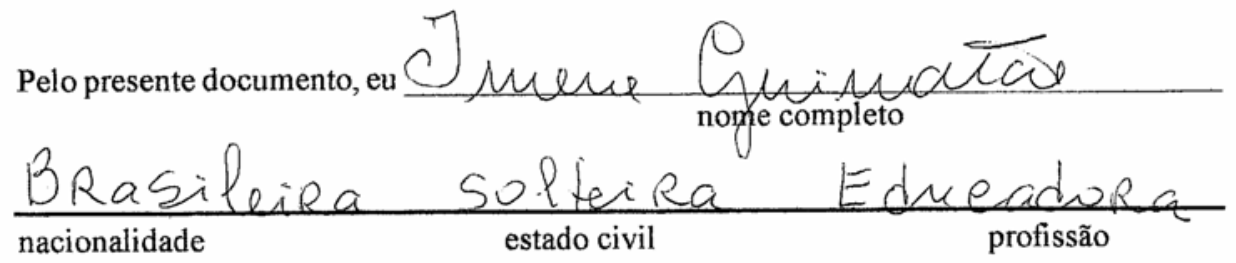

$\frac{00067229620 \quad M-89143 \text {-Seeretaria de Se- }}{\text { CPF }}$ fupanea Püblica Rua Montes Paros-828. Anehiets Belo Horisonte endereço completo

declaro ceder , sem quaisquer restrições quanto aos seus efeitos patrimoniais e financeiros, a plena propriedade e os direitos autorais do depoimento de caráter histórico e documental que prestei à pesquisadora Rita de Cássia de Souza, estudante de doutorado da Faculdade de Educação da Universidade de São Paulo na cidade de Belo Horizonte, em 06 de abil de 2004 . Autorizo a utilizar, divulgar e publicar o mencionado depoimento no todo ou em parte, bem como permito a terceiros o acesso ao mesmo para fins de pesquisa, resguardada sua integridade e a indicação da fonte e do autor.

$$
3 \text { elo Horizonte, } 6 \text { de } 7 \text { brilde } 1904
$$

Local e data

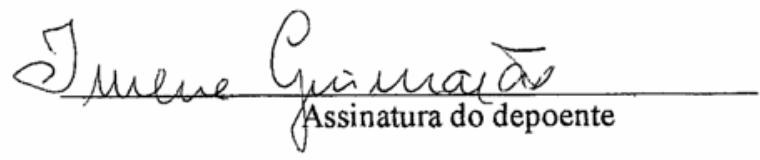


758

ATO DE AUTORIZAÇÃO

Pelp presente documento, su Jose Fermal Bicelho

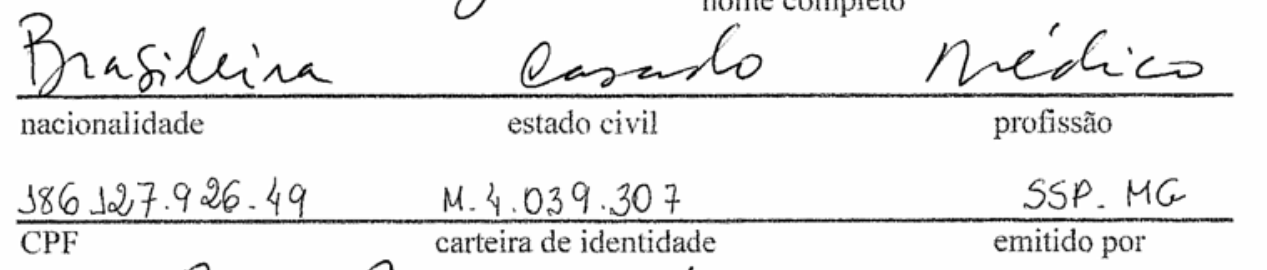

residente Prue Pains $35 / 1201$

continuação do endereço

declaro ceder, sem quaisquer restrições quanto aos seus efeitos patrimoniais e financeiros,

a plena propriedade e os direitos autorais do depoimento de caráter histórico e documental

que prestei à pesquisadora Rita de Cássia de Souza, estudante de doutorado da Faculdade

de Educação da Universidade de São Paulo na cidade de Belo Horizonte, em

$2 / 9 / 04$

Autorizo a utilizar, divulgar e publicar o

mencionado depoimento no todo ou em parte, bem como permito a terceiros o acesso ao

mesmo para fins de pesquisa, resguardada sua integridade e a indicação da fonte e do

autor.

BeloHorizonte, 2/9/04

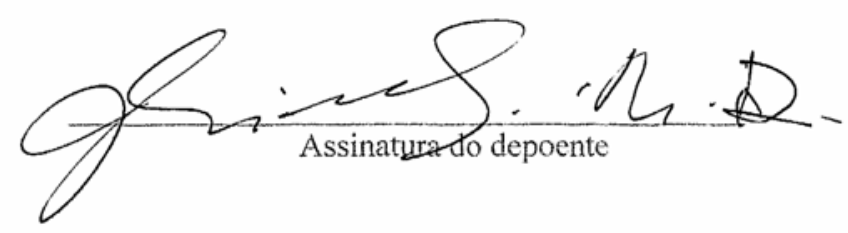


Peio presente documento, cu Saria fparecida Qrindade Pantor $\frac{\text { brasilira, riúva, professora aposentada }}{\text { nacionalidade }}$

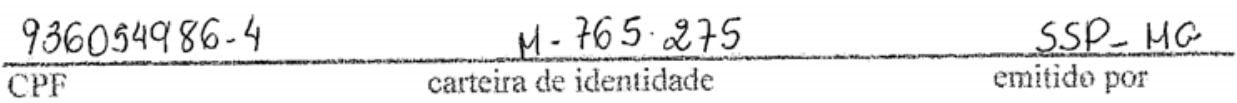
residente rua Trofessov Dincoln bontinentino n' 10 apto 201. bairuo Qidade Mova. Belo Horizonte. Mg. declaro ceder, sem quaisquer restriçóes quanto aos seus efeitos patrimoniais e financeiros, a plena propriedade e os direitos autorais do depoimento de caráter histórico e documental que prestei à pesquisadora Rita de Cássia de Souza, estudante de doutorado da Faculdade de Educação da Universidade de São Paulo na cidade de Belo Horizonte, em 21 de dezembo de 2004 . Autorizo a utilizar, divulgar e publicar o mencionado depoimento no todo on em parte, bem como permito a terceiros o acesso ato mesmo para tinns de pesquisa, resguardada sua integridade e a indicaçăo da fonte e do autor.

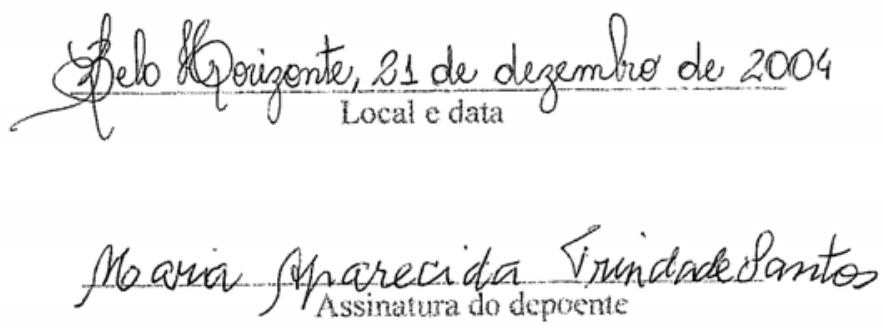




\section{ATO DE AUTORIZAÇÃO}

Pelo presente documento, eu forma Lencia folemente $\frac{\text { Brasiteira Divoreiada }}{\text { nacionalidade }} \frac{\text { yposentade }}{\text { profissão }}$ \begin{tabular}{lll}
$0.48514716 .53 \quad M G .700 .855$ & $S$ SP \\
\hline CPF & carteira de identidade
\end{tabular} residente Pra Araxá $468 / 401$ - Baino bagoinha declaro ceder, sem quaisquer restrições quanto aos seus efeitos patrimoniais e financeiros, a plena propriedade e os direitos autorais do depoimento de caráter histórico e documental quie prestei à pesquisadora Rita de Cássia de Souza, estudante de doutorado da Faculdade de Educação da Universidade de São Paulo na cidade de Belo Horizonte, em 02-0.2004. Autorizo a utilizar, divulgar e publicar o mencionado depoimento no todo ou em parte, bem como permito a terceiros o acesso ao mesmo para fins de pesquisa, resguardada sua integridade e a indicação da fonte e do autor.
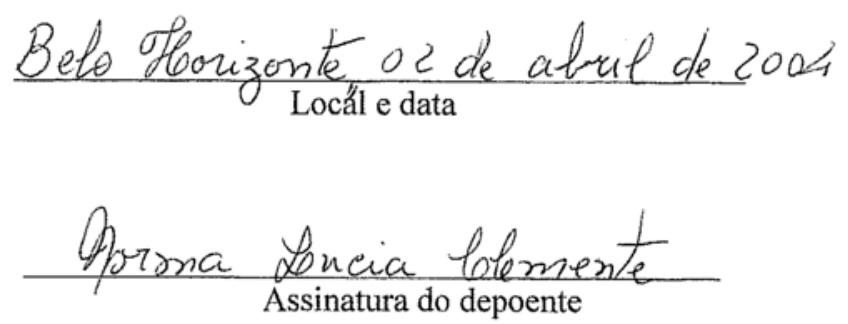
"NÃO PREMIARÁS, NÃO CASTIGARÁS, NÃO RALHARÁS..." dispositivos disciplinares em Grupos Escolares de Belo Horizonte (1925-1955)

\section{DOCUMENTOS APRESENTADOS PELA} ENTREVISTADA

ELZA DE MOURA 
Roteiro de entrevista para a profa Rita de Cássia de Souza.

Elza de Moura

04/08/15 - Solteira - Superior - Professora aposentada

2 A ISCOLA PRTIRRIA

Entrei para o grupo escolar, aos 6 anos de idade, no Henrique Diniz, no Bairw ro Santa Efigênia, construída em uma chácara, com excelentes professoras, com classes mistas, recreio bom gozado. Só havia separação de alunos nas aulas de trabalhos manuais: as meninas ficavam na sala bordando, e os meninos iam para o curso técnico fazer carpintaria e outros trabalhos。 Un dos fatos marcantes eram a distribuição de mangas aos alunos à hora da saída. As carteiras eram colocadas uma atrás da outra. As meninas se sentavam com meninas e os meninos com meninos. Quanto aos materiais, eu só me lenbro dos bons livros de leitura. 0 uniforme era obrigatório. 0 nome da diretorado meu tempo foi a notável professora Do Zélia Rabelo.

Quanto à disciplina, era a de todos o grupo escolara respeito às professoras. Não me lembreo de nenhum caso grave de indisciplina. hs regras eram as comms de respeito e estudo. Os castigos eram ficar depois da aula, ir para o gabinete da diretora. A causa para esses castigos era a quebra das regras: falta de estudo, maj̧criação, briga entre colegas. Em geral era a professora da classe que aplicava o castigo, quando mito grave, envolvian a diretora e a família. Quencio necessário, a família era chamada ao grupo. Quanto às punições físicas, a professora costumava aplicar um puxão de orelha, um beslicão, um te tapa, mais de advertência do que para machucar. Munca vi palmatória no grupo escolar, só viNconhecê-la em exposição pedagógica. Dar reguada era bem comum, em qualquer escola. Se havia regras diferentes para meninos e meninas, era questão da prófessora. Levados havia meninos e meninas. Tanto "pintava" uns como os outroś.

Testes psicológicos - no meu tempo não havia. Isso veio muito depois, com a Escola de Aperfeiçoamento. Não me lembro de nenhuma organização escolar.

Haviam, sum, aulas de educação física e canto, nũo sei se a de cinástica era es especializada, só sei que a de canto sabia tocar piano. A meninada gostra dessas aulas e não havia uniforme específico para a educação física,brcursões sempre houve, não me lembro de suas organizações。

Havia aulas de religião, dadas por uma professora escolnida, os não católicos ñ̃o frequentavam essas aulas。

Havia as provas finais, não me lembro das mensais. Havia reprovação, sim, com justiça: quem não estudava não passava. A coisa era séria, e as crianças do meu tempo saiam muito bem preparadas do 49 ano d do grupo escolar。

Nas aulas de trabalho manuais as meninas aprendiam uma variedade interessante de bordados, bainhas, ponto de cruz, ráfia. Os meninos trabalhavam no curso técnico com um professor só para eles, com carpintaria. Os trabalhos não eram comercializados, eram das alunas, e o material era trazido de casa. Os livros de leitura eram os de Erasmo Braga, Thales de Andrade, Jão Kopke, Bilac e Bonfim e muitos outros. A minha formação teve grande influencia do livro de Leitura de Olavo Bilac e Manuel Bonfim, uma antologia que nos punha em contato com os grandes escritores do Brasil e do mundo.Foi una revelação, Não me lombro de professores difíceis e nem de alguma discippina desagradável. Esse período de minha vida é muito remoto e não tenho nenhum material desse tempo, só as boas lembranças.

$$
\begin{aligned}
& 29 / 03 / 2004 \\
& \text { sefiza de Qnouna }
\end{aligned}
$$


O roteiro é nuito extenso, abraçando uma longa vida profissional e de estudos e, nem sempre, a memória ajuda。

E interessante enfrentar uma longa entreviatr desse tipo porque vamos nos lembrando de muita coisa que estava esquecida.

A profa Helena Antipoff aconselhava o diário, e as nossas alunas da antiga Escola Mormal Rural, da Fazenda do Rosário, apresentaval, todos os dias, os diários, lidos à hora das refeições。 O interessante era a evolução desses trabalhos, no prinícpio, pobre, depois, com o exercício, ficavam muito ricos, tanto na literatura, como nas observações dos acontecimentos. Mitos desses diários ainda existem e são objetos de estudo. No progresso na escrita desses diários é que vemos a certeza dos ensinamentos da profa Iúcia Casasanta sobre a prática da composição diária. t o processo mental sendo usado e desenvolvido, sem sofrimento e naturalmente。

Iamentável é que o professorado de hoje não pratica porque não conhece - ensino da composição (redação)。 o que existe é a produção de textos, como se escrever dependesse de oficinas, de regras, etc.

Isso é apenas um desabafo $e_{9}$ se fosse responder ao roteiro completo, poderia sair um Iivro.

Sobre a Escola Normal, deixo para depois, na entrevista.

Estou enviando material sobre o assunto. od da profa Ana Maria Casasanm ta Peirote é muito importante。

Espero que goste.

Unn abraço da

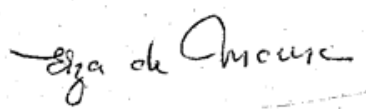

Belo Horizonte, 30 de março de 2004

Frofessora Rita de Cássia de Souza.

Despejei essas notas sobre o papel, Iivremente, sem pensar muito. Quando escrevo sobre qualquer assunto, sempre faço assim. Se a gente pensa muito, a naturalidade fica prejudicada.

Desejo que as suas pesquisas sobre a sua tese estejam bem encaminham das. Não é fácil catar documentos e depoimentos, mas o difícil é que tem graça. Goethe já falava sobre isso。

Um bom dia, Elzc 


\section{EM 19/03/2,001 \\ Saudades do meu grupo escolar \\ 'ELZA DE MOUIA \\ 'Prufrssora aposcutati \\ "A escola era risonha $\mathrm{e}$ franca"...}

No meu tempo de crianca, a minha escola era risonha e franca, embora o respeito pelas pro'fessoras fosse muito grande. Mas esse respeito 'não impedia o riso e a liberdade; e o espaço lar'go, as árvores robustas faziam o nosso cotidiaino na escola. I: havia segurança no nosso viver. : E tínhanos aulas de canto, de ginástica, de trabalhos manuais. I) Ilinário Fscolar saiam os cânticos da P'ilria o mesmo sion ententler bem as palavrats, o ratuto mos empelgiva:

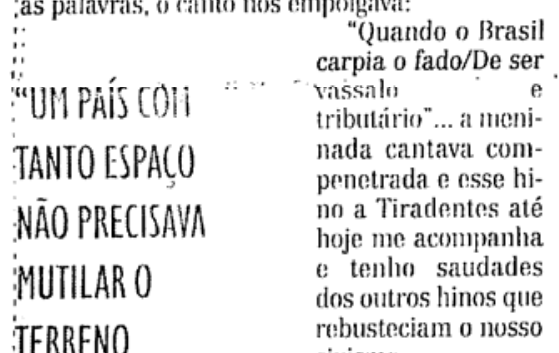
civismo.

\section{DAS ESCOLAS"}

() nosso grupo escolar estava dentro de umma chácara. Será que as crianças ide hoje, estudaudo em salas abarrotadas, confiinadas em pátios pequenos na hora do recreio 'potlem imaginar uma chácara contendo tuma escola?

- Os meninos de hoje podem pensar na criançada dos grupos escolares brincando de roda, de pião, de passa-passa, gaviāo o todos aqueles 'brinquedos de outrora em lugares espaçosos e 'seguros?

Nas aulas de trabalhos manuais, as meninas bordavam, fiziam bainhas artísticas, crochê...

Os meninos iam para a sala do curso técnico e, na carpintaria. produziam lindos brinquedos de mardeira Fuçuiunion as mãos trabalhavam, o cérebro já tinha imaginado a peça que ia sendo pro'duzida

Com tanlas mangueiras o laranjeiras, a tentacão era muita e a gente acaluava surrupiando al'guma fruta. Firil pura peraltice porque as frutas 'eram destinadas aos alunos. Maduras, postas em grandes latas, eram distribuídas à meninada, à hora da saída.

Que saudado!! Até a construçāo do meu antigo igrupo escolar foi modificada e aquele ar de fazenda velha foi modernizado. A chácara encoitheu. dividida, ruas abertas no lugar do arvoredo. Um país com tanto espaço não precisava mutilar o terreno das escolas, yue se tornaram apertadas, sem jardius, sem pátios arluorizados. E as brincadeiras, pripprias de grandes espaços, tornaram-se impraticáveis.

Que pena! A criança de hoje entre quatro pa'redes, imobilizada, vendo TV.

\author{
EM 24/04/2,001 \\ s \\ io

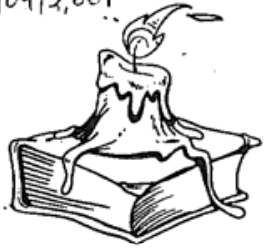 \\ I LITERATURA II \\ BH ainda tem \\ bons livreiros

\section{Elza de Moura} \\ Belo Horizonte \\ "Li, dia desses, no EM, \\ reclamaçōes de leitores sobre \\ vendedores de livros mal \\ preparados para a função. \\ Quero dizer que há ainda em \\ $\mathrm{BH}$ livreiros dos bons tempos, \\ conhecedores do mundo dos \\ livros, de prosa agradável $\mathrm{e}$ \\ culta. Entre livreiros e \\ vendedores de livro com gente \\ gabaritada podemos citar a \\ Minas Gerais, de livros \\ técnicos e outros, com equipe \\ de grande conhecimento, onde \\ sentimos a ausência do \\ falecido Moacir; na mesma \\ 1. rua Espírito Santo, há a \\ Livraria Moderna, do senhor \\ Roberto, onde existe até um \\ banquinho para uma boa \\ prosa com o livreiro \\ experimentado; e ninguém \\ pode esquecer o traquejado \\ Sabino, de longos anos no \\ trato com os livros, na Livraria \\ Villa Rica, na Floresta, perto \\ a da Escola Barāo de Macaúbas. \\ Já para quem gosta de um \\ I cafezinho, há o Café Book, na \\ Padre Rolim, pertinho da \\ e avenida Brasil. 0 livreiro, \\ Álvaro, conhece bem 0 mundo \\ das letras. Se alguns \\ vendedores da nova geração \\ deixam a desejar, é possivel \\ ainda encontrar simpatia, \\ cultura, boa vontade e um \\ bate-papo gostoso sobre \\ autores e obras. Porque \\ concordo que o trato com 0 \\ a livro requer amor."
}




\section{Museus na educação e cultura de Minas}

"..A IMPORTÂNCIA
DOS MUSEUS É
decisiva na vida
de um povo..."
ELZA dE MouRA*

Há pouco o ESTADO DE MINAS fez uma sondagem com o povo a respeito dos museus de Belo Horizonte e muitos não sabiam da existência deles, revelando ignorância, desinteresse e distanciamento. De quem a culpa? De todos nós: do governo, da familía e, principalmente, da escola.

Em Belo Horizonte há vários museus, além das exposições comemorativas de algum acontecimento histórico ou cultural. Vale lembrar a mostra sobre os holandeses no Brasil e o mais recente sobre as bravas gentes brasileiras. Essas exposições deveriam ser transformadas em museus e assim contribuindo para diminuir a nossa ignorância e a nossa indiferença pelas nossas coisas.

Visitando a exposição "Bravas Gen-

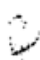

tes Brasileiras" e encantada com tanta riqueza do material apresentado, fui surpreendida com um par de óculos e logo abaixo a carteira de identidade da professora Helena Antipoff. Esses dois simples objetos me comoveram profundamente e fiquei pensando na grande mestra que veio de tão longe para marcar a educação em Minas. Mergulhada nesses pensamentos, ouço alguém perguntar: "Você sabe quem foi Gustavo Capanema?" Voltando ao presente, vejo um grupo de adolescenies, de caderno nas mãos, anotando. Não resisti e me intrometi: "Quem ś que perguntou sobre Gustavo Capanema? Vocês não sabem quem foi esse grande homem?" E esclareci 0 assunto. Não sei a que escola pertenciam esses alunos, mas o conhecimento deles sobre nossa história era nulo. E 0 assunto Capanema estava sendo muito focalizado pela imprensa, pois comemorava-se o seu centenário de nascimento.

A importância dos museus é decisiva na vida de um povo. Pais e professores deveriam constantemente levar seus filhos e alunos a visitá-los, mas visitas inteligentes que provocassem curiosidade, que levaria à procura de

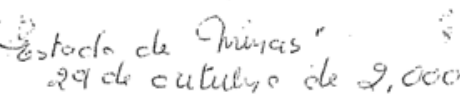

outras informações, um nunca acabar de enriquecimento. E o interesse não morreria no fim da visita, mas seria continuado.

Em Belo Horizonte há vários museús, cada um com seu material próprio. Um deles é o do Centro de Referència do Professor, na antiga Secretaria da Educação (Praça da Liberdade), que conta a história da educação em Minas, faz-nos voltar ao passado: móveis, fotos, documentos, material didático usado nos nossos grupos escolares e até uma palmatória, objeto clesconhecido hoje, está lá, felizmente posto de lado para felicidade da meninada.

Comemorando, agora, os 70 anos da Secretaria de Estado da Educação, sua história está sendo contada através do Museu do Centro de Referência do Professor e, nesses longos anos, a educação em Minas mostra a sua força. Nosso Estado tem tradição cultural. As crianças, os jovens e adultos precisam conhecer essa história. É questão de honra para a nossa sociedade.

\footnotetext{
*Professora aposentada como diretora de ensino fundamental e professora de ensino médlo
} 


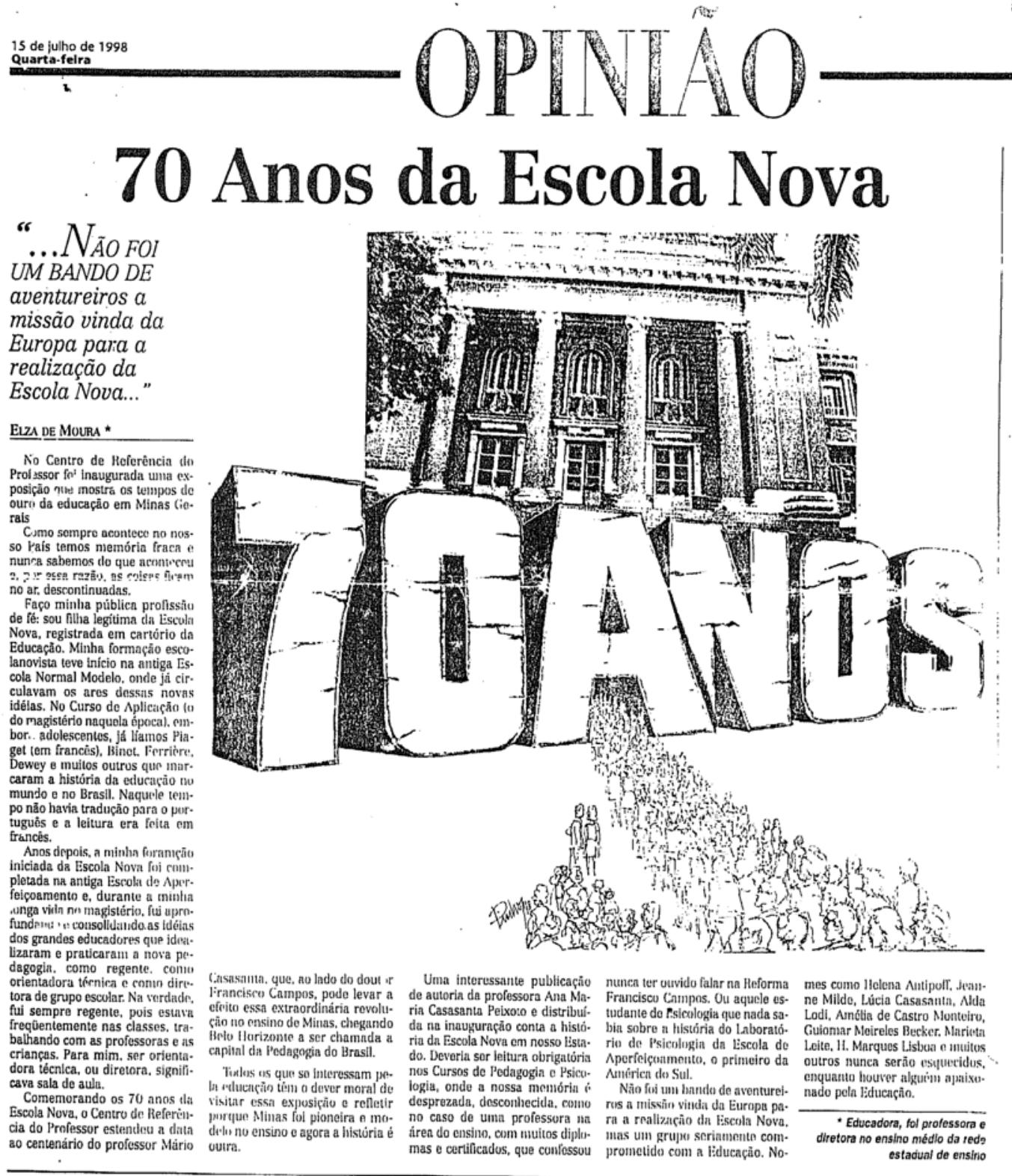




\section{IMPRESSO}

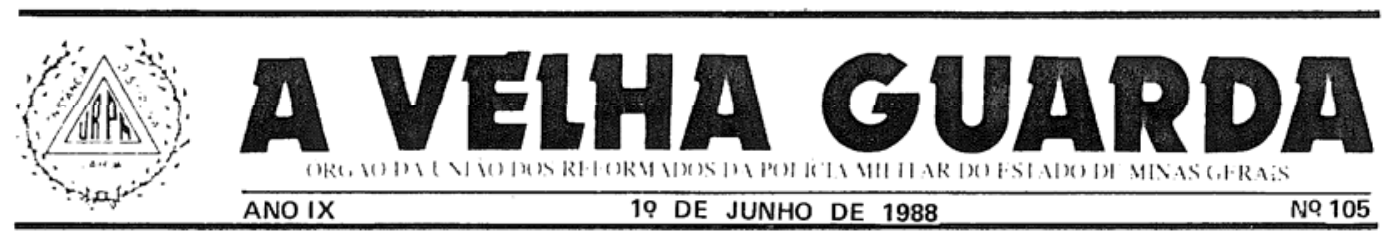

\section{A POLÍCIA MILITAR E OLAVO BILAC}

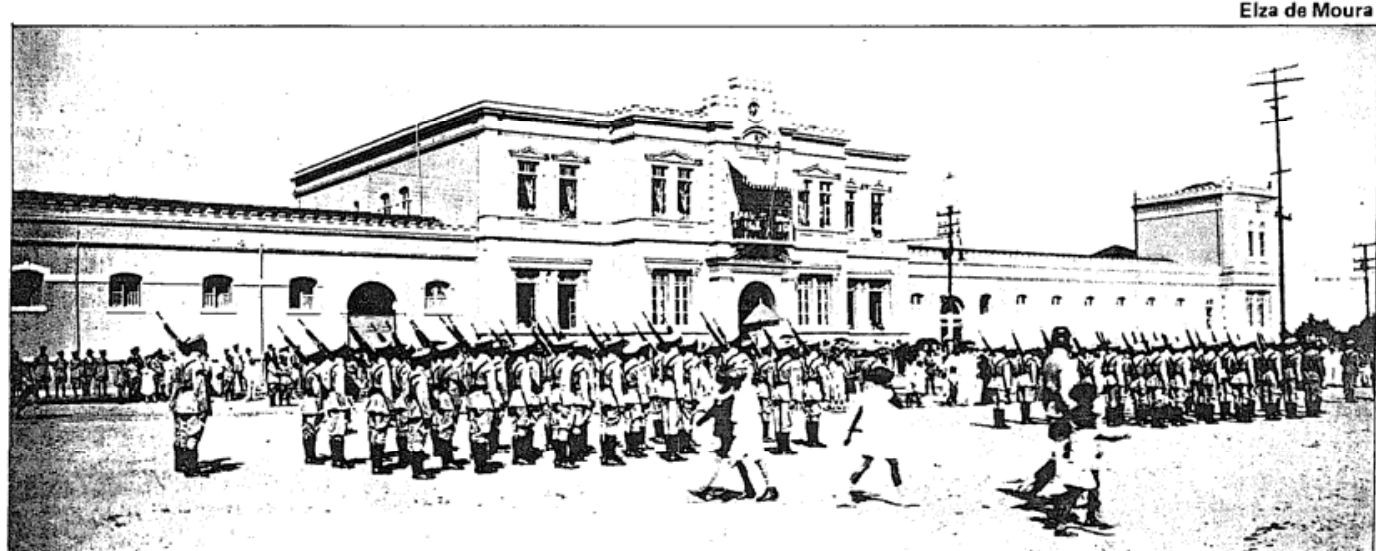

Quando eu trabalhava no Grupo Escolar "Henrique Diniz", como orientadora técnica, lá encontrei um corpo docente cheio de entusiasmo, contagiando os alunos.

Em prédio novo, a saudade bate à nossa porta, lembrando a ve. tha construção, uma das mais tradicionais da cidade, parecendo uma fazenda mineira, cercada de jardins e pomares.

Veio o chamado "progresso" e tudo foi destruido, inclusive uma fonte no jardim, que deveria ser conservada, como um memo. rial. E mais uma vez foi embora a memória nacional. A chácara foi desmembrada, a Av. Churchil rasgou o verde, pondo abaixo mangueiras vetustas, laranjeiras com sabiás e muitas laranjas.

O antigo Grupo Escolar "Henrique Diniz" podia se orgulhar de ter abrigado em suas salas nomes notáveis do ensino em Minas: Inácia Guimaräes, Zélia Rabelo, as irmãs Luisa e Benedita Valadares, Zorái da Moura, Anita Santa Cecília, Aracy Brandão, Hebe Renault e muitas outras professoras ilustres que a nossa lembrança não esquece.

0 culto à língua pátria, ao civismo, à responsabilidade eram fatos e não ficção pedagógica.

Quantos militares de Santa Efigênia passaram pelo "Henrique Diniz"? O Cel. Décio Pereira da Silva, presidente da URPM, foi um deles.

No meu trabalho de orientação técnica no "Henrique Diniz", aproveitando o grande interesse dos alunos na cultura geral, costumava apresentar, quinzenalmente, três questöes variadas. $\mathrm{E}$ a curiosida. de das crianças era tảo grande que envolvia até a família.

Lembro-me de uma das perguntas: Por que a Bandeira da Cruz Vermelha é a da Suiça, mas com as cores trocadas?

$\mathrm{O}$ interesse foi tão forte sobre a pergunta que um aluno, com a ajuda do pai, fez um trabalho completo sobre Henri Dunant.

Mas o que nos interessa aqui foi a presença do quartel do $1^{\circ}$. Batalhäo para resolver uma dessas perguntas: Por que é comum em quartel o retrato de Olavo Bilac, o príncipe dos poetas brasileiros, e que não fci militar?
Quando discutiamos os resultados dos trabalhos de pesquisa, ficava sabendo das minúcias para a solução das perguntas. $\mathrm{O}$ caso de Bilac levou um grupo de crianças ao quartel do 10 : Batalhăo. Chegan do à porta, perguntaram à sentinela se no quartel havia um retrato de Bilac.

E a sentinela respondeu que não sabia.

Quando apresentei essa pergunta, assegurei às crianças que no quartel, no salão nobre, havia um magnífico retrato do poeta. Esse retrato o vi quando trabalhei com éscoteiros, lobinhos e fadas, no referido quartel.

A sentinela não esclareceu, mas as crianças ficaram sabendo toda a história de Bilac, o campeão do serviço militar, o incentivador do escotismo, enfim, um poeta a serviço do civismo.

Não sei se esse retrato ainda existe no salão nobre do $1^{\circ}$ Bata Ihão. Parece que a nossa História anda esquecida, e o fervor cívico desapareceu, restando apenas a lembrança daqueles bons tempos do grupo escolar.

E Olavo Bilac, exemplo de patriotismo, bem que poderia ser evocado, como naqueles tempos em que as crianças recitavam: "Ama com fé e orgulho a terra em que nasceste". E, hoje, mais do que nunca, quando a nossa lingua é tão maltratada, precisamos o do respeito: "Úlnima flor do Lácio, incultatada, precisamos ouvir, respeito: "Ultima flor do Lácio, inculta e bela". E na crise moral dos
nossos dias, Bilac nos acena:

'Nem sempre durareis, eras sombrias

De miséria morall $A$ aurora esperas,

O Pátria! e ela virá, com outras eras.

Outro sol, outra crença em outros dias.

$E$ mais adiante, deseja o poeta:

"As nobres ambições, força e bondade,

Justiça e paz virão sobre estas zonas,

Da confusa fusão da ardente escória..."

E assim seja, desejamos nós! 


\section{0 ensino rural foi ignoradc}

“..A REFORMA

AGRÁRIA SÓ SERÁ

vitoriosa

acompanhada

da educação..."

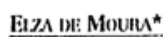

A nova Le: de Diretrizes e Basos da Educaçäo National (I.DBEN) dedica poucus linhias ao ensino rural. $\Lambda$ população çẫo esperial. Mesta-noś a esperança da regulamentaçâo do artigo 2

Ilá várius tipos de zonas rurais con suas características particulares, sua produchán a as atividades agricolas, en"Ssn razín, a cescola tem que ter o seu cor lendirlo prticular. $\mathrm{a}$ a cducoza tem que estar volunda para todos esses aspectos.

Us politicens de Brasilia devem pensa (qute o millon, of feijio, 0 arroz nascem no isfialto e que das sintusidades das rodosias vem o leite. Arnold Toynbee proclama: " $\Lambda$ ngritculturn a a criacaio de animais forratil, cam certrza, as mais importantes de toxlas as invençiōes humanas ató hoje".

$\wedge$ formação do profiessor rural tem que difierir da formaçân do profiessor urbaum. F: Maru four hri as linhlas gorais pa-

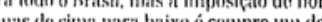
serste (y)

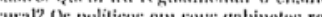

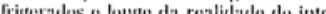
rior hrasileines?

lonstaria

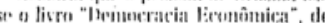
Prahhal llanjan Sarkar filosofo himdu, comm os pis nia terrai. A ludia tem problemass srmellamters ans mossos: fome, desemprego, analfahetismo e corrupcão, - mas o escritor-filósofo sugere solucōes introlighutes o simples para essers proble-

No brasil hii milharess die proferssoras

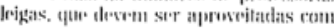

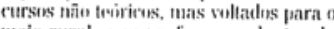
imeio rural, coun professores tentro da

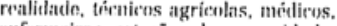
Isso ji foi realizado com extraordinário Oxito An lizenda

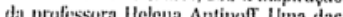
mons a do cuancen

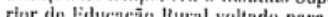
furmacio do profeser do com a 'gento desse meio. Se for enviada para ensinar na roça uma profossora de cidade, formada em curso superiur do Pedagogia, será um erro. Essa professora com posco ou nenhum conheciment mana para voltar à cidade com seus shoppings" mo mestra será duvidosa

Conheço livros que o MEC distribuiu à ccolas rurais sem nenhum apelo telúr co. São livros para escolas de cidade. Por quo nấo se reeditar a coleção de Tales do Andrade? Por que sấo desconhecidos os livros de Motta Prego, de Amadeu do Queiroz nas nossas escolas rurais? 0s Itvros de Tales de Andrade, Vida na Roça. Saudade e outros sảo indispensáveis, despertando e aumentando o amor à terr. Tales de Andrade fol ecologista antes do tempo e sua série "Encanto e VordaJus para tincia dos temias, o autor sabe dimporgungem elevada, o autor sabe usar lincriança a gostar de ler. É um crime a não recdicĩo dessas obras que deveriam se Spalhadas pelas escolas rurais de todo Brasil. Seria atitude patriótica, educativil, além de despertar o gosto pela boa literatura

população do campo pode e deve ter cultura, conforto, ser valurizada e assim não sairá de lá para inchar as cidades com Tavelas. Lomos que alguns prefeitos do Minas estấo de:sejando os MST porquin, assentados, estẫo produzindo $\theta$ a Comdo as rendas do municipin. Com essa mania de modernidade sem

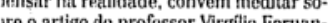
les Alumidn yue,

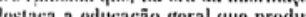

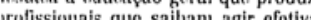
urnte nos novos tempos, atravís da lit ratura artes, flosof (ESTADO DE MINAS de 13/02), 0 livro nẫo pode s substituito por míquina bill pode ser dor do computor, confesso: "Os, crin(thos terio am, computador "Os meus ins terĩn livros". lim zona rural, set mertia eletricta para que Antes da míquina precisamos fazer do homem um bom animal, como queris Etmerson.

No mis 4/02, lemos artigo de Joåo Cláudio Todorov, sobre $A$ agricultura familiar $e$ educaça. A agricultura fanillar é im. portantissima na zona rural. $A$ reforma da educacâa.

'Especlallsta em educação, co-fundadora da antlga Escola Normal Rural da Fazenda do Rosárlo

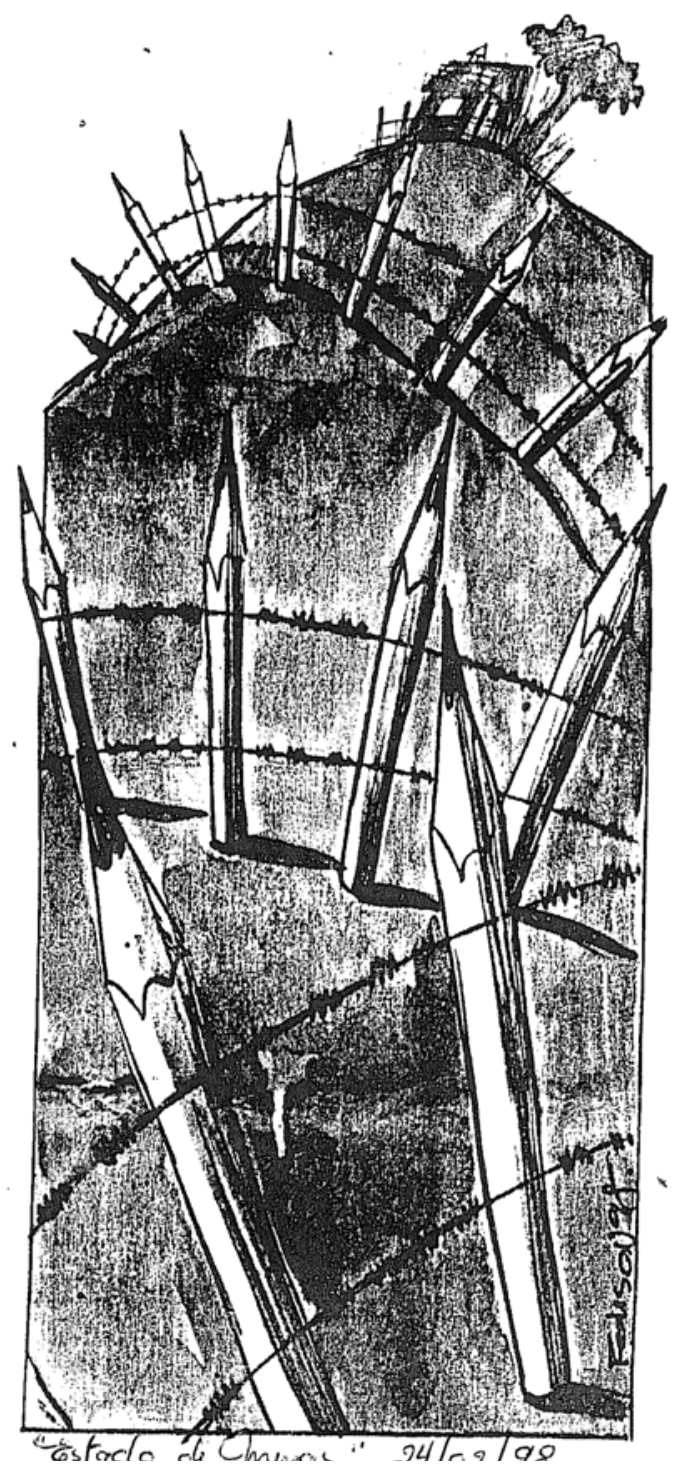



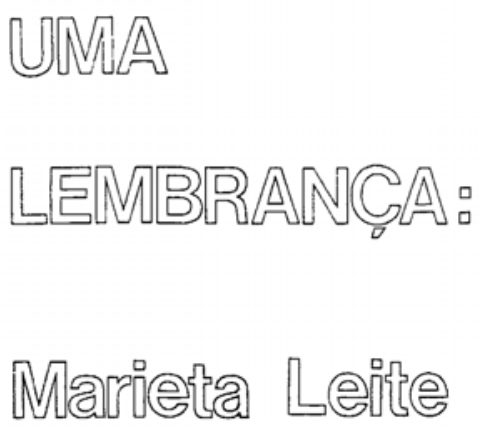

Quem leu A Poesia no Curso Primário sente a força do trabalho, sob o ponto de vista poético e metodológico. .larieta Leite era uma das autoras, ao lado de Alaíde Lisboa de Oliveira e Zilah Frota.

Esse livro nos mostra a importância fundamental da poesia na vida da criança. As autoras sairam da antiga Escola de Aperfeiçoamento que, depois de tantos anos extinta. ainda revela frutos espalhados por aí. desde as Gerais até ao Rio Grande do Sul e à Amazonia.

Pituchinha foi leitura de vírias geraçoes. leitura obrigató. ria como material suplementar, obrigatória no bom sentido, não imposta. mas pelo prazer que despertava na garotada: "Pé lá, pé cá”....

E como é gostosa a poesia Chapelinho Iermelho de Marieta Leite? E as outras, como Os Sinos do Brasil Colonial, de tão belo efeito em coro falado? E o comovente. Yandiocal da Bondade? E a graça da Folhinha Verde?

Conheci Vlarieta Leite como professora da cadeira de Socialização na antiga Escola de Aperfeiçoamento. Dali nasceu nossa amizade que iria durar anos, entre mestra e discípula que fui dela.

Marieta foi o tipo de mulher que nos impressionou pela privilegiada inteligência e firmeza de conviç̧ão. $\AA$ primeira vista nos assustava,a nós ahınas, que a julgávamos distante $e$ difícil. Isso foi o começo. mas o convivio na escola e depois fora dela, levou-nos a uma aproximação mais íntima.

E eu me aproximei mais ainda, por várias razőes, e o teatro de bonecos foi uma delas. Vendo uma representação de teatro de fantoches na escola, eu me interessei tanto pelo as sunto que resolvi entrar nele. E entrei mesmo, transformandome em "pelotiqueira amadora" e vivia dando espetáculos em tudo que fosse festa infantil que nos convidassem. $O$ teatro de bonecos me uniu mais ainda à essa autora. Lima ocasião ela nos pediu (o grupo era de três) para uma apresentação na Cidade Ozanam, comunidade de velhos desamparados.

As aulas de socialização de Marieta Leite eram extraordinárias aulas de Sociologia . Naquele tempo dava-se muita im. portância à socialização nas escolas. Hoje, fala-se muito em integração escola-comunidade, mas é falsa essa integração. De um lado, a escola isolada, lutando sozinha para não soçobrar; $e$ do outro, a comunidade alienada, usando a escola em seu benefício, mas pouco ou nada fazendo por ela. A socialização, era um modo de aproximar a escola da comunidade. A profes. sora demonstrava isso, expondo com segurança, demonstrando grande cultura. Nós, as suas alunas, nunca a vimos titubear ou vacilar perante alguma pergunta capciosa. Suas respostas eram claras e limpas, esclareciam qualquer dúvida, ou nos colocava no campo da pesquisa.

Quando se aposentou em Minas, foi para o Rio trabalhar na Fundação Getúlio Vargas e outras atividades de educadora, que a prenderam fora daqui. Voltando para \linas, não perma. neceu ociosa. continuou seu trabalho, em favor da educação.

A sua morte é, certamente, uma perda para a educação, para a literatura infantil de modo particular. Mas sempre nos lembraremos da inventora da Pituchinha e as mil Pituchinhas desse mundo não se cansarão de ler e reler a história encanta. dora, tão suave, da boneca que fugiu para buscar o doce e todas as peripécias porque passou para consegui-to.

" $E$ desde esse dia, as bonequinhas, - coitadinhas -

V'èm sempre amarradas nas caixinhas". 


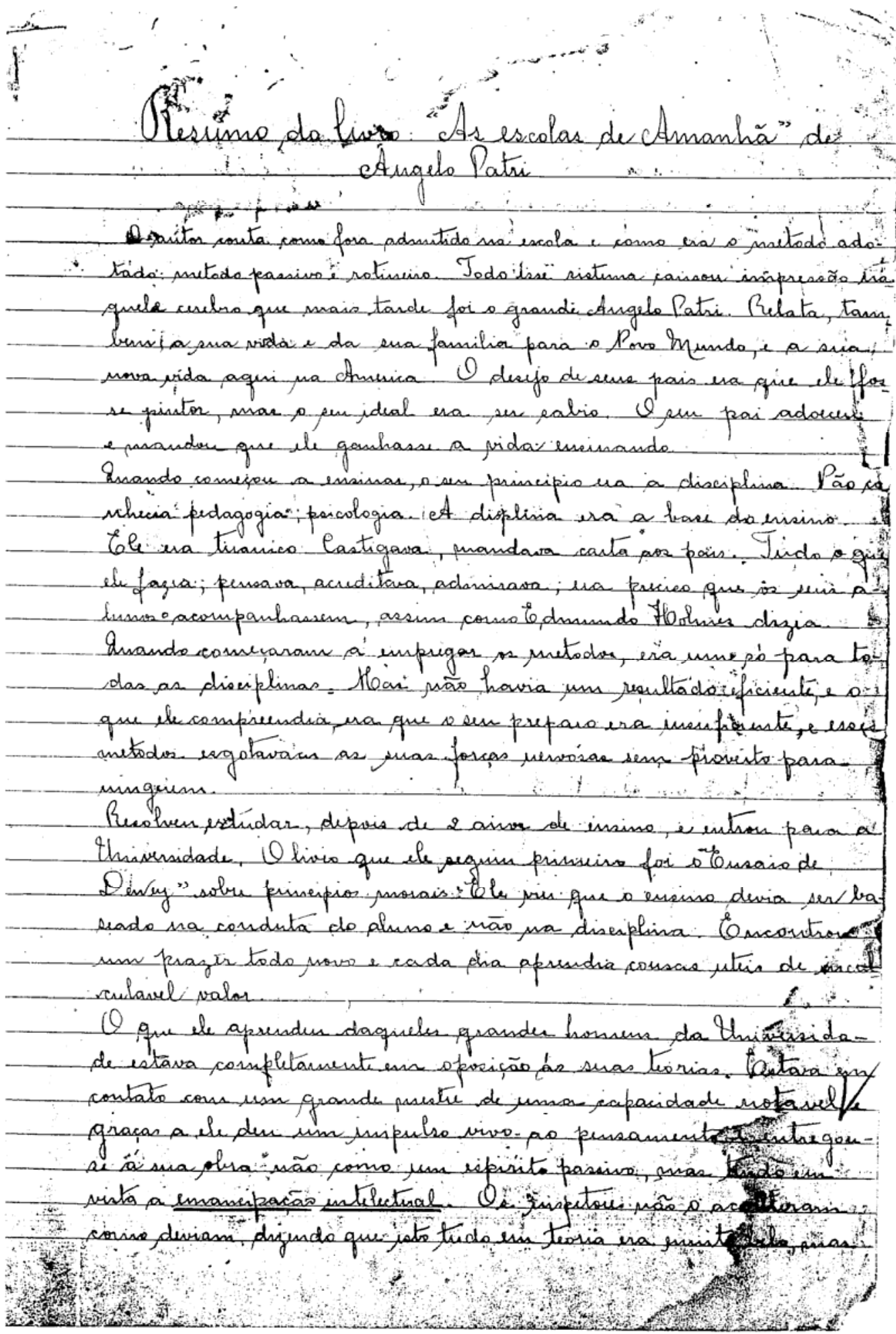


prathca surgia barrenas de difical transposiçäe.

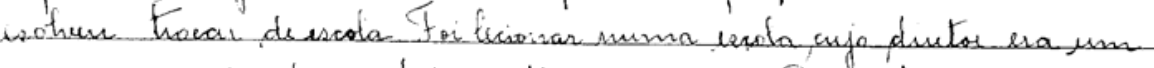

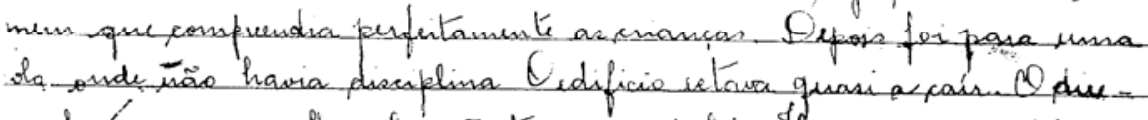

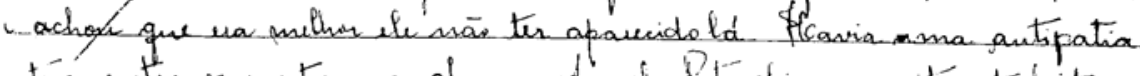

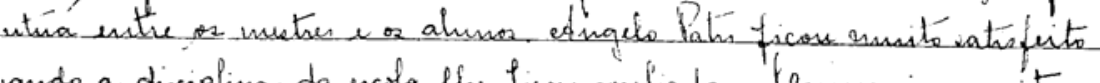

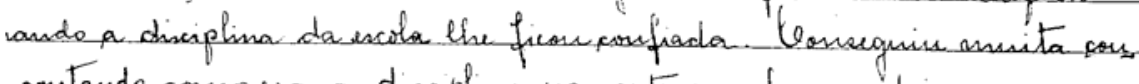

contando cono ua a disciplina nas entras unotas, coles xan que a res=

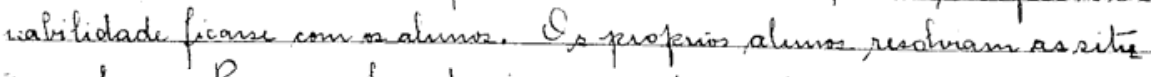

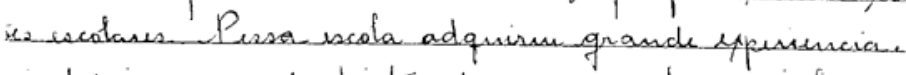

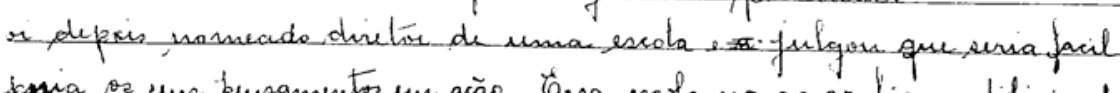

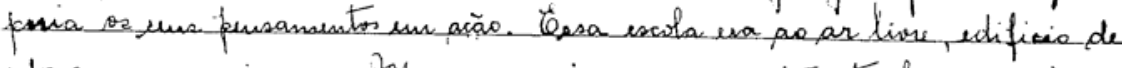

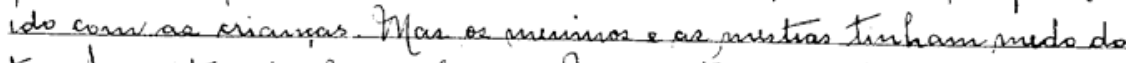

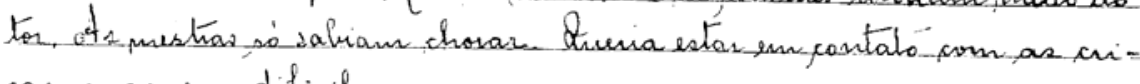
ear, mas era dificil

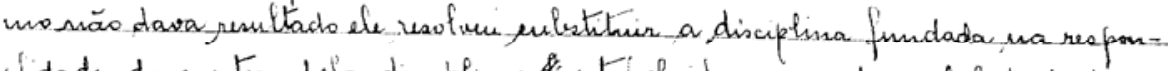

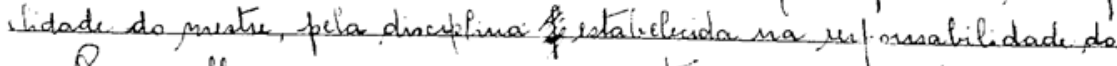

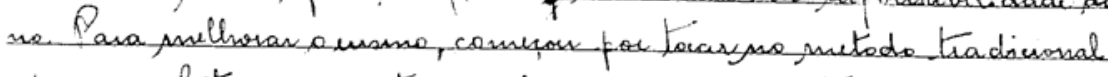

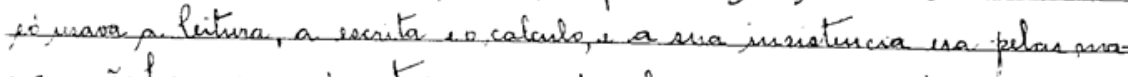

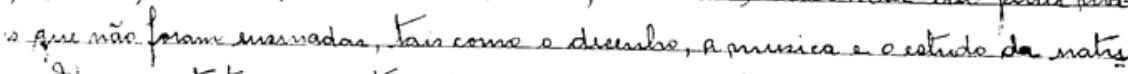

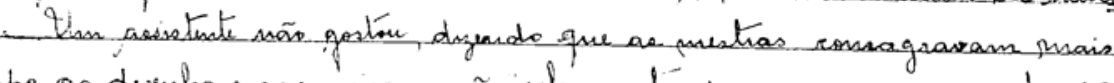

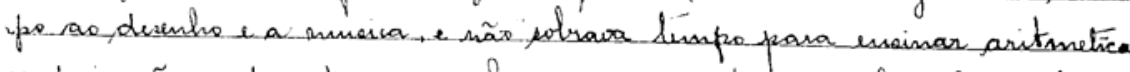

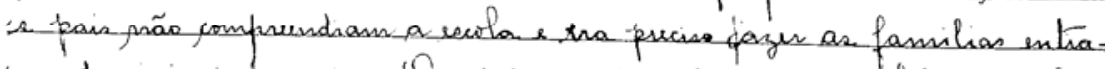

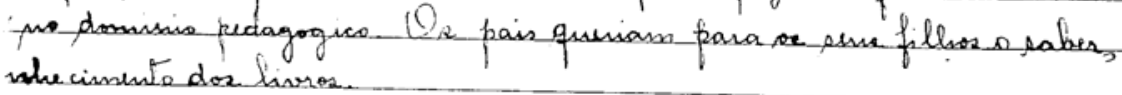
a ele: "A undade e contromidade eão 2 fatores eficassissinnor ma vida

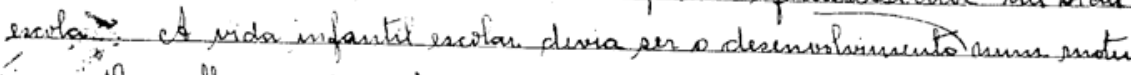
ssmo Ur prethour miso deviam er para de vida mais rude, eas

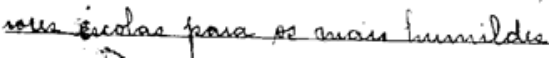

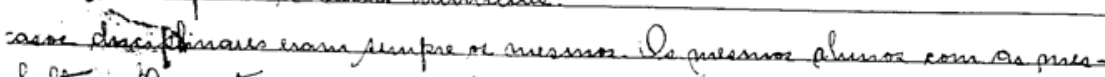

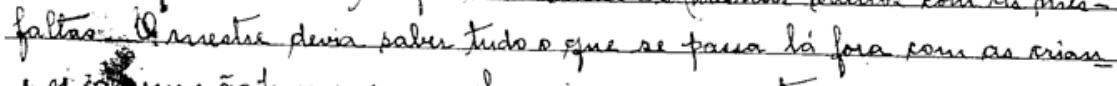

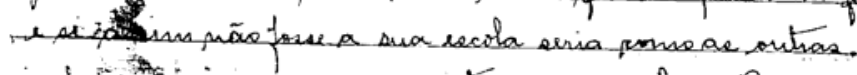

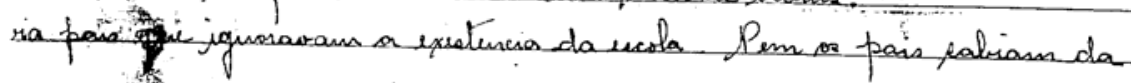




\section{$-2$}

\section{$t^{2}$}

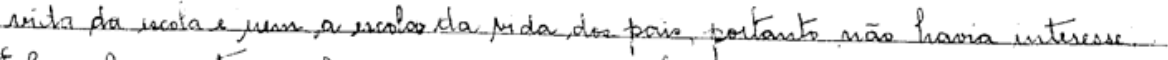

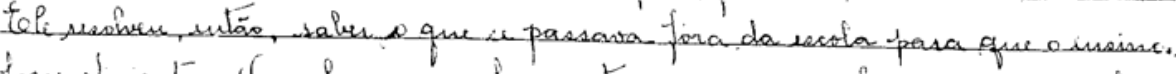

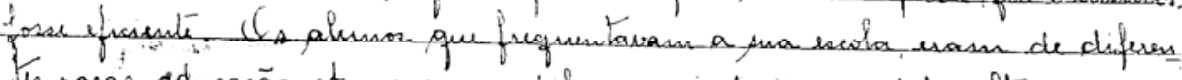

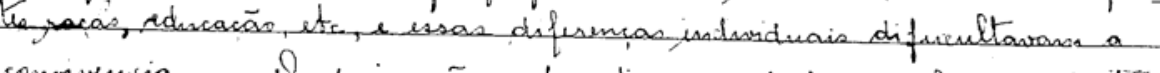
. Qs pais rão comprendian a cidack, a recola, cos proprio os filines et acoía para lec mäo va a contimindade do far Ii a fisiahidáde da ucota ra preporar a, crianca para a vida, pais reclamavam

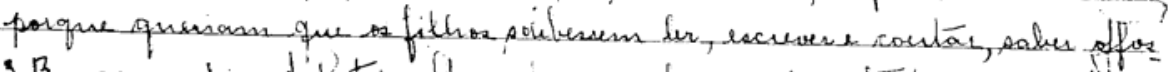

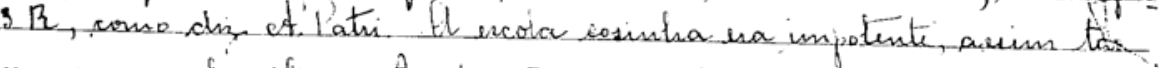

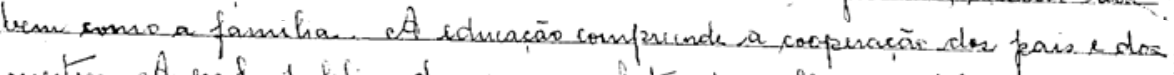

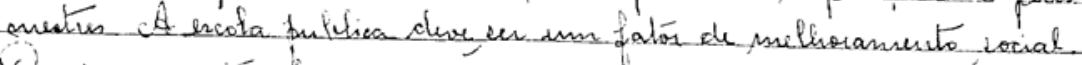

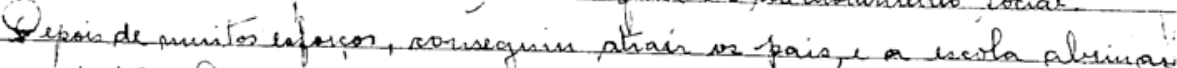

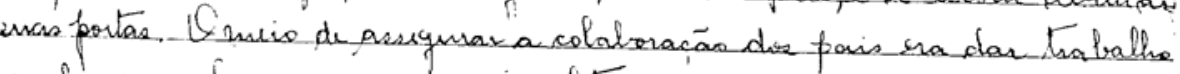
a eles pasa luvaram co rus apoio coletioo

Tora organjadouma senie de unsiōts, couferencias populares, concertos. Cinterses dos pais is interence dos fitios.

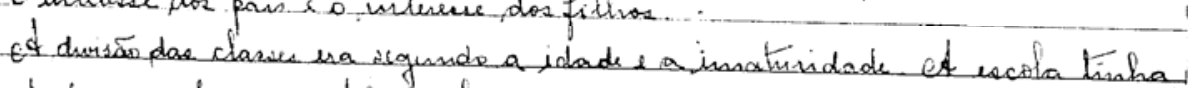

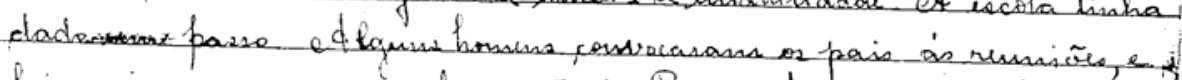

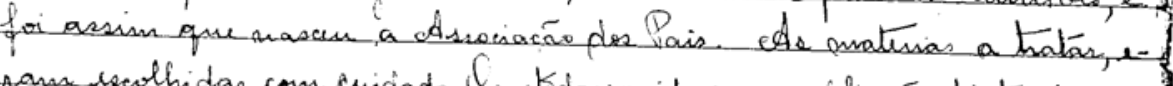

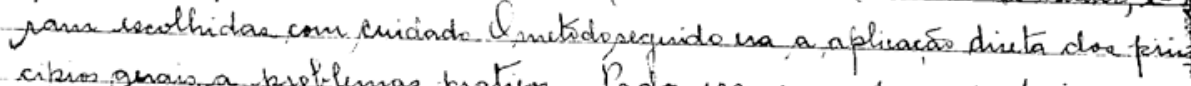

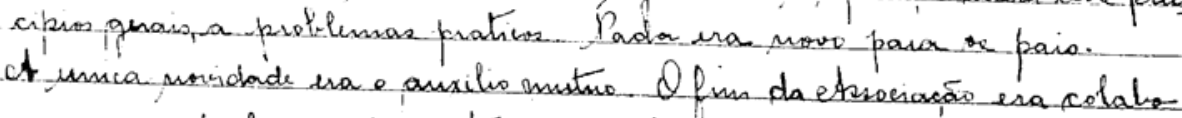

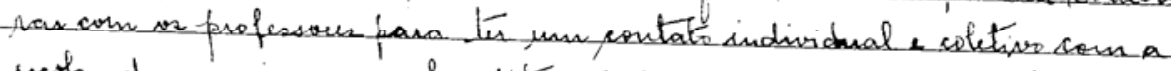

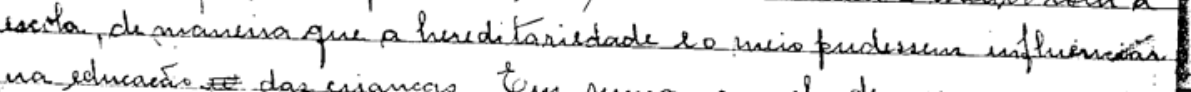

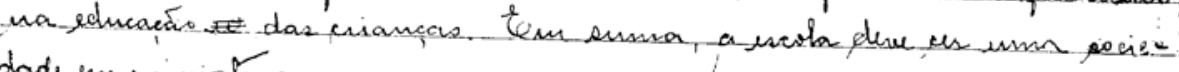
dade en minniatrina

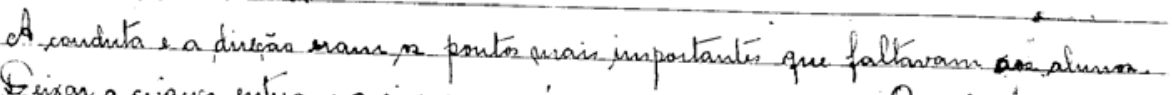

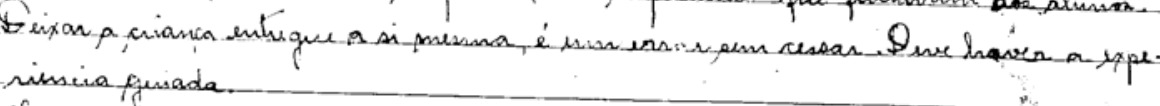
rimsura fies

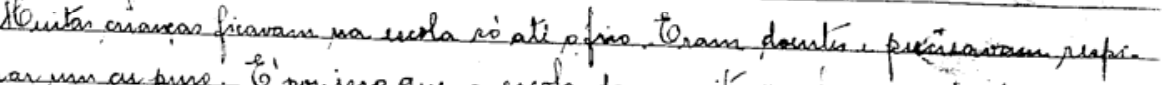

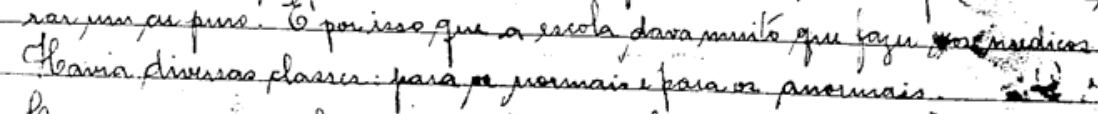

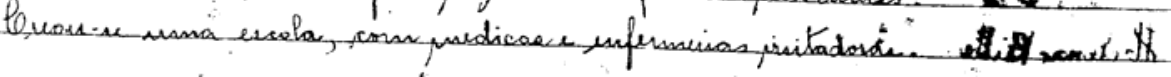

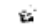




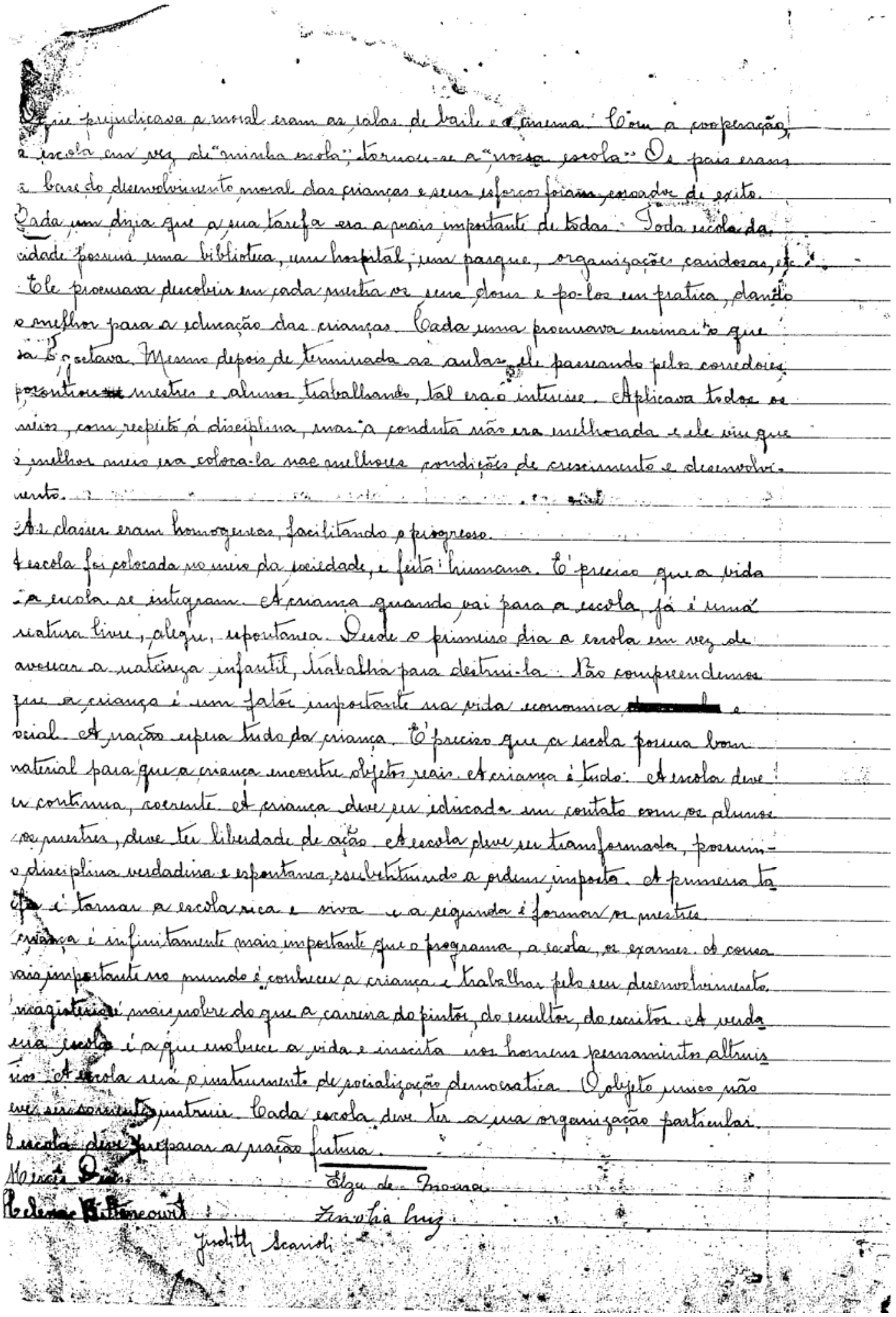


"NÃO PREMIARÁs, NÃo CASTIGARÁS, NÃO RALHARÁS..." dispositivos disciplinares em Grupos Escolares de Belo Horizonte (1925-1955)

\title{
DOCUMENTOS APRESENTADOS PELA
}

\author{
ENTREVISTADA
}

IMENE GUIMARÃES 
Suiça, e parecia ter raio $\mathrm{X}$ no olhar.

Eram quase todas jovens professoras. um tanto afoitas, curiosas, desconfiadas, atraidas pela personalidade da estrangeira, de sotaque carregado completamente avessa a falar de si mesma.

Todas as aulas de D. Helena eram muito bem planejadas, motivadas, ricas em conteúdo. Assim ela conseguia manter o interesse, a atenção e exigia esforço e trabalho. De uma delas, não me esqueço. Antes de inicar o estudo sobre inteligência, resolveu fazer uma experiência para demonstrar a diferença entre duas crianças, uma excepcionalmente bem dotada, e outra muito retardada.

Para a experiência chamou um aluno das Classes anexas à Escola de Aperfeiçoamento, considerado muito inteligente e outro do Instituto Pestalozzi, muito retardado. E aplicou-lhes testes de inteligência verbal e espacial.

O resultado nâo foi o esperado pela mestra: o inteligente confirmou sua fama no teste de inteligência verbal, mas fracassou lamentavelmente no teste de inteligência espacial. O outro, que deveria fracassar em ambos. saiu-se muito bem nos testes de inteligência espacial, apesar do fracasso na prova de capacidade verbal.

$O$ resultado teria certamente inibido qualquer demonstradora de menos recursos didáticos.

D. Helena, ao contrário, tirou grande partido da demonstração e, após ter confessado que, por momentos. ficara um tanto perturbada ao sentir seu plano de aula prejudicado, nos deu uma brilhante lição sobre várias formas de inteligência, salientando que aquela criança retardada poderia chegar a ser um ajudante de mecânica, tão útil e necessário como um juiz ou um diplomata, cada um em seu devido lugar e produzindo de acordo com seus interesses, aptidðes e capacidades.

Cabe ao educador descobrir o tipo de inteligência de cada aluno e encaminhá-lo no rumo certo.

A inteligência é uma faculdade muito complexa e pode até ter picos e abismos.

Em outra turma, a mestra, para motivar o estudo da inteligência, fez a cada uma das professoras-alunas a pergunta: que é a inteligência? $E$ foi anotando as respostas.

Depois leu uma série de definiçōes de inteligència, e os nomes de scus respectivos autores. fara concluir que uma faculdade tão complexa como a intcligência é muito dificil de ser bem definida.

Antes de iniciar o estudo do julgamento colocou na parede da sala de aula um quadro e pediu que ele fosse observado com muita atenção. Depois de retirar o quadro, ela entregou a cada professora-aluna um

questionário previamente preparado. Uma das perguntas era: quantos urubus estāo desenhados no quadro? Houve uma que declarou ter visto 1 urubus, apesar de não haver, no quadro. um sequer. Depois as professoras-alunas foram encaminhadas, duas a duas para uma outra sal onde, em cima de uma mesa, havia uma miniatur de jangada cearense,com um pano embebido en tinta vermelha.

Ao lado, uma folha de papel com a trágic estória do jangadeiro que havia perdido a filha guardava suas roupas manchadas de sangue.

Cada uma recebeu novo questionário algumas respostas foram tão disparatadas que provocaram risadas, apesar de se tratar de um acontecimento tăo tristc.

Em seguida D.Helena contou que Claparede. para mostrar como pode ser falho o julgaments humano, certo dia $\mathrm{cm}$ que discutia o assunto com um grupo de alunos, teve a sala de aula invadida por supostos policiais que provocaram um grande. alvoroço. derrubando mesas e cadeiras, ameaçando o mestre e seus discípulos.

Depois que cada um fez seu depoimento sobre o que havia acontecido, com grande diferenças e contradiçठes. Claraparede esclarece que tudo fora preparado por ele para mostrar como $t$ difícil e até perigoso julgar.

(E nós poderíamos acrescentar as palavras de Cristo: não julgueis e assim não sereis julgado)

D. Helena continuou dando uma aula tăo rica D.Amél que, entusiasmada, uma professora-aluna lhe Alda Lo perguntou se ela pretendia escrever um tratado de Psicologia.

Não me lembro exatamente de suas palavras para a mas guardei bem o que elas queriam dizer. Escrever experiên um livro de Psicologia nāo é muito difícil. Basta reunir os melhores tratados sobre o assunto d aproveitar o que de melhor houver em cada ur. deles. Mas isto não é importante. Importante seria experimentar, pesquisar, discutir, colher muitos dados, estudá-los e tirar conclusões próprias, para: então publicar.

D.Helena não nos deixou um tratado de criança . Psicologia, mas publicou muita coisa importante em sluna, $\mathrm{cc}$ revistas, arquivos, boletins. etc.

Felizmente, agora seus tabalhos forar reunidos e publicados. para conhecimento de codos principalmente dos mais novos que nåo tiveram a ventura receber que fice 1.rman uamac ssusta ldado am gra perio de Lima e tataiele aronteci J: Mek mediu à para cst: aiv has avia Sc ecionas cdigido

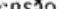
aher qu $P$ Amél 0 splicav nsistin ") Iruço iuração. chérios 
Biografia

Imene Guimarães

Nasci em Belo Horizonte, no dia 08 de janeiro de 1911, décima filha de uma família de onze irmãos.

Meu pai, Manoel Lopes Guimarães era português e minha mãe Judith de Faria Guimarães, nascida em Barbacena, sobrinha bisneta do Padre Mestre Correia de Almeida, poeta satírico, cujas poesias são até hoje conhecidas e citadas.

Quando eu deveria ser matriculada na escola, meu pai adoeceu gravemente. Teve um câncer e sofria muito. Minha mãe preocupada comigo vendo os sofrimento de meu pai, resolveu me mandar para a fazenda de minha avó em Santa Barbara do Túgurio, naquela época município de Barbacena, hoje cidade.

Depois da morte de meu pai voltei para Belo Horizonte.

Em 1920, com nove anos de idade fui matriculada no Grupo Barão do Rio Branco onde durante 4 anos tive a mesma professora Olinda Alves de Albuquerque, ótima educadora que me ensinou a ler e escrever e a amar a Pátria e os que a amaram e engrandeceram. Em dezembro de 1923 recebi o certificado de conclusão do curso primário com distinção.

Fiz prova escrita e oral de Língua Pátria, Geografia Aritmética e Ciências Naturais. A Comissão Examinadora foi enviada pela Secretaria da Educação. Considerada a melhor aluna recebi a Medalha de Mérito.

!924 - Exame de admissão à Escola Normal Modelo de Belo Horizonte, hoje Instituto de Educação. Era apenas 30 vagas. Fui aprovada. Freqüentei a excelente Escola até 1927. Aprendi muito, porque os professores eram ótimos. Eu gostava das aulas, prestava muita atenção, tomava notas e estudava em casa.

1928 - Escola de Aplicação - Criada tendo em vista e Reforma do Ensino do Presidente Antônio Carlos Ribeiro de Andrada.

Funcionava no prédio onde é o Fórum. 
O Diretor era o professor Firmino Costa.

Um bondinho especial que saia da Rua Tamoios, perto da Igreja de São José nos levava até a Escola e ostentava a placa - Escola de Aplicação.

O prédio era muito grande. Nele já funcionava uma Escola Infantil, cuja diretora, era a professora Elisena Costa.

Depois foram instaladas classes anexas para pratica de ensino.

$\mathrm{O}$ currículo da Escola de Aplicação era constituído das seguintes disciplinas: Biologia e Higiene, Psicologia Educacional, História da Civilização e da Educação, Metodologia ( Didática ) e Pratica de Ensino.

Os professores eram muito bons, destacando-se o de Psicologia Educacional, Iago Pimentel, e de Metodologia e Pratica de Ensino Luiza Valadares Ribeiro.

Terminado o curso recebi um diploma de $2^{\underline{0}}$ grau.

Quando eu estava terminando o curso, a diretora do Grupo Barão de Rio Branco, Professora Elvira Brandão, que era chamada de Dona Nha-Nha me convidou para ser estagiária no ano seguinte.

Fiquei muito contente com o convite e comecei a trabalhar em fevereiro, com uma classe de $4^{\underline{0}}$ ano repetente. Mas fiquei pouco tempo no meu querido Barão do Rio Branco porque o Dr, Mário Casassanta que era, se não me engano, Diretor Geral da Instrução Pública e o mais importante colaborador do Secretário da Educação Dr. Francisco Luiz da Silva Campos ( o Chico Ciência ) na implantação da Reforma do Ensino do Presidente Antônio Carlos, foi à minha casa e me convidou para lecionar nas Classes Anexas à Escola de Aperfeiçoamento, que estava começando a funcionar.

Fiquei muito satisfeita com o convite, mas disse ao Dr. Mário Casassanta que tinha um compromisso com a Diretora do Grupo Barão do Rio Branco.

Ele então me aconselhou a procurar a Diretora e lhe explicar porque ia deixar o trabalho no Grupo.

Assim o fiz, mas a Diretora não concordou, e ficou muito zangada e ameaçou até a dispensar as alunas que ficariam sem professora.

Quando contei ao Dr. Mário a reação da Diretora, ela disse: até aqui era um convite, agora uma ordem.

Ordem de Chefe todos cumprem.

Por isto deixei o Grupo Barão do Rio Branco e fui lecionar nas classes anexas à Escola de Aperfeiçoamento, no começo do ano de 1929. Estava com 18 anos de idade.

O trabalho não era fácil. Minhas aulas eram assistidas, comentadas e criticadas pelas Professoras-alunas. 
Em 04 de Setembro de 1930 fui nomeada pelo Presidente Antônio Carlos Ribeiro de Andrada, Professora da $4^{\underline{a}}$ classe primária anexa à Escola de Aperfeiçoamento da Capital.

Quando completei 2 anos de magistério, tempo exigido pela legislação, fui matriculada na Escola de Aperfeiçoamento.

A Escola de Aperfeiçoamento ficou conhecida em todo o Brasil e foi freqüentada por professoras de outros Estados, como o Rio Grande do Sul. do País.

Por causa dela Belo Horizonte recebeu o titulo de Capital Pedagógica

Nas comemorações do centenário de D. Helena Antipoff fiz uma palestra sobre a referida Escola. Enviei uma cópia ao Centro de Referência do Professor onde está emprestado o meu diploma.

Terminado o Curso de Aperfeiçoamento fui convidada por D. Helena Antipoff para trabalhar no Instituto Pestalozzi, recentemente instalado, para o atendimento de crianças excepcionais.

Trabalhei em dois horários. De manhã atendia os pais no consultório médico-pedagogico fazia anamnese, aplicava o Teste Binet-Terman que era usado, na época, para o cálculo do QI. retardadas.

Almoçava e depois tinha a meu cargo uma classe de crianças muito

Depois de alguns anos passei a ser Auxiliar da Diretora, professora Ester Assunção.

Em 1944 fiz prova de Habilitação no Departamento Administrativo do Serviço Público, o famoso DASP, para Inspetor de Ensino Secundário do Ministério de Educação e Saúde. Fui aprovada e nomeada em 1946. Secundário.

Continuei a trabalhar no Instituto Pestalozzi e como Inspetora de Ensino

Preocupada com a acumulação de cargos fiz uma consulta ao DASP que considerou legal por se tratar de um cargo técnico e outro de magistério.

Fui Inspetora em vários estabelecimentos da Capital, como Instituto de Educação, Colégio Dom Silvério, Colégio Padre Machado, Colégio Nossa Senhora do Monte Calvário.

Em 1946 resolvi deixar o Instituto Pestalozzi e voltar para o meu querido Barão do Rio Branco, como Orientadora Educacional.

A Diretora do Grupo era D. Ondina Amaral Brandão, grande educadora, que prestou muitos serviços ao ensino de Minas.

D. Ondina se aposentou e eu fui nomeada Diretora pelo Presidente Juscelino Kubistchek em 28 de abril de 1953, com vencimentos de CR\$ 1920,00 . Era um bom vencimento na época. 
Em 08 de maio de 1954 por ato do Secretário da Educação Dr. Odilon Behrens, fui designada para diretora do Grupo Barão do Rio Branco, que era considerado como a melhor escola primária de Belo Horizonte porque suas professoras eram preparadas, estudiosas, tinham muita preocupação com os alunos e uma dedicação extraordinária.

Freqüentado por filhos da chamada classe alta e também por muitos favelados que recebiam gratuitamente merenda, uniforme, material escolar igual dos colegas que podiam comprar. Não havia qualquer discriminação.

Em 1955 pedi aposentadoria porque minha mãe estava muito velha e doente precisando muito de minha companhia.

Fui aposentada como Diretora em 19 de março de 1955.

Em 1959 terminei o curso de Orientação Educacional, na Pontificia Universidade Católica de Belo Horizonte.

Continuei trabalhando como Inspetora de Ensino Secundário.

Em 11 de junho de 1964, fui designada para exercer a função gratificada Símbolo $1 \mathrm{~F}$, Inspetora Seccional de Belo Horizonte.

Em 1967 fui condecorada com a Medalha da Inconfidência Mineira.

Em 16 de agosto de 1968 fui designada para Coordenadora do Ministério da Educação e Cultura no Estado de Minas Gerais e Goiás, em 03 de dezembro de 1968 para exercer também as funções de Coordenadora da Comissão Estadual do Livro Técnico e do Livro Didático ( COLTED).

Em dezembro fui nomeada também para fazer parte do PREMEM Programa de Expansão e Melhoria do Ensino Médio.

Maio de 1970 fui designada pelo Governador do Estado Dr. Israel Pinheiro para participar da Comissão Estadual de Moral e Civismo.

Em outubro de 1971 fui nomeada para exercer o cargo, em comissão Símbolo 4C de Delegada do Ministério da Educação e Cultura, no Estado de Minas Gerais, cargo que foi incluído no Grupo Direção e Assessoramento Superior [ DAS - 101.2].

O trabalho de implantação da Delegacia fui muito dificil, porque a ela foram incorporados vários órgãos do Ministério da Educação.

Em agosto de 1971 entrou em vigor a Lei 5692 fixa Diretrizes e Bases para o ensino de $1^{\varrho}$ e $2^{\underline{0}}$ graus.

Estudei a referida Lei com muito cuidado a atenção. Organizei um fichário com cópias de todos os Pareceres do Conselho Nacional de Educação relativos ao Ensino de $2^{\underline{0}}$ grau, publicados na Revista Documenta.

Em 1975 recebi do prezado Mestre, Dr. Gildásio Amado, então diretor do Ensino Secundário, uma dificil e honrosa tarefa: organizar, instalar e fazer funcionar, em convênio com a Secretaria da Educação, um Centro de 
Treinamento de Professores de Artes Práticas; Artes Industriais, Técnicas Agrícolas, Técnicas Comerciais e Educação para o Lar.

O CTP GOT foi instalado em um grande prédio, em Betim, cedido pelo governo do Estado e dirigido por um Conselho Técnico e Administrativo do qual eu era Presidente e composto pelos Professores: Duntalmo Prazeres, Dora Parma, Wander Soares e pela Diretora Zilda Ferreira.

Em 1973 fui incluída por decreto do Presidente da Republica na Ordem Nacional do Mérito Educativo.

Recebi a Medalha no Paiácio do Itamaraty, no dia 10 de julho de 1973, numa cerimônia muito bonita.

Em 27 de agosto recebi Diploma de Honra conferido pela Associação de Professores Público de Minas Gerais.

Recebi inúmeros certificados de participação em importantes órgãos. Citarei apenas o da Sociedade Mineira de Psicologia: Certificado de Participação na Diretoria desta Sociedade, de 23 de outubro de 1967 a 15 de abril de 1970, no cargo de Conselheiro Fiscal.

Com a saída do Ministro da Educação Jarbas Passarinho, entreguei o cargo de Delegada ao Ministro Ney Braga.

Fui dispensada e requeri aposentadoria no cargo de Técnico em Assuntos Educacionais ( Ex. Inspetor de Ensino Secundário ).

Fui aposentada a partir de 10 de janeiro de 1978.

Todas as minhas contas como Inspetora Seccional, Coordenadora e Delegada foram aprovadas. Conservo em meu arquivo os comprovantes.

( Diário Oficial ).

Completei 90 anos em janeiro deste ano.

Gozo de boa saúde, pressão baixa. Tenho uma baixa de audição mais enxergo muito bem.

Moro em casa própria no Bairro Anchieta com três sobrinhas.

Leio muito: Jornais, Revistas, Livros. Atualmente estou lendo Baudolino, de Umberto Eco. Tenho uma ótima biblioteca.

Bordo ( mal ) ponto de cruz, faço crochê. Decifro palavras cruzadas da Recreativa.

Recebo muitas visitas de parentes e amigos e sou feliz.

Imene Guimarães 


\section{A Escola de Aperfeiçoamento de Professores com D. Helena Antipoff}

IMENE GUIMARĀES $(*)$

Corria o ano de 1928. Governava Minas Gerais o grande Presidente Antônio Carlos Ribeiro de Andrada, estadista de larga visão, que escolheu seus colaboradores entre os mais capacitados e estabeleceu como uma das principais metas do seu governo a reforma do ensino.

Ele estava convencido de que "Se a escola é o professor e o professor é a escola, renovar o professor é renovar a própria escola". como disse mais tarde D. Helena Antipoff. Por isto. criou a Escola de Aperfeiçoamento de Professores, que começou a funcionar em 1929.

Para a Secretaria do Interior que, naquela ćpoca, era também responsável pela Educação, foi nomeado o Dr. Francisco Luiz da Silva Campos, que o povo, na sua "apropriada" irreverência, chamava de Chico Ciència ou Chico Sabença.

Para Diretor Gcral da Instrução foi escolhido o Dr. Mário Casassanta que amanhecia nos grupos Escolares, entrando sempre pelas portas dos fundos. surpreendendo Diretoras e Professoras, já nas salas de aula, ou conversando com as serventes nos corredores.

Ele queria conhecer de perto a realidade do ensino em Minas Gerais para melhor colaborar com a implantação da reforma planejada pclo Governo do Estado.

Belo Horizonte era então uma cidade pequena. com aproximadamente 200.000 habitantes. tranqüila. servida por bondes vagarosos, sem ônibus, com poucos automóveis, e foi "invadida" por um numeroso grupo de professoras, vindas de vários pontos do Estado. Muitas eram jovens, algumas muito bonitas, que tinham sido eleitas "misses" em suas cidades. outras mais maduras. mães de família e até avós, todas ânsiosas por cntender melhor por que e para que foram convocadas pelo Governo.

As explicaçōes vieram logo. Escolhidas como capacitadas e dedicadas professoras do interior do Estado, foram convocadas para, juntamente com algumas colegas da capital. freqüentarem a Escola de Aperfeiçoamento de Professores, recentemente criada, onde seriam chamadas de Professoras alunas. Terminando o curso voltariam para as suas escolas como Orientadoras Técnicas, encarregadas de colocar em prática $\mathrm{c}$ transmitir às colegas o que aprenderam $\mathrm{em}$ dois anos de estudo.
Elas moravam em Pensōes, andavam $\mathrm{cm}$ grupos. usavam grandes boinas vermelhas, azuis. marinho, os chapéus de feltro porque. naquela provocavam alvoroço na cidade. motivando até o jomalista Moacir Andrade a escrever um romance a que deu o nome de República Decroly, cuja principal personagem era uma professora do interior que freqüentava o "Pedagogium".

O livro fez sucesso, vendeu muito, apesar de tentativas para impedir sua comercialização.

O currículo da Escola de Aperfeiçoamento de Professores era constituido das seguintes disciplinas; Metodologia Geral, Metodologia da Lingua Pátria. Metodologia da Aritmética. Metodologia das Ciéncias Naturais. da Geografia e da História. Pedologia e Psicologia. Socializaçâto.

O Corpo Docente. a princípio. cra formado perlas professoras: Amélia de Casıro Monteiro. Alda Lodi. Lúcia Schmidt Montciro de Castro (depois Lúcia Monteiro Casassanta), que haviam se preparado na Universidade de Colúmbia, nos Estados Unidos. Maria Luiza de Almeida Cunha. Guiomar Meirelies, Renato Andrade e completado pelos professores estrangeiros Leon Waler. Madame Arthus Perrelet, sendo indicado para primeiro Diretor o Dr. Lúcio dos Santos, que foi substituído pela Professora Amélia de Castro Monteiro.

O Secretário era Antônio Orsini.

Leon Walter e Madame Arthus Perrelel

foram substituídos respectivamente pelas Professoras Helena Antipoff e Jeanne Milde, que ficaram conosco. sendo que a última ainda encantis os mineiros com sua arte.

Assim começou a funcionar a Escola de Aperfeiçoamento de Professores que mais tarde. freqüentada também por professoras de outros Estados, exerceu neles uma grande influência e Belo Horizonte, naquela época. foi considerada a Capital Pedagógica do país.

(*) IMENE GUIMARÄES: Ex-aluna de Helena Antipoff na Escola de Ape'rfeiçoamento Pedagógico de B. Horizonte. Ex-Inspetora do MEC. Ex-Delezada do MEC (Delegacia Regional do Ministério da Educašão em Minas Gerais). época, nenhuma mulher saía à rua sem chapéu. E Desenho e Modelagem, e Educação Física. obede tarde. Sucial bisce canto. ulest: una d iivros. ientre :mpo Direto h.ra n กอิ en fato q1 iggilâı do $t c ́$ tiber disser precis inmar entrar falar $\mathrm{c}$ repeti chega' กมี้อ er horári

onde $f$ de $\mathrm{Mi}$ Cienet Antip institt Binsil criada como con: $C$ 
O horário de funcionamento era longo e larde. de segunda-feira a sàbado.

em Nos sábados à tarde havia uma Reunião

uis. Social, quando era servido chá com limão, torradas ela e biscoitinhos.

. E Do programa constavam números de música, é o canto, brincadeiras diversas e obrigatoriamente,

e a palestras sobre uma cidade mineira, proferida por uja uma das professoras-alunas.

ior Assistência às aulas, estudo, leitura de vários livros, trabalhos que tinham que ser apresentadas de dentro dos prazos marcados, ocupavam todo o tempo das professoras-alunas.

de As que moravam em Pensōes pediram à es Diretora da Escola que as aulas terminassem uma da hora mais cedo, porque quando chegavam em casa :a. năo encontravam água quente para o banho.

le $\mathrm{O}$ pedido foi negado. Então aconteceu um io. Fato que contrariou muito D.Amélia.

Algumas professoras-alunas, burlando a do vigilância do "Seu Paulino", o porteiro, saíram antes o. do término das aulas e foram ao Palácio da

ro Liberdade. Atendidas pelo Chefe do Gabinete

se' disseram que não tinham audiência marcada mas.

Js precisavam muito falar com o Presidente, que. ao

a. Iomar conhecimento do assunto, disse: mandem

lo entrar, professora não precisa marcar audiência para falar comigo.

Corno os tempos mudaram!

i) Elas reclamaram do horário da Escola. repetindo o que já haviam dito à Diretora, isto é. chegavam muito tarde nas pensð̃es onde moravam e não encontravam água quente para tomar banho.

O presidente riu, conversou muito, mas o s horário não foi modificado.

Para completar o Corpo Docente da Escola, onde faltava um professor de Pedagogia, o Governo de Minas Gerais enviou o Dr. Alberto Alvares à

Genebra, na Suiça, para contratar Madame Helena Antipoff, assistente de Edouard Claparede no if Instituto Jean Rousseau, para trabalhar dois anos no Brasil como professora de uma escola, recentemente criada.

D. Helena ficou animada com o convite, mas, i como tinha compromissos de trabalho assumidos com Claparede, que não gostou da idéia de liberá-la, : não aceitou o convite e indicou o colega Leon Walter para substituí-la. Ele veio para o Brasil, mas : ficou pouco tempo.

Era necessário encontrar outro professor para a Escola de Aperfeiçoamento.
O Dr. Alberto Alvares voltou a insistir com Madame Helena Antipoff que, depois de consultar Claparede resolveu vir para Belo Horizonte.

Assinou um contrato, por dois anos, recebendo uma quantia equivalente a CRS $20.000,00$ mensais, de acordo com a informação de seu filho Daniel.

E foi assim que a Escola de Aperfeiçoamento enriqueceu seu corpo Docente com Madame Antipoff, russa de nascimento. mais tarde D. Helena. brasileira por opção e pelo desejo de todos nós que aprendemos a admirá-la. respeitá-la e amála pelas suas excepcionais qualidade de inteligência, cultura, capacidade de realização e principalmente pela sua bondade e solidariedade para com as crianças e jovens menos protegidos pela sorte.

D. Helena viajou para o Brasil no Transaltântico italiano "Júlio Cesar" e desembarcos em Santos onde era esperada por Leon Walter. Lourenço Filho e Nocmy Silveira Rudolf.

Alguns anos depois ela nos contou que. se não me engano. cm Recife. teve permissão para dar um passeio pela cidade. onde enconırou três meninos: um muito claro, louro de olhos azuis. um mulato e outro pretinho. Brincavam juntos, riam e até abraçavam o pretinho.

Então ela sorriu para eles e pensou: este ć um país civilizado, não tem discriminação racial.

D. Helena começou a trabalhar na Escola de Aperfeiçoamento, em agosto de 1929. dando aulas em francês, muito bem planejadas e motivadas, que despertam grande interesse nas professoras-alunas.

Enquanto aguardava a chegada dos aparelhos comprados na Europa para instalar o Laboratório de Psicologia, aprendia rapidamente o português, tomando aulas com o professor Lourenço de Oliveira, ouvindo muito, e ensaiando as primeiras palavras da nossa lingua. A maior dificuldade que ela encontrava era na acentuação das palavras. Durante bastante tempo falou imbécil em vez de imbecil.

Logo depois começou a dar aulas em português, apesar das professoras-alunas the pedirem para continuar com o francês, porque assim iam se familiarizando com a língua.

D. Helena respondeu que precisava muito mais aprender o português que elas o francês e insistiu para que a ajudassem. corrigindo-lhe os erros.

A princípio nós a chamávamos de Madame. Sabiamos apenas que era russa trabalhava com Claraparede no Instituto Jcan Jacques Rousseau. na 
Suíça, e parecia ter raio X no olhar.

Eram quase todas jovens professoras, um tanto afoitas, curiosas, desconfiadas. atraídas pela personalidade da estrangeira, de sotaque carregado e completamente avessa a falar de si mesma.

Todas as aulas de D. Helena eram muito bem planejadas, motivadas, ricas em conteúdo. Assim ela conseguia manter o interesse, a atenção e exigia esforço e trabalho. De uma delas, não me esqueço. Antes de inicar o estudo sobre inteligência. resolveu fazer uma experiência para demonstrar a diferença entre duas crianças, uma excepcionalmente bem dotada, e outra muito relardada.

Para a experiĉncia chamou um aluno das Classes anexas à Escola de Aperfeiçoamento, considerado muito inteligente e outro do Instituto Pestalozzi, muito retardado. E aplicou-lhes testes de inteligência verbal e espacial.

O resultado não foi o esperado pela mestra: o inteligente confirmou sua fama no teste de inteligência verbal, mas fracassou lamentavelmente no teste de inteligência espacial. O outro, que deveria fracassar em ambos. saiu-se muito bem nos testes de inteligência espacial, apesar do fracasso na prova de capacidade verbal.

$O$ resultado teria certamente inibido qualquer demonstradora de menos recursos didáticos.

D. Helena, ao contrário, tirou grande partido da demonstração e. após ter conf́cssado que, por momentos. ficara um tanto perturbada ao sentir seu plano de aula prejudicado, nos deu uma brilhante lição sobre yárias formas de inteligência, salientando que aquela criança retardada poderia chegar a ser um ajudante de mecânica, tão útil e necessário como um juiz ou um diplomata. cada um em seu devido lugar e produzindo de acordo com seus interesses, aptidðes e capacidades.

Cabe ao educador descobrir o tipo de inteligência de cada aluno e encaminhá-lo no rumo certo.

A inteligência é uma faculdade muito complexa e pode até ter picos e abismos.

Em outra turma, a mestra, para motivar o esludo da inteligência, fez a cada uma das professoras-alunas a pergunta: que é a inteligência? $E$ foi anotando as respostas.

Depois leu uma série de definições de ntcligència, e os nomes de seus respectivos autores. ara concluir que uma faculdade tão complexa como a inteligência é muito dificil de ser bem definida.

Antes de iniciar o estudo do julgamento :olocou na parede da sala de aula um quadro e pediu 12 que ele fosse observado com muita atenção.

Depois de retirar o quadro, ela entregou a cada professora-aluna um

questionário previamente preparado. Uma das perguntas era: quantos urubus estão desenhados no quadro? Houve uma que declarou ter visto 10 urubus, apesar de nāo haver, no quadro, um sequer.

Depois as professoras-alunas foram encaminhadas, duas a duas para uma outra sala onde, em cima de uma mesa, havia uma miniatura de jangada cearense,com um pano embebido $\mathrm{cm}$ tinta vernelha.

Ao lado, uma folha de papel com a trágica estória do jangadeiro que havia perdido a filha guardava suas roupas manchadas de sangue.

Cada uma recebeu novo questionário algumas respostas foram tão disparatadas que provocaram risadas, apesar de se tratar de um acontecimento tão tristc.

Em seguida D.Hciena contou que Claparede. para mosirar como pode ser falho o juigamente: humano. certo dia $\mathrm{cm}$ que discutia o assunto con: um grupo de alunos, teve a sala de aula invadida por supostos policiais que provocaram um grande alvoroço. derrubando mesas e cađeiras, ameaçande. o mestre e seus discípulos.

Depois que cada um fez seu depoimento sobre o que havia acontecido, com grande diferenças e contradiçōes. Claraparede esclareceu que tudo fora preparado por ele para mostrar como $t$ difícil e até perigoso julgar.

(E nós poderíamos acrescentar as palavras de Cristo: não julgueis e assim não sereis julgado)

D. Helena continuou dando urna aula tão rica que, entusiasmada, uma professora-aluna lhe perguntou se ela pretendia escrever um tratado de Psicologia.

Não me lembro exatamente de suas palavras. mas guardei bem o que elas queriam dizer. Escrever um livro de Psicologia não é muito difícil. Basta reunir os melhores tratados sobre o assunto $c$ aproveitar o que de melhor houver em cada ur. deles. Mas isto não é importante. Importante scria experimentar, pesquisar, discutir, colher muitos dados, estudá-Ios e tirar conclusōes próprias, para então publicar.

D.Helena nāo nos deixou um tratado de Psicologia, mas publicou muita coisa importante em revistas, arquivos, boletins. etc.

Felizmcnte, agora seus tabalhos forar: reunidos e publicados. para conhecimento de todos principalmente dos mais novos que nåo tiveram a 
ventura de conhecê-la, ouvi-la e trabalhar com ela.

Em 1930 D. Helena teve a satisfação de receber a tâo esperada visita de Edouard Claparede. $\mathrm{ma}$ que ficou hospedado no grande hotel.

10s

Mas não foi muito feliz para Claparede a permanência em Belo Horizonte, porque começou a

r. chamada Revolução de 1930 e ele ficava muito

am assustado com o sibilar das balas atiradas pelos ale soldados do $12^{\circ} \mathrm{RI}$.

ur Ascola de Aperfeiçoamento funcionava em en. um grande Prédio na Avenida Paraopeba 1549. perto do $12^{2} \mathrm{RI}$

Atualmente a avenida se chama Augusto de

Lima e no referido prédio, está instalado o Forum Lafaiete.

if Estávamos em plena revolução, quando ut sconteceu o inesperado.

in D. Alda Lodi, uma extraordinária professora de Metodologia Geral e Metodologia da Aritmética. te pediu às professoras-alunas seus planos de aulas. iti para estudo.

iा $\quad$ prazo já estava se esgotando e uma delas o: năo havia ainda recebido os planos de aulas que de havia solicitado à Dirciora do Grupo Escolar onde di lecionava.

Por isso passou para ela um telegrama assim tc redigido: mande planos urgente.

Je De madrugada, a polícia bateu a porta da ev pensão, procurando a signatária do telegrama para e. saber quais eram os planos.

Por mais que a professora explicasse, a de polícia não se deu por satisfeita. E foi necessária a presença da Diretora da Escola de Aperfeiçoamento. c2. D.Amélia de Castro Monteiro e da Professora D. if Alda Lodi para que as explicaçðes fossem aceitas.

de Organizado o Laboratório de Psicologia, D.Helena inicou o preparo das professoras-alunas s) para aplicação de testes, coleta de dados, er: experiências diversas.

1a Ela apresentava o material necessário. i explicava qual a finalidade do teste ou experiência, $r$ insistindo sempre na rigorosa obediência às i2 instruçōes, cronometragem correta dos tempos de !' duração, padronizaçāo dos resultados de acordo com critérios estabelecidos. etc.

Depois a Mestra aplicava o teste $\mathrm{cm}$ uma criança ou, conforme o caso, em uma professorait aluna, com assistência discreta da turma.

D.Helena colhia muitos dados relativos às professoras-alunas. através de iestes, questionários. experiências, conversas.

Todo o matcrial era por cla estudado c colecionado em pastas individuais, juntamente com fichas onde a Mestra fazia anotaçðes.

Diplomada a primeira turma da Escola de Aperfeiçoamento, D. Helena convidou algumas Orientadoras Técnicas, título que as professoras. alunas recebiam depois de formadas, para Auxiliares do Laboratório de Psicologia, aumentando seu número e fazendo substuituiçōes, a medida que outras concluíam o curso.

Maria Angélica de Castro. Helena Paladini. Zilda Augusta Cunha Francisco, foram dedicadas e eficientes auxiliares de D. Helena, cujos nomes me recordo, pedindo desculpas por possíveis èrros ou omissōes.

Orientadas por D. Helena. as Auxiliares de Laboratório trabalhavam muito, experimentando. aplicando testes. apurando resultados e colaborando no preparo de publicaçōes nos boletins de Secretaria de Educação e Saúde Pública, entre eles: Ortopedia Mental c Homogeneização das Classes Escolares (Bolclim $\left.n^{0} 14\right)$. Infäncia Excepcional (Boletim $n^{\circ}$ 16). Ideais e Interesses das Crianças de Belo Horizonte (Boletim n $\left.{ }^{\circ} 6\right)$. Desenvolvimento Fisico e Psíquico das Crianças e adolescentes (Boletim $n^{\circ}$ 20). cic.

As outras professoras diplomadas pela Escola de Aperfeiçoamento voltaram às suas escolas como Orientadoras Técnicas ou Diretoras. incumbidas de por em prática e transmitir às colegas o que aprenderam c continuaram ligadas à Escola de Aperfeiçoamento, recebendo material, instruçðes, participando de trabalhos.

Podemos dizer que foram elas que realmente renovaram o ensino em Minas .

Um dos primeiros trabalhos das Orientadoras Técnicas foi a homogeneização das classes escolares, considerada muito necessária para o desempenho das professoras e melhor aproveitamento dos alunos, e foi iniciada em 1931.

Como primeira medida foi feita a separação dos novatos dos repetentes.

Para a organização das classes de $2^{\circ}, 3^{\circ}$ e $4^{\circ}$ anos, foram aproveitadas as notaš obitidas no ano anterior.

Quanto às classes do $1^{\circ}$ ano escolar. a homogencização foi feita de acordo com os resultados dos testes de inteligência geral, expressos cm Quocicntes Intelectuais, considerados como melhores do que simplesmente a idade mental.

Entretanto surgiu uma série de dificuldades. para o cílculo do Q.l, porque. na época, nảo cr: cxigida a certidũo do Registro Civil para a matricula 

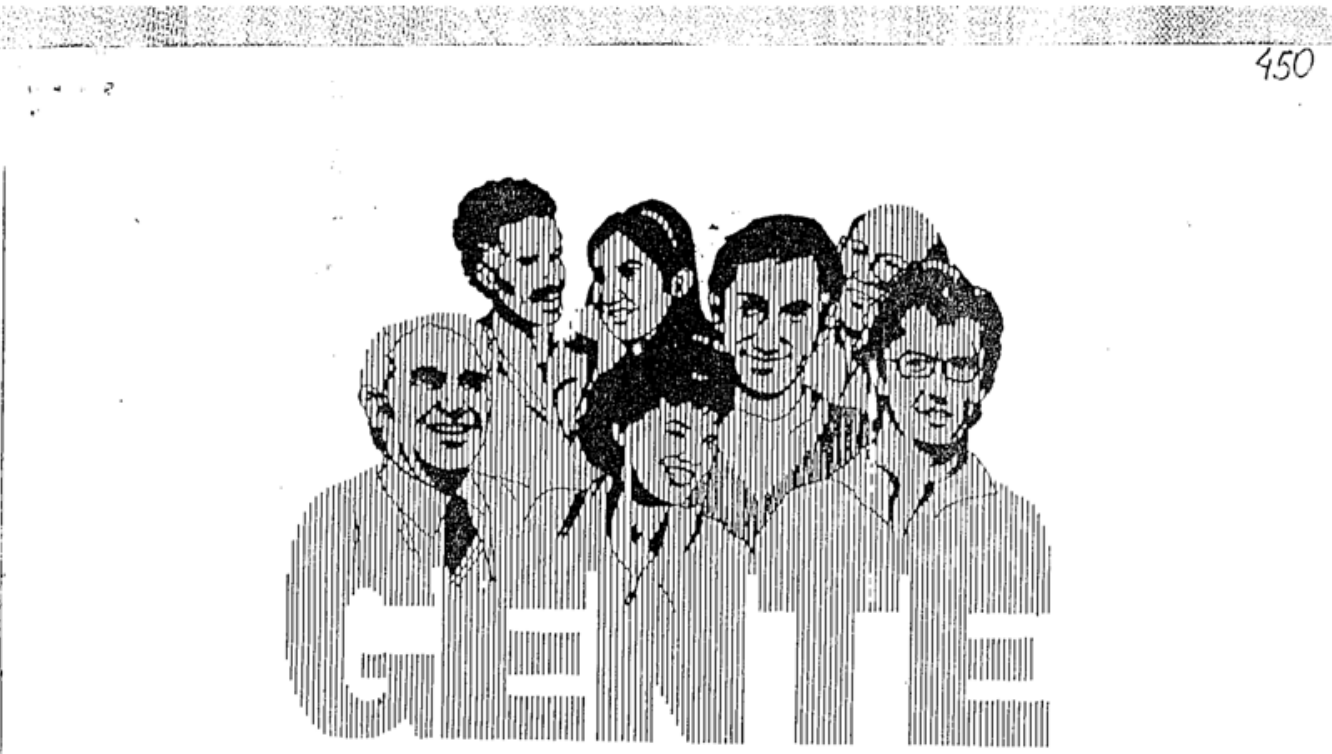

Imene Guimarães

\section{"Bons tempos aqueles"}

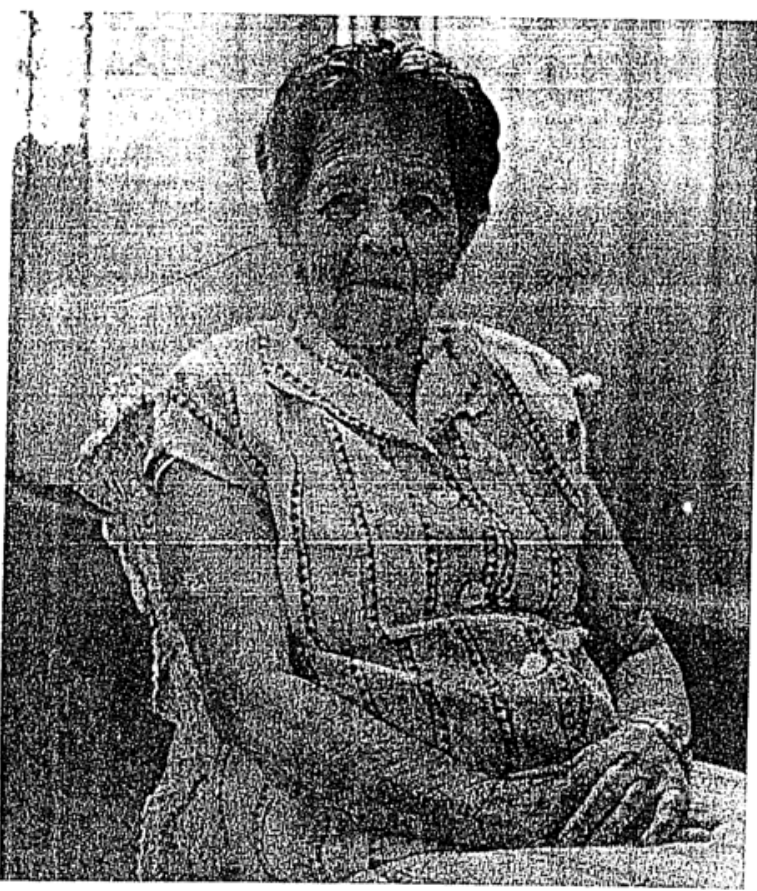

里

Shente do acolles.

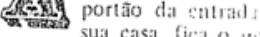
de uma escolas a canem. casa de seu irmão: atris a pátical igreja do bairro. É cercada pelos trés elenerinos mais tories de sua vida caçâo, fumilia c religio

ela vive mansamente os tite aposenta depois de unas. sagem forte e mois de umá : sino minciro.

Quem กร̃

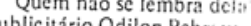
pubicitatho Odilon Behreils es. co especial quando se con anth. com d lmene, diretora dus seus bons tempos do Crupo bas rão do Rio Branco. Um abraco. assim tõo especial the dabraço bém ex-ministro Ibratá tam. Ackel, quando os dois son. tarem para por en dis tarem para por cnt diw

gas lembranças da épo de ensino, ela a delegada. 


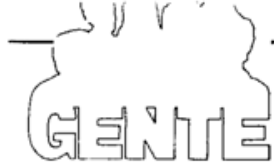

Bons tempos em Minas, recorda-se Imene Guimarães, batalhadora incansável em outras décadas, hoje marcando seu tempo com uma preocupação constante com o atual sistem de ensino, sem conseguir fugir a uma triste comparação: "Antigamente havia um entusiasmo crescente de todas as pessoas envolvidas com o processo edu. ca ívo. Hoje, o nível está des. cendo, há um desespero geral. O Governo é o culpado de tudo".

\section{Sempre a primeira}

No princípio, ela se acostu. mou a tirar o primeiro lugar em Português, Matemática, Psicolo. gia e Geografia e História. Depois, vencer já era tôn corr. Dero em sua vida que ninguém se po ensto assustor qua do começou a lar certo qu vida profissional. As pessous ja sabiam que aque. a professorinha que pegava o "Bonde Aplicaçã̃o" todos os lias para assistir às aulas no $\mathrm{C}$ égio de Aplicaçăo ia ocupa im lugar de muito sol no ens. 10 das Gerais.

Assim, com 17 anos, Ime e Guimarães encarou seu priveiro trabalho no Grupo Barão - Rio Branco: uma turma de spetentes da 4a série primária petentes da 4a série primaria, nde a diferença de tamanho lade era tăo pequena entre rofessora e alunos que um dia Onde já se viu vir sem uniforOnde já se viu vir sem uniforlenina - e que menina

Um mês depois era requisi ıda por Márcio Casassanta, ditor geral da Instrução, para abalhar nas classes anexas scola de Aperfeiçoamento, m uma classe pobre de ter!iro ano e cujas aulas eram as. stidas por alunas do Curso ormal - um grande sal to na ormal - um grande sal to na ira que se iniciava

E naquela pacata Belo Hori inte do tempo do bonde, os as já eram pequenos para aene Guimarães: quando quis impletar o curso na Escola de perfeiçoamento, ali ficava em mpo integral, aproveitando a sra do almoço na escola para tudos e pesquisas, que resulvam sempre em

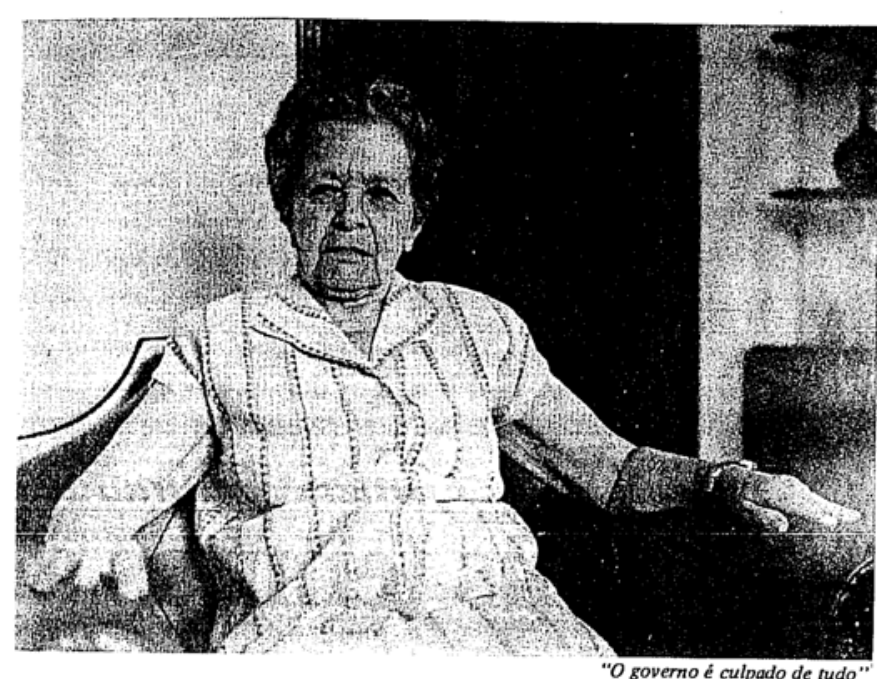

\section{Novos desafios}

Para quem viaja pelo interior de Minas, sempre haverá uma cantina em alguma escola com o nome de Imene Guimarāes, pois esta foi outra atividade que encantou a professora, pioneira em merenda escolar através da Associação das Cantinas Escolares. Ali ela colocava em ação seu talento administrativo e dirigia pessoalmente a com-

Sua dedicaça a levou ao Ins. tituto Pestalozzi, no trato com crianças de retardo profundo uma experiência que elando uma experiencia que ela consinhasse pouco e trabalhasse muito."

Foi quando resolveu aceitar outro desafio: concurso para inspetor de ensino do DÁSP, concorrendo com médicos, dvogados e engenheiros, es uudando todas as noites ábados e domingos em busc do compensador salário de 980 mil réis. Em 1947, foi nomeada inspetora de ensino no interior, passando depois para o Colégio Dom Silvério, Instituto Padire mesmo tempo que voltava ao Barāo do Rio Branco como orientadora técnica e diretora, completando o círculo na esco onde começara como aluna. Em defesa de suas idéias, não temia colocar seu cargo à disposição, como aconteceu quando o secretário de Educacão quis passar para três turnos diurnos o funcionamento da escola a fim de abrir mais yagas. Imene Guimarães pediu gas. Imene Guimarães pediu tário, não posso "Senhor Secremeninos já ficam tão pouco menios ja ficam tão pouco ma escola, năo podem quem sabe das coisas complequem " sabe das coisas comple ou. há uma casa para ser alugada. A gente faz mais salas de aula lá.

Caso contrário, deixo o cargo." Foi assim que o Grupo Ba. rão do Rio Branco ganhou mais alunos. Sem perder a diretora.

\section{Dias difíceis}

Em 1964, foi nomeada inspetora seccional de Belo Horizonte no Ministério da Educa. ção, enfrentando um período difícil, onde proliferavam as escolas abertas sem autorizaço com funcionamento ilegal.

Depois apaixonou-se pela Lri de Diretrizes e Bases do mais entendida sobre o assunto em Minas, com um arquivo particular requisitado por todos os professores, e viajando pelo Bra. sil fazendo reuniøes. Dirigiu ainda O Centro do PREMEM, dotado de oficinas de trabalho, em convênio com a Escola de paro de professores de Minas e Espírito Santo. Para isso mon. oficinas de carpintaria e educaçāo para o lar, onde os professores recebiam licenciatura de 10 grau.

Nesta vida de tantas conquis. tas, faltava ser a primeira De. legada de Minas e Goiás do Mirecebendo, em 1973, a Ordem Nacional do Mérito Éducativo, rinho na caixa de cetin uranco e no seu coração chcio elembranças. Naquele épo foram extintos 13 órgãos, passando o 10 e $2 \%$ graus para a responsa bilidade do Estado, e ficando d. Imene com todo o impacto da situação, tendo sol sua respaixados na funcion the dos, carga dobrada Filosofia da UFMG, para o pretou uma casa completa com nistério da Educação e Cultura, medalha hoje guardada com ca ponsabilidade funciontu res- 
D. Imene acha que passou por tudo sem ferir ninguém sem se machucar, pois as coisas eram levadas mais a sério e havia um profundo respeito pelo profissional de educação. O colegas gostavam de dizer que ela tinha "memória de elefante" e "fanatismo pelo cumprimento do dever" enquanto ela mento do dever", enquanto el se explica: "Tenho facilidade de adaptaçăo a todas as circunstâncias da vida."

\section{Doces lembranças}

Aposentada em 1977, não em frustrações - apenas boas embranças. De uma família de nais de dez irmãos, diz brinzando que é a casa matriz, semre cercada de parentes e amitos.
E, como quem foi rei sempre será majestade é a la que toda a família se dirige nas dú vidas escolares, assim como foi ela quem ensinou aos irmãos o francés que aprendeu na Es cola Normal.

Acompanha tudo sobre ensino de Minas, lamentando estar longe á́poca em que Presidente de Minas Antono Casidente de Minas, Antônio Carlos, afirm nẫo precisa de hora Professor no Palácio eu recebo é na hora". E rí melancólica ao citar o motivo que levara o pequeno grupo de professores ao Palácio: reclamar que o chuveiro da escola não estava com água quente.

Bons tempos aqueles. Ao contrário da música de Ataulfo Alves, d. Imene era feliz e saAlves,

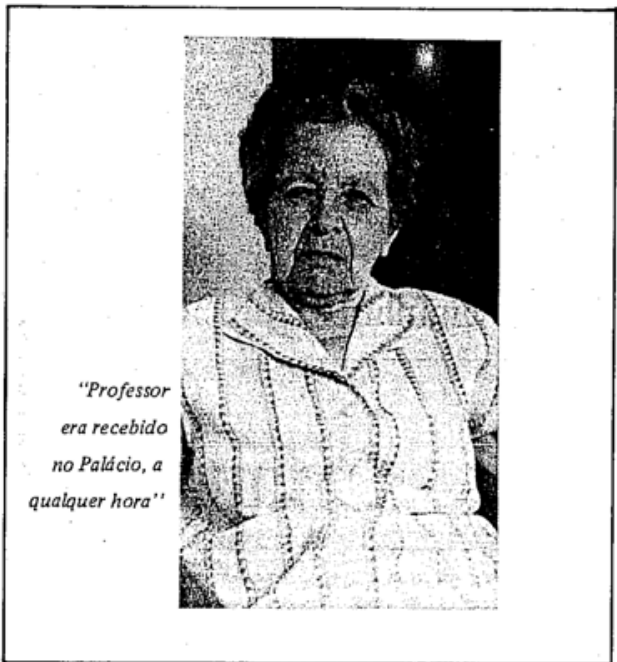

\section{"Figura admirável"}

Tive o privilégio de conhecer bem de perto Imene Guimarães. Uma vida inteiramente dedicada, com capacidade invejóvel, à causa da educação. Acompanhei suas atividades sobretudo na Inspetoria Seccional do Ensino Se cundario e gional do MEC em Minas Gerais, ocupando em ambas o posto mais elevado, nele dexxando bem gravada a marca de sua personalidade. Sua capacidade administrati'a, traduzida em atos corajosos $e$ decishes prontas $e$ acertadas, tornaram-se bem conhecidas graças ao testemunho cie seus auxiliares. Por isso mesmo, todos os inspetores e funciongrentiau srabahavam sob sua direção, sentiam-se seguros, porque bem orientados é prestigiados. Por outro lado $e$ sem exceçäo conhecida, diretores, pro fessores e até mesmo alunos dos estabelecimentos de ensino localizados na área de sua jurisdição, acatavam suas deliberaçōes, porque invariavelmente calcadas no seguro conhecimento da lei e na sua inteligente interpretação.

Meus parabéns à Revista Dois Pontos, do Colégio Pitágoras, pondo em destaque a figura admirável de Imene Guimarães, um exemplo para tantas Guimarães, um exemplo para tantas
pessoas colocadas em postos importanpessoas colocadas em postos importantes, às quais falta porem coragem ou capacidade para o desempenho de suas funções com seriedade e patriotismo. Imene Guimarāes é realmente esse grande exemplo. Eu aprendi muito com ela.

Idalmo Motta 

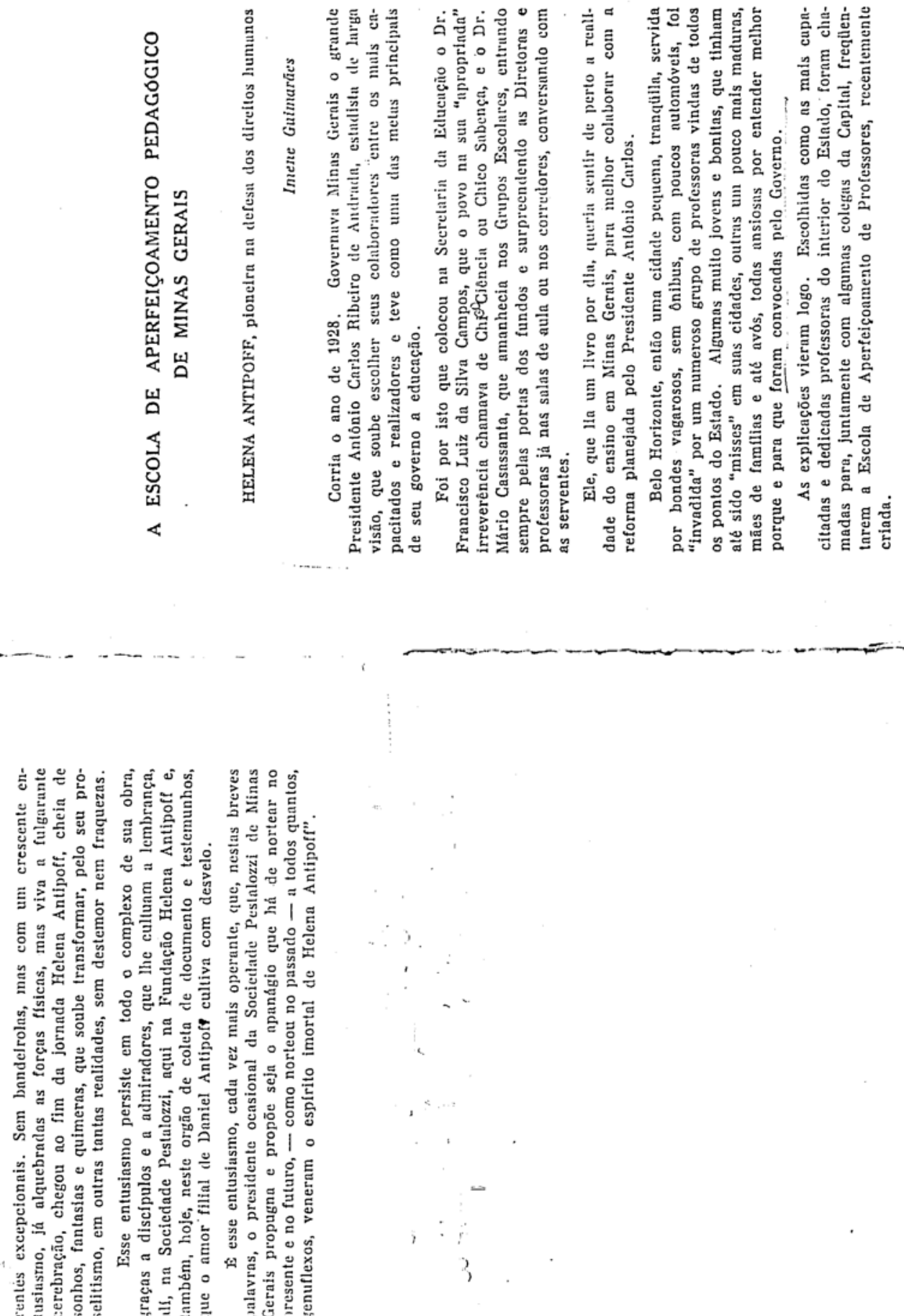


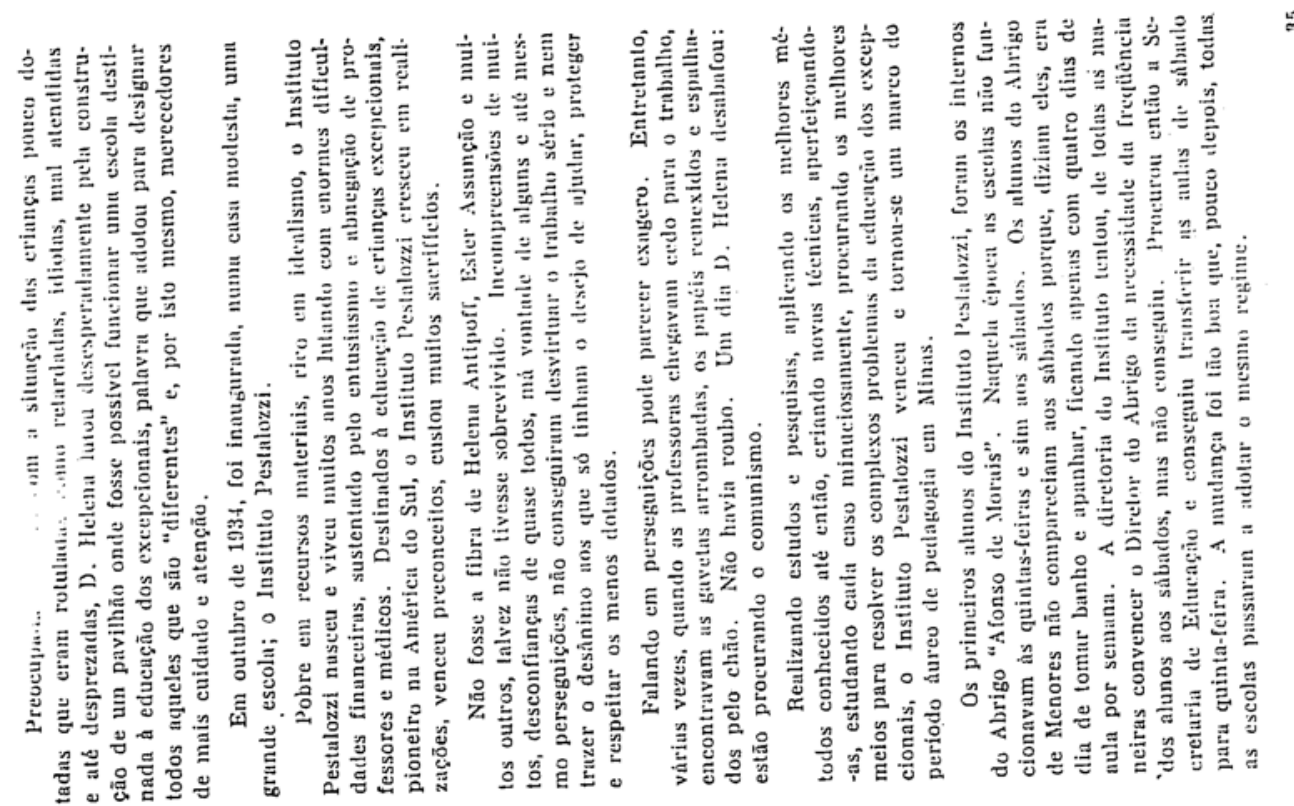

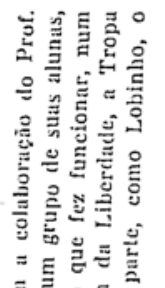

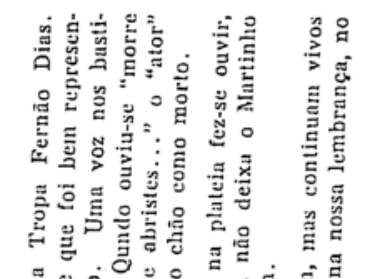

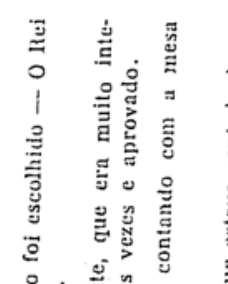

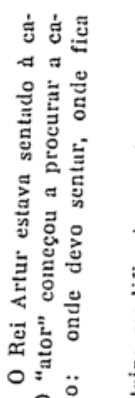

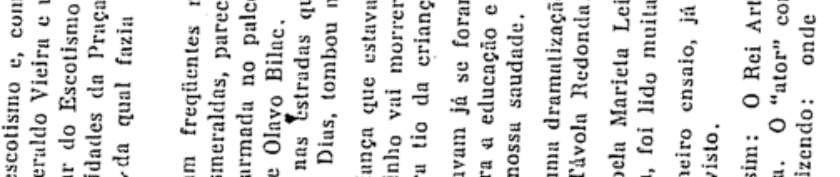

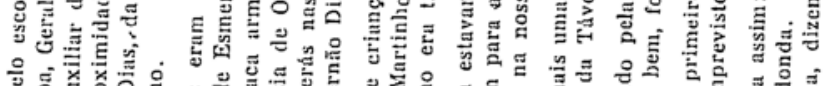

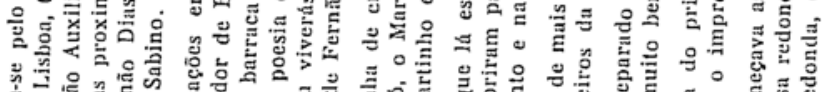

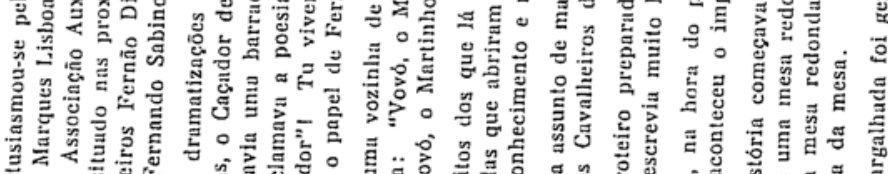

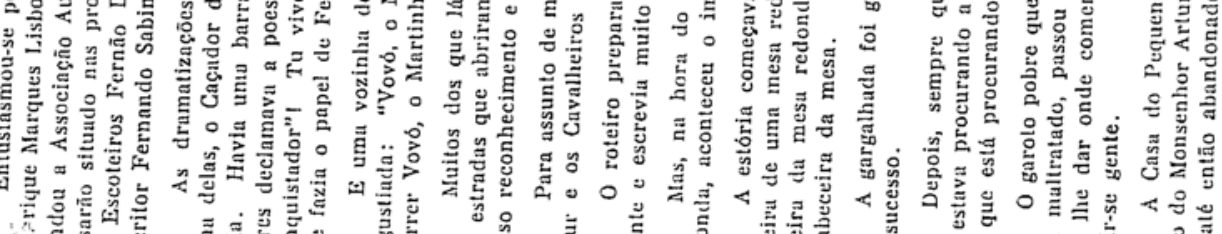

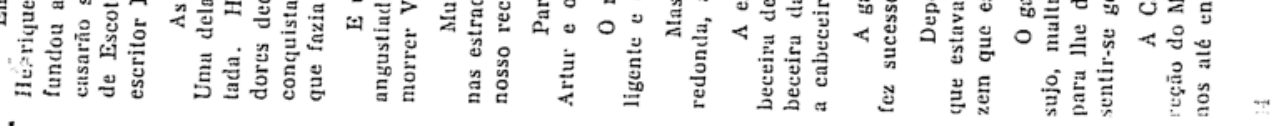




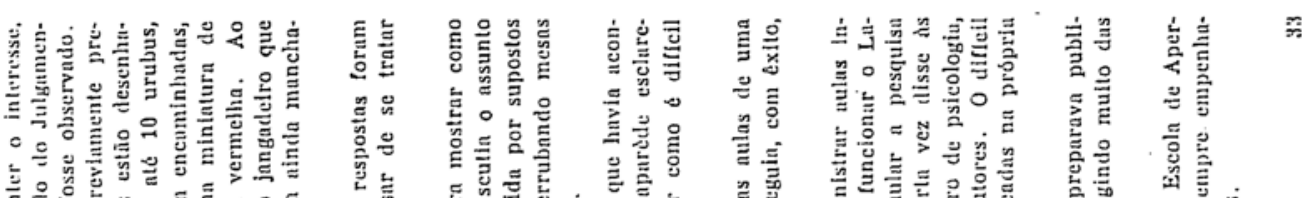

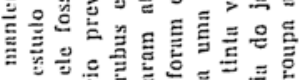

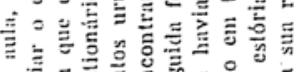

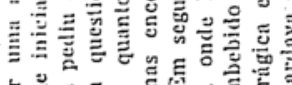

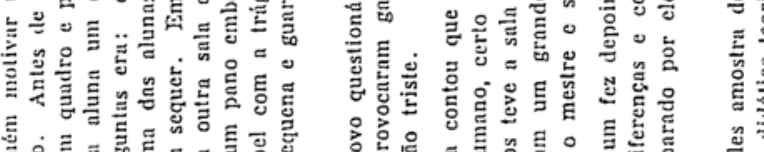

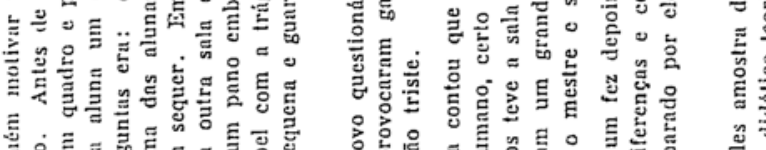

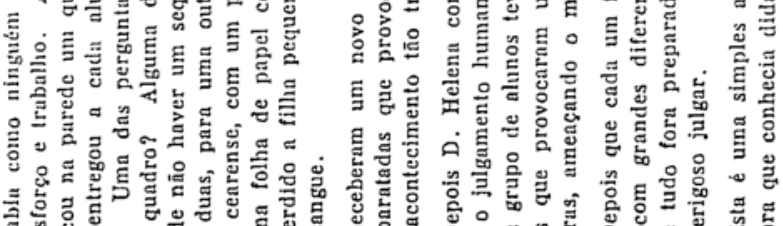

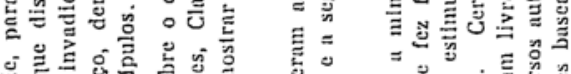

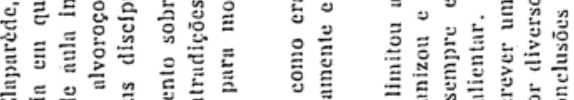

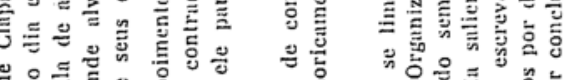

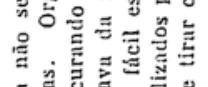

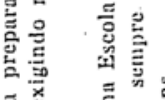 政,

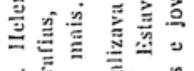

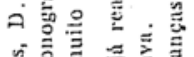

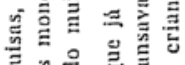

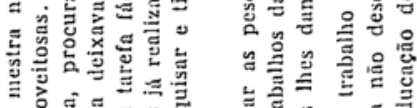

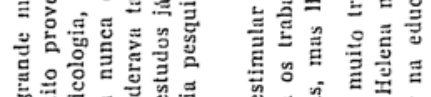

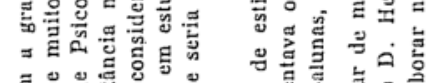

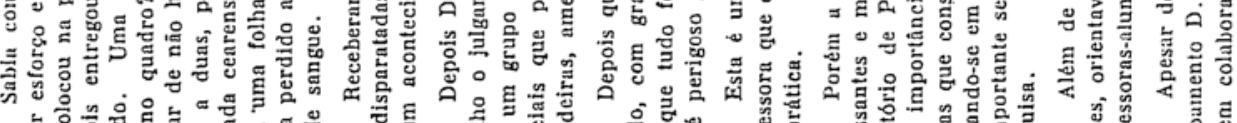

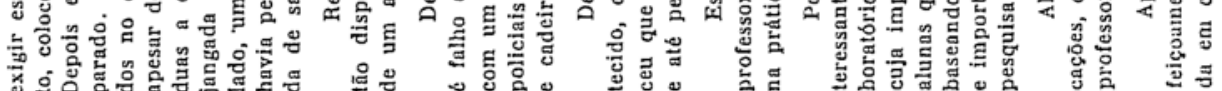

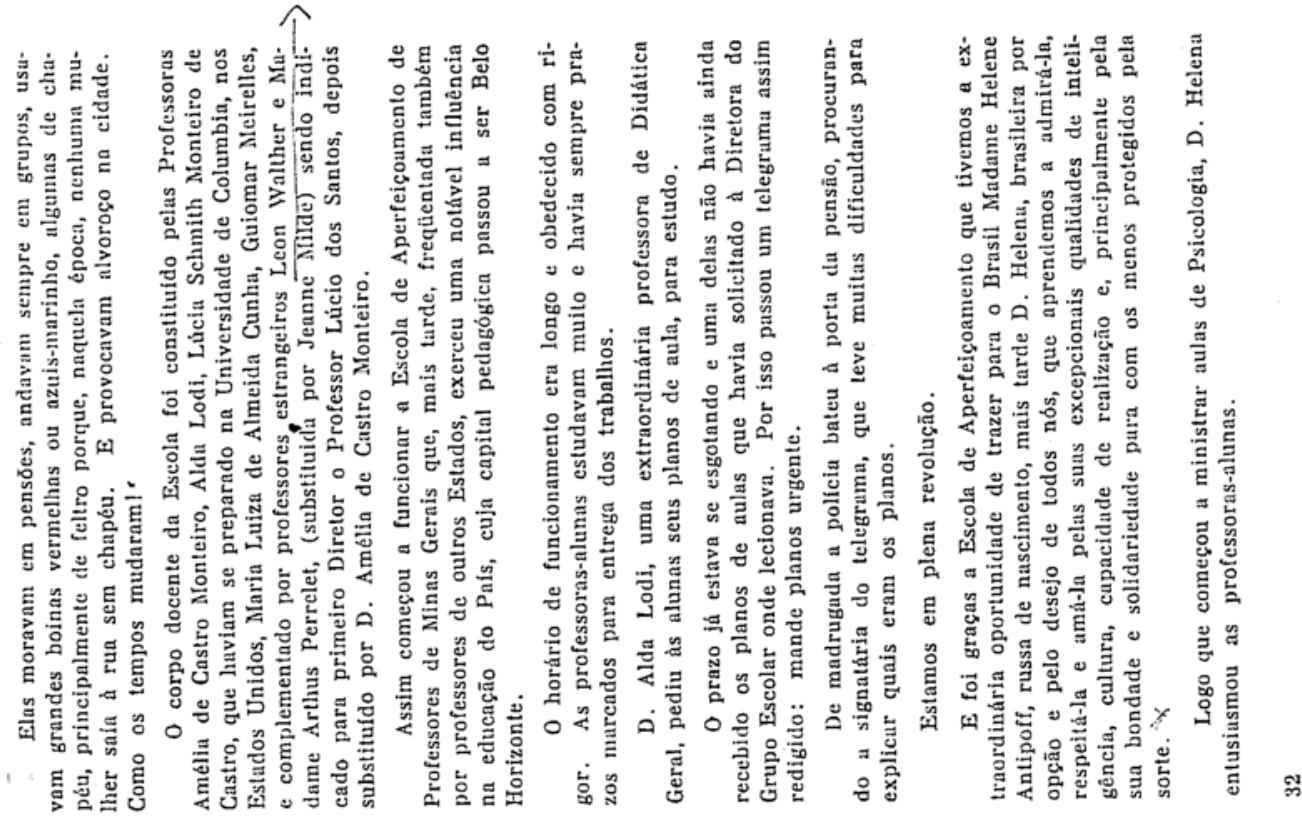



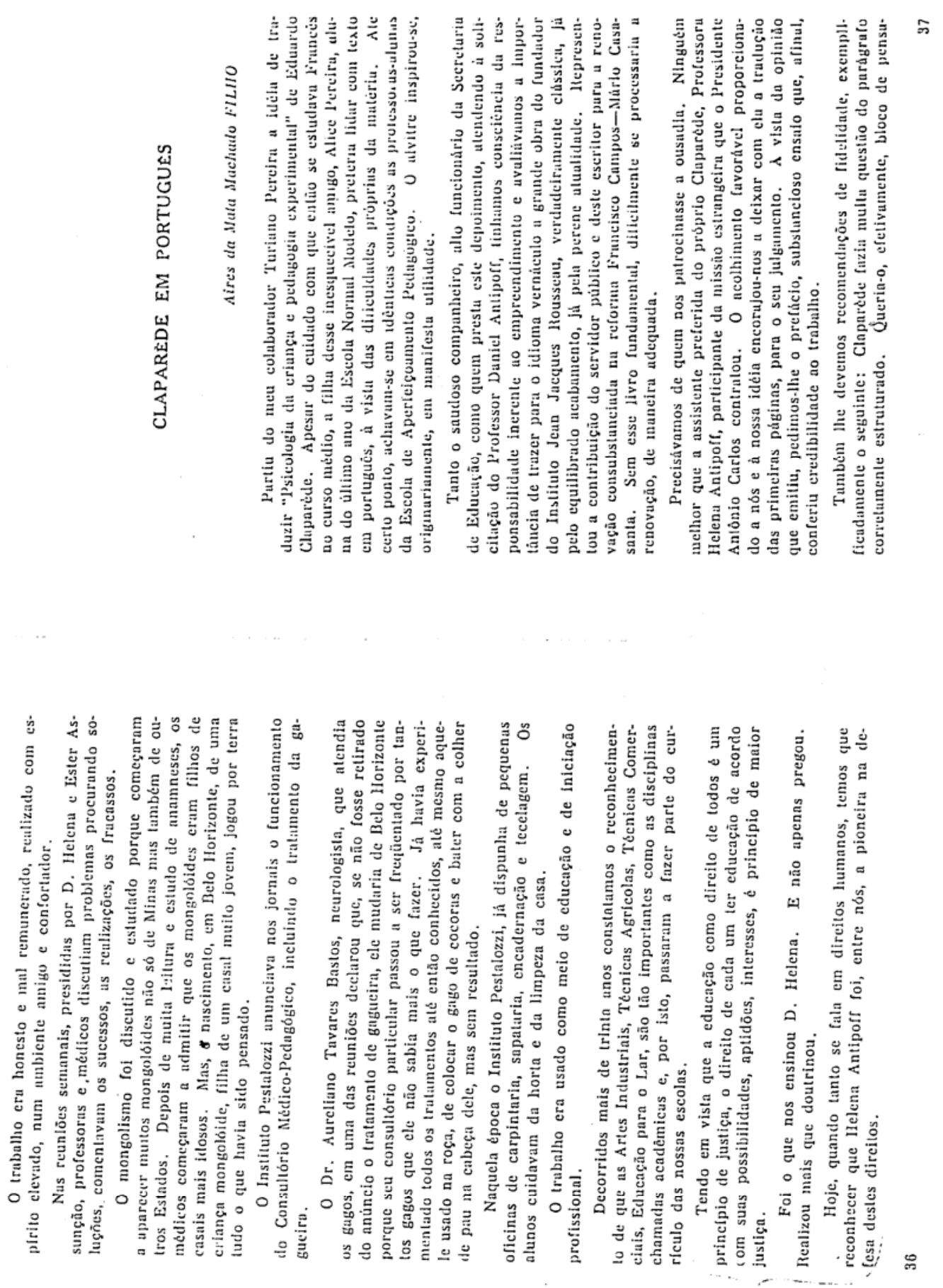


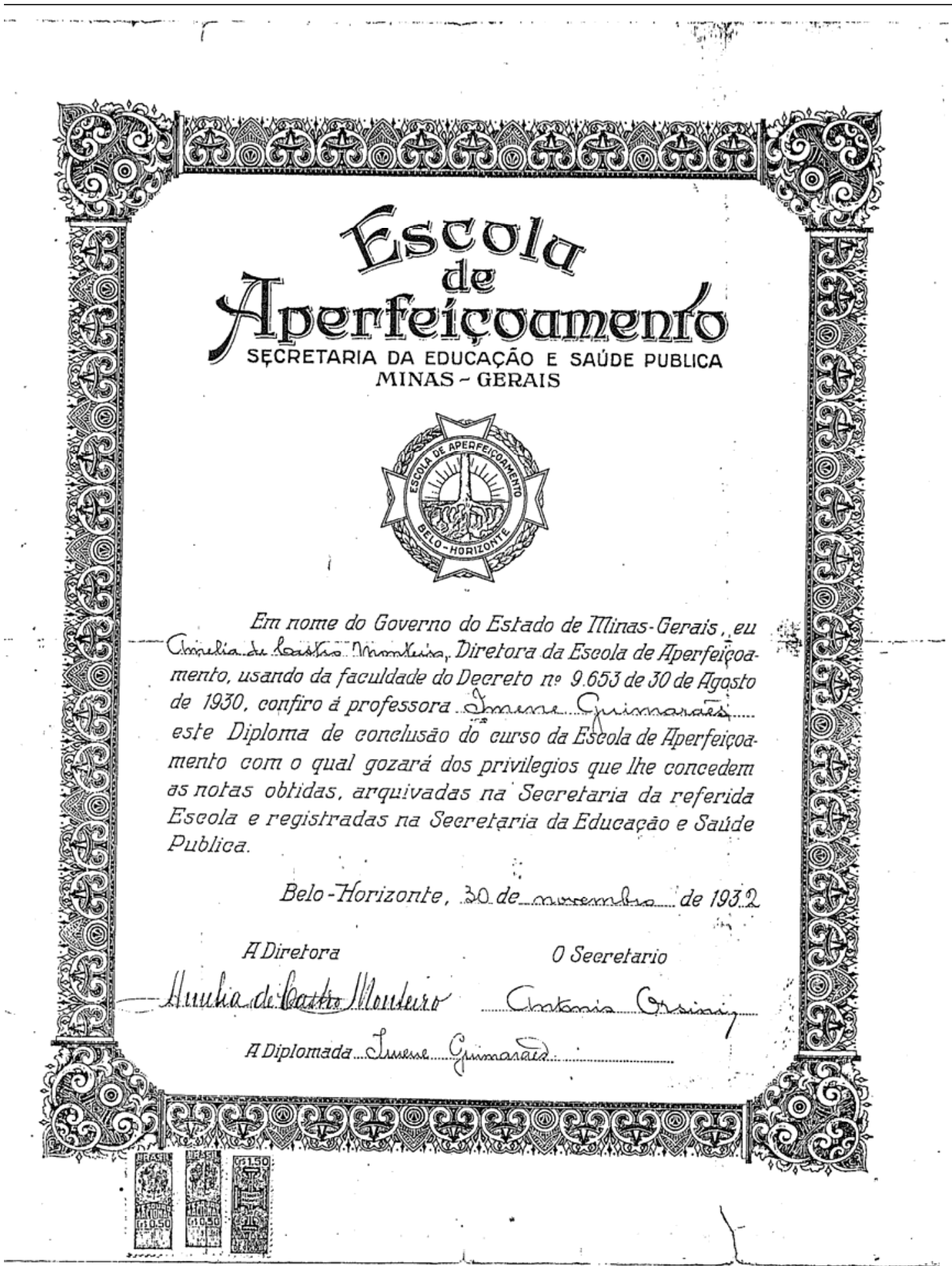


๑ง. SECCSÃO

Registrado ús fls. fo do livro n. 1

Pagou cie direito rs...514t Toro

conforme 1. co n. ${ }^{\circ}-4.7$ expedido pela

coletoria ie Bula teravente

em.21 de finoveriso 1933

Secretaria da Educaçăo, 15 de onaréo

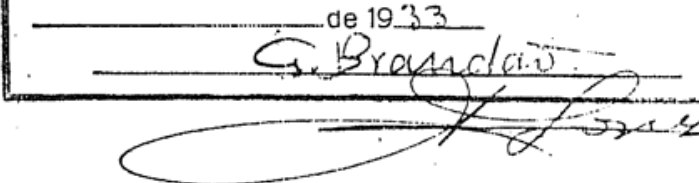

RELAÇÃO DAS NOTAS OBTIDAS:

Metodologia Geral.

haz

Metodologia da Lingua Patria Wes

Metodologia da Aritmética hoveremeio $(9,5)$ Metodologia das Ciencia. Naturais, da Geografiae

$\because$ da Historia, o Biotiga hes (10)

Pedologia e Psicologia hl hez ........ (1.0)

Socialização h....... huremeing $(9,5) v$

Desenho e Modelagem Gifremein $(8,5) \sqrt{ }$

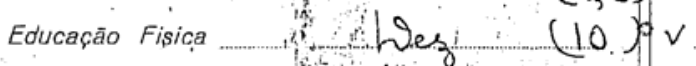

SSEcretario,

Chistion (o)

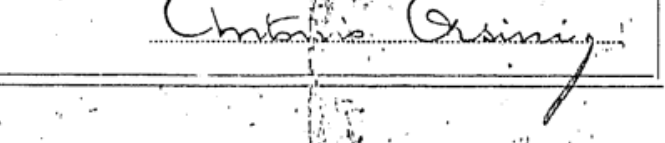

$\therefore \quad$,

1:

(3)

$\therefore$ 


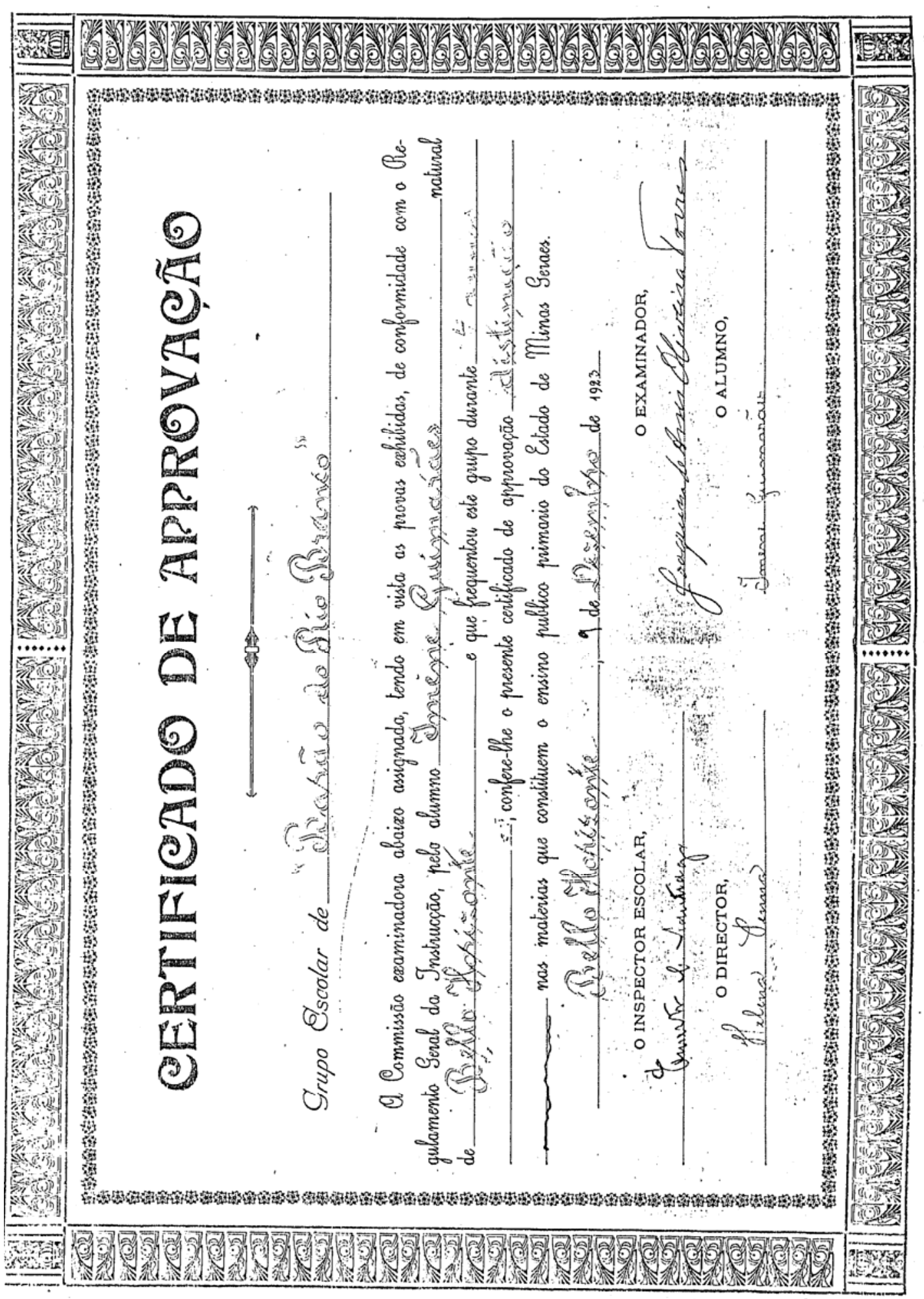


“NÃO PREMIARÁS, NÃO CASTIGARÁS, NÃO RALHARÁS...” dispositivos disciplinares em Grupos Escolares de Belo Horizonte (1925-1955)

\section{DOCUMENTOS APRESENTADOS PELA} ENTREVISTADA

\section{LUÍZA TRAVASSOS RIBEIRO CAMPOS}


ALUNAS DA ESCOLA NORMAL DE BELO HORIZONTE - [1935?]

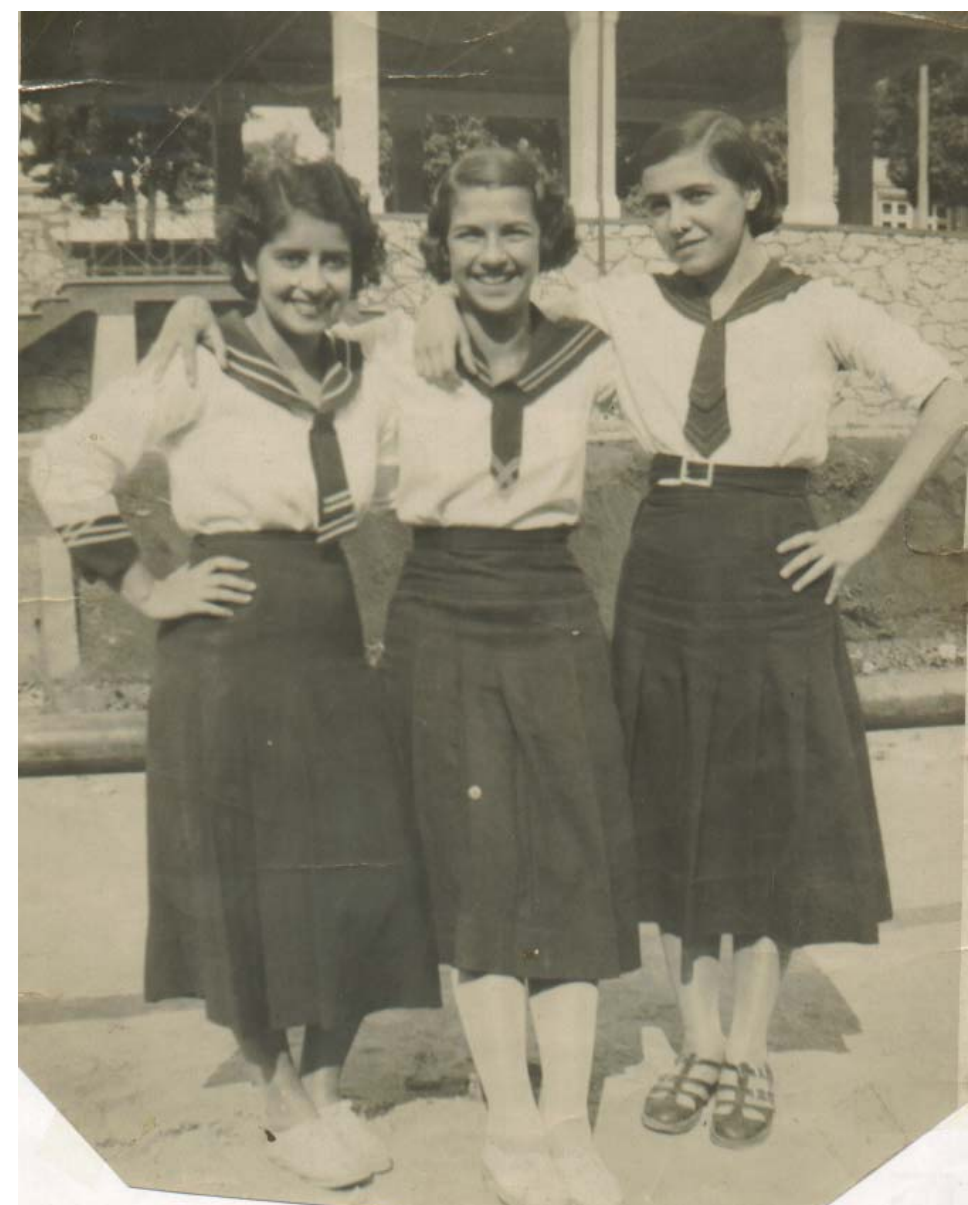

Luiza Travassos Ribeiro Campos, Desdêmona e Mariana Ávila

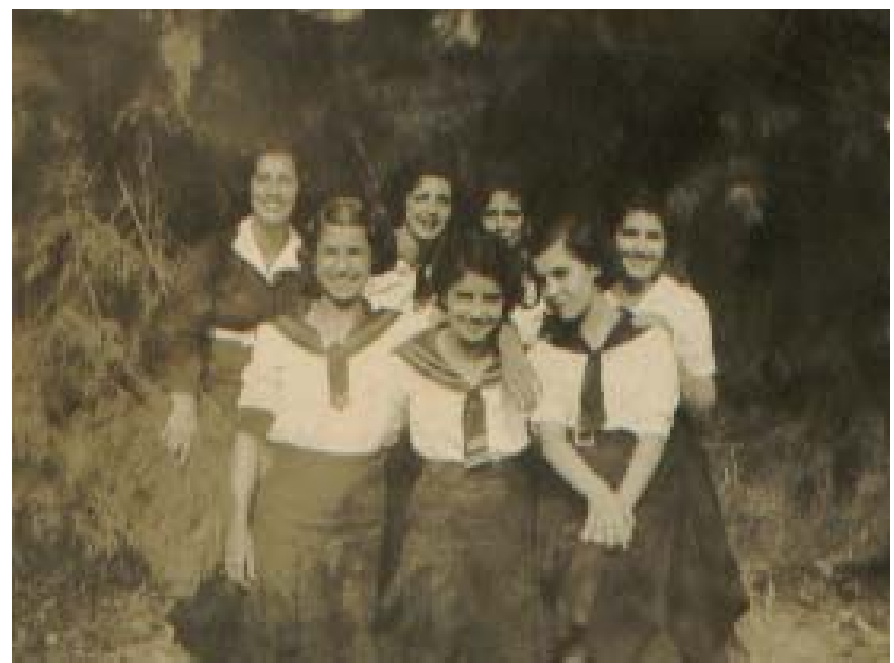

Luiza Travassos Ribeiro Campos ao centro. 
ALUNAS DA ESCOLA NORMAL EM 1937 [?]

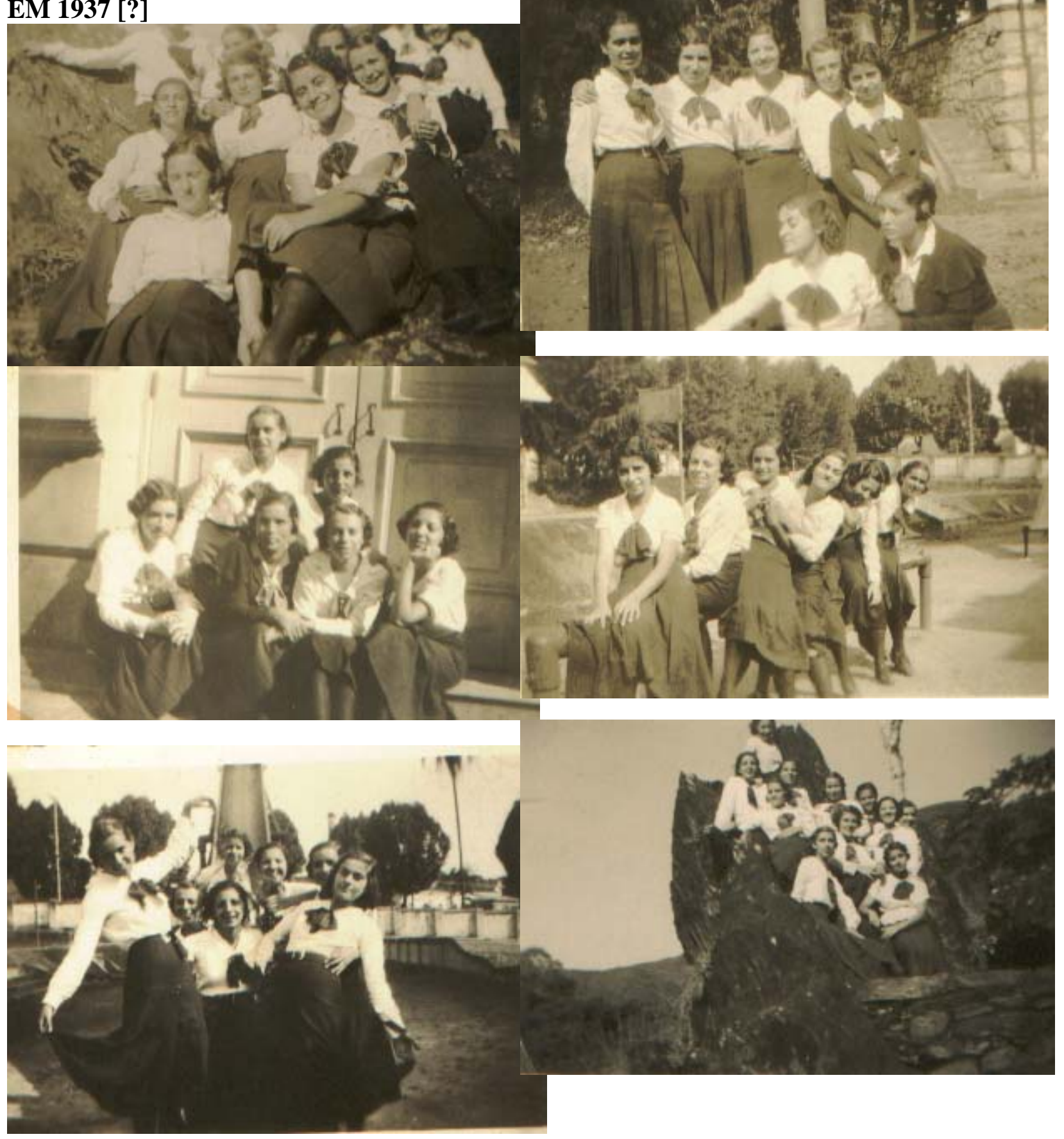



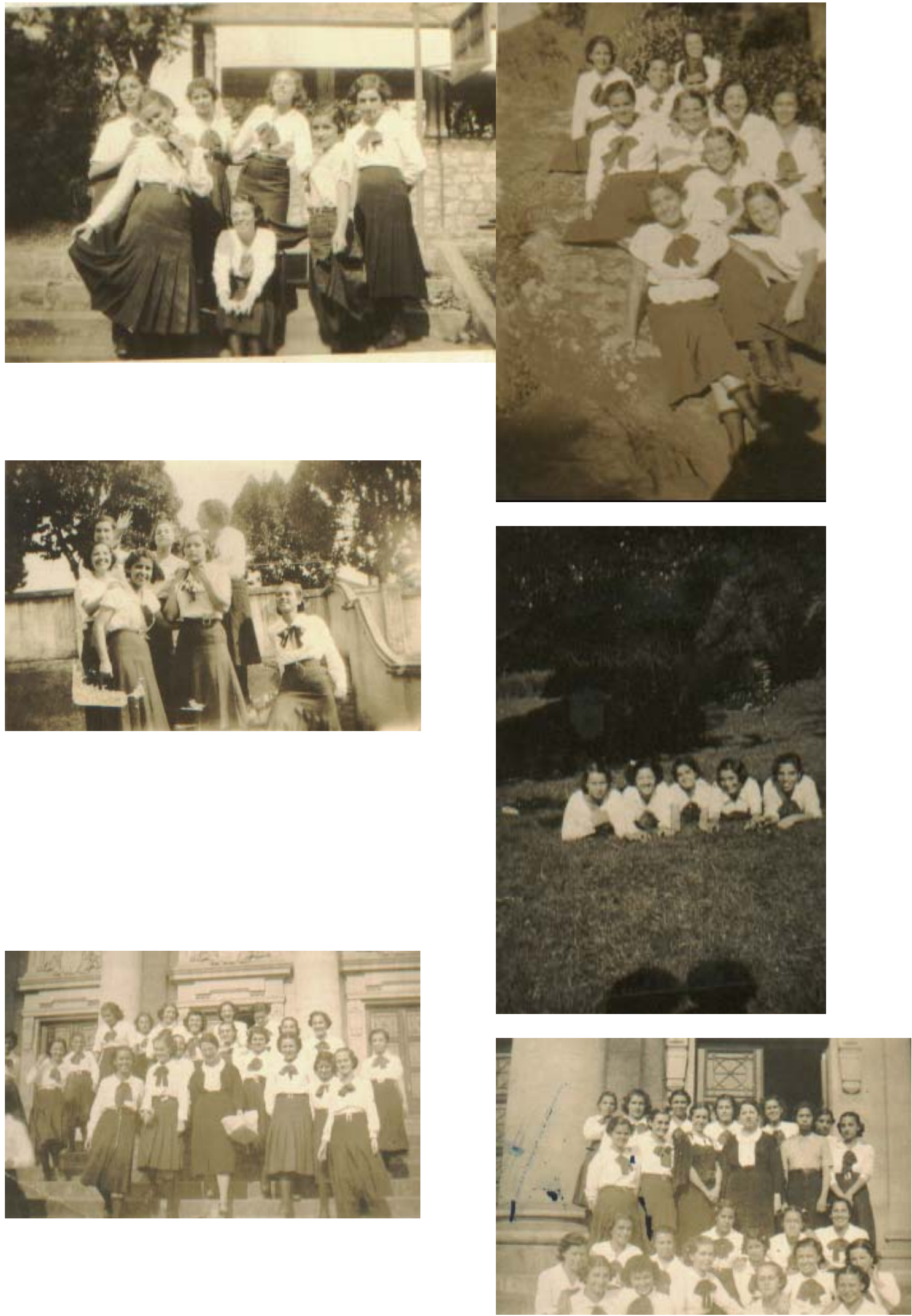
Cartão de Matrícula de Luiza Travassos Ribeiro Campos na Escola Normal de Belo Horizonte em 1936

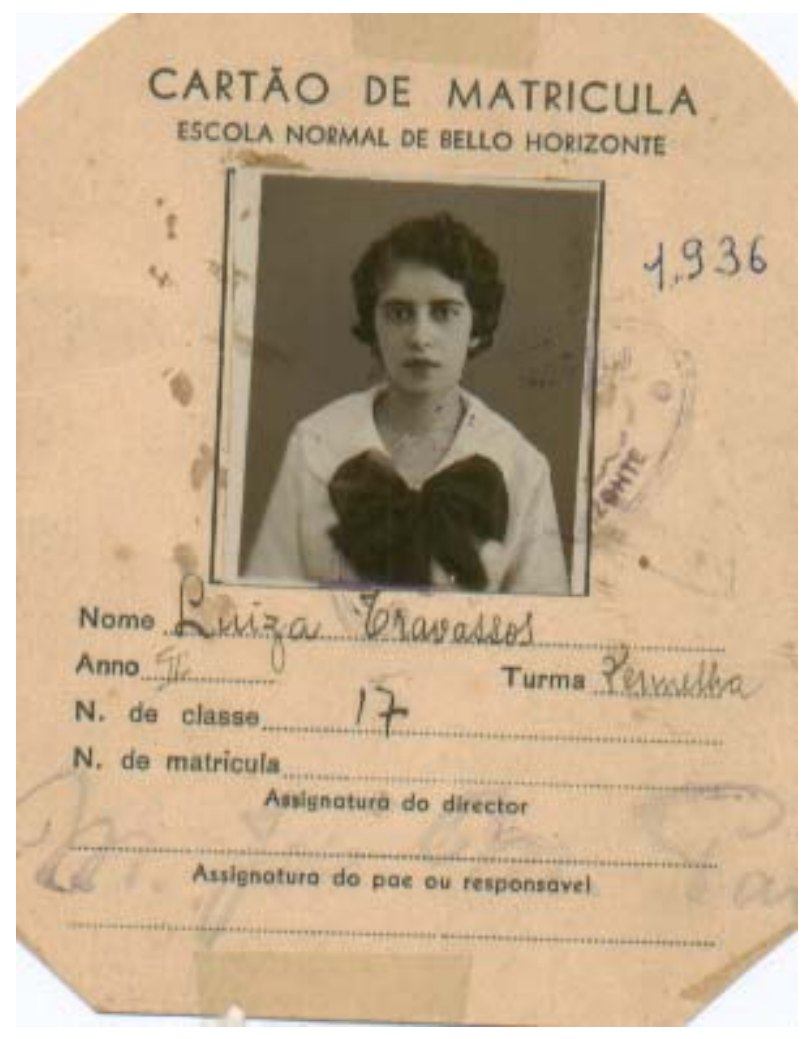

Lembrança da entronização de Cristo na Escola Normal em 1937 de Luiza Travassos Ribeiro Campos.

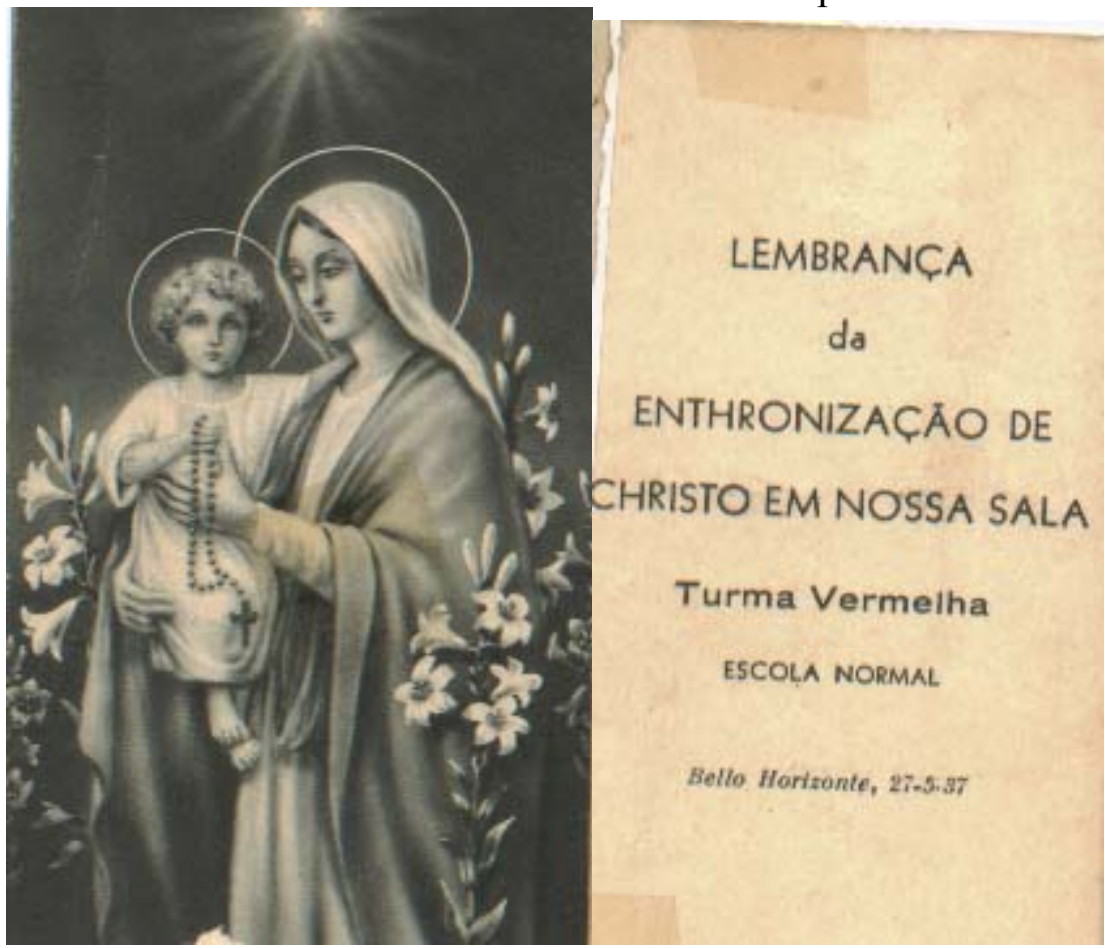




\section{AS FORMANDAS DE 1937 DA ESCOLA NORMAL NA FESTA DAS BODAS DE OURO DA FORMATURA}
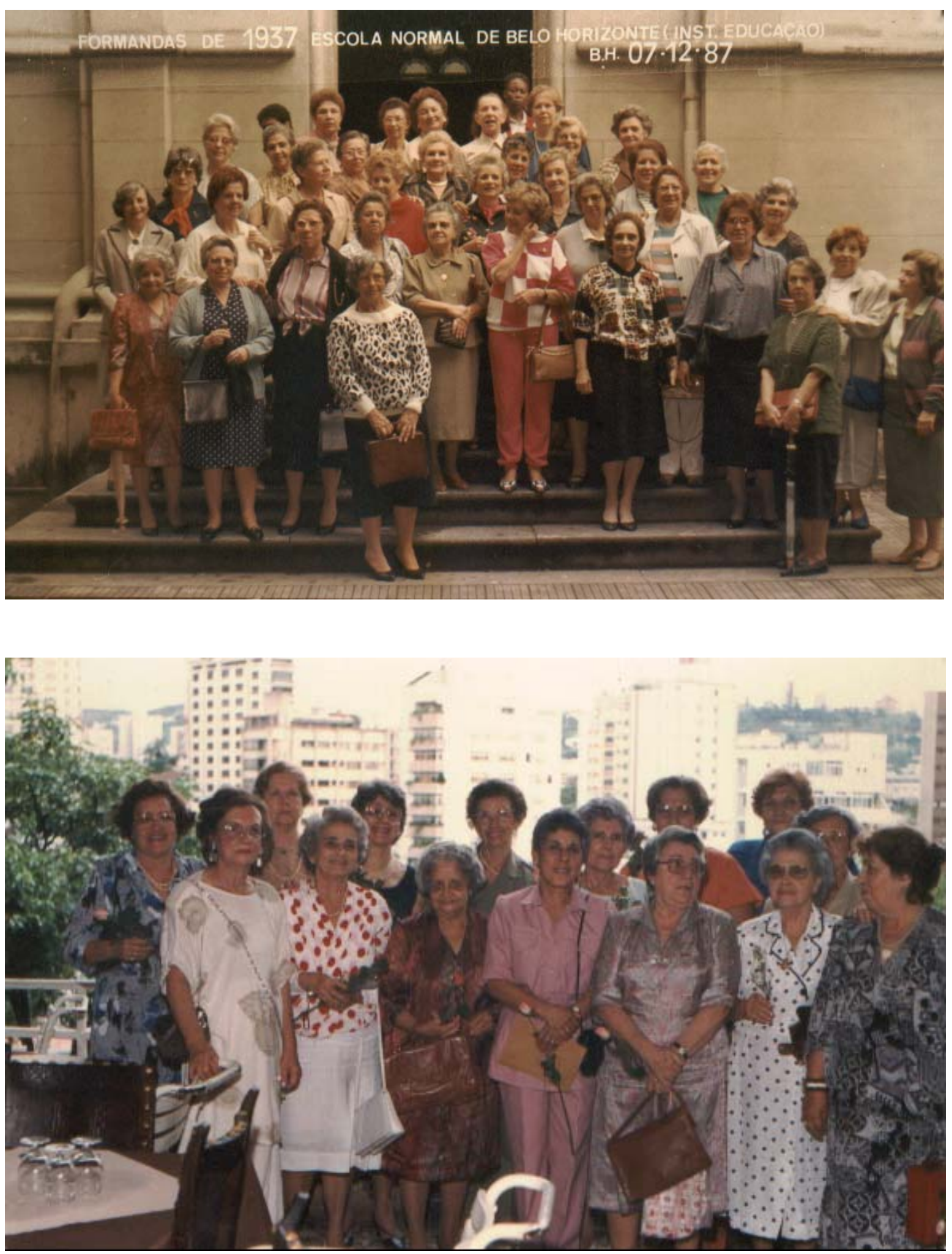
413

LEMBRANÇA DAS BODAS DE PRATA DAS ALUNAS FORMANDAS DA ESCOLA NORMAL EM 1937 (1937-1962)

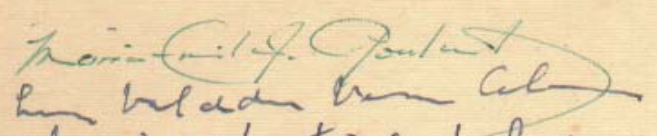

elaria, elartius defaiva

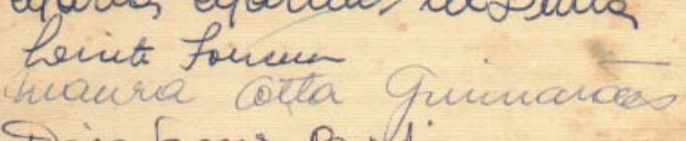
Doire fant Boy. havia Emial pogude ampis Plice Pintut rillns

Twe doflunida Laua Llaria duniliadon Parm de Cavalla Soria de Posurds Sadraio Aguia Diciala Caldeina de Castro Mliganif orres Ceimne toorrea da filven Martir Banc Horte sive forme Maria Yuse of. Dassos Lembransa das Boilas de Prata de formatu-
ra da furma "Vermelha" da Eacola Normal Modêto, hoje Inatítuio de Educaşäo. $7 \cdot 12-19787$
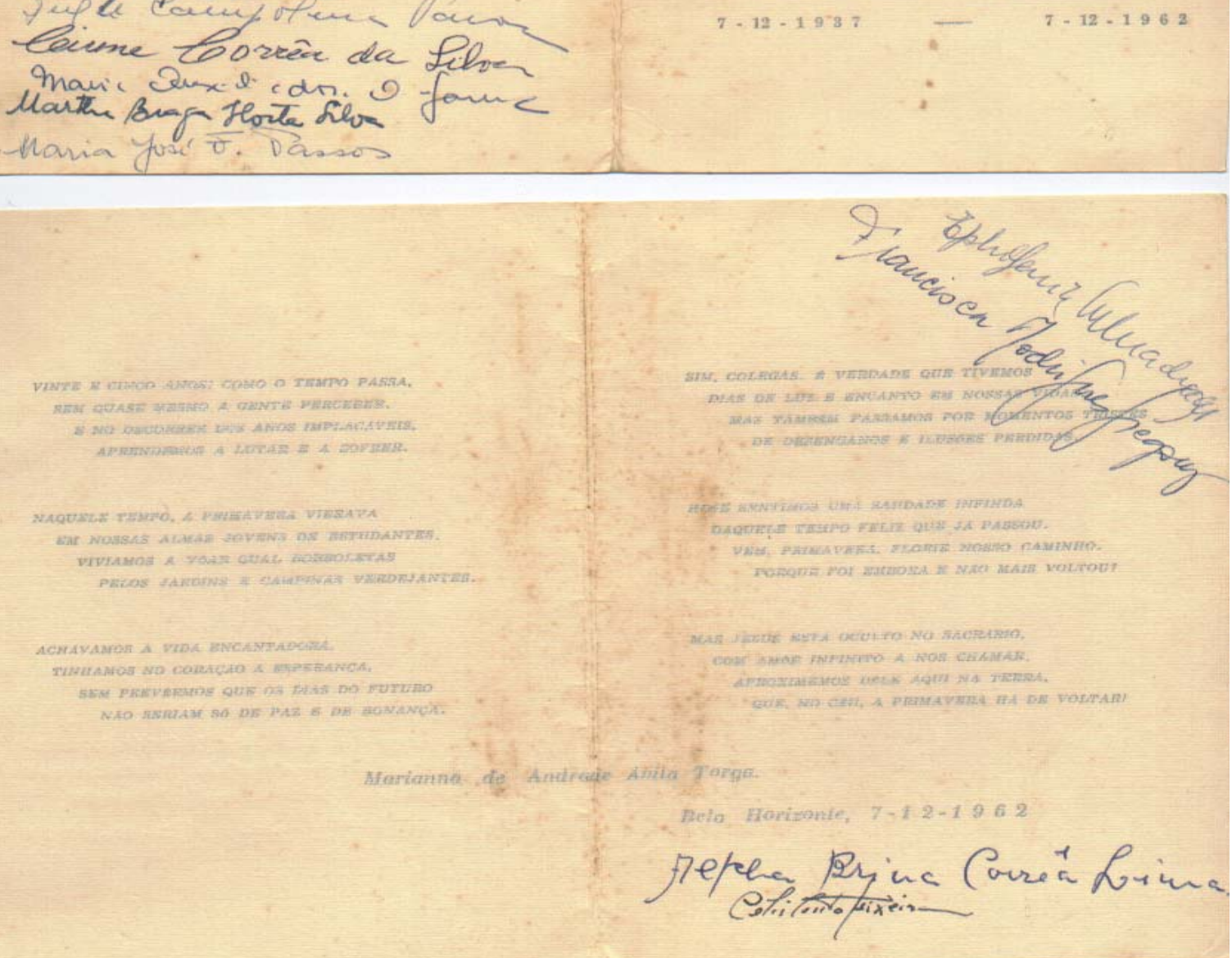
organizados, formavam a Monografia de uma classe. e era entregue a $D$. Helena que, depois de cxaminála, encarregava as Auxiliares do Laboratório de destacar cada uma das partes para novos estudos.

As professoras-alunas recebiam orientação constante, treinavam na aplicação de cada teste. inlerpretação de resultados, confecçōes de gráficos, spuração de dados estalísticos, etc.

D. Helena preparou também uma ficha de observaçăo do desenvolvimento mental das crianças, para uso dos psicólogos. médicos, ducadores e até mesmo dos pais.

D. Helena costumava designar algumas professoras-alunas para a realização de experiência sobre cores. Ela carregava uma caixa de madeira Jentro da qual se encontravam muitos lacinhos de linha. sendo dois de cada cor.

Aproveitando o intervalo do almoço, ela hamava cada dia uma colega para se submeter à experiencia que consistia em enconirar os dois lucinhos da mesma cor e responder perguntas, omo: qual a cor que você mais gosıa, qual a cor juc você não gosta. etc.

E foi Marieta Leite que fez os versos em que Nha Maruca", que tinha vindo "Se aperfeiçoa. lizia:

Se a "madama preguntá

Qual a cô que você mais gosta.

Vá andando..

Num dê resposta.
D. Helena achou os versos muito engraçados,

Foi no laboratório de Psicologia da Escola de Aperfeiçoamento que a Mestra elaborou o teste $M$ M- Minhas Mãos, caracterizado por ela como: "um instrumento para o diagnóstico psicopedagógico individual e para o controle da açăo educativa da escola "ou" uma prova para melhor conhecimento dos alunos e estudo objetivo da sua personalidade, aptidðes, interesses."

A Fundação Estadual de Educação Rural FEER, em 1975, publicou importante trabalho sobre o teste $\mathrm{MM}$

O precioso e rico material do Laboratório de Psicologia foi levado para o Curso de Administração Escolar do Instituto de Educaçâo. depois que a Escola de Aperfeiçoamento encerrou suas atividades. e foi destruído por um incêndio.

Mas, as grandes realizaçōes de D. Helena permaneceram.

E. é com muita saudade e reconhecimento que nos lembramos da mestra querida e respeitada. formadora de outras mestras. mãe das crianças excepcionais. criadora de grandes obras, inspiradora de outras. que muito fez por uma Pátria onde não nasceu, mas adotou como sua e the deu amor. trabalho, sacrificios. 